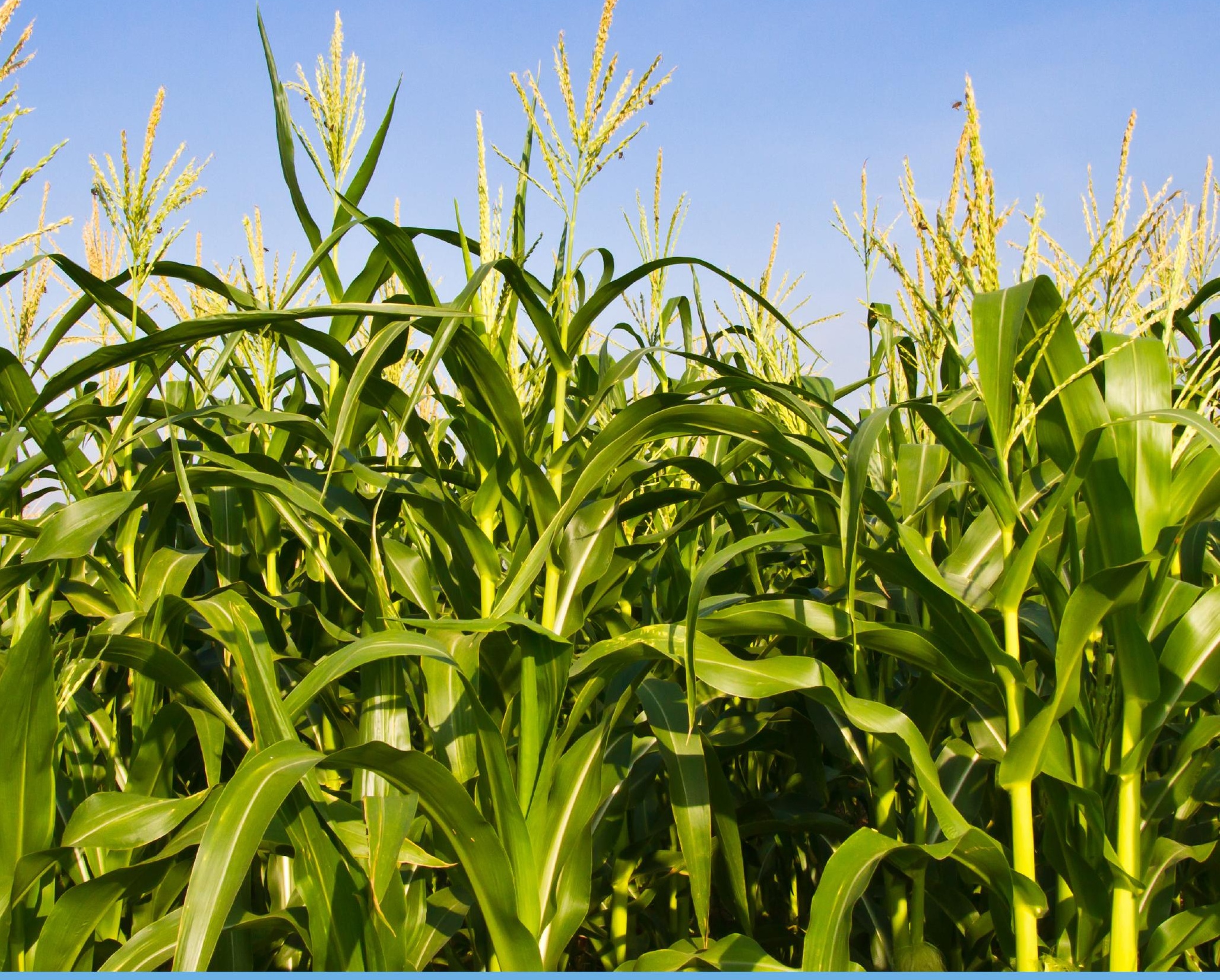

\title{
Handboek Snijmaïs
}

$\square$ WAGEN I N E EN 


\section{Handboek snijmaïs}

December 2017 


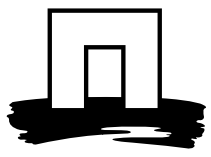

\section{WAGENINGEN} UNIVERSITY\& RESEARCH

\section{Colofon}

\section{Uitgever}

Wageningen Livestock Research Postbus 338, $6700 \mathrm{AH}$ Wageningen

Telefoon 0317 - 483953

E-mail info.livestockresearch@wur.nl Internet http://www.wur.nl/livestock-research

\section{Redactie en fotografie}

Wageningen Livestock Research

\section{Copyright}

(C) 2018 Wageningen Livestock Research, onderdeel van Wageningen University \& Research Overname van de inhoud is toegestaan, mits met duidelijke bronvermelding.

\section{Aansprakelijkheid}

Wageningen Livestock Research aanvaardt geen aansprakelijkheid voor eventuele schade voortvloeiend uit het gebruik van de resultaten van dit onderzoek of de toepassing van de adviezen.

Wageningen Livestock Research en Wageningen Bioveterinary Research, beiden onderdeel van Stichting Wageningen Research vormen samen met het Departement Dierwetenschappen van Wageningen University de Animal Sciences Group van Wageningen University \& Research.

De certificering volgens ISO 9001 door DNV onderstreept ons kwaliteitsniveau. Op al onze onderzoeksopdrachten zijn de Algemene Voorwaarden van de Animal Sciences Group van toepassing. Deze zijn gedeponeerd bij de Arrondissementsrechtbank Zwolle.

\section{Referaat}

$\mathrm{Na}$ gras is snijmaïs het belangrijkste gewas voor de melkveehouderij. Dit handboek beschrijft de actuele stand van zaken over teelt, oogst, voeding en economie van snijmaïs.

Werkgroep Handboek snijmaïs Eindredactie: Herman van Schooten (Wageningen Livestock Research), Bert Philipsen (Wageningen Livestock Research), en Jos Groten (Wageningen Plant Research)

Handboek 35

https://doi.org/10.18174/442764

Trefwoorden: snijmaïs, grondbewerking, bemesting, rassenkeuze, zaaien, onkruidbestrijding, ziekten \& plagen, oogst, opslag \& bewaring, voeding, economie 


\section{Inhoudsopgave}

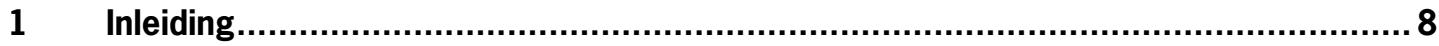

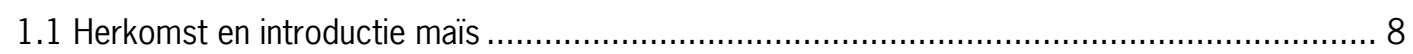

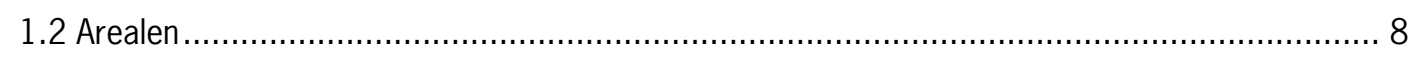

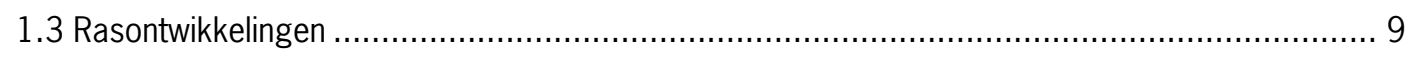

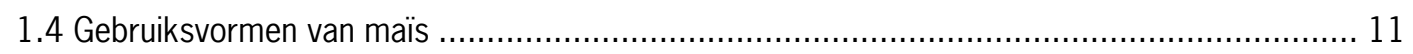

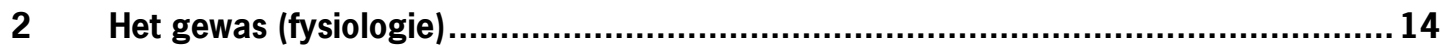

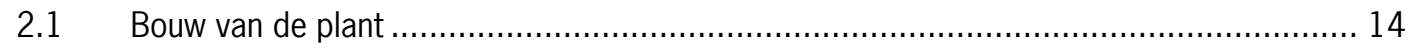

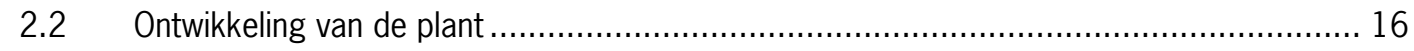

2.3 Beïnvloeding op ontwikkeling, productie en kwaliteit.............................................. 25

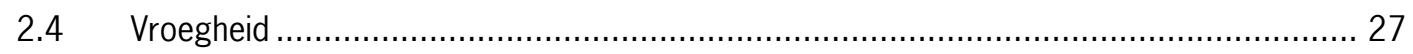

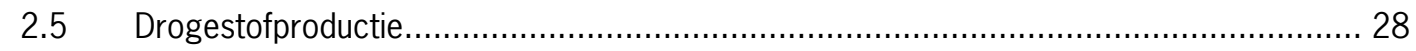

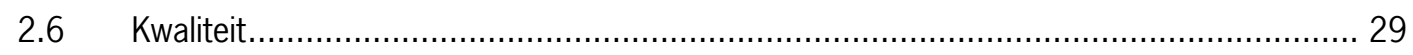

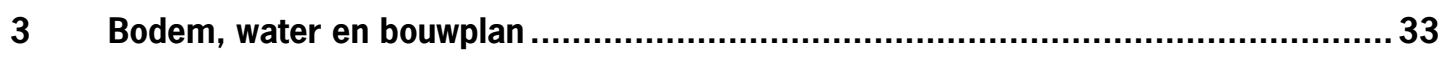

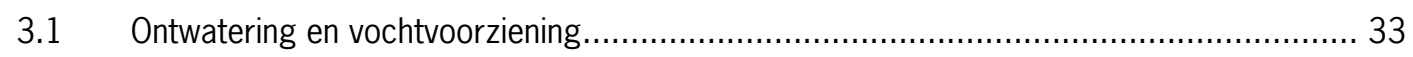

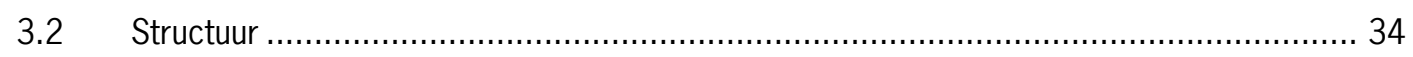

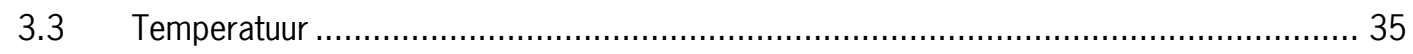

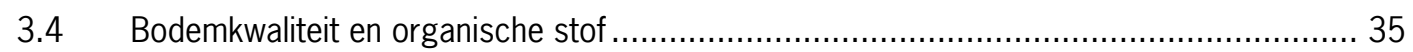

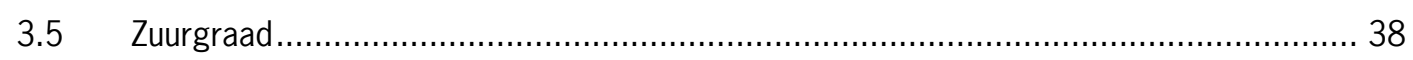

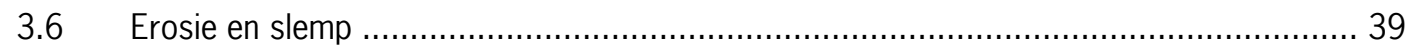

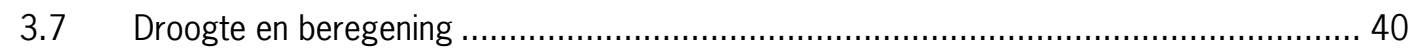

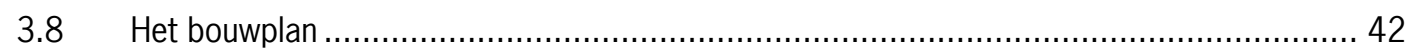

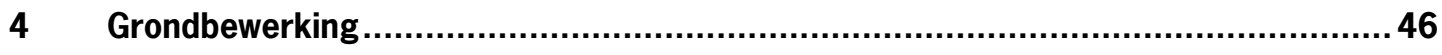

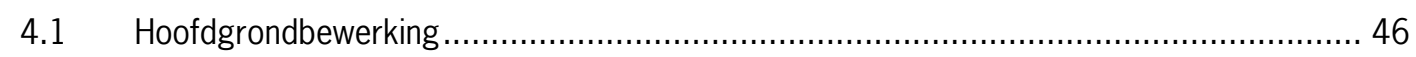

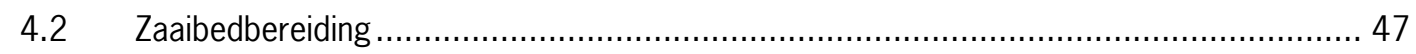

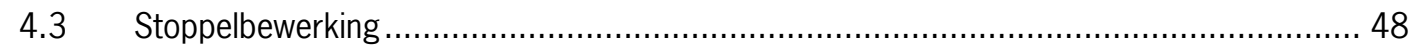

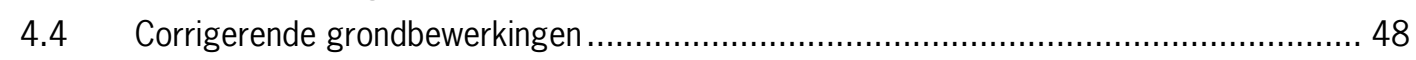

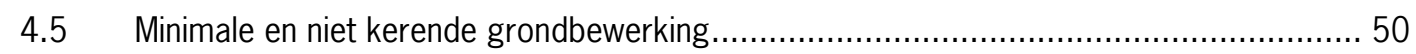

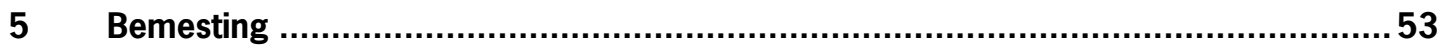

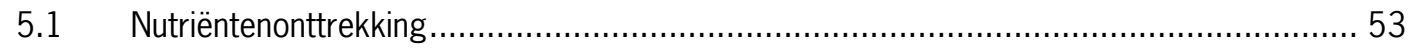

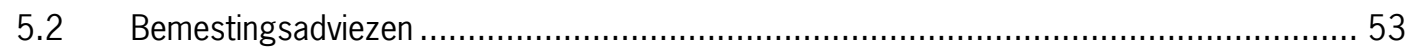

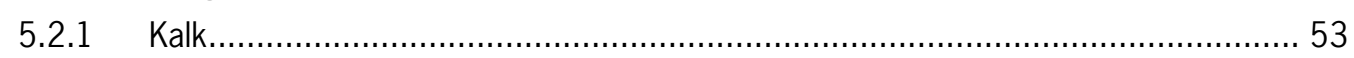

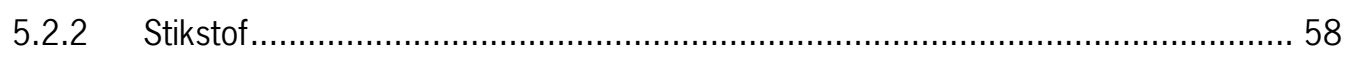

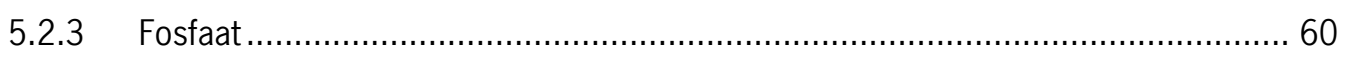

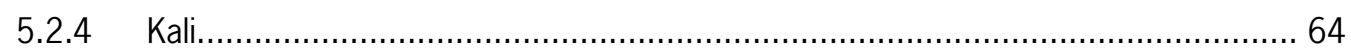

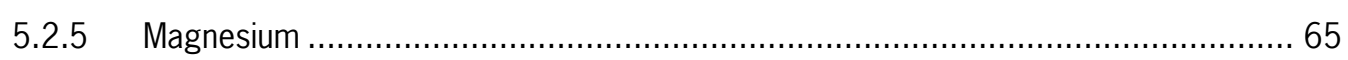

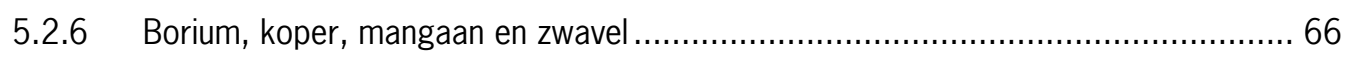




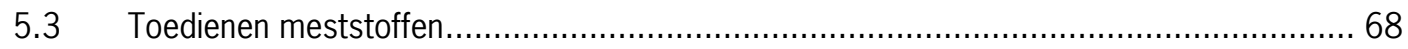

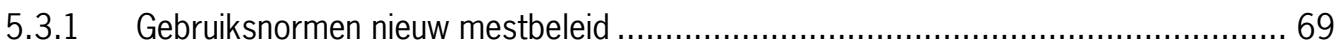

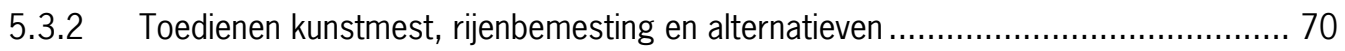

5.3.3 Dierlijke mest aanwenden ........................................................................... 72

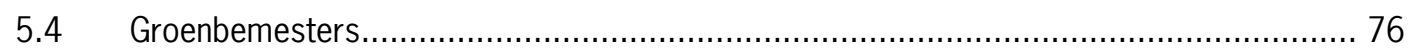

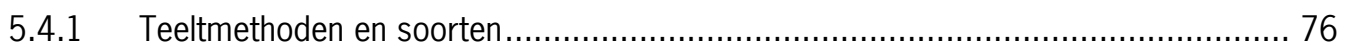

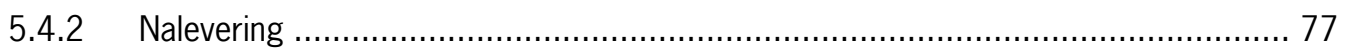

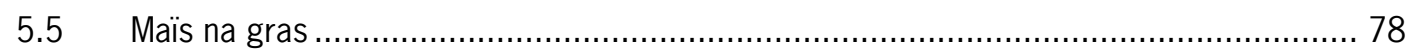

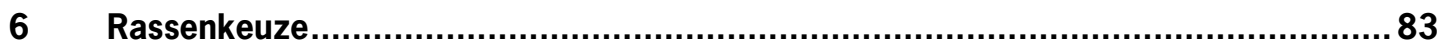

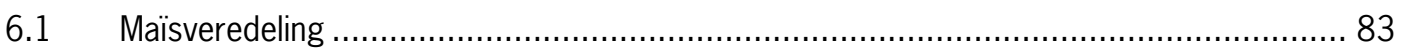

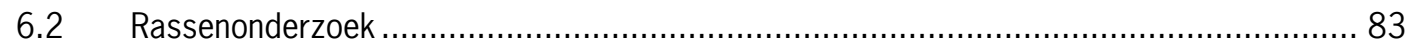

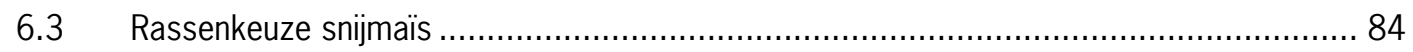

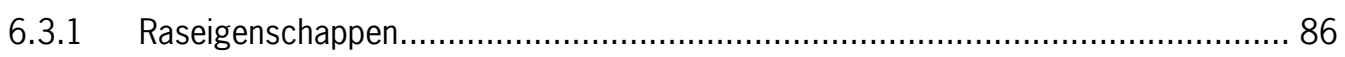

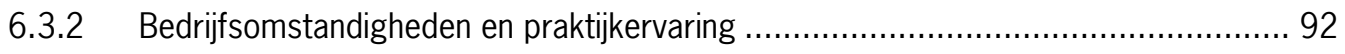

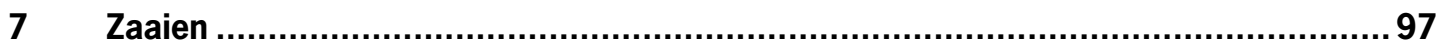

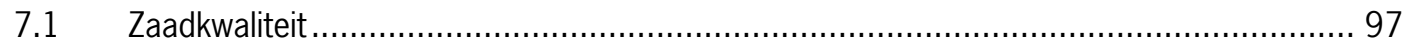

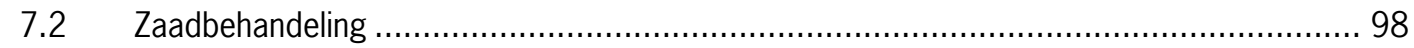

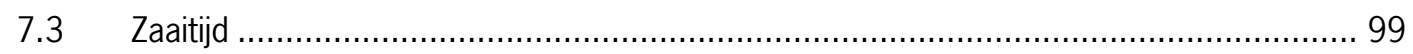

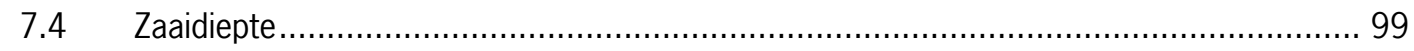

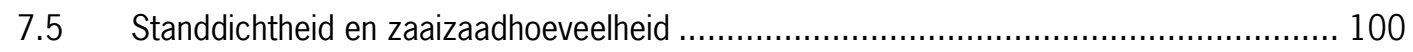

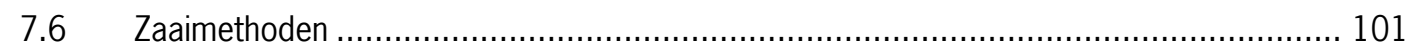

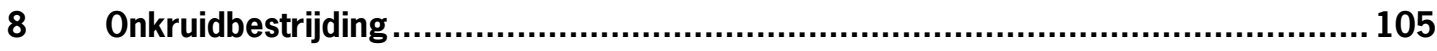

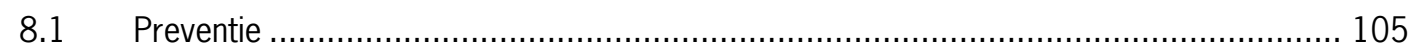

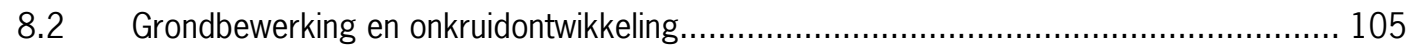

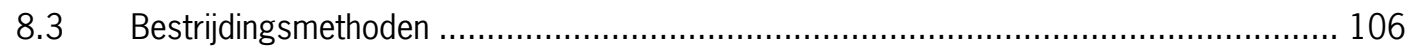

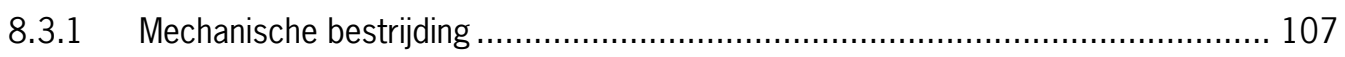

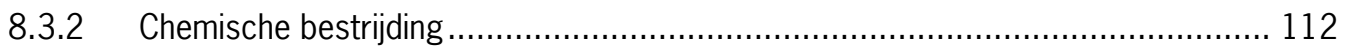

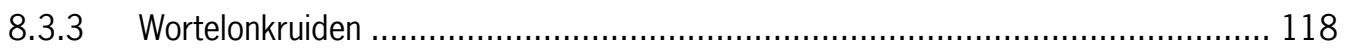

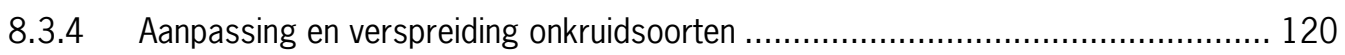

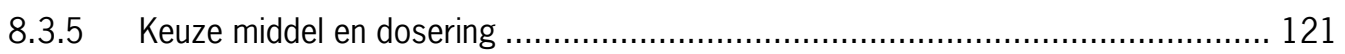

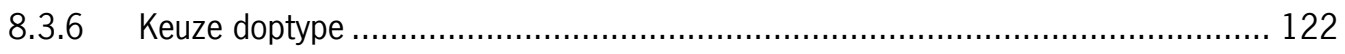

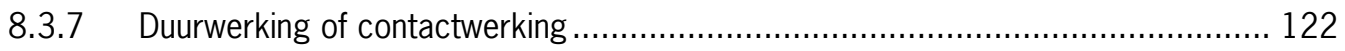

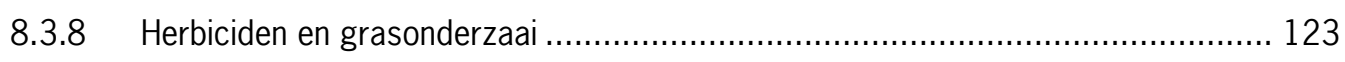

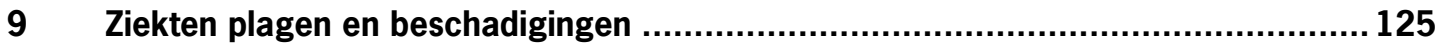

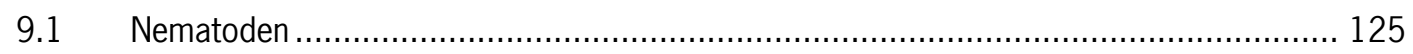

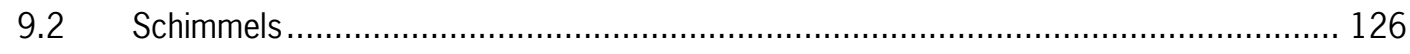

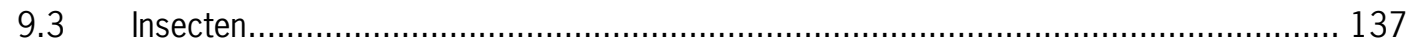

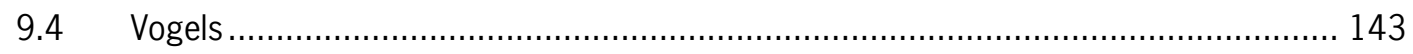




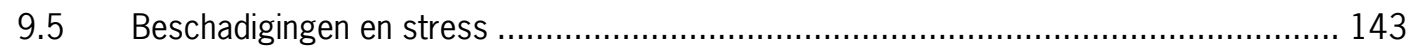

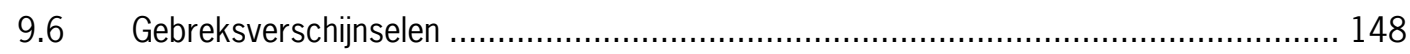

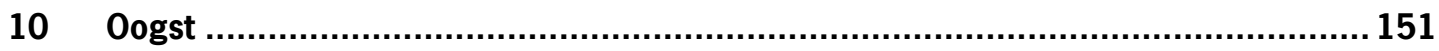

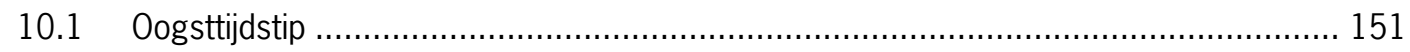

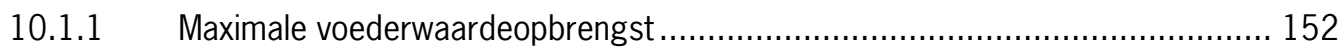

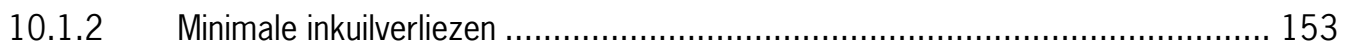

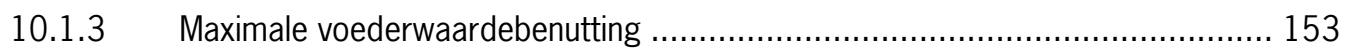

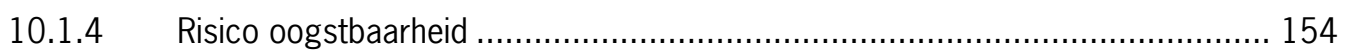

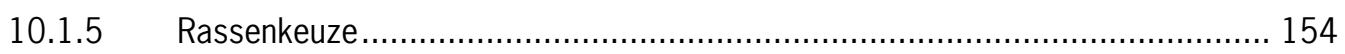

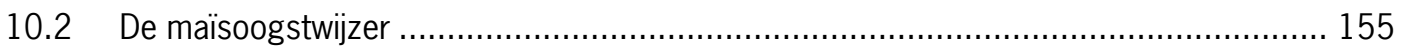

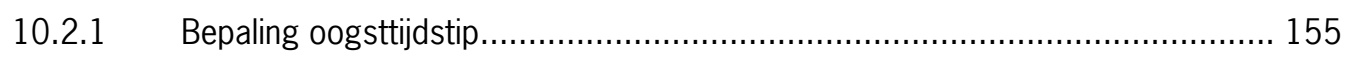

10.2.2 Inschatting drogestofgehalte van snijmaïs ................................................ 158

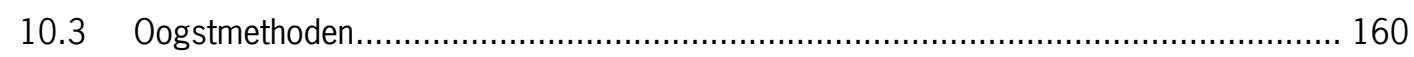

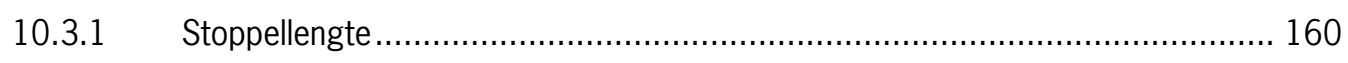

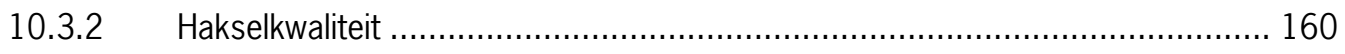

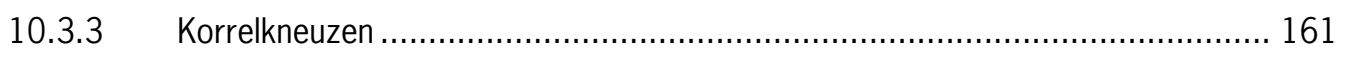

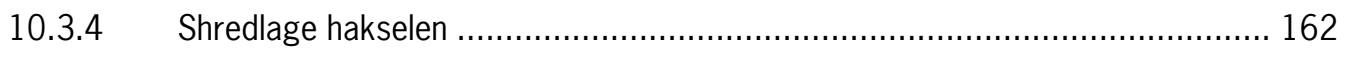

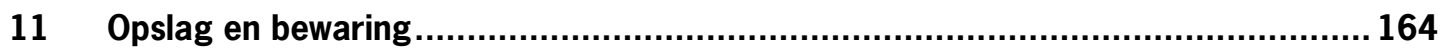

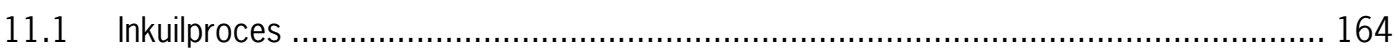

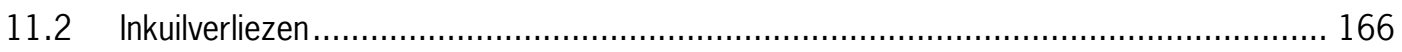

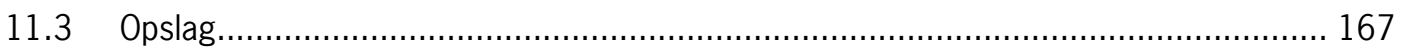

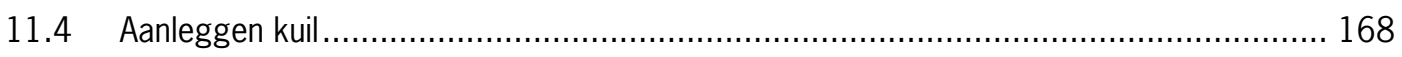

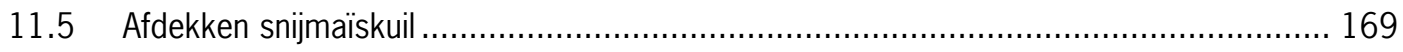

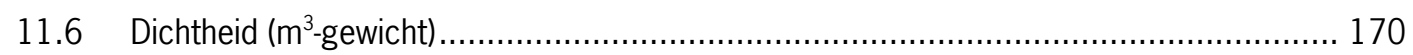

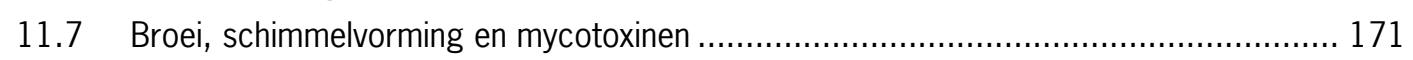

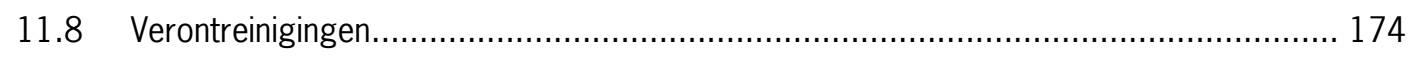

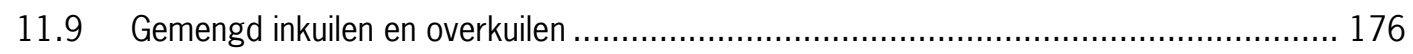

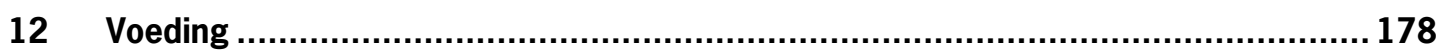

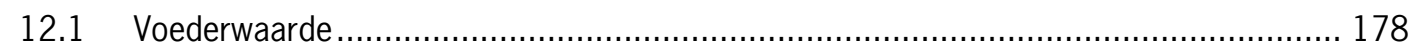

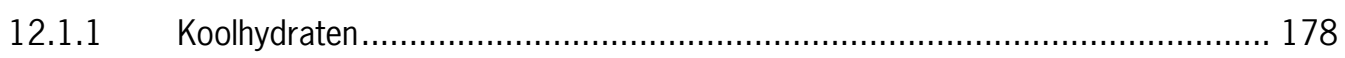

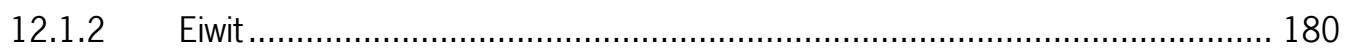

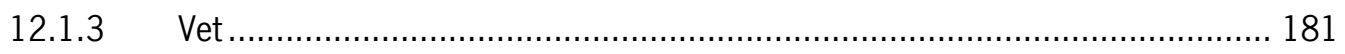

12.1.4 Mineralen, sporenelementen en vitaminen ............................................... 181

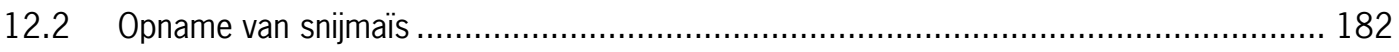

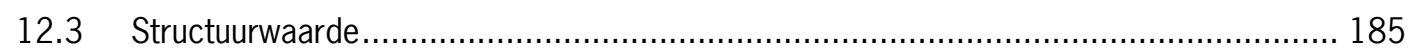

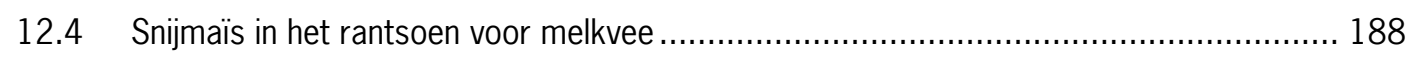

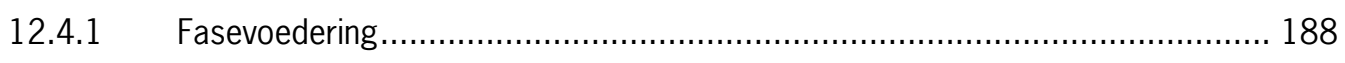

12.4.2 Uitsluitend snijmaïs als ruwvoer ............................................................. 190 
12.4.3 Snijmaïsbijvoeding tijdens weideperiode .............................................. 191

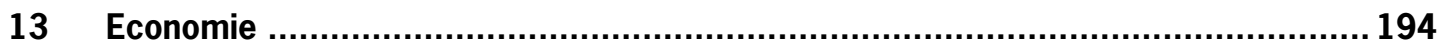

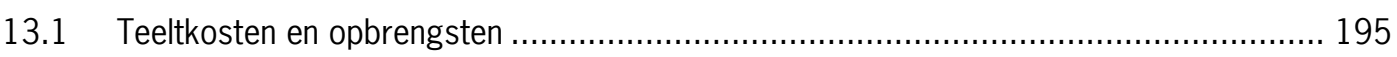

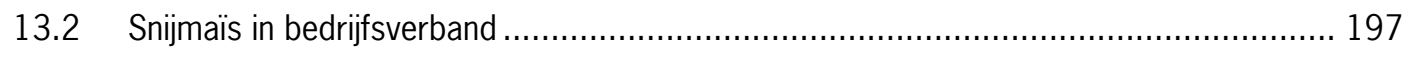

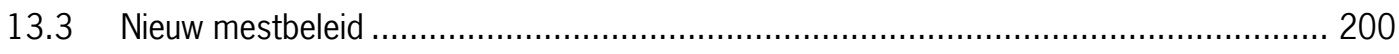

13.4 Aankoop en verkoop snijmaïs in melkveehouderij................................................... 201 


\section{$1 \quad$ Inleiding}

1.1 Herkomst en introductie maïs ...... 8

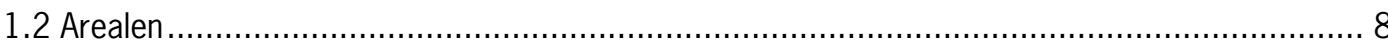

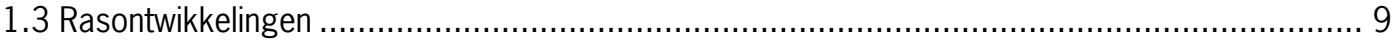

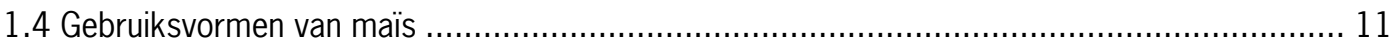




\section{Inleiding}

Na gras is snijmaïs het belangrijkste gewas voor de melkveehouderij. Een optimale teelt en benutting van dit gewas zijn daarmee van belang voor het rendement van de sector. Een actueel en compleet overzicht van de nieuwste informatie kan daar een belangrijke bijdrage aan leveren. De nieuwe informatie en ontwikkelingen over teelt en gebruik van maïs komen vaak nogal versnipperd en soms beperkt bij de melkveehouders. Dit heeft tot gevolg dat het lastig is voor de gebruiker om de juiste informatie te vinden. Dit handboek beschrijft de actuele stand van zaken over teelt, oogst, voeding en economie van snijmaïs. Jaarlijks wordt het handboek geactualiseerd met de nieuwste informatie.

\subsection{Herkomst en introductie maïs}

De maïsplant komt oorspronkelijk uit Midden-Amerika. Na de ontdekking van Centraal-Amerika in 1492 door Columbus is het gewas verspreid naar andere werelddelen als Europa, Azië en Afrika. Maïs wordt in Nederland geteeld vanaf de jaren dertig. Het ging toen met name om korrelmaïs op gemengde bedrijven. Tot midden jaren vijftig nam het areaal toe tot 15.000 ha. Door de ongunstige afrijpingsomstandigheden en marktontwikkelingen nam het areaal korrelmaïs eind jaren vijftig snel af. Vanaf dat moment steeg de belangstelling voor maïs in de vorm van snijmaïs. Er kwamen betere rassen en de teelt- en oogsttechniek werden geoptimaliseerd. Op de zandgronden kwam snijmaïs in de plaats van voederbieten en rogge. Momenteel is snijmaïs na gras verreweg het grootste voedergewas.

\subsection{Arealen}

In figuur 1.1 is de ontwikkeling van het snijmaïsareaal weergegeven. Vanaf 1970 is het areaal sterk uitgebreid tot rond de 200.000 ha eind jaren tachtig. Begin jaren negentig steeg het areaal nog wat verder tot 220-230.000 ha.

Voor het succes van het gewas zijn een aantal oorzaken aan te wijzen. Snijmaïs is een vrij gemakkelijk te telen ruwvoergewas met een goede productie van hoge, constante kwaliteit. De hoge VEM-waarde van het product heeft een positief effect op de melkproductie. Door de hoge energie/eiwit-verhouding past het goed naast gras en graskuil. Ook de eenvoudig uit te voeren onkruidbestrijding en oogst en de tolerantie tegen hoge mestgiften hebben bijgedragen aan de sterke uitbreiding. Het gewas kan men bovendien op afstand van het bedrijf telen en volledig aan de loonwerker uitbesteden. In 2017 werd ruim 60\% van de snijmaïs geteeld op de zandgronden van Overijssel, Gelderland en Noord-Brabant. Door de ontwikkeling van vroegere rassen teelt men ook in noordelijke gebieden steeds meer maïs. De afgelopen 15 jaar is het areaal in de provincies Groningen, Friesland en Noord Holland verdubbeld naar circa 35.000 ha. 
Figuur 1.1 Verloop snijmaïsareaal in Nederland

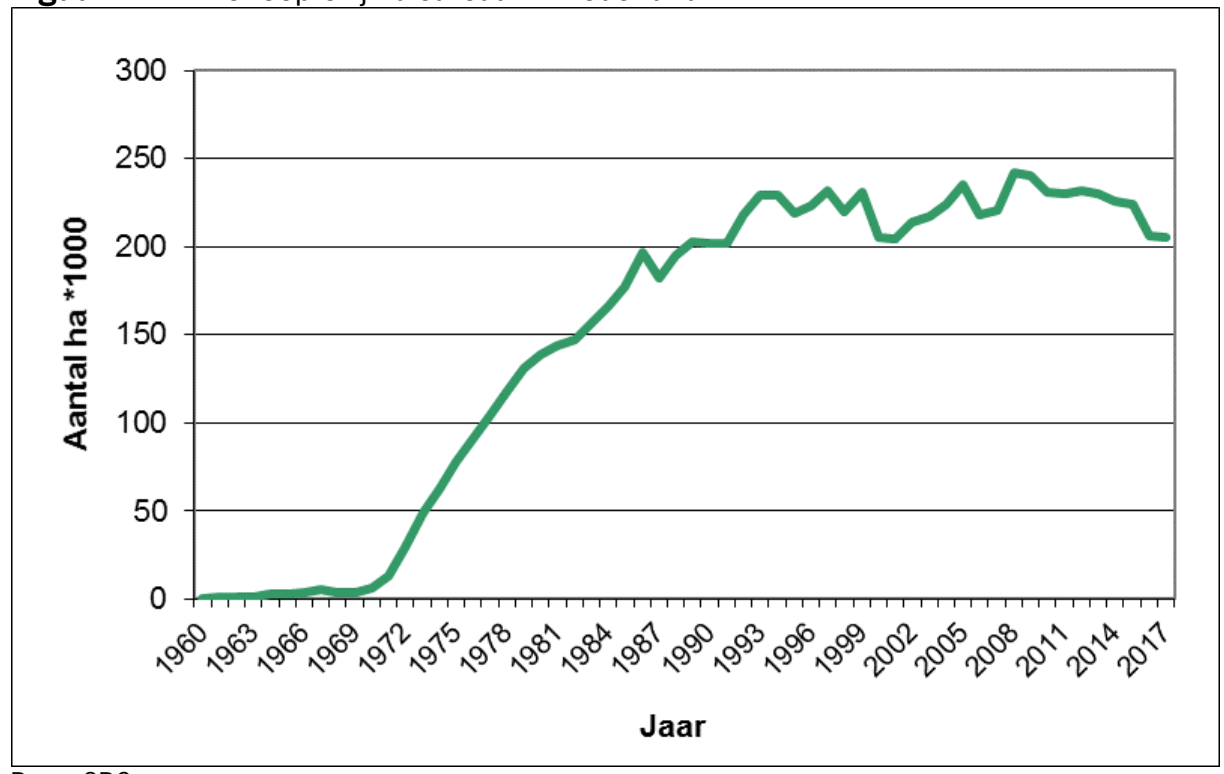

Bron: CBS

\subsection{Rasontwikkelingen}

Door de jaren heen is de rassenkeuze en daarmee de veredeling in het algemeen gericht geweest op bedriifszekere rassen. In de zeventiger jaren werden vooral laatrijpe snijmaïsrassen met een hoge opbrengst geteeld. Het drogestofgehalte van deze rassen was bij de oogst meestal vrij laag (23-28\%). Om inkuilverliezen te beperken waren daarom vroegere rassen gewenst. Begin jaren 80 was de rassenkeuze dan ook meer gericht op vroegheid en opbrengst. De zeer vroege rassen bereiken momenteel zonder enig probleem een drogestofgehalte van 32-35\%. Met deze rassen is nu maïsteelt in het noorden en westen van Nederland mogelijk en in het zuiden is de maïs daarmee eventueel 3 weken eerder te oogsten.

Met de komst van de melkquotering (1986) werd de kwaliteit van ruwvoer belangrijker en kwam de nadruk bij de rassenkeuze wat meer te liggen op de voederwaarde en kolfaandeel. In de periode 1985 tot 1992 is de voederwaarde (VEM/kgds) door betere rassen toegenomen met 6\% (figuur 1.2 ) en is het niveau van 1972 weer bereikt. Deze verbetering werd met name gerealiseerd door kortere rassen te kweken met een hoger kolfaandeel (zetmeelgehalte). Vanaf 1992 tot 2017 is de voederwaarde vervolgens in totaal met $9 \%$ toegenomen. Een verbetering die zowel door een hoger zetmeelgehalte, maar de laatste 15 jaar met name ook door een hogere celwandverteerbaarheid is gerealiseerd. In 1985 lag het gemiddelde niveau rond 875 VEM/kgds, in 2017 lag het niveau rond de $1008 \mathrm{VEM} / \mathrm{kgds}$. 
Figuur 1.2 Ontwikkeling van de VEM-waarde in de drogestof van 1972 - 2016. Per jaar is de gemiddelde waarde van de $\mathrm{A}$ - en $\mathrm{N}$-standaardrassen als relatieve waarde opgenomen, waarbij 1972 op 100 is gesteld

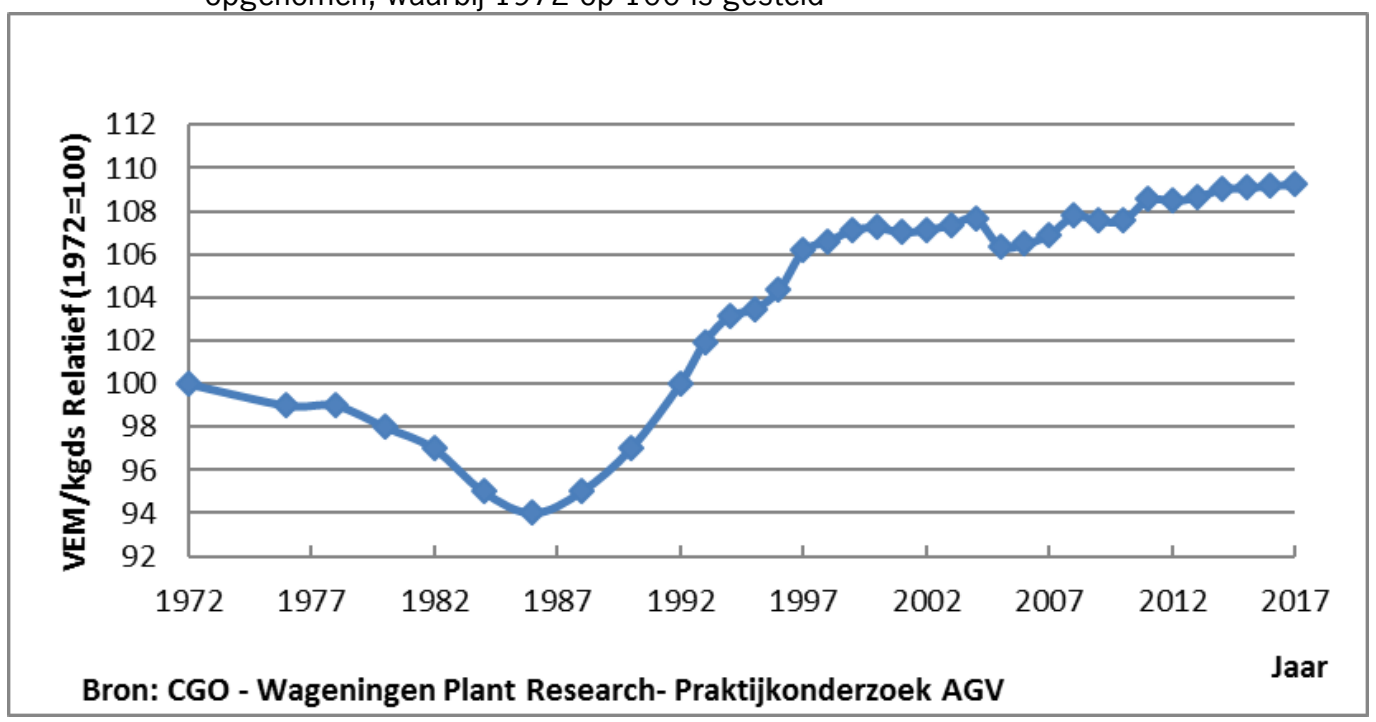

De vooruitgang in vroegheid, drogestofopbrengst, VEM/kgds en VEM-opbrengst in de periode 1992 tot en met 2017 is weergegeven in figuur 1.3. Wat opvalt is de enorme vooruitgang in VEMopbrengst. In 25 jaar is de VEM-opbrengst met $52 \%$ toegenomen. Dat betekent een gemiddelde vooruitgang van bijna $1,8 \%$ per jaar. Deze vooruitgang is vooral gerealiseerd door een hogere drogestofopbrengst van ruim 39\% (1,4\% per jaar). Daarnaast is VEM/kgds in die zelfde periode gestegen met $9 \%$, of te wel bijna $0,4 \%$ per jaar.

Figuur 1.3 Relatieve ontwikkeling van de vroegheid (ds\%), drogestofopbrengst, voederwaarde (VEM/kgds) en VEM-opbrengst. Per jaar is de gemiddelde waarde van de A- en Nstandaardrassen als relatieve waarde opgenomen, waarbij 1992 op 100 is gesteld

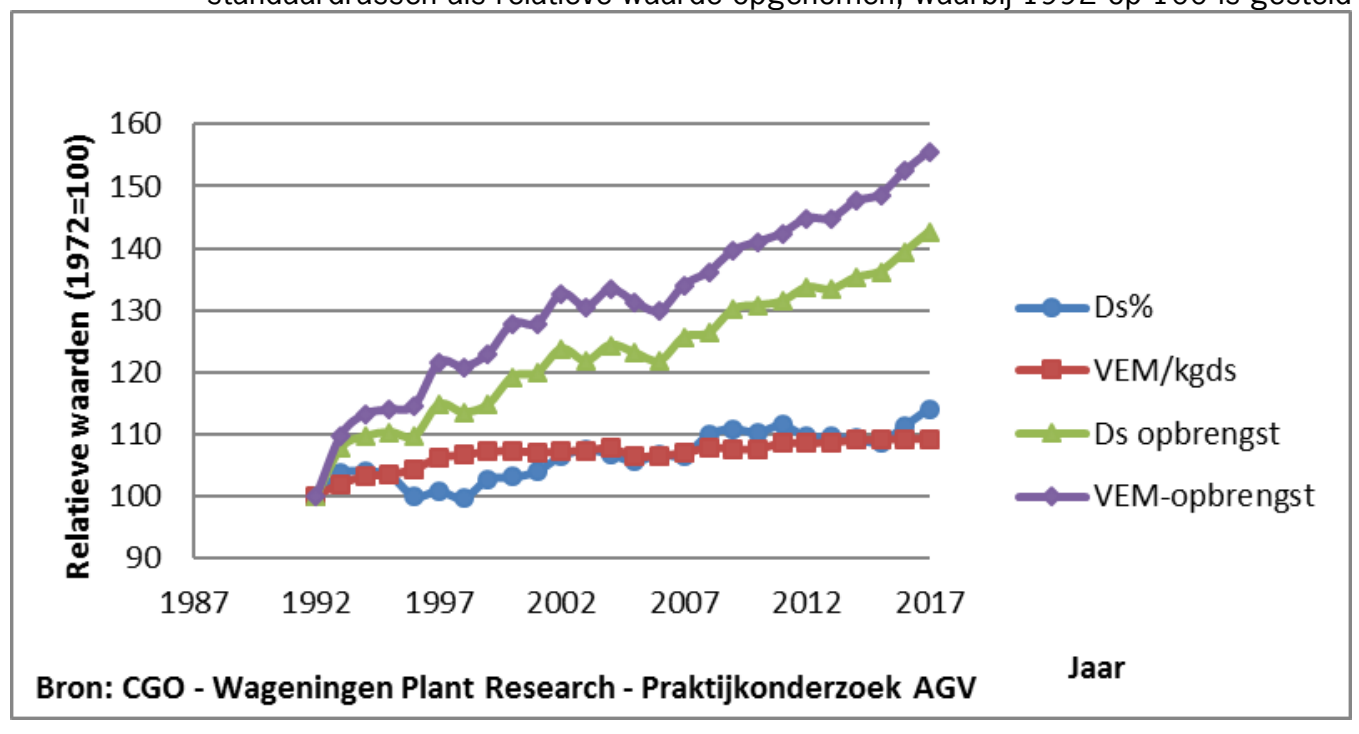


Momenteel is er in Nederland een sortiment aan middenvroege tot zeer vroege rassen beschikbaar. Maïstelers van Noord tot Zuid kunnen met deze range in vroegheid goed uit de voeten. In Noord Nederland is de laatste jaren, door koude en natte omstandigheden, daarnaast wat meer behoefte aan ultra vroege snijmaisrassen. Het gemiddelde sortiment op de Aanbevelende Rassenlijst is de laatste 20 jaar 10\% vroeger geworden. De verhoging vanaf 2006 wordt veroorzaakt doordat men mais nu het liefst oogst rond 35-36\% drogestof, terwijl het daarvoor meer gericht was op $32 \%$.

Hét veredelingsdoel voor de eerstkomende jaren is het produceren van hoog opbrengende rassen met stabilisatie van voederwaarde en goede resistentie en/of tolerantie tegen maiskopbrand en bladvlekkenziekten. Door de opheffing van de melkquotering in 2015 kon de melkproductie per bedrijf weer verhoogd worden. Melkveehouders zijn meer vee gaan houden en hadden dus meer ruwvoer nodig. Ook $80 \%$ gras, die aan de derogatie is gekoppeld heeft de focus op drogestofopbrengst en daaraan gerelateerd VEM-opbrengst verschoven. De focus op VEM/kgds (verteerbaarheid) was wat afgenomen, hoewel een daling van de VEM/kgds niet te verwachten is. Veel melk uit eigen ruwvoer produceren blijtt noodzakelijk, waardoor kwaliteitsruwvoer vereist is en blijt. Zeker nu de fosfaatrechten in beeld komen, is blijft een hoge voerefficiëntie essentieel. Verder zal i.v.m. op peil houden van het organische stofgehalte van de bodem de teelt van een goed geslaagde groenbemester steeds belangrijker worden. Een tijdige oogst rond half september is hiervoor vereist. Dat mogelijk ook als wettelijk verplicht zal worden ingevoerd. Belangrijk hiervoor is de keuze van een voldoende vroeg maisras of onderzaai van groenbemesters.

\subsection{Gebruiksvormen van maïs}

In Nederland wordt maïs verreweg het meest geteeld in de vorm van snijmaïs. Afhankelijk van de situatie teelt men maïs voor andere doelen. Hoewel dit handboek zich beperkt tot de teelt en het gebruik van snijmaïs worden hieronder kort de andere gebruiksvormen beschreven.

\section{Korrelmaïs}

Bij korrelmaïs gaat het om de droge korrel. Het gewas wordt gedorst en het stro blijt achter op het land. In ongunstige jaren moet men de korrels aanzienlijk drogen (tot $16 \%$ vocht), wat flinke kosten met zich meebrengt. De korrel wordt op dit moment vooral verwerkt in pluimveevoeders.

\section{Corn cob mix (CCM)}

Bij CCM wordt de korrel met een deel van de spil geoogst. Het geoogste product wordt vervolgens gemalen en ingekuild. CCM gebruikt men als krachtvoer en kan naar gelang het aandeel spil worden gevoerd aan zowel varkens ( $25-50 \%$ spil) als rundvee (100\% spil). De mengvoerindustrie gebruikt CCM ook wel als grondstof voor varkensvoer en met name voor biggen.

Maïskolvensilage (MKS)

MKS is het gehakselde product van de gehele kolf inclusief de binnenste schutbladeren, de kolfsteel en in sommige gevallen nog wat blad. Het product wordt ingekuild en gebruikt als krachtvoer voor rundvee. 


\section{Suikermaïs}

De kolven van deze maïssoort hebben een hoger suikergehalte omdat de inhoud van het zaad gedeeltelijk blijft bestaan uit suikers. Men oogst de kolven vroegtijdig en eet ze als groente. Het gewas wordt in Nederland op beperkte schaal geteeld.

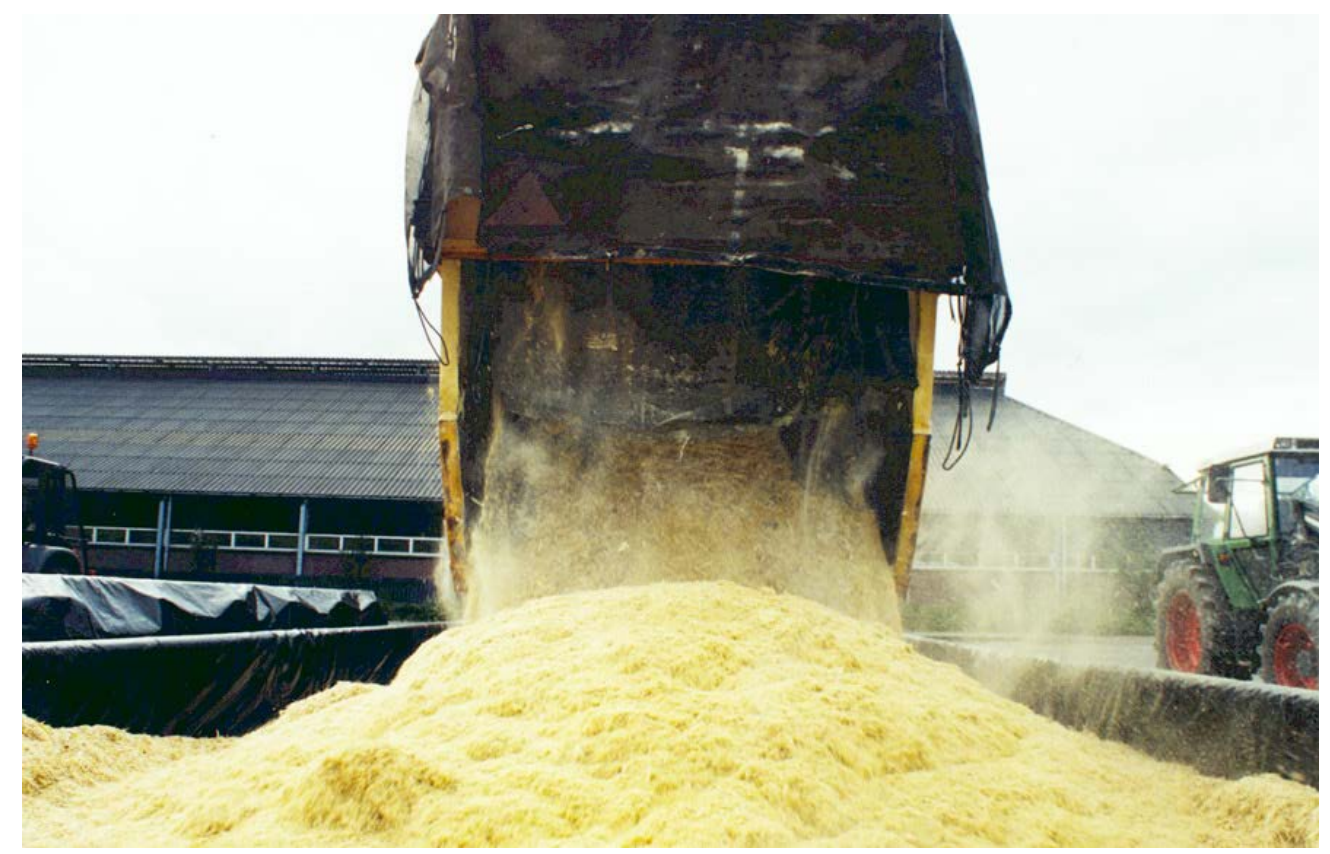

Mais geoogst als MKS 


\section{Het gewas (fysiologie)}

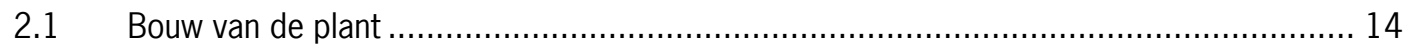

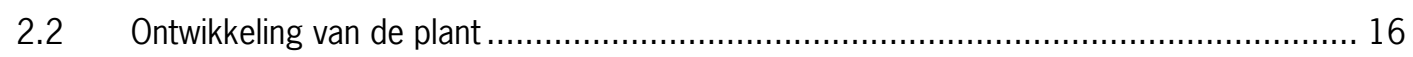

2.3 Beïnloeding op ontwikkeling, productie en kwaliteit................................................. 25

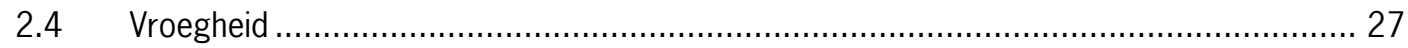

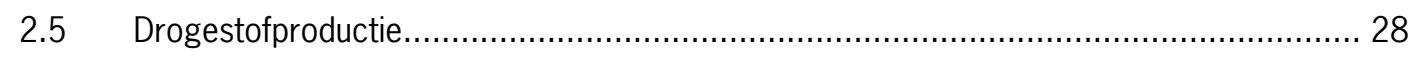

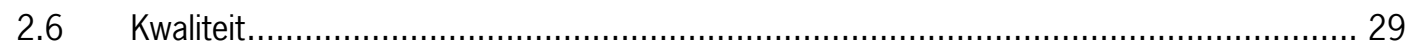




\section{Het gewas (fysiologie)}

Maïs (Zea mays L.) behoort tot de familie van de Gramineeën of Grasachtigen. Van oorsprong is maïs een subtropisch gewas. In onderstaande paragrafen wordt beschreven hoe de plant is opgebouwd en hoe de fysiologische ontwikkeling verloopt onder Nederlandse omstandigheden.

\subsection{Bouw van de plant}

De maïsplant bestaat bovengronds uit een vegetatief gedeelte, de stengel en de bladeren, en een generatief gedeelte, de kolf en de pluim. Ondergronds vormt de plant een uitgebreid wortelstelsel. In deze paragraaf worden genoemde delen kort beschreven.

\section{Stengel en bladeren}

De maïsplant bestaat na opkomst eerst alleen uit bladeren. Het eerst gevormde blad heeft een ovaalvormige bladschijf. De schijven van de volgende bladeren zijn lijnvormig.

Vanaf het 4-5 bladstadium begint de stengelgroei. De stengel is onderverdeeld in 15-16 stengelleden. De bladeren staan ingeplant op de knopen van de stengel. De bladeren met de grootste oppervlakte bevinden zich ter hoogte van de bovenste kolf. De lengte van de stengel kan variëren van 1 tot 4 meter. In een normaal gewas ontstaan er vrijwel geen zijstengels. Alleen bij zeer lage standdichtheden en aan de randen van het perceel kan dit wel optreden. Het ene ras vormt sneller zijstengels dan het andere ras.

Figuur 2.1 Schematische weergave van pluim (A en B) en kolf (C)

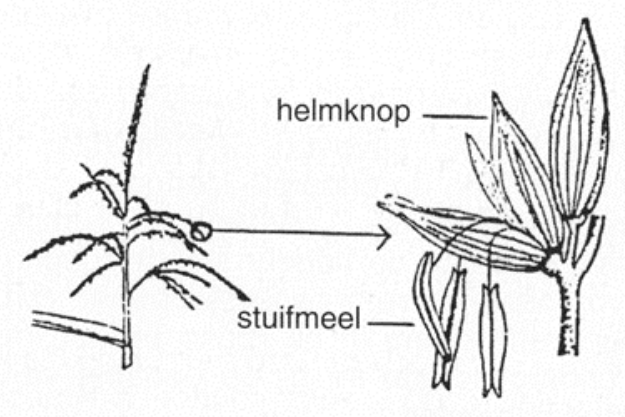

A
B

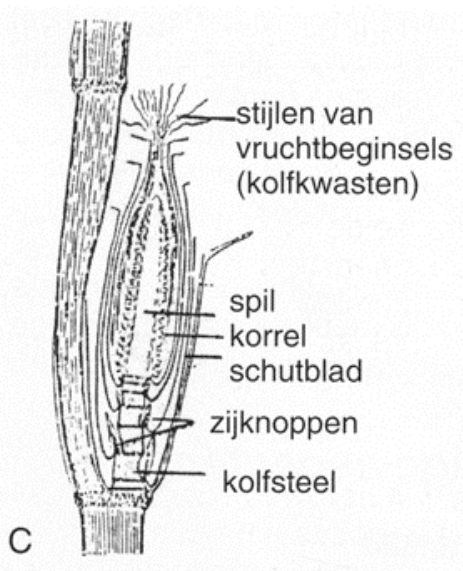

\section{Kolf en pluim}

Maïs is een eenslachtige en eenhuizige plant. Dat wil zeggen dat mannelijke en vrouwelijke bloemen van elkaar gescheiden zijn, maar wel op één plant aanwezig zijn. De mannelijke bloeiwijze, de pluim, verschijnt aan de top van de stengel terwijl de vrouwelijke bloeiwijze, de kolf, in de bladoksels wordt aangelegd. De pluim heeft een aantal horizontaal uitstaande zijtakken waarop zich de helmknoppen bevinden (figuur 2.1). In de helmknoppen bevindt zich het stuifmeel. 


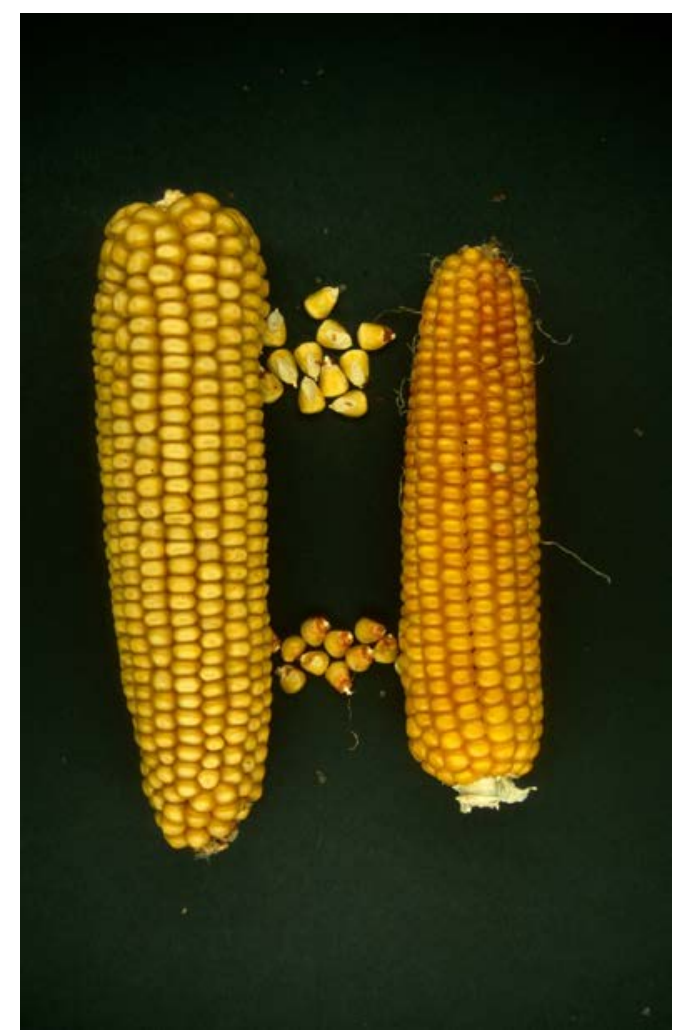

Dent- (links) en flintmaïs (rechts)

De kolf bevindt zich op een korte steel en bestaat uit een spil die bezet is met een even aantal rijen vruchtbeginsels waaruit later de korrels groeien. De kolf is omgeven door schutbladeren. Bij de bloei groeien de stijlen vanuit de vruchtbeginsels naar buiten toe. Dit is zichtbaar aan het verschijnen van de kolfkwasten. In een normaal gewas ontwikkelt zich in het algemeen één vruchtbare kolf per plant. Alleen in zeer open gewassen en in randrijen kunnen zich meerdere kolven ontwikkelen.

\section{Wortels}

Maïs vormt slechts één kiemwortel waaraan zijwortels worden gevormd. Spoedig daarna verschijnen aan de onderste stengelknopen de eerste kroonwortels. De later gevormde kroonwortels aan de hogere stengelknopen zijn voornamelijk verantwoordelijk voor een stevige verankering in de grond en spelen een ondergeschikte rol bij de opname van vocht en nutriënten.

\section{Korrel}

Een maïskorrel bestaat uit een kiem en endosperm (reservevoedsel) dat veelal in de vorm van zetmeel aanwezig is. Kiem en endosperm zijn omgeven door een zaadhuid. Naar vorm kunnen we twee soorten korrels onderscheiden: dents en flints. Dent-types zijn langgerekter en platter. Tijdens de afrijping ontstaan indeukingen in de top van de korrel (zie bovenstaande foto). Flint-types zijn ronder en vormen geen indeukingen tijdens de afrijping. Flints zijn in het algemeen minder koudegevoelig en vertonen een sterkere beginontwikkeling dan dents. Dents bloeien in het algemeen wat later dan flints, maar rijpen sneller af. De in Nederland geteelde rassen zijn overwegend combinaties van dent- en flintlijnen. 


\subsection{Ontwikkeling van de plant}

De ontwikkeling van de maïsplant kunnen we in verschillende stadia onderscheiden. De belangrijkste stadia zijn kieming, vegetatieve ontwikkeling, bloei, korrelvulling en afrijping. Deze stadia kunnen weer worden opgedeeld. Een beschrijving van de verschillende stadia tot en met de bloei staat in tabel 2.1.

Tabel 2.1 De ontwikkeling van maïs $\mathrm{t} / \mathrm{m}$ de bloei, uitgaande van een zaaitijdstip van 1 mei

\begin{tabular}{|c|c|c|}
\hline Stadium* & Datum (circa) ** & Gewashoogte (circa) * * $^{*}$ \\
\hline \multicolumn{3}{|l|}{ Kieming } \\
\hline Droog zaad & $1 \mathrm{mei}$ & \\
\hline \multicolumn{3}{|l|}{ Opzwellen zaad } \\
\hline \multicolumn{3}{|l|}{ Verschijnen kiemwortel } \\
\hline \multicolumn{3}{|l|}{ Verschijnen kiemschede uit zaad } \\
\hline \multicolumn{3}{|l|}{ Opkomst en kiemplantfase } \\
\hline \multicolumn{3}{|l|}{ Kiemschede boven de grond } \\
\hline $1^{\mathrm{e}}$ bladstadium & & \\
\hline $2^{\mathrm{e}}$ bladstadium & 20 mei & $15-20 \mathrm{~cm}$ \\
\hline \multicolumn{3}{|l|}{$3^{\mathrm{e}}$ bladstadium } \\
\hline \multicolumn{3}{|l|}{ Stengelstrekking } \\
\hline $4^{\mathrm{e}}$ bladstadium & 7 juni & $30-40 \mathrm{~cm}$ \\
\hline $5^{\mathrm{e}}$ bladstadium & & \\
\hline $6^{\mathrm{e}}$ bladstadium & 20 juni & $50-75 \mathrm{~cm}$ \\
\hline \multicolumn{3}{|l|}{$7^{\mathrm{e}}$ bladstadium } \\
\hline $8^{\mathrm{e}}$ bladstadium & 1 juli & $100-120 \mathrm{~cm}$ \\
\hline $9^{\text {e }}$ bladstadium & & \\
\hline $10^{\mathrm{e}}$ bladstadium & 15 juli & $170-200 \mathrm{~cm}$ \\
\hline $11 \mathrm{e}$ bladstadium & & \\
\hline \multicolumn{3}{|l|}{$12^{\mathrm{e}}$ bladstadium } \\
\hline $13^{\mathrm{e}}$ bladstadium (of hoger) & 20 juli & $220-240 \mathrm{~cm}$ \\
\hline \multicolumn{3}{|l|}{ Bloei } \\
\hline \multicolumn{3}{|l|}{ Begin mannelijke bloei } \\
\hline $50 \%$ mannelijke bloei & 20 juli & \\
\hline $50 \%$ vrouwelijk bloei & 25 juli & \\
\hline Einde bloei & 5 aug & $260-280 \mathrm{~cm}$ \\
\hline
\end{tabular}


Hieronder staan een aantal afbeeldingen van de verschillende groeistadia.

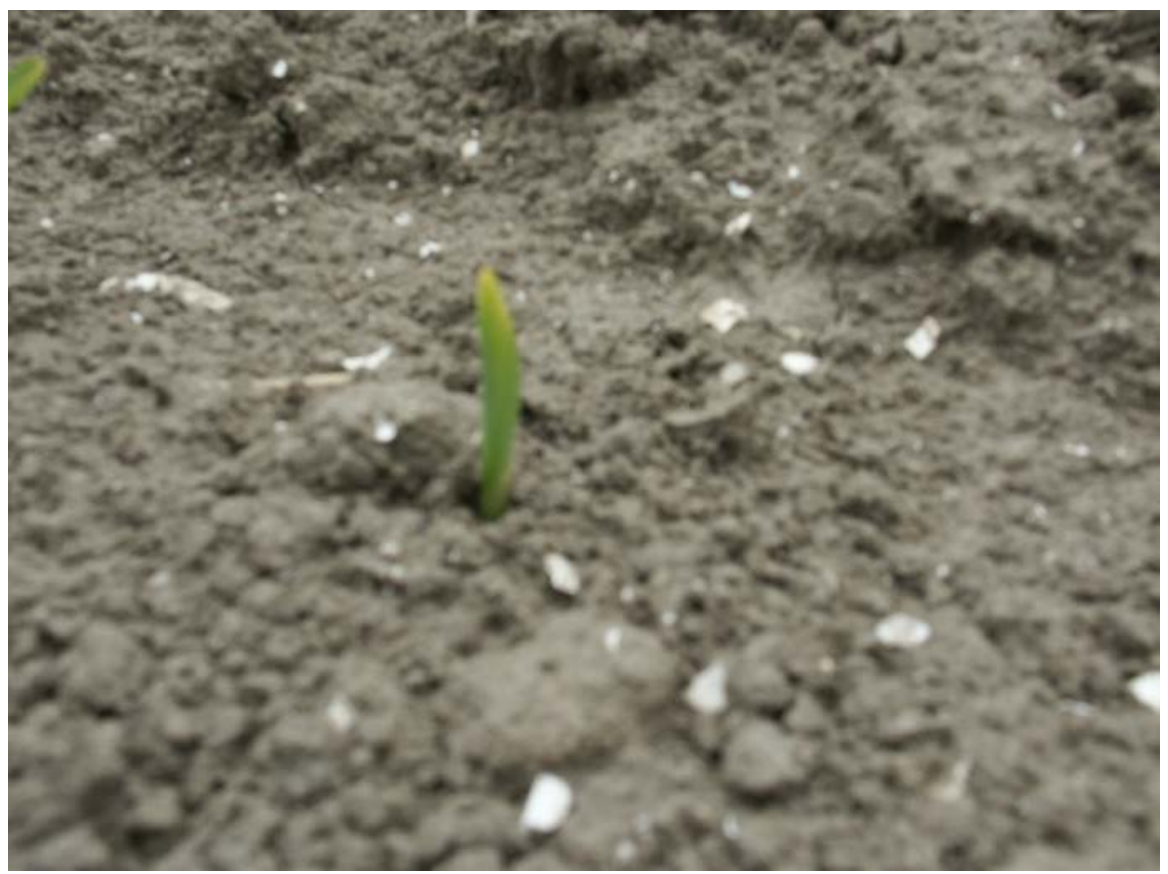

Spijkerstadium

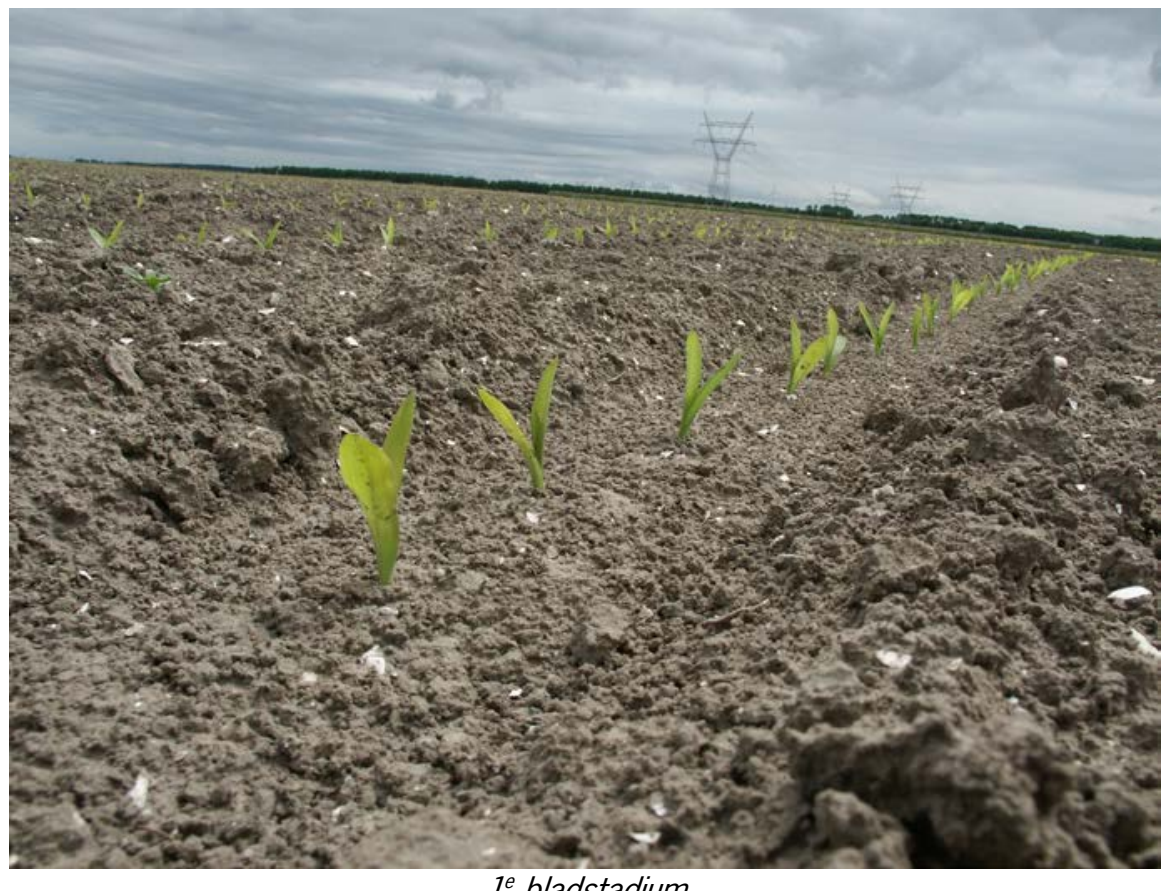

$1^{e}$ bladstadium 

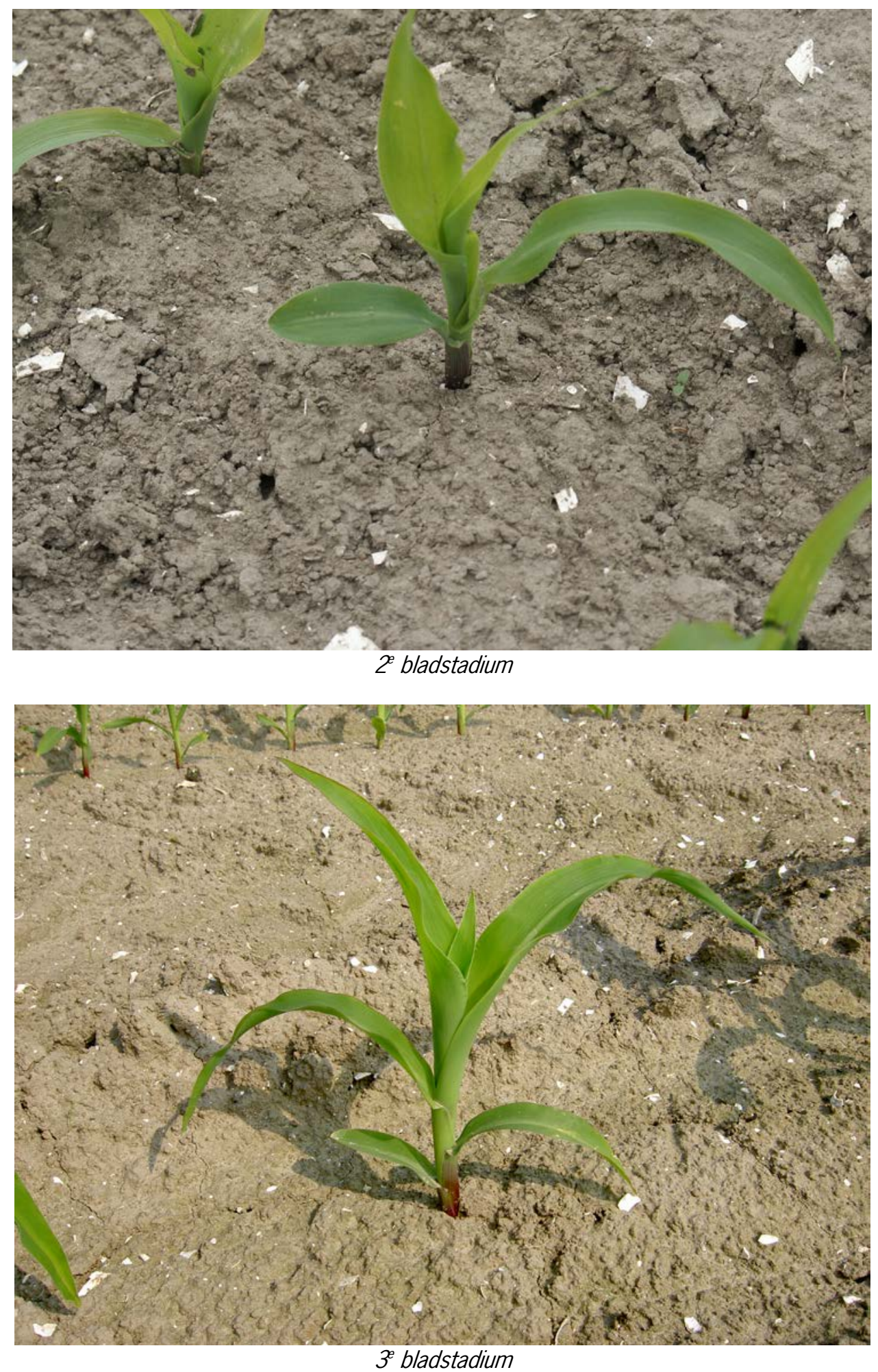

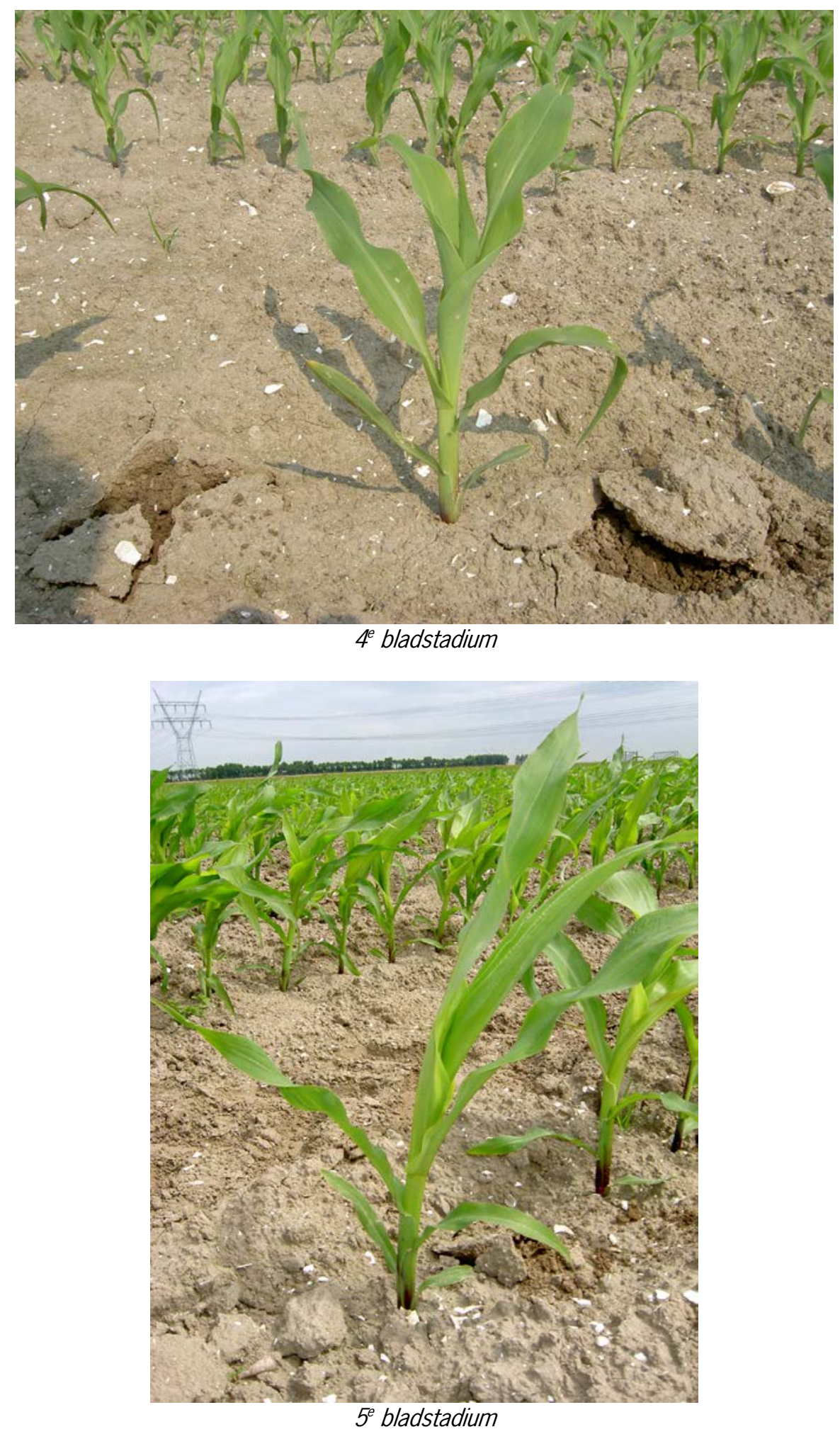

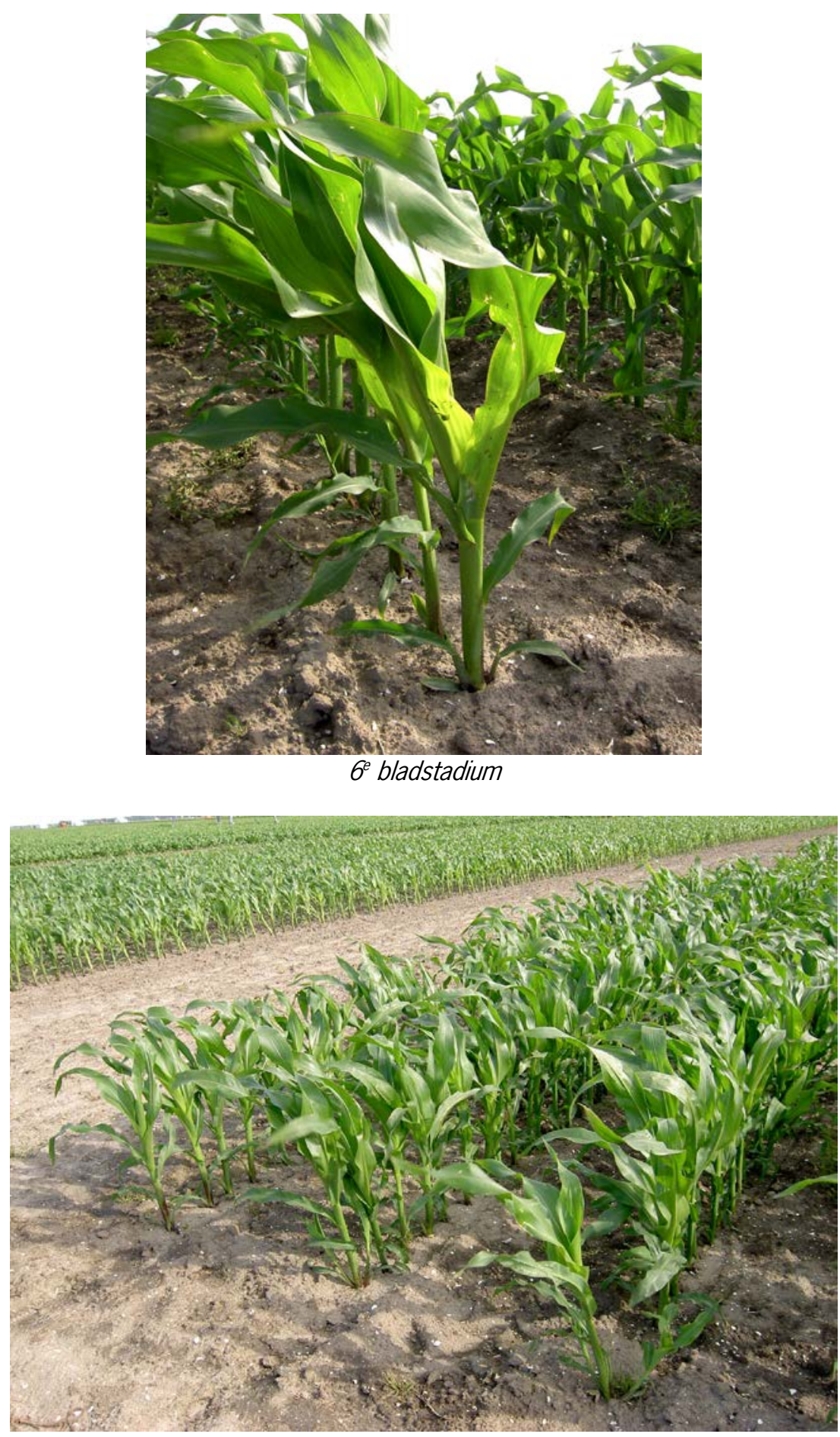

$\sigma^{e}$ bladstadium gewas 

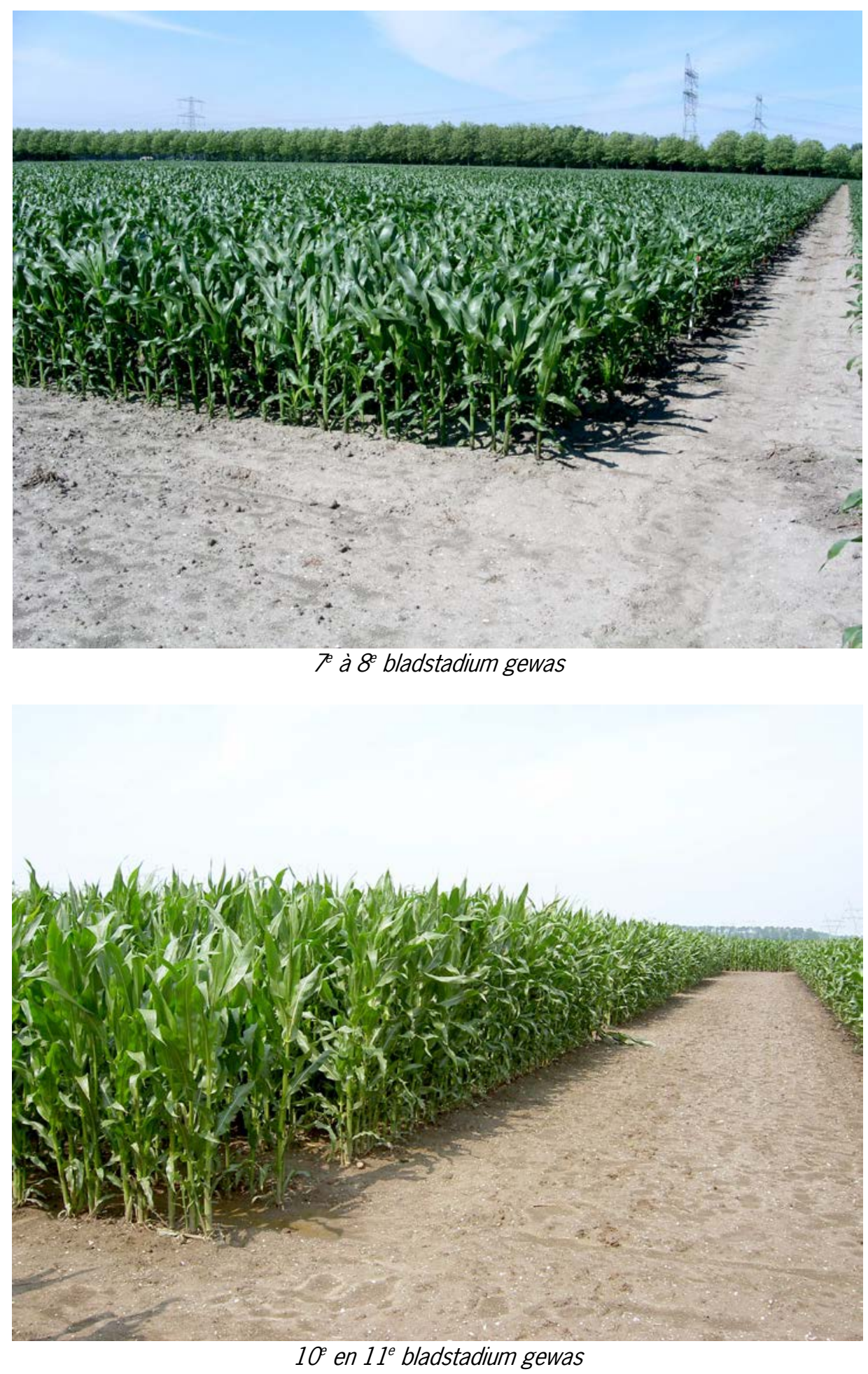

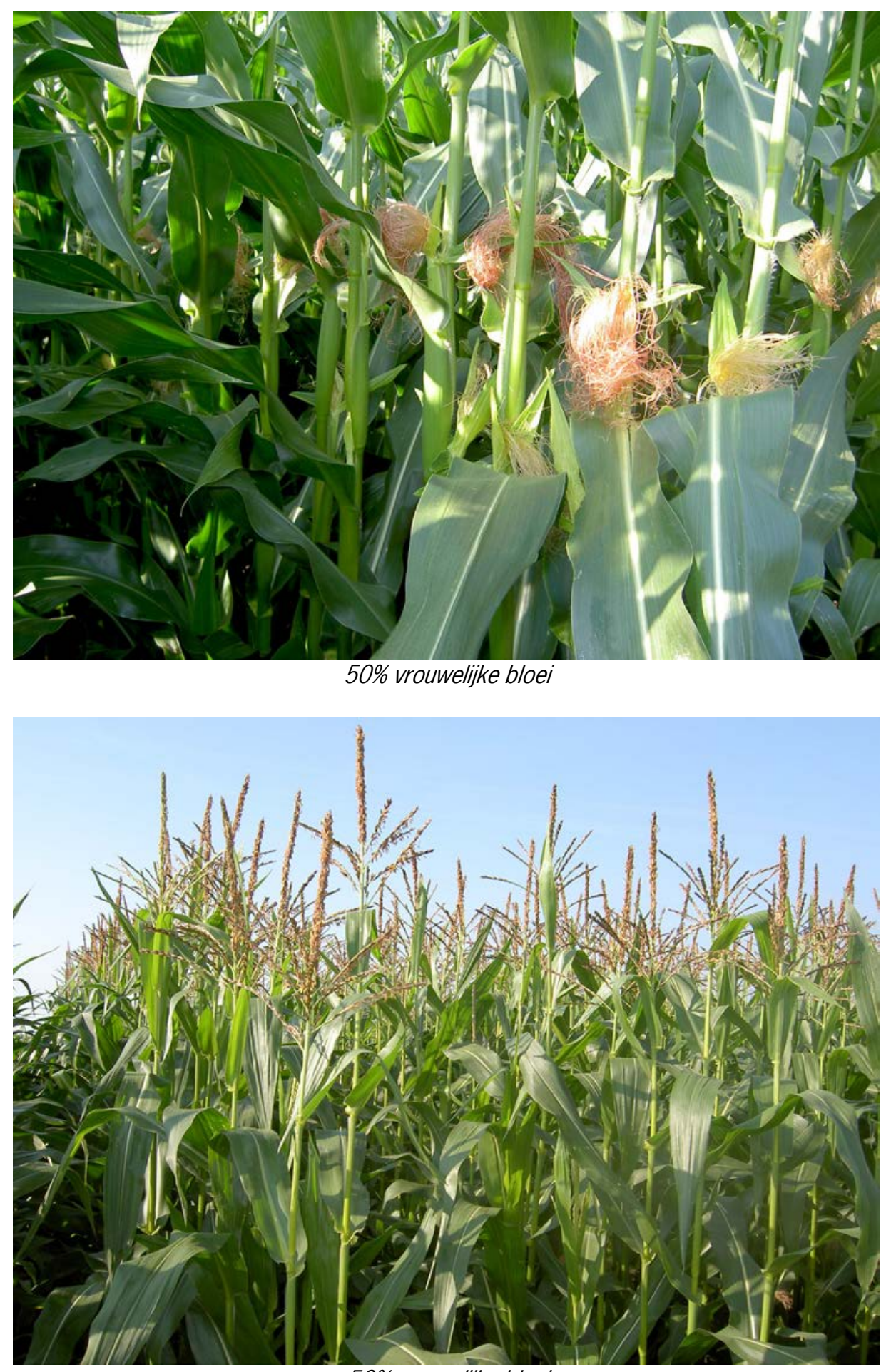

50\% mannelijke bloei 


\begin{abstract}
Kieming
Maïszaad kiemt bij een minimum bodemtemperatuur van 8-10 ${ }^{\circ} \mathrm{C}$. Gemiddeld bereikt de bodem op zaaidiepte (circa $5 \mathrm{~cm}$ ) deze temperatuur tussen 20 en 30 april. De kieming verloopt het snelst bij 30$32{ }^{\circ} \mathrm{C}$. Naast een voldoende hoge temperatuur moeten ook de water- en zuurstofvoorziening van het zaad voldoende zijn. Bij de kieming verschijnt eerst één kiemwortel die recht naar beneden groeit. Kort daarna verschijnt de kiemschede waarin zich het groeipunt bevindt. Afhankelijk van temperatuur en zaaidiepte verlopen tussen zaai en opkomst gemiddeld 1 tot 3 weken.
\end{abstract}

\title{
Blad- en stengelontwikkeling
}

De bladeren verschijnen in een regelmatig tempo. Gemiddeld verschijnt elke 6 dagen een nieuw blad. Het totaal aantal bladeren bedraagt bij de Nederlandse rassen 15-16. Het groeipunt bevindt zich tot aan het vierde à vijfde bladstadium onder de grond. Door het achterwege blijven van stengelstrekking in deze fase ontstaat een knopenstapel. Na dit stadium komt het groeipunt omhoog door de vorming van een stengel onder het groeipunt. De stengelstrekking gaat door tot na de bloei.

Uitgaande van een zaaitijdstip van eind april sluit het gewas zich in een gemiddeld jaar omstreeks eind juni. De maximale bladoppervlakte wordt omstreeks de bloei bereikt. Zowel het tijdstip van sluiting van het gewas als de maximale bladoppervlakte zijn afhankelijk van zaaitijdstip, jaar, ras en grondsoort.

\section{Wortelontwikkeling}

Tot circa 3 weken na zaaien is het wortelstelsel beperkt tot een kiemwortel en drie tot vier kroonwortels. Daarna ontstaan, tot aan de bloei, telkens nieuwe kransen bijwortels op iedere knoop. De bewortelingsdiepte hangt sterk af van bodem- en weersomstandigheden. Ongeveer 6 weken na zaai bedraagt de bewortelingsdiepte circa $40 \mathrm{~cm}$. Bij koud en nat weer kan dit aanmerkelijk minder zijn. Daarna kan in een ongestoord profiel de beworteling in potentie een diepte bereiken van circa $120 \mathrm{~cm}$. Vlak voor de bloei wordt de maximale bewortelingsdiepte bereikt. Na de bloei worden er vrijwel geen wortels meer gevormd en sterven er per saldo meer oude wortels af dan er nieuwe bijkomen. In het algemeen blijkt dat circa $90 \%$ van de wortels zich in de bovenste helft van de bewortelde laag $(0-40 \mathrm{~cm})$ bevindt.

De groeirichting van de wortels hangt af van de temperatuur. Bij lage temperaturen is de beworteling meer horizontaal gericht, terwijl bij hogere temperaturen de beworteling meer de diepte ingaat. Ook bij een vochttekort na opkomst zoeken de wortels meer de diepte op. In het algemeen duurt het 5 tot 7 weken voordat men wortels aantreft midden tussen de maïsrijen.

\section{Bloei}

De bloei is de overgang van de vegetatieve naar de generatieve ontwikkeling. Vanaf dat moment is alle activiteit van de plant gericht op de ontwikkeling van de kolf. De mannelijke (pluim) en de vrouwelijk bloeiwijze (kolf) worden reeds aangelegd in het 4-5 bladstadium. De mannelijke bloei is herkenbaar aan het zichtbaar worden van de meeldraden op de pluim. De vrouwelijke bloei is herkenbaar aan het tevoorschijn komen van de kolfkwasten. In het algemeen toont de mannelijke bloei een geringe voorsprong in tijd op de vrouwelijke bloei. Dit beperkt de kans op zelfbestuiving en bevordert kruisbestuiving. Kort na de bloei sterft de pluim af. In een gemiddeld jaar zal, uitgaande van een zaaitijdstip van eind april, de vrouwelijke bloei omstreeks 20 juli plaatsvinden (circa 7 weken na zaai). Het tijdstip van bloei is sterk rasafhankelijk. Daarnaast spelen groeiomstandigheden, met name temperatuur, een belangrijke rol. Tijdens en vlak na de bloei is het gewas erg gevoelig voor stressfactoren, wat een slechte korrelzetting door abortie van vruchtbeginsels tot gevolg kan hebben. De meest voorkomende stressfactor in deze periode is vochttekort. Daarnaast zijn ook temperatuur, lichtintensiteit en beschikbaarheid van borium van invloed op de bevruchting. 


\section{Korrelvulling en afrijping}

Tijdens de korrelvulling vindt er herverdeling plaats van suikers en nutriënten uit met name de stengel naar de kolf toe. Tegelijkertijd verouderen de vegetatieve delen. De veroudering is echter veel minder uitgesproken dan bij andere zaadgewassen als granen en peulvruchten. Bij de afrijping van de korrel kunnen de volgende zeven stadia worden onderscheiden:

1. Waterrijp:

2. Begin melkrijp:

korrelkleur wit, waterig, zoete inhoud; drogestofgehalte kolf $25 \%$

3. Melkrijp: kleur roomwit, iets geel, inhoud iets melkachtig; drogestofgehalte kolf $30 \%$

4. Zachtdeegrijp: kleur geel, veel spanning in de korrel, de inhoud lijkt op melk; drogestofgehalte kolf $35 \%$

5. Deegrijp: kleur donkerder geel, de korrel spat nog bij stukknijpen, stevigheid en kleurintensiteit beginnen van de top af; drogestofgehalte kolf $40 \%$

6. Harddeegrijp: kleur donker, inhoud al stevig maar aan de spilzijde nog vochtig; drogestofgehalte kolf $50 \%$ inhoud stevig, moeilijk met de nagel te breken en er komt geen vocht meer uit, de bovenkant is al glazig of hoornig of begint in te deuken; drogestofgehalte kolf $55 \%$

7. Volledig rijp: harde korrel, niet meer met de nagel te breken, de glazige gedeelten hard als hoorn (fysiologisch rijp); drogestofgehalte kolf $60 \%$

Bij een drogestofgehalte van 60 tot $65 \%$ in de kolf is deze fysiologisch rijp. Dit stadium wordt gemarkeerd door de vorming van een bruin gekleurd laagje cellen op de plaats waar de korrel aan de spil vastzit. Dit laagje verhindert verder transport van suikers en mineralen naar het zaad toe. Het drogestofgehalte van de korrel neemt daarna verder toe door indroging. Dit is in Nederland echter alleen in gunstige jaren het geval. In een gemiddeld jaar bedraagt het drogestofgehalte in een rijpe korrel in Noord- en Zuid-Nederland resp. 60 en 70\%.

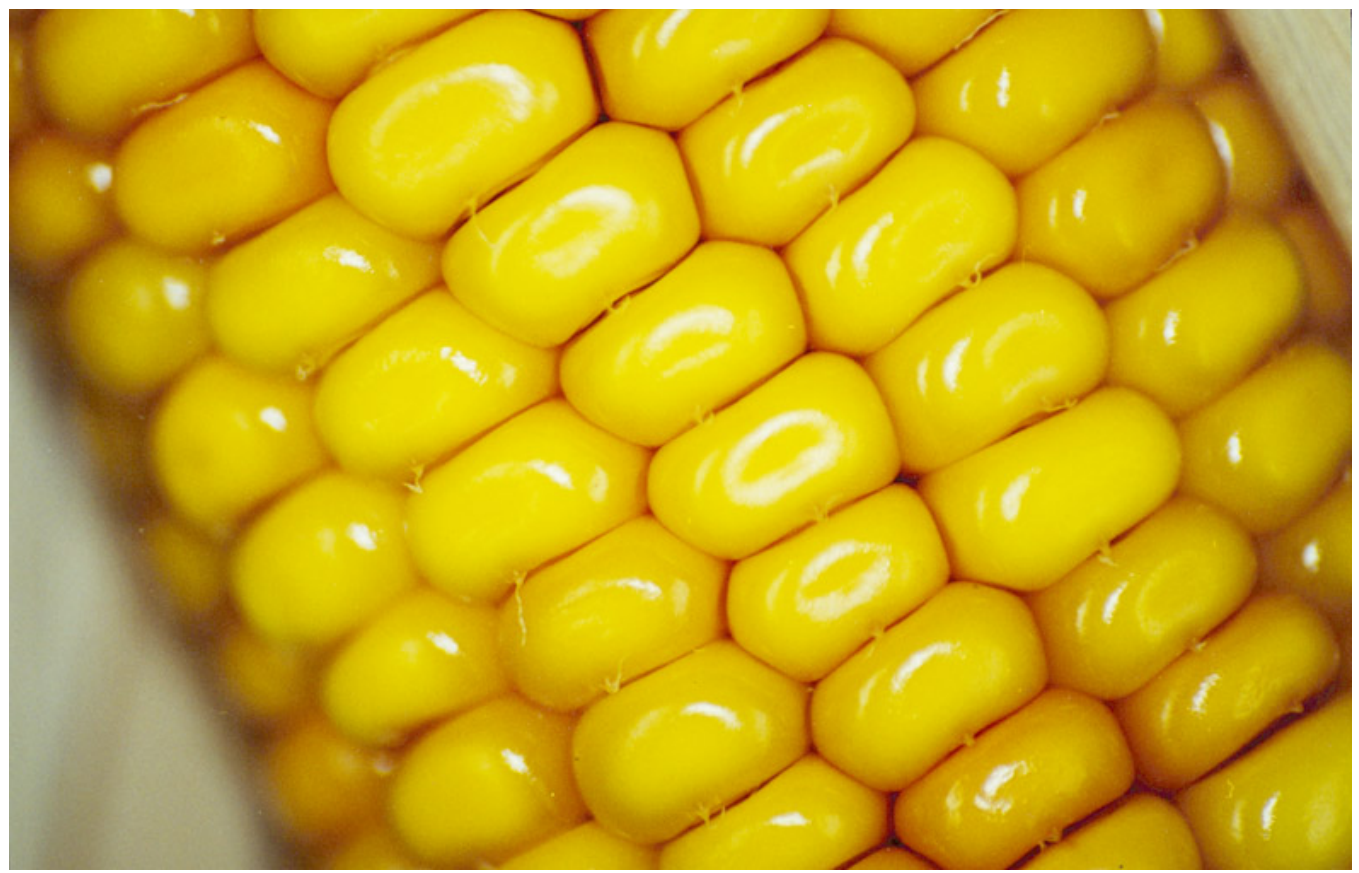

Een goed afgerijpte korrel 


\subsection{Beïnvloeding op ontwikkeling, productie en kwaliteit}

De ontwikkeling, productie en kwaliteit van maïs worden in belangrijke mate bepaald door verschillende omgevingsfactoren. In deze paragraaf worden de factoren daglengte, lichtintensiteit, temperatuur, vochtvoorziening en nutriëntenvoorziening behandeld.

\section{Daglengte en lichtintensiteit}

Maiis is een kortedagplant. Dat betekent dat ze sneller in bloei komt bij kortere dagen. De reactie op de daglengte is rasafhankelijk. Vroegrijpende rassen hebben in het algemeen minder behoefte aan korte dagen dan laatrijpende rassen. Langere dagen in de periode tot aan het 4-5 blad-stadium leiden in het algemeen tot meer bladeren per plant en langere planten. Dit is onder meer het geval bij verlate zaai.

Tijdens het assimilatieproces wordt lichtenergie omgezet in koolhydraten. De totale hoeveelheid licht die de plant in het groeiseizoen opvangt, hangt in sterke mate af van de weersomstandigheden. Door de in vergelijking met andere gewassen relatief late zaai en de trage jeugdontwikkeling laat maïs in de voorzomer veel licht onbenut. Pas eind juni, begin juli is er sprake van een volledige

lichtonderschepping waardoor de potentiële productie van maïs lager is dan van gewassen met een langer groeiseizoen. Maïs is echter een C4-gewas, wat betekent dat het licht ook bij hoge lichtintensiteiten en hoge temperaturen nog efficiënt wordt gebruikt. Bij C3-gewassen als granen en gras treedt onder die omstandigheden lichtverzadiging op.

In het najaar neemt de lichtintensiteit af. Gemiddeld is in Nederland ongeveer 10 oktober de lichtintensiteit dusdanig laag dat er geen extra productie meer plaatsvindt. Ook de verteerbaarheid van de totale plant zal dan niet meer toenemen. Naarmate in het najaar de instraling groter is kan de productie langer doorgaan en zal ook het kolfaandeel hoger zijn. Het zetmeelgehalte en de voederwaarde van de gehele plant zijn dan eveneens hoger.

\section{Temperatuur}

De temperatuur beïnvloedt in sterke mate de ontwikkeling en groei van het gewas. Bij hogere temperaturen zal de maïs sneller kiemen en vroeger bloeien. Een vroeger bloeiend gewas zal ook een hoger kolfaandeel en daarmee een hoger zetmeelgehalte en voederwaarde opleveren. Ook de afrijping verloopt sneller waardoor het drogestofgehalte op een vroeger tijdstip voldoende hoog is om te kunnen oogsten. Bij hoge temperaturen in het najaar gaat het verouderingsproces van de celwanden sneller, zodat de celwandverteerbaarheid dan sneller afneemt. De temperatuur beïnvloedt eveneens de productie. De optimumtemperatuur voor het fotosyntheseproces ligt tussen 25 en 30 ${ }^{\circ} \mathrm{C}$. De minimum en maximum temperatuur bedragen respectievelijk 8 en $40{ }^{\circ} \mathrm{C}$. Bij temperaturen van $15^{\circ} \mathrm{C}$ en lager neemt met name bij jonge maïsplanten de activiteit van groeiprocessen sterk af. Vooral in combinatie met een hoge lichtintensiteit kan een sterke geelverkleuring van het gewas optreden doordat de vorming van bladgroen achterwege blijt. Ook kan als gevolg van fosfaatgebrek de plant paars verkleuren. Bij stijging van de temperatuur is fosfaat weer beter beschikbaar en verdwijnen de verkleuringen. Vaak heeft echter het gewas ook tijd nodig om te herstellen van koudeperiodes. In veel gevallen blijft volledig herstel achterwege waardoor de groeikracht van het gewas afneemt. Tenslotte kan er ook sprake zijn van indirecte schade door lage bodemtemperaturen tijdens de opkomst. De opkomst zal vertraging ondervinden en er is ook kans op een lager plantaantal doordat kiemschimmels bij lage bodemtemperaturen meer kans krijgen om schade te veroorzaken. 


\section{Vochtvoorziening}

Tussen gewasproductie en waterverbruik bestaat een direct verband. De hoeveelheid water die maïs verbruikt per kg geproduceerde drogestof is afhankelijk van de klimatologische omstandigheden. In Nederland heeft maïs een vochtbehoefte van 160 à 190 liter per kg oogstbare drogestof. Dit is laag in vergelijking met verschillende andere voedergewassen (zie tabel 2.2). Echter, er zijn wel belangrijke verschillen tussen de gewassen in tijdstip waarop het gewas veel vocht nodig heeft. Bij maïs is een vochttekort omstreeks de bloei zeer schadelijk. De kans op een vochttekort in juli is relatief groot, zodat de kans op droogteschade bij maïs groter is dan bij de andere voedergewassen. Droogte tijdens de bloei leidt tot een slechte korrelzetting en dus ook tot een laag kolfaandeel en een laag zetmeelgehalte. Bij de bloei is het vochtverbruik maximaal (figuur 2.2). In een gemiddeld groeiseizoen verdampt het gewas circa $280 \mathrm{~mm}$ bij een productie van 16 ton drogestof per ha.

Tabel 2.2 Vochtbehoefte van een aantal voedergewassen

\begin{tabular}{lc}
\hline Gewas & Vochtbehoefte per kg oogstbaar drogestof (liters) \\
\hline Snijmaiis & $160-190$ \\
Triticale (GPS) & $225-240$ \\
Gras (na het inzaaijaar) & $300-400$ \\
Luzerne (na het inzaaijaar) & 400 \\
\hline
\end{tabular}

Op zandgronden waar verreweg de meeste maïs wordt verbouwd, is de productie in het algemeen sterk afhankelijk van de vochtvoorziening gedurende het groeiseizoen. Bij onvoldoende vocht sluit de plant de huidmondjes geheel of gedeeltelijk waardoor de productie en de opname van nutriënten terugloopt. Bij droogte na de bloei zal de korrelvulling minder goed verlopen. Droogte en de daarmee gepaard gaande hogere gewastemperatuur leidt ook tot een versnelde veroudering van de celwanden en daarmee tot een lagere celwandverteerbaarheid. In welke mate de gewasgroei hierdoor wordt beïnvloed hangt af van de bewortelingsdiepte, de hoeveelheid gemakkelijk beschikbaar vocht in het doorwortelde profiel en het verdampingsniveau. 
Figuur 2.2 Vochtverbruik van maïs gedurende het groeiseizoen

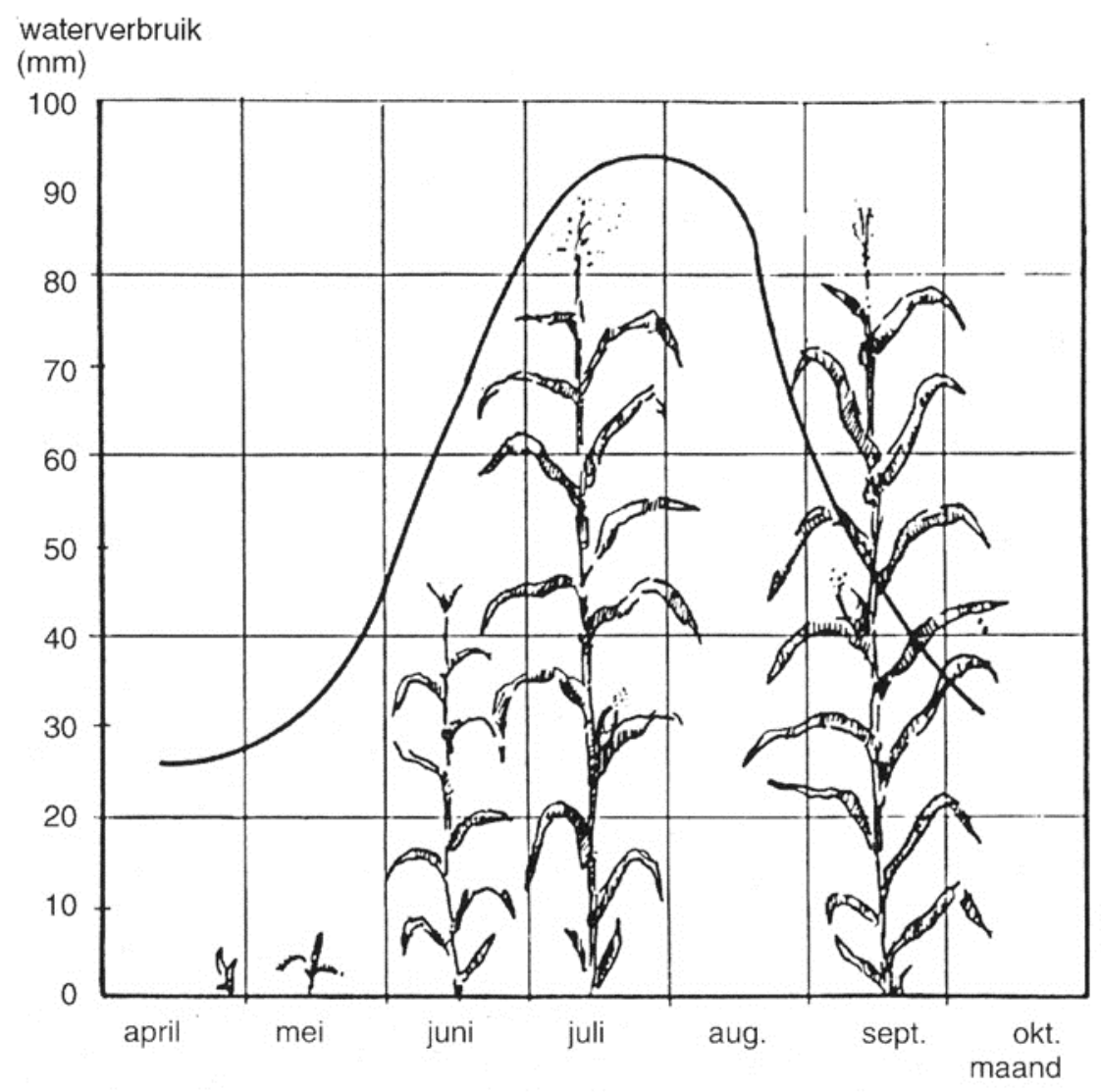

bron: Stiboka

\section{Nutriëntenvoorziening}

Voor een optimale groei van het gewas moet het aanbod de behoefte aan nutriënten dekken. Het grootste deel van de totale hoeveelheid nutriënten wordt voor de bloei opgenomen. Na de bloei vindt herverdeling plaats van stikstof en fosfaat en in veel mindere mate kali van stengel en blad naar de kolf. Hierdoor is bij de oogst het grootste deel van de totale hoeveelheid opgenomen stikstof en fosfaat aanwezig in de kolf, en het grootste deel van de kali in het stro. In het hoofdstuk 5 wordt op de behoefte aan verschillende nutriënten ingegaan.

\subsection{Vroegheid}

Het drogestofgehalte van het gehakselde product is bepalend voor de inkuilverliezen door gisting en/of afvloeien van perssap. Vooral bij drogestofgehalten lager dan $28 \%$ zijn deze verliezen hoog. Het optimale drogestofgehalte bij de oogst bedraagt circa 35\%. Bij hogere drogestofgehalten neemt de kans op broei in de kuil toe door een teveel aan ingesloten lucht. Het drogestofgehalte hangt sterk af van het oogsttijdstip (zie ook hoofdstuk 10), maar ook van het bloeitijdstip, de snelheid van afrijping, het kolfaandeel en de mate van aantasting door stengelrot. De weersomstandigheden spelen hierbij 
een grote rol. Naarmate het groeiseizoen kouder is, zal later een voldoend hoog drogestofgehalte bereikt worden. In het noorden van het land ontwikkelt het maïsgewas zich dan ook langzamer dan in het zuiden. Ook door een te geringe instraling vertraagt de afrijping. Een laag drogestofgehalte kan ook veroorzaakt worden door een late zaaidatum. Een aantasting door stengelrot heeft een versnelde toename van het drogestofgehalte tot gevolg. Er zijn grote verschillen tussen de rassen in vroegheid en in resistentie tegen stengelrot.

\subsection{Drogestofproductie}

Bij snijmaiis wordt de totale bovengrondse drogestofproductie geoogst en ingekuild. Met name in verband met de kwaliteit is naast de totale productie ook de drogestofverdeling over kolf en vegetatieve delen van belang.

\section{Opbrengsten}

In potentie kunnen in Nederland bij snijmaïs bovengrondse producties behaald worden van 20 tot 25 ton drogestof per ha. De werkelijk behaalde opbrengsten bedragen echter 11,5-16,5 ton drogestof per ha. Dat de actuele productie beduidend achterblijtt bij de potentiële productie komt doordat de groeiomstandigheden vaak niet optimaal zijn door minder gunstige weers- (licht, temperatuur en vocht) of bodemomstandigheden (grondsoort en profielopbouw, ontwatering). Ook een minder goede perceelsverzorging (bodemstructuur) en verlate zaai kunnen leiden tot opbrengstdepressies.

Hoewel Nederland maar een klein oppervlak beslaat, treden toch duidelijke regioverschillen op. In het algemeen zijn in Zuid-Nederland door gunstiger klimatologische omstandigheden, met name temperatuur, de opbrengsten hoger dan in Noord-Nederland. Daarnaast spelen ook factoren als vochtvoorziening en grondsoort een belangrijke rol. In droge jaren worden op zwaardere gronden vaak hogere opbrengsten behaald dan op lichtere gronden. In natte jaren is vaak het omgekeerde het geval.

\section{Productiepatroon}

In figuur 2.3 is de drogestofverdeling over de verschillende bovengrondse organen weergegeven tijdens het groeiseizoen. In de eerste 1,5 à 2 maanden wordt vrijwel alle droge stof in het blad geïnvesteerd en daarna tot aan de bloei de meeste droge stof in de stengel. De koolhydraten die niet gebruikt worden voor structuurweefsel worden in de stengel opgeslagen. Na de bloei concentreert de productie zich volledig op de kolf. In deze fase neemt het stengelgewicht veelal af door verplaatsing van suikers naar de kolf. Het aandeel van de kolf in de totale bovengrondse droge stof ligt bij gewassen die niet te lijden hebben gehad van droogte gemiddeld rond de $50-55 \%$ bij de oogst en is sterk afhankelijk van teeltwijze, ras en groeiomstandigheden. Het spilaandeel in de kolf varieert tussen 10 en $18 \%$ (op basis van droge stof) bij gewassen die niet te lijden hebben gehad van droogte en hangt af van ras en teeltomstandigheden. Bij een slechte korrelzetting en -vulling kan het kolfaandeel sterk afnemen en het spilaandeel in de kolf aanzienlijk toenemen (15-25\%).

De ondergrondse productie aan wortels bedraagt 1000 tot $3000 \mathrm{~kg}$ droge stof per ha. Doordat in de loop van het groeiseizoen het accent van de productie steeds sterker op de bovengrondse delen komt te liggen, neemt de spruit/wortelverhouding, de verhouding tussen bovengrondse en ondergrondse productie, toe van circa 2 in de jeugdfase tot soms meer dan 10 tijdens de afrijping. De spruit/wortelverhouding is voorts afhankelijk van temperatuur en bemestingsniveau. Bij hoge temperaturen en een ruim bemestingsniveau neemt deze toe. 
Figuur 2.3 Patroon van de drogestofverdeling over de bovengrondse delen van maïs gedurende het groeiseizoen

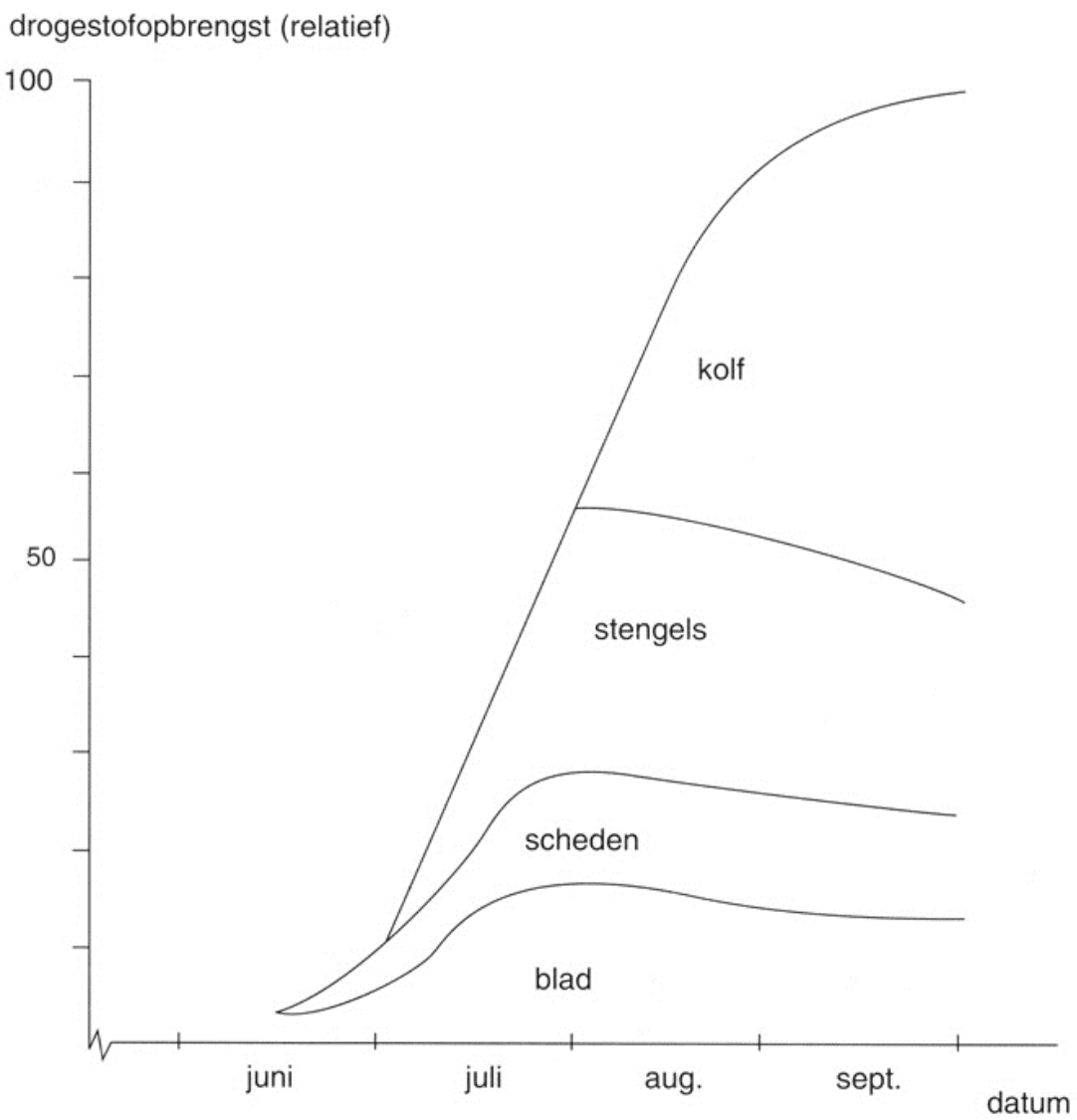

\subsection{Kwaliteit}

Voederwaarde, zetmeelgehalte en celwandverteerbaarheid zijn de belangrijkste eigenschappen die de kwaliteit van het snijmaïsgewas bepalen. Hieronder gaan we kort in op deze kwaliteitskenmerken. Meer informatie is te vinden in de hoofdstukken 6 en 12 .

\section{Voederwaarde en samenstelling}

De voederwaarde is een maat voor de mate waarin de koe de droge stof kan benutten en wordt uitgedrukt in voedereenheden melk (VEM; melkvee) of voedereenheden vlees (VEVI; vleesvee) per $\mathrm{kg}$ droge stof en is gebaseerd op de verteerbaarheid van de organische stof. Het kolfaandeel en de verteerbaarheid van de celwandbestanddelen zijn de belangrijkste factoren voor de voederwaarde van snijmaiis. Gemiddeld genomen bedraagt het kolfaandeel 50 à $55 \%$, maar dit kan variëren onder invloed van de groei- en teeltomstandigheden. De kolf bestaat voor het overgrote deel uit zetmeel dat $98 \%$ verteerbaar is. Van de celwanden die zich voornamelijk in stengel en blad bevinden is gemiddeld genomen $51,5 \%$ verteerbaar. De totale celinhoud is voor ongeveer $93 \%$ verteerbaar. Zowel het zetmeelgehalte als de verteerbaarheid van de celwanden moeten hoog zijn 
om een zo hoog mogelijke voederwaarde te realiseren. Het zetmeelgehalte en de celwandverteerbaarheid geven inzicht in de samenstelling van de voederwaarde. In figuur 2.4 is de gemiddelde samenstelling van $1 \mathrm{~kg}$ snijmaïs aangegeven.

Figuur 2.4 Samenstelling van $1 \mathrm{~kg}$ droge stof verse snijmaïs bij 32\% droge stof

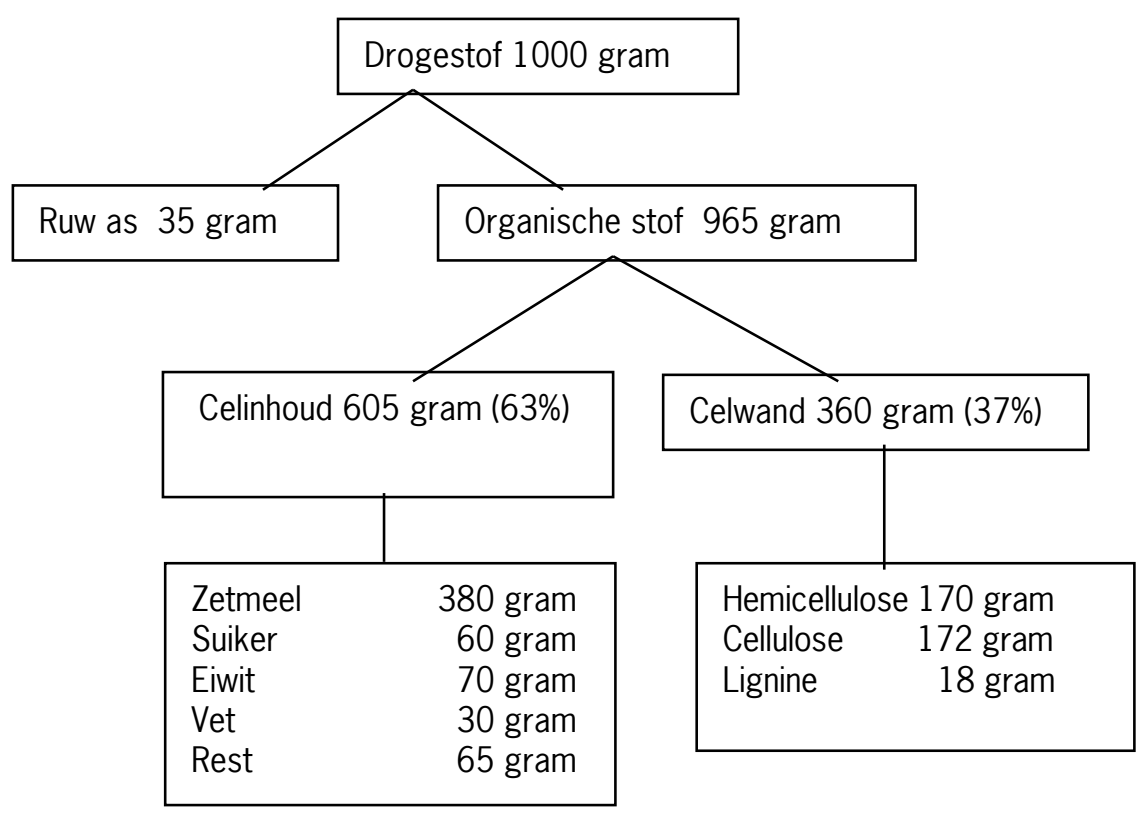

De verteringscoëfficiënt van de organische stof is gemiddeld $77,5 \%$ oftewel per $\mathrm{kg}$ drogestof is 748 gram verteerbare organische stof. Celinhoud is $93 \%$ verteerbaar oftewel 563 gram, dat is $75 \%$ van de totale verteerbare organische stof. Het zetmeel levert hiervan $50 \%$ en de rest van de celinhoud (o.a. suiker, eiwit, vet) $25 \%$. De verteerbaarheid van de celwanden is gemiddeld $51,5 \%$. Daarmee leveren ze (360 gram x 51,5\%) 185 gram verteerbare organische stof en dus ook $25 \%$. Gemiddeld is de invloed van het zetmeelgehalte op de voederwaarde op gewasniveau twee keer zo groot als de invloed van het celwandgehalte.

\section{Zetmeelgehalte}

Het zetmeelgehalte hangt direct samen met het kolfaandeel. De opslag van koolhydraten in de kolf vindt namelijk plaats in de vorm van zetmeel. Naarmate de snijmaiis afrijpt, neemt het aandeel van de kolf in de droge stof toe. Bij toename van het drogestofgehalte is er dus een toename van het zetmeelgehalte. Er bestaan duidelijke rasverschillen in zetmeelgehalte.

Lage temperaturen in de eerste helft van het groeiseizoen zullen een later bloeiend gewas tot gevolg hebben met een lager kolfaandeel. Een slechte vochtvoorziening tijdens de bloei geeft eveneens een laag kolfaandeel. Naarmate de instraling tijdens de korrelvulling hoger is, neemt het kolfaandeel toe. Hoge temperaturen tijdens de afrijping zijn ongunstig voor het kolfaandeel. 


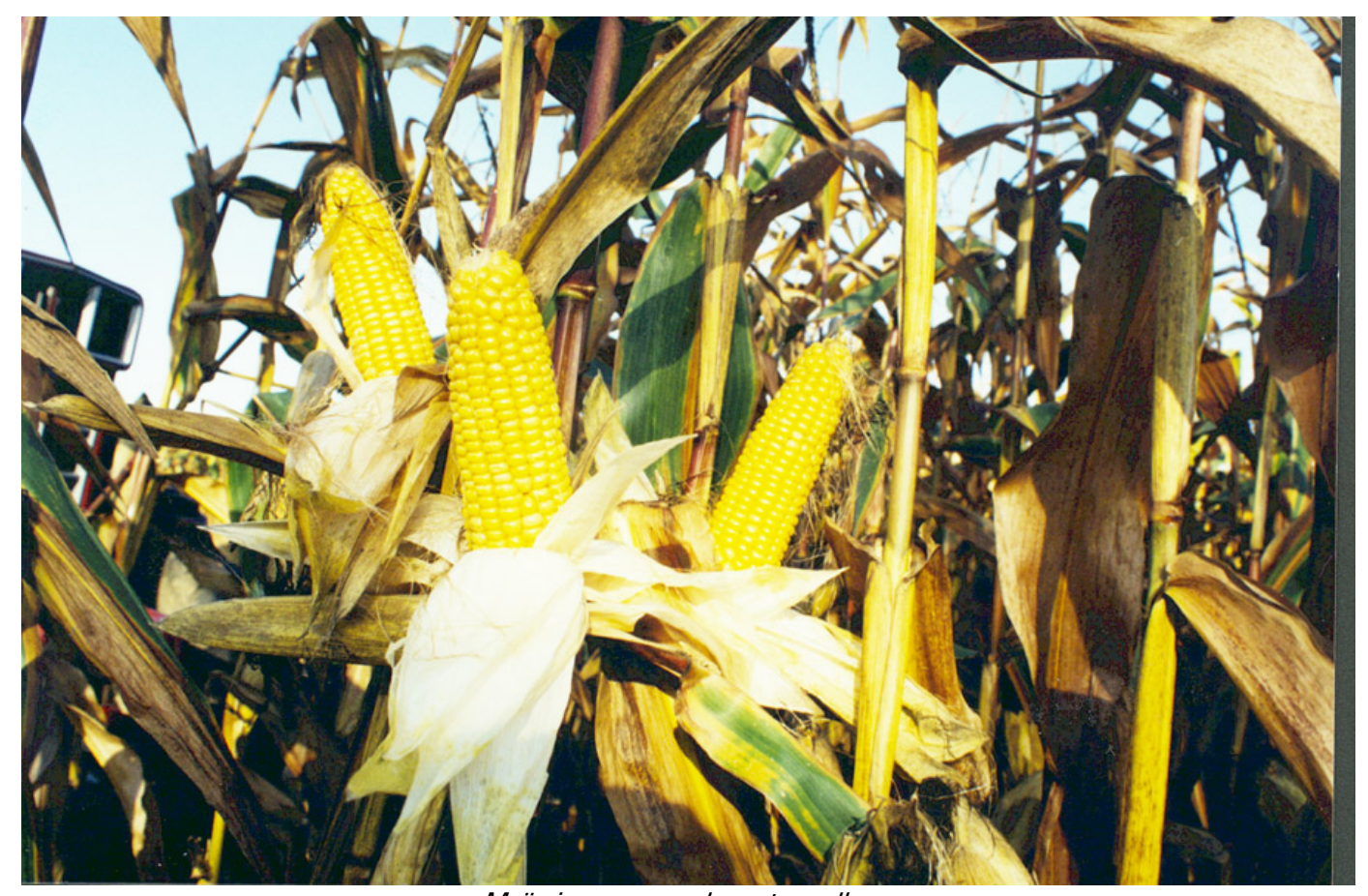

Mais is een goede zetmeelbron

\section{Celwandverteerbaarheid}

De celwanden bestaan voornamelijk uit hemicellulose, cellulose en lignine. Het aandeel van de verschillende bestanddelen, maar met name de verbindingen zowel binnen als tussen de bestanddelen, bepalen in grote mate de verteerbaarheid van de celwand. Door een toename van het zetmeelgehalte ( $\mathrm{gr} / \mathrm{kg} \mathrm{ds}$ ) neemt het celwandgehalte ( $\mathrm{gr} / \mathrm{kg} \mathrm{ds}$ ) tijdens de afrijping af. De invloed van de celwanden op de voederwaarde wordt dus tijdens de afrijping minder.

De verteerbaarheid van de celwanden neemt af naarmate de celwanden ouder worden. Dit verouderingsproces gaat sneller naarmate de temperatuur hoger is. Hoge temperaturen na de bloei zijn dan ook ongunstig voor de celwandverteerbaarheid. De meeste celwanden worden aangelegd voor de bloei. Na de bloei neemt de verteerbaarheid van de celwanden af, terwijl tegelijkertijd het kolfaandeel toeneemt. In Nederland blijt door deze twee tegenstrijdige effecten in een gemiddeld najaar de verteerbaarheid van de totale plant hierdoor na de bloei min of meer op hetzelfde peil. In sombere najaren en relatief hoge temperaturen zal de verteerbaarheid afnemen, terwijl in najaren met veel instraling en relatief lage temperaturen de verteerbaarheid toeneemt. 


\section{Bodem, water en bouwplan}

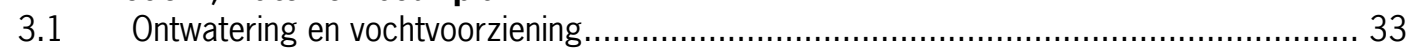

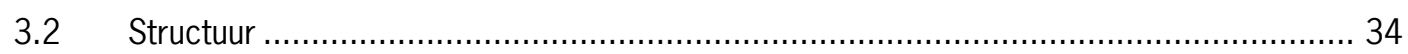

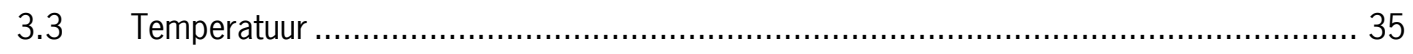

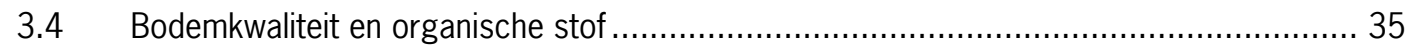

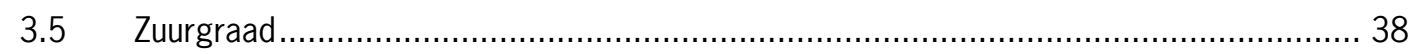

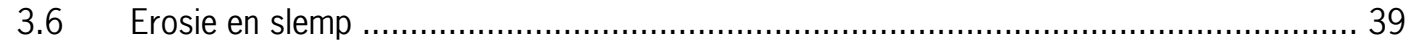

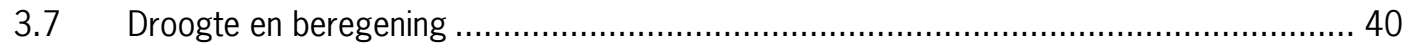

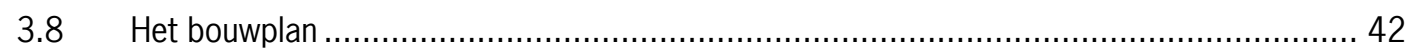




\section{Bodem, water en bouwplan}

De bodem vormt de basis voor een goede nutriënten- en vochtvoorziening. In dit hoofdstuk worden een aantal onderdelen behandeld die te maken hebben met de grond en het grondgebruik. Eerst gaan we in op een aantal aspecten die een rol spelen bij de geschiktheid van de grond voor de teelt van maïs. Daarna wordt ingegaan op de extreme situaties droogte, erosie en slemp. Als laatste kijken we naar inpasbaarheid van maïsteelt op een bedrijf en op de effecten van continuteelt en wisselbouw.

\section{Geschiktheid grond}

In principe kan men maïs op de meeste grondsoorten in Nederland telen. Van belang zijn een goede en tijdige berijdbaarheid en bewerkbaarheid. Bij de beoordeling van de geschiktheid van de grond spelen een aantal aspecten een rol:

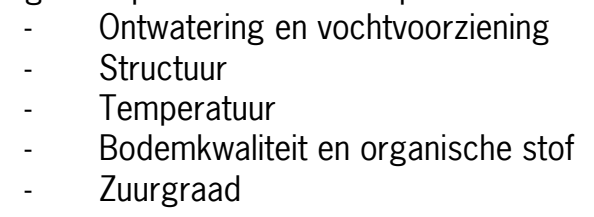

\subsection{Ontwatering en vochtvoorziening}

Voor een goede opbrengst is een goede ontwatering van belang. In het voorjaar is een goede ontwatering belangrijk om de grond tijdig te kunnen bewerken en voor een voldoende snelle opwarming van de bodem. Natte gronden warmen in het voorjaar veel trager op dan droge gronden. Daarnaast dient er voldoende lucht in het profiel aanwezig te zijn voor de wortelgroei. In het najaar is een goede ontwatering belangrijk om de maïs te kunnen oogsten zonder structuurschade te veroorzaken aan de bodem.

Een grond is goed ontwaterd wanneer de grondwaterstand gemiddeld nooit hoger komt dan $40 \mathrm{~cm}$ beneden maaiveld (winterstand). Naast een goede ontwatering is voldoende vochtvoorziening in het groeiseizoen belangrijk voor goede maïsopbrengsten. Ook hier speelt het niveau van het grondwater een belangrijke rol. Als de bewortelde laag in contact staat met het grondwater vindt er door capillaire werking opwaarts transport plaats van vocht. Als de grondwaterstand fluctueert tussen 40 en $150 \mathrm{~cm}$ beneden het maaiveld in combinatie met een klei- of leemhoudende ondergrond wordt door capillaire nalevering vanuit het grondwater de vochtvoorziening het gehele of een deel van het groeiseizoen gewaarborgd.

De hoeveelheid beschikbaar vocht voor het gewas wordt naast de vochtlevering vanuit het grondwater (capillaire opstijging) ook bepaald door de neerslaghoeveelheid en opslagcapaciteit van de bodem. De hoeveelheid bodemvocht die gemakkelijk beschikbaar is voor het gewas varieert per grondsoort. In humusarm grof zand is circa $8 \mathrm{~mm}$ per bodemlaag van $10 \mathrm{~cm}$ beschikbaar. In humeus, matig leemhoudend fijn zand is dit circa $18 \mathrm{~mm}$. Op zavel en lichte kleigronden is er ongeveer 20 tot $25 \mathrm{~mm}$ per $10 \mathrm{~cm}$ beschikbaar. Hoe dieper het gewas kan wortelen, hoe meer het gewas kan profiteren van het in de bodem beschikbare vocht. Op humeuze zandgronden met een diep profiel is er ongeveer $150 \mathrm{~mm}$ vocht voor het gewas beschikbaar, op ondiepe humusarme zandgronden slechts $50 \mathrm{~mm}$ en soms zelfs minder. Deze verschillen kunnen aanzienlijke opbrengstverschillen tot gevolg hebben. 


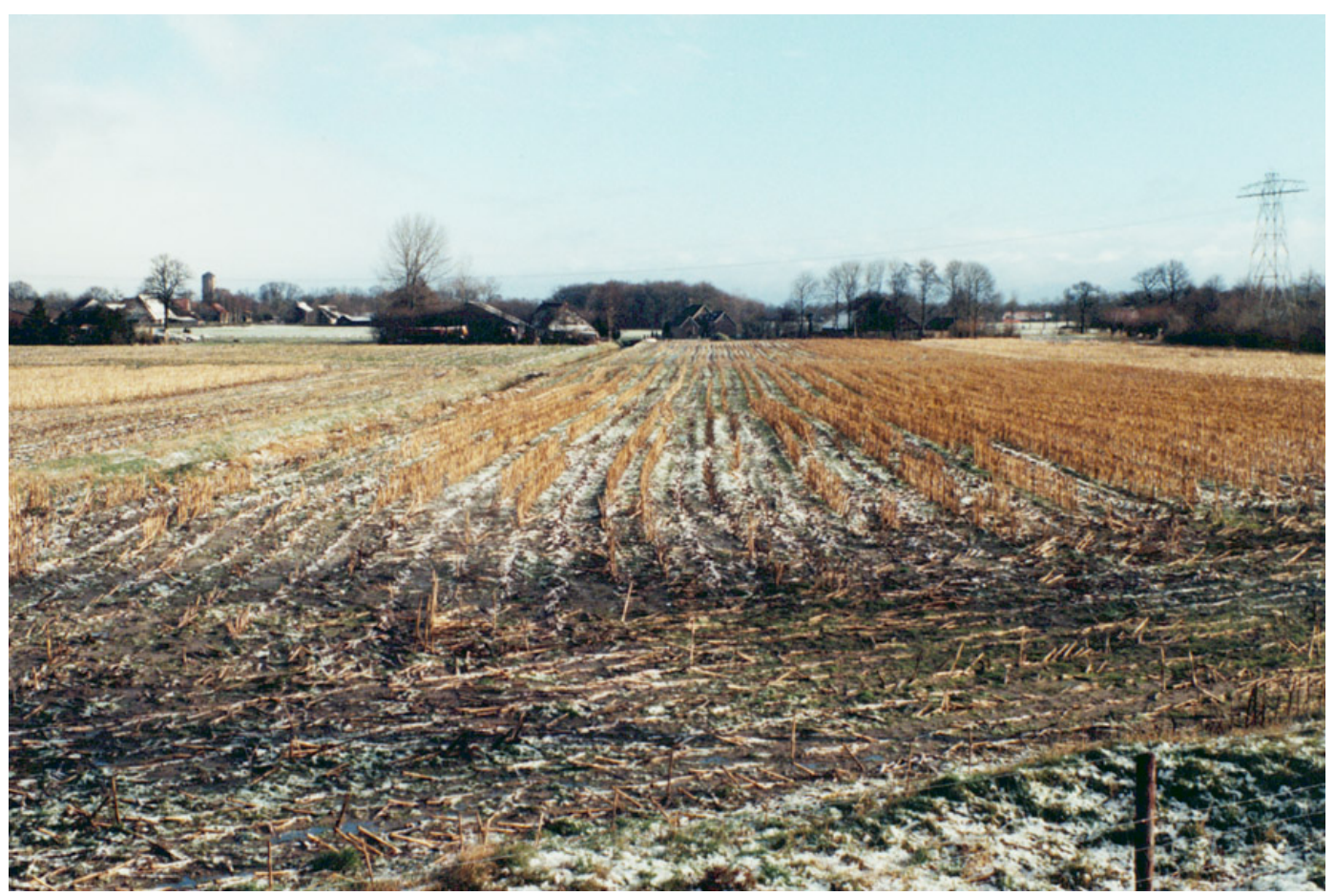

Goede ontwatering van groot belang

\subsection{Structuur}

Structuur heeft te maken met de ruimtelijke ordening van de bodemdeeltjes. Deze ruimtelijke ordening is van groot belang voor het transport van water en lucht, de beworteling en de stabiliteit en stevigheid van de grond. Een goede structuur wordt over het algemeen gekenmerkt door een kruimelstructuur.

De bewortelingsdiepte van maïs bedraagt in profielen zonder belemmeringen circa $120 \mathrm{~cm}$. $0 p$ de meeste gronden is de bewortelingsdiepte echter aanzienlijk geringer door de aanwezigheid van storende lagen. Storende lagen voor de beworteling kunnen een gevolg zijn van plotselinge overgangen in grofheid van de gronddeeltjes of humusgehalte en van een dichte pakking van de grond.

In sommige gronden met een storende laag of afwijkende ondergrond blijt de bewortelingsdiepte beperkt tot de bovenste laag, die vaak niet dikker is dan $25 \mathrm{~cm}$.

Ook op gronden die van nature diep doorwortelbaar zijn kunnen door zware mechanisatie bij het uitbrengen van dierlijke mest en bij de oogst verdichtingen ontstaan. Op gronden met een laag humusgehalte kan de laag onder de bouwvoor tussen 30 en $70 \mathrm{~cm}$ diepte zodanig verdicht worden dat maïswortels er niet meer in kunnen doordringen. Het bodemvocht dat zich in de verdichte laag en daaronder bevindt is dan niet meer beschikbaar voor het gewas waardoor de kans op vochttekorten toeneemt. Kies daarom voor een lage bandenspanning en voorkom dat er onder natte omstandigheden op het land wordt gereden (zie ook hoofdstuk 4). 


\subsection{Temperatuur}

Tot aan het 4-5 bladstadium bepaalt de temperatuur van het zaaibed de ontwikkelingssnelheid van de plant doordat de groeipunt van de plant zich tot dat moment onder de grond bevindt. Naast straling en luchttemperatuur bepalen kleur, humusgehalte, poriënfractie en vochtgehalte van de grond in belangrijke mate de snelheid waarmee grond in het voorjaar opwarmt. Natte gronden met een vaste structuur warmen in het voorjaar veel trager op dan droge gronden met een losse structuur. Door een laag poriënvolume en een hoog vochtgehalte is er meer energie nodig voor opwarming en gaat er bovendien meer warmte verloren door warmtetransport naar de ondergrond en verdamping van water. Doordat zandgronden gemiddeld sneller opwarmen dan klei- en veengronden zijn deze over algemeen meer geschikt voor de teelt van maïs.

\subsection{Bodemkwaliteit en organische stof}

Bodemkwaliteit kunnen we op diverse manieren definiëren. Een landbouwkundige definitie is: "Het vermogen van de bodem om gewassen op langere termijn van voldoende water en nutriënten te voorzien zodat de gewassen tot een hoge productie per eenheid productiefactor komen met een lage belasting voor de omgeving". Organische stof speelt een centrale rol bij bodemkwaliteit omdat dit een functie heeft bij verschillende processen in de bodem:

Levering van nutriënten. Bij de afbraak van organisch materiaal komen nutriënten (met name

$\mathrm{N}, \mathrm{P}$ en S) vrij. In de literatuur wordt een kritisch gehalte van 1,7\% genoemd. Beneden dit gehalte lijken gewassen op uiteenlopende grondsoorten bij een gematigde stikstof bemesting de potentiële opbrengst niet te kunnen halen. Als indicatie wordt ook wel genoemd dat de extra stikstoflevering op deze zandgronden als gevolg van een hoger organisch stofgehalte wordt geschat op $25 \mathrm{~kg}$ per hectare per procent organische stof.

Vochthoudend vermogen. Het effect van organische stof op de hoeveelheid beschikbaar vocht is afhankelijk van de grondsoort. Vooral op zandgronden neemt de hoeveelheid beschikbaar vocht toe bij een hoger organisch stofgehalte. Voor bodems met een fijne textuur (zoals klei) is het effect veel kleiner. Uit berekeningen blijkt dat in een bouwvoor $(25 \mathrm{~cm})$ van gronden met een laag lutumgehalte (3\%) minimaal $1 \%$ organische stof nodig is om $40 \mathrm{~mm}$ vocht te kunnen leveren. In een grond zonder lutum (zoals zandgrond) is hiervoor al gauw een organisch stofgehalte nodig van $2 \%$. Voor zandgronden met een organische stofgehalte van 2 tot $8 \%$ geldt globaal dat $1 \%$ meer organisch stof $4-6 \mathrm{~mm}$ meer vocht geeft.

Vermogen van de grond om nutriënten vast te houden. Organische stof heeft net als kleideeltjes het vermogen om nutriënten (kationen) vast te houden (adsorberen). Naarmate een grond een groter adsorptievermogen heeft, is het in staat om langer nutriënten na te leveren. Het adsorptievermogen van organische stof is pH-afhankelijk. Voor zandgronden lijkt een organisch stofgehalte van 3\% minimaal gewenst om bij een gangbare pH-KCL van 5 nog een redelijke adsorptiecapaciteit te hebben. Voor kleigronden ligt het minimaal gewenste organische stofgehalte lager, omdat de kleideeltjes ook voor adsorptiecapaciteit zorgen. Bodemleven en ziektewerend vermogen. Naast het gehalte aan organische stof, de afbreekbaarheid en de $\mathrm{C} / \mathrm{N}$ verhouding van het materiaal, spelen ook de aanwezigheid en de activiteit van het bodemleven een rol bij de uiteindelijke nutriënten levering (met name stikstof). De aanwezigheid en activiteit van het bodemleven worden voornamelijk bepaald door de omgevingsfactoren zoals type organisch materiaal, de $\mathrm{pH}$, de bodemtemperatuur en het vochtgehalte. Organische stof kan ook het ziektewerend vermogen van een bodem verhogen door meer biologische activiteit en een grote diversiteit aan bodemorganismen. 
Structuur, verkruimelbaarheid en slempgevoeligheid. Organische stof heeft een positieve invloed op de structuur. Het geeft een betere binding tussen de bodemdeeltjes waardoor de aggregaat stabiliteit wordt vergroot. Daarnaast heeft organische stof een positief effect op de structuur door de volgende processen:

- De dichtheid wordt lager doordat de minerale fractie door het organische materiaal wordt verdund.

- Organische stof geeft meer kleine poriën. Dit heeft over het algemeen een positief effect op het transport van water en lucht door een betere verhouding tussen het aandeel grote en kleine poriën.

- Organische stof heeft een positief effect op het bodemleven waardoor ook het aantal gravende organismen toeneemt. Het graven van "gangen" heeft een positief effect op de structuur.

In de literatuur worden gehalten genoemd van 3-3,5\% organische stof voor voldoende binding van bodemdeeltjes. Omdat er een sterke correlatie bestaat tussen klei en organisch stofgehalte is het minimum gewenste organische stofgehalte erg afhankelijk van het bodemtype.

Uitspoeling van stikstof. Een toename van het organische stofgehalte kan enerzijds leiden tot meer gevoeligheid voor uitspoeling van stikstof door extra mineralisatie. Dit risico is er vooral wanneer de organische stof aanwezig is in een jonge gemakkelijk afbreekbare vorm met een lage $\mathrm{C} / \mathrm{N}$ verhouding. Het risico kan dus beperkt worden door organische materiaal aan te voeren dat vrij stabiel is en langzaam afbreekt. Anderzijds leidt een toename van het organische stofgehalte tot een beperking van de gevoeligheid voor stikstofuitspoeling doordat het vochthoudend vermogen van de grond toeneemt. Gezien dit positieve effect van organische stof op de uitspoeling wordt voor zandgronden soms een gehalte van 2,5\% genoemd als ondergrens.

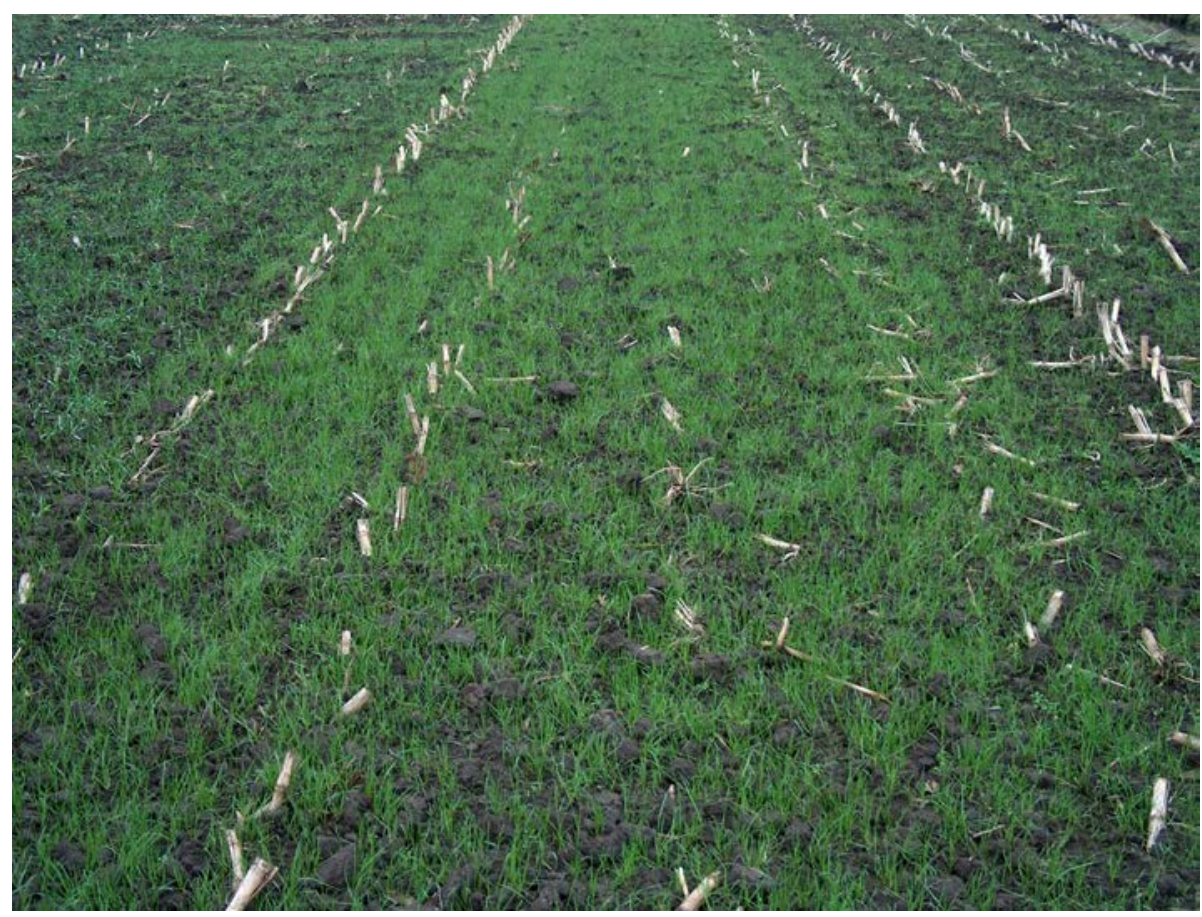

Organische stof aanvoer door inzaai groenbemester 
Uit het voorgaande blijkt dat het gewenste organische stofgehalte afhankelijk is van uiteenlopende aspecten. Voor de Nederlandse gronden zijn dan ook nog geen streeftrajecten bekend. Naast het organische stofgehalte zijn er diverse andere chemische, fysische en biologische indicatoren die in een laboratorium kunnen worden bepaald en die ook een rol spelen bij bodemkwaliteit. Bodemkwaliteit is echter een complex begrip en niet met één indicator te beoordelen. Daarnaast ontbreekt vaak nog een goede richtwaarde, bijvoorbeeld bij biologische indicatoren.

Bodemkwaliteit kan men ook met het blote oog beoordelen. Een profielkuil van een meter diep brengt de verschillende bodemlagen in beeld en kunnen de bewortelingsdiepte en de verticaal kruipende wormen tonen. Minder bewerkelijk is het uitsteken van een $30 \times 30 \mathrm{~cm}^{2}$ brok grond van $25 \mathrm{~cm}$ diep en vervolgens de verkruimelbaarheid beoordelen.

\section{Organische stofbalans en groenbemester}

In de bodem wordt organische stof afgebroken door natuurlijke processen. De hoeveelheid die afgebroken wordt is o.a. afhankelijk van grondsoort, organische stofgehalte, bouwvoordikte, bewerkingsintensiteit, vocht, temperatuur en $\mathrm{pH}$. Bij een organische stofgehalte van $3 \%$ en een bouwvoordikte van $25 \mathrm{~cm}$ wordt jaarlijks al gauw $2-3000 \mathrm{~kg}$ organische stof afgebroken. Deze afbraak moet worden gecompenseerd met aanvoer van organische stof uit gewasresten, mest en de teelt van een groenbemester. De bijdrage vanuit gewasresten is bij snijmaïs beperkt en binnen het nieuwe mestbeleid is ook de aanvoer vanuit mest beperkt. M.n. op de lichtere (zand)gronden is de teelt van een groenbemester daarom een must om het organische stofgehalte op peil te houden. Het opstellen van een organische stofbalans is een goed hulpmiddel om inzicht te krijgen in de aan- en afvoerposten van organische stof. Op de aanvoerzijde van de balans staan de posten organische mest, gewasresten incl. wortels en stoppels en eventueel een groenbemester. Op de afvoerzijde staat de onvermijdelijke jaarlijkse afbraak van organische stof in de bouwvoor. Bij de balansberekening wordt uitgegaan van de effectieve organische stof (eos). Dit is de hoeveelheid organische stof die na een jaar na toediening nog in de bodem aanwezig is. Er zijn normen opgesteld over de toevoer van effectieve organische stof door wortel- en gewasresten, dierlijke mest en groenbemesters In tabel 3.1 zijn een aantal normen weergegeven die bij de snijmaïsteelt van belang zijn.

Tabel 3.1 Effectieve organische stof levering van gewasresten, mest en goed geslaagde groenbemesters

\begin{tabular}{lc}
\hline Product & Effectieve organische stof levering \\
\hline Gewasresten snijmaïs (kg/ha/jaar) & 675 \\
Mest (kg/ton) & 50 \\
$-\quad$ runderdrijfmest & 26 \\
$-\quad$ varkensdrijfmest & 109 \\
- Vaste mest rundvee & \\
Groenbemester (kg/ha/jaar) & 1080 \\
- Raaigrassen (Italiaans, westerwolds, Engels) & 850 \\
- Wintergranen, bladkool, bladrammenas & \\
\hline
\end{tabular}

De leveringen van effectieve organische stof van groenbemesters in tabel 3.1 zijn gebaseerd op een goed geslaagd gewas. Om deze hoeveelheden effectieve organische stof te bereiken moet er een bovengrondse opbrengst staan van circa $2500 \mathrm{~kg}$ drogestof. In de praktijk wordt deze opbrengst vaak lang niet gehaald omdat groenbemesters in het najaar te laat (na half september) 
worden gezaaid en/of in het voorjaar te vroeg (voor eind maart) worden vernietigd. In dat geval zal dan ook gerekend moeten worden met een lagere aanvoer van effectieve organische stof uit de groenbemester dan in tabel 3.1 aangegeven.

\section{Voorbeeld organische stofbalans}

Uitgangspunten: zandgrond $3 \%$ organische stof

Afbraak bodem-organische stof $2,5 \%$ per jaar

Bouwvoor $25 \mathrm{~cm}$

$40 \mathrm{~m}^{3}$ runderdrijfmest per jaar

Groenbemester winterrogge, goed geslaagd

\begin{tabular}{|c|c|c|c|}
\hline \multicolumn{4}{|c|}{ Effectieve organische stof $(\mathrm{kg} / \mathrm{ha})$} \\
\hline Aanvoer & & & \\
\hline $\begin{array}{l}35 \mathrm{~m}^{3} \text { runderdrijfmest } \\
\text { Gewasresten }\end{array}$ & $\begin{array}{r}1750 \\
675\end{array}$ & Afbraak & 2625 \\
\hline Totaal & 2425 & Totaal & 2625 \\
\hline $\begin{array}{l}\text { Tekort zonder groenbemester } \\
\text { Groenbemester, matig geslaagd }\end{array}$ & $\begin{array}{l}200 \\
400\end{array}$ & & \\
\hline Tekort met groenbemester & -200 & & \\
\hline
\end{tabular}

\subsection{Zuurgraad}

De zuurgraad van de grond wordt uitgedrukt met $\mathrm{pH}$. Hoe lager de $\mathrm{pH}$ hoe zuurder de grond, wat duidt op een kalkarme toestand. Een grond is neutraal bij een pH van 7. Zand-, dal- en veengronden hebben van nature een vrij lage $\mathrm{pH}$. De meeste jonge zeekleigronden zijn neutraal en kalkrijk. Bij oudere zeekleigronden kunnen ook lage pH's voorkomen. De pH is van invloed op o.a. de beschikbaarheid van nutriënten voor het gewas en de biologische activiteiten in de bodem. Op kleigrond hangt de optimale $\mathrm{pH}$ ook af van de gevolgen voor de bodemstructuur. Bij een te lage $\mathrm{pH}$ vallen kleimineralen, en daarmee bodemdeeltjes uit elkaar, waardoor gemakkelijk slemp ontstaat. De optimale $\mathrm{pH}$ verschilt per grondsoort en hangt af van het organische stof- en lutumgehalte. We geven per grondsoort de streefwaarden van de $\mathrm{pH}-\mathrm{KCl}$ weer. Een uitgebreide waardering van de $\mathrm{pH}-\mathrm{KCl}$ is te vinden in "Adviesbasis bemesting grasland en voedergewassen" www.bemestingsadvies.nl. Wanneer de $\mathrm{pH}$ lager is dan de streefwaarde is het nodig deze te verhogen. De berekening van de kalkgift wordt beschreven in hoofdstuk 5 .

\section{Zand, dalgrond en veen}

Bij zand, dalgronden en veen is de gewenste $\mathrm{pH}$ afhankelijk van het organische stofgehalte. In tabel 3.2 is de gewenste $\mathrm{pH}-\mathrm{KCl}$ voor deze gronden weergegeven.

Tabel 3.2 Streefwaarden $\mathrm{pH}-\mathrm{KCl}$ van zand, dalgronden en veen Organische stofgehalte van de grond (\%) Gewenste $\mathrm{pH}$

$\begin{array}{cc}<5,0 & 5,3-5,7 \\ 5,0-7,9 & 5,1-5,5 \\ 8,0-14,9 & 5,0-5,4 \\ >15,0 & 4,8-5,2\end{array}$




\section{Rivierklei en overgangsgronden zand/rivierklei}

Bij rivierklei en overgangsgronden tussen zand en rivierklei is de gewenste $\mathrm{pH}$ afhankelijk van het lutumgehalte. In tabel 3.3 is dit weergegeven.

Tabel 3.3 Streefwaarden $\mathrm{pH}-\mathrm{KCl}$ van rivierklei en overgangsgronden tussen zand en rivierklei Lutumgehalte van de grond (\%) Gewenste $\mathrm{pH}$

$\begin{array}{ll}<8 & 6,0-6,3 \\ 8-12 & 6,2-6,5 \\ >12 & 6,4-6,7\end{array}$

\section{Löss en overgangsgronden zand/löss}

Bij löss en overgangsgronden tussen zand en löss is de gewenste $\mathrm{pH}$ afhankelijk van het lutumgehalte van de grond. Bij een lutumgehalte kleiner dan 10 ligt de gewenste $\mathrm{pH}-\mathrm{KCl}$ tussen 6,3 en 7,0. Bij een lutumgehalte van 10 of hoger ligt de gewenste $\mathrm{pH}-\mathrm{KCl}$ tussen 6,6 en 7,5.

\section{Zeeklei en overgangsgronden zand/zeeklei}

Bij zeeklei en overgangsgronden tussen zand en zeeklei is de gewenste $\mathrm{pH}$ afhankelijk van het organische stofgehalte en van het lutumgehalte van de grond. In tabel 3.4 staat de gewenste pH$\mathrm{KCl}$ voor deze gronden. Zie voor een meer gedetailleerde tabel "Adviesbasis bemesting grasland en voedergewassen" www.bemestingsadvies.nl.

Tabel 3.4 Streefwaarden $\mathrm{pH}-\mathrm{KCl}$ van zeeklei en overgangsgronden tussen zand en zeeklei

\begin{tabular}{ccccccccc}
\hline Lutumgehalte van de & \multicolumn{7}{c}{ Organische stofgehalte van de grond (\%) } \\
\cline { 2 - 8 } grond (\%) & $1,0-$ & $2,0-3,0-4,9$ & $5,0-9,9$ & $10,0-$ & $15,0-$ & $25,0-$ & $>34,9$ \\
& 1,9 & 2,9 & & & 14,9 & 24,9 & 34,9 & \\
\hline$<8$ & $>6,6$ & $>6,1$ & $>5,8$ & $>5,4$ & $>5,0$ & $>4,6$ & $>4,2$ & $>3,9$ \\
$8-12$ & $>6,6$ & $>6,2$ & $>5,9$ & $>5,6$ & $>5,2$ & $>4,8$ & $>4,4$ & $>4,0$ \\
$12-18$ & $>6,6$ & $>6,3$ & $>6,1$ & $>5,9$ & $>5,4$ & $>5,0$ & $>4,5$ & $>4,1$ \\
$18-25$ & $>6,7$ & $>6,5$ & $>6,3$ & $>6,0$ & $>5,6$ & $>5,1$ & $>4,6$ & $>4,2$ \\
$25-30$ & $>7,0$ & $>6,8$ & $>6,6$ & $>6,3$ & $>5,8$ & $>5,3$ & $>4,7$ & $>4,3$ \\
$30-35$ & $>7,1$ & $>7,0$ & $>6,9$ & $>6,5$ & $>6,0$ & $>5,5$ & $>4,9$ & $>4,4$ \\
$>35$ & $>7,1$ & $>7,1$ & $>7,0$ & $>6,7$ & $>6,2$ & $>5,6$ & $>5,0$ & $>4,5$ \\
\hline
\end{tabular}

\subsection{Erosie en slemp}

Wind en water veroorzaken bodemerosie. Erosie door wind komt vooral voor op de veenkoloniale gronden in Noordoost-Nederland, watererosie vooral op de hellingen in Zuid-Limburg. Erosie is ongewenst omdat vruchtbare bovengrond wordt afgevoerd. Bij watererosie nemen bovendien de risico's van afspoeling van mineralen naar oppervlaktewater toe.

Slemp komt vooral voor op lichte zavelgronden met een laag organisch stofgehalte. Ook een laag calciumgehalte verhoogt de kans op slemp. Bij slemp vloeien onder natte omstandigheden bodemdeeltjes ineen waardoor na opdroging een dicht hard laagje wordt gevormd. Hierdoor neemt de luchtdoorlatendheid af, waardoor de ontwikkeling van de maïs vertraagt. 


\section{Grondbewerking}

Grondbewerking vergroot de kans op het ontstaan van erosie en slemp, omdat de structuur van de bovengrond wordt gebroken. Een beperkte, niet-kerende grondbewerking in combinatie met de inzaai van een bodembedekker heeft de voorkeur. Hierdoor blijven meer gewasresten bovenin de bodem waardoor risico's van erosie en slemp verminderen. Wanneer er toch wordt geploegd kan men ter voorkoming van watererosie op hellingen het beste met de hoogtelijnen mee ploegen.

\section{Bodembedekker als erosiebestrijding}

De risico's van erosie en slemp kan men verminderen door na de oogst van het gewas voorafgaand aan maïs een bodembedekker in te zaaien. Hiervoor kan men de gangbare

groenbemestingsgewassen gebruiken. De bodembedekker moet 3 weken voor het zaaien van de maïs worden gedood om te voorkomen dat de grond te veel uitdroogt. Vorstgevoelige gewassen zoals gele mosterd vriezen tijdens de winter vaak al kapot.

De teelt van maïs in een bodembedekker zonder verdere grondbewerking gaf een afname van bodemverlies van $80-90 \%$. Dit systeem kost echter wel opbrengst en vraagt een aangepaste teelttechniek (zaaitechniek, onkruidbestrijding en mesttoediening). Door een oppervlakkige grondbewerking (frees) uit te voeren kan opbrengstreductie worden voorkomen. Ook kan men een zaairijenfrees gebruiken waarbij gelijktijdig met het zaaien smalle stroken van circa $10 \mathrm{~cm}$ breed worden losgemaakt waarin men het zaad zaait. Naarmate de bewerking intensiever is, neemt de erosiebescherming af. De afname van het bodemverlies bij genoemde bewerkingen bedraagt 70-80\% bij een zaairijenfrees en $20-70 \%$ bij een oppervlakkige zaaibedbereiding.

Mechanische onkruidbestrijding is slechts in zeer beperkte mate mogelijk. Eventueel kan men met een rijenbespuiting de gewasrij onkruidvrij houden en vanaf het 4-5-bladstadium het onkruid tussen de gewasrijen met een rijenfrees bestrijden.

\subsection{Droogte en beregening}

Veel zandgronden in het zuiden en oosten van Nederland zijn gevoelig voor droogte in het groeiseizoen. Het voorkomen van bodemverdichting om de bewortelingsdiepte en daarmee de vochtopname maximaal te houden is daarom erg belangrijk. Daarnaast kan het risico van verdroging op droogtegevoelige gronden worden verkleind door:

- maiis te telen met een lagere plantdichtheid dan de gebruikelijke 100.000 per ha en/of rassen bladarmere rassen te gebruiken. Onder droge omstandigheden is minder bladmassa gunstig. Er verdampt dan relatief minder water;

- $\quad$ rassen te telen die vroeg bloeien en een goede celwandverteerbaarheid hebben. Vroegbloeiende rassen hebben tijdens de korrelzetting een grotere kans te ontsnappen aan een vroegtijdig vochttekort omdat de kans op droogte in de loop van het seizoen toeneemt. Wanneer tijdens de korrelzetting toch een vochttekort optreedt, blijt de voederwaarde van rassen met een goede celwandverteerbaarheid beter op peil dan van rassen met een hoog kolfaandeel.

Bij vochttekort kan men de hoeveelheid neerslag aanvullen met beregening. Om tijdig te kunnen beginnen met beregenen is het nodig om de actuele vochtvoorraad te weten. Deze kan op meerdere manieren worden ingeschat.

- $\quad$ De grond met een gutsboor tot bouwvoordiepte bekijken en in de hand te kneden. Hiermee kan men in korte tijd een indruk krijgen van de vochtvoorraad van de bovengrond. Voor zandgrond geldt dat wanneer de grond nog goed kneedbaar is beregenen nog niet nodig is. Wanneer de grond niet meer kneedbaar is en brokkelig, kruimelig en iets stoffig, is beregenen nodig. 
- $\quad$ Met behulp van de beregeningswijzer die door Wageningen Livestock Research is ontwikkeld kunt u 'op maat beregenen' De wijzer is te bestellen via de website www.livestockresearch.wur.nl. De methode is gebaseerd op het drogen van grond (bijv. in een magnetron). Hiermee kan men op eenvoudige wijze de actuele vochttoestand van de bovengrond bepalen. Nodig zijn een gutsboor, een magnetron en een keukenweegschaal. Met een aantal steken met de gutsboor verzamelt men grond en droogt dit in de magnetron. $\mathrm{Na}$ het drogen wordt de hoeveelheid vocht die de grond bevat berekend. In de beregeningswijzer kan men aflezen of dit voor de betreffende grondsoort voldoende is.

- $\quad$ De vochtvoorraad berekenen met een vochtboekhouding. Dit is een dagelijkse optel- en aftreksom van de hoeveelheid water van neerslag, beregening en capillaire nalevering en verdamping. Gewasverdamping onttrekt water aan de wortelzone en neerslag, beregening en capillaire nalevering vullen de vochtvoorraad in de wortelzone aan.

Voor het beregenen van maïs wordt geadviseerd het juiste tijdstip te bepalen met de gutsboor en door eventueel grond te drogen in de magnetron. Het opstellen van een vochtboekhouding is voor maïs vrij gecompliceerd, door een toenemende bewortelingsdiepte in de loop van het seizoen en een referentieverdamping die gecorrigeerd moet worden met een gewasfactor.

Wanneer de vochtvoorraad onvoldoende is, kan men beregenen. De gift moet worden gerelateerd aan de bewortelingsdiepte. Voor een inschatting van de dikte van de wortelzone kan men rekenen met een beworteling van $30 \mathrm{~cm}$ bij $50 \%$ bodembedekking, oplopend naar maximaal $60 \mathrm{~cm}$ bij $100 \%$ bedekking en maximaal $90 \mathrm{~cm}$ bij bloei. De maximale bewortelingsdiepte wordt echter niet altijd bereikt en is afhankelijke van de grondsoort.

Voor de meeste gronden geldt dat er circa $8 \mathrm{~mm}$ beregend kan worden per $10 \mathrm{~cm}$ bewortelbare zone. Uitgaande van een bewortelbare zone van minimaal $60 \mathrm{~cm}$ kan men zo'n $50 \mathrm{~mm}$ beregenen. Dit is te veel om in één gift te geven. De maïsplanten van een volgroeid gewas veroorzaken een slechte verdeling van het beregeningswater naar en in de bodem. Met name in de maïsrij komt door stroming langs stengel en blad het meeste water. Dit veroorzaakt kans op plasvorming. Beter is het om twee giften achter elkaar te geven van $25 \mathrm{~mm}$. Met mooi zonnig weer verdampt in de maïs 5 tot $7 \mathrm{~mm}$ per dag (referentie gewasverdamping $x$ gewasfactor). Dit betekent dat onder dergelijke omstandigheden elke 10 dagen beregend moet worden.

Het meeste voordeel van beregenen behaalt men in de periode van bloei tot korrelvulling. Maïs gaat dan efficiënter om met water dan gras. Het advies is om bij een neerslagtekort in die periode het beregenen van snijmaïspercelen voorrang te geven boven graslandpercelen. Bij beregening in maïs moet men door het gewas rijden, waardoor 2-5\% van de oppervlakte niet meer productief is. Uit berekeningen in bedrijfsverband is gebleken dat beregenen van snijmaïs op droge zandgrond gunstig is voor de mineralenbenutting en voor verlaging van het nitraatgehalte in grondwater. Of beregenen van snijmaïs financieel aantrekkelijk is, hangt af van de extra kosten die men voor beregenen maakt (zie ook hoofdstuk 13). Wanneer men de beschikking heeft over een regeninstallatie, is maïs beregenen bij droogte zeker zinvol.

\section{Praktisch handvat voor beregenen}

Een eerste zichtbare verschijnsel van een vochttekort is dat het blad overdag gaat krullen. In het begin herstelt zich dat 's nachts weer. Een praktisch handvat om te beginnen met beregenen is wanneer 's morgens het blad nog gekruld is. 


\subsection{Het bouwplan}

Het maximale aandeel snijmaïs dat men op een veehouderijbedrijf kan telen, wordt bepaald door het aandeel percelen met een geschikte grondsoort. De hoeveelheid maïs die uiteindelijk wordt geteeld is afhankelijk van diverse factoren. Daarbij speelt de verkaveling vaak een duidelijke rol. Maïs is een gewas dat men eenmalig per jaar hoeft te oogsten. Daarom is het aantrekkelijk om op percelen op afstand van het bedrijf maïs te telen. Om voldoende beweidingsruimte te houden, teelt men maïs vaak niet op percelen die beweid kunnen worden door het melkvee. Het aandeel maïs in het rantsoen (zie hoofdstuk 12) is ook van invloed op het aandeel maïs in het bouwplan. Daarnaast zijn nog een aantal economische factoren van invloed op het aandeel snijmaïs (zie hoofdstuk 13).

\section{Continuteelt}

Maïs heeft weinig last van bodemgebonden ziekten en plagen en kan daarom relatief goed in continuteelt worden verbouwd. De kans op aantasting door de schimmelziekte wortelverbruining neemt echter toe bij continuteelt (zie hoofdstuk 9). Daarnaast kunnen ook het aantal van de wortelaaltjes Pratylenchus en Tylenchorhynchus toenemen. Schade door aaltjes is echter nog nooit aangetoond.

Continuteelt heeft gemiddeld een negatieve invloed op de bodemkwaliteit. Door het relatief late oogsttijdstip is de kans dat er onder natte omstandigheden moet worden geoogst vrij groot. Hierdoor ontstaat structuurbeschadiging. Daarnaast is de bewortelingsdiepte en -intensiteit niet groot en de inbreng van organische stof door het gewas in de bodem beperkt.

Om het organische stofgehalte op peil te houden zijn naast organische mest voor de bemesting extra maatregelen nodig, zoals het gebruik van een groenbemester en eventueel aanvoer van organische stof via compost. Het toedienen van voldoende organische stof brengt echter vaak met zich mee dat fosfaat wordt overgedoseerd. Immers, alleen $40 \mathrm{~m}^{3}$ runderdrijfmest is al voldoende om de fosfaatonttrekking door maïs te dekken, maar compenseert meestal niet de afbraak aan organische stof in de bodem.

Continuteelt geeft een snellere vermeerdering van onkruiden die minder gevoelig zijn voor gangbare herbiciden en kan leiden tot resistentie van onkruiden tegen herbiciden.

Door bovenstaande effecten kan continuteelt leiden tot opbrengstderving van $10-20 \%$. 


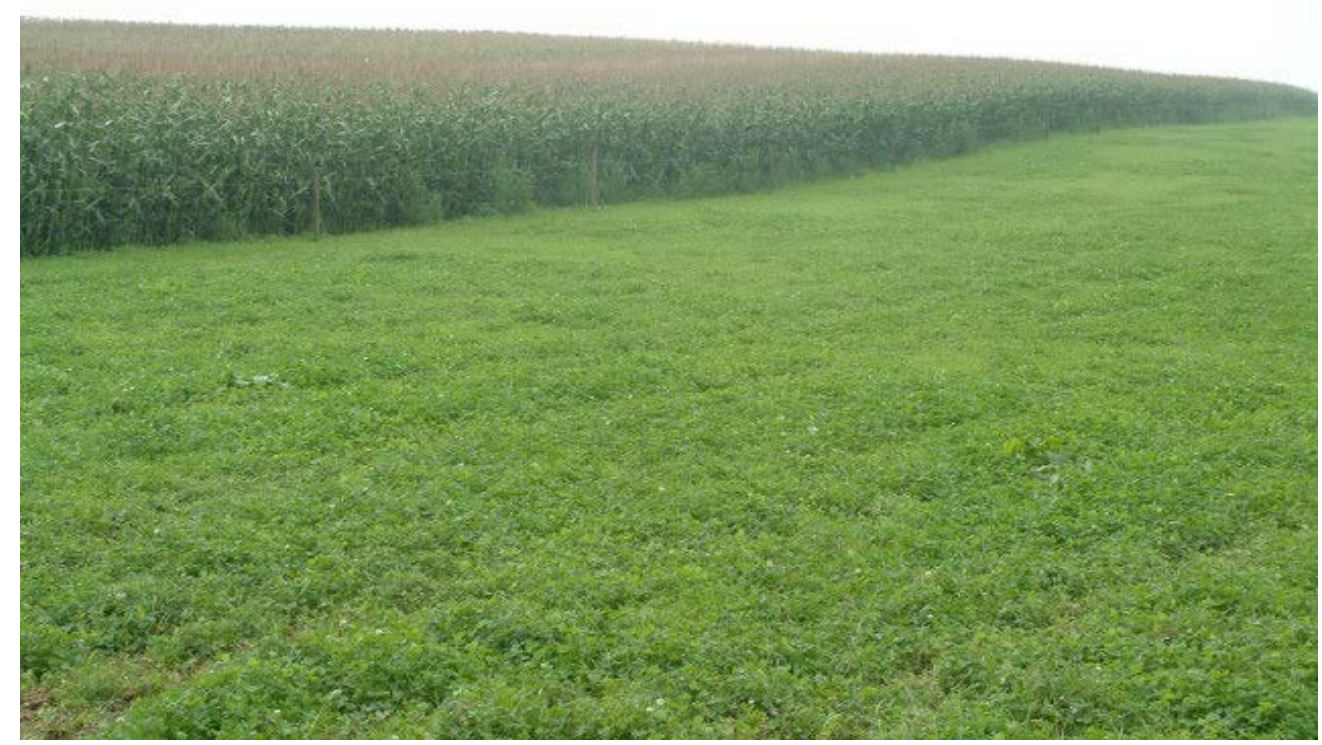

Mais afwisselen met gras is goed voor de bodem

\section{Wisselbouw}

Op melkveehouderijbedrijven komt het afwisselen van maïs met andere gewassen vaak neer op wisselbouw van maïs en gras. Door wisselbouw kan men organische stofgehalte van het bouwlanddeel op peil houden. Wanneer maïs na gras wordt geteeld kan het profiteren van de stikstofnalevering uit de ondergeploegde zode (zie hoofdstuk 5.5).

Daarnaast leidt wisselbouw in vergelijking met continuteelt tot een extra maïsopbrengst van 3-7\%. Dit wordt dus veroorzaakt door andere factoren dan organische stofgehalte en de stikstofnalevering en is afhankelijk van de leeftijd van het grasland (zie tabel 3.4).

Tabel 3.4 Vruchtwisselingseffect (\% extra opbrengst) bij wisselbouw van gras en maïs

\begin{tabular}{lccc}
\hline & \multicolumn{4}{c}{ Leeftijd grasland } \\
\cline { 2 - 4 } Jaren & 2 & 3 & $\geq 4$ \\
\hline Extra opbrengst (\%) & 3 & 5 & 7 \\
\hline
\end{tabular}

Tegenover het hogere organische stofgehalte van het maïsland staat dat organische stof van het graslanddeel wordt afgebroken. In hoeverre dit leidt tot lagere graslandopbrengsten is afhankelijk van de grondsoort.

Vaak wordt verondersteld dat vruchtwisseling ook voordelig is voor de onkruidbestrijding, met name voor lastige wortelonkruiden. Wanneer een grote voorraad van zaadonkruiden in de bodem zit is het door de grote persistentie van deze zaden vaak moeilijk om door wisselbouw deze onkruiden te bestrijden. Wisselbouw is dan ook meer een systeem om hoge onkruiddruk te voorkomen dan om onkruiddruk te verlagen.

Wisselbouw is echter lang niet altijd uitvoerbaar. In verband met beweiden verbouwt men maïs vaak op percelen verder van het bedrijf. Gras kan beter worden verbouwd op de lagere vochtige gronden die in het voorjaar lang nat en koud blijven en in het najaar kans op problemen bij de snijmaïsoogst 
geven. Hooggelegen, drogere gronden zijn meer geschikt voor de maïsteelt. Ook moet economisch gezien het voordeel van vruchtwisseling opwegen tegen de extra graslandkosten (inzaai, afrastering). In algemeen geldt voor de praktijk dat wisselbouw vooral interessant is voor het maïsdeel en aantrekkelijker wordt naarmate gronden landbouwkundig gezien slechter (droog zand met laag organisch stofgehalte) zijn en de mogelijkheid tot het gebruik van meststoffen en water beperkter zijn.

\section{Vruchtwisseling met akker- en tuinbouwgewassen}

Op akker- en tuinbouwbedrijven wordt maïs meestal afgewisseld met andere akker- en tuinbouwgewassen. Op deze bedrijven vervangt maïs vaak een graangewas. Afhankelijk van de snijmaïsprijzen en de afrijpingsomstandigheden wordt het gewas ook wel afgezet als korrelmaïs of CCM. Voor bedrijven op lichte gronden is het belangrijk om te weten dat maïs hoge dichtheden maïswortelknobbelaaltjes (Meloidogyne chitwoodi) en wortellesieaaltjes (Pratylenchus penetrans) nalaat. Deze aaltjes veroorzaken ernstige opbrengst- en kwaliteitsschade in diverse gewassen. Vanaf 2006 is de inzaai van een groenbemester na snijmaïs verplicht op zand- en lössgrond. Bij de keuze van de groenbemester moet men rekening houden met de aaltjessituatie. Ook op melkveebedrijven teelt men soms naast gras en maïs andere voedergewassen, bijvoorbeeld GPSteelt van graan. Doorbreking van de continuteelt met dergelijke gewassen is gunstig voor de bodemgezondheid (vermindering wortelverbruining) en voor de bodemstructuur, doordat vooral graan veel organische stof achterlaat in de bodem en een intensievere beworteling heeft. 


\section{$4 \quad$ Grondbewerking}

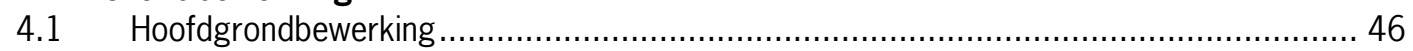

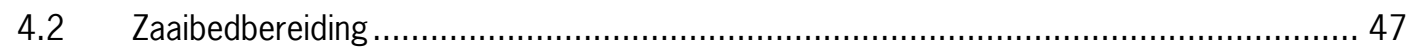

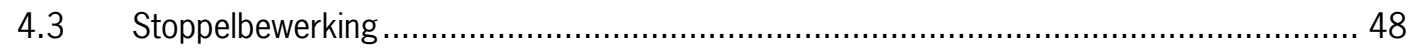

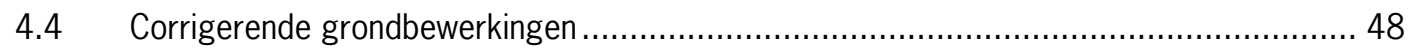

4.5 Minimale en niet kerende grondbewerking ............................................................. 50 


\section{Grondbewerking}

Voor een ongestoorde groei is een snelle en intensieve doorworteling van de bodem vereist. Hierbij is een goede bodemstructuur van groot belang. Om deze te behouden moet de grond met zorg worden behandeld bij berijding. Dat betekent zo min mogelijk onder natte omstandigheden op het land rijden en letten op een juiste bandenspanning. Kies voor banden waarbij een lage bandenspanning mogelijk is en zonodig voor brede banden eventueel aangevuld met een drukwisselsysteem om verdichting te voorkomen. Voor de bodem varieert een optimale bandenspanning van 0,4 bar (voorjaarswerkzaamheden) tot 0,8 bar (andere werkzaamheden). Dit is in praktijk vaak moeilijk haalbaar. Een praktisch compromis is een bandenspanning van de trekker van $1-1,2$ en van de werktuigen van 0,8-1,0 bar.

Ook een juist uitgevoerde grondbewerking speelt een belangrijke rol bij het in stand houden van een goede bodemstructuur. In dit hoofdstuk behandelen we de hoofdgrondbewerking, zaaibedbereiding, stoppelbewerking en corrigerende grondbewerkingen.

\subsection{Hoofdgrondbewerking}

Een belangrijk doel van de hoofdgrondbewerking is het onderwerken van gewasresten en onkruiden. Andere redenen zijn verbetering van de afvoer en berging van overtollige neerslag en wegnemen van oppervlakkige verdichtingen ontstaan bij de oogst.

Op zandgrond vindt de hoofdgrondbewerking doorgaans in het voorjaar plaats, op kleigrond meestal in het najaar. Bij een najaarsgrondbewerking heeft de grond voldoende tijd om te verweren en te bezakken, zodat er in het voorjaar sprake is van een goede aansluiting met de ondergrond. Op zandgrond is de tijd tussen hoofdgrondbewerking en zaaibedbereiding vaak kort (1-2 weken), omdat voor de hoofdgrondbewerking eerst nog dierlijke mest wordt uitgereden. Voor een goede benutting kan men dit het beste zo laat mogelijk doen. Hierdoor is er onvoldoende tijd voor een voldoende bezakking van de bouwvoor. In dat geval kan de hoofdgrondbewerking het beste in combinatie met een vorenpakker worden uitgevoerd. Het voordeel hiervan is dat men hiermee tegelijkertijd een zaaibed klaarlegt. Naarmate men de bewerking dieper uitvoert, moet een dikkere grondlaag worden aangedrukt en is een grotere vorenpakker nodig. Bij een diepte van $20-25 \mathrm{~cm}$ is een vorenpakker met een doorsnede van $70 \mathrm{~cm}$ voldoende.

Dierlijke mest toedienen na de hoofdgrondbewerking heeft het voordeel dat de mest ondiep kan worden toegediend. Ook kan de hoofdgrondbewerking dan vroeger worden uitgevoerd. Nadeel is dat de risico's van structuurschade toenemen, vooral op lagere, natte gronden.

Een bewerkingsdiepte van $20-25 \mathrm{~cm}$ is meestal voldoende. Een diepere bewerking verhoogt het risico dat schralere grond naar boven wordt gehaald. Bovendien komt vóór de hoofdgrondbewerking toegediende dierlijke mest dieper in de bouwvoor terecht. Dit is ongunstig voor de benutting. Wanneer onder ongunstige omstandigheden is geoogst, is soms een diepere bewerking nodig.

Bij de hoofdgrondbewerking is er de keuze tussen een kerende en een mengende bewerking. Een kerende grondbewerking wordt meestal uitgevoerd met een ploeg. Het voordeel is dat men gewasen onkruidresten goed wegwerkt. Ondergronders aan een ploeg kunnen verdichtingen vlak onder de bouwvoor opheffen. Spitten geeft vooral onder natte omstandigheden een beter resultaat dan ploegen doordat er minder kans is op versmering, wielslip en vastrijden van de ploegvoor. Een mengende bewerking is mogelijk met een vastetandcultivator. Hiermee kunnen tevens verdichtingen vlak onder de bouwvoor worden opgeheven. Voordeel is dat het organisch materiaal bovenin de bouwvoor blijft. Dit spaart het bodemleven en kan een positieve invloed hebben op de 
structuur. Te diep losmaken van de grond verhoogt wel het risico dat de vochtlevering van onder uit het profiel stagneert. Verder wordt dierlijke mest minder diep ondergewerkt dan bij een kerende bewerking.

Nadeel van zowel de vastetandcultivator als de spitmachine is dat de gewasresten minder goed worden weggewerkt. Dit is vooral van belang wanneer een groenbemester is geteeld. Ook is de onkruiddruk in het algemeen hoger.

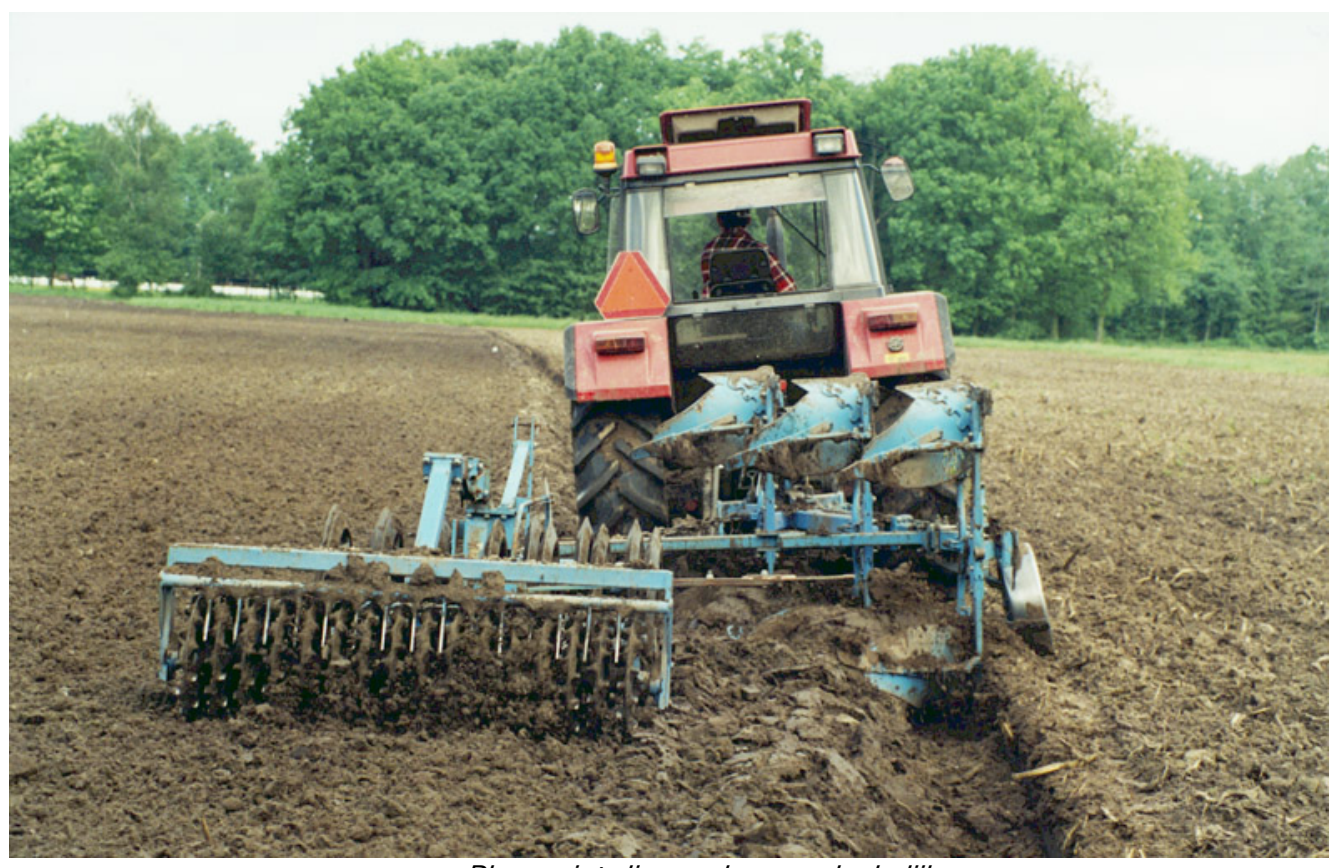

Ploeg niet dieper dan noodzakelijk

\subsection{Zaaibedbereiding}

Bij een goed uitgevoerde zaaibedbereiding moet de grond tot op zaaidiepte losliggen. Een losse bovengrond die gemakkelijk opdroogt, warmt sneller op dan een natte, zodat de kieming en begingroei vlot kunnen verlopen. Het zaad wordt net in de vaste ondergrond gezaaid zodat er voldoende vocht is voor de kieming.

Bij de zaaibedbereiding is een vlakke ligging noodzakelijk, vooral bij mechanische onkruidbestrijding. Ook bij de oogst voorkomt een vlakke ligging van de grond vervuiling van snijmaïs met grond. Indien men de hoofdgrondbewerking met een vorenpakker uitvoert, is geen extra zaaibedbereiding nodig. Wanneer geen vorenpakker wordt gebruikt, kan men op zandgrond de triltandcultivator gebruiken. Als de grond nog onvoldoende bezakt is, kan een combinatie worden gebruikt met pakker/aandrukrol voor een voldoende stevige ondergrond. Het wiel aan wiel aanrijden met dubbellucht raden we af. Dit veroorzaakt een ongelijke ligging van het zaaibed en verschillen in dichtheid in de bouwvoor. Vooral de toplaag wordt dan verdicht.

Op kleigrond wordt, afhankelijk van de omstandigheden (zwaarte, slempgevoeligheid), gebruik gemaakt van zowel niet als wel aangedreven werktuigen. De grond moet niet te fijn liggen vanwege slempgevaar. 


\subsection{Stoppelbewerking}

Een belangrijk doel van de stoppelbewerking is de afvoer van overtollige neerslag en het opheffen van oppervlakkige verdichtingen. Dit is vooral belangrijk wanneer onder ongunstige omstandigheden is geoogst. Met een stoppelbewerking wordt ook overblijvend onkruid bestreden en stoppelresten ingewerkt zodat ze beter verteren. Tenslotte kan men tegelijkertijd een zaaibed klaarmaken voor de inzaai van een groenbemester. Op zand en lössgronden is de teelt van een groenbemester verplicht. Voor de stoppelbewerking gebruikt men meestal een cultivator en soms een stoppelploeg. Bij de inzaai van groenbemesters wordt ook wel gebruik gemaakt van zaaibedbereiding-zaai-combinaties. Er moet voor gewaakt worden dat de grond niet te fijn wordt gemaakt om verslemping gedurende de winter te voorkomen.

\subsection{Corrigerende grondbewerkingen}

Op veel zandgronden is sprake van verdichte lagen onder de bouwvoor als gevolg van zware machines bij mest uitrijden en bij de oogst. Door de verdichting op te heffen kunnen het vochtleverend vermogen en de bewortelingsdiepte worden vergroot. Anderzijds wordt overtollig water sneller afgevoerd. Daarnaast kan tijdens de jeugdfase de bovengrond dichtslaan als gevolg van overtollige neerslag.

\section{Opheffen verdichte lagen}

$\mathrm{Na}$ het diep losmaken van het profiel is de grond zeer gevoelig voor nieuwe verdichtingen. Het is dan ook belangrijk de bewerking onder droge omstandigheden uit te voeren en de grond na de bewerking geruime tijd te laten bezakken. Het beste tijdstip is het najaar vlak na de maïsoogst, mits de grond droog is. De bewerking mag niet dieper worden uitgevoerd dan de diepte waarop zich de verdichting bevindt.

Bij een diepe grondbewerking met als doel verdichtingen op te heffen is het niet de bedoeling om diepe, schale bodemlagen te mengen met vruchtbare bovengrond. Ter plekke van de verdichting mag wel enige menging plaatsvinden.

Het meest effectief zijn de plaatwoeler en de spitfrees. De plaatwoeler is opgebouwd uit een frame met twee of drie tanden met aan de onderkant een brede plaat van $20 \times 20 \mathrm{~cm}$ die onder een hoek van 15 graden met de horizontaal op de gewenste diepte door de grond wordt getrokken. Aan de tanden kunnen een aantal kleinere platen zijn bevestigd. Het werktuig tilt de boven de plaat gelegen kolom grond op. Deze grondkolom zakt na het passeren van de woeler weer iets terug. De spitfrees is opgebouwd uit roterende tanden die door de grond draaien. Het gaat om smalle tanden die de grond niet mengen.

Het voordeel van een dieper doorwortelbaar profiel is groter naarmate de plantenwortels makkelijker een grote voorraad vocht kunnen bereiken. De dure bewerking is dan ook alleen rendabel als daarna het gewas aanzienlijk meer vocht aan het profiel kan onttrekken. Dit is vooral het geval als de wortels in een laag kunnen komen waar, door capillaire opstijging, een constante aanvoer van water vanuit het grondwater plaatsvindt.

Verdichtingen zullen opnieuw optreden als de mechanisatie niet wordt aangepast. Onderzoek heeft uitgewezen dat dit ook het geval is wanneer na de diepe bewerking een diepwortelend gewas wordt geteeld. Er is een direct verband tussen wieldruk en verdichting. Op makkelijk verdichtbare gronden, zoals zandgronden met een humusgehalte van minder dan $4 \%$, zal in 6 tot 8 jaar de bodem weer in dezelfde mate verdicht zijn als voor het losmaken. Alleen een lagere belasting van de grond of een 
hoger organische stofgehalte kan herverdichting voorkomen. Ook vruchtwisseling met gewassen waarbij minder zware berijding plaatsvindt kan hierbij een positieve rol spelen.

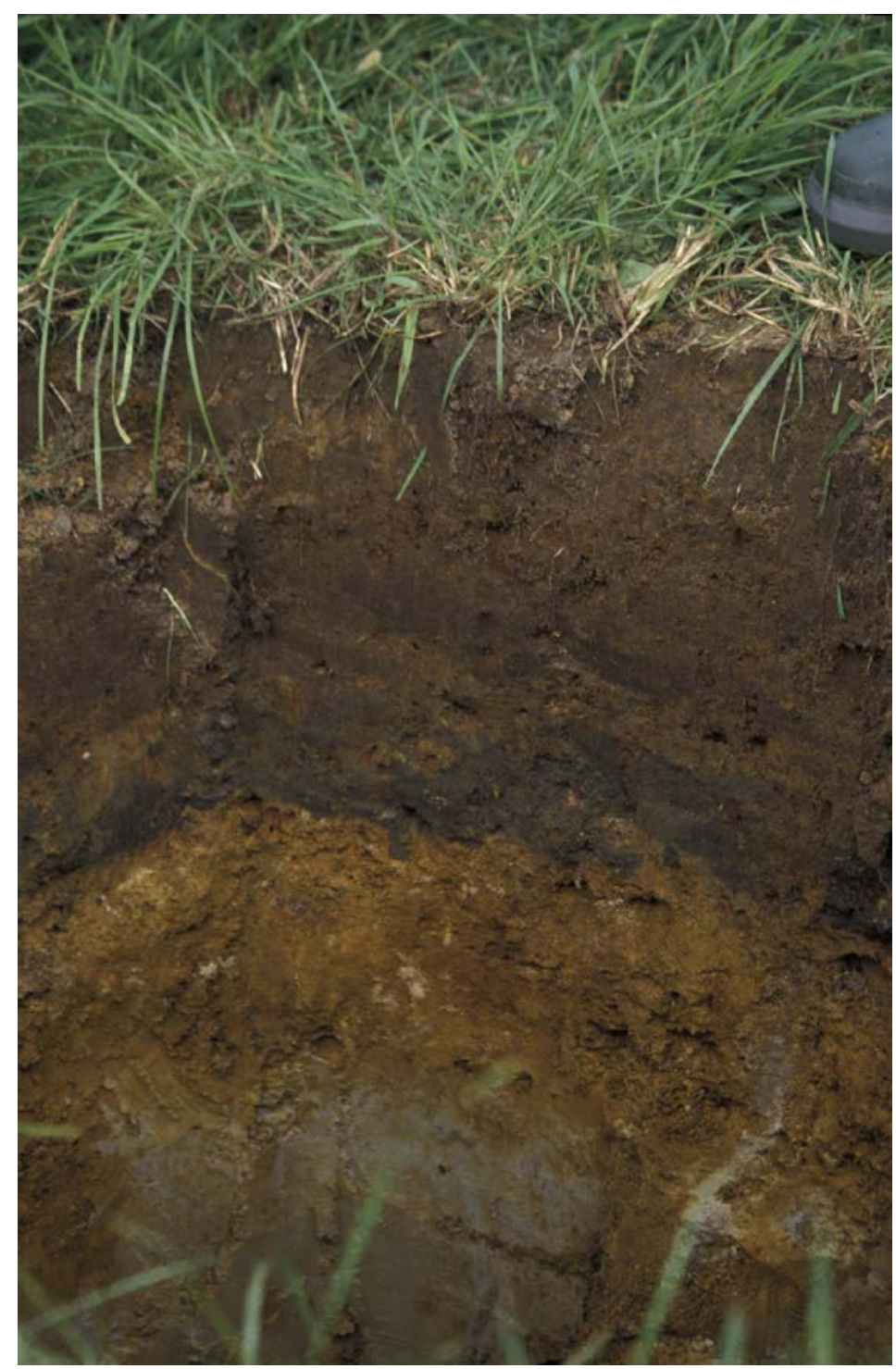

Kijk eens in de grond

\section{Bewerking tijdens de teelt}

Door intensieve neerslag kan de bodem dichtslaan. Hierdoor verslechtert de waterafvoer en warmt de bodem minder snel op. Vooral in de jeugdfase ondervindt het gewas hiervan hinder. Onder die omstandigheden kan het gunstig zijn de grond los te maken door een bewerking tussen de rijen uit te voeren. Dit kan het beste met een schoffelbalk. Het is belangrijk niet dichter dan $15 \mathrm{~cm}$ bij de rijen te komen en de grond niet dieper los te maken dan $5 \mathrm{~cm}$ om wortelbeschadiging te voorkomen. 


\subsection{Minimale en niet kerende grondbewerking}

Bij systemen met minimale en niet kerende grondbewerking wordt de grond zo min mogelijk bewerkt. Er kunnen daarbij verschillende systemen worden onderscheiden, zoals:

- Alleen een oppervlakkige niet-kerende bewerking uitvoeren en vervolgens te zaaien.

- Woelen op een diepte van 25-30 cm met daarnaast een oppervlakkige zaaibedbereiding.

- $\quad$ Een oppervlakkige niet-kerende bewerking waarbij tevens een groenbemester oppervlakkig wordt ingezaaid (mulchzaai).

- Maïsteelt in stroken. Hierbij wordt een rijenfrees gebruikt, die alleen op de plek van de maïsrij een strook van 10-12 cm breed freest.

- Directzaai. Hierbij wordt helemaal geen grondbewerking uitgevoerd, maar wordt met een speciale zaaimachine in de onbewerkte grond gezaaid.

Een aantal belangrijke motieven om over te stappen van ploegen op minimale of niet kerende grondbewerking zijn:

- Behoud van bodemvruchtbaarheid doordat minder organische stof wordt afgebroken en doordat de organische stof bovenin wordt gehouden.

- Verbeterde bodemstructuur en -stabiliteit, betere drainage en waterberging;

- $\quad$ Bodemleven wordt minder verstoort.

- Verbeterde draagkracht van de bodem waardoor beter berijdbaar onder natte condities.

- Verminderde kans op erosie.

- Kostenbesparing door minder werkgangen, lager energieverbruik, minder benodigde arbeid en minder machineonderhoud.

Wanneer geen kerende grondbewerking wordt toegepast worden gewasresten en onkruid(zaden) niet goed ondergewerkt. Dit heeft tot gevolg dat vooral op percelen met een hoge onkruiddruk de onkruidbeheersing een knelpunt kan vormen. Verder warmt de bodem in het algemeen minder snel op, waardoor de ontwikkeling van de maïs wat kan achterblijven. Voordeel van directzaai in grasland is een betere draagkracht doordat de zode zoveel mogelijk in tact wordt gehouden. Onderzoek heeft laten zien dat in vergelijking met ploegen de maïsopbrengst bij minimale en niet kerende grondbewerking op korte termijn meestal wat achterblijt. Diverse ervaring in de praktijk geven aan dat de opbrengst zich op termijn herstelt omdat het bodemleven tijd nodig heeft om zich aan te passen en een stabiele bodem met een goede structuur te vormen.

In de huidige praktijk komen systemen met een niet kerende grondbewerking vooral in beeld in gebieden waar intensieve grondbewerking minder goed past i.v.m. erosiegevaar zoals op de hellingen in Zuid-Limburg. Het behoud van draagkracht bij strokenteelt en directzaai is vooral een voordeel op minder draagkrachtige gronden zoals venige gronden en enkele kleigronden.

\section{Maïsteelt in graszode}

In de praktijk zijn inmiddels diverse ervaringen opgedaan met strokenteelt en directzaai van maïs in grasland. Daarvoor zijn twee verschillende systemen ontwikkeld: Systeem Pol, ontwikkelt door $\mathrm{H}$. Pol te Uffelte en De Hunter van Evers-agro. De Hunter is inmiddels door Evers-agro uit productie genomen. Bij het systeem Pol wordt de maiis al of niet in één werkgang in gefreesde strookjes gezaaid. Tevens kan er mest in de gefreesde strookjes worden gegeven. Bij de Hunter wordt de zode alleen opengesneden met een schijfkouter en een woelpoot. De maïs wordt in de snede gezaaid. Met beide systemen kunnen goede opbrengsten worden gehaald wanneer ze op een goede manier (juiste afstelling en regelmatige zaaidiepte) en onder de juiste omstandigheden (grond met goede structuur en niet te lang gras) worden ingezet. Het systeem Pol is wat breder inzetbaar onder verschillende omstandigheden en op verschillende grondsoorten omdat er een strookje wordt gefreesd waarin het zaad komt te liggen. Dit geeft gemiddeld een beter zaaibed dan 
alleen een snede in de zode. Wanneer stroken frezen, mest toedienen en zaaien in één werkgang worden uitgevoerd wordt de lage zaaicapaciteit soms als nadeel ervaren. Met de huidige GPStechnieken is het echter mogelijk om de verschillende bewerkingen apart uit te voeren Voor goede resultaten moet het gras kort voor het zaaien doodgespoten worden.
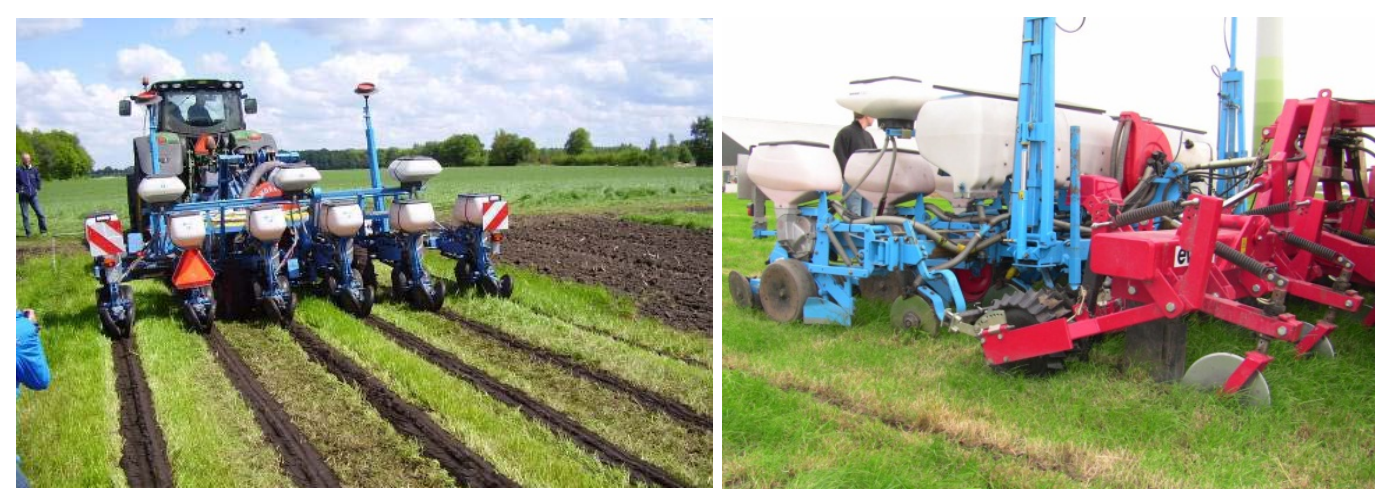

Mais in graszode zaaien met het strokenfreessysteem (systeem Pol, links) en met de Hunter van Evers-Agro (rechts)

In de praktijk is gebleken dat bij relatief grote hoeveelheden neerslag het water in de gefreesde strookjes kan lopen waardoor de maïsplantjes in hun ontwikkeling worden geremd door wateroverlast. Om dit te voorkomen heeft Henk Pol de ondergrondse strokenploeg ontwikkeld. Hiermee wordt onder de zode een rug gemaakt en de onbewerkte bovenlaag ligt tegen de helling van de rug. Het water loopt daardoor van de maïsrij af en kan in de grond trekken tussen de rijen mais. Met deze techniek wordt de bodem nog minder bewerkt dan met de strokenfrees.
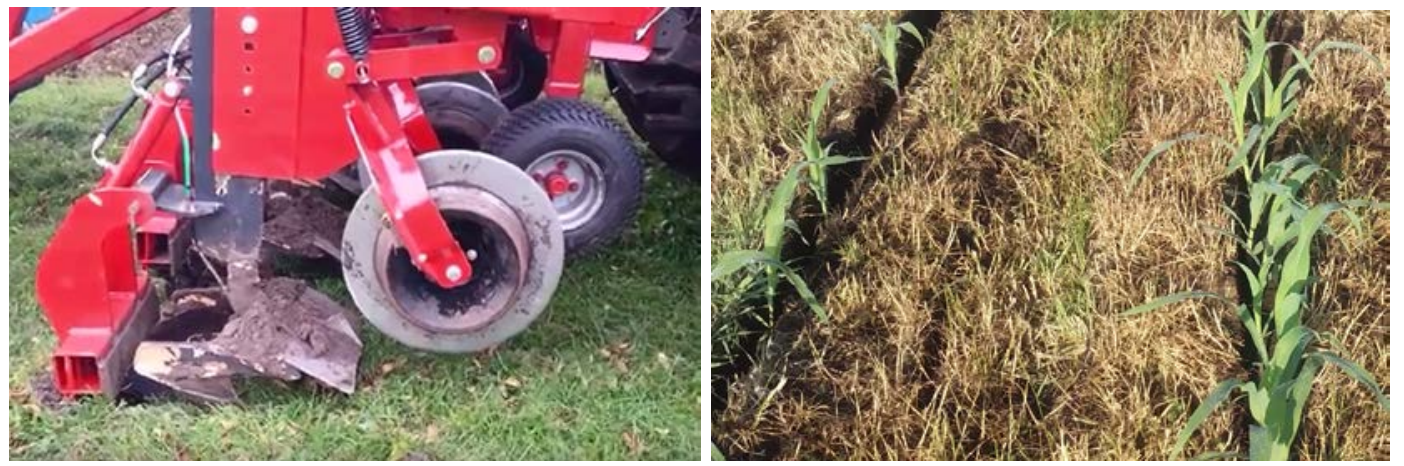

Ondergrondse strokenploeg (links) en mais gezaaid in graszode met ondergrondse strokenploeg (rechts) 


\section{$5 \quad$ Bemesting}

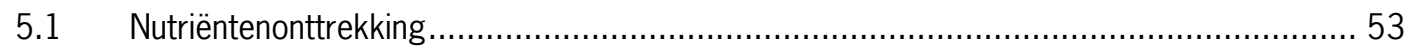

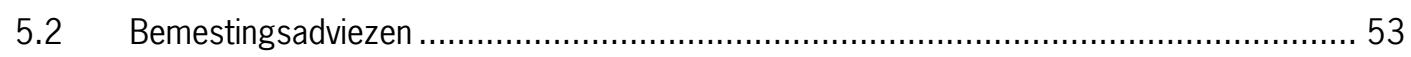

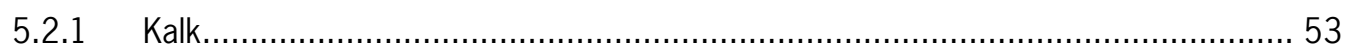

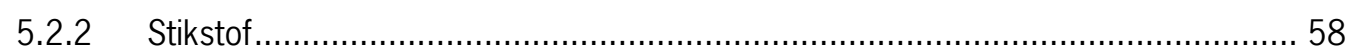

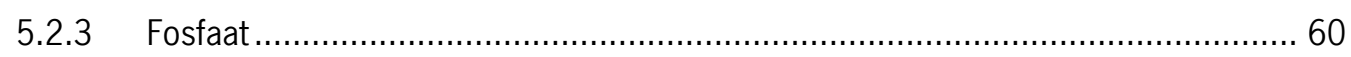

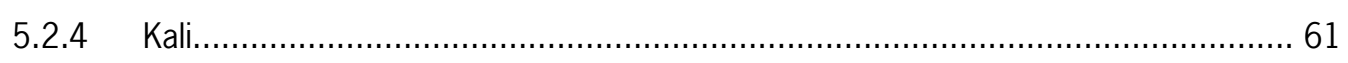

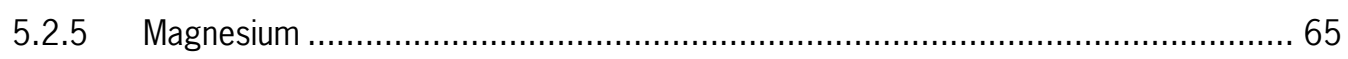

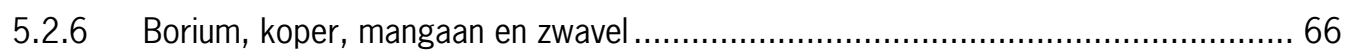

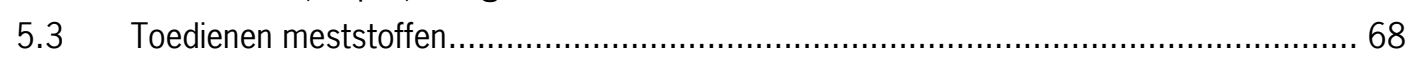

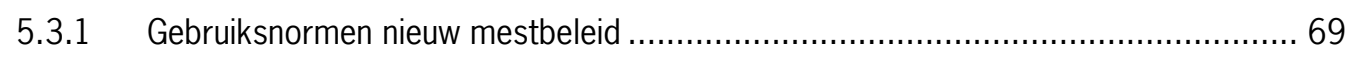

5.3.2 Toedienen kunstmest, rijenbemesting en alternatieven ........................................ 70

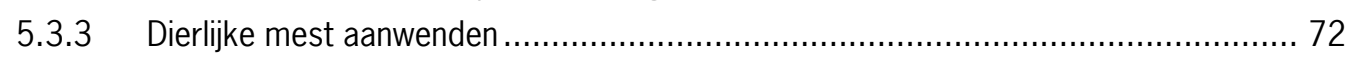

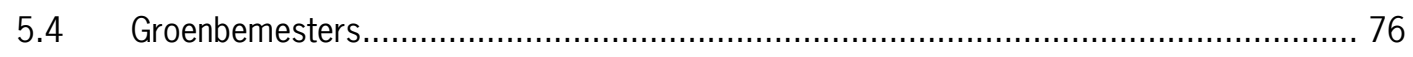

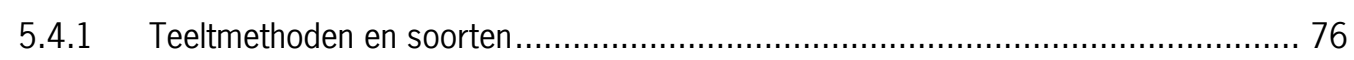

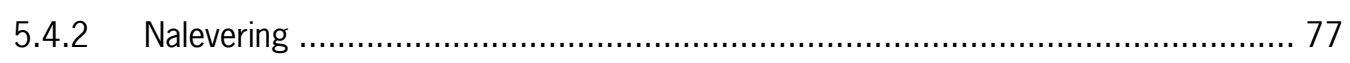

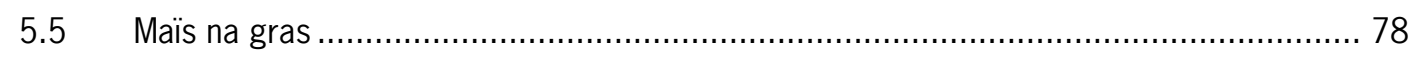




\section{Bemesting}

Voor een optimale teelt moet men de bemesting afstemmen op de behoefte van het gewas. De bemestingsadviezen in dit hoofdstuk zijn gebaseerd op de adviezen van de Commissie Bemesting Grasland en Voedergewassen (www.bemestingsadvies.nl). Deze commissie is ingesteld door LTONederland en bestaat uit vertegenwoordigers van onderzoek, voorlichting en bedrijfsleven. De adviezen van deze commissie zijn onafhankelijk en voor iedereen beschikbaar.

In dit hoofdstuk gaan we in op de nutriëntenonttrekking en de behoefte per element, daarna op het toedienen van meststoffen.

\subsection{Nutriëntenonttrekking}

Onder onttrekking wordt verstaan de totale opname van nutriënten in de geoogste delen van het gewas gedurende het groeiseizoen. De onttrekking door een gewas verkrijgen we door het gehalte aan bepaalde nutriënten te vermenigvuldigen met de opbrengst van het gewas. De onttrekking hoeft niet per definitie jaarlijks te worden aangevoerd in de vorm van bemesting. Daarbij spelen ook andere factoren zoals bodemtoestand, andere nutriëntenbronnen en -verliezen een rol. In tabel 5.1 zijn onttrekkingscijfers weergegeven van snijmaïs bij verschillende opbrengstniveaus.

Tabel 5.1 Onttrekking van $\mathrm{N}, \mathrm{P}_{2} \mathrm{O}_{5}, \mathrm{~K}_{2} \mathrm{O}$ en $\mathrm{MgO}(\mathrm{kg} / \mathrm{ha})$ door snijmaïs bij verschillende opbrengstniveaus

\begin{tabular}{lccc}
\hline Nutriënt & \multicolumn{3}{c}{ Opbrengstniveau (ton ds/ha) } \\
\cline { 2 - 4 } & 12,0 & 16,0 & 20,0 \\
\hline $\mathrm{N}$ & 140 & 185 & 235 \\
$\mathrm{P}_{2} \mathrm{O}_{5}$ & 55 & 70 & 90 \\
$\mathrm{~K}_{2} \mathrm{O}$ & 185 & 240 & 295 \\
$\mathrm{MgO}$ & 25 & 35 & 45 \\
\hline De onttrekkingscijers zijn gebaseerd op gehaltes van Eurofins Agro 2011-2015 en CVB 2012 en gegevens van K\&K \\
bedrijven 2000-2009
\end{tabular}

\subsection{Bemestingsadviezen}

Grondonderzoek vormt de basis van de bemestingsadviezen. Het advies is voor elk perceel één keer in de 4 jaar grondonderzoek te laten uitvoeren. Hieronder behandelen we de bemestingsadviezen per element.

\subsubsection{Kalk}

Een te lage $\mathrm{pH}$ van de bodem heeft negatieve effecten op de nutriënten opname en de bodemkwaliteit en daarmee op de opbrengst. De streefwaarden voor de $\mathrm{pH}$ staan in paragraaf 3.5. $\mathrm{De} \mathrm{pH}$ van de bodem daalt jaarlijks door o.a. gewasonttrekking, uitspoeling, en eventueel de verzurende werking van meststoffen. De $\mathrm{pH}$ wordt verhoogd door het gebruik van kalkmeststoffen. Bij bekalking kan men kiezen voor onderhoudsbekalking of voor reparatiebekalking. Bij onderhoudsbekalking bemest men jaarlijks om de $\mathrm{pH}$ op peil te houden. Bij een reparatiebekalking wordt naar aanleiding van grondonderzoek de $\mathrm{pH}$ verhoogd tot de gewenste $\mathrm{pH}$.

De neutraliserende werking van een kalkmeststof wordt aangeduid met de term neutraliserende waarde (nw), voorheen met de term zuurbindende waarde. $1 \mathrm{nw}$ komt overeen met $1 \mathrm{~kg} \mathrm{CaO}$. 
Voer de bekalking bij voorkeur in het najaar uit zodat de vertering van gewasresten wordt bevorderd.

Bij giften groter dan $4000 \mathrm{~kg} \mathrm{nw}$ adviseren we deze giften in meerdere keren te geven. In het algemeen worden giften groter dan $8000 \mathrm{~kg}$ nw niet geadviseerd. Pas vlak na een bekalking geen $\mathrm{N}$-bemesting toe met een minerale meststof die ammonium bevat en/of organische mest, omdat dan extra verliezen uit deze meststoffen kunnen optreden.

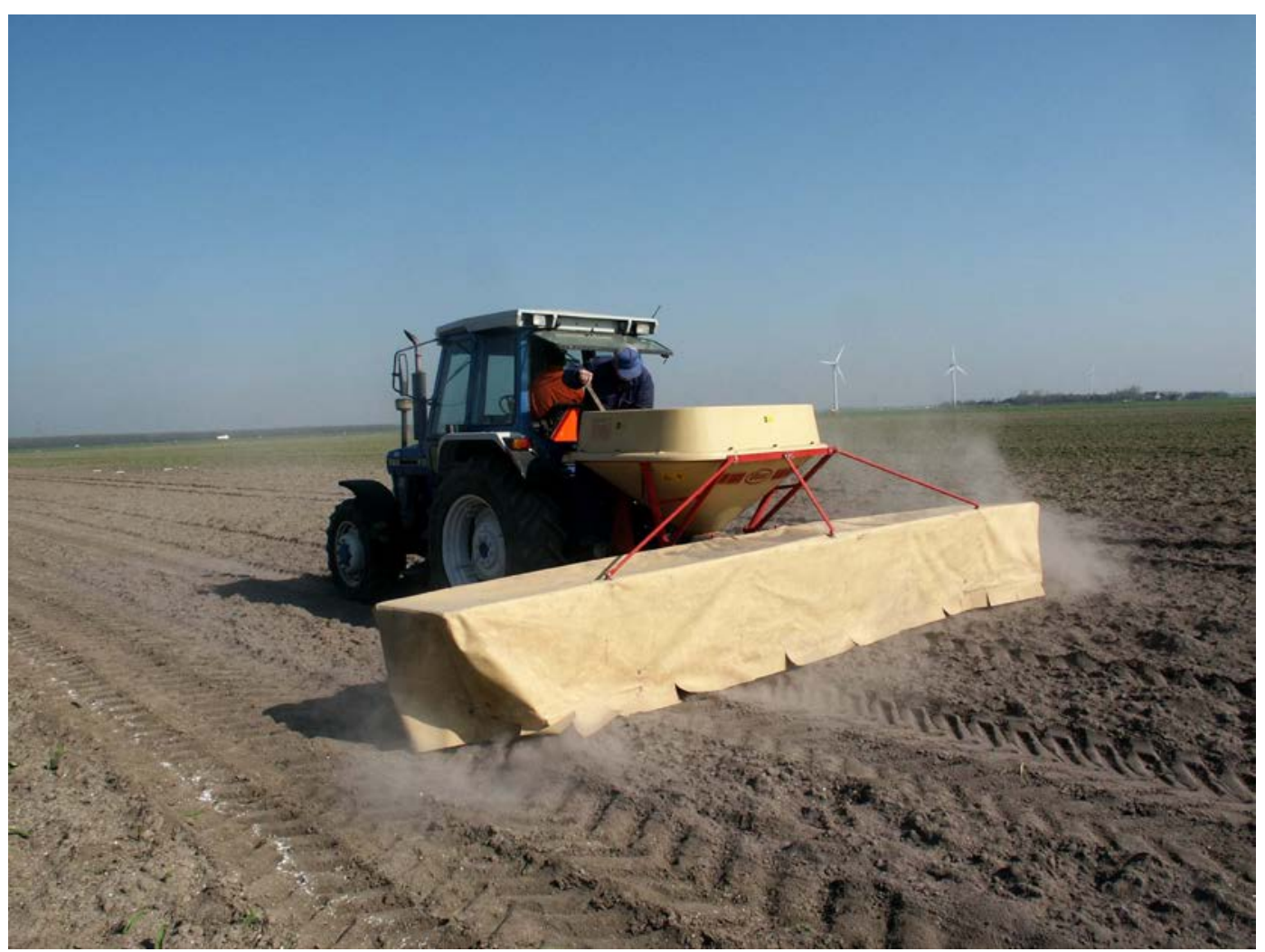

Een goede $\mathrm{pH}$ is een eerste vereiste

\section{Onderhoudsbekalking}

Voor de berekening van de kalkgift voor onderhoudsbekalking worden de grondsoorten verdeeld in drie categorieën:

\section{- $\quad$ Zand, dalgrond en veen}

- $\quad$ Rivier en zeeklei

- Löss

\section{Zand, dalgrond en veen}

De hoeveelheid kalk die per jaar nodig is om de verliezen uit de bouwvoor voor deze gronden aan te vullen is afhankelijk van het organische stofgehalte, de pH en de dikte van de bouwvoor. In tabel 5.2 is de geadviseerde kalkgift ( $\mathrm{kg}$ nw/ha) per 4 jaar weergegeven bij een bouwvoordikte van 20 $\mathrm{cm}$. Wanneer de bouwvoordikte hiervan afwijkt, kan de kalkgift in dezelfde verhouding worden aangepast. 
Tabel 5.2 Benodigde jaarlijkse onderhoudsbekalking ( $\mathrm{kg} \mathrm{nw} / \mathrm{ha}$ ) voor zand, dalgrond en veen bij een bouwvoordikte van $20 \mathrm{~cm}$

\begin{tabular}{cccc}
\hline Organische stofgehalte (\%) & \multicolumn{3}{c}{$\mathrm{pH}$} \\
\cline { 2 - 4 } & 4,5 & 5 & 5,5 \\
\hline 1 & 40 & 60 & 80 \\
5 & 90 & 150 & 210 \\
10 & 140 & 240 & 330 \\
15 & 180 & 300 & 420 \\
20 & 210 & 350 & 500 \\
25 & 240 & 400 & 550 \\
30 & 260 & 430 & 600 \\
35 & 280 & 460 & 640 \\
40 & 290 & 480 & 680 \\
45 & 300 & 500 & 700 \\
50 & 310 & 520 & 730 \\
55 & 320 & 540 & 750 \\
60 & 330 & 550 & 770 \\
65 & 340 & 560 & 790 \\
70 & 340 & 570 & 800 \\
\hline
\end{tabular}

Rivier en zeeklei

Op kleigronden wordt de hoeveelheid kalk die gemiddeld nodig is om de verliezen uit de bouwvoor aan te vullen geschat op $400 \mathrm{~kg}$ nw per jaar. Op lichte gronden zal de hoeveelheid iets kleiner, op zware gronden iets groter zijn. Op kalkrijke kleigronden (meer dan $2 \% \mathrm{CaCO}_{3}$ ) adviseren we geen onderhoudsbekalking.

Löss

De hoeveelheid onderhoudsbekalking die per jaar nodig is voor deze grondsoort is afhankelijk van het organische stofgehalte, de $\mathrm{pH}$, het lutumgehalte en de dikte van de bouwvoor. Tabel 5.3 toont de geadviseerde kalkgift (kg nw/ha) per jaar bij een bouwvoordikte van $20 \mathrm{~cm}$. Wanneer de bouwvoordikte afwijkt van deze waarde, moet de kalkgift in dezelfde verhouding worden aangepast.

Tabel 5.3 Benodigde jaarlijkse onderhoudsbekalking (kg nw/ha) voor löss bij een bouwvoordikte van $20 \mathrm{~cm}$

\begin{tabular}{|c|c|c|c|c|c|c|c|c|c|}
\hline \multirow[t]{2}{*}{ \% Lutum } & \multicolumn{3}{|c|}{$\begin{array}{c}\text { pH } 5.5 \\
\text { org.stof (\%) }\end{array}$} & \multicolumn{3}{|c|}{$\begin{array}{c}\text { pH } 6.0 \\
\text { org.stof (\%) }\end{array}$} & \multicolumn{3}{|c|}{$\begin{array}{c}\text { pH 6.5 } \\
\text { org.stof (\%) }\end{array}$} \\
\hline & 1 & 6 & 12 & 1 & 6 & 12 & 1 & 6 & 12 \\
\hline 5 & 40 & 90 & 130 & 70 & 140 & 210 & 100 & 200 & 300 \\
\hline 10 & 80 & 110 & 160 & 120 & 180 & 250 & 170 & 250 & 350 \\
\hline 15 & 110 & 140 & 180 & 170 & 220 & 280 & 240 & 310 & 400 \\
\hline 20 & 140 & 170 & 200 & 220 & 260 & 320 & 310 & 370 & 450 \\
\hline 25 & 170 & 190 & 220 & 270 & 300 & 360 & 380 & 430 & 500 \\
\hline 30 & 200 & 220 & 250 & 320 & 340 & 390 & 450 & 480 & 550 \\
\hline
\end{tabular}




\section{Reparatiebekalking}

Voor de berekening van de kalkgift voor reparatiebekalking worden de grondsoorten verdeeld in twee categorieën:

- $\quad$ Zand, dalgrond en veen

- $\quad$ Rivierklei, zeeklei en löss

Zand, dalgrond en veen

De kalkgift die nodig is voor een reparatiebekalking bij deze grondsoorten, is afhankelijk van het organische stofgehalte, de gewenste $\mathrm{pH}$ verhoging en de bouwvoordikte. In tabel 5.4 is de geadviseerde kalkgift ( $\mathrm{kg}$ nw/ha) per jaar weergegeven bij een bouwvoordikte van $20 \mathrm{~cm}$. Wanneer de bouwvoordikte afwijkt van deze waarde, moet de kalkgift in dezelfde verhouding worden aangepast

Tabel 5.4 Benodigde hoeveelheid reparatiebekalking (kg nw/ha) voor zand, dalgrond en veen bij een bouwvoordikte van $20 \mathrm{~cm}$

\begin{tabular}{ccccc}
\hline Organische stofgehalte (\%) & \multicolumn{4}{c}{ Gewenste $\mathrm{pH}$ verhoging } \\
\cline { 2 - 5 } & 0,2 & 0,4 & 0,6 & 0,8 \\
\hline 1 & 180 & 370 & 550 & 740 \\
5 & 480 & 960 & 1440 & 1920 \\
10 & 760 & 1520 & 2280 & 3040 \\
15 & 970 & 1940 & 2910 & 3880 \\
20 & 1130 & 2270 & 3400 & 4540 \\
25 & 1270 & 2530 & 3800 & 5070 \\
30 & 1380 & 2750 & 4130 & 5500 \\
35 & 1470 & 2930 & 4400 & 5860 \\
40 & 1540 & 3090 & 4630 & 6170 \\
45 & 1610 & 3220 & 4830 & 6440 \\
50 & 1670 & 3330 & 5000 & 6670 \\
55 & 1720 & 3440 & 5150 & 6870 \\
60 & 1760 & 3520 & 5290 & 7050 \\
65 & 1800 & 3600 & 5410 & 7210 \\
70 & 1840 & 3670 & 5510 & 7350 \\
\hline
\end{tabular}

Rivierklei, löss en zeeklei

Bij de berekeningen van de hoeveelheid kalk die nodig is om de gewenste $\mathrm{pH}$ te bereiken worden voor deze grondsoorten twee trajecten onderscheiden, namelijk bekalking tot $\mathrm{pH}$ 6,4 en bekalking vanaf $\mathrm{pH} 6,4$ tot de gewenste $\mathrm{pH}$. Indien de gevonden $\mathrm{pH}$ lager is dan 6,4 en de gewenste $\mathrm{pH}$ is hoger dan 6,4, moet men eerst de kalkgift over het $\mathrm{pH}$-traject tot pH 6,4 berekenen (tabel 5.5). Vervolgens dient de kalkgift over het $\mathrm{pH}$-traject van 6,4 tot de gewenste $\mathrm{pH}$ te worden berekend (tabel 5.6). De totale gift is dan de som van beide kalkgiften. 
Tabel 5.5 Hoeveelheid benodigde kalk (kg nw/ha) voor zeeklei, rivierklei en löss om de pH te verhogen tot 6,4 bij een bouwvoordikte van

\begin{tabular}{|c|c|c|c|c|c|c|c|c|c|c|c|c|c|}
\hline \multirow{2}{*}{$\begin{array}{c}\text { Gewenste } \\
\text { PH } \\
\text { Verhoging }\end{array}$} & \multirow{2}{*}{$\begin{array}{c}\text { Org. } \\
\text { stof (\%) } \\
\text { Lutum (\%) }\end{array}$} & \multicolumn{4}{|c|}{1} & \multicolumn{4}{|c|}{5} & \multicolumn{4}{|c|}{10} \\
\hline & & 8 & 16 & 32 & 64 & 8 & 16 & 32 & 64 & 8 & 16 & 32 & 64 \\
\hline \multicolumn{14}{|l|}{ Zeeklei } \\
\hline 0.2 & & 230 & 410 & 760 & 1460 & 400 & 550 & 840 & 1440 & 580 & 720 & 983 & 1518 \\
\hline 0.4 & & 470 & 820 & 1520 & 2920 & 790 & 1090 & 1690 & 2870 & 1160 & 1430 & 1966 & 3036 \\
\hline 0.6 & & 700 & 1230 & 2280 & 4380 & 1190 & 1640 & 2530 & 4310 & 1750 & 2150 & 2949 & 4554 \\
\hline 0.8 & & 940 & 1640 & 3040 & 5840 & 1590 & 2180 & 3370 & 5750 & 2330 & 2860 & 3932 & 6071 \\
\hline \multicolumn{14}{|c|}{ Voor rivierklei en löss moeten bovenstaande uitkomsten vermenigvuldigd worden met onderstaande factor in dezelfde kolom } \\
\hline Rivierklei & & 1.07 & 1.08 & 1.09 & 1.09 & 1.04 & 1.05 & 1.07 & 1.08 & 1.02 & 1.04 & 1.05 & 1.07 \\
\hline Löss & & 1.25 & 1.29 & 1.31 & 1.33 & 1.13 & 1.19 & 1.24 & 1.28 & 1.08 & 1.13 & 1.19 & 1.24 \\
\hline
\end{tabular}


Tabel 5.6 Hoeveelheid benodigde kalk (kg nw/ha) voor zeeklei, rivierklei en löss om de pH te verhogen vanaf 6,4 bij een bouwvoordikte van $20 \mathrm{~cm}$

\begin{tabular}{|c|c|c|c|c|c|c|c|c|c|c|c|c|c|c|}
\hline \multirow[t]{2}{*}{$\overline{\mathrm{pH}}$} & \multirow{2}{*}{$\begin{array}{l}\text { Gewenste } \\
\text { PH } \\
\text { verhoging }\end{array}$} & \multirow{2}{*}{$\begin{array}{c}\text { Org. } \\
\text { stof (\%) } \\
\text { Lutum }\end{array}$} & \multicolumn{4}{|c|}{1} & \multicolumn{4}{|c|}{5} & \multicolumn{4}{|c|}{10} \\
\hline & & & 8 & 16 & 32 & 64 & 8 & 16 & 32 & 64 & 8 & 16 & 32 & 64 \\
\hline \multicolumn{15}{|c|}{ Zeeklei } \\
\hline \multirow[t]{4}{*}{6.4} & 0.2 & & 350 & 610 & 1140 & 2190 & 600 & 820 & 1260 & 2150 & 870 & 1070 & 1470 & 2280 \\
\hline & 0.4 & & 880 & 1530 & 2850 & 5480 & 1490 & 2050 & 3160 & 5390 & 2180 & 2680 & 3690 & 5690 \\
\hline & 0.6 & & 1640 & 2860 & 5320 & 10220 & 2780 & 3820 & 5900 & 10050 & 4070 & 5010 & 6880 & 10630 \\
\hline & 0.8 & & 4090 & 7160 & 13290 & & 6950 & 9550 & 14740 & & 10180 & 12520 & 17200 & \\
\hline \multirow[t]{3}{*}{6.6} & 0.2 & & 530 & 920 & 1710 & 3286 & 890 & 1230 & 1900 & 3230 & 1310 & 1610 & 2210 & 3420 \\
\hline & 0.4 & & 1290 & 2250 & 4180 & 8030 & 2180 & 3000 & 4630 & 7900 & 3200 & 3940 & 5410 & 8350 \\
\hline & 0.6 & & 3740 & 6550 & 12150 & & 6350 & 8730 & 13480 & & 9310 & 11450 & 15730 & \\
\hline \multirow[t]{2}{*}{6.8} & 0.2 & & 760 & 1330 & 2470 & 4750 & 1290 & 1770 & 2740 & 4670 & 1890 & 2330 & 3200 & 4930 \\
\hline & 0.4 & & 3220 & 5630 & 10440 & 20080 & 5460 & 7500 & 11580 & 19750 & 8000 & 9840 & 13520 & 20870 \\
\hline 7 & 0.2 & & 2460 & 4300 & 7970 & & 4170 & 5730 & 8850 & & 6110 & 7510 & & \\
\hline
\end{tabular}

Voor rivierklei en löss moeten bovenstaande uitkomsten vermenigvuldigd worden met onderstaande factor in dezelfde kolom

\begin{tabular}{lllll|llll|llll} 
Rivierklei & 1.07 & 1.08 & 1.09 & 1.09 & 1.04 & 1.05 & 1.07 & 1.08 & 1.02 & 1.04 & 1.05 & 1.07 \\
Löss & 1.25 & 1.29 & 1.31 & 1.33 & 1.13 & 1.19 & 1.24 & 1.28 & 1.08 & 1.13 & 1.19 & 1.24 \\
\hline
\end{tabular}

\subsubsection{Stikstof}

Het grootste deel van de stikstof bevindt zich in de eiwitverbindingen van de plant. In bladeren is chlorofyl zo'n belangrijke eiwitverbinding. Stikstof is daarom erg belangrijk voor de groei en ontwikkeling van de plant. De stikstof kan afkomstig zijn uit verschillende bronnen. In het huidige stikstofadvies wordt naast de werkzame stikstof uit dierlijke mest en kunstmest ook rekening gehouden met de stikstofvoorraad in de bodem in het voorjaar en de nalevering uit een ondergeploegde gewas(resten). Er bestaat een relatie tussen de totale hoeveelheid beschikbare stikstof uit genoemde bronnen en de opbrengst. Deze relatie is weergegeven in figuur 5.1. 
Figuur 5.1 Relatie tussen de totale hoeveelheid werkzame stikstof en de relatieve opbrengst

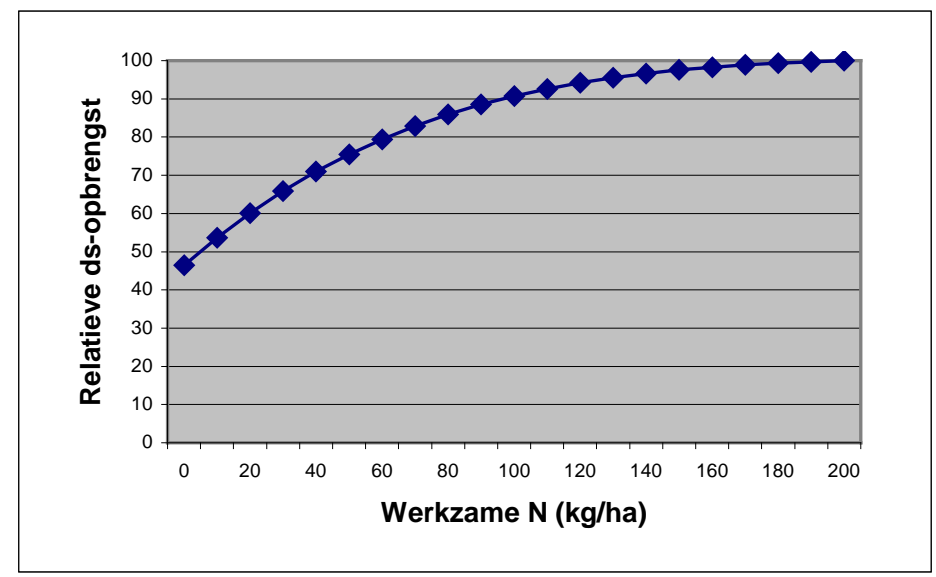

Bron: Schröder, 1998

Het huidige stikstofadvies voor snijmaïs is gericht op een economische optimale gewasopbrengst. De gift blijkt daarbij niet afhankelijk te zijn van het opbrengstniveau. Onderzoek gaf tot nu toe geen aanleiding om onderscheid in grondsoorten te maken. De basis van het advies staat in tabel 5.7. Het advies geldt zowel voor continuteelt als voor teelt in vruchtwisseling.

Tabel 5.7 Advies voor stikstofbemesting van snijmaïs (kg werkzame stikstof/ha)

\begin{tabular}{lll}
\hline & \multicolumn{2}{c}{ Drijfmestgebruik (m³/ha/jaar) in het verleden } \\
\cline { 2 - 3 } & Minder dan 10 & Meer dan 50 \\
\hline Advies voor zaai & $205-\mathrm{Nmin}(0-30 \mathrm{~cm})-\mathrm{N}$-nalevering & $180-\mathrm{Nm}$ min(0-30cm) - N-nalevering \\
Advies juni & $210-\mathrm{Nmin}(0-60)$ & $210-\mathrm{Nmin}(0-60)$ \\
\hline
\end{tabular}

\section{Drijfmestgebruik in het verleden}

Ligt het niveau van drifmestgebruik in het verleden tussen 50 en $10 \mathrm{~m}^{3} / \mathrm{ha}$ dan dient als advies een passende evenredige waarde tussen de 180-Nmin en 205-Nmin te worden gekozen. De lengte van de periode waarover het drijfmestgebruik in het verleden moet worden vastgesteld is niet exact vanuit het onderzoek aan te geven, maar is in ieder geval meer dan 5 jaar.

\section{Nmin-gehalte bij advies voor zaai}

Op zandgrond hoeft het $\mathrm{N}$-min gehalte voor zaai niet apart te worden bepaald. Wanneer men geen groenbemester teelt, kan hiervoor gemiddeld $20 \mathrm{~kg} / \mathrm{ha}$ worden aangehouden. Alleen na droge winters en op zwaardere gronden is het zinvol een aparte bepaling te laten uitvoeren. Bij een goed geslaagde groenbemester kan men gemiddeld een $\mathrm{N}$-min-gehalte van $10 \mathrm{~kg} / \mathrm{ha}$ aanhouden, omdat ongeveer $10 \mathrm{~kg} \mathrm{~N}$-min wordt vastgelegd in de groenbemester.

De bemonstering voor de Nmin-bepaling dient zo kort mogelijk voor het zaaien te gebeuren. Daarbij moet rekening houden met de tijd die nodig is voor analyse en rapportage van de uitslag.

\section{N-nalevering}

Zie voor nalevering van stikstof paragraaf 5.4 en 5.5. 


\section{Nmin-gehalte bij advies juni}

Een Nmin-bepaling is alleen zinvol als het voorjaar uitzonderlijk koud en nat was waardoor twijfels bestaan over de beschikbaarheid van voldoende Nmin door geringe mineralisatie.

Een bemesting na opkomst en vóór het 6-bladstadium is alleen lonend als de hoeveelheid Nmin lager is dan $175 \mathrm{~kg} / \mathrm{ha}$. In het algemeen wordt een strategie met gedeelde giften niet aanbevolen. De bemonstering voor de Nmin-bepaling voor het advies in juni dient 15 tot $20 \mathrm{~cm}$ naast de rij plaats te vinden en in het 3- of 4-bladstadium, zodat men een eventuele bemesting voor het 6-bladstadium kan uitvoeren.

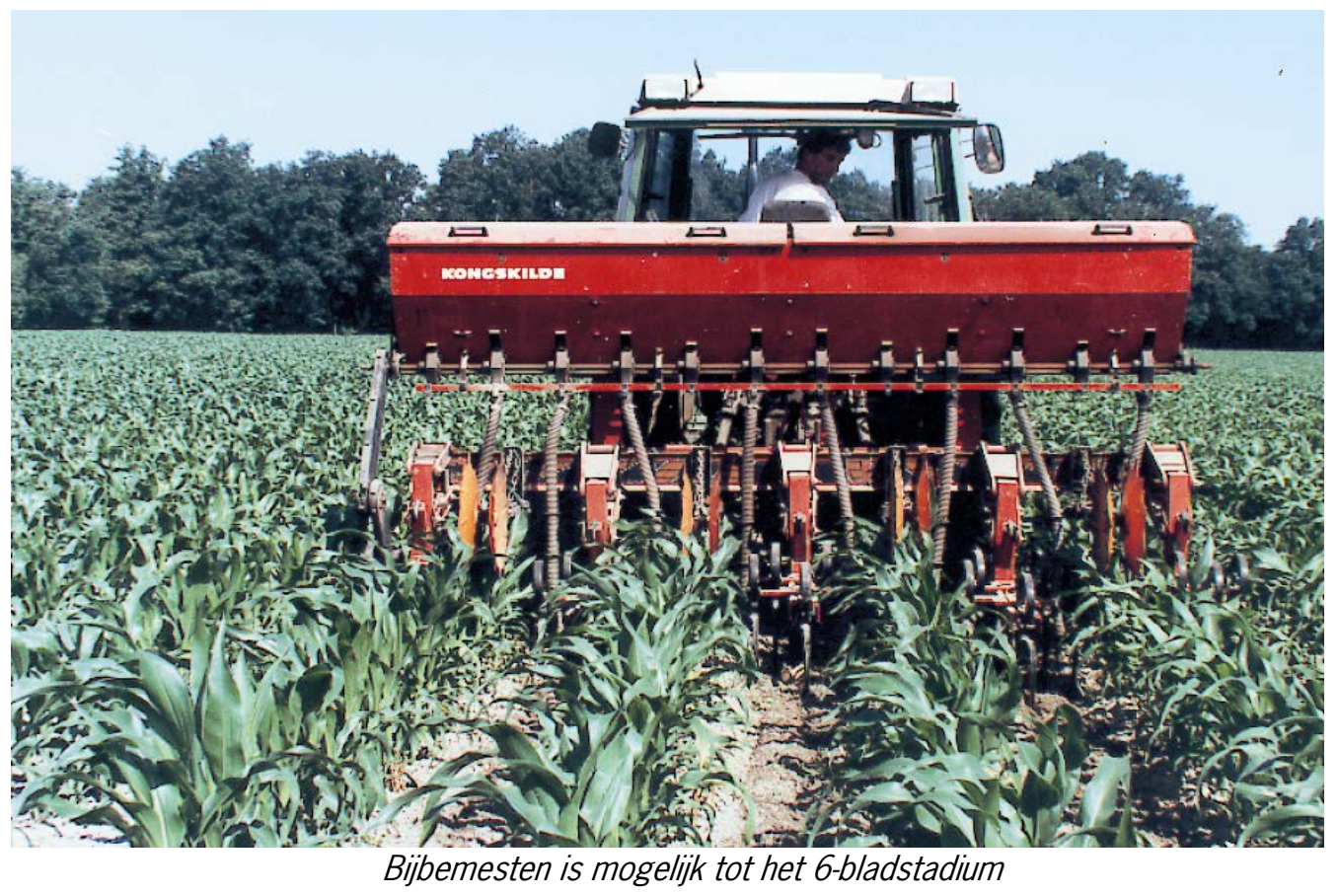

\section{NLV}

Tegenwoordig vermeld het Blgg AgroXpertus op het verslag van grondonderzoek evenals bij grasland ook bij bouwland het stikstofleverend vermogen (NLV). Dit is een door Blgg Agro Xpertus ontwikkeld systeem, gebaseerd op het $\mathrm{N}$-totaal gehalte en de $\mathrm{C} / \mathrm{N}$-verhouding van de bodem. $\mathrm{Op}$ basis van deze NLV wordt het stikstofadvies gecorrigeerd. Het is echter niet door de Commissie Bemesting Grasland en Voedergewassen geaccordeerd. Binnen het onderzoek wordt bekeken in hoeverre een NLV-systeem voor bouwland mogelijk is.

\subsubsection{Fosfaat}

Fosfaat komt in de plant hoofdzakelijk voor in eiwitten en is van grote betekenis voor de stofwisselingsprocessen.

De behoefte aan fosfaatbemesting is afhankelijk van grondsoort, de fosfaattoestand van de bodem en de onttrekking door het gewas. Het advies bestaat uit een gewasgericht en een bodemgericht advies. Aan beide adviezen moet worden voldaan voor een landbouwkundig goed resultaat. 


\section{Bodemgericht advies}

Voor het bodemgericht advies wordt op bouwland de fosfaattoestand aangegeven met het Pwgetal. Voor de waardering van de fosfaattoestand zie "Adviesbasis bemesting grasland en voedergewassen" www.bemestingsadvies.nl.

Tabel 5.8 geeft de streefwaarde voor een optimale opbrengst en de range waarin geadviseerd wordt de fosfaattoestand te handhaven. Voor het handhaven van een bestaande fosfaattoestand moet gemiddeld over het bouwplan de fosfaatafvoer door de gewassen en de onvermijdbare fosfaatverliezen worden gecompenseerd. Voor de onvermijdbare verliezen kan worden uitgegaan van $20 \mathrm{~kg} \mathrm{P} \mathrm{O}_{5} / \mathrm{ha} / \mathrm{jaar}$. De gemiddelde fosfaatafvoer kan worden geschat door de opbrengst van de verschillende gewassen te vermenigvuldigen met een gemiddeld fosfaatgehalte. Met snijmaiis wordt bij een gemiddeld opbrengstniveau van 16,5 ton ds/ha circa $75 \mathrm{~kg}$ fosfaat per ha afgevoerd.

Tabel 5.8 Gewenste Pw-getal en het traject waarbinnen geadviseerd wordt de toestand te handhaven

\begin{tabular}{lcc}
\hline Grondsoort & Streefgetal & Toestand handhaven \\
\hline Zeeklei & 25 & $25 \mathrm{t} / \mathrm{m} \mathrm{45}$ \\
Zand, rivierklei, löss & 30 & $30 \mathrm{t} / \mathrm{m} \mathrm{45}$ \\
\hline
\end{tabular}

Naast het compenseren van de fosfaatonttrekking en verliezen kan het nodig zijn de fosfaattoestand van de bodem te verhogen. Tabel 5.9 geeft de hoeveelheid fosfaat die boven de onttrekking nodig is om het Pw-getal te verhogen tot Pw-getal 25 op zeeklei en Pw-getal 30 op de overige gronden. Er wordt geadviseerd niet meer dan $500 \mathrm{~kg}$ fosfaat per ha te geven om negatieve effecten van het geven van grote fosfaatgiften te voorkomen.

Tabel 5.9 Hoeveelheid fosfaat $\left(\mathrm{kg} \mathrm{P}_{2} \mathrm{O}_{5} / \mathrm{ha}\right.$ ) die boven de onttrekking nodig is om het Pw-getal te verhogen tot Pw-getal 25 op zeeklei en Pw-getal 30 op de overige gronden

\begin{tabular}{lcc}
\hline Pw-getal & Zeeklei & Zand, rivierklei, löss \\
\hline 1 & 1500 & 1710 \\
5 & 1130 & 1340 \\
10 & 780 & 990 \\
15 & 490 & 700 \\
20 & 230 & 440 \\
25 & 0 & 210 \\
30 & 0 & 0 \\
\hline
\end{tabular}

\section{Gewasgericht advies inclusief handhaving bodemvruchtbaarheid}

Het advies is opgedeeld in een deel voor de optimale gewasproductie en een deel voor handhaving van de bodemvruchtbaarheid. Het advies voor de optimale gewasproductie geeft aan hoeveel fosfaat in de rij nodig is om een optimale productie in het jaar van bemesting te behalen. Dit advies ligt beneden de onttrekking van fosfaat door snijmaïs. In de loop van de tijd zal de bodemvruchtbaarheid bij deze bemesting dalen en daarmee de opbrengst. Daarom wordt geadviseerd om aan te vullen tot onttrekking om de bodemvruchtbaarheid te handhaven. Met snijmaïs wordt bij een gemiddeld opbrengstniveau van 16,5 ton ds/ha circa $75 \mathrm{~kg}$ fosfaat per ha afgevoerd. In tabel 5.10 staan de fosfaatgiften in de rij vermeld die nodig zijn bij de huidige fosfaattoestand, uitgedrukt in P-AL en P-Calciumchloride (P-PAE), om de economisch optimale opbrengst te bereiken. Dit is gegeven zonder een breedwerpige gift en met een breedwerpige gift van $60 \mathrm{~kg}$ fosfaat per ha. De fosfaat in de rij kan gegeven worden met kunstmest of met dierlijke mest. Om de mest goed in de bouwvoor te kunnen werken wordt aanbevolen om bij rijenbemesting met drijfmest niet meer dan 35-40 $\mathrm{m}^{3}$ per ha toe te dienen. 
Tabel 5.10 Gewasgericht advies voor fosfaat rijenbemesting in $\mathrm{kg}_{2} \mathrm{O}_{5}$ per ha voor maïs in continuteelt en vruchtwisseling op alle grondsoorten naast $60 \mathrm{~kg} \mathrm{P}_{2} \mathrm{O}_{5}$ breedwerpig (ca. 35-40 m3 per ha runderdrijfmest ( $\mathrm{rdm})$ ) en zonder een breedwerpige gift

\begin{tabular}{|c|c|c|c|c|c|}
\hline \multirow{2}{*}{$\begin{array}{l}\text { P-CaCl } \\
\text { (P-PAE) }\end{array}$} & \multirow{2}{*}{$\begin{array}{l}\text { P-AL- } \\
\text { getal }\end{array}$} & \multicolumn{2}{|c|}{ 35-45 m3 RDM per ha } & \multicolumn{2}{|c|}{ Geen breedwerpige gift } \\
\hline & & $\begin{array}{l}\text { Advies in de rij } \\
\left(\mathrm{kg} \mathrm{P}_{2} \mathrm{O}_{5} / \mathrm{ha}\right)\end{array}$ & $\begin{array}{l}\text { Basisgift breed- } \\
\text { werpig uit RDM } \\
\left(\mathrm{kg} \mathrm{P}_{2} \mathrm{O}_{5} / \mathrm{ha}\right)\end{array}$ & $\begin{array}{l}\text { Advies in de rij } \\
\left(\mathrm{kg} \mathrm{P}_{2} \mathrm{O}_{5} / \mathrm{ha}\right)\end{array}$ & $\begin{array}{c}\text { Advies ivm } \\
\text { handhaving } \\
\text { bodemvruchtbh }\end{array}$ \\
\hline 1 & 10 & 27 & 60 & 34 & \\
\hline 1 & 15 & 25 & 60 & 32 & \\
\hline 1 & 20 & 23 & 60 & 29 & \\
\hline 1 & 25 & 21 & 60 & 27 & Advies: \\
\hline 1 & 30 & 20 & 60 & 25 & opvullen tot \\
\hline 1 & 35 & 18 & 60 & 23 & onttrekking \\
\hline 1 & 40 & 17 & 60 & 22 & \\
\hline 1 & 45 & 17 & 60 & 22 & \\
\hline 1 & 50 & 17 & 60 & 22 & \\
\hline 1 & 55 & 17 & 60 & 22 & \\
\hline 1 & 60 & 17 & 60 & 22 & \\
\hline 1 & 65 & 17 & 60 & 22 & \\
\hline 1 & 70 & 17 & 60 & 22 & \\
\hline 2 & 15 & 20 & 60 & 26 & \\
\hline 2 & 20 & 20 & 60 & 25 & \\
\hline 2 & 25 & 19 & 60 & 24 & \\
\hline 2 & 30 & 18 & 60 & 23 & Advies: \\
\hline 2 & 35 & 18 & 60 & 22 & opvullen tot \\
\hline 2 & 40 & 17 & 60 & 22 & onttrekking \\
\hline 2 & 45 & 16 & 60 & 21 & \\
\hline 2 & 50 & 16 & 60 & 20 & \\
\hline 2 & 55 & 15 & 60 & 19 & \\
\hline 2 & 60 & 15 & 60 & 18 & \\
\hline 2 & 65 & 14 & 60 & 18 & \\
\hline 2 & 70 & 13 & 60 & 17 & \\
\hline 3 & 20 & 15 & 60 & 19 & \\
\hline 3 & 25 & 15 & 60 & 19 & \\
\hline 3 & 30 & 14 & 60 & 18 & Advies: \\
\hline 3 & 35 & 14 & 60 & 18 & opvullen tot \\
\hline 3 & 40 & 14 & 60 & 17 & onttrekking \\
\hline 3 & 45 & 13 & 60 & 17 & \\
\hline 3 & 50 & 13 & 60 & 17 & \\
\hline 3 & 55 & 13 & 60 & 16 & \\
\hline 3 & 60 & 12 & 60 & 16 & \\
\hline 3 & 65 & 12 & 60 & 15 & \\
\hline 3 & 70 & 12 & 60 & 15 & \\
\hline
\end{tabular}


Handboek snijmaïs

\begin{tabular}{|c|c|c|c|c|c|}
\hline \multirow[t]{2}{*}{$\mathrm{P}-\mathrm{CaCl}{ }_{2}$} & \multirow{2}{*}{$\begin{array}{l}\text { P-AL- } \\
\text { getal }\end{array}$} & \multicolumn{2}{|c|}{ 35-45 m3 RDM per ha } & \multicolumn{2}{|c|}{ Geen breedwerpige gift } \\
\hline & & $\begin{array}{l}\text { Advies in de rij } \\
\left(\mathrm{kg} \mathrm{P}_{2} \mathrm{O}_{5} / \mathrm{ha}\right)\end{array}$ & $\begin{array}{c}\text { Basisgift breed- } \\
\text { werpig uit RDM } \\
\left(\mathrm{kg} \mathrm{P}_{2} \mathrm{O}_{5} / \mathrm{ha}\right)\end{array}$ & $\begin{array}{l}\text { Advies in de rij } \\
\left(\mathrm{kg} \mathrm{P}_{2} \mathrm{O}_{5} / \mathrm{ha}\right)\end{array}$ & $\begin{array}{c}\text { Advies ivm } \\
\text { handhaving } \\
\text { bodemvruchtbh }\end{array}$ \\
\hline 4 & 30 & 11 & 60 & 14 & \\
\hline 4 & 35 & 11 & 60 & 14 & Advies: \\
\hline 4 & 40 & 11 & 60 & 13 & opvullen tot \\
\hline 4 & 45 & 10 & 60 & 13 & onttrekking \\
\hline 4 & 50 & 10 & 60 & 13 & \\
\hline 4 & 55 & 10 & 60 & 13 & \\
\hline 4 & 60 & 10 & 60 & 12 & \\
\hline 4 & 65 & 10 & 60 & 12 & \\
\hline 4 & 70 & 10 & 60 & 12 & \\
\hline 5 & 30 & 8 & 60 & 11 & \\
\hline 5 & 35 & 8 & 60 & 10 & Advies: \\
\hline 5 & 40 & 8 & 60 & 10 & opvullen tot \\
\hline 5 & 45 & 8 & 60 & 10 & onttrekking \\
\hline 5 & 50 & 8 & 60 & 10 & \\
\hline 5 & 55 & 8 & 60 & 10 & \\
\hline 5 & 60 & 8 & 60 & 10 & \\
\hline 5 & 65 & 8 & 60 & 9 & \\
\hline 5 & 70 & 7 & 60 & 9 & \\
\hline 6 & 35 & 6 & 60 & 8 & \\
\hline 6 & 40 & 6 & 60 & 8 & Advies: \\
\hline 6 & 45 & 6 & 60 & 8 & opvullen tot \\
\hline 6 & 50 & 6 & 60 & 8 & onttrekking \\
\hline 6 & 55 & 6 & 60 & 7 & \\
\hline 6 & 60 & 6 & 60 & 7 & \\
\hline 6 & 65 & 6 & 60 & 7 & \\
\hline 6 & 70 & 6 & 60 & 7 & \\
\hline 7 & 40 & 5 & 60 & 6 & \\
\hline 7 & 45 & 5 & 60 & 6 & Advies: \\
\hline 7 & 50 & 5 & 60 & 6 & opvullen tot \\
\hline 7 & 55 & 5 & 60 & 6 & onttrekking \\
\hline 7 & 60 & 0 & 60 & 6 & \\
\hline 7 & 65 & 0 & 60 & 6 & \\
\hline 7 & 70 & 0 & 60 & 5 & \\
\hline 8 & 45 & 0 & 0 & 0 & \\
\hline 8 & 50 & 0 & 0 & 0 & \\
\hline 8 & 55 & 0 & 0 & 0 & \\
\hline 8 & 60 & 0 & 0 & 0 & \\
\hline 8 & 65 & 0 & 0 & 0 & \\
\hline 8 & 70 & 0 & 0 & 0 & \\
\hline 10 & 50 & 0 & 0 & 0 & \\
\hline 10 & 55 & 0 & 0 & 0 & \\
\hline 10 & 60 & 0 & 0 & 0 & \\
\hline 10 & 65 & 0 & 0 & 0 & \\
\hline 10 & 70 & 0 & 0 & 0 & \\
\hline 10 & 75 & 0 & 0 & 0 & \\
\hline
\end{tabular}




\subsubsection{Kali}

Kali wordt vooral aangetroffen in jonge weefsels en in transportorganen. In tegenstelling tot stikstof en fosfaat komt kali vrijwel niet voor in organisch gebonden vorm. Kali is van belang voor de stevigheid van de plant en is nodig voor de werking van een groot aantal enzymen en het goed functioneren van transportfuncties van de plant. Ook speelt het een positieve rol bij resistentie tegen ziektes, met name fusarium, en tegen droogte.

De behoefte aan kalibemesting is afhankelijk van grondsoort, kalitoestand van de bodem en teeltsysteem. De kalitoestand wordt uitgedrukt met het K-getal. Voor de waardering van de kalitoestand van de bodem zie "Adviesbasis bemesting grasland en voedergewassen" www.bemestingsadvies.nl. In tabel 5.11 is het bemestingsadvies voor kali weergegeven voor continuteelt. Dit advies is een combinatie van een bodem- en gewasgericht advies. Toepassing hiervan leidt tot een optimale gewasopbrengst en voorkomt dat de kalitoestand te laag wordt.

Tabel 5.11 Advies voor kalibemesting voor snijmaïs in continuteelt

\begin{tabular}{ccccc}
\hline K-getal & \multicolumn{4}{c}{ Grondsoort } \\
\cline { 2 - 5 } (KHCL voor Löss) & Veen & Zand- en dalgrond & Zee- en rivierklei & Löss \\
\hline$\leq 11$ & 300 & 300 & 300 & 300 \\
12 & 280 & 260 & 300 & 300 \\
14 & 250 & 210 & 300 & 260 \\
16 & 230 & 160 & 240 & 190 \\
18 & 200 & 110 & 190 & 120 \\
20 & 180 & 60 & 140 & 60 \\
22 & 150 & 30 & 90 & 0 \\
24 & 130 & 0 & 40 & 0 \\
26 & 100 & 0 & 0 & 0 \\
28 & 80 & 0 & 0 & 0 \\
30 & 50 & 0 & 0 & 0 \\
32 & 30 & 0 & 0 & 0 \\
34 & 0 & 0 & 0 & 0 \\
\hline
\end{tabular}

In tabel 5.12 is het bemestingsadvies weergegeven voor teelt in vruchtwisseling. In tegenstelling tot het advies bij continuteelt is dit advies alleen gericht op een optimale gewasopbrengst. Indien men de kalitoestand wil handhaven moet men rekening houden met de onttrekking van gemiddeld $230 \mathrm{~kg}$ per ha plus een onvermijdbaar verlies van $50 \mathrm{~kg}$ per ha. 
Tabel 5.12 Advies voor kalibemesting voor teelt van snijmaïs in vruchtwisseling

\begin{tabular}{ccccc}
\hline K-getal & \multicolumn{4}{c}{ Grondsoort } \\
\cline { 2 - 5 } (KHCL voor Löss) & Veen & Zand- en dalgrond & Zee- en rivierklei & Löss \\
\hline$\leq 4$ & 220 & - & - & 160 \\
6 & 190 & 160 & 180 & 150 \\
8 & 160 & 130 & 160 & 130 \\
10 & 130 & 100 & 130 & 110 \\
12 & 110 & 70 & 110 & 90 \\
14 & 90 & 50 & 80 & 70 \\
16 & 70 & 30 & 60 & 40 \\
18 & 60 & 0 & 40 & 0 \\
20 & 50 & 0 & 0 & 0 \\
22 & 40 & 0 & 0 & 0 \\
24 & 30 & 0 & 0 & 0 \\
26 & 0 & 0 & 0 & 0 \\
\hline
\end{tabular}

\subsubsection{Magnesium}

Magnesium is een bestanddeel van het chlorofyl en dus van belang bij het fotosyntheseproces. Het speelt bovendien een rol bij de opbouw van eiwitten. De behoefte aan magnesium is in eerste instantie afhankelijk van de grondsoort. Er wordt een onderscheid gemaakt tussen enerzijds zand, dalgrond en löss en anderzijds kleigrond en alluviaal zand (zeezand).

\section{Zand, dalgrond en löss}

Het streefgetal voor de magnesiumtoestand is $75 \mathrm{mg} \mathrm{MgO} \mathrm{per} \mathrm{kg}$ grond. Voor zand, dalgrond en löss is het advies voor magnesiumbemesting afhankelijk van de magnesiumtoestand, het aantal jaren na grondonderzoek, het organische stofgehalte en de bouwvoordikte. Tabel 5.13 toont het advies voor magnesiumbemesting bij een bouwvoordikte van $25 \mathrm{~cm}$. Wanneer de bouwvoor dikker of dunner is, moet het advies in dezelfde verhouding worden aangepast. Het magnesiumadvies is gebaseerd op de werking van magnesiumsulfaat. De werking van magnesium in dierlijke mest is hieraan gelijk. 
Tabel 5.13 Advies voor magnesiumbemesting (kg Mg0 per ha) voor zand-, dal- en lössgronden bij een bouwvoor dikte van $25 \mathrm{~cm}$

\begin{tabular}{|c|c|c|c|c|c|c|}
\hline \multirow{2}{*}{$\begin{array}{l}\text { Mg0-gehalte } \\
\text { (mg MgO per kg } \\
\text { grond) }\end{array}$} & \multirow[t]{2}{*}{ Jaren na onderzoek } & \multicolumn{5}{|c|}{ Organische stofgehalte (\%) } \\
\hline & & 1 & 5 & 10 & 15 & 20 \\
\hline \multirow[t]{2}{*}{$\overline{0-75}$} & $1^{1}$ & $0-276$ & $0-240$ & $0-206$ & $0-182$ & $0-161$ \\
\hline & $2 \mathrm{t} / \mathrm{m} 4$ & 76 & 66 & 57 & 50 & 45 \\
\hline \multirow[t]{2}{*}{$75-109$} & 1 & \multicolumn{3}{|c|}{ Geen bemesting } & & \\
\hline & $2 \mathrm{t} / \mathrm{m} 4$ & 76 & 66 & 57 & 50 & 45 \\
\hline \multirow[t]{2}{*}{$110-174$} & 1 en 2 & \multicolumn{3}{|c|}{ Geen bemesting } & & \\
\hline & 3 en 4 & 76 & 66 & 57 & 50 & 45 \\
\hline \multirow[t]{2}{*}{$175-300$} & $1 \mathrm{t} / \mathrm{m} 3$ & \multicolumn{3}{|c|}{ Geen bemesting } & & \\
\hline & 4 & 76 & 66 & 57 & 50 & 45 \\
\hline$>300$ & $1 \mathrm{t} / \mathrm{m} 4$ & \multicolumn{3}{|c|}{ Geen bemesting } & & \\
\hline
\end{tabular}

\section{Kleigronden en alluviaal zand (zeezand)}

Voor kleigrond en zeezand zijn geen richtlijnen. Een bemesting met magnesium heeft op deze gronden doorgaans geen effect. Wanneer zich gebreksverschijnselen voordoen kan magnesiumgebrek op korte termijn het beste worden bestreden door een bespuiting met magnesiummeststoffen. Op basis van het MgO-gehalte van de grond kan de kans op een magnesiumgebrek worden ingeschat. Het streeftraject loopt van 60 tot $120 \mathrm{mg} \mathrm{MgO/kg} \mathrm{grond.}$ Beneden $60 \mathrm{mg} / \mathrm{kg}$ neemt met name op de lichtere kalkrijke kleigronden de kans op gebreksverschijnselen toe.

\subsubsection{Borium, koper, mangaan en zwavel}

\section{Borium}

Borium is in de plant aanwezig in groeipunten, bloeiwijzen, bladeren en in een deel (floëem) van het transportweefsel. Borium stimuleert de bloei en vruchtzetting. De kans op boriumgebrek is het grootst bij droogte en een te hoge $\mathrm{pH}$. Het advies voor boriumbemesting is voor alle grondsoorten gelijk en afhankelijk van de bodemtoestand. Tabel 5.14 toont de richtlijn voor boriumbemesting per jaar.

Tabel 5.14 Advies voor jaarlijkse boriumbemesting

\begin{tabular}{lc}
\hline $\begin{array}{l}\text { B-gehalte grond } \\
\text { (mg per } \mathrm{kg})\end{array}$ & $\begin{array}{c}\text { Bemesting } \\
\text { (kg B per ha) }\end{array}$ \\
\hline$<0,20$ & 0,4 \\
$0,20-0,29$ & 0,3 \\
$0,30-0,35$ & 0,2 \\
$>0,35$ & Geen \\
\hline
\end{tabular}


Het borium advies geldt voor één jaar. Een voorraadbemesting voor meer dan 2 jaar heeft geen zin, omdat borium gemakkelijk uitspoelt. Te hoge giften kunnen schade opleveren. De boriumonttrekking bedraagt jaarlijks circa 150 gram. Mest bevat circa 4 gram borium per ton. Met mest gegeven borium kan in mindering op het bemestingsadvies worden gebracht.

Wanneer dierlijke mest onvoldoende borium geeft, kan het aangevuld worden door:

- $\quad$ het gebruik van een rijenmeststof met borium;

- $\quad$ het strooien van een vaste specifieke boriumhoudende meststof (bijv., Borax);

- $\quad$ een bespuiting vóór de opkomst van het gewas;

- $\quad$ een boriumbespuiting over het groeiende gewas. Aanbevolen wordt om in het 8-9 bladstadium te spuiten met $0,2 \mathrm{~kg} B$ per ha.

\section{Koper}

Koper is evenals borium belangrijk voor de korrelzetting. Het advies voor koper is gelijk voor alle grondsoorten. Tabel 5.15 geeft het bemestingsadvies voor koper weer. In het algemeen wordt met dierlijke mest voldoende koper gegeven.

Tabel 5.15 Advies voor koperbemesting

\begin{tabular}{cc}
\hline $\begin{array}{c}\text { Cu-gehalte grond } \\
\text { (mg/kg) }\end{array}$ & $\begin{array}{c}\text { Bemesting } \\
\text { (kg Cu/ha) }\end{array}$ \\
\hline$<3,0$ & 6 \\
$3,0-3,9$ & 2,5 \\
$4,0-9,9$ & 0 \\
$>10,0$ & 0 \\
\hline
\end{tabular}

\section{Mangaan}

Mangaan (Mn) activeert enzymen die een rol spelen bij de ademhaling, de fotosynthese, de celdeling en de vorming van eiwitten en bladgroen. Daarnaast speelt het een rol bij de omzetting van nitraat naar ammoniumverbindingen. Planten met mangaangebrek hebben dan ook een hoger nitraatgehalte. Mangaangebrek uit zich in een doffe olijfgroene kleur van het blad en dorre bladpunten. Ook is de groei geremd waardoor de planten er wat gedrongen uitzien. Voor de behoefte aan mangaan wordt alleen onderscheid gemaakt tussen de grondsoorten zeeklei en zand. Eventueel mangaangebrek kan men tegengaan door een bespuiting met 1,5\% mangaansulfaat (1000 I/ha) en dit naderhand eventueel te herhalen. In de praktijk wordt nauwelijks gecorrigeerd voor mangaangebrek.

Op zeeklei kan grondonderzoek wel een aanwijzing geven of een gebrek te verwachten is. Bemesting is zinvol als het Mn-gehalte lager is dan:

- $\quad 60 \mathrm{mg} / \mathrm{kg}$ bij een organische stofgehalte lager dan 2,5\%

- $100 \mathrm{mg} / \mathrm{kg}$ bij een organische stofgehalte hoger dan 2,5\%.

Op zandgronden heeft de mangaantoestand weinig invloed op de mangaanvoorziening van het gewas. Hier is met name de $\mathrm{pH}$ bepalend. Bij een pH-KCl lager dan 5,4 bestaat er in het algemeen geen gevaar voor mangaangebrek.

\section{Zwavel}

Zwavel (S) is een bestanddeel van eiwitten in de plant. Dit betekent dat zwavel nodig is voor de eiwitvorming. Mais neemt tussen 12 en $25 \mathrm{~kg}$ zwavel (S) per ha op in de vorm van sulfaat. Door de sterk gedaalde zwaveldepositie (minder dan $10 \mathrm{~kg} \mathrm{~S}$ per ha) en het vaak beperkte zwavel leverend vermogen (SLV) van de bodem bestaat er een risico ven tekort aan zwavel voor optimale groei. Het 
zwavel bemestingsadvies is gebaseerd op het SLV en het producti vermogen van het perceel. Het advies maakt geen onderscheid tussen breedwerpige S-bemesting en toediening in de rij. De geadviseerde hoeveelheid zwavel (tabel 5.16) dient via minerale meststoffen verstrekt te worden omdat er via mineralisatie vanuit organische mest slechts weinig $S$ beschikbaar komt.

Tabel 5.16 Advies voor zwavelbemesting

\begin{tabular}{lcc}
\hline $\begin{array}{l}\text { Productievermogen perceel } \\
\text { (ton ds/ha) }\end{array}$ & $\begin{array}{c}\text { SLV } \\
\text { (kg S/ha) }\end{array}$ & $\begin{array}{c}\text { Bemesting } \\
\text { (kg S/ha) }\end{array}$ \\
\hline$<14$ & $<12$ & 10 \\
& $12-20$ & 5 \\
& $>20$ & 0 \\
\hline $14-18$ & $<12$ & 20 \\
& $12-20$ & 15 \\
& $>20$ & 10 \\
\hline 18 & $<5$ & 30 \\
& $5-12$ & 25 \\
& $12-20$ & 20 \\
& $>20$ & 15 \\
\hline
\end{tabular}

\subsection{Toedienen meststoffen}

De meeste snijmaïs wordt op veehouderijbedrijven geteeld. Dit is een goede methode om een deel van de bemesting te geven met dierlijke mest en het resterende deel aan te vullen met kunstmest. Voor ondersteuning van de jeugdgroei is het raadzaam om in ieder geval 20 á $30 \mathrm{~kg}$ stikstof per ha van de adviesgift als rijenbemesting tijdens het zaaien met kunstmest toe te dienen. Vaak wordt tegelijkertijd eenzelfde hoeveelheid fosfaat gegeven. Dit is echter alleen zinvol wanneer de behoefte nog niet gedekt wordt door de hoeveelheid fosfaat uit dierlijke mest.

In extensieve situaties met weinig mest en wanneer de draagkracht te slecht is om nog dierlijke mest te kunnen geven is het te overwegen om alle mest voor grasland te bestemmen en de maïs alleen met kunstmest te bemesten.

Voor een zo hoog mogelijke benutting van stikstof kan men deze, of het nu kunstmest of dierlijke mest betreft, het best zo kort mogelijk voor het zaaien geven. Deling van de gift verdient geen voorkeur. Onderzoek heeft uitgewezen dat deling van de stikstofgift niet leidt tot een hogere opbrengst of een hogere benutting van stikstof. Door de beperkte wortelgroei en -activiteit in de jeugdfase moet de stikstofvoorziening bij maïs al in een vroeg stadium zijn gewaarborgd. Alleen bij de teelt van maïs op gronden met een sterk beperkte bewortelingsdiepte in combinatie met grote hoeveelheden neerslag kan deling aantrekkelijk zijn. Eventuele aanvullende kunstmestgiften naast dierlijke mest kunnen dan ook het best gelijk bij het zaaien worden gegeven.

Wanneer op basis van een bemonstering in het 3-4 bladstadium is gebleken dat een aanvullende bemesting noodzakelijk is, kan men deze het best met kunstmest geven. Dit kan dan worden toegediend in één werkgang met schoffelen. Het gebruik van een kunstmeststrooier raden we af, omdat hierdoor gemakkelijk verbranding kan optreden doordat kunstmestkorrels in de bladkoker terechtkomen.

Wanneer maïs wordt geteeld in rotatie met akkerbouwgewassen kan men ervoor kiezen om de fosfaat en kalibemesting aan het meest behoeftige gewas te geven (zie www.bemestingsadvies.nl). 


\subsubsection{Gebruiksnormen nieuw mestbeleid}

Maïs kan zeer grote giften organische mest verdragen. Grote giften geven echter een lage mineralenbenutting en zijn voor de grondwaterkwaliteit niet gewenst. Om de belasting van het milieu zo veel mogelijk te beperken voert Nederland al jaren een mestbeleid. Vanaf 2006 geldt een nieuw mestbeleid. Centraal onderdeel in dit nieuwe beleid is het stelsel van gebruiksnormen. Deze normen geven aan hoeveel stikstof en fosfaat er jaarlijks in de vorm van dierlijke mest en in totaal gebruikt mag worden. Voor ieder bedrijf gelden drie soorten gebruiksnormen:

- De gebruiksnorm voor dierlijke mest. Deze norm geeft aan hoeveel dierlijke mest, uitgedrukt in kilogrammen stikstof, ieder jaar per hectare gebruikt mag worden.

- De stikstofgebruiksnorm. Deze norm is gewas afhankelijk en geeft aan hoeveel werkzame stikstof in totaal per hectare per jaar gebruikt mag worden.

- De fosfaatgebruiksnorm. Deze norm bepaalt hoeveel fosfaat in totaal per hectare per jaar gebruikt mag worden.

Op dit moment zijn de normen voor 2018 nog niet definitief vastgesteld. Ook is nog niet duidelijk of Nederland ook na 2017 derogatie krijgt en onder welke voorwaarden. Hieronder zijn de normen t/m 2017 weergegeven:

- Gebruiksnorm dierlijke mest:

De gebruiksnorm dierlijke bedraagt in principe $170 \mathrm{~kg} \mathrm{~N}$ per ha. Als u voldoet aan de zgn. derogatie-voorwaarden, dan mag u $250 \mathrm{~kg}$ stikstof uit graasdierenmest gebruiken. Heeft u zand- en lössgronden in gebruik die liggen in de provincie Overijssel, Gelderland, Utrecht, Noord-Brabant of Limburg, dan mag u voor die percelen $230 \mathrm{~kg}$ stikstof per hectare per jaar in de vorm van graasdierenmest gebruiken. Minimaal $80 \%$ van uw totale oppervlakte landbouwgrond moet grasland zijn en u mag geen fosfaat uit kunstmest gebruiken. Meer informatie over voorwaarden kunt u vinden op www.rvo.nl.

- Stikstofgebruiksnorm:

De stikstof gebruiksnorm voor snijmaiis is afhankelijk van grondsoort en of een bedrijf derogatie heeft. In tabel 5.17 zijn de normen voor 2016 t/m 2017 weergegeven. Deze normen zijn inclusief de norm van de aansluitend geteelde groenbemester.

Tabel 5.17 Stikstofgebruiksnormen (kg werkzame N/ha) voor snijmaïs

\begin{tabular}{|c|c|c|c|c|}
\hline & Klei & $\begin{array}{c}\text { Zand excl. } \\
\text { zuidelijk zand }{ }^{1)}\end{array}$ & $\begin{array}{l}\text { Zuidelijk zand }{ }^{1)} \\
\text { en Löss }\end{array}$ & Veen \\
\hline & 2015-2017 & $2015-2017$ & 2015-2017 & $2015-2017$ \\
\hline & 160 & 140 & 112 & 150 \\
\hline Bedrijven zonder derogatie & 185 & 140 & 112 & 150 \\
\hline
\end{tabular}

1) Zandgronden in de provincies Noord-Brabant en Limburg

${ }^{2)}$ De gebruiksnormen voor Löss gelden alleen als het grond betreft die is ontstaan in eolisch materiaal en binnen $80 \mathrm{~cm}$ van het maaiveldvoor meer dan de helft bestaat uit leem (fractie kleiner dan $50 \mu \mathrm{m})$. Voor de overige lössgronden gelden de gebruiksnormen die voor Zand gelden.

- Fosfaatgebruiksnorm:

Bij de fosfaatgebruiksnormen wordt alleen onderscheid gemaakt tussen grasland en bouwland. Vanaf 2010 is de fosfaatgebruiksnorm afhankelijk van de P-toestand van de bodem. In tabel 5.18 zijn de normen voor bouwland weergegeven. Voor fosfaatarme en fosfaatfixerende gronden geldt een gebruiksnorm van $120 \mathrm{~kg}$ per ha. Een perceel bouwland geldt als 
fosfaatarm als Pw-getal kleiner is dan 25. Zie voor verdere voorwaarden over hoe u dit moet aantonen www.rvo.nl.

Tabel 5.18 Fosfaatgebruiksnormen $\left(\mathrm{kg} \mathrm{P}_{2} \mathrm{O}_{5} /\right.$ ha) voor bouwland

\begin{tabular}{llccc}
\hline P-toestand (Pw) & Categorie & 2015 & 2016 & 2017 \\
\hline$<36$ & Laag & 75 & 75 & 75 \\
$36-55$ & Neutraal & 60 & 60 & 60 \\
$>55$ & Hoog & 50 & 50 & 50 \\
\hline
\end{tabular}

De stikstofgebruiksnorm is gebaseerd op de werkzame stikstof. Voor het berekenen van de hoeveelheid werkzame stikstof wordt gebruik gemaakt van een werkingscoëfficiënt. Voor kunstmest is deze $100 \%$. Voor organische meststoffen is deze afhankelijk van mestsoort, herkomst, type bedrijf (met of zonder beweiding) en tijdstip van aanwenden. In tabel 5.19 zijn de werkingscoëfficiënten weergegeven van op het eigen bedrijf geproduceerde drijfmest. Zie voor werkingscoëfficiënten van andere mestsoorten en omstandigheden www.rvo.nl.

Tabel 5.19 Stikstofwerkingscoëfficiënten (\%) van op eigen bedrijf geproduceerde runderdrijfmest

\begin{tabular}{lr} 
& $2015-201$ \\
\hline Bedrijf met beweiding & 45
\end{tabular}

Bedrijf zonder beweiding $\quad 60$

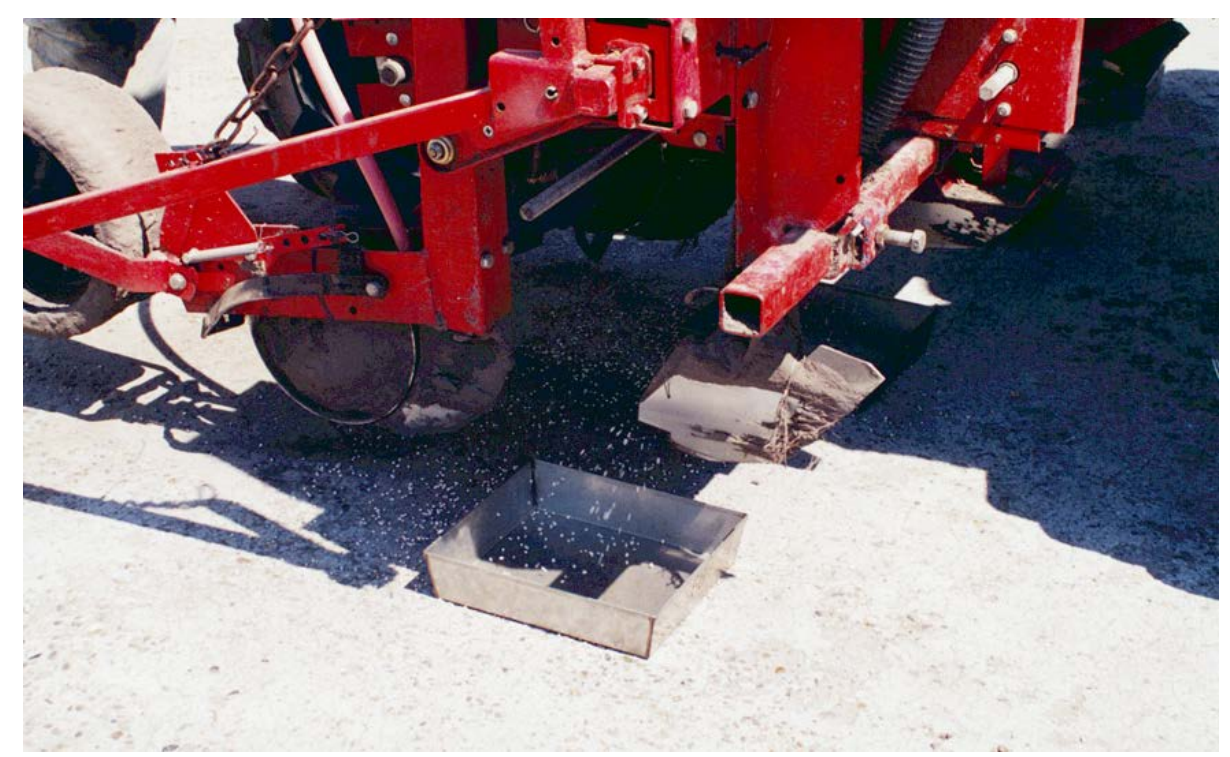

Rijenbemesting stimuleert de jeugdgroei van maïs

\subsubsection{Toedienen kunstmest, rijenbemesting en alternatieven}

De nutriëntenbehoeftes (paragraaf 5.2) gelden voor breedwerpige toediening. Rijenbemesting geeft echter een hogere benutting van de meststoffen. Daarom zijn de maïszaaimachines standaard uitgerust met rijenbemestingsapparatuur. Voor een optimale werking is het van belang dat de meststof op de juiste plek terechtkomt. Dit is circa $5 \mathrm{~cm}$ naast en 3-4 onder het zaad. 
Rijenbemesting met stikstofkunstmest verbetert de stikstofwerking met een factor 1,25. Dit betekent dat van het deel van het advies als rijenbemesting 20\% kan worden afgetrokken. Fosfaatkunstmest mag alleen gebruikt worden op bedrijven zonder derogatie (zie ook paragraaf 5.3.1). Rijenbemesting met fosfaat geeft een veel betere werking dan breedwerpige toediening. Sinds 2010 is de betere werking in het advies geïntegreerd. Om gewasschade te voorkomen adviseren we om niet meer dan totaal $120 \mathrm{~kg}$ zuivere stikstof plus fosfaat als rijenbemesting te geven.

Wanneer de volledige bemesting in de vorm van kunstmest wordt gegeven is het dus raadzaam om alle benodigde hoeveelheid fosfaat in de vorm van rijenbemesting te geven. Het resterende deel tot in totaal $120 \mathrm{~kg}$ per ha kan men dan aanvullen met stikstof. De overige hoeveelheid stikstof en de kalibemesting moet men dan breedwerpig geven. Dit kan het best na het ploegen en voor de zaaibedbereiding worden gegeven, zodat het bovenin de bouwvoor wordt gewerkt.

\section{Nitrificatieremmers}

Stikstof kunstmeststoffen bevatten stikstof (N) in de vorm van nitraat (NO3-), ammonium (NH4+), ureum (CH2N2O) of combinaties van deze vormen. Maïs kan stikstof opnemen in de vorm van nitraat of als ammonium. Nitraat wordt gemakkelijk opgenomen, maar is ook gevoelig voor uitspoeling. Ureum en ammonium spoelen moeilijk uit. Ureum is niet direct opneembaar door het gewas. Het moet eerst in de bodem omgezet worden in ammonium waarbij kans op vervluchtiging bestaat in de vorm van ammoniak.

In de bodem wordt een deel van de ammonium omgezet in nitraat door nitrificerende bacteriën. De snelheid van het proces is afhankelijk van bodemtemperatuur. Bij 20 graden wordt de ammonium uit meststoffen in een paar dagen omgezet in nitraat. Bij lagere temperaturen gaat het langzamer. Bij nitrificatie wordt naast nitraat afhankelijk van de bodemomstandigheden, zoals temperatuur en vocht, meer of minder lachgas (N2O) gevormd.

Nitrificatieremmers hebben als doel om het omzettingsproces van ammonium naar nitraat te vertragen, waardoor (bij gebruik in de landbouw) minder nitraat in de bodem aanwezig is en er dus minder nitraat uit kan spoelen. Daarnaast blijkt het mogelijk, om met behulp van

nitrificatieremmers, de uitstoot van lachgas aanzienlijk te reduceren.

Dierlijke mest bevat naast organisch gebonden stikstof ook minerale stikstof in de vorm van ammonium.

Nitrificatieremmers kunnen daarom aan zowel kunstmest als dierlijke mest toegevoegd worden. Uit onderzoek is gebleken dat het niet zinvol is een nitrificatieremmer aan de mest toe te voegen en tevens kunstmest met een nitrificatieremmer te gebruiken. Een van beide is voldoende.

Er zijn verschillende soorten nitrificatieremmers. In Nederland zijn de volgende toegelaten:

- Dicyaandiamine (DCD)

- Triazol-3MP (Piadin)

- 3,4-Dimethylpyrazole phosphate (DMPP).

De werking van de verschillende soorten nitrificatieremmers is vergelijkbaar. In Nederland zijn recent vooral ervaringen opgedaan met de producten DMPP, toegevoegd aan

ammoniumsulfaatsalpeter kunstmest (Entec) en Piadin, toegevoegd aan drijfmest. DCD wordt vanwege lage werking niet meer gebruikt. Onderzoek op grasland heeft aangetoond dat nitrificatieremmers toegevoegd aan kunstmest vooral in het voorjaar onder natte omstandigheden een positief effect kunnen hebben op stikstofbenutting. Gemiddeld over de jaren is het echter lastig om de extra kosten (€ 20-25/ha) terug te verdienen omdat er ook jaren (vooral droge) zijn waarbij het geen effect heeft. De effecten van toevoegen aan drifmest zijn minder onderzocht en daardoor nog minder duidelijk. 
Er is geen gedegen onafhankelijk onderzoek bekend met de toepassing van nitrificatieremmers in de snijmaïsteelt. Onderzoek met andere akkerbouwgewassen geven geen eenduidige positieve effecten op de stikstofbenutting te zien.

Het gebruik van nitrificatieremmers brengt een aantal potentiële risico's mee voor mens, dier en milieu. Ook is er discussie over de selectieve werking op de nitrificerende bacteriën en daarmee een mogelijk negatief effect op het bodemleven. Op basis van de onderzoeksresultaten tot nu toe zijn bij het beoogde gebruik geen negatieve neveneffecten te verwachten.

\section{Alternatieven voor standaard NP-kunstmest rijenbemesting}

Rijenbemesting kan ook in vloeibare vorm worden gegeven. In hoeverre dit interessant is, hangt voornamelijk af van de prijs. Daarnaast wordt in de praktijk de standaard NP-rijenbemesting met korrelmeststoffen soms (deels) vervangen door coating van het zaad met een meststof, door microgranulaat meststoffen of door korrelmeststoffen waaraan wortelgroei stimulerende stoffen zijn toegevoegd. Met een meststof-coating wordt een kleine hoeveelheid nutriënten direct op het zaad gebracht. Het doel is om op deze manier de opname van nutriënten tijdens de beginontwikkeling te bevorderen. Dit heeft een positief effect op de benutting van nutriënten waardoor de totale nutriëntengift omlaag kan. Met microgranulaat meststoffen wordt eenzelfde doelstelling beoogd. Met deze meststoffen wordt een kleine hoeveelheid nutriënten in combinatie met stoffen die de ontwikkeling van het wortelstelsel bevorderen als rijenbemesting gegeven. De praktijk heeft diverse positieve ervaringen met dergelijke producten. Door leveranciers worden besparingen van rond de $25 \mathrm{~kg}$ stikstof en fosfaat genoemd. Door Wageningen Livestock Research is er in de periode 2008-2010 onderzoek uitgevoerd naar de effecten van verschillende vormen van rijenbemesting bij verschillende bemestingsniveaus van stikstof en fosfaat. De volgende vormen rijenbemesting van rijenbemesting werden vergeleken:

NP meststof: $26 \% N+7 \%$ P205 + B.

Humifirst: $15 \% \mathrm{~N}+7 \%$ P205 + B. De toegevoegde humus- en fulvozuren moeten zorgen voor een betere wortelontwikkeling.

Iseed: meststofcoating van het zaad met een laagje fosfaat moet de beginontwikkeling stimuleren.

Physiostart: $8 \% \mathrm{~N}+28 \% \mathrm{P} 205+23 \% \mathrm{SO} 3+2 \% \mathrm{Zn}$. Adviesdosering is $20 \mathrm{~kg}$ per ha. Het product dat gebaseerd is op zeewier is erop gericht om de wortelontwikkeling te stimuleren. Entec: $26 \% \mathrm{~N}+7 \%$ P205 +B. Deze meststof bevat een nitrificatieremmer om de omzetting van ammoniumstikstof in nitraatstikstof te vertragen, waardoor de kans op uitspoeling vermindert. Daarnaast moet de positieve lading van de ammoniumstikstof de fosfaatopname positief beïnvloeden.

De conclusie was dat er met de onderzochte alternatieve vormen van rijenbemesting geen besparing aan stikstof en fosfaat kon worden aangetoond. De positieve ervaringen in de praktijk heeft waarschijnlijk te maken met het feit dat in veel situaties de aanvullende rijenbemestingsgift zonder opbrengstderving naar beneden had gekund, ook zonder toepassing van een alternatieve vorm.

\subsubsection{Dierlijke mest aanwenden}

Het uitrijden van drijfmest op bouwland (alle grondsoorten) is toegestaan van 1 februari tot 1 augustus. Uitrijden tot 1 september is toegestaan als u uiterlijk 31 augustus van dat jaar 
winterkoolzaad of een groenbemester teelt of in het najaar bloembollen plant. Uitrijden van vaste mest op bouwland op zand en lössgrond mag van 1 februari tot 1 september. Op klei en veengrond mag $u$ het hele jaar vaste mest uitrijden. Verder geldt dat het verboden is om dierlijke mest uit te rijden op besneeuwde of bevroren grond en als de bovenste laag verzadigd is met water. Voor meer informatie over uitrijperioden van dierlijke mest zie www.rvo.nl. Drijfmest moet emissiearm aangewend worden. Daarbij wordt de mest:

- op beteeld bouwland onmiddellijk in de grond gebracht in sleufjes. De sleufjes mogen daarbij niet breder zijn dan $5 \mathrm{~cm}$; of

- op niet beteeld bouwland onmiddellijk in de grond gebracht in sleufjes. De sleufjes mogen daarbij niet breder zijn dan $5 \mathrm{~cm}$ en moeten minimaal $5 \mathrm{~cm}$ diep zijn; of

$\mathrm{U}$ mag ook de drijfmest in één werkgang met één machine op de grond aanbrengen en onderwerken. Zorg er dan voor dat de mest direct na het aanbrengen wordt ondergewerkt of intensief met de grond wordt gemengd. De mest is dan niet meer zichtbaar op het grondoppervlak.

\section{Mestsamenstelling}

Om de bemesting goed op de gewasbehoefte af te stemmen is het nodig om de gehaltes in de mest te weten. In tabel 5.20 staat de gemiddelde samenstelling van een aantal belangrijke organische meststoffen. Zie voor een uitgebreidere tabel "Adviesbasis bemesting grasland en voedergewassen" www.bemestingsadvies.nl. Uitgaan van deze gemiddelden kan tot fouten leiden omdat in de praktijk aanzienlijke verschillen in gehalten voorkomen. Beter is het om een mestmonster te laten analyseren van goed gemixte mest.

Tabel 5.20 Gemiddelde samenstelling van een aantal belangrijke organische meststoffen

\begin{tabular}{|c|c|c|c|c|c|c|c|c|c|}
\hline & $\begin{array}{l}\text { Droge } \\
\text { stof }\end{array}$ & $\begin{array}{l}\text { Org. } \\
\text { stof }\end{array}$ & $\begin{array}{l}\mathrm{N}- \\
\text { totaal }\end{array}$ & N-min & N-org & $\mathrm{P}_{2} \mathrm{O}_{5}$ & $\mathrm{~K}_{2} \mathrm{O}$ & $\mathrm{MgO}$ & $\mathrm{Na} 2 \mathrm{O}$ \\
\hline \multicolumn{10}{|l|}{ Dunne mest } \\
\hline Rundvee & 92 & 71 & 4,0 & 1,9 & 2,1 & 1,5 & 5,4 & 1,2 & 0,8 \\
\hline Vleesvarkens & 107 & 79 & 7,0 & 3,7 & 3,3 & 3,9 & 4,7 & 1,5 & 1,2 \\
\hline Zeugen & 67 & 25 & 5,0 & 3,3 & 1,7 & 3,5 & 4,9 & 1,4 & 0,9 \\
\hline \multirow{2}{*}{\multicolumn{10}{|c|}{ Gier }} \\
\hline & & & & & & & & & \\
\hline Rundvee & 25 & 10 & 4,0 & 3,8 & 0,2 & 0,2 & 8,0 & 0,2 & 1,0 \\
\hline Vleesvarkens & 20 & 5 & 6,5 & 6,1 & 0,4 & 0,9 & 4,5 & 0,2 & 1,0 \\
\hline Zeugen & 10 & 10 & 2,0 & 1,9 & 0,1 & 0,9 & 2,5 & 0,2 & 0,2 \\
\hline \multicolumn{10}{|l|}{ Vaste mest } \\
\hline Rundvee & 267 & 155 & 7,7 & 1,1 & 6,6 & 4,3 & 8,8 & 4,1 & 1,1 \\
\hline Varkens & 260 & 153 & 7,9 & 2,6 & 5,3 & 7,9 & 8,5 & 2,5 & 0,9 \\
\hline Pluimvee (mestband) & 562 & 416 & 28,4 & 2,9 & 25,7 & 23,0 & 19,2 & 5,5 & 1,7 \\
\hline Kippen, strooiselmest & 677 & 359 & 29,0 & 3,7 & 25,3 & 25,6 & 18,2 & 7,5 & 3,4 \\
\hline GFT-compost & 696 & 242 & 8,9 & 0,8 & 8,1 & 4,9 & 7,9 & 3,3 & - \\
\hline Groen compost & 599 & 179 & 5,0 & 0,5 & 4,5 & 2,2 & 4,2 & 1,8 & - \\
\hline
\end{tabular}

\section{Werking dierlijke mest}

Om verliezen door vervluchtiging te beperken moet men de mest direct inwerken. Dit is wettelijk verplicht, met uitzondering van vaste mest. De wijze van inwerken heeft invloed op de vervluchtigingsverliezen en daarmee op de werking van de stikstof uit de mest. Deze werking wordt uitgedrukt door middel van werkingscoëfficiënten. De minerale stikstof uit de mest is sneller voor de plant beschikbaar dan de organisch gebonden stikstof. Anderzijds kan door 
ammoniakvervluchtiging minerale stikstof verloren gaan. Daarom gelden voor deze twee fracties afzonderlijke werkingscoëfficiënten. De stikstofwerkingscoëfficiënten van verschillende mestsoorten staan in tabel 5.21. Deze coëfficiënten gelden bij ondiep inwerken in april. Bedenk dat dit gemiddelde getallen zijn. De werkelijke werking kan sterk variëren door wisselende omstandigheden. De werkingscoëfficiënten die hier genoemd zijn, komen niet overeen met de werkingscoëfficiënten in paragraaf 5.3.1. De hier genoemde zijn teelt technische werkingscoëfficiënten terwijl in paragraaf 5.3.1 de vastgestelde forfaitaire werkingscoëfficiënten genoemd zijn ten behoeve van de stikstofgebruiksnorm binnen het nieuwe mestbeleid.

Tabel 5.21 Stikstofwerkingscoëfficiënten Wm en Worg in \% van Nmin en Norg bij toediening in maart/april en ondiep inwerken van verschillende mestsoorten

\begin{tabular}{llll}
\hline Mestsoort & Toedieningstechniek & Wm & Norking \\
& & & \\
\hline Dunne mest & & 95 & 20 \\
Rundvee & Injecteur & 80 & 20 \\
Kalveren & Oppervlakkig inwerken & 95 & 20 \\
& Injecteur & 80 & 20 \\
Varkens & Oppervlakkig inwerken & 95 & 60 \\
& Injecteur & 80 & 60 \\
Kippen & Oppervlakkig inwerken & 95 & 45 \\
& Injecteur & 90 & 45 \\
Vaste mest & Aangedreven werktuig & 75 & 45 \\
Rundvee & Cultivator & & \\
Leghennen (droge mest) & & 80 & 15 \\
Champost & & 80 & 60 \\
\hline
\end{tabular}

Ondiep inwerken kan men naast in tabel 5.20 genoemde methoden ook realiseren door diepe injectie voor het ploegen.

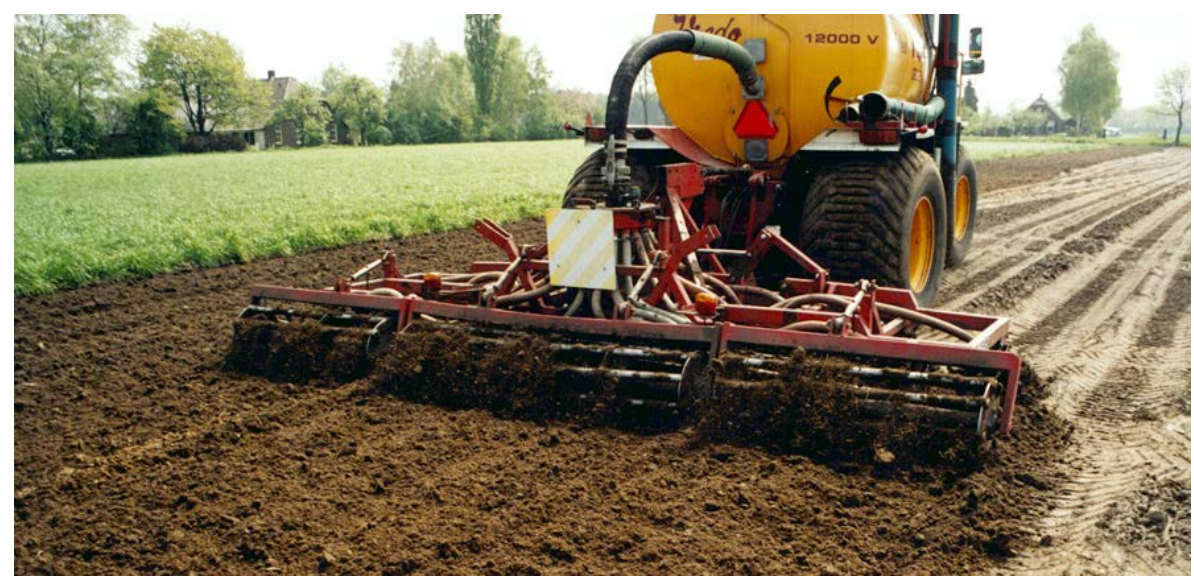

Injecteren geeft een goede mestbenutting 


\section{Tijdstip toedienen}

Voor een maximale werking van nutriënten is het belangrijk om de mest vlak voor zaaien toe te dienen. Toediening in februari of maart geeft slechts $80 \%$ stikstofwerking van in tabel 5.17 genoemde werking. Het uitrijden van drijfmest op bouwland (alle grondsoorten) is toegestaan van 1 februari tot 1 augustus. Onder voorwaarden mag u drijfmest uitrijden tot 1 september. Zie voor meer informatie over uitrijden van meststoffen www.rvo.nl. Uitrijden van vaste mest op bouwland op zand en lössgrond mag van 1 februari tot 1 september. Op klei en veengrond mag het hele jaar vaste mest worden uitgereden. Het beste kan in het voorjaar een $\mathrm{N}$-mineraal monster worden genomen omdat de verliezen en daardoor de werking afhangen van de hoeveelheid neerslag gedurende de winter (zie ook paragraaf 5.2.2). Bij de bepaling van de stikstofgift kan men rekening houden met extra mineralisatie van respectievelijk 20 en 25\% van de Norg-fractie voor respectievelijk rundermest en varkens/kippenmest.

Er komen steeds meer machines die goed in staat zijn om met zo min mogelijk structuurschade mest toe te dienen. Voorbeelden hiervan zijn het sleepslangensysteem en machines met brede banden die niet spoorvolgend zijn. Wanneer gewacht wordt tot de bodemomstandigheden goed zijn is het vaak goed mogelijk om ook op kleigronden in het voorjaar mest toe te dienen.

\section{Rijenbemesting met drijfmest}

Men kan ook de drijfmest tijdens het zaaien in één werkgang toedienen. De drijfmest wordt daarbij aan beide kanten op een afstand van 8-10 cm van de rij geïjecteerd. De machine bestaat uit een drijfmesttank waarachter een zaaimachine is gebouwd. Dit systeem is minder geschikt voor structuurgevoelige gronden. Daarom is er ook al een systeem ontwikkeld waarbij de drijfmest wordt aangevoerd met een sleepslangensysteem. Rijenbemesting met dierlijke mest geeft een betere werking van stikstof en fosfaat dan een vollevelds toediening. Evenals bij rijenbemesting met kunstmest wordt voor stikstof de factor 1,25 aangehouden. De betere werking van fosfaat is sinds 2010 in het advies geïntegreerd. Bij rijenbemesting met drijfmest is het over het algemeen niet mogelijk om meer dan 35-40 $\mathrm{m}^{3}$ per ha netjes te injecteren. Veel loonwerkers ervaren de lagere zaaicapaciteit als bezwaarlijk. Tegenwoordig is het mogelijk om de rijenbemesting met drijfmest en het maïs zaaien in aparte werkgangen uit te voeren. De drijfmest wordt daarbij als rijenbemesting aangewend op $75 \mathrm{~cm}$ rijafstand m.b.v. automatische besturing met rtk-gps en deze gegevens worden daarna gebruikt door de trekker met de zaaimachine. Door deze methode is de zaaicapaciteit niet meer afhankelijk van de mest aanvoer capaciteit.

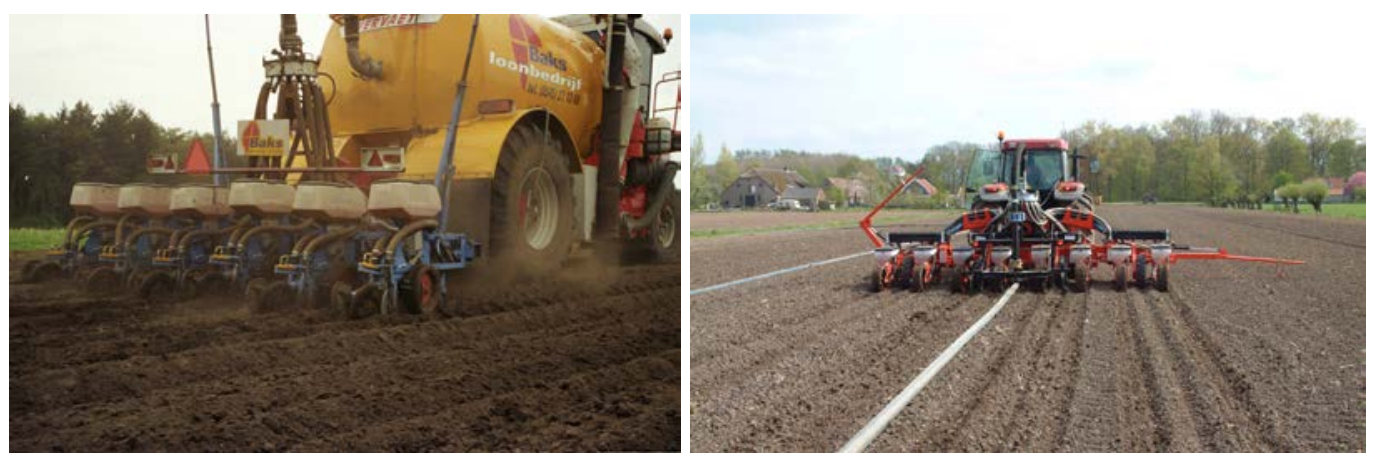

Zaaien en rijenbemesting met drijfmest in één werkgang

Tegenwoordig kan dit ook in aparte werkgangen m.b.v. rtk-gps besturing 


\section{Pas op voor tekorten aan kali en borium bij lage drijfmestgiften}

Bij drijfmestgiften van $50 \mathrm{~m}^{3} \mathrm{RDM}$ per ha of meer wordt praktisch altijd voldaan aan de kali en boriumbehoefte. In het verleden was daarom een aanvulling met kali of borium uit kunstmest amper nodig. Tegenwoordig wordt de hoeveelheid drijfmest steeds beter afgestemd op de stikstofbehoefte. Hierdoor wordt steeds vaker $40 \mathrm{~m}^{3}$ drijfmest per ha of minder gegeven. Bij dergelijke giften kunnen eerder kali- en boriumtekorten optreden en kan aanvulling met kunstmest nodig zijn.

\subsection{Groenbemesters}

$\mathrm{Na}$ de maïsoogst kan men een groenbemester of vanggewas telen. Het nieuwe mestbeleid dat per 1 januari 2006 is ingegaan, stelt nateelt op zand- en lössgronden verplicht. Groenbemesters worden om een aantal redenen geteeld:

1. Beperken van de stikstofverliezen door het vastleggen van stikstof die na de oogst van de maïs in de bodem achterblijtt (vanggewas).

2. Op peil houden van de bodemvruchtbaarheid door aanvoer van organische stof

3. Verbeteren van de structuur door aanvoer van organische stof en doorworteling van de bouwvoor in de winterperiode.

\subsubsection{Teeltmethoden en soorten}

\section{Toegestane soorten}

De vanggewassen die momenteel volgens het nieuwe mestbeleid op zand- en lössgronden mogen worden geteeld zijn: gras, winterrogge, wintertarwe, wintergerst, triticale, Japanse haver, bladkool en bladrammenas. De geschiktheid hangt af van mogelijke zaaitijd, winterhardheid en vermeerdering van plantparasitaire aaltjes. Gezien het zaaitijdstip kan na de oogst van de maïs het beste Italiaans raaigras, graan of een mengsel van Italiaans raaigras en graan worden ingezaaid. Het oogsttijdstip van maiis is over het algemeen te laat voor bladkool of bladrammenas. Daarbij zijn bladkool en bladrammenas vrij vorstgevoelig. Italiaans raaigras en mengsels van Italiaans raaigras en rogge dienen voor begin oktober te zijn gezaaid. Winterrogge, wintertarwe, wintergerst en triticale kunnen nog tot eind oktober worden gezaaid.

Wat betreft plantparasitaire aaltjes wordt momenteel aangenomen dat rogge en in iets mindere mate ook Italiaans raaigras verschillende aaltjes in meer of mindere mate vermeerderen. Van de toegelaten groenbemesters lijkt wat betreft aaltjesvermeerdering bladrammenas de beste keus. Welke groenbemester $u$ kiest is vooral van belang als na de maiis akkerbouw, groente of andere gewassen geteeld worden die schade kunnen ondervinden van aaltjes.

\section{Nateelt}

Onder gunstige omstandigheden kan het zaaibed worden gemaakt door na de oogst het land 10-15 $\mathrm{cm}$ los te trekken met een cultivator. Bij sporen en op kopakkers is het beter om het land wat dieper $(20-25 \mathrm{~cm})$ los te trekken. Het beste kan men zaaien met een pijpenzaaimachine. Granen kunnen ook gezaaid worden met een kunstmeststrooier. Voor een goede opkomst en om vogelvraat te voorkomen is het aan te bevelen om het zaad licht in te werken. Voor rogge is circa $100 \mathrm{~kg}$ zaaizaad per ha nodig, voor Italiaans raaigras $30-40 \mathrm{~kg}$ en voor een mengsel van Italiaans raaigras en rogge $50-75 \mathrm{~kg}$. Voor een goede effectiviteit als stikstofvanggewas moet de vanggewassen zo snel mogelijk na de oogst ingezaaid worden, het liefst zelfs voor half september. 


\section{Onderzaai}

In plaats van nateelt is het mogelijk om gras onder de maïs te zaaien. Dit beperkt de stikstofverliezen gemiddeld wat meer dan nateelt. Onderzaai kan wanneer de maïs $40-50 \mathrm{~cm}$ hoog is en bijna gesloten (3-4 bladstadium) met Italiaans raaigras of tussen zaaien en opkomst van de maïs met Rietzwenkgras. Bij onderzaai met Italiaan raaigras in het 3-4 bladstadium bepaalt het zaaitijdstip het succes van de teelt. Het gras moet op tijd worden gezaaid om zich voldoende te kunnen ontwikkelen, maar moet ook weer niet concurreren met de jonge maïsplanten. Men kan zaaien met een pijpenzaaimachine waarvan de pijpen boven de maïsrij zijn opgetrokken. Een andere mogelijkheid is om het in één werkgang met het schoffelen te zaaien. Per ha is $25-30 \mathrm{~kg}$ zaaizaad nodig. Rietzwenkgras is trager in opkomst dan Italiaans raaigras en kan daarom tussen zaaien en opkomst van de maïs worden gezaaid. Het kan gezaaid worden met een wiedeg waarop een zaaiunit is gemonteerd. Per ha wordt $15-20 \mathrm{~kg}$ zaaizaad geadviseerd.

Bij onderzaai van gras dient men enigszins rekening te houden met het gebruik van verschillende bodemherbiciden bij de onkruidbestrijding. (zie hoofdstuk 8).

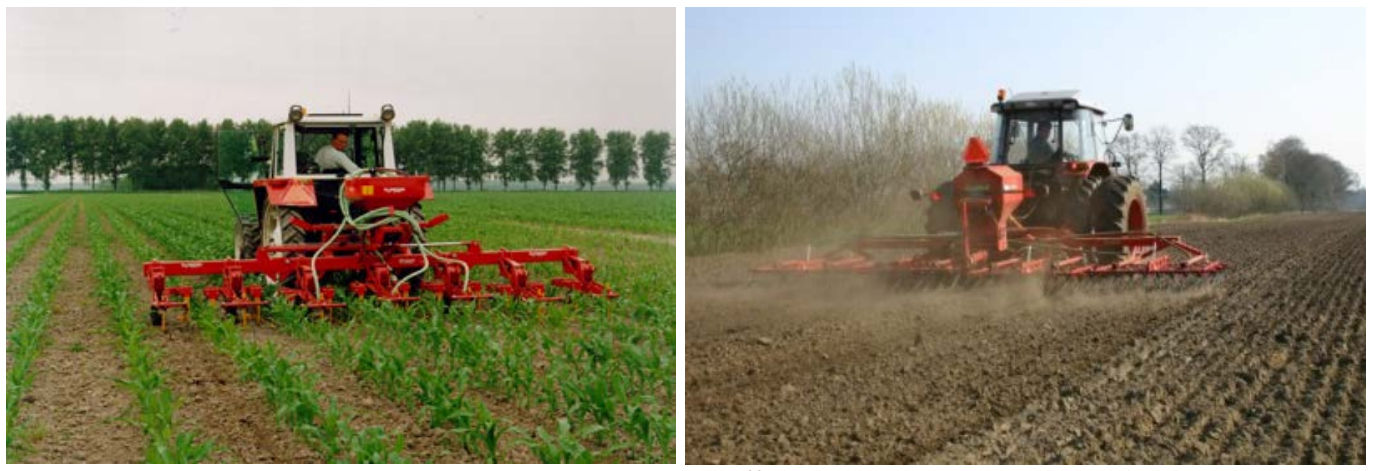

Italiaans raaigras kan in één werkgang met het schoffelen worden gezaaid (links) en Rietzwenkgras kan tussen zaaien en opkomst van de maïs met een wiedeg plus zaaiunit worden gezaaid (rechts)

\subsubsection{Nalevering}

Wanneer in het voorjaar de groenbemester wordt ondergewerkt komt er door mineralisatie stikstof vrij die het volggewas kan opnemen. De hoeveelheid stikstof die door mineralisatie vrijkomt is afhankelijk van temperatuur en vocht. Bij voldoende vocht en hoge temperaturen komt er meer stikstof vrij dan bij droogte en lage temperaturen. Voor een goed geslaagde groenbemester kan circa $25 \mathrm{~kg}$ stikstof per ha van de adviesgift worden afgetrokken. Voorwaarde is wel dat men het eind maart onderwerkt.

Een nauwkeuriger inschatting van de nawerking is mogelijk via gewashoogtemeting met de grashoogtemeter. Een gewashoogte van $1 \mathrm{dm}$ komt daarbij overeen met een nawerking van $20 \mathrm{~kg}$ stikstof per ha.

Uit een recente studie is gebleken dat de hoeveelheid kali $\left(\mathrm{K}_{2} \mathrm{O}\right)$ die beschikbaar kan komen uit Italiaans raaigras of rogge als vanggewas sterk afhankelijk is van de stand bij onderwerken. Bij Italiaans raaigras is de nalevering 25, 70 en $120 \mathrm{~kg}$ per hectare bij resp. een slechte, redelijke en uitbundige stand. Bij winterrogge is resp. 20, 50 en $85 \mathrm{~kg}$ per hectare. 


\section{Nalevering na het oogsten van een snede}

Bij een groenbemester waarvan eerst een snede wordt geoogst alvorens het wordt ondergeploegd komt stikstof vrij uit de ondergeploegde zode en daarnaast uit de eventuele in het voorjaar toegediende mest. In tabel 5.22 zijn de hoeveelheden vermeld die van de adviesgift kunnen worden afgetrokken. In verband met de benutting van fosfaat en kali is het advies om het voorgewas niet meer dan $25 \mathrm{~m}^{3}$ runderdrifmest per ha te geven.

Tabel 5.22 Mogelijke stikstofkorting op het advies bij een groenbemester na eerst een snede oogsten en uit de bemesting die daarvoor is gegeven

\begin{tabular}{ccc}
\hline N-bemesting vanggewas & \multicolumn{2}{c}{ Mogelijke stikstofkorting } \\
\cline { 2 - 3 } (kg per ha) & Uit zode vanggewas (kg N per ha) & Uit mest (kg N per ton) \\
\hline $0-50$ & 5 & 0,5 \\
$50-100$ & 10 & 0,5 \\
\hline
\end{tabular}

\section{Effect groenbemester op opbrengst}

In een langjarig (1988-2002) onderzoek op Praktijkcentrum Aver Heino met continuteelt van snijmaïs is onder andere gekeken naar het effect van een groenbemester bij verschillende stikstofbemestingsniveaus.

De toepassing van rogge als groenbemester had een duidelijk effect op de maïsopbrengst. Het effect was het hoogst bij lage bemestingsniveaus. In tabel 5.23 is het gemiddelde effect op de opbrengst weergegeven van de laatst drie jaar (2000-2002) van het onderzoek.

Tabel 5.23 Meerjarig effect door toepassing van rogge als groenbemester op de maïsopbrengst ten opzichte van braak in de winter bij verschillende bemestingsniveaus

\begin{tabular}{lc}
\hline Bemesting per ha & Extra opbrengst (\%) \\
\hline $20 \mathrm{~kg}$ kunstmeststikstof in de rij & 16 \\
$15 \mathrm{~m}^{3}$ runderdrijfmest $+20 \mathrm{~kg}$ kunstmeststikstof in de rij & 10 \\
$30 \mathrm{~m}^{3}$ runderdrijfmest $+20 \mathrm{~kg}$ kunstmeststikstof in de rij & 7 \\
$50 \mathrm{~m}^{3}$ runderdrijfmest $+20 \mathrm{~kg}$ kunstmeststikstof in de rij & 4 \\
\hline
\end{tabular}

\subsection{Maïs na gras}

Wanneer maïs op gescheurd grasland wordt geteeld komt er door mineralisatie van de ondergeploegde zode stikstof vrij die de maïs kan opnemen. Daarom kan bij de teelt van maïs na gras een hoeveelheid stikstof van de adviesgift worden afgetrokken. De hoeveelheid is vooral afhankelijk van de leeftijd van de zode en het aantal jaren na scheuren. In tabel 5.24 zijn de hoeveelheden vermeld. 
Tabel 5.24 Mogelijke stikstofkorting op het advies (kg N/ha/jaar) na scheuren van grasland

\begin{tabular}{clccc}
\hline \multirow{2}{*}{$\begin{array}{c}\text { Aantal jaren na } \\
\text { scheuren }\end{array}$} & Grondsoort & \multicolumn{3}{c}{ Leeftijd gescheurde zode } \\
\cline { 3 - 5 } & & 1 jaar & 2 jaar & 3 jaar en ouder \\
\hline 1 & Alle gronden & 50 & 100 & 100 \\
2 & Klei-op-veen & 0 & 0 & 60 \\
& $\begin{array}{l}\text { Overige } \\
\text { gronden }\end{array}$ & 0 & 0 & 30 \\
\hline
\end{tabular}

De in tabel 5.24 vermelde leeftijden van de gescheurde zode hebben betrekking op volledige productiejaren van het grasland. Om de genoemde stikstofnalevering volledig te kunnen benutten moet de zode tijdig worden gescheurd. Half maart is de beste periode. Wanneer later wordt gescheurd komt de stikstof te laat vrij voor een optimale benutting.

\section{Geen mest nodig op maïs na gras}

Jarenlang onderzoek op proefbedrijf De Marke laat zien dat maïs op droogtegevoelige zandgrond dat volgt op een graslandfase prima zonder mest kan. De opbrengst van eerstejaars maïs na gras is hoger dan van latere jaren wanneer wel bemest wordt (zie figuur 5.1)

Figuur 5.1 Opbrengst van $\mathrm{N}$ en van droge stof in maïs na gras.

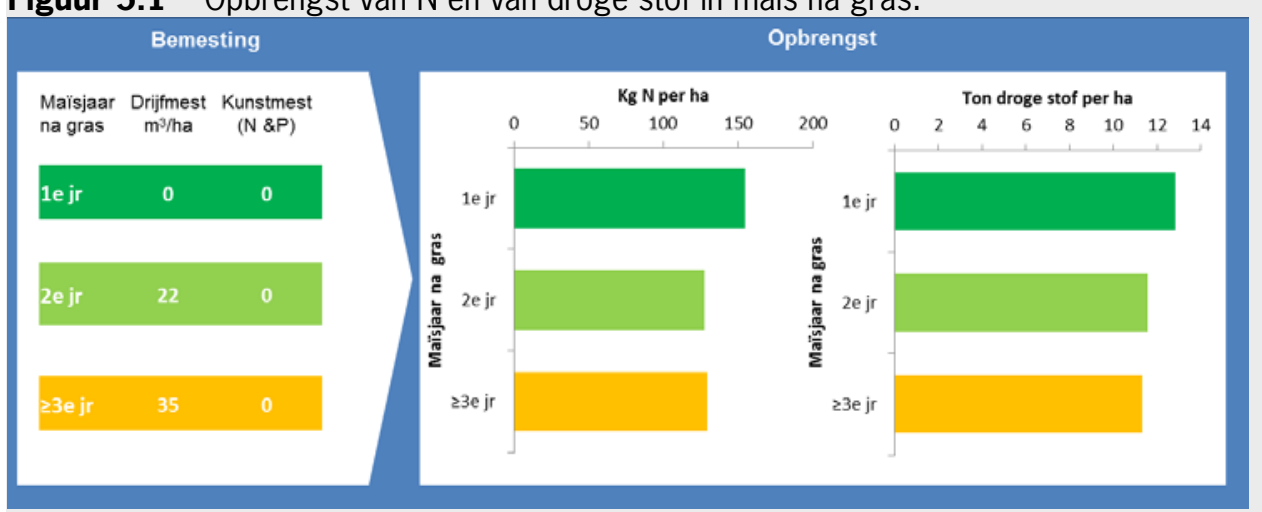

Uit recent onderzoek is gebleken dat na het onderwerken van meerjarig grasland in het vroege voorjaar (eind maart, begin april) vanuit boven- en ondergrondse delen $130 \mathrm{~kg} \mathrm{~K} 20$ per hectare vrijkomt.

Uit de ondergeploegde zode komt naast stikstof en kali ook fosfaat vrij. Hierover zijn echter geen onderzoeksgegevens bekend. Als richtlijn wordt daarom aangehouden dat de verhouding tussen stikstof en fosfaat die vrijkomt door mineralisatie van de ondergeploegde zode overeen komt met de verhouding tussen stikstof en fosfaat in het gras. De $\mathrm{N}: \mathrm{P}_{2} \mathrm{O}_{5}$ verhouding in gras is ongeveer $1: 0,4$. Dit betekent dat wanneer er bijvoorbeeld $100 \mathrm{~kg}$ stikstof uit de zode vrijkomt er daarnaast $40 \mathrm{~kg}$ fosfaat vrijkomt. 


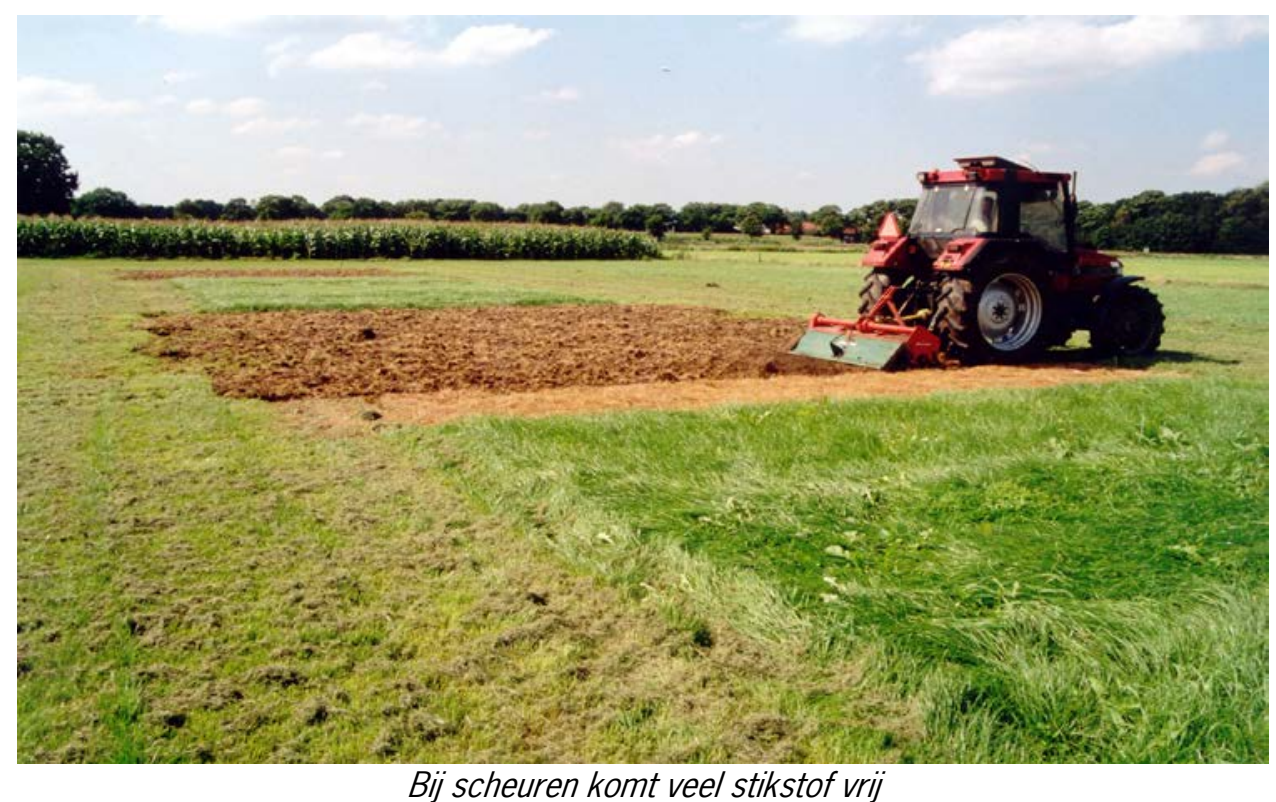

\section{Nalevering na het oogsten van een snede}

Bij grasland waarvan eerst een snede wordt geoogst komt na het scheuren stikstof vrij uit de ondergeploegde zode en daarnaast uit de eventueel in het voorjaar toegediende mest. In tabel 5.25 zijn de hoeveelheden vermeld die van de adviesgift kunnen worden afgetrokken.

Tabel 5.25 Mogelijke stikstofkorting op het advies bij gescheurd grasland na eerst een snede oogsten en uit de bemesting die daarvoor is gegeven

\begin{tabular}{lcc}
\hline Leeftijd graszode & \multicolumn{2}{c}{ Mogelijke stikstofkorting } \\
\cline { 2 - 3 } & Uit graszode (kg N per ha) & Uit mest (kg N per ton) \\
\hline 1 jaar & 50 & 0,5 \\
3 jaar & 65 & 0,5 \\
5 jaar en ouder & 75 & 0,5 \\
\hline
\end{tabular}

\section{Fosfaat en kali}

Bij het oogsten van een snede gras wordt een hoeveelheid fosfaat en kali onttrokken. Uit de ondergeploegde zode komt stikstof, maar ook fosfaat en kali beschikbaar voor de maïs. Uit een recente deskstudie is geconcludeerd dat na de oogst van een eerste snede er $95 \mathrm{~kg} \mathrm{K20} \mathrm{per}$ hectare beschikbaar komt.

Bij bemesting volgens het stikstofadvies kan, afhankelijk van de bemesting van het voorgewas, met $15-30 \mathrm{~m}^{3}$ runderdrijfmest worden volstaan. In veel gevallen is dan, ook als rekening wordt gehouden met de levering uit de zode, een aanvulling met fosfaat en kali nodig. De hoogte van deze aanvulling is afhankelijk van de fosfaat- en kalitoestand van de bodem. Daarom wordt aanbevolen om het grasland, voorafgaand aan de bemesting in het voorjaar, te laten bemonsteren in de laag $0-25 \mathrm{~cm}$. 


\section{Voorbeeld berekening bemesting snijmaïs}

\section{Uitgangspunten}

* Zandgrond (oost Nederland) * Bouwlandinjectie $40 \mathrm{~m}^{3}$ runderdrijfmest

* Continuteelt

* Pw getal 45 P-PAE 1,9 P-AL 48

* Groenbemester

* K-getal 9

* Bemestingshistorie ca. $50 \mathrm{~m}^{3}$ drijfmest

* Boriumgehalte 0,32

\section{Adviesbemesting per ha}

Stikstof (N) (zie paragraaf 5.2.2) 180

(Verleden $50 \mathrm{~m}^{3}$

(Gem. aanwezig N-min bij goed drijfmest) geslaagd groenbemesters)

\section{$-25$}

(Nalevering goed geslaagd groenbemester)

Fosfaat $\left(\mathbf{P}_{2} \mathbf{O}_{5}\right)$ (zie paragraaf 5.2.3)

Kali $\left(\mathrm{K}_{\mathbf{2}} \mathbf{O}\right)$ (zie paragraaf 5.2 .4 continuteelt)

Borium (B) (zie paragraaf 5.2.6)
$=60 \mathrm{~kg}$ breedw. $+16 \mathrm{~kg}$ in de rij $=300 \mathrm{~kg}$$$
=0,25 \mathrm{~kg}
$$

$=145 \mathrm{~kg}$

3. Gebruiksnormen per ha (zie paragraaf 5.3.1)

Stikstof: 140 kg (2015-2017)

Fosfaat: 60 kg (2015-2017) bij Pw 45)

4. Beschikbaar uit drijfmest per ha (zie ook paragraaf 5.3.2)

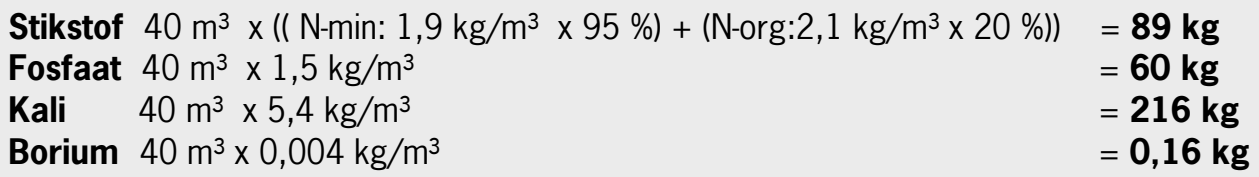

\section{Aanvullen uit kunstmest per ha}

\section{Stikstof}

Volgens advies $145 \mathrm{~kg}-89$ (uit drijfmest)

Of als rijenbemesting $25 \%$ betere werking: $56: 1,25$

Gebruiksnorm is voor bedrijf met beweiding niet beperkend:

$=56 \mathrm{~kg}$ (breedwerpig)

$=\mathbf{4 5} \mathbf{~} \mathbf{g}$ (in de rij)

$140 \mathrm{~kg}$ (gebruiksnorm) $-40 \mathrm{~m}^{3} \times 4 \mathrm{~kg} / \mathrm{m}^{3} \times 0,45$ (werkingscoëff. gebruiksnorm) $=68 \mathrm{~kg}$

Fosfaat

Breedwerpig advies wordt gedekt met drijfmest. Advies in de rij is $16 \mathrm{~kg}$.

Echter gebruiksnorm en/of derogatievoorwaarde is beperkend

Eventueel drijfmest als rijenbemesting geven (zie paragraaf 5.3.3)

Kali

300 (advies) - 216 (uit drijfmest)

Borium

0,2 (advies) - 0,16 (uit drijfmest)

$$
\begin{aligned}
& =0 \mathrm{~kg} \\
& =84 \mathrm{~kg} \\
& =0,04 \mathrm{~kg}
\end{aligned}
$$

Er zijn verschillende $\mathrm{N}$ maïsmeststoffen met borium op de markt. Praktisch gezien kan het beste gekozen worden voor een maïsmap+B. Zorg in ieder geval dat de N-behoefte zoveel mogelijk is gedekt. Daarnaast moet er nog $84 \mathrm{~kg} \mathrm{~K}_{2} \mathrm{O} /$ ha gestrooid worden. 


\section{$6 \quad$ Rassenkeuze}

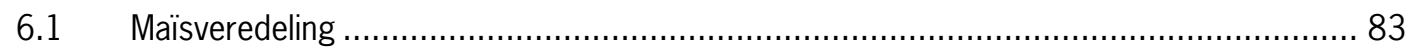

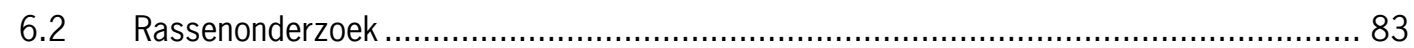

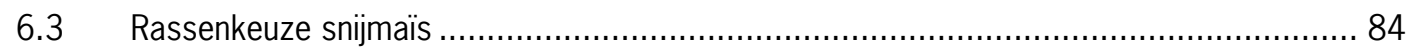

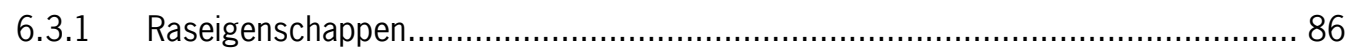

6.3.2 Bedrijfsomstandigheden en praktijkervaring .................................................. 92 


\section{Rassenkeuze}

Voor een optimale teelt is een juiste rassenkeuze belangrijk. Voordat de teelt van een ras op een bedrijf mogelijk is, is al een heel traject afgelegd. Het begint met het kweken door veredelingsbedrijven. Daarna doorlopen rassen het officiële wettelijk geregelde rassenonderzoek ter verkrijging van kwekersrecht en ter bepaling van de cultuur- en gebruikswaarde van de rassen. De teler kan vervolgens op basis van de specifieke bedrijfsomstandigheden het beste ras uit deze lijst kiezen. Deze aspecten komen in dit hoofdstuk aan de orde.

\subsection{Maïsveredeling}

Jaarlijks zijn internationaal opererende bedrijven bezig met het veredelen van nieuwe maïsrassen. Dit levert voortdurend verbeterde rassen op of rassen die beter passen bij de eisen van de praktijk. De veredeling van maïsrassen is gebaseerd op het ontwikkelen van hybriderassen, door inteeltlijnen met elkaar te kruisen. Inteeltlijnen ontstaan door een aantal generaties zelfbestuiving toe te passen en bezitten een grote mate van erfelijke zuiverheid. De inteeltlijnen zijn vaak zwakke groeiers met minimale opbrengsten. Als twee inteeltlijnen met elkaar worden gekruist, ontstaat er een enkelvoudige hybride. Bij een kruising van goed bij elkaar passende inteeltlijnen ontstaan grotere planten met een hogere opbrengst dan het oorspronkelijke materiaal. Dit noemen we heterosis effect.

Een drieweghybride ontstaat als men een enkelvoudige hybride kruist met een derde inteeltlijn. Bij hybriderassen is het niet mogelijk zaad voor een vervolgteelt te oogsten. Hierdoor moet elk jaar nieuw zaad geproduceerd worden.

Tot circa 30 jaar geleden waren bijna alle Nederlandse rassenlijstrassen drieweghybriden. Momenteel bestaat ongeveer de helft van de rassenlijstrassen uit enkelvoudige hybriden.

\section{Genetisch gemodificeerde rassen (GGO)}

Sinds 2000 staat een genetisch gemodificeerd ras (Chardon-LL) op de Nationale Rassenlijst. Dit ras is een herbicide-tolerante (glufosinaat-ammonium) variant van het ras Orient. Het ras wordt in Nederland echter niet geteeld. De noodzaak voor herbicide-tolerante rassen is er niet en de melkverwerkende industrie staat er afwiizend tegenover, dit in relatie tot onze export positie. Het EG-beleid is rond GGO's behoorlijk terughoudend. Zeker voor wat betreft de teelt ervan. Mochten de maïswortelkever en de maïsstengelboorder zich in Nederland verspreiden dan is het belang van GGO's echter groot, want dit biedt dan de belangrijkste (milieuvriendelijke) oplossing. In Spanje wordt ruim 100.000 ha genetisch gemodificeerde mais geteeld in verband met maiswortelkever.

In algemene zin heeft het gebruik van GGO's altijd een risico. Elke modificatie staat op zich en de risico's hiervan moet men van modificatie tot modificatie bekijken. Vooralsnog zijn er geen verontrustende geluiden vanuit landen waar men GGO's op grote schaal toepast. In 2008 zijn er door een aantal kweekbedrijven toch rassenproeven in Nederland uitgevoerd. Doel is om genetisch gemodificeerde rassen toegelaten te krijgen voor Europa.

\subsection{Rassenonderzoek}

In Nederland is het onderzoek aan en de opname van rassen voor de Nationale Rassenlijst wettelijk geregeld. Uit dit zelfde onderzoek wordt ook de Aanbevelende Rassenlijst samengesteld. Op de Nationale Rassenlijst staan rassen die volgens EU-criteria voldoende cultuur- en gebruikswaarde hebben en geen risico vormen voor de snijmaïsteelt in Nederland en Europa. Op de Aanbevelende Rassenlijst staat een topselectie van rassen van de Nationale Rassenlijst en de Europese Rassenlijst, die voor de teelt in Nederland worden aanbevolen. 
De Commissie Samenstelling Aanbevelende Rassenlijst (CSAR), waarin Plantum, de Branche organisatie (BO-)Akkerbouw en LTO-Nederland samenwerken, beslist over de opname van maïsrassen op deze lijst. Zij doen dit op basis van gegevens, die afkomstig zijn van het hier bovengenoemde wettelijk geregelde onafhankelijk maïsrassenonderzoek in Nederland.

Praktijkonderzoek AGV onderdeel van Wageningen University \& Research voert dit onderzoek uit volgens een door CSAR en Raad voor plantenrassen (RvP) in samenspraak met telers en kwekers goedgekeurd protocol. Voor een juiste en betrouwbare advisering worden nieuwe rassen pas na drie jaar onderzoek op de rassenlijst geplaatst.

Sinds teeltjaar 2012 worden de rassen in dit onderzoek getest in twee vroegheidsgroepen, zeer vroeg/vroeg en middenvroeg/middenlaat. Dit is aangepast om de opbrengstpotentie en kwaliteit van alle rassen op correcte wijze te bepalen. Uiteindelijk levert dat twee afzonderlijke rassenlijsten op die niet met elkaar te vergelijken zijn.

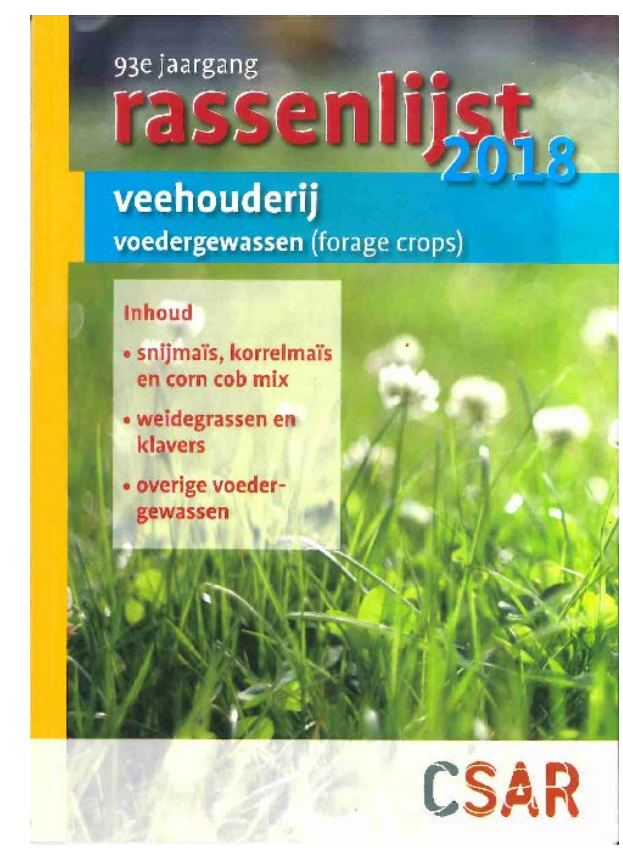

Kies een ras uit de Aanbevelende Rassenlijst

\subsection{Rassenkeuze snijmaïs}

Voor een juiste rassenkeuze op basis van onafhankelijke resultaten kan men het beste gebruik maken van de Aanbevelende Rassenlijst voor Landbouwgewassen. Deze Rassenlijst aangevuld met gegevens van rassen die twee jaar onderzocht zijn, staan jaarlijks in het persbericht van CSAR. De tabellen uit het persbericht met de aanbevolen rassen staan vermeld in tabel 6.1 en 6.2. Het volledige persbericht (incl. meerjarig onderzochte rassen en korrelmais) is te vinden op de internetpagina van CSAR http://www.rassenlijst.info. Belangrijk te weten is dat de tabel 6.2 niet is te vergelijken met de tabel 6.1. Het zijn verschillende vroegheidsgroepen met resultaten van verschillende proeven die vergeleken zijn met verschillende standaarden. Bij de keuze van het snijmaïsras zal de teler dan ook eerst moeten besluiten welke vroegheid voor zijn specifieke situatie gewenst is. In Noord- en West Nederland zal dit hoofdzakelijk een ras uit de zeer vroege vroege groep zijn. In Zuid-, Oost- en Midden-Nederland kan dit een ras uit beide groepen zijn. In 
geval van een kort groeiseizoen door late zaai of vroege oogst heeft ook hier een ras uit de zeer vroege - vroege groep de voorkeur. In alle andere gevallen kan ook uit de middenvroege middenlate groep gekozen worden, waarmee over het algemeen een hogere opbrengst gerealiseerd kan worden.

Bij gelijke omstandigheden bereikt een ras uit de groep zeer vroeg - vroeg een drogestofgehalte van $35 \%$ gemiddeld twee tot drie weken eerder dan een ras uit de groep middenvroeg middenlaat.

Tabel 6.1 Aanbevelende Rassenlijst: Overzicht van raseigenschappen bij snijmaïs, aanbevolen zeer vroege en vroege rassen, gemiddelde resultaten over $2012 \mathrm{t} / \mathrm{m} 2017^{11}$.

\begin{tabular}{|c|c|c|c|c|c|c|c|c|c|c|c|c|c|c|c|c|c|c|}
\hline 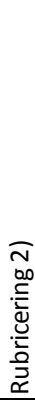 & 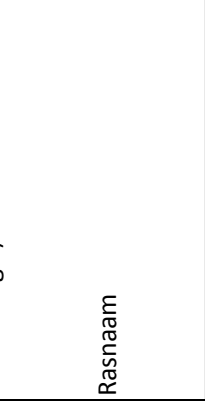 & 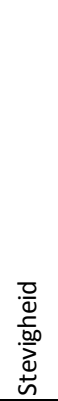 & 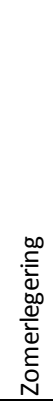 & 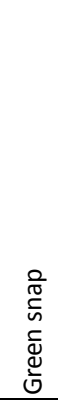 & 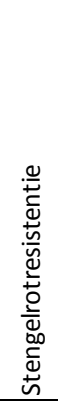 & 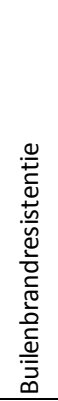 & 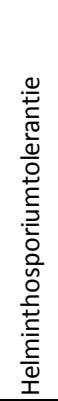 & 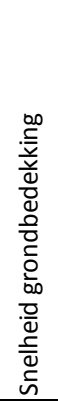 & 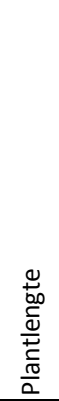 & $\begin{array}{l}\widehat{m} \\
\overline{0} \\
\frac{0}{0} \\
\overline{0} \\
\frac{0}{0} \\
\frac{1}{b 0} \\
\frac{0}{0} \\
\stackrel{0}{>}\end{array}$ & 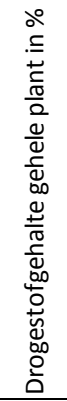 & 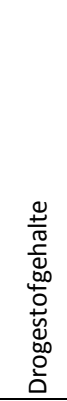 & 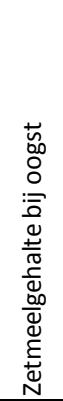 & 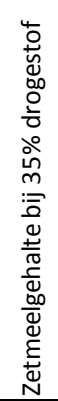 & 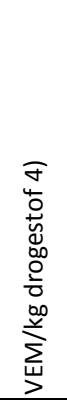 & 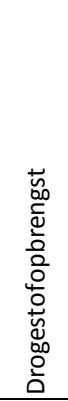 & 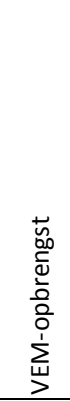 & 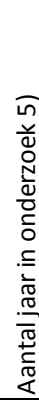 \\
\hline \multicolumn{19}{|c|}{ AANBEVOLEN RASSEN - Snijmaïs, zeer vroeg en vroeg } \\
\hline \multirow[t]{2}{*}{$\mathrm{N}$} & MAS 08F & 7.5 & $*$ & $*$ & 6 & 8.5 & * & 7 & 93 & 8 & 40.7 & 110 & 105 & 103 & 101 & 96 & 97 & 3 \\
\hline & Asgaard & 8.5 & 8.5 & $*$ & 7 & 8 & * & 7 & 98 & 8.5 & 40.4 & 109 & 105 & 106 & 100 & 97 & 97 & 5 \\
\hline \multirow[t]{8}{*}{$\mathrm{N}$} & Absalon & 8.5 & 8 & $*$ & 7.5 & 8.5 & $*$ & 7 & 94 & 8.5 & 40.4 & 109 & 105 & 104 & 101 & 96 & 97 & 4 \\
\hline & LG 30.209 & 8 & 8 & $*$ & 7 & 8.5 & $*$ & 7.5 & 100 & 8 & 38.7 & 104 & 103 & 100 & 100 & 99 & 99 & 6 \\
\hline & DKC3333 & 8.5 & 8 & $*$ & 7 & 8.5 & $*$ & 7.5 & 97 & 7 & 38.4 & 103 & 98 & 94 & 101 & 99 & 99 & 6 \\
\hline & LG 31.211 & 7 & 7 & $*$ & 7.5 & 8 & $*$ & 7.5 & 100 & 8 & 38.1 & 103 & 102 & 101 & 101 & 101 & 102 & 5 \\
\hline & Leovoxx & 7.5 & 7.5 & 8.5 & 7.5 & 8.5 & $*$ & 8 & 97 & 8 & 38 & 102 & 99 & 96 & 101 & 97 & 98 & 6 \\
\hline & LG 31.218 & 7 & 7.5 & $*$ & 7.5 & 8.5 & $*$ & 7.5 & 102 & 8 & 37.7 & 102 & 101 & 101 & 101 & 100 & 100 & 5 \\
\hline & LG 30.211 & 8 & 8.5 & 8.5 & 8 & 7.5 & 7.5 & 7 & 99 & 8 & 37.6 & 102 & 100 & 99 & 99 & 98 & 98 & 6 \\
\hline & P8057 & 8.5 & 8 & 8.5 & 8 & 8.5 & 8.5 & 6.5 & 100 & 8 & 37.5 & 101 & 101 & 100 & 101 & 98 & 99 & 6 \\
\hline $\mathrm{N}$ & RGT Koleoxx & 7.5 & $*$ & $*$ & 8.5 & 8.5 & $*$ & 8.5 & 105 & 7.5 & 37.4 & 101 & 101 & 98 & 98 & 100 & 98 & 3 \\
\hline $\mathrm{N}$ & DKC3172 & 8 & $*$ & $*$ & 8 & 8.5 & $*$ & 7.5 & 99 & 7.5 & 37.3 & 100 & 97 & 94 & 101 & 102 & 103 & 3 \\
\hline \multirow[t]{2}{*}{$\mathrm{N}$} & SY Rotango & 7.5 & $*$ & $*$ & 6 & 7.5 & $*$ & 6.5 & 102 & 7.5 & 37.2 & 100 & 103 & 101 & 100 & 100 & 100 & 3 \\
\hline & Farmezzo & 7 & 6 & $*$ & 7.5 & 8 & $*$ & 7.5 & 106 & 7.5 & 37 & 100 & 100 & 98 & 99 & 102 & 101 & 5 \\
\hline \multirow[t]{3}{*}{$N$} & Stacey & 8.5 & 7.5 & $*$ & 7.5 & 8.5 & $*$ & 8 & 98 & 8 & 36.7 & 99 & 100 & 101 & 100 & 102 & 102 & 4 \\
\hline & Kompetens & 7.5 & 8 & $*$ & 8 & 8.5 & $*$ & 7 & 99 & 8 & 36.7 & 99 & 102 & 101 & 100 & 101 & 101 & 5 \\
\hline & Movanna & 8 & 7 & $*$ & 7.5 & 7.5 & $*$ & 7.5 & 105 & 7 & 36.6 & 99 & 98 & 98 & 97 & 101 & 98 & 6 \\
\hline $\mathrm{N}$ & LG 31.226 & 7.5 & $*$ & $*$ & 8 & 6 & $*$ & 7.5 & 104 & 7.5 & 36.4 & 98 & 98 & 96 & 101 & 105 & 106 & 3 \\
\hline \multirow[t]{3}{*}{$N$} & SY Skandik & 7 & 7 & $*$ & 7.5 & 8.5 & $*$ & 6.5 & 100 & 7.5 & 36.4 & 98 & 98 & 99 & 100 & 103 & 103 & 4 \\
\hline & LG 30.215 & 7.5 & 7.5 & $*$ & 8 & 8.5 & $*$ & 8.5 & 106 & 8 & 36.4 & 98 & 103 & 104 & 99 & 100 & 99 & 5 \\
\hline & MAS $12 \mathrm{H}$ & 8 & 8 & $*$ & 8 & 8.5 & $*$ & 6.5 & 104 & 7.5 & 36.4 & 98 & 102 & 102 & 99 & 98 & 97 & 6 \\
\hline \multirow[t]{5}{*}{$\mathrm{N}$} & Smoothi CS & 7.5 & 7 & $*$ & 6.5 & 8.5 & $*$ & 8 & 105 & 7 & 36.3 & 98 & 97 & 98 & 97 & 102 & 98 & 4 \\
\hline & LG 30.218 & 8.5 & 8.5 & 9 & 7 & 8.5 & 7.5 & 7.5 & 96 & 7.5 & 36 & 97 & 99 & 100 & 100 & 99 & 100 & 6 \\
\hline & Denny & 6.5 & 6.5 & $*$ & 7 & 8.5 & $*$ & 7 & 100 & 7.5 & 35.9 & 97 & 99 & 100 & 99 & 101 & 100 & 6 \\
\hline & LG 30.223 & 8 & 8 & 8.5 & 7 & 8 & $*$ & 8 & 98 & 7.5 & 35.6 & 96 & 95 & 96 & 100 & 103 & 103 & 6 \\
\hline & LG 30.225 & 7.5 & 8 & 8.5 & 8 & 8.5 & 8 & 7.5 & 99 & 7.5 & 35.5 & 96 & 95 & 96 & 100 & 100 & 100 & 6 \\
\hline \multirow[t]{3}{*}{$\mathrm{N}$} & Benedictio KWS & 8 & $*$ & $*$ & 7.5 & 9 & $*$ & 8.5 & 108 & 7 & 35.5 & 96 & 95 & 95 & 98 & 107 & 105 & 3 \\
\hline & LG 30.224 & 7 & 7.5 & 8.5 & 8 & 8.5 & $*$ & 6.5 & 101 & 7 & 34.9 & 94 & 91 & 93 & 101 & 103 & 103 & 6 \\
\hline & SY Milkytop & 7 & 7 & 8 & 7.5 & 8 & $*$ & 8.5 & 94 & 8 & 34.9 & 94 & 101 & 103 & 100 & 100 & 100 & 6 \\
\hline \multicolumn{10}{|c|}{$100=.$. resp. in cm, \%, gr/kgds (2x), VEM/kgds, ton/ha, $1000 \mid 286$} & & & 37.1 & 400 & 391 & 1010 & 21.6 & 21.8 & \\
\hline
\end{tabular}

Bron: CSAR, Aanbevelende Rassenlijst 2016 
Tabel 6.2 Aanbevelende Rassenlijst: Overzicht van raseigenschappen bij snijmaïs,

middenvroege en middenlate rassen, gemiddelde resultaten over de jaren 2012 $\mathrm{t} / \mathrm{m} \mathrm{2017^{11 }}$

\begin{tabular}{|c|c|c|c|c|c|c|c|c|c|c|c|c|c|c|c|c|c|c|}
\hline 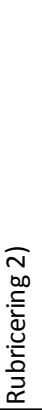 & $\begin{array}{c}E \\
\mathbb{E} \\
\mathbb{D} \\
\tilde{D} \\
\tilde{n} \\
\widetilde{D} \\
\sim\end{array}$ & 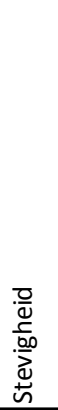 & 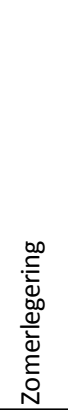 & $\begin{array}{l}00 \\
\frac{0}{0} \\
\frac{1}{n} \\
\frac{1}{d} \\
\frac{1}{0}\end{array}$ & 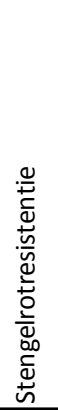 & 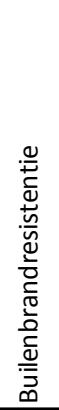 & 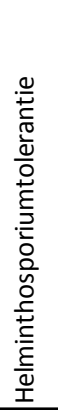 & 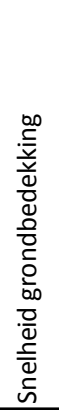 & 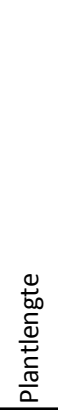 & $\begin{array}{l}\widehat{m} \\
\frac{0}{0} \\
\frac{0}{0} \\
\frac{0}{0} \\
\frac{0}{0} \\
\frac{1}{00} \\
0 \\
\frac{0}{>}\end{array}$ & 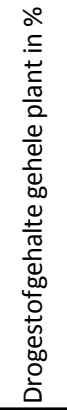 & 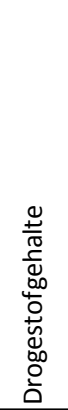 & 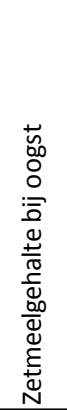 & 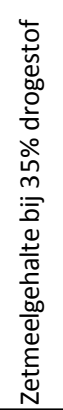 & 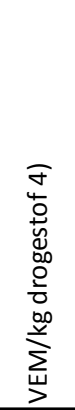 & 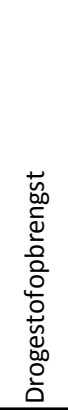 & 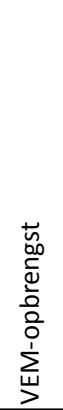 & 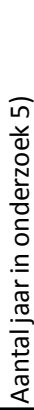 \\
\hline \multicolumn{19}{|c|}{ AANBEVOLEN RASSEN - Snijmais middenvroeg en midden| } \\
\hline & Juvento & 8 & 8.5 & $*$ & 8.5 & 8 & 7 & 9 & 98 & 8.5 & 38.7 & 106 & 102 & 98 & 101 & 98 & 100 & 5 \\
\hline \multirow[t]{3}{*}{$N$} & Farmerino & 7.5 & $*$ & $*$ & 7.5 & 7.5 & $*$ & 7 & 100 & 7.5 & 37.9 & 104 & 106 & 104 & 99 & 96 & 95 & 4 \\
\hline & Farmfire & 5.5 & 7.5 & $*$ & 7 & 8.5 & 7 & 7.5 & 102 & 7 & 37.4 & 102 & 98 & 96 & 99 & 102 & 100 & 6 \\
\hline & LG 30.232 & 8 & 8.5 & 8.5 & 8.5 & 7 & 7 & 8.5 & 97 & 8 & 37.1 & 102 & 94 & 92 & 100 & 99 & 99 & 6 \\
\hline \multirow[t]{3}{*}{$N$} & Genialis KWS & 8 & $*$ & $*$ & 8 & 8.5 & 8 & 8 & 97 & 7.5 & 36.9 & 101 & 100 & 100 & 100 & 102 & 102 & 4 \\
\hline & Torres & 8 & 7 & 7 & 8 & 8.5 & 8 & 8.5 & 100 & 8.5 & 36.9 & 101 & 104 & 101 & 101 & 98 & 99 & 6 \\
\hline & Fenizia & 5.5 & 6.5 & $*$ & 7 & 6.5 & 6.5 & 8 & 104 & 7.5 & 36.9 & 101 & 99 & 98 & 98 & 101 & 99 & 5 \\
\hline$N$ & SY Madras & 7 & 6 & $*$ & 8 & 7.5 & 7 & 9 & 100 & 8 & 36.5 & 100 & 95 & 94 & 100 & 101 & 101 & 5 \\
\hline$N$ & Farmerkel & 6.5 & $*$ & $*$ & 7 & 7.5 & 8 & 8 & 101 & 7.5 & 36.5 & 100 & 103 & 106 & 99 & 103 & 102 & 4 \\
\hline$N$ & LG 31.235 & 7.5 & $*$ & $*$ & 8.5 & 7.5 & 7.5 & 7 & 98 & 7.5 & 36.2 & 99 & 96 & 98 & 102 & 98 & 100 & 4 \\
\hline$N$ & P8333 & 6.5 & $*$ & $*$ & 7.5 & 7 & $*$ & 7.5 & 106 & 6.5 & 35.9 & 98 & 92 & 93 & 98 & 105 & 103 & 3 \\
\hline$N$ & Praefekt & 6 & $*$ & $*$ & 6.5 & 7 & 8 & 7.5 & 103 & 7 & 35.5 & 97 & 97 & 100 & 98 & 102 & 99 & 3 \\
\hline \multirow[t]{3}{*}{$N$} & Kalideas & 8.5 & $*$ & $*$ & 6.5 & 8.5 & $*$ & 8.5 & 99 & 7 & 35.2 & 96 & 97 & 99 & 100 & 102 & 102 & 3 \\
\hline & Mokka & 7.5 & 7.5 & 8 & 8 & 8 & 7.5 & 7 & 96 & 8 & 34.6 & 95 & 100 & 103 & 100 & 97 & 97 & 6 \\
\hline & SY Fanatic & 8 & 7 & $*$ & 8 & 8 & 8 & 6.5 & 102 & 7 & 34.5 & 94 & 94 & 98 & 102 & 99 & 101 & 5 \\
\hline $\mathrm{N}$ & Farmidabel & 7 & $*$ & $*$ & 7.5 & 7 & $*$ & 7 & 101 & 7.5 & 33.5 & 92 & 98 & 104 & 99 & 99 & 98 & 3 \\
\hline \multicolumn{9}{|c|}{$100=.$. resp. in cm, \%, gr/kgds (2x), VEM/kgds, ton/h } & 307 & & & 36.6 & 397 & 388 & 1007 & 22.9 & 23 & \\
\hline
\end{tabular}

Bron: CSAR, Aanbevelende Rassenlijst 2016

1) Plantlengte, drogestofgehalte, zetmeelgehalte, VEM/kgds, drogestofopbrengst en VEM-opbrengst weergegeven in verhoudingsgetallen. Drogestofgehalte ook in absolute waarde. Overige eigenschappen in waarderingscijfers, waarbij een hoog cijfer voor een gunstige waardering staat.

2) Rassen staan gerangschikt op volgorde van vroegheid. Rassen die 1 of 2 jaar op de lijst staan zijn aangeduid met een N-Nieuw Aanbevolen.

3) De vroegheid van vrouwelijke bloei is vooral van belang in ongunstige jaren. Bij rassen met een gelijk drogestofgehalte hebben laat bloeiende rassen in die jaren vaak een lager drogestofgehalte

4) De VEM/kgds is bepaald met NIRS, gekalibreerd op Tilley en Terry.

5) Na minimaal 3 jaar onderzoek kan een ras worden aanbevolen. Betrouwbaarheid van cijfers is groter bij meer jaren van onderzoek. Sommige rassen staan al langer dan 6 jaar op de Rassenlijst, maar resultaten worden gebaseerd op de laatste 6 jaar.

* Onvoldoende resultaten beschikbaar

\subsubsection{Raseigenschappen}

Op basis van het drogestofgehalte bij de oogst is het rassenassortiment ingedeeld in twee vroegheidsgroepen zeer vroeg/vroeg en midden vroeg/midden laat. In een gemiddeld jaar en bij gelijke uitzaai bereikt een zeer vroeg ras 2 tot 3 weken eerder een drogestofgehalte van $35 \%$ dan een middenvroeg ras. Hieronder volgt een toelichting op de verschillende raseigenschappen die van belang zijn voor een optimale groei van het gewas. 


\section{Legering}

Legering van maïs is een resultante van een gebrek aan stevigheid en stengelrotaantasting. In het cultuur- en gebruikswaardeonderzoek wordt voor beide eigenschappen een aparte waardering gegeven.

\section{Stevigheid (greensnap, zomerlegering en herfstlegering)}

Bij gebrek aan stevigheid nemen de risico's voor legering toe. Een gebrek aan stevigheid wordt veroorzaakt door wortelzwakte en/of stengelzwakte. Gedurende het jaar doen zich verschillende vormen voor. In het voorjaar, tot een gewaslengte van circa $1.25 \mathrm{~m}$ zijn bepaalde rassen gevoelig voor afknappen van planten (green snap - stengelzwakte). Deze afgeknapte planten moeten als verloren worden beschouwd. Met name in 2005, 2011 en 2015 kwam dit in Nederland voor. Vanaf ongeveer $1.50 \mathrm{~m}$ gaat voor sommige rassen de gevoeligheid voor zomerlegering (meestal rond bloei) meespelen. Planten vallen om met name door wortelzwakte en soms door stengelzwakte. Bij zomerlegering treedt meestal herstel van het gewas op. Er vormen zich dan de karakteristieke "wandelstokken". Dit kost echter wel opbrengst omdat het gewas tijdelijk minder efficiënt licht onderschept en er een langere stoppel achterblijt na de oogst.

Bij een legering in het najaar wordt er gesproken over herfstlegering, waarbij onderscheid wordt gemaakt in wortelzwakte en stengelzwakte. Legering door wortelzwakte (wortel heeft onvoldoende verankering in de grond), waarbij de planten bij de grond scheefgroeien of omvallen, komt zowel bij korte als bij lange rassen voor. Bij lange rassen is het risico op legering echter groter. Bij legering door stengelzwakte breken of knikken de groene stengels meestal een meter boven de grond. Dit komt hoofdzakelijk voor bij lange rassen met een hoge tot zeer hoge kolfaanzet. Bij een hoger plantaantal neemt over het algemeen de gevoeligheid voor legering door stengelzwakte toe. In 2017 kwam zeer veel legering voor, door een herfststorm rond half september. De stevige rassen (boordelingscijfers 7 en hoger) op de Aanbevelende Rassenlijst lieten vrijwel geen tot geen legering zien.

Zomerlegering en greensnap wordt op dit moment als apart cijfer weergegeven in de rassenlijst. Alle planten die bij de oogst omliggen of hangen worden meegeteld in het beoordelingscijfer voor de eigenschap "stevigheid".

\section{Stengelrot}

Stengelrot wordt veroorzaakt door Fusariumschimmels en komt vooral voor bij een afrijpend gewas. Het is te herkennen aan de voze stengelvoet, hangende kolven en het omvallen van de voze stengels. $\mathrm{Na}$ droogte bestaat er een grotere kans op een stengelrotaantasting. Daarnaast neemt door een dichte stand de kans op een stengelrotaantasting toe. Stengelrot kan leiden tot een sterke verhoging van het drogestofgehalte en een verlaging van de verteerbaarheid.

De mate van aantasting door stengelrot wordt zowel bepaald door de resistentie die het ras bezit, als door het rijpingsstadium waarin het gewas verkeert. Een ras met een laag cijfer voor stengelrotresistentie moet men daarom tijdig oogsten. Dit zal bij zeer vroege rassen minder snel problemen geven dan bij latere rassen.

\section{Builenbrand}

Builenbrand treedt vooral op in droge, warme jaren bij gewassen die te lijden hadden van droogte. Zie voor meer informatie over deze ziekte Hoofdstuk 9 (Ziekten en plagen).Tussen rassen bestaan wel verschillen in de mate van resistentie tegen deze ziekte. Bij een zware ziektedruk kan het percentage aangetaste planten tussen de rassen uiteenlopen van 0 tot 70\%. Lange tijd kwamen er slechts lage percentages builenbrand voor in Nederland. In 2015 en 2016 kwamen er toch weer meer aantastingen voor, afhankelijk van het ras tot maximaal respectievelijk 10\% en 20\%. In 2017 kwamen verspreid over het hele land zeer hoge aantastingen voor. Met name in het zuiden was het (voor)jaar relatief droog. In het noorden kwamen aantastingen voor tot $40 \%$ en in het zuiden tot $50 \%$. 
Laatste jaren relatief weinig builenbrand, met name ook door hoge resistentieniveau van de rassen. In 2015 op rasniveau toch tot maximaal $10 \%$ aantasting.

\section{Bladvlekkenziekte (Helminthosporium en Kabatiella zeae)}

Sinds 2007 wordt maïs in Nederland op vrij grote schaal aangetast door bladvlekkenziekten, veroorzaakt door de schimmel Helminthosporium (H. turcicum en ook $\mathrm{H}$. carbonum). Zie voor meer informatie over deze ziekte Hoofdstuk 9 (Ziekten en plagen). Zowel de korrelopbrengst als de VEMopbrengst worden negatief beinvloed door een Helminthosporiumaantasting. De schade is het grootst bij een vroege aantasting (juli). Tevens maakt Helminthosporium mais gevoeliger voor een aantasting door Fusarium (stengelrot).

Helminthosporium is nu reeds gedurende meerdere jaren waargenomen. De rasvolgorde per jaar is zeer consistent. Nieuwe rassen zijn steeds beter resistent.

$\mathrm{Na}$ de bloei wordt het maisgewas gevoeliger voor Helminthosporium, omdat de plant zich meer gaat richten op de productie van de kolf en minder op het in stand houden van het bladapparaat. Rassen die vroeger bloeien zijn daardoor iets gevoeliger voor een aantasting van Helminthosporium. Hierdoor is het beter rassen van vergelijkbare vroegheid (van bloei) met elkaar te vergelijken. Later bloeiende rassen zijn over het algemeen iets minder gevoelig. Dit moet echter niet worden overtrokken, want er zijn ook zeer vroeg bloeiende rassen, die een goede tot zeer goede resistentie hebben.

Sinds 2010 wordt de mais ook op grotere schaal hoofdzakelijk in Noord Nederland aangetast door de schimmel Kabatiella zeae (zie hoofdstuk 9). Het veroorzaakt kleine vlekjes, een soort oogjes, waardoor deze ook wel Eyespot wordt genoemd. Directe schade op opbrengst en kwaliteit is nog niet direct geconstateerd, maar wel staat het gewas bij de oogst soms dood op het veld als gevolg van deze ziekte. De mate van gevoeligheid wordt nog niet op de Rassenlijst weergegeven omdat een direct effect op opbrengst en kwaliteit nog niet is vastgesteld.

\section{Snelheid grondbedekking}

De snelheid grondbedekking geeft weer hoe snel een ras een bepaalde massa vormt en de grond bedekt. Tevens dus een maat voor de onkruidonderdrukking. Deze is afhankelijk van het ras, maar ook van de kwaliteit van het zaaizaad. Tussen een waardering van een 6 en een 9 op de rassenlijst zit jaarsafhankelijk gemiddeld 1,5 week in sluiten van het gewas.

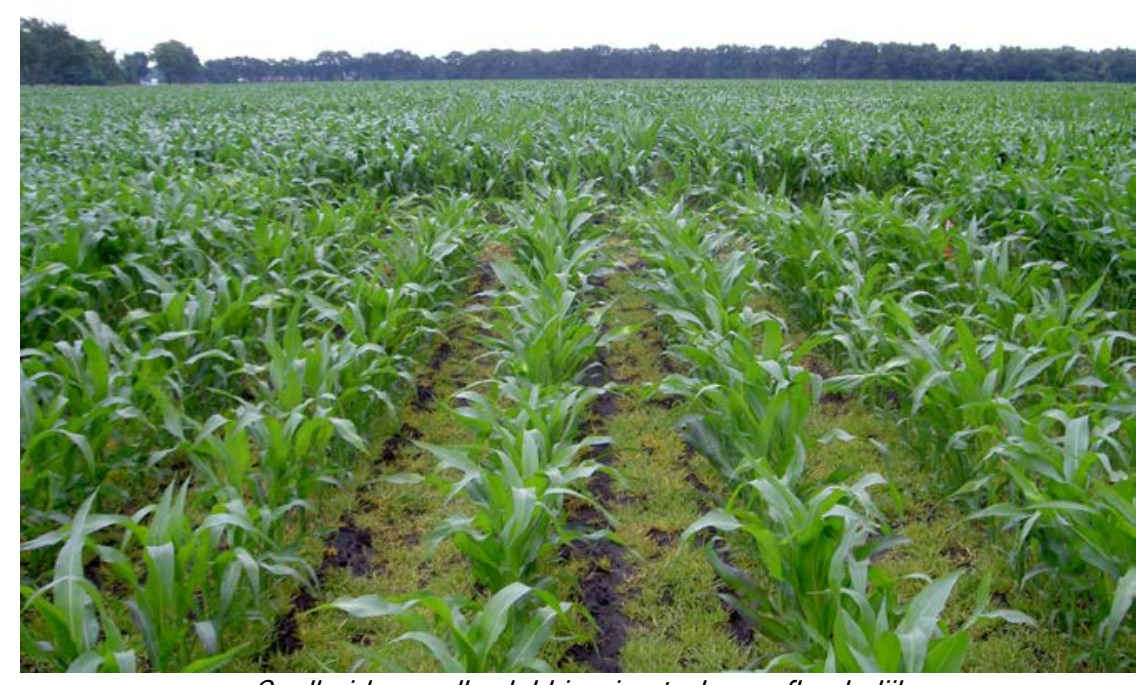

Snelheid grondbedekking is sterk rasafhankelijk 


\section{Plantlengte}

De eigenschap lengte moet in relatie worden gezien met de stevigheid van een ras. Het risico van legering, door hoofdzakelijk stengelzwakte, kan men op basis van deze twee eigenschappen beter inschatten. Daarnaast geeft de lengte informatie over de massaliteit van een gewas, wat van belang kan zijn bij verkoop op stam. Bedenk hierbij dat de langste rassen kwalitatief vaak niet de beste zijn.

\section{Vroegheid van vrouwelijke bloei}

Laatbloeiende rassen moeten ten aanzien van het drogestofgehalte een achterstand inhalen bij vroegbloeiende rassen. In jaren met een vroege bloei en gunstige afrijpingsomstandigheden lukt dit meestal wel. Wanneer het moeilijk is een drogestofgehalte van 30\% te bereiken, vallen laat bloeiende rassen vaak tegen in drogestofgehalte. Daarnaast hebben vroegbloeiende rassen tijdens korrelzetting een grotere kans te ontsnappen aan een vroegtijdig vochttekort, omdat de kans op droogte in de loop van het groeiseizoen toeneemt. Dit wordt echter sterk bepaald door de neerslagverdeling gedurende het groeiseizoen. Een vroege bloei verhoogt de bedrijfszekerheid van een ras. Gemiddeld over de jaren ligt het tijdstip van vrouwelijke bloei bij het huidige rassensortiment op circa 84 dagen na zaaien. Het verschil in bloeitijdstip tussen het vroegst en het laatst bloeiende rassenlijstras bedraagt circa 14 dagen. Gemiddeld bloeit de maïs in Nederland dus rond 20 juli, maar afhankelijk van jaar en ras kan dit 2-3 weken vroeger of later zijn.

\section{Drogestofgehalte}

Het drogestofgehalte wordt bepaald door het tijdstip van vrouwelijke bloei, de snelheid van afrijping, het kolfaandeel en de mate van aantasting door stengelrot. Het meest optimale drogestofgehalte ligt bij 35-36 \%. De balans tussen productie, inkuilverliezen en opname en benutting door de koe is dan het meest optimaal. In gunstige jaren wordt de maximale opbrengst bij een drogestofgehalte rond $40 \%$ bereikt, maar goed inkuilen wordt dan lastiger, waardoor kans op broei bij uitkuilen toeneemt. In minder gunstige jaren kan bij een drogestofgehalten boven de 38\% de voederwaarde negatief beïnloed worden door een sterke stengelrotaantasting.

Het optreden van inkuil- en perssapverliezen is sterk afhankelijk van het drogestofgehalte. Voor beperking van inkuilverliezen is een minimaal drogestofgehalte van $28 \%$ noodzakelijk. De rassen op de Aanbevelende Rassenlijst hebben veelal een harmonische afrijping tussen kolf en plant, waardoor de hoeveelheid aan perssapverliezen bij een oogst rond $32 \%$ drogestof minimaal is.

\section{Kwaliteit}

Eén kilo drogestof snijmais bestaat voor ca. $96.5 \%$ uit organische stof. Gemiddeld bestaat deze organische stof voor $38 \%$ uit zetmeel, voor $36 \%$ uit celwanden en bijna $25 \%$ uit overige bestanddelen zoals eiwit (7\%), vet (3-4\%), suiker (6\%) en organische zuren. Het zetmeel is voor ca. $98 \%$ verteerbaar en de celwanden voor 50 tot $55 \%$. Van de totale energie uit een kilo snijmais (VEM/kgds) komt daardoor gemiddeld 50\% uit zetmeel en 25\% uit celwanden. Door de rassenkeuze zijn deze percentages te beïnvloeden. Voor een juiste beoordeling van de kwaliteit van snijmaisrassen is de VEMwaarde per kg drogestof de belangrijkste parameter. De opname capaciteit van een koe is beperkend voor de hoogte van de melkproductie, daarom is een hoge energiewaarde per kilo opgenomen drogestof essentieel.

De VEM/kgds geeft aan hoeveel energie een koe per kg ds beschikbaar kan krijgen. Daarnaast zijn zetmeelgehalte en restplantverteerbaarheid (celwandgehalte en -verteerbaarheid, suiker, vet en eiwit) de belangrijkste eigenschappen die de kwaliteit van het snijmaïsgewas bepalen. Een inschatting van het verschil in restplantverteerbaarheid tussen 2 rassen kan worden gemaakt, door de VEM/kgds en het zetmeelgehalte van de rassen met elkaar te vergelijken. Een hogere VEM/kgds en een lager zetmeelgehalte duidt op een hogere restplantverteerbaarheid en omgekeerd.

Uit conserveringsonderzoek van Wageningen Livestock Research in 2003 en 2004 bleek dat de voederwaardeverliezen en verandering van zetmeelgehalte en restplantverteerbaarheid niet 
afhankelijk zijn van het rastype. Dit betekent dat de rasvolgorde in kwaliteit niet verandert als gevolg van inkuilen.

\section{Voederwaarde (VEM)}

De berekening van de VEM-waarde van snijmaïs, berust op de verteerbaarheid van de organische stof (VC-os) en het anorganische stof gehalte (as), dat hierin een negatieve rol speelt. In het rassenonderzoek wordt de VC-os vanaf 2007 bepaald via NIRS gekalibreerd op de pensvochtmethode van Tilley\&Terry. De VC-os wordt enerzijds bepaald door de samenstelling van de organische stof en anderzijds door de verteerbaarheid van de diverse componenten, waarbij celwanden en zetmeel de belangrijkste elementen zijn. Een ras moet zowel een hoog zetmeelgehalte als een zeer goede verteerbaarheid van de celwanden hebben om een topvoederwaarde te realiseren. Het zetmeelgehalte en de celwandverteerbaarheid geven inzicht in de samenstelling van de voederwaarde. Deze samenstelling is medebepalend voor de voederwaarde op dierniveau, zie hiervoor het hoofdstuk Voeding.

De voederwaarde (VEM/kgds) is in het oogsttraject van snijmaïs niet afhankelijk van het oogsttijdstip en hoeft niet gecorrigeerd te worden naar drogestofgehalte. Gemiddeld over de jaren blijt de voederwaarde tussen 28 en 38\% drogestof gelijk, zolang er geen zware stengelrotaantasting optreedt. De voederwaarde blijt in dit traject gelijk doordat een afname in de celwandverteerbaarheid wordt gecompenseerd door een toename in het zetmeelgehalte. Gemiddeld over de A- en N-rassenlijstrassen (100=) is de voederwaarde 1010 en 1007 VEM/kgds (verse maïs) voor respectievelijk de zeer vroege/vroege groep en de middenvroege/middenlate groep. Rassen met een voederwaarde van relatief 98 worden door de handel en de maisteler regelmatig als onvoldoende betiteld, maar gezien het hoge niveau waar de Aanbevelende Rassenlijst voor staat is dit zeker niet terecht. Door het veredelen van nieuwe rassen is de voederwaarde is de laatste 20 jaar met $10 \%$ gestegen. Deze verbetering wordt naast een hoog zetmeelgehalte de laatste jaren vooral veroorzaakt door verbeteringen in celwandverteerbaarheid. Voor een top melkproductie is een hoog zetmeelgehalte van zeer groot belang. Zeker in de eerste helft van de lactatie kan een koe grote hoeveelheden (bestendig) zetmeel aan. Om te voorkomen dat er in dit deel van de lactatie te weinig energie op pensniveau beschikbaar is en/of de koe te veel in conditie achteruit holt, is ook een hoge celwandverteerbaarheid zeer belangrijk. Energie uit celwanden komt namelijk hoofdzakelijk op pensniveau beschikbaar. Daarnaast geeft een hogere celwandverteerbaarheid een hogere passagesnelheid, waardoor de koe een hogere drogestof opname per dag en daarmee een hogere productie kan realiseren. Tot slot is het zo, dat alles wat de koe benut niet in de mest terecht komt. In de tweede helft van de lactatie moet voorkomen worden dat door te veel (bestendig) zetmeel de koeien gaan vervetten.

Naast een zeer hoog zetmeelgehalte is een hoge celwandverteerbaarheid dus van essentieel belang voor een topmelkproductie, een goede conditie van uw veestapel en een lagere mestproductie.

\section{Zetmeelgehalte}

Een optimale raskeuze op voederwaarde is een keuze op de hoogste VEM/kgds en vervolgens op een zetmeelgehalte die het beste past op bedrijfsniveau. Met de hoge melkproducties in Nederland wordt er over het algemeen niet snel te veel zetmeel gevoerd. Een hoog zetmeelgehalte is niet per definitie positief, daarom is het zetmeelgehalte slechts een beschrijvende en geen aanbevelende eigenschap op de Rassenlijst.

Het zetmeelgehalte wordt sterk bepaald door het kolfaandeel. Naarmate de snijmaiis afrijpt, neemt het aandeel van de kolf in de drogestof toe. Bij toename van het drogestofgehalte is er dus een toename van het zetmeelgehalte. Per ras is dit verband verschillend. Om een goed beeld te krijgen van het verloop in zetmeelgehalte en in de rasvolgorde hierin, is het daarom gewenst zowel het zetmeelgehalte bij oogst, als bij het voor snijmais optimale dsgehalte van $35 \%$ weer te geven. 
Bij zetmeel kan men afhankelijk de specifieke bedrijfssituatie kiezen voor een hoog of laag gehalte aan zetmeel. In Nederland gaat de voorkeur overwegend uit naar een hoog gehalte (bestendig) zetmeel.

Voor de vergelijking van rassen op het zetmeelgehalte zal moeten worden in geschat, welk drogestofgehalte de mais op het betreffende perceel kan bereiken.

Gedurende het groeiseizoen kan men afhankelijk van de kolfontwikkeling het uiteindelijke zetmeelgehalte sturen door vroeger of later te oogsten. Bij zeer vroege rassen, die eerder in het groeiseizoen een bepaald drogestofgehalte bereiken, is de mogelijkheid te sturen groter dan bij middenvroege rassen.

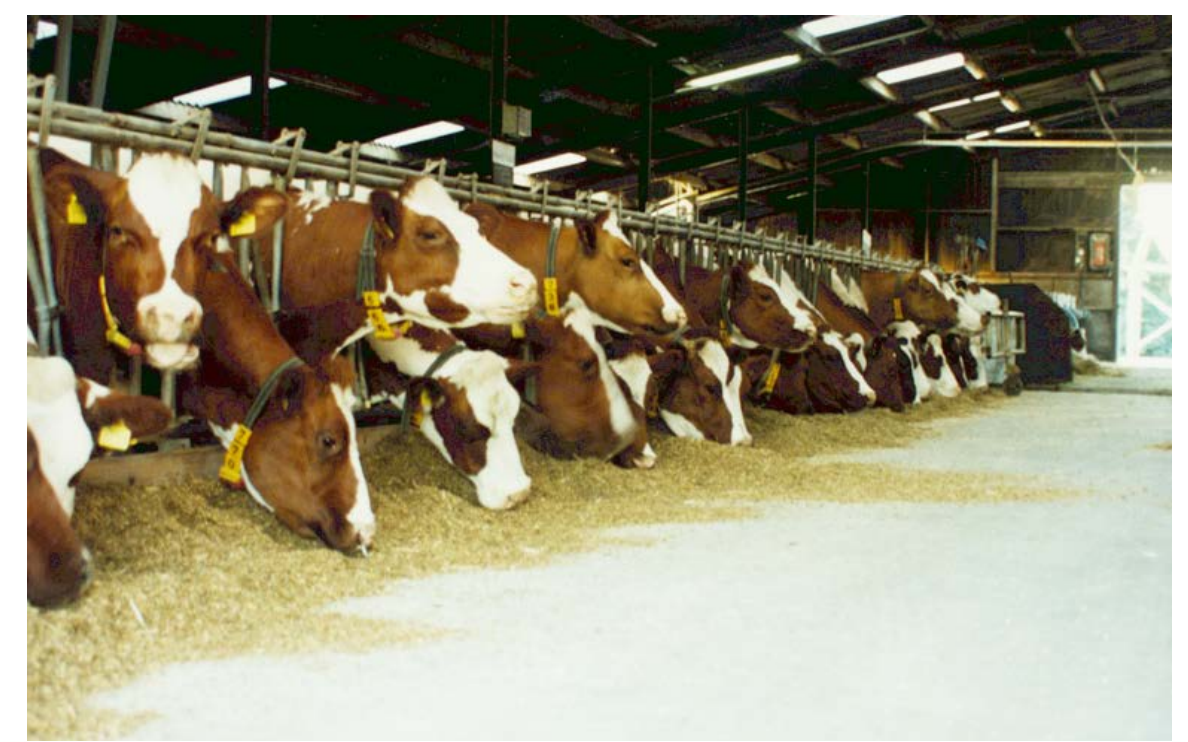

Bestendig zetmeel is goed voor productie in eerste fase van lactatie

\section{Celwandverteerbaarheid}

De celwand bestaat uit hemicellulose, cellulose en lignine. Het aandeel van de verschillende bestanddelen en de verbindingen zowel binnen als tussen de bestanddelen bepalen in grote mate de verteerbaarheid van de celwand. De celwandverteerbaarheid geeft aan hoe makkelijk de celwanden op pensniveau afbreekbaar zijn en de energie beschikbaar komt.

Door een toename van het zetmeelgehalte neemt het celwandgehalte gedurende de afrijping af. De invloed van de celwanden op de voederwaarde wordt dus gedurende de afrijping minder. Bij rassen met een hoog zetmeelgehalte is de invloed van de celwanden op de voederwaarde minder dan bij rassen met een laag zetmeelgehalte, omdat de celwanden bij de eerstgenoemde rassen een kleiner deel van de organische stof uitmaken. Naast een afname van het celwandgehalte neemt ook de verteerbaarheid hiervan tijdens de afrijping af. Binnen dezelfde vroegheidsgroep hebben de vroegere rassen daardoor gemiddeld een lagere celwandverteerbaarheid dan latere rassen, omdat ze vaker geoogst worden bij een hoger drogestofgehalte.

Een hogere celwandverteerbaarheid bij maïs heeft géén negatief effect op de structuurwaarde van het rantsoen.

\section{Drogestof- en VEM-opbrengst}

Voor beoordeling van snijmaïsrassen is de drogestofopbrengst een belangrijke eigenschap. Het geeft aan hoeveel ruwvoer er per ha geoogst kan worden. De VEM-opbrengst is echter zeker zo belangrijk omdat we hiermee de energie-opbrengst per ha aanduiden. Het doel van een geslaagde maïsteelt is een zo 
hoog mogelijke VEM-opbrengst per ha. Of men hierbij meer nadruk legt op de drogestofopbrengst of de voederwaarde is met name afhankelijk van de ruwvoerpositie op een bedrijf.

Voor het weergeven van de energieproductie per ha, is bij snijmais de VEM-opbrengst de enig juiste parameter. Hierin wordt zowel de energie-opbrengst vanuit de kolf (zetmeel) als vanuit de plant op waarde geschat. Enkel de weergave van de zetmeelopbrengst geeft een onvolledig beeld. De zetmeelopbrengst geeft slechts ongeveer $40 \%$ van de drogestofopbrengst en $50 \%$ van de energieopbrengst weer.

\subsubsection{Bedriffsomstandigheden en praktjkervaring}

Om een goed ruwvoer te winnen is het in eerste instantie van belang dat de teelt slaagt, deze de gewenste opbrengst en kwaliteit oplevert, die uiteindelijk op bedrijfsniveau de hoogste benutting geeft. Een juiste rassenkeuze is hierbij van zeer groot belang. Uit onderzoek, uitgevoerd in 2003 en 2004, bleek dat het optimale oogststadium niet afhankelijk is van het rastype. Ook is er geen noemenswaardig verschil in oogstelasticiteit tussen de stay green en dry down typen. Uit voedingsonderzoek kwam geen verschil naar voren in opname, voederwaarde en productie tussen het stay green type en dry down type. Dit betekent dat men bij de raskeuze geen rekening hoeft te houden met deze aspecten. De raskeuze blijft dus afhankelijk van het teeltrisico, gebruiksdoel en gewenste opbrengst en kwaliteitsaspecten. Deze worden bepaald door de specifieke bedrijfsomstandigheden, waarop men de optimale rassenkeuze dan ook moet afstemmen (tabel 6.3). Aan de hand van de geldende omstandigheden en de ervaringen van de teler kan hij het beste ras kiezen.

\section{Teeltrisico's}

Teeltrisico's zijn uit te sluiten door op perceelsniveau het juiste ras te kiezen. Omstandigheden die de teeltrisico's bepalen zijn de lengte van het groeiseizoen, de onkruiddruk, de kans op droogte, gebrek aan stevigheid en ziekten.

Afhankelijk van de lengte van het groeiseizoen kiest men voor een meer of minder vroeg ras. Bij een kort groeiseizoen, zoals in Noord- en West-Nederland, bij late zaai, vroege oogst, kleigrond, natte zandgrond kiest men dus voor zeer vroege rassen. Is de onkruiddruk hoog, kies dan een ras met een zeer vlotte grondbedekking. Is er kans op legering door gebrek aan stevigheid, zoals op klei- en natte zandgronden, kies dan voor stevige en eventueel korte rassen.

Op droogtegevoelige gronden kiest men voor rassen waarbij de bloei al plaatsvindt voordat het droog wordt. Na een droge periode is er grotere kans op een stengelrot- en builenbrandaantasting, dus dient men hier extra rekening mee te houden. Droogte kan ten koste gaan van de kolfontwikkeling en dus van het zetmeelgehalte. Rassen met een goede celwandverteerbaarheid hebben al een goede basis voederwaarde en zijn dan minder afhankelijk van het zetmeelgehalte. De eigen ervaring van de teler speelt natuurlijk ook een belangrijke rol. Gebruikt een teler naar tevredenheid op kleigrond al jaren zonder problemen rassen met een minder goede stevigheid, dan is het daar waarschijnlijk niet echt noodzakelijk een ras met een zeer goede stevigheid te kiezen, hoewel deze rassen wel meer risico met zich meebrengen.

Als er de laatste jaren een zware Helminthosporiumaantasting in de mais op een perceel voorkwam, dan moet er zeker gekozen worden voor een ras met een resistentiecijfer van 7 of hoger. Kwam er de laatste jaren vrijwel geen Helminthosporium voor dan kan ook voor een meer gevoelig ras gekozen worden.

\section{Gebruiksdoel}

Teelt men maïs voor eigen gebruik en is de opbrengst belangrijk, kies dan in eerste instantie op basis van drogestofopbrengst en vervolgens op VEM-opbrengst. Kiest men meer voor kwaliteit, dan 
zijn voederwaarde, vroegheid van bloei (tijdige kolfontwikkeling) en VEM-opbrengst belangrijke eigenschappen.

In specifieke gevallen kan men kiezen voor meerdere kuilen of verbouw op twee verschillende percelen, die toch tegelijk ingekuild worden. Kies dan rassen die verschillen in vroegheid (drogestofgehalte en vroegheid van bloei). Wil men de mogelijkheid voor een uitgestelde oogst houden, zorg dan dat het geteelde ras een voldoende resistentie heeft tegen stengelrot en bladvlekken.

Bij de verkoop van maïs op stam kijkt men veelal naar de massa die er op het veld staat. Het geeft echter geen nauwkeurige informatie over de drogestofopbrengst. Plantlengte wordt ook nogal eens gebruikt als oneigenlijk verkoopargument. Veel beter is de gekochte maïs te wegen, de voederwaarde hiervan te bepalen en op basis hiervan een prijs af te spreken. Bij maïs draait het om de kwaliteit en veel minder om de opbrengst. Verder is het bij de verkoop op stam natuurlijk van belang dat er geen ziekten voorkomen, daarom is een zeer goede resistentie zeer belangrijk.

\section{Benutting kwaliteit}

De voederwaarde op gewasniveau, als getal alleen, is onvoldoende om de voederwaarde op dierniveau aan te geven. Niet alleen de hoogte, maar ook de opbouw van de voederwaarde heeft invloed op de opname en de benutting door het dier.

Voor een hoge melkproductie is een goede energievoorziening onontbeerlijk. Voor de hoogste melkproductie moet men rassen kiezen met de hoogste energieinhoud (VEM/kg ds). Deze energie wordt bij maïs vooral geleverd door zetmeel, maar ook door de verteerbare celwanden. Er is geen bovengrens aan het aandeel verteerbare celwanden in het rantsoen. Voor nieuwmelkte koeien geldt dat er ook geen bovengrens is voor de hoeveelheid zetmeel in het rantsoen. Echter, koeien in de tweede helft van de lactatie lopen een risico op vervetting bij een een zetmeelrijk rantsoen. (zie hoofdstuk 12). Wanneer melkkoeien in productiegroepen kunnen worden gehouden of het aandeel snijmais beperkt is tot ca. $40 \%$ van het ruwvoer kan zonder bezwaar worden gekozen voor snijmaïsrassen met een hoog zetmeelgehalte. Bedrijven die geen productiegroepen willen of kunnen maken en meer dan 60\% maïs in het rantsoen hebben zouden kunnen overwegen snijmaïsrassen met een hoge celwandverteerbaarheid en een relatief lager zetmeelgehalte te telen.

Tabel 6.3 Belangrijke raseigenschappen bij diverse bedrijfsomstandigheden.

\begin{tabular}{ll}
\hline Bedrijfsomstandigheid & Belangrijke raseigenschappen \\
\hline Teeltrisico & Drogestofgehalte, vroegheid van bloei, snelheid \\
groeiseizoen & \\
Noord- / West- Nederland & Late Zaai \\
Vroege oogst & \\
Kleigrond / Natte zandgrond & \\
Hoge onkruiddruk & \\
Kans op gebrek aan stevigheid & Snelheid grondbedekking \\
Kleigrond / Natte zandgrond & Stevigheid, zomerlegering, green snap, plantlengte \\
$\quad$ Hoge plantaantallen & \\
Kans op droogte & \\
& $\begin{array}{l}\text { Vroegheid bloei, stengelrotresistentie, } \\
\text { builenbrandresistentie, }\end{array}$ \\
Kans op ziekten & $\begin{array}{l}\text { Celwandverteerbaarheid } \\
\text { Stengelrotresistentie, builenbrandresistentie, } \\
\text { bladvlekkenziekten }\end{array}$ \\
\hline
\end{tabular}


Handboek snijmaïs

\section{Gebruiksdoel}

Verkoop op stam

Massa, kolf, mooi ogende maïs Eigen gebruik opbrengst belangrijk Weinig beschikbare grond

Ruwvoer te kort

Eigen gebruik kwaliteit belangrijk Voldoende grond beschikbaar Hoogproductieve veestapel Ruwvoeroverschot

Eigen gebruik met oogstspreiding Meer kuilen maken

Zelf hakselen

\section{Benutting kwaliteit}

$<60 \%$ maïs in het rantsoen en hoog productieve veestapel (12.000kg melk) $<60 \%$ maïs in het rantsoen en gemiddeld productieve veestapel $(8.500 \mathrm{~kg}$ melk) $>60 \%$ maïs in het rantsoen en hoog productieve veestapel (12.000kg melk)

$>60 \%$ maïs in het rantsoen en gemiddeld Voederwaarde, celwandverteerbaarheid, zetmeelgehalte productieve veestapel ( $8.500 \mathrm{~kg}$ melk)
Stevigheid, zomerlegering, stengelrotresistentie, plantlengte, vroegheid bloei, bladvlekkenziekten

\section{Drogestofopbrengst, VEM-opbrengst}

Voederwaarde, vroegheid bloei, VEM-opbrengst

Drogestofgehalte, vroegheid bloei, stengelrotresistentie

Voederwaarde, zetmeelgehalte,

celwandverteerbaarheid, ds-gehalte

Voederwaarde, zetmeelgehalte

Voederwaarde, zetmeelgehalte, celwandverteerbaarheid

Drogestofgehalte, vroegheid bloei, stengelrotresistentie 


\section{Teeltdoel}

In de praktijk is men nog wel eens op zoek naar "dubbeldoel-rassen". Dit zijn rassen waarbij men pas bij de oogst besluit of men ze afzet als snijmais, maïskolvensilage, corn cob mix of korrelmaïs. Deze rassen moet men echter per teeltdoel bij een verschillende standdichtheid telen. Dubbeldoelgewassen geven nooit een optimaal resultaat voor alle gebruiksdoeleinden. In verband met rassenkeuze en teeltwijze moet dan ook reeds vóór uitzaai het teeltdoel vaststaan. Wanneer dit niet vaststaat, richt dan de teelt op korrelmaïs, dit geeft de minst negatieve effecten. De resultaten van korrelmaïs en corn cob mix zijn te vinden op de website van CSAR www.rassenlijst.info.

\section{Rassenmengsels}

Tegenwoordig zijn er enkele rassenmengsels op de markt. Daarnaast worden in de praktijk soms twee of drie rassen volledig gemengd gezaaid. Ook wordt er in de praktijk soms gekozen om rijen van het ene maisras af te wisselen met rijen van een ander maisras. De argumenten hiervoor zijn risicospreiding en voederwaarde technische overwegingen. Vanuit onderzoek zijn tot nu toe echter geen aanwijzingen voor positieve effecten gevonden. Uit onderzoek, uitgevoerd door Praktijkonderzoek AGV van Wageningen University \& Research waarbij mengsels zijn vergeleken met de afzonderlijke rassen uit het mengsel bleek dat het mengsel nooit beter is dan het gemiddelde van de rassen en dat het beste ras altijd beter is dan het mengsel. Tevens is het aanbod van maisrassen zo divers, dat voor elke situatie wel het meest geschikte ras gekozen kan worden en mengsels niet nodig zijn. 


\section{Zaaien}

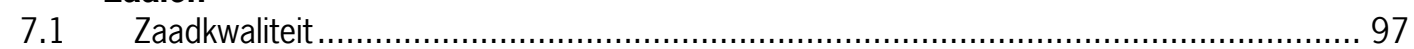

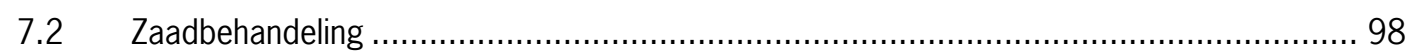

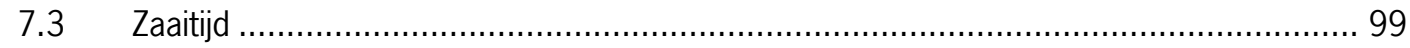

$7.4 \quad$ Zaaidiepte

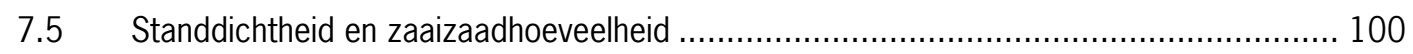

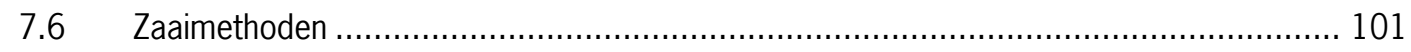




\section{Zaaien}

De zaadkwaliteit, zaaimethode en het zaaitijdstip zijn van belang voor een goede opkomst en beginontwikkeling van de maïs. In dit hoofdstuk komen eerst de zaadkwaliteit en de bescherming van het zaad door het te behandelen aan de orde. Daarna behandelen we de zaaitijd en zaaidiepte. Tot slot schenken we aandacht aan de standdichtheid, zaaizaadhoeveelheid en zaaimethoden.

\subsection{Zaadkwaliteit}

Voor een optimale opbrengst van het gewas is het van belang dat er voldoende planten staan. Een zo hoog mogelijke veldopkomst is hierbij belangrijk. De veldopkomst wordt bepaald door de kiemkracht van het zaad en de omstandigheden in het veld tijdens de kieming. Het Nederlands Algemeen Keuringsstation (NAK) bepaalt in het laboratorium onder ideale omstandigheden de kiemkracht. Deze moet voldoen aan de eis dat uit minimaal $90 \%$ van de zaden een normale kiemplant groeit. Op basis van de kiemkracht wordt het zaad voorzien van een certificaat. Alleen gecertificeerd zaad mag in de handel.

De veldopkomst is niet alleen afhankelijk van de kiemkracht. Dit komt doordat de kiemingsomstandigheden in het veld vaak veel ongunstiger zijn dan in het laboratorium. Maïs krijgt tijdens de kieming nogal eens te maken met lage temperaturen, waardoor de veldopkomst sterk kan afwijken door inwerking van kiemschimmels. Daarom adviseren we om bij vroeg zaaien meer zaden per ha te gebruiken dan bij later zaaien (zie paragraaf 7.5).

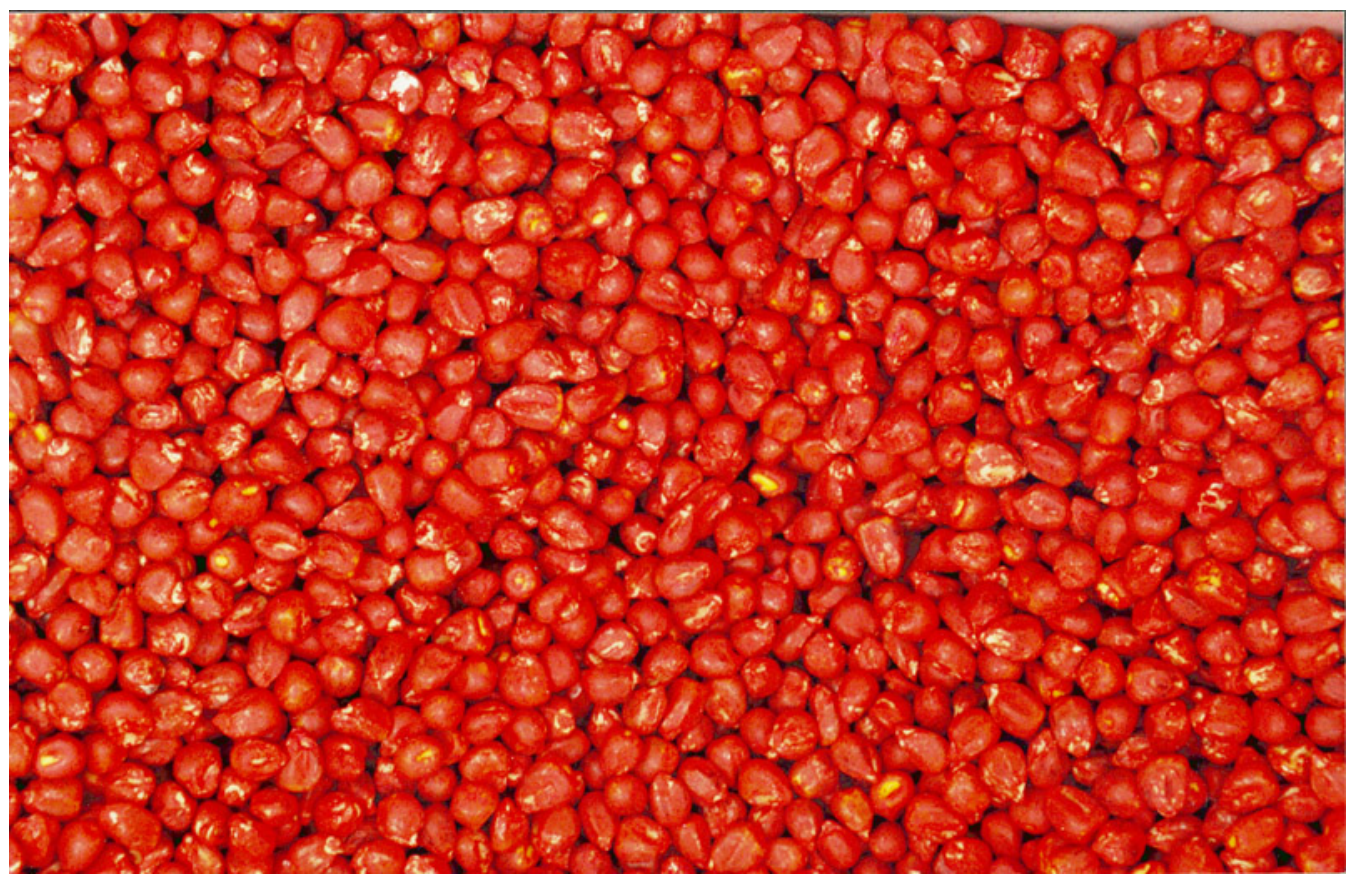

Begin met goed zaad 


\section{Goedkoop kan duurkoop zijn}

In de praktijk wordt nog wel eens gekozen voor goedkoop zaaizaad. Dit brengt echter risico's met zich mee voor de kwaliteit. Vaak is het zaad van B-rassen, van rassen die net van de rassenlijst zijn afgevoerd of van rassen die op een buitenlandse rassenlijst staan. Het komt voor dat dit wat ouder zaad is of overjarig en gemengd met nieuw zaad om toch een redelijke kwaliteit te krijgen. Onder ongunstige omstandigheden kan dit behoorlijke opkomstproblemen geven.

\subsection{Zaadbehandeling}

Om de kiemplant te beschermen tegen ziekten en plagen wordt het zaaizaad in het algemeen ontsmet aan de teler geleverd. Bodemschimmels, meestal Pythiumsoorten en soms ook Fusariumsoorten, zijn een belangrijke groep belagers. Deze veroorzaken een bruinachtige verkleuring van de wortels.

Aantasting treedt met name op bij lage temperaturen wanneer de kieming traag verloopt. Het gevolg is een onregelmatige opkomst en een trage groei. Bestrijding vindt plaats door zaadontsmetting, meestal met middelen op basis van thiram (standaard ontsmetting). Ook beschikbaar is het middel Maxim XL met de actieve stoffen fludioxonil en mefonaxam.

Naast bodemschimmels kunnen ook vogels behoorlijke schade aanrichten. Deze kunnen zowel zaden als jonge planten meepikken. Meestal is het zaaizaad behandeld met methiocarb (Mesurol FS), wat bescherming geeft tegen vogelvraat. Zaaizaadontsmetting met methiocarb geeft ook bescherming tegen de larve van de fritvlieg.

Wanneer de maïs op gescheurd grasland wordt gezaaid, kan schade optreden door ritnaalden. De schade kan optreden tot 3 jaar na scheuren, maar met name in het tweede jaar na scheuren is het risico het grootst. Door het zaad te behandelen met een middel op basis van thiacloprid (Sonido) of Tefluthrine (Force 20CS) kan schade door ritnaalden deels worden voorkomen.

Sinds 2011 wordt mais in bepaalde delen van Nederland aangetast door een schimmel (Sphacelotheca reiliana), die maiskopbrand veroorzaakt. De schimmel tast de mais in het 2 tot 4 bladstadium via de wortels aan. De wortels en daarmee de plant zijn enigszins ( $50 \%$ reductie) te beschermen door een zaaizaadbehandelling met fungiciden. Op dit moment zijn twee middelen beschikbaar Alios (triticonazole) en Feuver (prothioconazool). Voor het opbrengen op het zaaizaad is in Nederland geen toelating maar in het buitenland wel. Behandeld zaad kan wel worden geïmporteerd en vervolgens worden uitgezaaid.

Voor een beschrijving van de aantastingsverschijnselen van de larven van de fritvlieg, ritnaalden en maiskopbrand wordt verwezen naar hoofdstuk 9.

\section{Vogelvraat beperken bij onbehandeld zaad}

Op dit moment zijn er nog geen goede alternatieven voor methiocarb (Mesurol) als behandelingen van zaaizaad tegen vogelvraat. Dit levert met name bij de biologische teelt problemen op omdat daar zaadbehandeling met chemische middelen niet is toegestaan. Vogelvraat kan men beperken door voldoende diep te zaaien $(5-6 \mathrm{~cm}$ ) in een fijn zaaibed en door tijdens het zaaien geen zaad te morsen. Daarnaast zijn er methoden om de vogels te verjagen, zoals ophangen van vlaggen, nep-roofvogels, CD's of DVD's of plaatsen van gaskanonnen, (bewegende) poppen of een apparaat dat angstkreten produceert. Als gevolg van gewenning werken alle methoden maar enkele dagen. Het beste effect wordt bereikt wanneer de methoden om de 3 á 4 dagen worden afgewisseld (matrix methode). 


\subsection{Zaaitijd}

De zaaitijd van maïs wordt in belangrijke mate bepaald door de bodemtemperatuur. Deze dient minimaal $8-10{ }^{\circ} \mathrm{C}$ te zijn. Onder Nederlandse omstandigheden wordt deze bodemtemperatuur afhankelijk van grondsoort en regio tussen 20 april en 1 mei bereikt. Bij vroeger zaaien neemt het risico toe van meer plantuitval door te lage bodemtemperaturen. Bovendien is er dan nog kans op nachtvorstschade. Ook grondsoort en perceelskeuze spelen een rol. Zwaardere gronden en lagere percelen warmen minder snel op in het voorjaar. Op deze gronden wordt de maïs meestal de eerste helft van mei gezaaid. Ook door onvoorziene omstandigheden als nat weer kan men de zaai moeten uitstellen. Laat zaaien (na 10 mei) biedt met name voor de biologische teelt voordelen. Door de snelle kieming en ontwikkeling van de kiemplanten is de kans op aantasting door bodemschimmels kleiner. Daarnaast heeft de maïs door de snelle ontwikkeling een betere concurrentiepositie ten opzichte van het onkruid. Dit vereenvoudigt de mechanische onkruidbestrijding.

Zeer laat zaaien (na 15 mei) heeft gevolgen voor zowel de opbrengst als de kwaliteit. Een later zaaitijdstip leidt in het algemeen tot iets lagere opbrengsten, een lager drogestofgehalte, een lager zetmeelgehalte (kolfaandeel), en de gewassen zijn vaak langer en slapper. Daarnaast is het oogsttijdstip van laat gezaaide maïs later waardoor de kans dat er onder ongunstige weers- en bodemomstandigheden moet worden geoogst groter is.

\section{Huidige rassen kunnen wat later gezaaid worden}

Een vuistregel vanuit oud onderzoek is dat elke dag later zaaien na 1 mei 80 tot $100 \mathrm{~kg}$ droge stof per ha minder opbrengst geeft. Deze regel lijkt voor het huidige rassenassortiment niet meer te gelden. Uit onderzoek van het Wageningen Plant Research - Praktijkonderzoek AGV naar het effect van vals zaaibed bleek later zaaien tot 10-15 mei nauwelijks effect op de opbrengst te hebben. Op praktijkcentrum Cranendonck werd gedurende 3 jaar het voorjaarsgebruik van vanggewassen onderzocht. Half mei zaaien in combinatie met voorafgaand oogsten van een vanggewas en wat later oogsten gaf zelfs de hoogste maïsopbrengst. Het lijkt erop dat de langere groeiperiode aan het eind van het seizoen meer opleverde dan een langere periode aan het begin. Wel was de voederwaarde lager met name door een lager zetmeelgehalte (kolfaandeel).

\subsection{Zaaidiepte}

Het zaad dient men op de grens van losse en vaste grond te leggen. De optimale zaaidiepte van maïs bedraagt 4 tot $5 \mathrm{~cm}$. Bij een droog zaaibed en bij een mechanische onkruidbestrijding moet iets dieper gezaaid worden $(5$ tot $6 \mathrm{~cm}$ ). Dieper zaaien dan volgens dit advies leidt tot een trage opkomst, meer plantuitval en een lagere opbrengst en kwaliteit. Bij te ondiep zaaien kan de vochtvoorziening in het geding komen. Daarnaast kan de verankering in de grond te wensen overlaten en is de kans op vogelvraat groter.

Van belang is verder dat het zaad regelmatig op een bepaalde diepte wordt neergelegd. Bij zaaien in te losse grond of wanneer de grond niet regelmatig is aangedrukt, lukt dit niet. Dit heeft een onregelmatige opkomst tot gevolg. 


\subsection{Standdichtheid en zaaizaadhoeveelheid}

\section{Plantgetal}

De standdichtheid is van invloed op de voederwaarde. De optimale economische standdichtheid wordt bepaald door het ras en groeiomstandigheden (zie tabel 7.1). De optimale standdichtheid van bladarme rassen is hoger dan van bladrijke rassen. Op gronden met gemiddeld ongunstige groeiomstandigheden (droogtegevoelige gronden en late, natte gronden) ligt de optimale standdichtheid wat lager dan op gronden met gunstige groeiomstandigheden.

Tabel 7.1 Gewenste standdichtheid (aantal planten per ha)

\begin{tabular}{lcc}
\hline Rastype & \multicolumn{2}{c}{ Groeiomstandigheden } \\
\cline { 2 - 3 } & Gemiddeld tot gunstig & Ongunstig \\
\hline Bladarm & 110.000 & 100.000 \\
Normaal & 100.000 & 90.000 \\
Bladrijk & 90.000 & 80.000 \\
\hline
\end{tabular}

\section{Zaaizaadhoeveelheid}

Om het gewenste aantal planten te realiseren moet men meer zaden zaaien, omdat de veldopkomst nooit $100 \%$ is en afhangt van de kiemingsomstandigheden. De hoogte van deze toeslag hangt vooral af van de zaaitijd. Onder gemiddelde omstandigheden wordt geadviseerd om bij zaaien voor 30 april 10-15\% extra zaad te gebruiken. Bij zaai na 1 mei kan men volstaan met een toeslag $0-5 \%$. In tabel 7.2 zijn de gewenste standdichtheid en het zaaitijdstip gecombineerd tot een zaaitabel.

Tabel 7.2 Zaaitabel voor snijmaïs

\begin{tabular}{cccc}
\hline $\begin{array}{c}\text { Gewenste standdichtheid } \\
\text { (Aantal planten per ha) }\end{array}$ & Zaaitijdstip & Aantal zaden per ha & $\begin{array}{c}\text { Zaadafstand (cm) bij } \\
75 \mathrm{~cm} \text { rijafstand }\end{array}$ \\
\hline 80.000 & Voor 1 mei & 92.000 & 14,5 \\
& Na 1 mei & 84.000 & 15,9 \\
90.000 & Voor 1 mei & 104.000 & 12,8 \\
& Na 1 mei & 95.000 & 14,0 \\
100.000 & Voor 1 mei & 115.000 & 11,6 \\
& Na 1 mei & 105.000 & 12,7 \\
110.000 & Voor 1 mei & 127.000 & 10,6 \\
& Na 1 mei & 116.000 & 11.5 \\
\hline
\end{tabular}

\section{Bij- en overzaaien}

Bij forse plantuitval door bijvoorbeeld vraat of nachtvorst moet de keuze gemaakt worden tussen al of niet bij- of overzaaien. De standdichtheid waarbij de voordelen van bijzaaien (tot aan de gewenste dichtheid) opwegen tegen de zaaizaad- en loonwerkkosten bedraagt gemiddeld 45.000 planten/ha, maar varieert afhankelijk van weersomstandigheden en prijsverhoudingen van 30.000 tot 60.000 planten/ha. Bij prijspeil volgens KWIN 2014-2015 (zie hoofdstuk 13) is bijzaaien rendabel beneden 55.000 planten per ha. Beneden de 20.000 planten/ha is overzaaien te verkiezen boven bijzaaien. In geval van bijzaaien of overzaaien verdient het de voorkeur dit zo vroeg mogelijk te doen en met een zeer vroeg ras. Een dergelijk ras kan een groter deel van de opgelopen achterstand in ontwikkeling inlopen. We adviseren in geval van (pleksgewijs) bijzaaien circa $10 \mathrm{~cm}$ naast de oude rijen te zaaien. Een nieuw zaaibed maken is niet nodig. Bespuitingen hoeven niet te worden herhaald. 


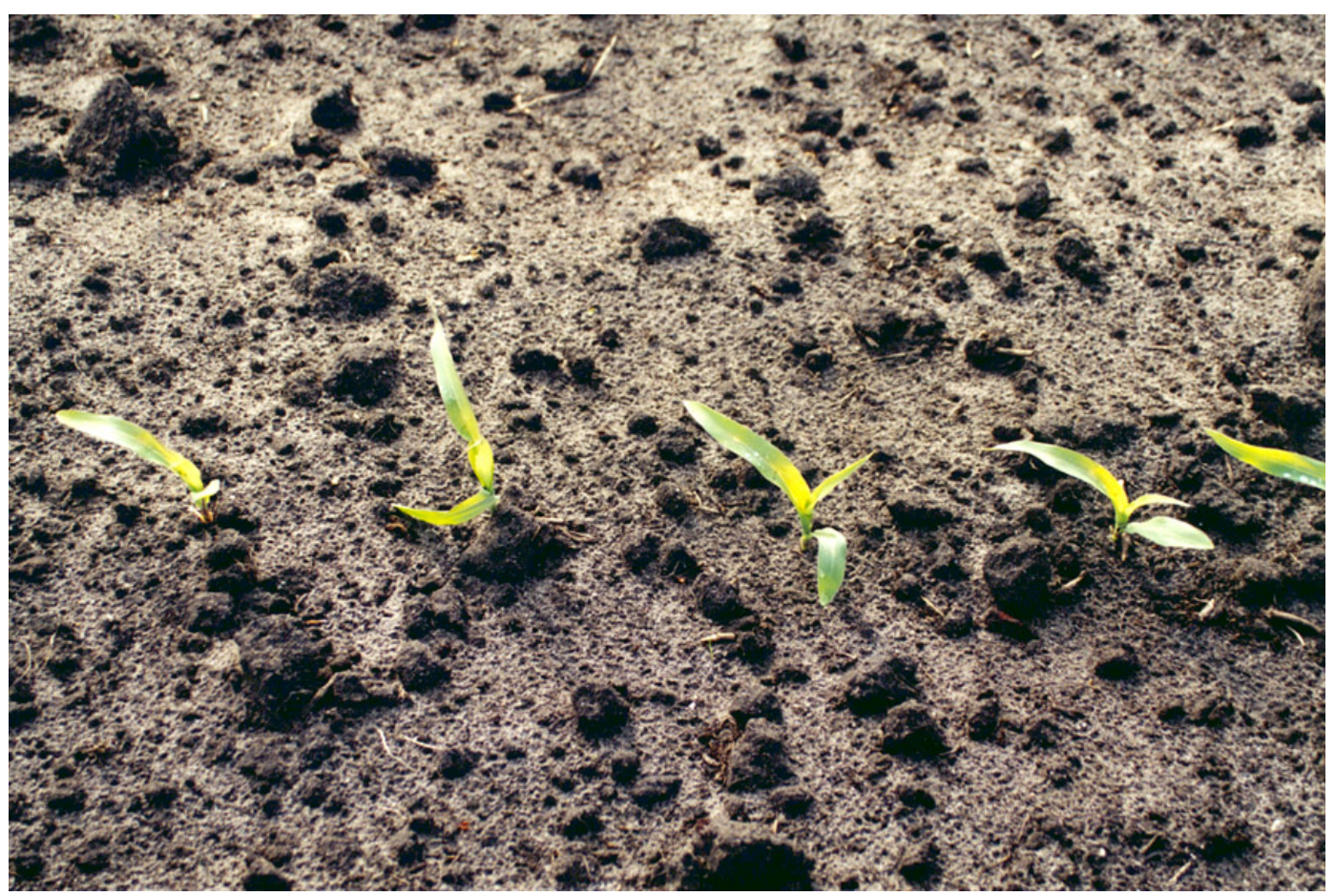

Kies de juiste zaaidichtheid

\subsection{Zaaimethoden}

Men kan maïs het beste zaaien met een precisiezaaimachine. Deze brengt zaden op de juiste diepte en afstand in de grond. In de praktijk worden hoofdzakelijk pneumatische zaaimachines gebruikt. Deze werken met een verticaal geplaatste zaaischijf met openingen die door de zaadvoorraad loopt. Door onderdruk worden de zaden in de openingen gezogen. Wanneer de onderdruk wegvalt, vallen de zaden in de reeds gemaakte zaaivoor en worden gelijk toegedekt en licht aangedrukt.

Maïs zaait men in het algemeen op een rijafstand van $75 \mathrm{~cm}$. De opkomst van rijonafhankelijke oogstmethoden geeft meer mogelijkheden voor andere zaaiverbanden, zoals zaaien op nauwere rijafstand (50 of $37,5 \mathrm{~cm}$ ), stereozaai en deltazaai (zie figuur 7.1). De invloed op de opbrengst van deze zaaiverbanden is echter beperkt tot maximaal 1 á $2 \%$. Over het algemeen treedt alleen een voorsprong in de ontwikkeling op tijdens de jeugdfase. Nadeel van vernauwing van de rijafstand is dat de mogelijkheden van mechanische onkruidbestrijding afnemen omdat de ruimte voor een bewerking tussen de rijen kleiner wordt. Met een rijenspuit is de besparing op chemische middelen geringer dan bij een rijafstand van $75 \mathrm{~cm}$. Een andere rijafstand kan een voordeel zijn wanneer men machines gebruikt voor de teelt van meerdere gewassen met dezelfde rijafstand. 
Figuur 7.1 Rangschikking planten bij verschillende zaaitechnieken

$\begin{array}{ll}75 \mathrm{~cm} & \\ \mathrm{x} & \mathrm{X} \\ \mathrm{X} & \mathrm{X} \\ \mathrm{X} & \mathrm{X} \\ \mathrm{X} & \mathrm{X} \\ \mathrm{X} & \mathrm{X} \\ \mathrm{X} & \mathrm{X} \\ \mathrm{X} & \mathrm{X} \\ \stackrel{ }{\longrightarrow}\end{array}$

$75 \mathrm{~cm}$

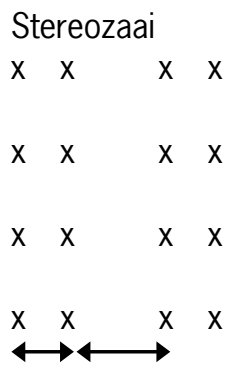

$10 \mathrm{~cm} 65 \mathrm{~cm}$

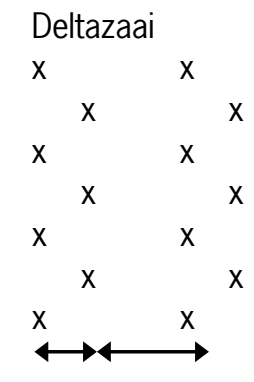

$17,5 \mathrm{~cm} 57,5 \mathrm{~cm}$

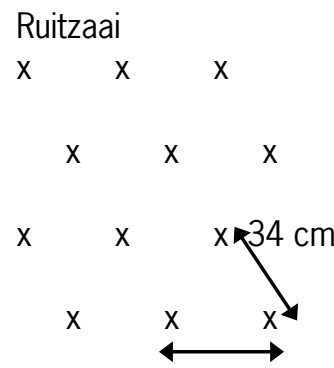

$34 \mathrm{~cm}$

\section{Andere zaaimethoden/systemen}

\section{Ruitzaai}

Een nieuwe ontwikkeling is het zaaien in driehoeksverband, ook wel ruitzaai genoemd (zie figuur 7.1). Bij dit systeem wordt de maiis zodanig gezaaid dat de afstand tussen aangrenzende planten overal gelijk is. Duits oriënterend onderzoek gaf een positief effect van 6-7\% op de opbrengst te zien. In Nederland is in 2015 door Kverneland een zaaimachine geïntroduceerd die de maïs in ruitverband kan zaaien bij een rijafstand van $37,5 \mathrm{~cm}$. In 2016 zijn er o.a. door Wageningen University \& Research verschillende proeven gestart. De meeste proeven lieten geen meeropbrengst zien van ruitzaai ten opzichte van standaard $75 \mathrm{~cm}$ rijafstand. In een enkele proef werd een lichte meeropbrengst gevonden van $4-5 \%$.

\section{Breedwerpig zaaien}

Op enkele plaatsen is ervaring opgedaan met het breedwerpig zaaien van maïs. Meestal gebeurt dit in één werkgang met spitten. Achterliggende gedachten zijn lagere teeltkosten en een gunstigere plantverdeling. Onder gunstige omstandigheden kan deze methode vergelijkbare opbrengsten geven met de traditionele methode. Echter door de wisselende zaaidiepte is met name onder ongunstige omstandigheden de opkomst onregelmatiger dan bij de traditionele methode. Bij deze methode is de plantverdeling gemiddeld niet beter, omdat de afstand tussen de planten erg wisselend is.

\section{Zaaien in groenbemester of gras(klaver)zode}

In de loop der jaren heeft men ook geprobeerd maïs in een groenbemester of gras(klaver)zode zonder grondbewerking te zaaien. De methode wordt toegepast om verschillende redenen: beperken van erosie, behoud van draagkracht en bodemkwaliteit, minder inzet van chemische onkruidbestrijdingsmiddelen en kostenbesparing door minder werkgangen. Voor het zaaien in groenbemester zijn er speciale zaaimachines met extra schijfkouters. Voor zaai in een graszode onderscheiden we globaal twee methodes. Men maakt met (schijf) kouters een snede in de zode waar het zaad vervolgens wordt ingelegd of men freest eerst een smalle strook. Met deze laatste methode kan er ook in groenbemesters worden gezaaid. Zie ook paragraaf 4.5.

\section{Mais onder folie}

Door maïs onder folie te zaaien kan enerzijds eerder worden gezaaid omdat de bodem onder de folie door de kaswerking meer wordt opgewarmd dan de bodem zonder folie. Anderzijds is door de hogere temperatuur onder de folie ook de beginontwikkeling van de maïs sneller. Sinds 2009 
worden er in de praktijk in Noord Nederland ervaringen opgedaan met het zaaien van maïs onder folie. Eind jaren tachtig is er ook al onderzoek gedaan naar maïs zaaien onder folie.

Maïs onder folie zaaien heeft een duidelijk effect op het moment waarop het optimale oogststadium is bereikt. Door maïs onder folie te zaaien kan het 1 tot 2 weken eerder geoogst worden. Daarnaast heeft het soms een positief effect op de opbrengst en op het zetmeelgehalte, met name in noord Nederland. Daar staan echter hoge extra kosten van $€ 225$,- tot $€ 300$,- per ha tegenover. Onder specifieke omstandigheden op koudere gronden met name in het noorden van Nederland kan deze teeltmethode mogelijk interessant zijn. Voor de zuidelijke en oostelijke zandgronden waar maïs relatief gemakkelijk kan worden geteeld wordt ingeschat dat de voordelen te klein zijn om op te kunnen wegen tegen de extra kosten.

\section{Zaaien op ruggen}

In onder andere Amerika past men dit toe om op berghellingen erosie tegen te gaan en om te kunnen irrigeren. Achterliggende gedachte voor Nederland is om onder natte omstandigheden langer te kunnen oogsten door over de ruggen te rijden. Daarnaast zou het de mineralenbenutting kunnen verbeteren doordat de vruchtbare grond naar de maïs wordt gebracht. Er zijn met dit systeem op beperkte schaal ervaringen opgedaan. Onderzoeksgegevens uit Denemarken laten erg wisselende resultaten zien. In 2009 is er door Wageningen Plant Research - Praktijkonderzoek AGV samen met Wageningen Livestock research onderzoek gestart met verschillende grondbewerkingsmethoden, waaronder ruggenteelt, op kleigrond. De opbrengst resultaten waren wisselend.

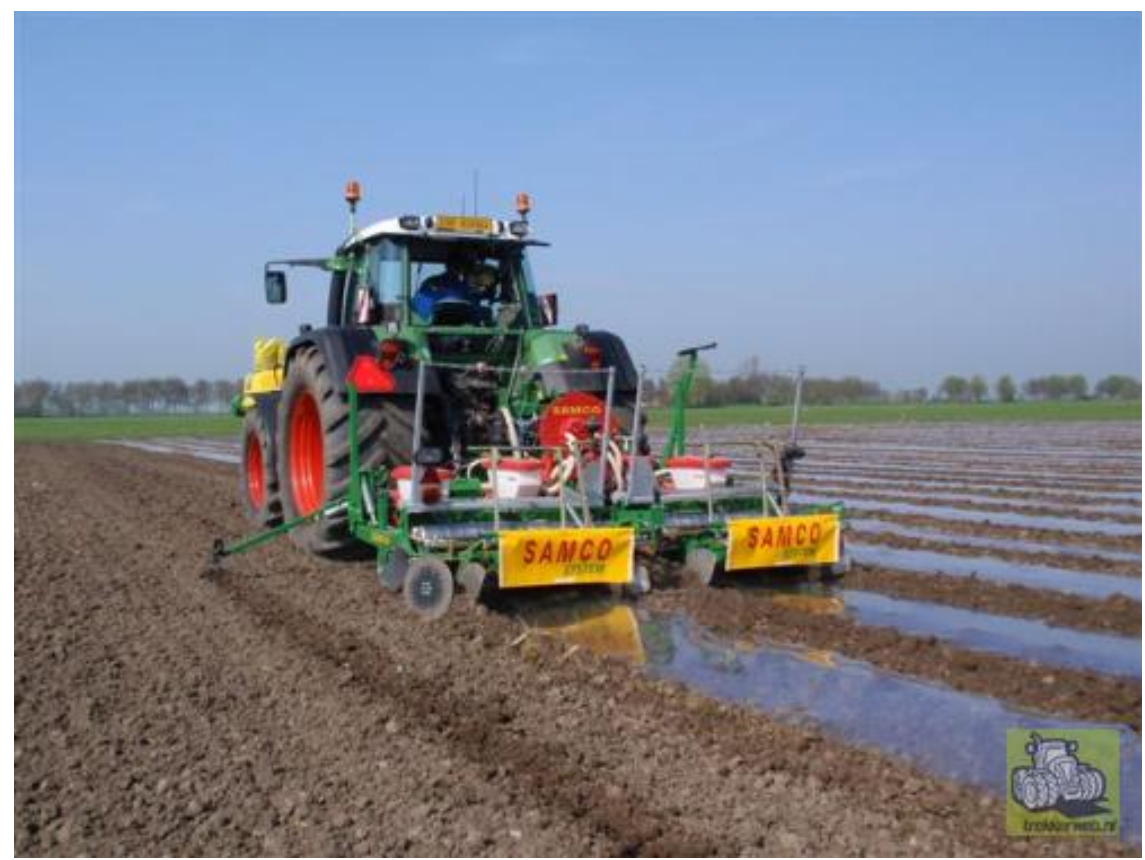

Maïs gezaaid onder folie ontwikkelt zich sneller 


\section{$8 \quad$ Onkruidbestrijding}

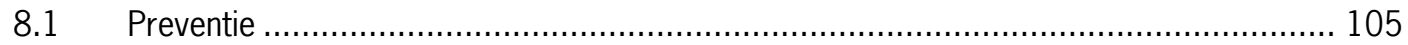

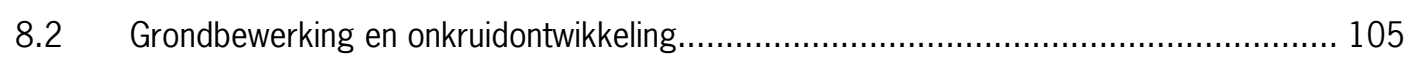

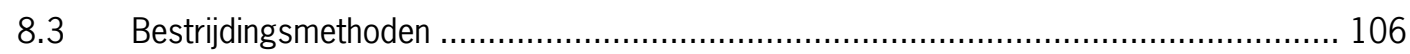

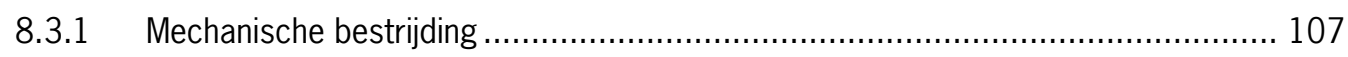

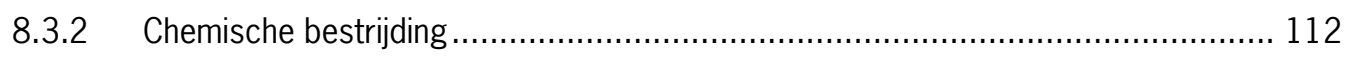

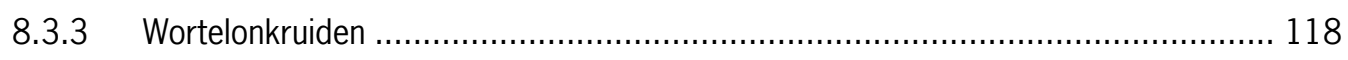

8.3.4 Aanpassing en verspreiding onkruidsoorten .............................................. 120

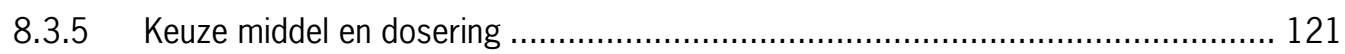

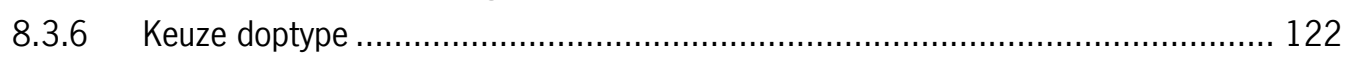

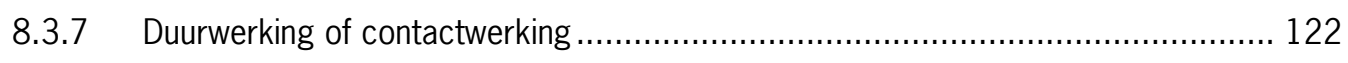

8.3.8 Herbiciden en grasonderzaai ....................................................................... 123 


\section{Onkruidbestrijding}

Maïs heeft een vrij trage beginontwikkeling. De perioden tussen zaaien en een volledige grondbedekking is gemiddeld 8 weken. Onkruiden vormen dan een bedreiging voor het gewas door concurrentie om vocht, licht en nutriënten. Het is belangrijk onkruid te bestrijden voordat het de groei van de maïs kan belemmeren. Als de maïs het veld volledig heeft bedekt krijgen onkruiden geen kans meer. De snelheid van de ontwikkeling hangt sterk samen met de temperatuur en het ras. Bij later zaaien is de gemiddelde temperatuur hoger en is de periode tussen zaaien en volledige bodembedekking korter. Rassen met een hoog cijfer voor snelheid grondbedekking bereiken, afhankelijk van perceel en weersomstandigheden, 2 tot 3 weken eerder een volledige bedekking dan rassen met een laag cijfer.

\subsection{Preventie}

Onkruidbestrijding hoeft in maïs geen probleem te zijn omdat er zowel mechanisch als chemisch veel methoden en middelen beschikbaar zijn. Het is echter wel zaak tijdig de juiste methode of het meest geschikte middel in te zetten. In de praktijk levert dit nog wel eens problemen op omdat maïs meestal in loonwerk wordt geteeld en men de percelen niet regelmatig controleert.

Op het grootste deel van het areaal wordt maïs jaar op jaar geteeld. Jaarlijks worden dan dezelfde herbiciden gespoten. Onkruiden die ongevoelig zijn voor de toegepaste middelen vermeerderen zich bij deze eenzijdige aanpak. Op den duur kunnen populaties onkruiden ontstaan die resistent zijn voor bepaalde herbiciden. Het afwisselen van bestrijdingsmethoden is belangrijk. Dit betekent dat, bij continu teelt, gecombineerd toepassen van chemische en mechanische methoden en het afwisselen van herbiciden belangrijk zijn om ook op de lange termijn onkruiden effectief te bestrijden tegen redelijk lage kosten. Als maïs in vruchtwisseling wordt verbouwd, is de kans op uitbreiding van probleemonkruiden kleiner.

Ook preventieve maatregelen kunnen bijdragen aan de onkruidsituatie op het perceel. Een kerende grondbewerking (ploegen) verlaagt de onkruiddruk. Een oppervlakkige grondbewerking 1 tot 2 weken voor het zaaien (vals zaaibed) kan de eerste kiemende onkruiden bestrijden en daarmee de onkruiddruk verlagen. Het bestrijden van wortelonkruiden als haagwinde en kweek na de oogst door mechanische bewerkingen of een chemische bespuiting helpen bij het in de hand houden van deze onkruiden in volgende jaren.

\subsection{Grondbewerking en onkruidontwikkeling}

De invloed van de hoofdgrondbewerking wordt soms onderschat. Een kerende grondbewerking "begraaft" resten van gewas en onkruid. Onkruiden die zaad hebben gevormd, worden diep weggestopt en kiemen daar niet. Het eerste jaar verliezen veel van deze zaden hun kiemkracht. In de regel gaat de kiemkracht van klein zaad sneller achteruit dan dat van grof zaad. Oliehoudende zaden blijven zeer lang, tientallen jaren, kiemkrachtig.

Een hoofdgrondbewerking met de cultivator, spitfrees of spitmachine werkt gewas en onkruidresten veel minder in de grond met als gevolg dat er in het voorjaar meer onkruid kiemt.

Zandgronden ploegt men in de regel kort voor het zaaien. Met het ploegen wordt de grond met een vorenpakker weer aangedrukt en ligt de grond zaaiklaar.

Met het ploegen brengt men ook zaden die in de ondergrond lagen naar de toplaag. Hier worden ze geprikkeld door temperatuurschommelingen, bemesting en licht en gaan kiemen. 
Op kleigrond ploegt men in de regel in het najaar en maakt men kort voor het zaaien een zaaibed. Dit gebeurt vaak met een aangedreven eg. Hierdoor worden onkruiden die al zijn gekiemd bestreden. Soorten als klein kruiskruid, muur en straatgras kiemen het hele jaar, andere soorten kiemen vooral in het voorjaar, bijvoorbeeld melganzevoet. Hanenpoot en zwarte nachtschade kiemen enkele weken later. Een vals zaaibed, een extra bewerking van de toplaag tot een diepte van circa $2 \mathrm{~cm}$ tussen ploegen en zaaien, verstoort de vroeg kiemende soorten. Het zaaien één of enkele weken uitstellen om een extra grondbewerking uit te voeren, wordt in de biologische teelt van maïs toegepast om onkruidbestrijding gemakkelijker te maken. Daarnaast is de beginontwikkeling van de maïs sneller omdat de gemiddeld de temperatuur dan hoger is.

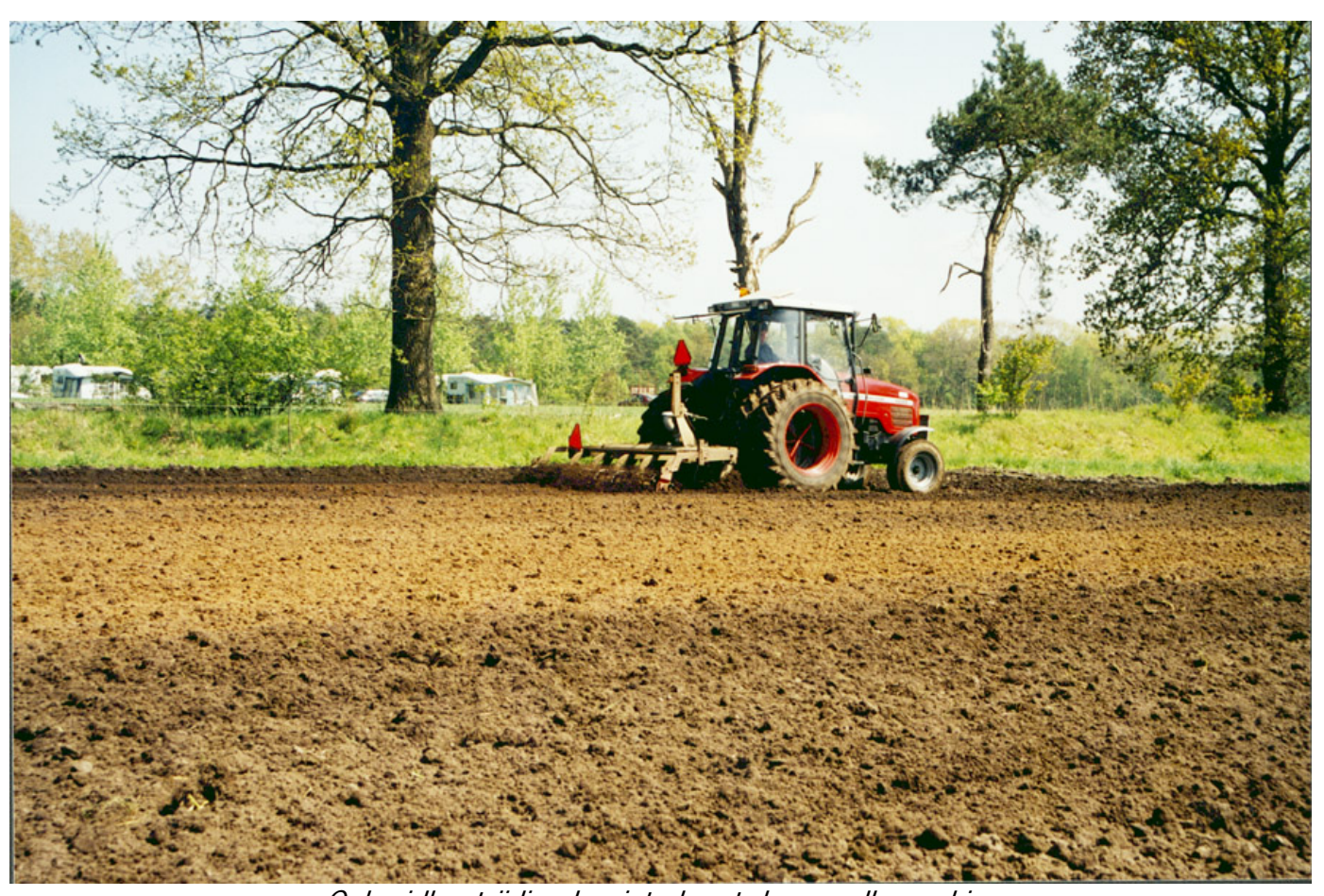

Onkruidbestrijding begint al met de grondbewerking

\subsection{Bestrijdingsmethoden}

Voor de onkruidbestrijding in de teelt kan een combinatie van mechanische en chemische bestrijding worden toegepast. In de praktijk voert men soms één mechanische bestrijding uit. Dit kan door te eggen of schoffelen tussen zaaien en opkomst, of door aan te aarden als de maïs ongeveer vier bladeren heeft. Door deze bewerkingen wordt de periode dat onkruiden chemisch moeten worden bestreden verkort. Daardoor kan men met lagere doseringen volstaan en kunnen langwerkende bodemherbiciden achterwege blijven of met een lagere dosering worden gespoten. Tot 2005 was toepassing van mechanische onkruidbestrijding en toepassing van lage doseringen vereist om aanspraak te maken op de volledige maïspremie. Deze cross-compliance regeling (minder middel in ruil voor subsidie) is in 2005 vervallen. Bij de invoering van deze regeling daalde het herbicidengebruik in de maïsteelt drastisch. Door het afschaffen van de cross-compliance regeling is het niet meer verplicht om een mechanische bestrijding toe te passen. De gewasbeschermingsfirma's gaan er bij de advisering nu eerder vanuit dat deze mechanische 
bestrijding nauwelijks meer wordt toegepast, waardoor de advies doseringen van de middelen zijn verhoogd om een goede onkruidbestrijding te kunnen garanderen. Terwijl het op een juiste manier toepassen van een mechanische bestrijding (juiste moment en afstelling) een aanzienlijke besparing van het herbicidengebruik kan bewerkstellingen. Ook vergroten hogere doseringen herbiciden de kans op groeiremming van de maïs. Onderzoek in de jaren negentig wees uit dat schade door herbiciden kan leiden tot 10-15\% lagere maïsopbrengsten.

Af en toe worden nog overschrijdingen van het Maximum toelaatbaar Risiconiveau (MTR) oppervlaktewater en/of de drinkwaternorm van de maïsherbiciden overschreden. Hierdoor kunnen milieuproblemen worden veroorzaakt, waardoor toelatingen van deze middelen onderdruk kunnen komen te staan. Daarnaast worden een aantal werkzame stoffen uit maisherbiciden ook toegepast in o.a. erwten, bonen, suikerbieten en diverse andere gewassen waaronder ook de sierteelten. Ook voor deze gewassen kunnen bij normoverschrijdingen de toelatingen onder druk komen te staan. Het is zowel in het belang van de akkerbouw- als de veehouderijsector (maïs wordt m.n. geteeld op veehouderijbedrijven) om tot een meer milieu kritische onkruidbeheersing in de maïs te komen. De onkruidbestrijding wordt op veehouderijbedrijven voornamelijk in loonwerk uitgevoerd. De middelenkeuze en uitvoering van de onkruidbestrijding ligt meestal volledig bij de loonwerker en distributeurs van gewasbeschermingsmiddelen. Het is belangrijk dat voor het toepassen van herbiciden en fungiciden de etiketten en voorlichtingsboodschappen worden nageleefd. Ook het twee keer spuiten met lage dosering kan een interessante bijdrage leveren. Daarnaast is er een erfemissie scan ontwikkeld waarop veel nuttige informatie is te vinden over hoe afspoeling en drift van gewasbeschermingsmiddelen kunnen worden voorkomen. Zie hiervoor de website: www.erfemissiescan.nl

\subsubsection{Mechanische bestrijding}

De hoofdgrondbewerking en de zaaibedbereiding zorgen ervoor dat er bij het zaaien geen onkruiden op het perceel staan. Met het klaarmaken van het zaaibed wordt echter ook een kiembed voor onkruiden gemaakt. Bij sterk veronkruidde percelen kan men het zaaien uitstellen tot de eerste onkruiden kiemen. Deze kan men dan eenvoudig met een egbewerking bestrijden. Een nadeel van het maken van een "vals zaaibed" is dat er later wordt gezaaid.

Bij het zaaien moet men al rekening houden met mechanische onkruidbestrijding.

- $\quad$ Het zaaibed moet vlak liggen en goed bezakt zijn zodat geen diepe sporen ontstaan.

- $\quad$ Het zaad moet gelijkmatig op een diepte van 5-6 cm liggen.

- $\quad$ De rijenafstand moet overal gelijk zijn voor mechanische onkruidbestrijding tussen en in de gewasrijen.

Voor mechanische onkruidbestrijding kunnen onderstaande werktuigen worden ingezet:

\section{Onkruidbestrijding tussen de rijen}

- eg

- vaste schoffel

- trilschoffel

- rijenfrees

- rolschoffel 


\section{Onkruidbestrijding in de rij}

- eg

- aanaarders

- vingerwieder

- $\quad$ torsiewieder

Om problemen bij aansluitrijen te voorkomen, moet de werkbreedte van zaaimachine en werktuigbalk even groot zijn. Om schoffelapparatuur nauwkeurig tussen de rijen door te laten lopen, kunnen stuursystemen worden toegepast. Bekende systemen zijn de gewasgeleide schoffel en de camera gestuurde schoffel.

Tractoren kunnen met DGPS-ontvangers en een automatische stuurinrichting uitgerust worden. Hiermee kan men nauwkeurig kaarsrechte parallelle banen zaaien en is ook de afstand tussen aansluitrijen overal gelijk. Ook kan met RTK-GPS de maïs gezaaid worden. Met behulp van de vastgelegde gegevens kan daarna weer geschoffeld worden. Door gebruik te maken van zowel trekker als machine besturing, kan nog preciezer geschoffeld worden. Hierdoor kan op een arbeidsvriendelijke manier snel en scherp op de rij geschoffeld worden.

Wiedapparatuur en stuursystemen worden steeds verbeterd. Camerageleide stuursystemen worden met geavanceerde beeldherkenningssoftware gecombineerd. Hierdoor kunnen gewas en onkruidplanten steeds beter worden onderscheiden.

\section{Machines voor mechanische onkruidbestrijding:}

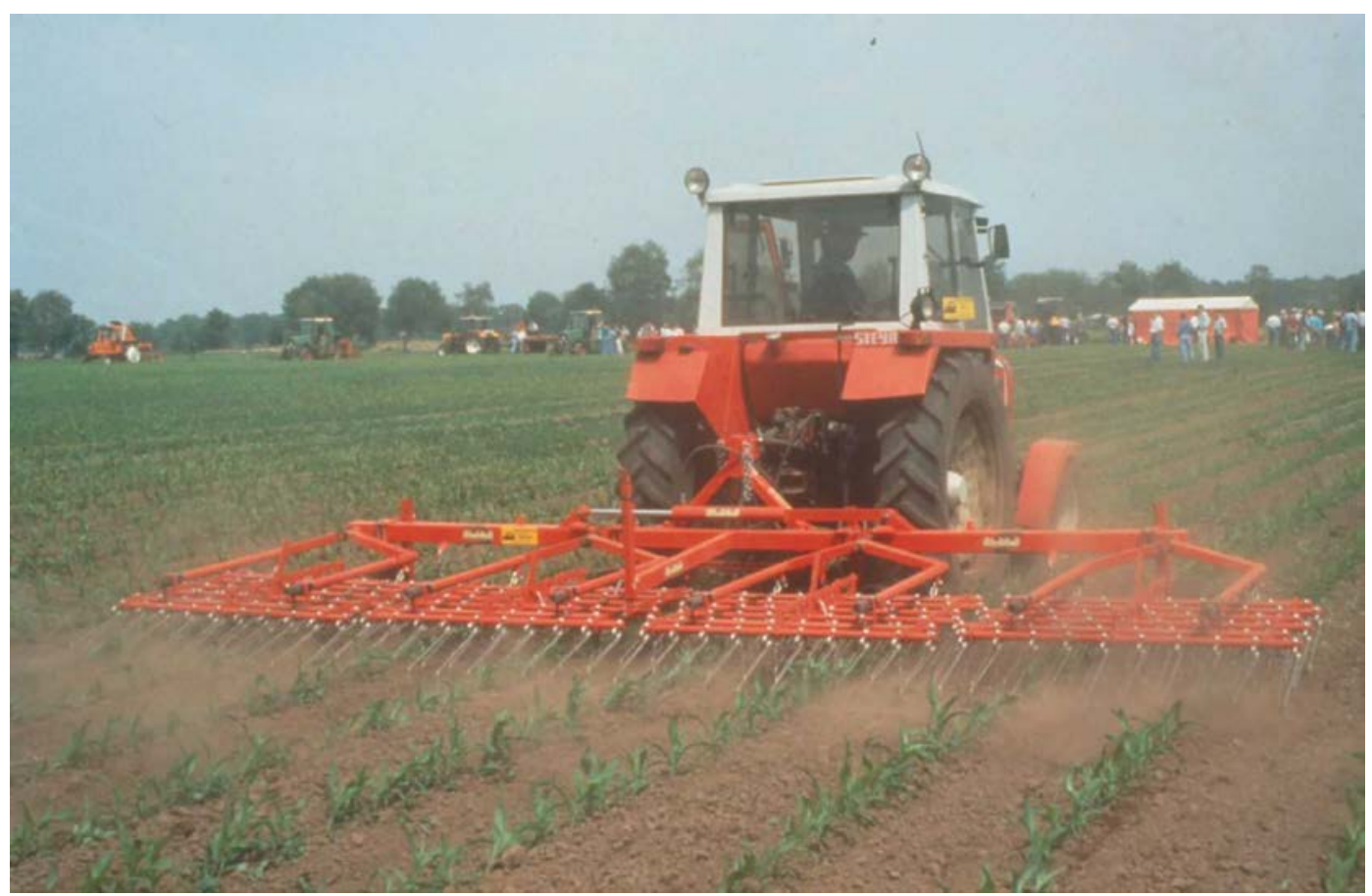

Eggen na opkomst van de maïs 


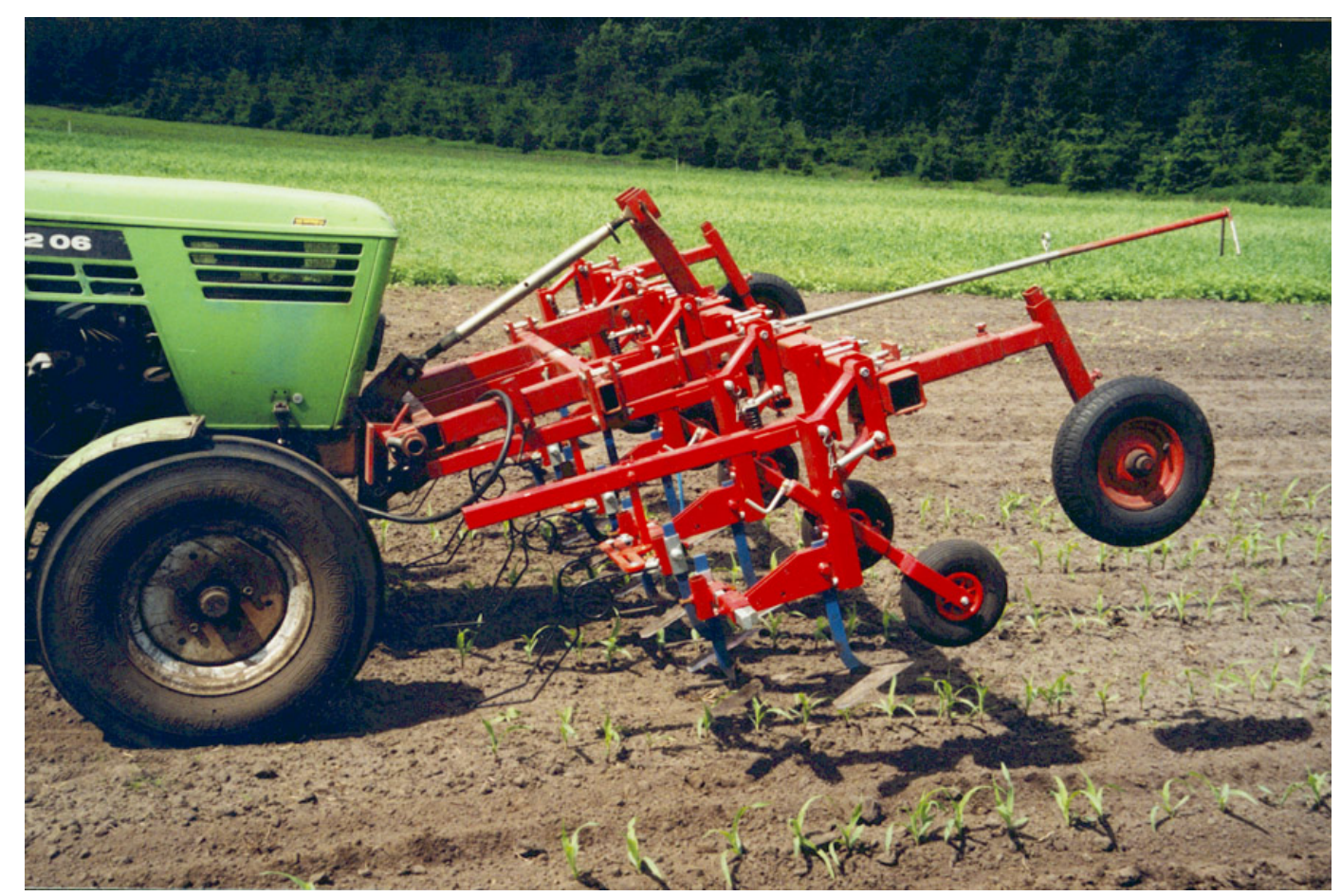

Frontschoffel met vaste schoffels

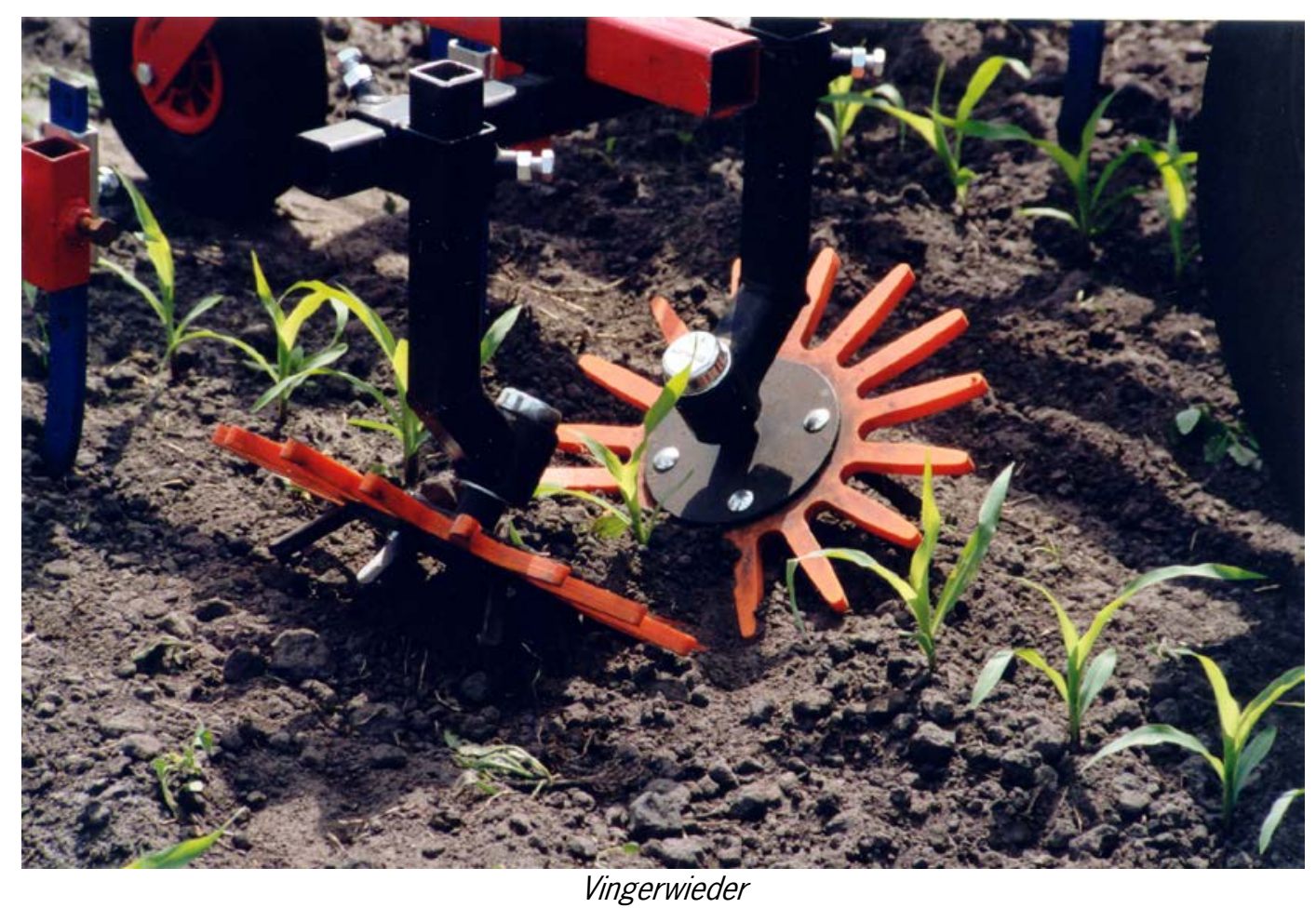




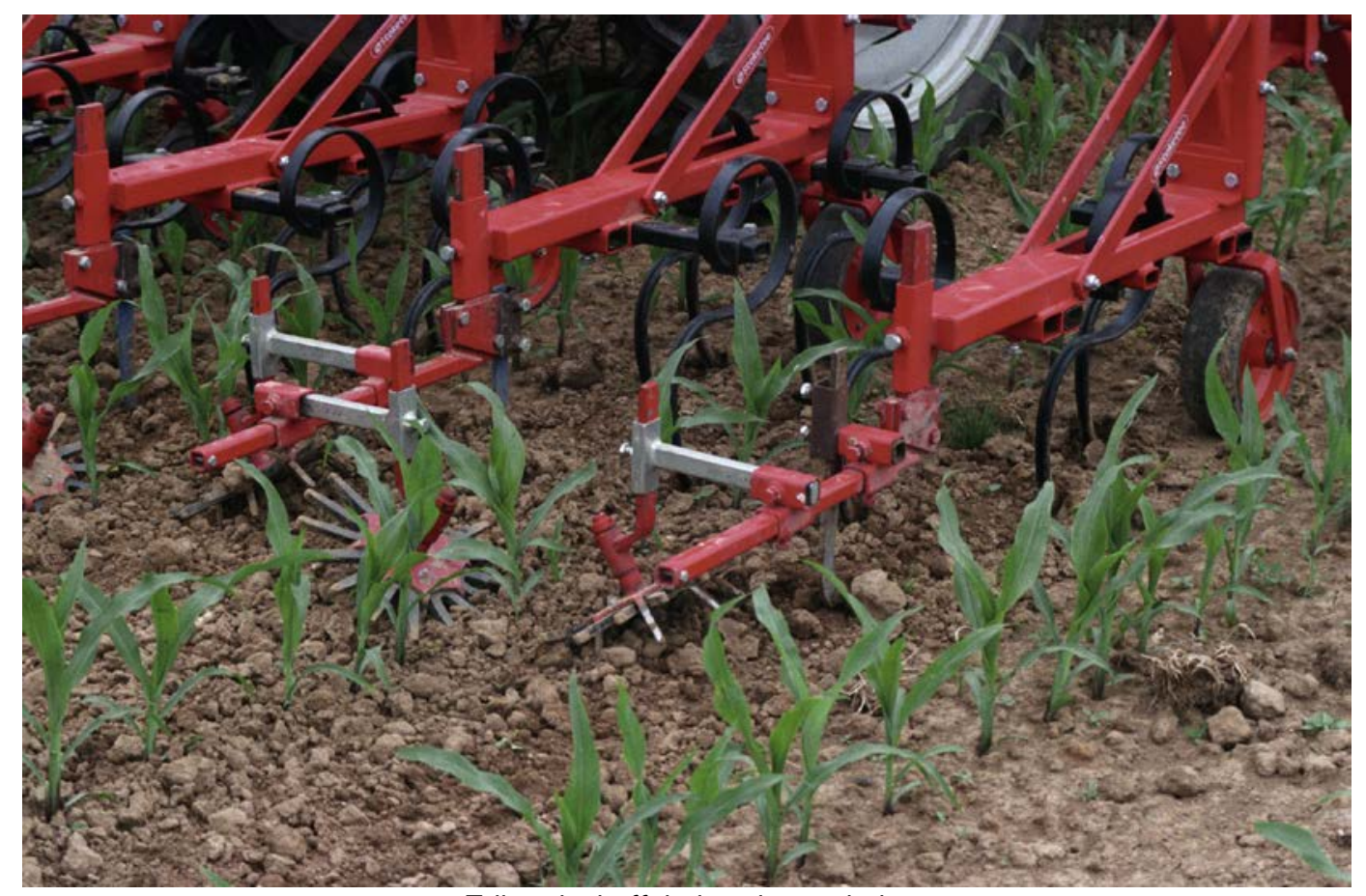

Triltandschoffel plus vingerwieders

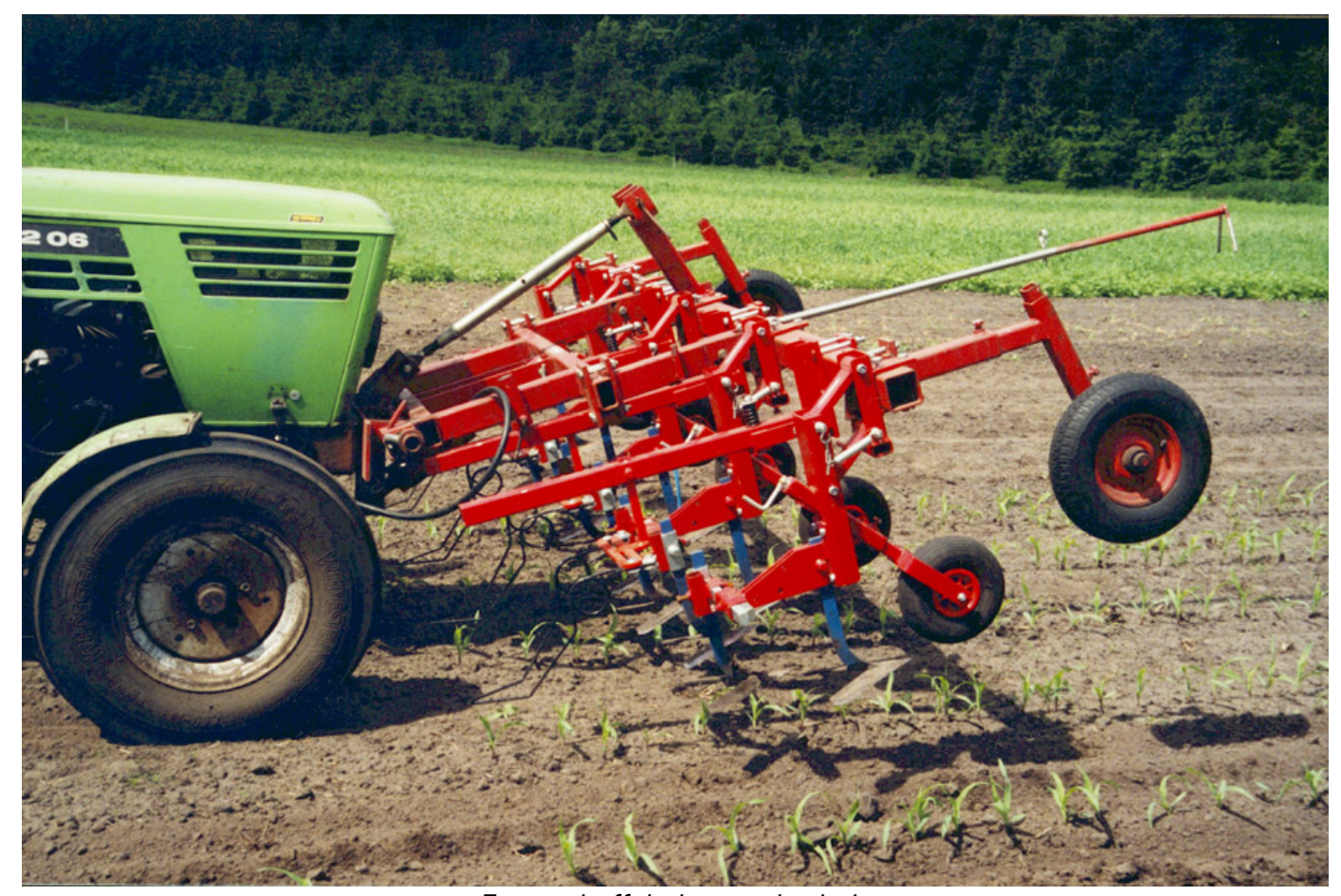

Frontschoffel plus torsiewieder 


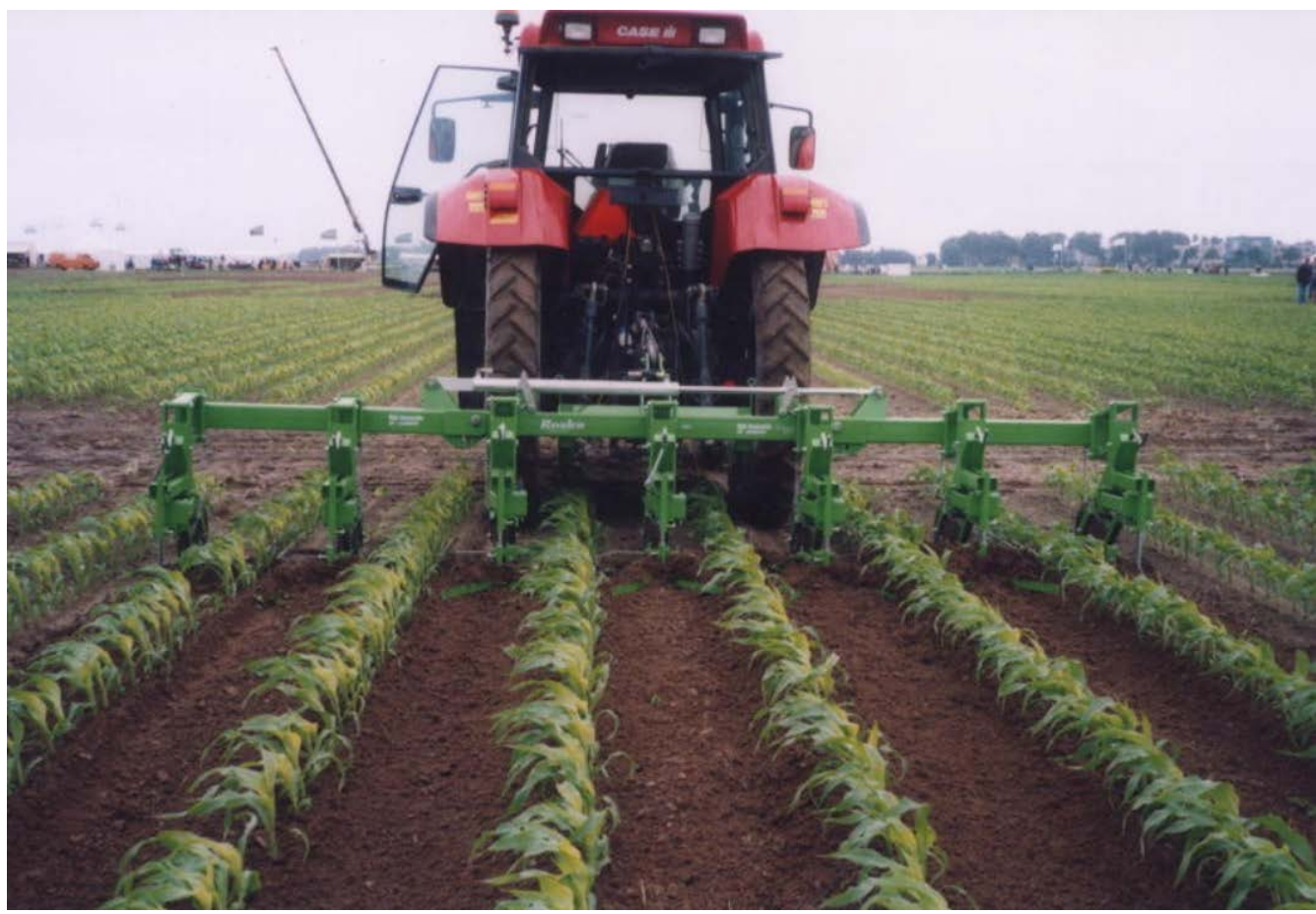

Gewasgeleideschoffel

\section{Onkruidbestrijding tussen zaai en opkomst}

De periode tussen zaaien en opkomst is afhankelijk van de bodemtemperatuur 1 tot 3 weken. Bij temperaturen onder $10{ }^{\circ} \mathrm{C}$ kan het nog langer duren.

Kiemende onkruiden en kiemplanten kan men in deze periode met volvelds eggen bestrijden. De egdiepte moet kleiner zijn dan de zaaidiepte. Als de tanden van de eg het kiemende maïszaad raken, worden deze uit de grond getrokken. De rijsnelheid kan hoog zijn (12 km/uur) en de werkbreedte van de eg is niet gelimiteerd door de zaaibreedte. Met een brede eg, 18 meter, en hoge snelheid kan men een hoge capaciteit halen. Op grote percelen kan 1 ha in minder dan 5 minuten worden geëgd. Zelfs in het "spijker-stadium" (het moment dat de kiemschede net boven de grond uitsteekt) is er bij vrij agressief eggen slechts een geringe kans op schade. Onder bepaalde omstandigheden zijn kiemen kwetsbaar. Vooral bij een plotselinge warme periode $\left(>22^{\circ} \mathrm{C}\right)$ na een periode met lage temperaturen (nachtvorst).

Door één of twee bewerkingen is het veld bij opkomst van de maïs onkruidvrij en zijn veel vroegkiemende onkruiden bestreden. Daarnaast zorgt eggen tussen zaai en opkomst voor een egalere opkomst van onkruiden. Hierdoor ontstaat er geen schaduwwerking tussen onkruiden onderling door verschil in kieming en opkomst en dit verbetert de effectiviteit van de chemische onkruidbestrijding aanzienlijk.

\section{Onkruidbestrijding na opkomst}

Vlak na opkomst zijn maïsplanten tot het 2-bladstadium zeer gevoelig voor beschadiging. Eggen kan in dit stadium beter niet plaatsvinden. Is het vanwege de onkruiddruk toch noodzakelijk eg dan met grote zorgvuldigheid: lage rijsnelheid, ondiep werken en de tanden verticaal.

$\mathrm{Na}$ het 2-bladstadium is de maïs weer bestand tegen bewerking met de wiedeg. Tot het 5-bladstadium kan enkele malen worden geëgd met een snelheid van $5-9 \mathrm{~km} / \mathrm{uur}$ en een iets stekende afstelling van de egtanden. 
Voor het beste effect moet men de afstelling en rijsnelheid aan grond en gewas aanpassen. Eggen bestrijdt alleen kleine onkruiden (kiemplanten). Op wortelonkruiden heeft eggen geen bestrijdend effect. Wordt eggen te lang uitgesteld en zijn onkruiden groter dan het kiemplantstadium, dan is schoffelen effectiever.

Eggen na opkomst heeft een risico van gewasbeschadiging. Van jaar tot jaar verschilt de gevoeligheid en schade. Bij warm en groeizaam weer zijn de planten weinig gevoelig en groeien bovendien snel door het gevoelige stadium heen.

$\mathrm{Na}$ het 6-bladstadium, gewashoogte $50-75 \mathrm{~cm}$, is het meestal nodig om nog eenmaal te schoffelen om de resterende onkruiden op te ruimen. Onkruiden in de gewasrij kunnen door flink aanaarden worden bedekt.

Kleinere onkruiden in de rij kan men met een torsie- of vingerwieder aanpakken. Deze kunnen in het 2 tot 4-bladstadium van de maïs worden ingezet.

De breedte van schoffelen kan men vergroten met RTK-GPS plus een stuursysteem dat de rijen nauwkeurig volgt. Daarnaast zijn er gewasgeleiders en cameragestuurde systemen op de markt. Volledig mechanische onkruidbestrijding van maïs vraagt gemiddeld vijf bewerkingen: driemaal eggen en tweemaal schoffelen waarvan tenminste eenmaal met aanaarden.

Naast starre schoffels kunnen triltandschoffels, strokencultivator of een strokenfrees worden ingezet. Het meest gangbare werktuig is de schoffel met aanaarders. Aanaarders kunnen na het 3-bladstadium van de maïs worden ingezet. Een strokenroleg is een minder bekend werktuig, maar levert een goed resultaat. Bij zware veronkruiding kan een strokenfrees uitkomst bieden.

\subsubsection{Chemische bestrijding}

In tabel 8.1 is de gevoeligheid van onkruiden voor verschillende herbiciden weergegeven. Om het meest geschikte middel of combinatie van middelen te kiezen, moet men weten welke onkruiden op het perceel voorkomen. Vooral het onderscheid tussen grasachtige onkruiden is moeilijk. Hanenpoot, glad vingergras, harig vingergras, groene naaldaar en krans naaldaar lijken vooral als kiemplant veel op elkaar. Maar ook kiemplanten van breedbladige onkruiden zijn moeilijk te onderscheiden. DLV heeft een CD-rom uitgegeven met de beschrijvingen en afbeeldingen van de meest voorkomende akkeronkruiden. Op de IRS-site (www.irs.nl, Betakwikmodule onkruidherkenning) vindt u ook informatie en plaatjes van breedbladige onkruiden. Gelukkig verandert de onkruidpopulatie op een perceel niet snel. De teler kan aan de hand van de gevoeligheidstabel (zie tabel 8.1) vaststellen welke middelen hij moet inzetten. Ook bieden de websites van fabrikanten vaak veel informatie m.b.t. werkingsspectra van middelen en worden steeds meer app's hiervoor ontwikkeld (zoals de herbiciden app van Bayer Crop Science en BASF).

Bij het gebruik van rimsulfuron (Titus) en nicosulfuron in de middelen Milagro, Milagro 40, Samson 4 SC, Samson Extra 6\% OD, Accent, Kelvin moet men rekening houden, dat deze groeiremming kunnen veroorzaken als de temperatuur tijdens of vlak na toepassing hoger is dan $18^{\circ} \mathrm{C}$. De schade neemt toe naarmate de temperatuur hoger is. Bij temperaturen onder $18^{\circ} \mathrm{C}$ is de kans op schade gering. Om risico's te mijden kan beter $75 \%$ van de dosering worden gespoten. Minder gevoelige onkruiden worden bij een lagere dosering echter minder goed bestreden. Ook de middelen Primus en in mindere mate MaïsTer Vloeibaar, Capreno en Monsoon Active hebben dit risico.

In 2008 is het middel Kart op de markt gekomen. Kart bevat twee actieve stoffen: fluroxypyr (o.a. werkzame stof in Starane Top, Kart) en florasulam (Primus). Het middel is sterk op o.a. kamille, knopkruid en veelknopigen (vooral zwaluwtong) en pakt ook andere éénjarige breedbladigen aan (o.a. muur en kleine brandnetel). Kart kan in alle onkruidsystemen tussen 3-6-bladstadium van de 
maïs worden toegepast. Het middel werkt zeer goed tegen haagwinde en kan ook enkelvoudig tegen deze onkruidsoort worden ingezet. Voor een goede haagwinde bestrijding is een dubbele bespuiting met bijvoorbeeld Kart aan te raden, eenmaal tussen het 3 en 6 blad stadium en een tweede maal in 6-8 bladstadium van de maïs. Dit kan volvelds en liefst met veel lucht.

In 2010 is Laudis (werkzame stof: tembotrione) op de markt gekomen. Het is een breedwerkend contactherbicide tegen de meest voorkomende breedbladigen en grasachtige onkruiden in maïs. Daarnaast heeft het een versterkend effect in een mix met middelen tegen aardappelopslag. Ooievaarsbek, kweek en raaigras worden niet bestreden. De fabrikant kent de volgende eigenschappen toe aan het middel: betere hechting van de spuitoplossing op het blad, beter en snellere verspreiding en herverdeling op het blad, betere en snellere opname/penetratie in het blad en herverdeling in het onkruid. Deze eigenschappen zorgen voor een brede werking en goede regenvastheid. Laudis bevat als enige 'triketone' maïsherbicide een 'safener. Deze stof zorgt ervoor dat de werkzame stof uit Laudis, en bij tankmenging ook de werkzame stoffen van andere'triketone'maïsherbiciden (zoals Calaris, Callisto of Sulcogan 300 SC), versneld worden afgebroken door de maïs. Dit maakt Laudis bijzonder gewasveilig. Laudis is ook als enige 'triketone' maïsherbicide veilig voor gevoelige volggewassen zoals suikerbieten en peulvruchten. Dit is belangrijk wanneer maïs in rotatie met andere gewassen wordt verbouwd.

In 2012 zijn de volgende middelen beschikbaar gekomen:

- Akris (dimethenamid-P/terbuthylazine) is een breed werkend bodem- en contactherbicide dat goed werkt op veelknopigen (zoals perzikkruid en zwaluwtong) en ooievaarsbek De werking tegen aardappelopslag, veenwortel, haagwinde en kweek is onvoldoende. Varkensgras wordt ook moeilijk bestreden.

- Peak (prosulfuron) is een contactherbicide dat goed werkt tegen haagwinde, veelknopigen en kamille met een nevenwerking op veenwortel. Het middel werkt langzaam en is zeer veilig voor het gewas, waardoor het tot in 10 bladstadium gespoten kan worden. Grasachtigen en kleefkruid worden niet bestreden. Zwarte nachtschade wordt moeilijk bestreden.

- Casper (prosulfuron/dicamba) is een contactherbicide die een vergelijkbare werking heeft als Peak. De bestrijding van haagwinde is wel beter. Het kan gespoten worden tot in het 6 bladstadium.

- Lontrel 100 (clopyralid) is een groeistof, dat een zeer goede werking heeft op melkdistel en akkermelkdistel. Toepassen bij groeizaam weer en vóór het bloeiknopstadium van de distels. Aan de middelen Kart, Laudis, Akris, Peak, Arrat, Casper en Lontrel 100 is geen onafhankelijk onderzoek uitgevoerd.

In 2013 is het middel Sulcogan 300 SC (werkzame stof sulcotrione) beschikbaar gekomen. Het werkt goed op breedbladige onkruiden en aardappelopslag.

In 2014 zijn Samson Extra 6\% OD, Milagro 40 en Harmony als nieuwe middelen beschikbaar gekomen:

Samson Extra 6\% OD is een sterk verbeterde nicosulfuron OD-formulering voor bestrijding van grassen en breedbladigen in maïs. Samson Extra 6\% OD is hoger geconcentreerd en bevat 60 $\mathrm{gr} / \mathrm{nicosulfuron}$. De krachtige OD-formulering en speciale adjuvanten zorgen voor een verbeterde effectiviteit in onkruidbestrijding, waarbij de selectiviteit naar de maïs gewaarborgd blijft. Daarbij geeft de OD-formulering een verbeterde werking van andere middelen in de maïsherbicide mix. Samson Extra 6\% OD is sneller regenvast. 
- Milagro 40 (nicosulfuron) is de vervanger van de Milagro. De dosering en de werking wijken niet af van de oude formulering. Wel is het nieuwe product veiliger voor gewas en iets beter regenvast.

- Harmony is met de werkzame stof thifensulfuron $(500 \mathrm{gr} / \mathrm{kg}$ ) toegelaten in mais. Dosering 15 gr/ha en het heeft een goede werking op o.a. zuring, kamille, ooievaarsbek en zwaluwtong.

In 2015 zijn Arrat en Wing-P beschikbaar gekomen:

- Arrat (tritosulfuron/dicamba) is een contactherbicide en kan gespoten worden tot in het 6-8 bladstadium.

- Wing P (dmta-p/pendimethalin) is een breed werkend bodem- en contactherbicide dat goed werkt op een breed onkruidspectrum waaronder veelknopigen (zoals perzikkruid, zwaluwtong, varkensgras), ganzevoetachtigen en meldes.

In 2016 is het middel Clio niet meer beschikbaar. Deze was zeer sterk op gladvingergras. Maar een hoge dosering van 2,25 I/ha Laudis geeft ook een goed effect, mits het tijdig wordt toegepast (voor het 3 bladstadium van het onkruid) in combinatie met een terbutylazine bevattend middel als Akris of Gardo Gold. Het wegvallen van Clio kan ook worden opgevangen door een tweevoudige bespuiting, dit om vingergras en gierstgras te kunnen bestrijden. De eerste bespuiting direct na zaai, dus vóór opkomst van de mais. Dit liefst op een vochtige grond of direct na een bui. De tweede bespuiting na opkomst. Voordeel is dat deze tweede bespuiting door het effect van de eerste bespuiting qua middelenkeuze, dosering en moment beter getimed kan worden.

In 2016 zijn Capreno, Auxo en Monsoon Active beschikbaar gekomen.

- Capreno bevat tembotrione, bekend van Laudus met daaraan toegevoegd thiencarbazone (TCM). De combinatie van de 2 actieve stoffen heeft een hele brede werking tegen zowel grassen als breedlbadige onkruiden. Capreno werkt ten opzichte van de huidige middelen beter op kamille en zwaluwtong. Capreno heeft een interessante nevenwerking tegen wortelonkruiden. Bij aanwezigheid van haagwinde heeft Capreno een versterkend effect op de geëigende middelen tegen haagwinde.

- Advies: 0,2-0,29 I/ha Capreno in een mix van middelen.

- Capreno is niet toegelaten in grondwaterbeschermingsgebieden.

Monsoon Active is een combinatie van foramsulfuron (FSN) en thiencarbazone-methyl (TCM). De combinatie van twee actieve stoffen uit een verschillende chemische groep draagt zorg voor een effectief ingebouwd resistentie-management. Monsoon Active is geformuleerd als een OD (olie dispersie). Het bestrijdt één- en meerjarige grassen zoals hanenpoot, naaldaar, raaigras, straatgras en kweek. Monsoon Active bestrijdt daarnaast een breed spectrum aan éénjarige breedbladige onkruiden zoals kamille soorten, veelknopigen, uitstaande melde en melganzenvoet. Monsoon Active heeft tevens een goede werking op diverse overblijvende onkruiden zoals akkerwinde, akkerdistel, haagwinde, akkermelkdistel, ridderzuring, paardenbloem en veenwortel. Het advies is om Monsoon Active toe te passen in een dosering van $0,75 \mathrm{I} /$ ha in een mix van middelen. Monsoon Active niet mengen met Laudis en vloeibare bladmeststoffen. Monsoon Active past ook prima als onderbladbespuiting tegen bv haagwinde of nakiemers van bv hanenpoot.

Auxo is een combinatie van tembotrione en bromoxynil. Het bestrijdt de meeste éénjarige breedbladige onkruiden zoals onder andere melganzenvoet, ganzevoet-soorten, uitstaande melde, meldesoorten, zwarte nachtschade, vogelmuur, perzikkruid, beklierde duizendknoop, zwaluwtong, varkensgras, echte kamille, kamille soorten, kleefkruid, knopkruid, herderstasje, herik en paarse dovenetel. Auxo heeft daarnaast een redelijke werking tegen hanepoot en andere eenjarige grassen. Advies is $1 \mathrm{I} /$ ha in een mix van middelen. 
Samenvattend: In 2 tot 6-bladstadium, afhankelijk van de onkruidbezetting, de weersomstandigheden en het maïsras, zijn de volgende mixkeuzes mogelijk:

1. Tegen breedbladigen en aardappelopslag, keuze uit: Calaris, Callisto, Sulcogan 300 SC, Laudis, Laudis WG , Auxo of Capreno.

Laudis werkt het beste tegen gladvingergras mits er wordt gespoten met volle doseringen (Laudis 2,25 I of Laudis WG 0,5 kg/ha icm Olie $1 \mathrm{I} / \mathrm{ha}$.

2. Aangevuld voor met name de bodemherbicide werking, tegen grassen en extra werking op breedbladigen, keuze uit: Dual Gold, Frontier Optima, Wing P, Stomp 400 SC, Akris, Gardo Gold.

3. Aangevuld met, extra werking tegen grassen, kweek en (lastige) breedbladige onkruiden, keuze uit: Samson Extra 6\% OD/Samson 4 SC, Milagro, Milagro 40, Accent, Kelvin, MaïsTer Vloeibaar, Monsoon Active (niet mengen met Laudis OD).

Bij alle sulfonylureum-verbindingen oppassen met te koud of te warm weer of te grote schommelingen in dag- en nachttemperatuur).

4. Aangevuld met, tegen haagwinde, veelknopigen en nevenwerking op aardappelopslag: Kart, Starane Top, Peak, Arrat, Casper, Banvel 4S, Monsoon Active of Primus maar pas bij de laatste op voor de rasgevoeligheid en werkt niet tegen aardappelopslag). Als nevenwerking tegen aardappelopslag werken Kart, Starane Top en Monsoon Active het best.

Als er haagwinde op het perceel voorkomt in elk geval 2 keer bestrijden. In 2 tot 6 bladstadium met een middel in de mix en vervolgens rond 8 bladstadium (zie paragraaf 8.3.3. Wortelonkruiden). Daarbij zijn onderblad-toepassingen een goede methode om de onkruiden op te ruimen en de mais te sparen voor schade.

Meestal wordt in de praktijk één maal gespoten in het 2 tot 6 bladstadium van de mais met een mix van middelen, voor een breed werkingsspectrum. Het is ook te overwegen de mais ook vóór opkomst al een keer te bespuiten. De middelen Merlin (isoxaflutool) in combinatie met Frontier Optima (dimethanamid-P), Dual Gold (s-metolachloor) of Wing-P (dimethanamide-P/pendimethalin) zijn geschikt om hiervoor in te zetten.

Op percelen met een lage onkruiddruk, zonder probleemonkruiden als haagwinde, zwaluwtong, varkensgras, kweek en andere grassen is één voor opkomst bespuiting (bv. Merlin, evt aangevuld met Frontier Optima, Dual Gold of Wing-P) vaak genoeg om het onkruid te bestrijden. Voordeel is dat de maïs dan niet wordt bespoten en er dus ook geen mogelijke bijbehorende negatieve effecten op de opbrengst zijn.

Ook op percelen met zware onkruiddruk kan men de vóór opkomst bespuiting toepassen. Dit voorkomt in koude voorjaren, waarbij niet goed zonder gewasschade kan worden gespoten, dat het onkruid de mais te veel gaat onderdrukken. Vervolgens kan op deze percelen een tweede bespuiting (eventueel in lage dosering) worden toegepast tegen laat kiemende en probleemonkruiden. 
Tabel 8.1 Gevoeligheidstabel onkruiden voor herbiciden ${ }^{1)}$

\begin{tabular}{|c|c|c|c|c|c|c|c|c|c|c|c|c|c|c|c|c|c|c|c|c|c|c|c|}
\hline & $\frac{\underset{\mathrm{D}}{\bar{J}}}{\overline{\bar{J}}}$ & $\begin{array}{l}\frac{D}{\bar{D}} \\
\frac{D}{2} \\
\text { D을 }\end{array}$ & 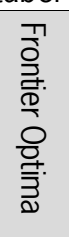 & $\underset{\substack{0 \\
0}}{\sum_{0}}$ & $\begin{array}{l}\text { 齐. } \\
\text { ज. }\end{array}$ & 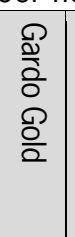 & $\begin{array}{l}\frac{\Omega}{0} \\
\frac{0}{\bar{ज}}\end{array}$ & 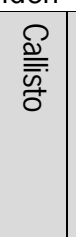 & 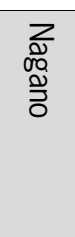 & 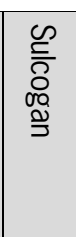 & $\begin{array}{l}\frac{\sigma}{m} \\
\frac{\bar{c}}{\omega}\end{array}$ & $\begin{array}{l}\frac{8}{0} \\
\frac{\mathbb{1}}{\mathbb{O}} \\
\frac{0}{0}\end{array}$ & $\begin{array}{l}\frac{\mathbb{D}}{\bar{N}} \\
\frac{\mathbb{D}}{w}\end{array}$ & 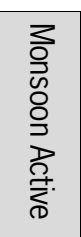 & 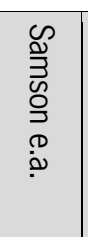 & 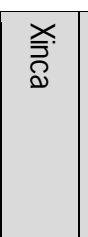 & $\begin{array}{l}\mathbb{D} \\
\frac{\mathbb{D}}{\lambda}\end{array}$ & 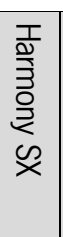 & 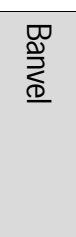 & 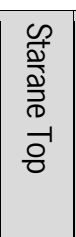 & 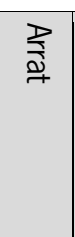 & 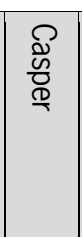 & $\frac{\bar{\jmath}}{7}$ \\
\hline ardap & - & - & - & - & - & + & +++ & ++ & +++ & $++(+)$ & ++ & ++ & ++ & ++ & - & + & & 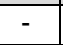 & + & ++ & ++ & + & ++ \\
\hline ken & t) & + & 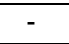 & $++(+)$ & +++ & \begin{tabular}{l|}
+++ \\
\end{tabular} & +++ & ++ & +++ & ++ & + & +++ & +++ & ++ & 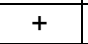 & 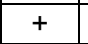 & \begin{tabular}{|c|}
$+(+)$ \\
\end{tabular} & + & 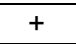 & - & $(+)$ & \begin{tabular}{|l|}
$+(+)$ \\
\end{tabular} & \\
\hline anze & & ++ & ++ & +++ & +++ & +++ & +++ & + & +++ & +++ & +++ & +++ & +++ & ++ & +++ & ++ & ++ & $r$ & ++ & + & $++(+)$ & +++ & $(+)$ \\
\hline Slad & + & ++ & +++ & & +++ & +++ & ++ & - & - & + & ++ & ++ & + & + & 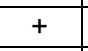 & & & & - & & 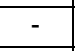 & - & - \\
\hline Groen & + & \begin{tabular}{l|}
+++ \\
\end{tabular} & +++ & & $++(+)$ & ++++ & ++ & - & ++ & - & ++ & ++ & ++ & $++(+)$ & $++(+)$ & - & - & - & - & - & - & - & - \\
\hline Haagn & & + & 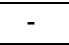 & & + & - & + & + & + & - & - & ++ & - & $++(+)$ & 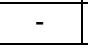 & + & ++ & & $+(+)$ & $++(+)$ & $++(+)$ & $++(+)$ & $++(+)$ \\
\hline Haner & $+(+)$ & +++ & +++ & +++ & +++ & +++ & ++ & ++ & + & ++ & +++ & +++ & +++ & +++ & $++(+)$ & - & - & - & - & - & - & - & - \\
\hline Henne & & & ++ & +++ & $++(+)$ & + & +++ & +++ & +++ & +++ & & +++ & +++ & +++ & +++ & + & & ++ & ++ & ++ & +++ & & $+(+)$ \\
\hline arde & ++ & ++ & ++ & + & $++(+)$ & +++ & +++ & +++ & +++ & ++ & ++ & +++ & +++ & +++ & +++ & +++ & +++ & ++ & ++ & + & +++ & +++ & +++ \\
\hline mille & +++ & \begin{tabular}{l|}
+++ \\
\end{tabular} & +++ & ++ & +++ & ++++ & ++ & ++ & +++ & ++ & ++ & +++ & +++ & +++ & ++ & +++ & \begin{tabular}{|l|}
+++ \\
\end{tabular} & ++ & ++ & - & +++ & +++ & $++(+)$ \\
\hline Kleefk & $+(+)$ & + & ++ & $+(+)$ & +++ & + & +++ & ++ & +++ & ++ & + & $++(+)$ & +++ & ++ & ++++ & ++ & - & + & ++ & ++++ & +++ & + & +++ \\
\hline eine & & + & & +++ & +++ & ++ & +++ & +++ & +++ & +++ & +++ & +++ & +++ & ++ & ++ & + & & & +++ & ++ & +++ & & $++(+)$ \\
\hline Kweek & & - & $-5+2>$ & - & - & - & - & - & - & 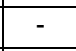 & - & $++(+)$ & +++ & +++ & +++ & $-5+2>$ & $-5+2>$ & $-5+2>$ & & - & - & & - \\
\hline Melde s & $+(+)$ & + & $+(+)$ & $++(+)$ & $++(+)$ & $+(+)$ & +++ & ++ & +++ & ++ & +++ & +++ & ++ & ++ & + & ++ & $++(+)$ & + & ++ & - & $++(+)$ & $++(+)$ & $(+)$ \\
\hline Muur & ++ & ++ & ++ & +++ & +++ & +++ & +++ & +++ & +++ & +++ & +++ & +++ & +++ & +++ & ++++ & ++ & $\begin{array}{l}+++ \\
\end{array}$ & ++ & ++ & +++ & +++ & +++ & +++ \\
\hline tars & +++ & + & +++ & +++ & +++ & ++ & +++ & +++ & ++++ & +++ & +++ & +++ & +++ & +++ & ++++ & + & $+(+)$ & + & + & + & ++ & ++ & + \\
\hline Papeg & ++ & + & ++ & & ++ & ++ & +++ & ++ & $++(+)$ & + & +++ & +++ & +++ & +++ & +++ & + & $+(+)$ & ++ & + & ++ & +++ & $++(+)$ & $+(+)$ \\
\hline Perzikkruid & \begin{tabular}{l|}
+++ \\
\end{tabular} & + & ++ & +++ & $++(+)$ & ++ & \begin{tabular}{l|}
+++ \\
\end{tabular} & \begin{tabular}{l|}
+++ \\
\end{tabular} & ++ & +++ & +++ & +++ & +++ & ++++ & ++ & ++ & +++ & ++ & +++ & +++ & +++ & ++++ & +++ \\
\hline Raaigrassen & $(+)$ & +++ & ++ & ++ & ++ & + & ++ & - & - & - & + & ++ & +++ & ++++ & $++(+)$ & - & - & - & - & - & - & - & - \\
\hline Straatgras & $(+)$ & +++ & ++ & $++(+)$ & ++ & ++ & ++ & + & + & + & + & ++ & +++ & +++ & +++ & 1 & 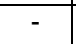 & 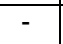 & 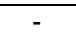 & 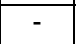 & - & - & - \\
\hline Varkensgras & $+(+)$ & + & + & +++ & $+(+)$ & + & ++ & ++ & +++ & + & ++ & +++ & ++ & +++ & + & ++ & $+(+)$ & + & ++ & ++ & ++ & $++(+)$ & +++ \\
\hline Veenwortel & -1 & - & - & - & - & - & + & + & + & + & - & & - & ++ & - & - & & $(+)$ & + & + & + & & + \\
\hline Waterpeper & & & ++ & + & $++(+)$ & & +++ & ++ & ++ & & +++ & $++(+)$ & ++ & & & & & ++ & ++ & & ++ & & \\
\hline Zachte ooievaarsbek & $(+)$ & ++ & ++ & +++ & +++ & ++ & +++ & - & & & - & $+(+)$ & + & $+(+)$ & & ++ & & ++ & & 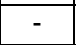 & $+(+)$ & & $+(+)$ \\
\hline$\angle$ Walumiong & $(+)$ & ++ & ++ & +++ & $++(+)$ & $+(+)$ & ++ & + & $++(+)$ & 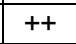 & + & ${ }^{+++}$ & + & +++ & ++ & $++(+)$ & +++ & ++ & ++ & $++(+)$ & ++ & +++ & +++ \\
\hline Zwarte nachtschade & +++ & +++ & ++ & +++ & $++(+)$ & +++ & +++ & +++ & +++ & +++ & +++ & +++ & +++ & +++ & +++ & +++ & + & + & + & ++ & +++ & $+(+)$ & +++ \\
\hline
\end{tabular}

${ }^{1}+++$ zeer gevoelig/ ++ gevoelig/ + matig gevoelig/- ongevoelig/blanco = onbekend. Bron: Delphy 


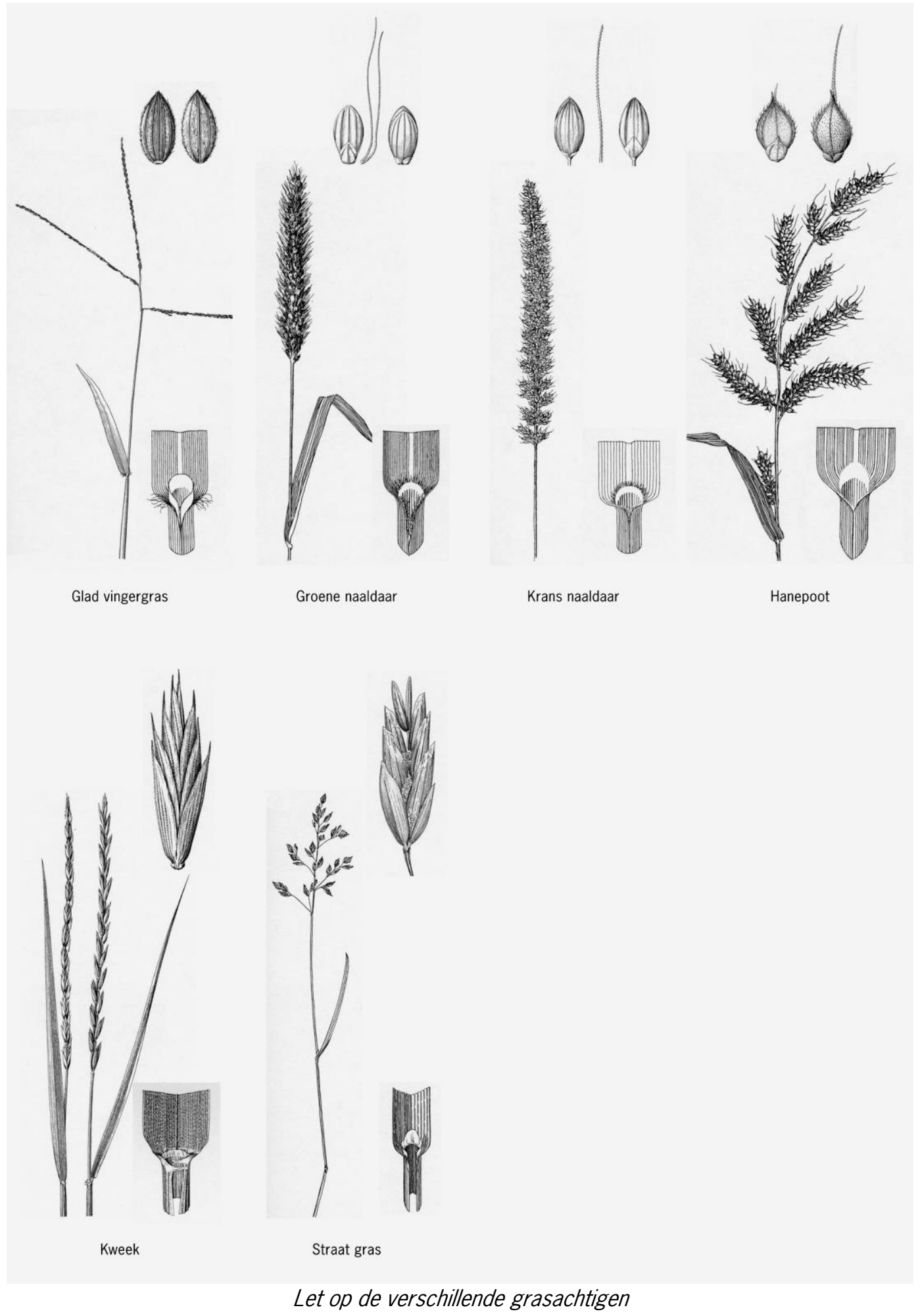




\subsubsection{Wortelonkruiden}

Tijdens de teelt van snijmaïs kunnen wortelonkruiden, zoals kweek en haagwinde, niet mechanisch worden bestreden, wel chemisch.

De groeistoffen fluroxypyr (Starane Top, Kart), dicamba (Banvel 4S, Casper), florasulam (Primus, Kart), tritosulfuron (Arrat), prosulfuron (Peak) en thiencarbazone (Monsoon Active) zijn effectief tegen haagwinde. Deze middelen worden via het blad opgenomen. Voor een goede werking moet het onkruid voldoende blad hebben. Voor haagwinde betekent dit eigenlijk dat de plant vaak al (deels) in de stengels van de maïs groeit. Voor Primus geldt dat het pas kan worden toegepast als de maïs 5-6 bladeren heeft. Daarbij moet de maximale dosering van het middel worden toegepast. Ook mag het nooit met andere herbiciden worden gemengd, vanwege kans op schade en een minder resultaat. Kart, Arrat, Starane Top Banvel 4S, Casper, Peak en Monsoon Active kunnen wel gemengd worden met andere herbiciden en kunnen ingezet worden op alle rassen. Monsoon Active niet mengen met Laudis. Voor een goede haagwindebestrijding is een tweede, extra bespuiting in een iets later stadium (6 tot 8-bladstadium) met Kart, Arrat, Starane TopBanvel 4S, Peak of Primus gewenst, Starane Top, Monsoon Active en Primus liefst via onderbladbespuiting. Kart kan tot een dosering van 0,7 I/ha en Arrat tot $0,2 \mathrm{~kg} / \mathrm{ha}$ volvelds worden ingezet, dit liefst uitvoeren met veel lucht, zodat de haagwinde onder de mais goed geraakt wordt. Haagwindebestrijding kan eventueel ook pleksgewijs worden toegepast. Bij veel haagwinde wordt geadviseerd om zowel middelen in de mix mee te nemen als een correctiebespuiting uit te voeren.

Kweek wordt met rimsulfuron (Titus), nicosulfuron (Milagro 40, Samson Extra 6\% OD of Accent), iodosulfuron+ foramsulfuron (MaïsTer Vloeibaar) of thiencarbazone (Monsoon Active) bestreden. Kweek moet circa $10 \mathrm{~cm}$ hoog zijn. Let op mogelijke temperatuurgevoeligheid van deze middelen. Naast de genoemde kweek en haagwinde kunnen distels een lastig wortelonkruid zijn. Dit geldt zowel voor de akkermelkdistel als voor de akkerdistel. Daar waar dicamba (Banvel 4S, Casper en Arrat) en MaïsTer Vloeibaar een nevenwerking hebben tegen distels, zijn Lontrel 100 en Monsoon Active zeer effectief voor de bestrijding van distels in mais. Voor een goede effectiviteit is het belangrijk dat de distels voldoende bladmassa hebben ontwikkeld en er voldoende groei in de planten zit. Afhankelijk van de vroegheid van het seizoen zal dat betekenen dat de Lontrel 100 en Monsoon Active de ene keer in de mix (zonder olie) kan worden mee gespoten, terwijl de andere keer een aparte bespuiting gewenst is. Lontrel 100 bestrijdt naast distels ook hoefblad effectief. Lontrel 100 kan volgens het etiket nog in het 6- en 10-bladstadium worden toegepast in een dosering van $1,2 \mathrm{l} / \mathrm{ha}$.

Om het onkruid beter te raken en/of gewasschade te voorkomen kunnen de middelen met een "onder blad bespuiting" worden toegepast. In 2007 en 2008 zijn een aantal zelfontwikkelde spuitmachines van loonwerkers (loonwerkersgroep Telen met Toekomst) en bestrijdingsmethoden tegen o.a. haagwinde getest. In 2007 werd voor de onderblad bespuiting een kappenspuit (zie foto), rijenspuit en zakpijpenspuit vergeleken. Ook werd de triltandschoffel als mechanische bewerking ingezet. In 2008 werd een correctiebespuiting met de kappenspuit vergeleken met alleen volvelds spuiten. Alle geteste machines gaven bij keuze van een goede mix een goed bestrijdingsresultaat.

Naast toevoeging van een specifiek haagwindemiddel zoals Kart, Arrat, Banvel 4S en Starane aan de standaardmix (bespuiting in 3-4 bladstadium) werd in het 8-9 bladstadium een correctiebespuiting uitgevoerd middels een volveldsbespuiting of een onderblad bespuiting. In 2007 zorgde eggen voor opkomst ervoor dat er minder grote éénjarige onkruiden waren. Daardoor konden de haagwindeplanten goed worden geraakt en had toevoeging van Banvel 4S, Starane 200 of Starane Top aan de standaardmix wel degelijk effect. In 2008 was het eg effect minder. Een zelfde effect mag verwacht worden van een vóór opkomst bespuiting met Merlin, Dual 
Gold, Frontier Optima of WingP. Alle melde en ganzevoet soorten worden dan als er sprake is van voldoende vocht in de bodem in ieder geval weggespoten.

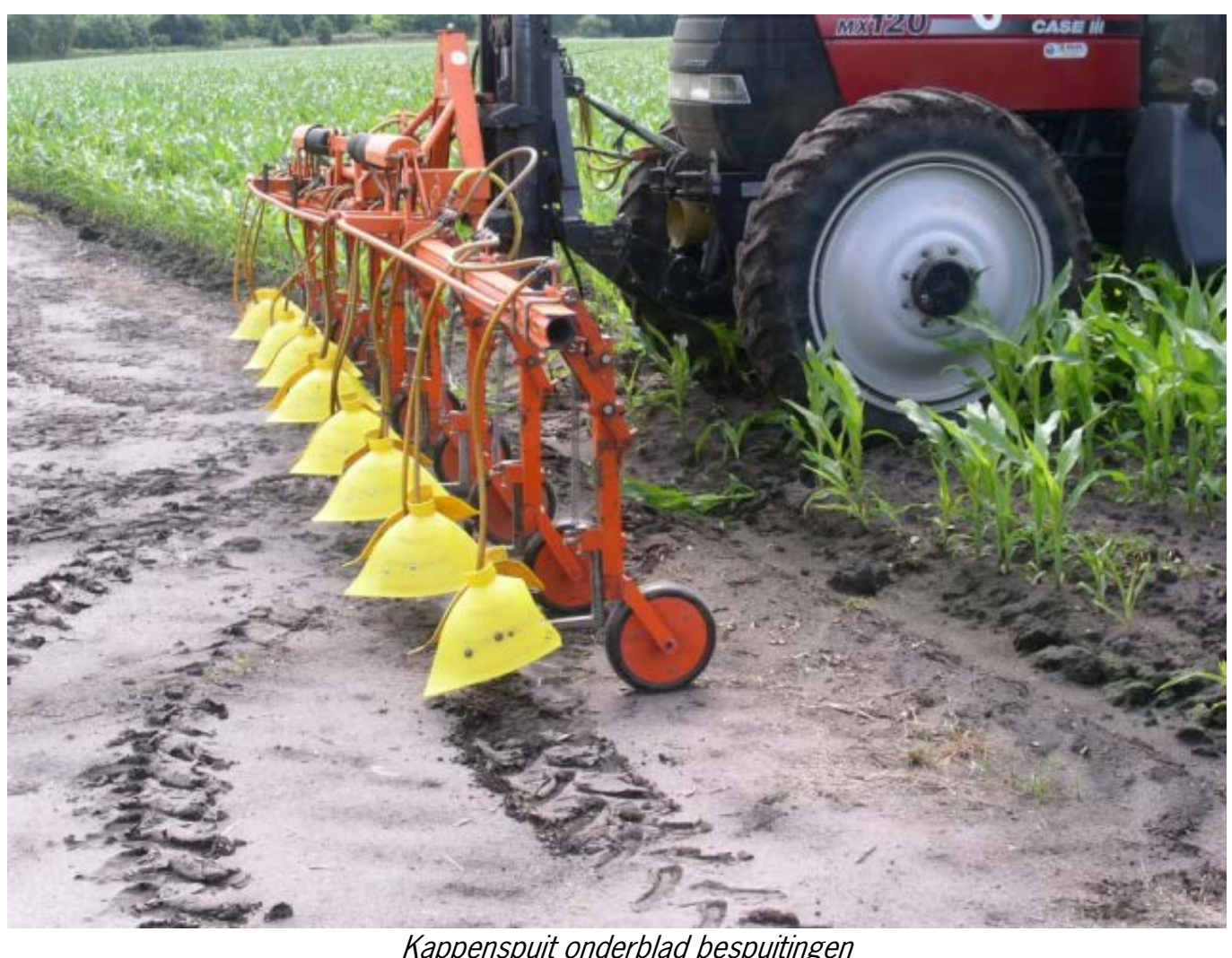

Voor het zaaien en na de oogst van de maïs kan kweek ook mechanisch worden aangepakt. Een nieuw type frees uit Denemarken werkt met verende pennen (KVIK UP) gooit grond en kweekwortels omhoog. De kweekwortels komen bovenop de grond terecht. Daarna kan men ze bij elkaar harken en afvoeren. De machine werkt het best op lichte grond. Op zware grond kan beter een pennenfrees met vaste pennen worden gebruikt.

Naar verwachting geeft frezen ook een goede bestrijding op haagwinde. Mechanische en chemische bestrijding zijn alleen effectief als wortelonkruiden actief zijn.

Kweek en grassen kunnen in de toekomst een groter probleem worden door de nieuwe regels die het vernieuwen van grasland in het najaar verbieden. Scheuren moet dus in het voorjaar gebeuren. Een daaropvolgende maïsteelt kan dan meer last hebben van grassen. Deels omdat het onderwerken secuur moet gebeuren. Gebeurt dat niet, dan kan het gras toch weer opkomen. Het gras kan ook eerst doodgespoten worden. Hergroei is dan niet meer aan de orde, maar kweek vormt daar een uitzondering op. Dat komt omdat kweek opnieuw kan uitlopen via de wortelstokken. Doodspuiten in het voorjaar heeft zeker geen 100 procent werking op kweek omdat in het voorjaar de sapstroom omhoog is gericht. De werkzame stof glyfosaat komt dan niet of niet overal in de wortelstokken terecht, waardoor er geen volledige doding plaatsvindt. Een chemische bestrijding van kweek in de maïs is voornamelijk beperkt tot het gebruik van MaïsTer Vloeibaar, Milagro 40, Samson Extra 6\% OD, Accent en Monsoon Active. Ook de bestrijding van kweek na de maïsteelt wordt lastiger. Vroeger kon drie weken gewacht worden tot er voldoende hergroei van kweek was. Deze mogelijkheid vervalt omdat het perceel maïs na de oogst direct ingezaaid moet worden met 
een groenbemester of vanggewas. Kweek kan nog wel aangepakt worden door binnen 24 uur na de oogst glyfosaat in te zetten mits er dan voldoende groene kweek aanwezig is.

\subsubsection{Aanpassing en verspreiding onkruidsoorten}

Het is belangrijk jaarlijks in de gaten te houden of de toegepaste middelen alle onkruidsoorten goed bestrijden. Als middelen een bepaalde soort niet bestrijden kan deze soort op den duur gaan overheersen. De verspreiding van hanenpoot over de maïspercelen in de jaren tachtig is hiervan een voorbeeld.

Er zijn grofweg zes oorzaken waardoor soorten aan bestrijding ontsnappen:

- Er wordt op te groot onkruid gespoten. De dosering is dan onvoldoende om de planten te doden. Onkruiden kunnen dan zaad vormen. Onkruiden die minder gevoelig zijn voor het toegepaste middel overleven en breiden uit. Dit proces noemt men selectie.

- Een andere vorm van selectie vindt plaats wanneer binnen een onkruidsoort planten ontsnappen die minder gevoelig zijn voor de toegepaste herbiciden. Dit wordt resistentie genoemd. Er wordt onderscheid gemaakt tussen genetische (target) en metabolische ( nontarget) resistentie.

Bij genetische resistentie heeft de plant zich aangepast, waardoor de herbicide de plant niet meer op zn target, bv een eiwit of enzym, kan aanvallen. Het herbicide kan het enzym niet meer uitschakelen, waardoor processen in plant normaal blijven verlopen. Dit is een genetische resistentie. Bij bespuiting met de herbicide zijn er bepaalde planten die overleven en zich vermenigvuldigen. Hierdoor ontstaat er in de tijd een steeds groter aantal van resistentie onkruidplanten.

Bij metabolische resistentie breken de onkruidplanten het herbicide versneld af. Bij metabolische resistentie is de mate van resistentie afhankelijk van de hoogte van de dosering. Binnen de populatie komen planten voor die niet of minder gevoelig zijn voor lagere doseringen. Bij bespuiting met een te lage dosering kunnen deze planten overleven en zich vermenigvuldigen. Om dit te voorkomen is het belangrijk om onder de juiste omstandigheden een voldoende hoge dosering te kiezen die de planten afdoende dood. Bij genetische resistentie komen binnen een populatie planten voor die zich genetisch hebben veranderd, waardoor de planten niet dood gaan en zich kunnen vermenigvuldigen. Deze vorm van resistentie treedt met name op wanneer jaar op jaar één herbicide (geen cocktail) wordt gebruikt (b.v. triazineresistenties (o.a. terbuthylazine). Om beide vormen van resistentie te voorkomen is het goed om herbiciden met verschillende werkzame stoffen met een verschillende werkingsmechanismen te mixen en bestrijdingsmethoden af te wisselen.

- Sommige onkruiden kiemen laat en komen pas op na het tijdstip dat de bodemherbiciden optimaal werkten en kunnen soms zelfs pas opkomen na een eventuele vervolgbespuiting met contactherbiciden later. Bijvoorbeeld gladvingergras (piek van kieming afhankelijk van warmte in periode mei-juli) en ooievaarsbek (in zachte winter in staat om het hele jaar door te kiemen). Ook wortelonkruiden zoals haagwinde kunnen na een eerste bespuiting weer terug komen.

- Nieuwe soorten worden op het perceel gebracht. Dit kan door wind, vogels, mens, machines en mest gebeuren. Als deze onkruiden niet gevoelig zijn voor de toegepaste herbiciden, kunnen ze zich over het perceel verspreiden.

Herbiciden die via de bodem werken worden door het bodemleven afgebroken voordat de plant ze opneemt. Het bodemleven heeft zich dan aan het herbicide aangepast. Dit proces heet adaptatie. Daar waar vroeger herbiciden soms weken werkzaam bleven is het soms binnen enkele dagen afgebroken (bekend van atrazin). 


\subsubsection{Keuze middel en dosering}

Er is een breed scala aan middelen in snijmaïs toegelaten. Het is dus mogelijk om, ook al wordt elk jaar maïs op maïs geteeld, toch te wisselen met herbiciden. Bovendien kunnen de meeste middelen met elkaar worden gemengd.

Wel kan door het gebruik van herbiciden aanzienlijke groeiremming ontstaan als de weersomstandigheden ongunstig zijn en er met een combinatie van middelen in de adviesdosering wordt gespoten. Het onkruid wordt dan goed bestreden maar onderzoek inde jaren negentig wees uit dat dit tot ongeveer 10-15\% lagere opbrengsten kan leiden dan bij een zorgvuldige mechanische bestrijding.

Het twee keer toepassen van een lage dosering ( 2 * $33 \%$ van de dosering) geeft goede onkruidbestrijdingsresultaten. Eerste keer in 2-3 bladstadium van de mais en 2e keer in 5-6 bladstadium spuiten. Dit geef ook minder gewasschade. In een onderzoek in 2016 werd een praktijkbespuiting met een relatief hoge dosering (mix van 2 I Laudis +2 I Akris $+0,5$ I Kart $+0,4$ I Samson Extra 6\% OD per ha) vergeleken met een aantal strategieën met een lagere dosering, waarbij 20-60\% op middel werd bespaard. De gewasopbrengst van de strategie waarbij twee keer met een lage dosering (per keer circa 33\% van de praktijkbespuiting) werd gespoten was $6 \%$ hoger dan van de strategie met de praktijkbespuiting.

Voor een goede onkruidbestrijding is het niet nodig om altijd de etiketdosering toe te passen. Om de juiste dosering te bepalen moet men zich afvragen:

1. Komen er onkruiden voor die weinig gevoelig zijn voor de gekozen herbiciden?

2. Hoe groot zijn de onkruiden? Hoeveel bladeren hebben de grootste onkruiden?

3. Zijn onkruiden door weersomstandigheden afgehard of gevoelig?

Ad 1. Voor het bestrijden van soorten die zeer gevoelig zijn, kan men vaak met een lagere dosering volstaan. Voor weinig gevoelige soorten is het beter een middel te kiezen dat die soort goed bestrijdt of een middel toe te voegen. Let bij mixen wel op eventuele kans op schade aan het gewas.

Ad 2. Onkruiden zijn in een jong stadium, kiemplanten tot eerste echte blaadjes, extra gevoelig. In het kiemplantstadium kan met hele lage doseringen worden volstaan. Er zijn via internet adviesprogramma's beschikbaar die aangeven welke doseringen nodig zijn voor een bepaalde herbicide - onkruid combinatie (ADS- of MLHD- systeem). ADS staat voor Aangepast DoseringsSysteem, een combinatie van middelen met een op de grootte en soorten afgestemde dosering. MLHD staat voor Minimum Lethale Herbicide Dosering en is de dosering waarbij onkruiden in een bepaald stadium net doodgaan.

Ad 3. De weersomstandigheden rond het tijdstip van spuiten bepalen hoe fel een middel werkt. Dit is afhankelijk van het weer, het ontwikkelingsstadium van de plant en het herbicide. Het programma GEWIS geeft een indicatie van de kans van slagen van een bespuiting en de mogelijkheid de dosering te verlagen.

Meer informatie over MLHD en GEWIS via www.opticrop.nl. Opticrop verzorgd ook een onkruidfax maïs.

Combinaties van middelen waarin Banvel 4S, Starane 200 en Starane Top is opgenomen werken agressief. Daarom geldt bij deze middelen: alleen toepassen als er onkruidsoorten voorkomen die door de andere middelen in de mix niet of matig worden bestreden en de dosering zo laag mogelijk houden. Starane wordt nauwelijks meer in de mix opgenomen en meestal onder blad gespoten. Het toepassen van hulpstoffen zoals plantaardige -, minerale olie of een synthetische uitvloeier kan gewasschade veroorzaken. Sommige middelen hebben echter een hulpstof nodig voor een goede werking. 
De werking van een aantal herbiciden verbetert in het algemeen als de actieve stof beter wordt opgenomen. Ook de gewasplanten nemen dan in de regel meer middel op. Hulpstoffen daarom niet toepassen bij middelen waarvan bekend is dat ze gemakkelijk gewasschade veroorzaken.

Als het weer gunstig is voor de toepassing van het middel kan ook bij middelen groeiremming optreden, terwijl ze bijna nooit gewasschade geven.

\subsubsection{Keuze doptype}

Naast de keuze van het middel, de dosering en het tijdstip van toepassing kan het doptype invloed hebben op het bestrijdingsresultaat. Toepassing van driftarme doppen kan voor sommige middelen een vereiste zijn. Dit geldt voor de middelen Dual Gold, Frontier Optima, Akris, Gardo Gold, Laddok N, Laudis, MaïsTer Vloeibaar, Collage, Milagro 40, Samson Extra 6\% OD, Accent, Xinca, Peak, Casper en Lontrel 100.

Op klein onkruid(van kiemplant tot eerste echte blaadjes), bestrijding van grassen en bij een lage doseringssysteem (LDS) is het gebruik van doppen met maximaal $75 \%$ driftreductie aan te raden. Bij het gebruik van bodemherbiciden, contactherbiciden met een standaarddosering en bespuiting op onkruid groter dan de eerste echte blaadjes geven doppen met $90 \%$ driftreductie ook een prima bestrijdingsresultaat.

In de meeste gevallen is de middelencombinatie en het toepassingstijdstip meer bepalend voor het bestrijdingseffect dan de keuze van de dop.

\subsubsection{Duurwerking of contactwerking}

Veel telers vinden het belangrijk dat snel na het spuiten de bestrijding zichtbaar is en dat een middel lang werkt. Bij vaak wat oudere middelen is de werking al na een paar dagen te zien. Bij de modernere sulfonylureum herbiciden, met name bij foramsulfuron + iodosulfuron-methyl-sodium (MaïsMaïsTer Vloeibaar), nicosulfuron (Milagro 40/Samson Extra 6\% OD/Accent), thiencarbazone (Monsoon Active), prosulfuron (Peak) en tritosulfuron (Arrat) duurt het vaak 2 weken voordat duidelijke symptomen zichtbaar worden. Vanaf het moment van spuiten groeien de onkruiden niet meer, maar blijven nog wel groen.

De meeste contactmiddelen hebben geen duurwerking maar wel een tamelijk snelle aanvangswerking, met name Calaris, Callisto, Sulcogan 300 SC, Capreno en Laudis.

Bodemherbiciden hebben wel duurwerking, zoals: isoxaflutool (Merlin), S-metolachloor (Dual Gold), S-metolachloor + terbuthylazine (Gardo Gold), dimethenamid-P (Frontier Optima), dimethenamid-P + pendimethalin (Wing P) en dimethenamid-P + terbuthylazine (Akris). Deze middelen werken enkele weken op kiemende zaden van de soorten die voor de middelen gevoelig zijn. Vooral op percelen met een zeer zware onkruiddruk zijn bodemherbiciden nodig om onkruiden beheersbaar te houden en de teelt na de onkruidbestrijding na opkomst (voldoende) vrij te houden van onkruid tot aan de oogst. Op percelen met een normale tot lichte onkruiddruk is een zorgvuldig gekozen mix van contactmiddelen voldoende voor een goede bestrijding. Bodemherbiciden zijn vaak persistent en (soms) schadelijk voor oppervlakte- en/of grondwater. Om de milieurisicos van middelen te kunnen vergelijken heeft CLM de milieumeetlat ontwikkeld. Deze kan men gratis via internet raadplegen: http://milieumeetlat.nl/

Bodemherbiciden worden vaak voor opkomst toegepast. Voor de werking van de middelen is vocht nodig. In jaren dat na toepassing 1 tot 2 weken geen neerslag valt, werken de middelen onvoldoende en moet men alsnog na opkomst onkruid bestrijden met hoge doseringen spuiten. De middelen Frontier Optima, Akris, en Dual Gold en Gardo Gold kan men voor het eggen toepassen. $\mathrm{Na}$ het spuiten van Merlin mag de grond niet meer worden bewerkt. 
Bij een hoge onkruiddruk is te overwegen een bodemherbicide voor opkomst van de maïs te gebruiken. De eerste onkruidgolf is hiermee in de toom te houden, waardoor bij de na opkomst bestrijding later kiemende onkruiden toch goed bestreden kunnen worden. Tevens wordt alvast een stuk onkruidconcurrentie om water, licht en ruimte, voorkomen. Bij droge weersomstandigheden kan de werking van bodemherbiciden tegen vallen, hoewel het middel vaak nog zijn werking doet, zodra er weer regen valt. Bij een lage onkruiddruk, zonder probleemonkruiden, kan een vóór opkomstbespuiting afdoende zijn.

Ondanks het wegvallen van de cross-compliance-regeling voor maïs is het belangrijk om een middel te kiezen dat met een lage dosering en een lage benodigde hoeveelheid werkzame stof per hectare een goede bestrijding geeft. Merlin voldoet aan deze eis. Frontier Optima, Akris, Dual Gold en Gardo Gold worden ook vaak aan de na opkomst bestrijding toegevoegd. Dan kan relatief vroeg op klein onkruid met relatief lage doseringen worden gespoten en wordt nawerking van de bespuiting verkregen door de toevoeging.

\subsubsection{Herbiciden en grasonderzaai}

Als men raaigras inzaait na de bespuiting met herbiciden, moet men daarmee bij de keuze van middelen rekening houden. In de gevoeligheidstabel staat of de herbiciden effectief zijn bij de bestrijding van raaigrassen. Dit betreft bespuitingen over raaigrasplanten. Uit onderzoek van Wageningen Plant Research in 2001 en 2002 bleek dat dimethenamid-P (Frontier Optima) desastreus was voor Italiaans raaigras dat enkele weken voor zaaien was gespoten. Dimethenamid$P$ is ook een bestanddeel in de producten Akris en Wing-P, dus hiermee ook oppassen bij grasonderzaai. In een proef in 2016 is ook de ervaring dat Akris schade aan Italiaans raaigras en rietzwenkgras onderzaai veroorzaakt.

S-metolachloor (Dual Gold/Gardo Gold) werd niet onderzocht, maar is verdacht omdat het een bodemherbicide met grassenwerking heeft. Nicosulfuron (Milagro of Samson) en foramsulfuron + iodosulfuron-methyl-natrium (MaïsTer Vloeibaar) gaven wel groeiremming maar het gras ontwikkelde zich uiteindelijk goed. Andere onderzochte middelen, terbuthylazine, bromoxynil, mesotrione (Callisto), sulcotrione (Sulcogan $300 \mathrm{SC}$ ), en bentazon (Laddok N) en isoxaflutool (Merlin), gaven nauwelijks groeiremming. Tembotrione (Laudis) is niet onderzocht, maar zou hetzelfde effect hebben.

Barenbrug heeft momenteel een rietzwenkgras (Proterra) beschikbaar dat tegelijk met mais gezaaid kan worden en waarop alle bovenstaande middelen gespoten kunnen worden, met uitzondering van Merlin als vóór opkomst toepassing. Zie voor exacte informatie de website van Barenbrug Holland (www.barenbrug.nl).

Toepassing van lage dosering van bodemherbiciden in een vroege bespuiting (2-3 bladstadium) lijken aanzienlijk minder schade aan de grasonderzaai te doen. De later kiemende onkruiden kunnen met de schoffel (bij grasonderzaai) en met een tweede bespuiting zonder bodemherbiciden worden bestreden.

De gras onderzaai in het 6 bladstadium levert enkele extra voordelen op. Veel al wordt er bij onderzaai ook geschoffeld. Dit is tevens een laatste onkruidbestrijding van onkruid tussen de rijen. Een combinatie schoffel en rijenspuit is nog mooier, want dan kan ook overgebleven onkruid in de rij nog bestreden worden. De schoffelbewerking brengt ook lucht in de grond en opent de mogelijk dichtgeslagen bovengrond. Zeker in koude, natte voorjaren kan dit een opbrengstverhogend effect veroorzaken tot $5 \%$. Slaagt de grasonderzaai, dan kan besloten worden de mais 1 tot 1.5 week later te oogsten om toch een geslaagde groenbemester na mais te bereiken, dit omdat het gras er al staat en niet nog na de maisoogst gezaaid hoeft te worden. 


\section{Ziekten plagen en beschadigingen}

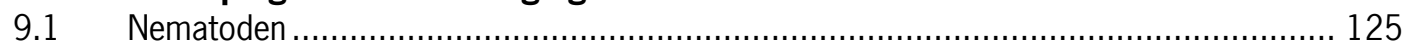

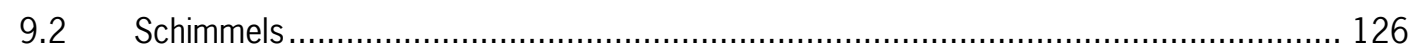

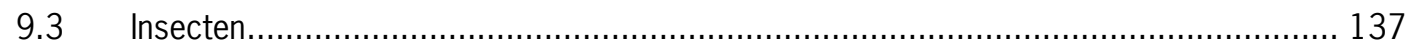

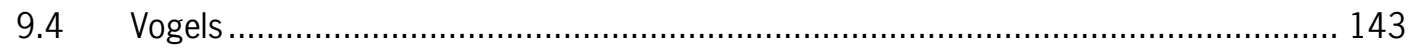

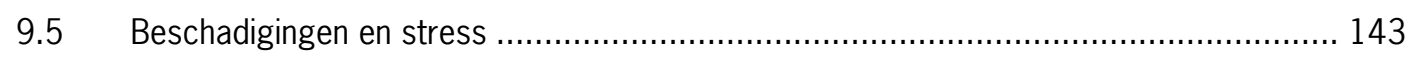

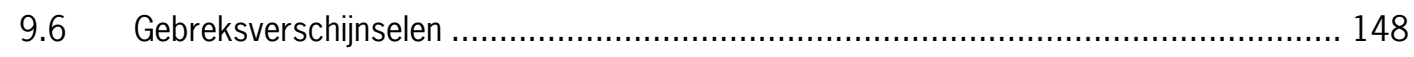




\section{Ziekten plagen en beschadigingen}

In vergelijking met verschillende andere gewassen is maïs in het algemeen een gezond gewas waarin men weinig chemische middelen gebruikt om ziekten en plagen te bestrijden. Alleen het zaaizaad wordt behandeld met een fungicide tegen kiemschimmels met incidenteel hieraan een insecticide toegevoegd. In dit hoofdstuk worden de symptomen en effecten van verschillende ziekten en plagen beschreven, evenals die van beschadigingen en tekorten aan nutriënten en vocht.

\subsection{Nematoden}

Schade ten gevolge van aaltjes treedt in maïs slechts in beperkte mate op. Wel speelt maïs een rol bij de vermeerdering van aaltjes die behoorlijke schade kunnen veroorzaken in gewassen die in rotatie met maïs worden geteeld.

\section{Aaltjesschade in maïs}

De meest algemeen voorkomende plantenparasitaire aaltjesgeslachten bij maïs zijn het wortellesieaaltje (Pratylenchus) en het vrijlevende wortelaaltje van het geslacht Tylenchorhynchus. Met name het wortellesieaaltje neemt toe wanneer frequenter maïs wordt geteeld. Wortellesieaaltjes zijn endoparasieten. Dit betekent dat de aaltjes de wortels binnendringen en van daaruit schade toebrengen. Tylenchorhynchus-aaltjes zijn ectoparasieten wat inhoudt dat deze de plant niet binnendringen maar de wortels aanprikken. Maïs kan enige schade van het wortellesieaaltje ondervinden. Tylenchorhynchusaaltjes zijn niet schadelijk voor maïs.

Het havercysteaaltje (Heterodera avenae) en het stengelaaltje (Ditylenchus dipsaci) kunnen incidenteel schade aanrichten. Het havercysteaaltje is te verwachten in graanrijke bouwplannen. Het aaltje kan zich niet vermeerderen op maïs zodat bij continuteelt geen schade te verwachten is. Bij aantasting blijft het gewas pleksgewijs achter in groei. De kiemwortels zijn vaak sterk vertakt en knoestig. Schade door stengelaaltjes uit zich in een sterk verdikte stengelvoet. De planten vallen gemakkelijk om door slechte wortelgroei. Schade komt met name voor in koude jaren.

Lichte schade kan ook optreden door het maïswortelknobbelaaltje (Meloïdogyne chitwoodi). De aantasting is te herkennen aan de kleine knobbeltjes op de wortels.

Vrijlevende wortelaaltjes van de geslachten Trichodorus en Paratrichodorus kunnen ook schade geven in maïs. Uit onderzoek van Wageningen Plant Research - Praktijkonderzoek AGV bleek dat bij een besmetting van Trichodorus similis bij snijmaïs de drogestofopbrengst kan dalen met 2,5 ton per ha. Trichodoriden komen voor op zandgrond en lichte zavelgronden en houden van vochtige omstandigheden. Vooral in een koel en vochtig voorjaar kunnen ze schade veroorzaken rond de opkomst en tijdens de jeugdfase. Bij zware aantasting vallen kiemplanten weg of blijven sterk achter in groei. De aantasting komt meestal grillig over een perceel voor. Gewasrijen met een goede groei worden afgewisseld met een rijen met een slechte groei, ook in de rijen komen afwisselend stukken met een goede en slechte groei voor. Melkveebedrijven met alleen gras en maïs kunnen weinig aan een besmetting doen, aangezien grassen ook goede waardplanten voor Trichodorus similis zijn. De vrijlevende Trichodorus en Paratrichodorus wortelaaltjes komen vooral voor in bouwplannen met veel granen, grassen of witlof. Daarentegen zijn waspeen, tulp en lelie niet schadegevoelig en tevens geen of slechte waardplant voor Trichodorus similis.

\section{Aaltjesvermeerdering op maïs}

Maïs kan verschillende aaltjes vermeerderen die problemen kunnen veroorzaken in volggewassen. Of in de volggewassen schade ontstaat, hangt onder andere af van de mate waarin het aaltje aanwezig is. In tabel 9.1 staat aangegeven welke aaltjes in staat zijn om zich te vermeerderen op maïs en welke 
volggewassen schade kunnen ondervinden. Voor meer informatie over aaltjes verwijzen we naar de aaltjesdatabase van Wageningen Plant Research - Praktijkonderzoek AGV agv Digitaal (o.a. te bereiken via www.kennisakker.nl onder advies).

Tabel 9.1 Vermeerdering van aaltjes op maïs en mogelijk schade in volggewassen

\begin{tabular}{|c|c|c|c|}
\hline Aaltjessoort & $\begin{array}{l}\text { Mate van } \\
\text { vermeerdering op maïs }\end{array}$ & $\begin{array}{l}\text { Volggewassen waarin } \\
\text { grote schade kan } \\
\text { optreden }\end{array}$ & $\begin{array}{l}\text { Volggewassen waarin } \\
\text { enige schade kan } \\
\text { optreden }\end{array}$ \\
\hline $\begin{array}{l}\text { Vrijlevende wortelaaltjes } \\
\text { (Trichodorus spp en } \\
\text { Paratrichodorus spp) }\end{array}$ & matig & $\begin{array}{l}\text { suikerbieten, uien, } \\
\text { witlof, gladiolen }\end{array}$ & $\begin{array}{l}\text { aardappelen, koolzaad, } \\
\text { prei en diverse } \\
\text { koolsoorten }\end{array}$ \\
\hline $\begin{array}{l}\text { Maïswortelknobbelaaltje } \\
\text { (Meloïdogyne chitwoodi) }\end{array}$ & & $\begin{array}{l}\text { aardappelen, erwten, } \\
\text { waspeen, schorseneren }\end{array}$ & suikerbieten \\
\hline $\begin{array}{l}\text { Wortellesieaaltje } \\
\text { (Pratylenchus } \\
\text { penetrans) }\end{array}$ & sterk & $\begin{array}{l}\text { waspeen, uien, } \\
\text { schorseneren, lelie, } \\
\text { aardbeien, } \\
\text { boomkwekerijgewassen }\end{array}$ & $\begin{array}{l}\text { aardappelen, erwten, } \\
\text { stamslabonen, tulpen } \\
\text { dahlia's, gladiolen }\end{array}$ \\
\hline $\begin{array}{l}\text { Stengelaaltje } \\
\text { (Ditylenchus dipsaci) }\end{array}$ & matig & $\begin{array}{l}\text { uien, luzerne, erwten, } \\
\text { tulpen }\end{array}$ & $\begin{array}{l}\text { aardappelen, vlas, } \\
\text { suikerbieten, haver }\end{array}$ \\
\hline $\begin{array}{l}\text { Vrijlevende wortelaaltjes } \\
\text { van het geslacht } \\
\text { Tylenchorhynchus }\end{array}$ & sterk & - & - \\
\hline
\end{tabular}

\subsection{Schimmels}

Er zijn verschillende schimmels die schade kunnen veroorzaken in maïs. Tot nu toe bestrijdt men alleen de kiemschimmels met chemische middelen. Bij de schimmelziekten stengelrot, builenbrand, Helminthosporium spp en maiskopbrand kan men door rassenkeuze de schade beperken. Bij maiskopbrand kan men de aantasting ook verlagen door een extra zaaizaaidbehandeling.

\section{Kiemschimmels}

Verschillende bodemschimmels kunnen het ontkiemende plantje aantasten. Het betreft meestal Pythium-, maar soms ook Fusariumsoorten. De schimmels veroorzaken een bruinachtige verkleuring van de wortels. Het gevolg is een onregelmatige opkomst en een trage groei. De aantasting treedt vooral op bij lage temperaturen wanneer de kieming traag verloopt. Bestrijding vindt plaats door zaadontsmetting met 2 - 3 gram Thiram $50 \%$ per $\mathrm{kg}$ zaad. Ook het middel Maxim $\mathrm{XL}$ met de actieve stoffen fludioxonil en mefonaxam kan worden toegepast.

\section{Wortelverbruining}

Wortelverbruining is een verkleuring van het wortelstelsel, veroorzaakt door Pythium- en Fusariumschimmels. De eerste aantastingen worden rond half juni zichtbaar. Naarmate het groeiseizoen vordert, neemt de bruinverkleuring van het wortelstelsel toe. Naarmate de grond vochtiger is, neemt de aantasting sneller toe.

Bestrijding is in de eerste plaats mogelijk door vruchtwisseling. Het optreden van wortelverbruining hangt sterk samen met de frequentie waarin maïs in het bouwplan voorkomt. Bij nauwere rotaties is de aantasting ernstiger dan in ruimere rotaties. In vruchtwisselingsonderzoek werden opbrengstdervingen van $10-20 \%$ door continuteelt gevonden. Dit moeten we waarschijnlijk voor een 
deel toeschrijven aan wortelverbruining. De schade kan men verkleinen door ervoor te zorgen dat het gewas ongestoord kan groeien. Een goede bodemstructuur is hierbij van groot belang.

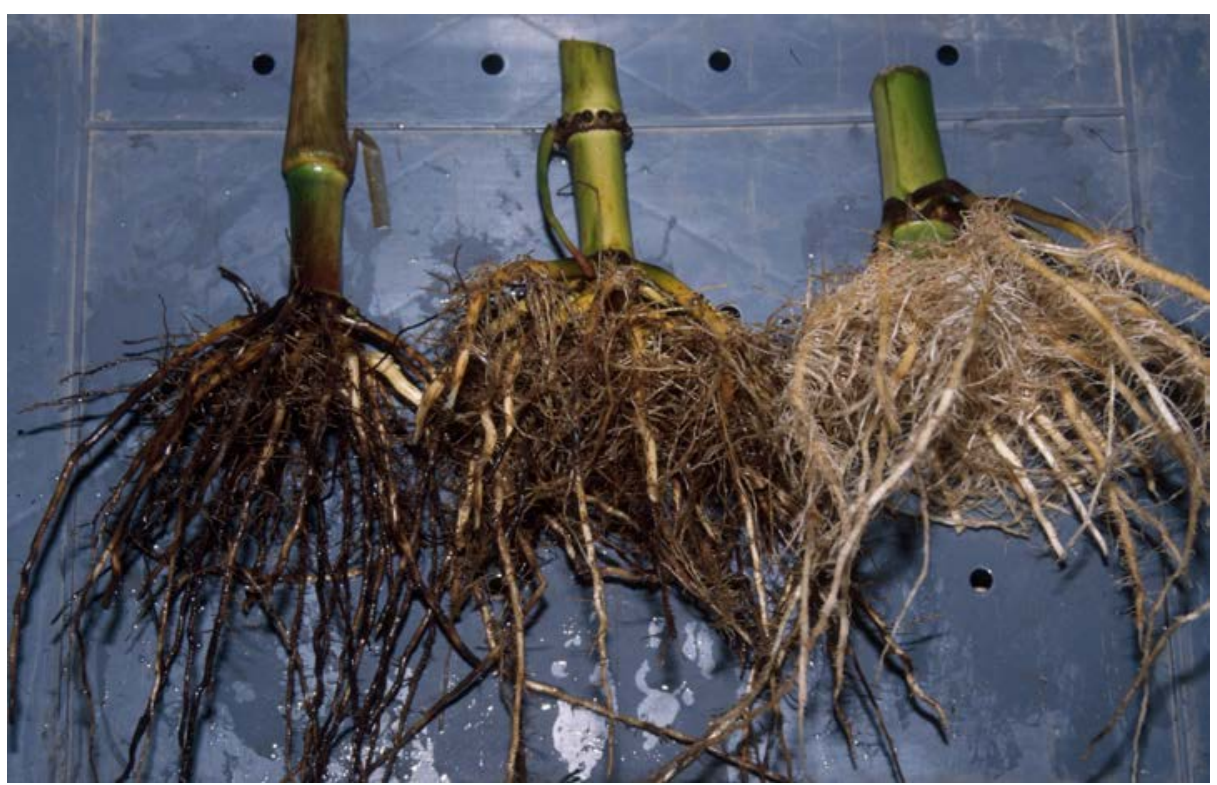

Wortelverbruining

\section{Builenbrand}

Builenbrand wordt veroorzaakt door de brandschimmel Ustilago maydis die bepaalde delen van de plant aantast. Aantasting vindt met name plaats in plantendelen waar sprake is van intensieve celdeling. Na infectie ontstaan grijsachtige gallen, de builen, die zijn omgeven door een vlies. Na verloop van tijd barsten de builen open en komen een groot aantal bruin-zwarte sporen vrij. De sporen kunnen wel 4 jaar in de grond overblijven en hun kiemkracht bewaren.

Builenbrand komt met name voor in droge, warme jaren op percelen waar maïs sterk van droogte te lijden heeft gehad. De ziekte is niet chemisch te bestrijden. Vruchtwisseling heeft weinig zin omdat de sporen zich ook door de lucht kunnen verplaatsen. Tussen rassen bestaan wel verschillen in resistentie tegen builenbrand (zie hoofdstuk 6). Ook het beperken van groei stagnaties verkleint de kans op aantasting; denk hierbij aan een goede bodemstructuur en beregenen in droge perioden. Aantasting heeft zowel gevolgen voor de opbrengst als voor de kwaliteit van de maïs (zie tabel 9.2). Uitgaande van een gemiddeld gewas dient men per 10\% zwaar aangetaste planten (de kolf vrijwel volledig aangetast) rekening te houden met de volgende verliezen:

- $\quad 4 \%$ aan drogestofopbrengst

- $\quad$ circa 14 VEM per kg droge stof

- $\quad$ 5,2\% aan VEM-opbrengst

De drogestofopbrengst van de kolven daalt sterker dan van het gehele gewas, zodat builenbrandpercelen beter niet voor korrelmaïs of ccm bestemd kunnen worden. Per $10 \%$ aangetaste kolven moet men rekening houden met een daling van de kolfopbrengst van ruim $8 \%$. De aantasting kan het beste worden vastgesteld door op meerdere, willekeurig gekozen plaatsen 100 opeenvolgende planten in een rij te beoordelen. Voor de gevolgen van builenbrand voor conservering en vervoedering wordt verwezen naar de hoofdstuk 11. 
Tabel 9.2 Invloed van builenbrand op opbrengst en kwaliteit van aangetaste maïsplanten

\begin{tabular}{lll}
\hline Grootheid & Gezond & Aangetast $^{1}$ \\
\hline Drooggewicht/plant (relatief) & 100 & 68 \\
Kolfaandeel (\%) & 39 & 3 \\
Drogestofgehalte (\%) & 32,7 & 24,6 \\
Voederwaarde (VEM per kg drogestof) & 937 & 720 \\
\hline
\end{tabular}

Bron: Van Dijk et al., 1993

${ }^{1}$ Zwaar aangetaste kolven
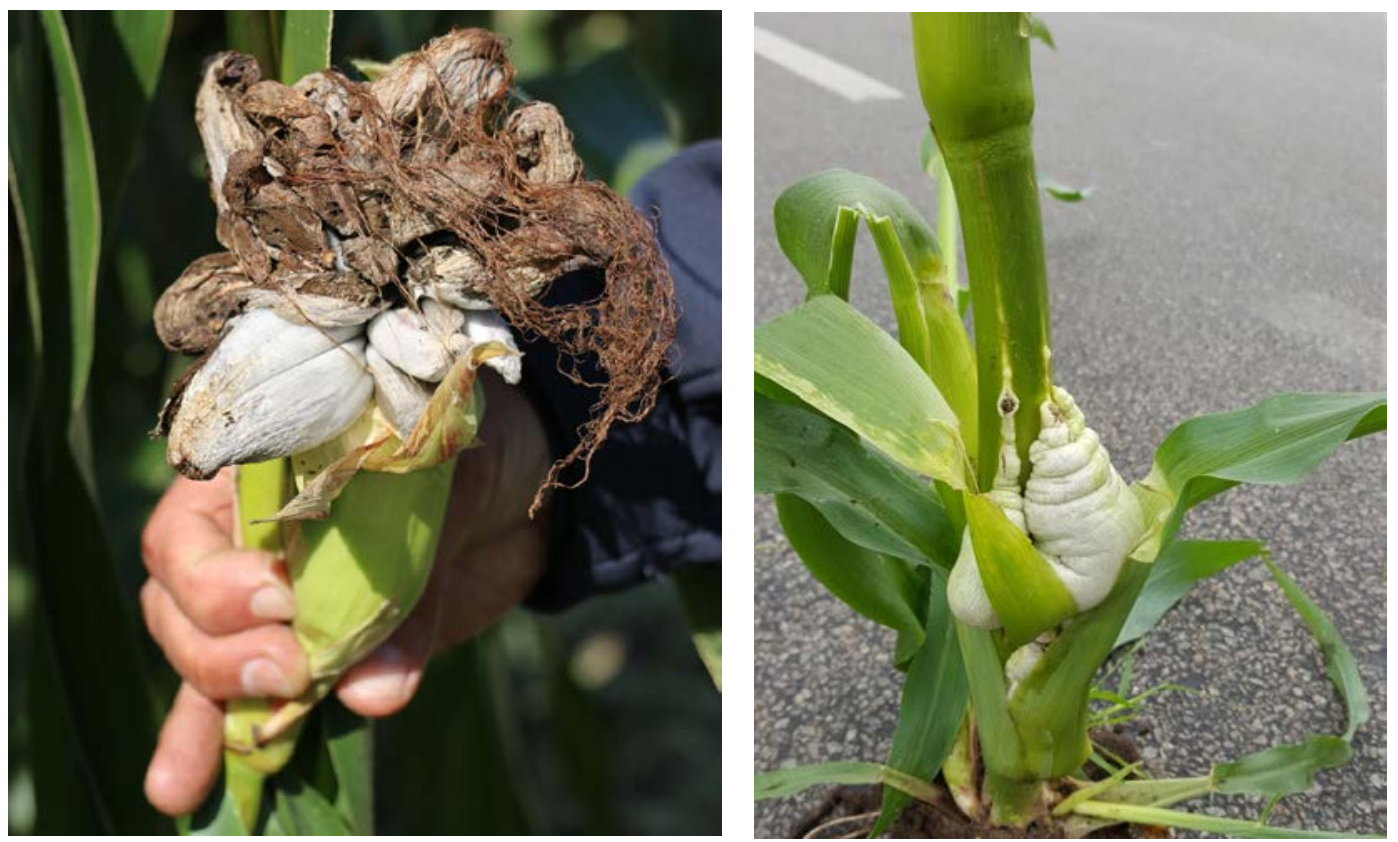

Builenbrand

\section{Stengelrot}

Stengelrot is in Nederland de meest voorkomende schimmelziekte bij maïs. De ziekte wordt veroorzaakt door Fusariumschimmels. Bij een ernstige aantasting verrot het merg van de stengelvoet. De stengels sterven hierdoor vroegtijdig af en knikken vaak vlak boven de grond om. De plant wordt aangetast vanuit de grond via de wortels of de onderste stengelknopen.

Een zware aantasting door stengelrot kan de oogst van de maïs sterk bemoeilijken. Ook kunnen aanzienlijke oogstverliezen optreden. Een door stengelrot aangetast gewas heeft in het algemeen ook een wat lagere voederwaarde. Gewassen die te lijden hebben gehad van droogte worden sneller aangetast. Aantasting door Fusarium kan tot gevolg hebben dat er mycotoxinen onstaan. Zie voor meer informatie over effecten van mycotoxinen bij voeren aan rundvee, paragraaf 11.8.

Stengelrot kan men niet chemisch bestrijden. De aantasting kan men voorkomen door te zorgen voor optimale groeiomstandigheden voor het gewas en door rassen te kiezen die minder vatbaar zijn voor stengelrot. Met name bij MKS, CCM en korrelmaïs is deze raseigenschap van belang omdat deze gewassen langer op het land moeten staan dan snijmaïs. Bij korrelmais wordt ook wat minder dicht gezaaid waardoor de ziektedruk iets kan worden verlaagd. Wanneer de ziekte massaal optreedt, kan men het beste zo snel mogelijk oogsten. 
In gewasrotaties met graan en mais is er mogelijk verhoogde kans op aantasting door Fusariumschimmels. Bij beide gewassen is er vervolgens een hogere kans op mycotoxinen ( $\mathrm{mn}$ DON en ZEA), Gewasresten onderploegen zou enig remmend effect kunnen hebben op de ontwikkeling van Fusarium.

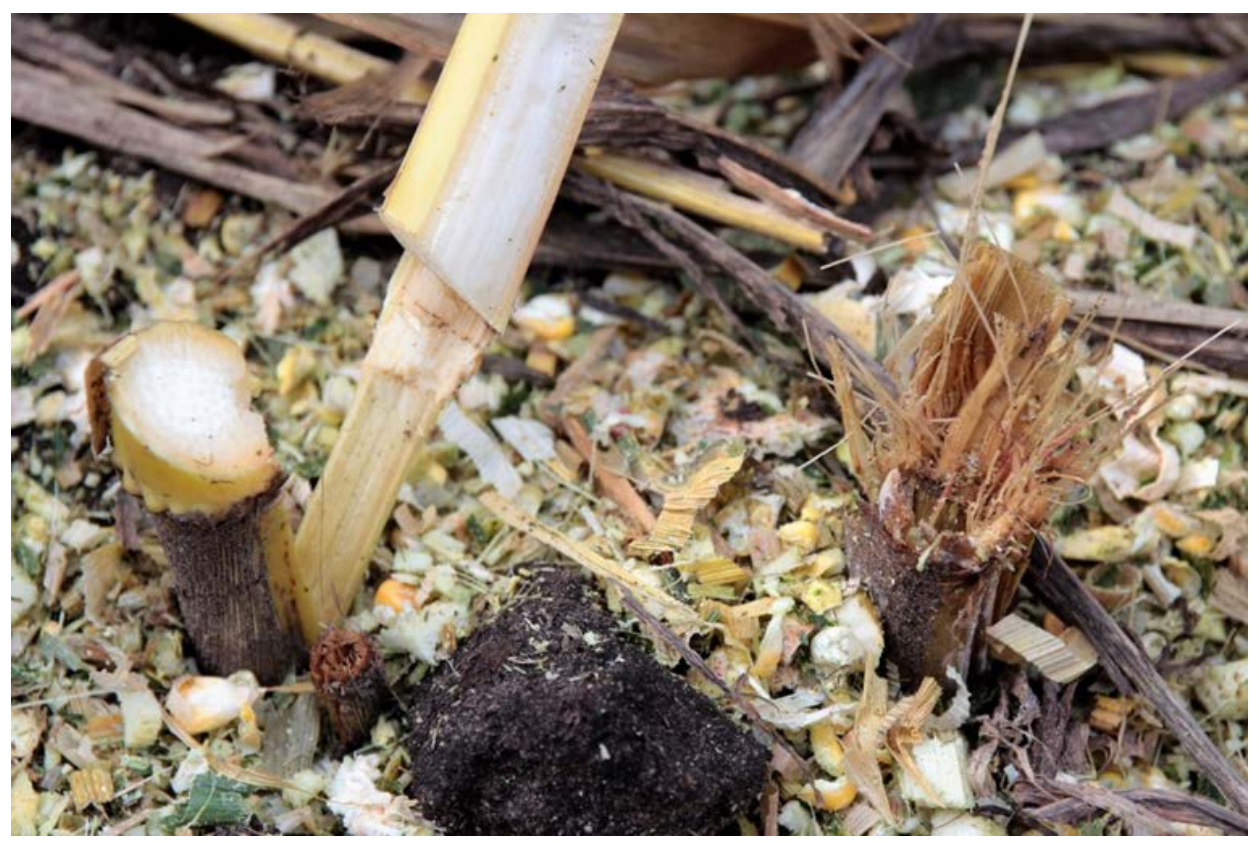

Rechts stengelrot, links gezonde plant

\section{Maïskopbrand}

Maïskopbrand of Head smut wordt veroorzaakt door de schimmel Sphacelotheca reiliana. De ziekte komt in Europa vrij algemeen voor. In Nederland is deze ziekte in 2012 voor het eerst officieel vastgesteld. Achteraf blijken een aantal telers de maïskopbrand ook in 2011 al gesignaleerd te hebben, maar hebben dit toen aangezien voor builenbrand. De besmette gebieden met maïskopbrand zijn de polders in Noord-Holland, gebieden ten zuid-westen van Utrecht, langs de Maas van Oss tot omgeving Boxmeer en langs de IJssel bij Doesburg. Over het algemeen de nattere gronden, waar mais in het voorjaar makkelijker groeivertraging op loopt. Eénmaal is er een aantasting waargenomen op een hoge esgrond in de buurt van Groenlo. Maiskopbrand is in besmette gebieden een jaarlijks terugkomend probleem.

De schimmel zelf komt sterk overeen met de schimmel, Ustilago maydis, dat de builenbrand veroorzaakt. De ziekteverschijnselen zijn echter anders. Beide schimmels blijven in de grond over. Head smut tast de maïs al in het kiemplantstadium aan via de wortel, dit maakt de mogelijke schade veel groter dan bij builenbrand. Pleksgewijs kan tot 100\% aantasting optreden. In 2012 lag het aantastingspercentage op perceelsniveau meestal tussen 10 en 30\%. De kans op een zware aantasting is groter als de beginontwikkeling van de maïs tot het 4 á 5 bladstadium slecht is a.g.v. stress (koude, verzadigde gronden, nachtvorsten, etc.). In 2013 is er opnieuw maiskopbrand opgetreden. Aantastingspercentages lagen dit jaar op maximaal 10\%. Mogelijk dat het droge voorjaar remmend heeft gewerkt op de aantasting door de schimmel. In 2014 was de maximale aantasting rasafhankelijk. Meest gevoelige ras had een aantasting van 30\%. Het minstgevoelige ras zat op het zelfde perceel op $0.5 \%$. 
Via de vaatbundels worden de bloeiwijzen, pluim en kolf, van binnen uit aangetast. Tot de bloei is aan de plant nauwelijks iets te zien, alleen de ontwikkeling blijt wat achter. Op moment van bloei ontstaat er in de pluim zwart schimmelpluis (zie foto) en verminderde stuifmeelproductie. In het schutblad op de plaats van de kolf ontstaat een grote harige schimmelbol, soms met groene uitlopers (foto2), die de gehele kolf vervangen heeft. Bij een aantasting boven de $10 \%$ kan het zetmeelgehalte en daarmee de voederwaarde erg tegenvallen doordat de kolf afwezig is. Ook de drogestofopbrengst is lager omdat deze gemiddeld voor $50 \%$ uit de kolf bestaat. Bij aantasting van $50 \%$ van de planten is het zetmeelgehalte gehalveerd en de opbrengst mogelijk $25 \%$ lager.

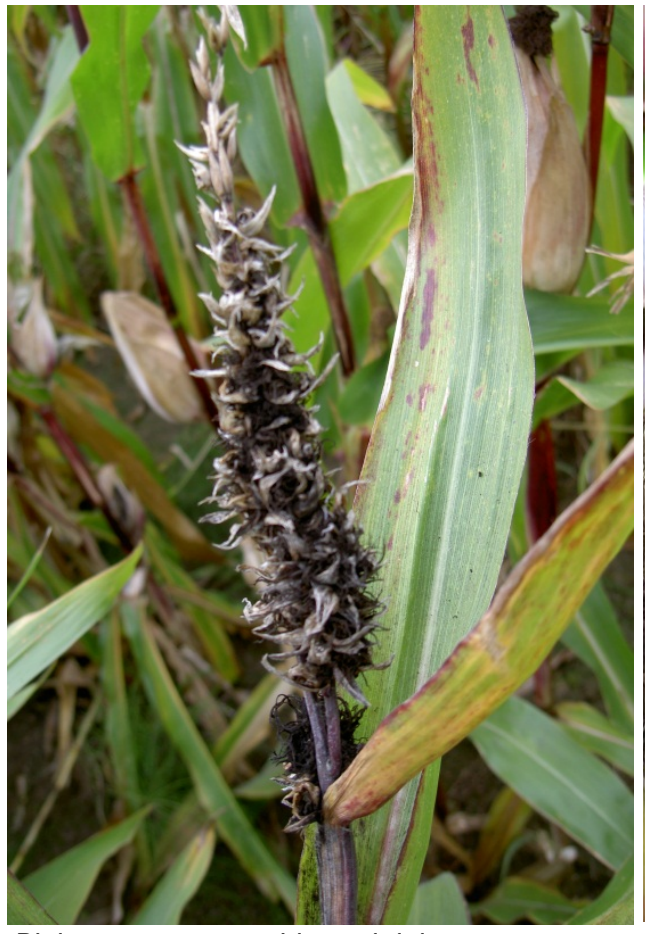

Pluim met zwart schimmelpluis

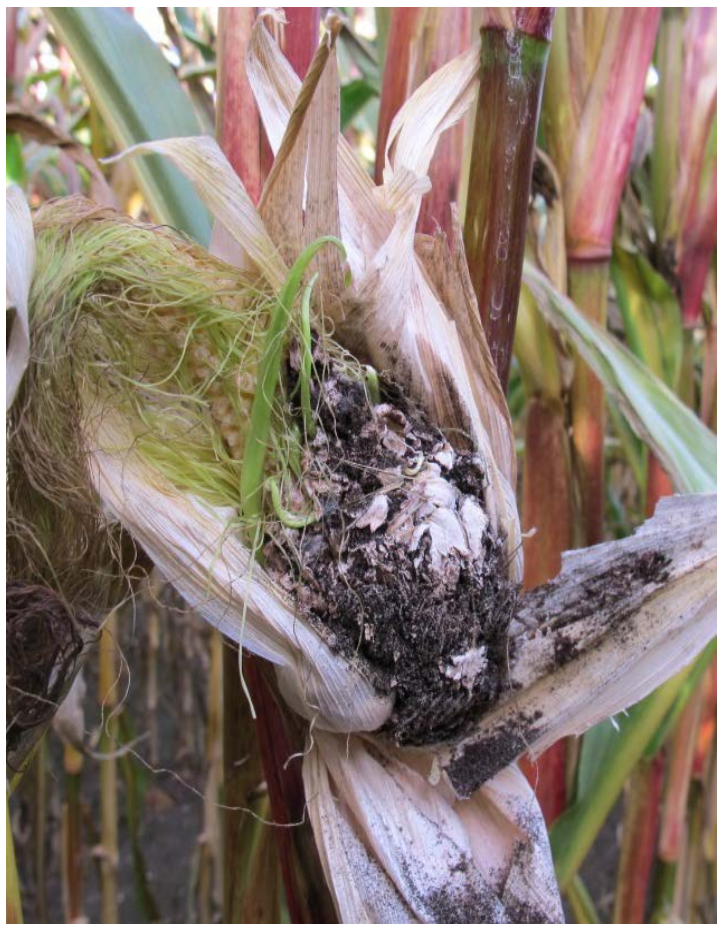

Harige schimmelbol op plaats van de kolf

Later in het seizoen gaan de schimmelbollen sporenvormen. De bollen gaan open en de sporen vallen op de grond of worden door de wind naar buurtpercelen verspreid. Bij zware aantasting zullen de sporen bij het hakselen een zwarte stofwolk om de hakselaar vormen. Ook dan vindt via de wind en de machines weer verspreiding plaats.

In de kuil veroorzaakt een zware aantasting een vieze zwarte laag, die lijkt op natte zwarte grond. Er is nog weinig bekend over eventuele giftigheid. Mogelijk valt het mee, omdat de schimmel sterk gerelateerd is aan builenbrand, die ook geen directe giftigheid heeft en waarschijnlijk ook geen mycotoxinen vormt. Wel wordt geadviseerd om maïs, waarbij meer dan $30 \%$ builenbrand voorkomt, niet vers te voeren. In extreme gevallen kan head smut veel meer dan $10 \%$ voorkomen, zelfs tot $100 \%$. Het lijkt dus ook verstandig deze maïs niet vers te voeren. Zwaar aangetaste maïs is veel minder smakelijk, blijkt uit ervaringen in de praktijk in 2012. 
Wordt er maïskopbrand geconstateerd dan is het volgende wellicht verstandig:

- Bij lichte aantasting, tot $5 \%$, gewoon inkuilen en voeren.

- Bij aantasting van 10-30\% apart inkuilen en later op basis van voederwaarde en mycotoxinen analyse beoordelen of maïs te voeren is.

- Bij zware aantasting 50-100\% maïs over het veld verspreiden.

- Machines na de oogst met lucht schoon blazen om extra verspreiding door machines te voorkomen.

Adviezen voor de volgteelt met maïs zijn:

- Gebruik resistente rassen. Rassen die op besmette percelen goed te telen zijn: P8057, Smoothi CS, Genialis KWS, SY Skandik, SY Madras, Megusto KWS, SY Telias, MAS12H, ES Crossman en PR39F58. Al deze rassen hebben minder dan 1\% aantasting. Bij Wageningen Plant Research - Praktijkonderzoek AGV (jos.groten@wur.nl) is meer info te verkrijgen.

- Gebruik zaaizaad dat met Alios (triticonazool) of Feuver (prothioconazool) is behandeld. Behandeling is in Nederland niet toegelaten, maar het is mogelijk om in het buitenland behandeld zaaizaad in Nederland te gebruiken.

- Voorkom groeivertraging door goede bodemkwaliteit, goede ontwatering, goede structuur en voldoende beschikbaar stikstof. Eventueel latere zaai (warmere bodem).

- Pas vruchtwisseling toe met gras of akkerbouwgewassen voor een periode van minimaal 3 á 4 jaar omdat sporen circa 4 jaar in de bodem overblijven en hun kiemkracht bewaren. Dit werkt alleen als er in de directe omgeving van het perceel geen mais wordt geteeld omdat sporen met de wind zich gemakkelijk kunnen verspreiden naar buurtpercelen. Dit blijkt ook uit het feit, dat in 2017 op percelen met eerstejaars mais na gescheurd grasland veel aangetaste planten voorkwamen.

Wageningen Plant Research - Praktijkonderzoek AGV heeft in 2013 een onderzoek naar de beheersmaatregelen voor maiskopbrand uitgevoerd. Hieruit kwam naar voren dat er significante verschillen zijn tussen rassen. Sommige rassen zijn goed te telen. Een zaaizaadbehandeling met een fungicide verlaagde de aantasting significant. Door het gebruik van Alios werd de aantasting gehalveerd. Maar bij zeer gevoelige rassen is deze reductie onvoldoende voor de praktijk. Alle andere maatregelen, zoals een latere zaai, zaaizaad behandeld met l-seed, geen bemesting, bodembehandeling met gips lieten in 2013 geen significante verschillen zien. Opgemerkt moet worden dat het om slechts eenjarig onderzoek gaat.

\section{Kolfsteelrot}

Evenals de stengel kan ook de kolfsteel aangetast worden door Fusariumschimmels. De kolven hangen hierdoor naar beneden en kunnen na verloop van tijd op de grond vallen. Bij een ernstige aantasting kunnen aanzienlijke verliezen optreden. De ziekte treedt op tijdens de afrijping. Wanneer kolfsteelrot in ernstige mate optreedt, moet men het gewas zo snel mogelijk oogsten. Er zijn rasverschillen in gevoeligheid voor kolfsteelrot, maar de aantasting komt te weinig voor om deze verschillen goed vast te leggen in de rassenlijst. De verschillen komen niet overeen met de rasverschillen in gevoeligheid voor stengelrot.

\section{Bladvlekkenziekten}

Bladvlekkenziekte bij maïs in Nederland wordt met name veroorzaakt door de schimmel Helminthosporium en Kabatiella zeae (eyespot). 


\section{Helminthosporium}

Hiervan zijn bij maïs drie soorten bekend:

1. Helminthosporium turcicum (Exserohilum turcicum of Setosphaeria turcica)

2. Helminthosporium carbonum (Bipolaris zeicola of Cochliobolus carbonum)

3. Helminthosporium maydis (Bipolaris maydis of Cochliobolus heterostrophus)

In Nederland was in 2007 de eerste aantasting van betekenis, het ging hierbij om $\mathrm{H}$. turcicum en $\mathrm{H}$. carbonum. De H. maydis is niet waargenomen.

De eerste besmetting vindt plaats vanuit gewasresten in de grond. Door opspattend sporen worden de planten geïfecteerd. De eerste aantasting (primair) vindt dus op de onderste bladeren plaats. Vervolgens kan de ziekte zich naar boven in het gewas ontwikkelen en via de schimmelsporen kan het zich over grote afstand verder verspreiden door de wind en andere percelen besmetten. Dit is de tweede (secundaire) aantasting. Hierbij worden vaak eerst de bovenste bladeren aangetast. De schimmel ontwikkelt zich het snelst onder vochtige (dauw) omstandigheden en temperaturen tussen $20-25^{\circ} \mathrm{C}$ waarbij de optimum temperatuur bij carbonum en maydis iets hoger is dan bij turcicum.

Bij een aantasting ontstaan er in het begin kleine grijsgroene vlekjes. Bij de Helminthosporium turcicum groeien die uit tot grote langwerpige grijs-bruine vlekken tot wel $15 \mathrm{~cm}$ lang (zie foto). Bij Helminthosporium carbonum (zie foto) en maydis ontstaan er uiteindelijk veel vlekjes van slechts 2 $-3 \mathrm{~cm}$ lang. Uiteindelijk vloeien de vlekken samen en kunnen grote delen van het blad afsterven. Opbrengstderving door bladvlekkenziekte is afhankelijk van het moment en de zwaarte van de aantasting. Bij een zware aantasting vóór de bloei kan de korrelopbrengst volgens de literatuur tot $50 \%$ lager uitvallen. Een lagere korrelopbrengst geeft een lager zetmeelgehalte en daarmee naast een lagere opbrengst ook een lagere voederwaarde. Vanuit bevindingen in 2007 en 2008 wordt de schade bij een zware vroege primaire aantasting (vanaf begin juli) ingeschat op 5 tot $10 \%$ in VEMopbrengst bij snijmaiis en op 5 tot $10 \%$ in korrelopbrengst bij korrelmaïs. In individuele gevallen kan dit echter hoger zijn. Het effect op de voederwaarde is geringer dan op de opbrengst. Bij een late aantasting (rond eind augustus), ook al is deze zwaar is de schade zeer gering. De inschatting is 1 à $3 \%$ in VEM-opbrengst.

Uit onderzoek in 2008 aan 12 kuilen met snijmaïs die in 2007 was aangetast door Helminthosporium bleek dat de voederwaarde nauwelijks lager was dan normaal. Het ds-gehalte varieerde van 28 tot $38 \%$ en de VEM-waarde van 930 tot 987 . Het zetmeelgehalte was gemiddeld $5 \%$ lager dan normaal terwijl de celwandverteerbaarheid praktisch gelijk was. De conservering was in de meeste kuilen normaal verlopen. Eén kuil met zwaar aangetaste maïs had een lager dan normaal melkzuurgehalte en een hoger azijnzuurgehalte. In de kuilen kwam niet meer broei voor dan normaal.

Sterk aangetaste maïs ziet er dood en verdord uit. Men is dan al gauw geneigd om het snel te oogsten, dit is lang niet altijd verstandig. Het ds-gehalte van de maïs valt dan vaak tegen omdat de stengel en de kolf nog vrij vochtig zijn. Tevens produceert maïs nog steeds bij, zelfs als er rond half september nog maar 3 bladeren groen zijn. Hoewel de opname van de in 2008 onderzochte kuilen als goed werd beoordeeld kan sterk aangetaste maïs mogelijk minder smakelijk zijn voor het vee. De schimmel is zover bekend niet giftig voor het vee.

Er bestaan rasverschillen in gevoeligheid voor de schimmel Helminthosporium (Zie hoofdstuk 6 Rassenkeuze). Door het telen van tolerante rassen kan de schade behoorlijk worden beperkt. Via teeltmaatregelen kan ook geprobeerd worden om de schade door de schimmel te beperken. De primaire aantasting veroorzaakt de meeste schade en is ook verantwoordelijk voor de secundaire aantasting. Het is daarom belangrijk de primaire aantasting, die veroorzaakt wordt door het opspatten van sporen met grond en water, te voorkomen. De schimmel overleefd op gewasresten in de grond. De schimmeldruk wordt verlaagd door de vertering van gewasresten te bevorderen. Hiervoor moet de stoppel in de herfst bewerkt worden met een niet kerende 
grondbewerking, zodat de vertering van gewasresten door het bodemleven bevorderd en er minder gewasresten in de grond overblijven. Het advies is vervolgens om in het voorjaar de overgebleven gewasresten goed onder te werken door een kerende grondbewerking, zodat de kans op opspattende sporen wordt verkleind. Ploegen lijkt de voorkeur te hebben boven spitten. In het buitenland bestaan er fungiciden tegen de bladvlekkenziekte in maïs. In Nederland is sinds januari 2013 Retengo Plust toegelaten op basis van de werkzame stoffen pyraclostrobine en epoxyconazool. In de loop van 2014 is ook Quilt Xcel beschikbaar gekomen, een product op basis van azoxystrobin en propiconazole. De middelen moeten worden gespoten vanaf moment dat de pluim nog net niet zichtbaar is. Retengo Plust en Quilt Xcel bieden een goede bescherming tegen de belangrijkste bladschimmels als Helminthosporium soorten, Eyespot, en roest. De teler heeft met dit middel de mogelijkheid om eventuele schade te voorkomen. Retengo Plust en Quilt Xcel dienen preventief toegepast te worden, dus voordat een maïsgewas ziek is. Is er echter een ras gekozen met een zeer goede tolerantie, dan is een preventieve bespuiting veelal niet nodig. De tolerantie geeft het gewas voldoende bescherming.

In de praktijk betekent dit dat voor het in pluim komen van de mais (rond het verschijnen van het vlagblad) beoordeeld moet worden of een preventieve bespuiting noodzakelijk is. Heeft men een minder tolerant ras gezaaid en zijn er reeds enkele vlekken te zien of heeft men de laatste jaren een zware aantasting op het perceel gezien, dan is een preventieve bespuiting aan te raden.
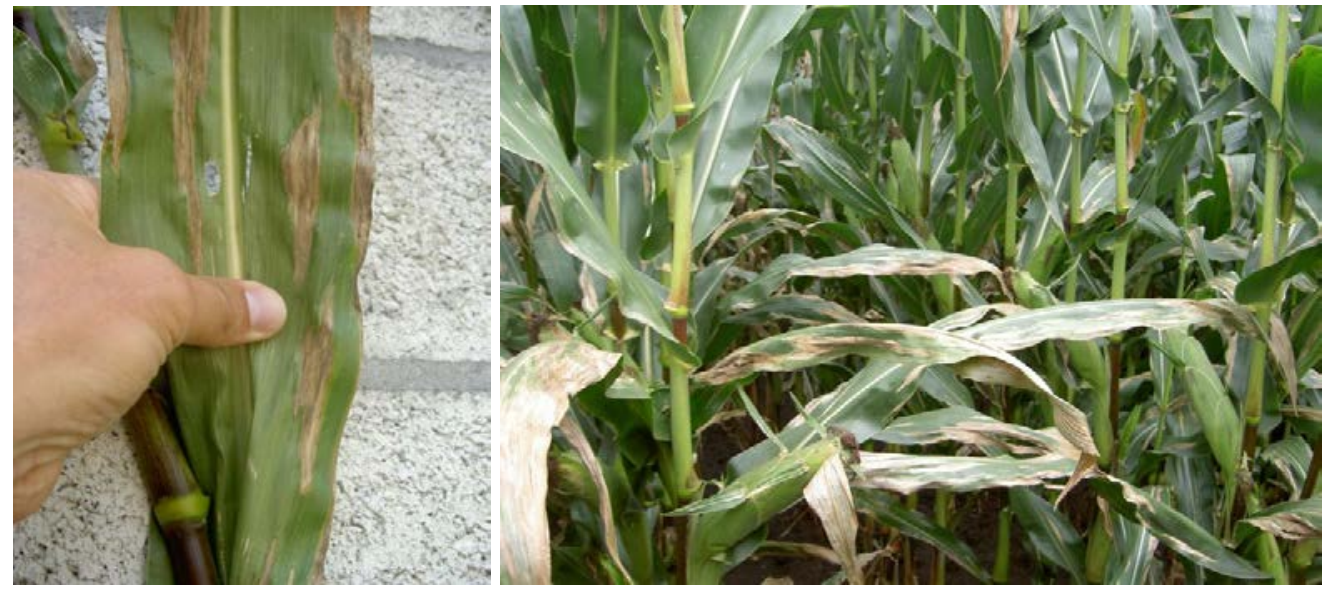

Aantasting door Helminthosporium turcicum 

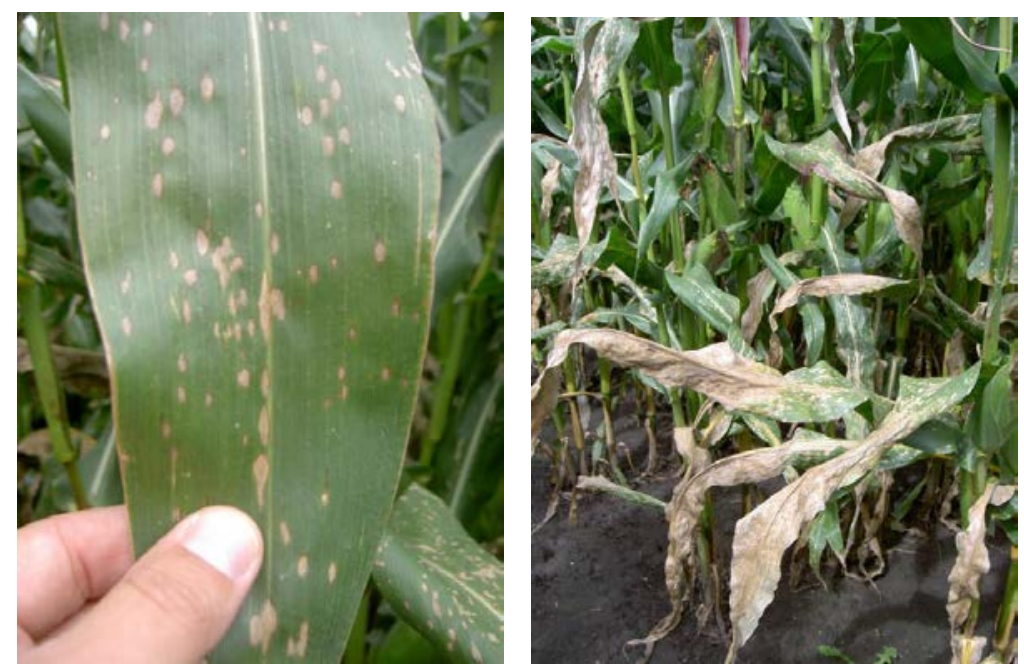

Aantasting door Helminthosporium carbonum

\section{Eyespot}

Eyespot is een bladvlekkenziekte die veroorzaakt wordt door de schimmel Kabatiella zeae, welke met name in koelere vochtige omstandigheden tot ontwikkeling komt. Vanaf 2000 zijn er zwaardere aantastingen in Engeland bekend. In Nederland is het vanaf 2004 tot nu alleen in Noord-Nederland waargenomen. Met name in 2011 en 2012 was de aantasting zwaar. De schade die de ziekte veroorzaakt is tot nu toe zeer gering, omdat deze zich in Nederland zeer laat (2-3 weken voor de oogst) heeft gemanifesteerd.

De schimmel veroorzaakt talrijke zeer kleine oogachtige vlekjes (1-4 mm) op het blad (zie foto). De vlekjes hebben een paarsbruin centrum en worden omgeven door een lichtgele rand. In het centrum van de vlek sterft het blad vervolgens af, waardoor deze lichter kleurt. Hierdoor ontstaat er lichte vlekjes met een paarsbruine rand en daarom heen weer een lichte rand. Hierdoor lijken de vlekjes oogjes. Bestrijding is goed mogelijk door middel van een preventieve bladbespuiting met Retengo Plust of Quilt Xcel. Daarnaast bieden mogelijk de toekomstige rassen een oplossing. Er zijn verschillen waargenomen tussen rassen en bij beschikbaarheid van voldoende cijfers zal de rassenlijst hiervoor worden aangepast.

Beoordeel op het moment van spuiten op basis van de situatie op het veld (weersomstandigheden en aanwezigheid schimmel) en de mate van aantasting in voorgaande jaren of een preventieve bespuiting gewenst is.

Deze schimmel blijt ook over op gewasresten in de grond. Dus ook hier zijn dezelfde geadviseerde teeltmaatregelen van kracht als ter voorkoming van Helminthosporium. 

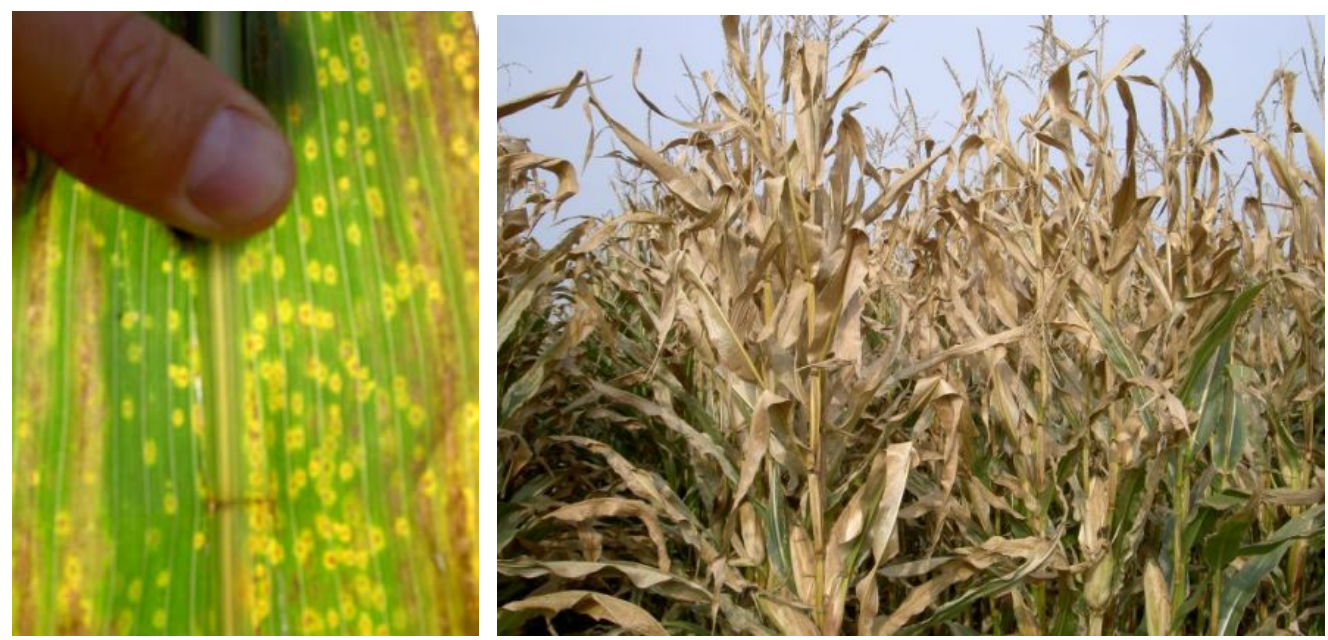

\section{Rhizoctonia}

Aantasting door Eyespot

Schade door Rhizoctonia is incidenteel in maïs waargenomen. Aangetaste planten hebben een minder goed ontwikkeld wortelstelsel en vertonen vaak legering. Op de stengel zijn soms vlekken zichtbaar die vergelijkbaar zijn met die van oogvlekkenziekte in granen. Rhizoctonia wordt door maïs in stand gehouden en kan zich ook vermeerderen. Vooral in suikerbieten, waspeen en schorseneren die men in rotatie met maïs teelt, is Rhizoctonia een belangrijke ziekte. Rhizoctonia is in deze gewassen op de lichtere gronden een toenemend probleem. In 2013 is er op wat grotere schaal aantasting door Rhizoctonia gezien, met name veroorzaakt door zeer koude voorjaar. De maiswortels ontwikkelden zich langzamer dan normaal, waardoor bodemschimmels, naast Rhizoctonia natuurlijk ook Pythium en Fusarium, kans zagen de wortels volledig weg te vreten. Dit veroorzaakt de typische valplekjes in een maïs perceel.

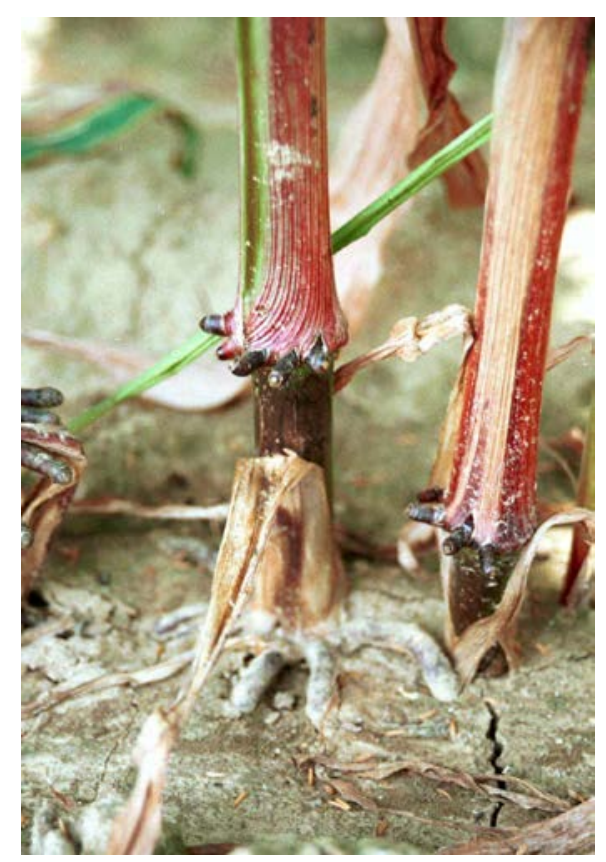

Rhizoctonia 


\section{Roest}

Soms treft men in sommige rassen een aantasting door roest aan, met name aan de bovenkant van het blad ontstaan verspreid voorkomende kleine, ronde, roestbruine sporenhoopjes. Vaak treedt de aantasting pas laat in het seizoen op. Schade door roest treedt in maïs dan ook nauwelijks op. Er zijn rasverschillen in gevoeligheid voor roest, maar de aantasting komt te weinig voor om een verantwoorde waardering in de rassenlijst te geven.

\section{Heksenbezem}

Dit verschijnsel wordt veroorzaakt door de schimmel Sclerophthora macrospora en is in 2012 op enkele percelen op de Veluwe geconstateerd. De schimmel kan de maïs aantasten als de maïs in het kiemplantstadium tot ongeveer 4-bladstadium kortstondig onderwater staat. Bij ruim wateraanbod zijn de sporen van de schimmel in staat de plant via de wortel binnen te dringen. De schimmel leidt tot een verkeerde ontwikkeling van de kolf. In plaats van korrels ontstaan er kleine blaadjes. De ziekte komt slecht sporadisch tot uiting op tijdelijk overstroomde en lage percelen. Het aantastingspercentage is vaak laag en daardoor valt de schade mee.

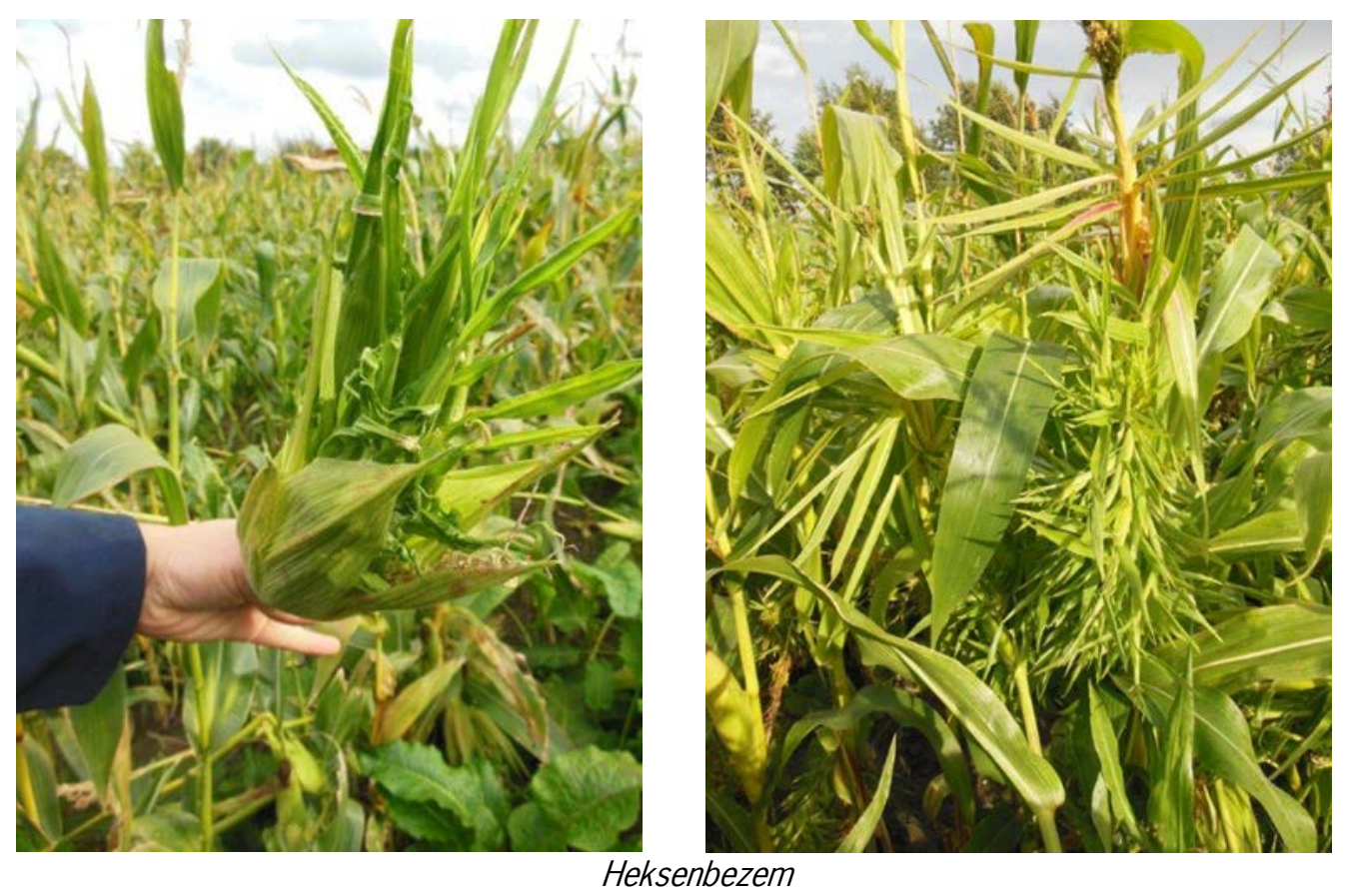




\subsection{Insecten}

Een aantal insecten, waarvan de fritvlieg en ritnaalden de belangrijkste zijn, veroorzaken schade in maïs. Door de algemeen toegepaste zaaizaadbehandelingen wordt de meeste schade voorkomen. In andere Europese landen komen insecten voor die mogelijk in de toekomst ook in Nederland een rol kunnen spelen.

\section{Fritvlieg}

De fritvlieg (Oscinella frit) overwintert op granen en grassen. De omvang van de aantasting hangt nauwelijks samen met de voorvrucht. De larve van de fritvlieg kan ernstige schade toebrengen aan maïsplanten. De fritvlieg legt haar eitjes doorgaans vóór het 3-4 bladstadium op de maïsplanten. De kleine doorschijnende larven beschadigen het groeipunt waardoor de hoofdstengel niet of zeer moeizaam uitgroeit. Aangetaste planten stoelen daardoor meer uit. De bladeren vertonen misvormingen en gaten en zijn gerafeld. Karakteristiek voor de aantasting is dat de bladpunten van de jongste bladeren blijven steken in de gaten van de oudste bladeren.

Wanneer het zaaizaad is ontsmet met methiocarb (Mesurol FS) geeft dit meestal een afdoende bescherming tegen de fritvlieg. Wanneer in de toekomst zaaizaadbehandelingen met Mesurol FS niet meer mogelijk zijn, kan fritvliegschade door de fritvlieg bestreden worden door het zaad te ontsmetten met thiacloprid (Sonido).

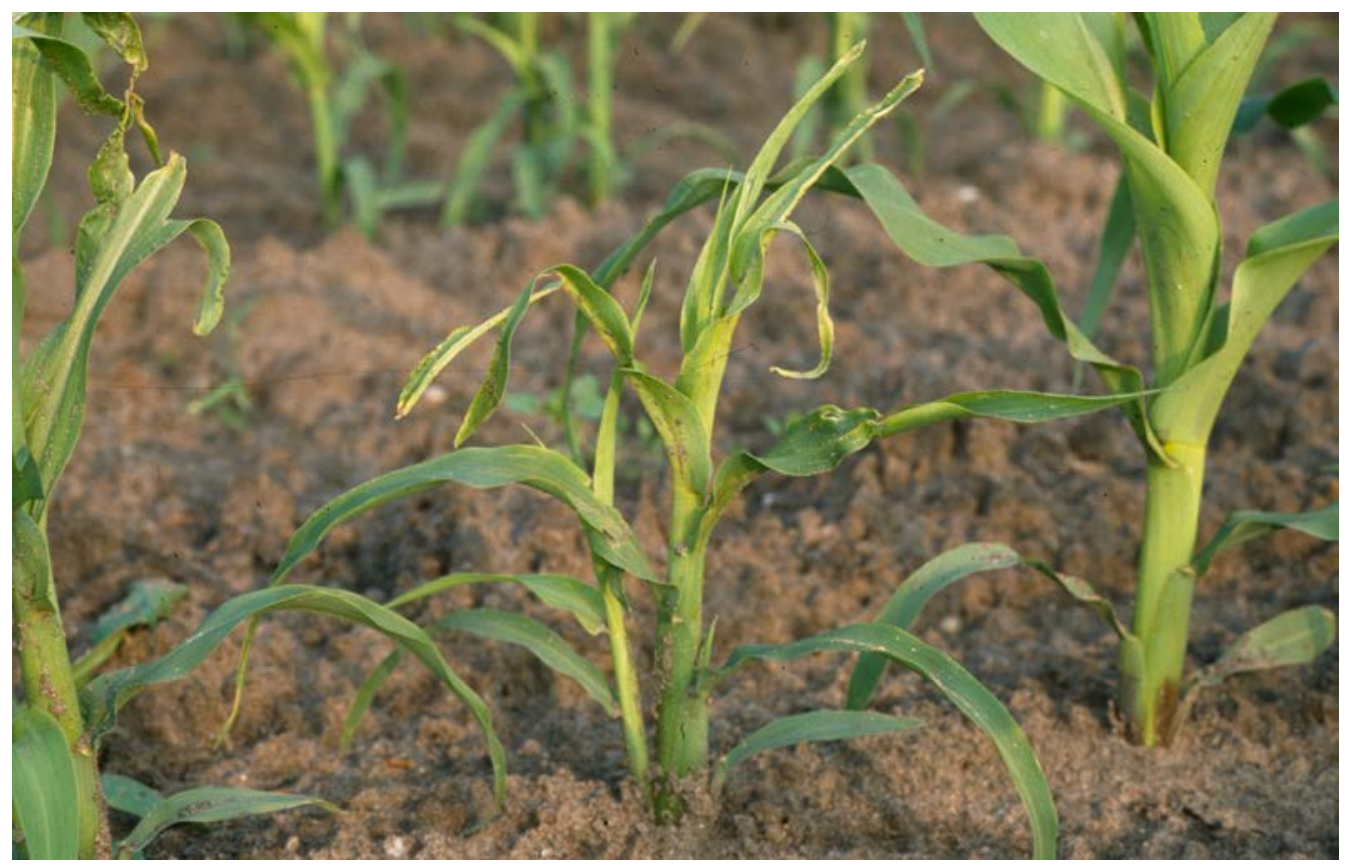

Fritvliegschade

\section{Ritnaalden}

Ritnaalden (Agriotes spp.) zijn de larven van de kniptor. De larven zijn donkergeel, hard en tot circa $2 \mathrm{~cm}$ lang. De larven boren zich in de stengelvoet en de wortels. Vooral bij jonge planten kan de schade zo groot zijn dat de plant in groei achterblijft of zelfs afsterft. Schade door ritnaalden treedt 
voornamelijk op in de eerste drie teeltjaren na het scheuren van grasland en dan met name in het tweede jaar. Doordat de opbouw van de ritnaalden populatie vrij langzaam verloopt, treedt bij het scheuren van kunstweides naar verwachting geen schade op. In dat geval kan bestrijding achterwege worden gelaten.

Ritnaaldenschade kan men voorkomen door zaaizaad te gebruiken dat met thiacloprid (Sonido) is behandeld. De werking van dit middel is wel iets minder dan van de tot nu toe gebruikte middelen op basis van neonicotinoiden. Het is mogelijk om een test uit te voeren op de aanwezigheid van ritnaalden. Doorgesneden aardappelknollen kunnen begin april op 10 a $20 \mathrm{~cm}$ diepte in de grond gelegd worden. Na 10 tot 14 dagen kan men beoordelen of er ritnaalden in het perceel zitten.

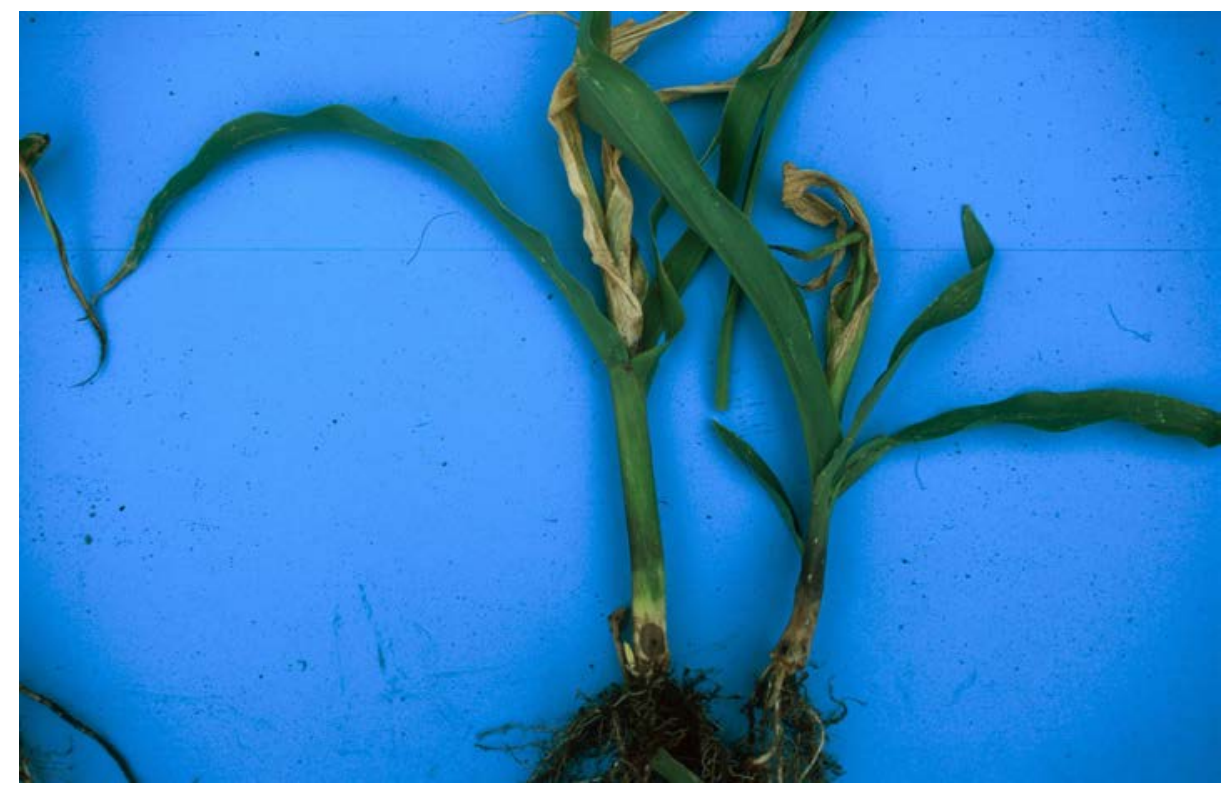

Schade door ritnaalden

\section{Maïsstengelboorder}

De maïsstengelboorder is de rups van de vlinder Ostrinia nubilalis. De rups boort zich in de stengel en de kolfstelen waardoor het transport van assimilaten en voedingsstoffen wordt onderbroken. Hierdoor neemt de productie van het gewas af. Daarnaast treedt legering en kolfverlies op. Het insect breidt zich langzaam vanuit zuidelijke landen naar het noorden van Europa uit. Gezien de eigenschappen van het insect en de ervaringen met dit insect in de ons omringende landen kan dit insect zich ontwikkelen tot een belangrijke plaag van economische betekenis.

Het is in een aantal belangrijke maisteeltgebieden in de wereld een van de belangrijkste economische plagen. Echter, de impact van dit insect op de maïsopbrengst wordt vaak onderschat omdat de mais wordt gehinderd optimaal te produceren als gevolg van een aantasting zonder dat dit duidelijk visueel zichtbaar is. Bovendien verschilt de druk van de maisstengelboorder sterk van jaar tot jaar. Dit maakt het moeilijk om uitspraken te doen over de economische schade. Vanaf 2013 zijn er in Zuid Limburg aantastingen door de maisstengelboorder geconstateerd. In 2014 en 2015 is op een aantal percelen aanzienlijke schade geconstateerd. In 2015 waren op aangetaste percelen circa 15-30\% van de planten aangetast. In 2017 vielen als gevolg van de herfststorm aantastingen extra op, omdat doorboorde planten meer waren geknikt. Schade beperkt zich nog steeds tot midden en zuid Limburg. 


\section{Levenscyclus}

Volwassen larven (vijfde larvale stadium) overwinteren in maïsstengels of plantenresten in of op de bodem. Ze verpoppen in het voorjaar als de temperaturen oplopen en zijn volwassen in het begin van de zomer (mei). Waar er in Zuid Europa sprake is van 2 generaties per jaar is er in Nederland sprake van 1 generatie per jaar. In de periode juni/juli zetten vrouwtjes eitjes af op de maisplanten. Ze kunnen tot 400 eitjes afzetten. Eieren komen onder normale omstandigheden uit na 7-14 dagen. De larvestadia worden vrij snel doorlopen tot het 5 e larvestadium. Na het $5 e$ larvestadium gaan ze verpoppen. Dit doen ze pas relatief laat. Overwinteren doen ze in het 5e larvestadium. Dit is een inactief stadium waarin geen groei plaatsvindt en wordt mede bepaald door een combinatie van afnemende daglengte, temperatuur en voedselkwaliteit. De larven zullen dus als volwassen larve ofwel worden meegeoogst/gehakseld met de mais ofwel ze blijven achter in de maisstoppel op het land. De stengelboorder overwintert in de stoppel of in de wortels van de maisplanten. Daar overleven ze ook een strenge winter. In het voorjaar verpoppen de rupsen, transformeren zich in vlinders en de cyclus begint opnieuw.

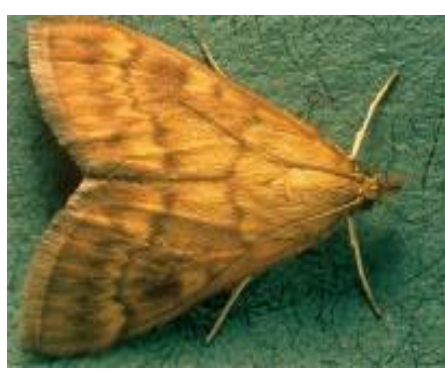

Volwassen vlinder

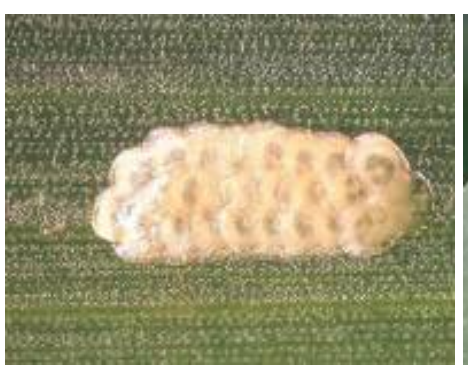

Ei afzetting

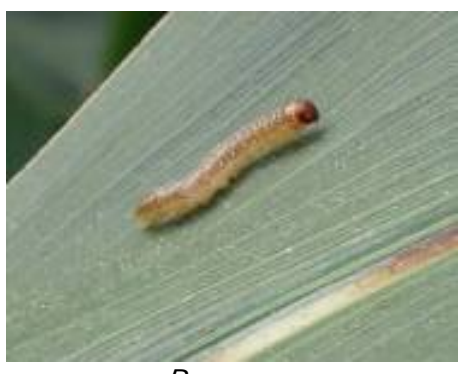

Rups

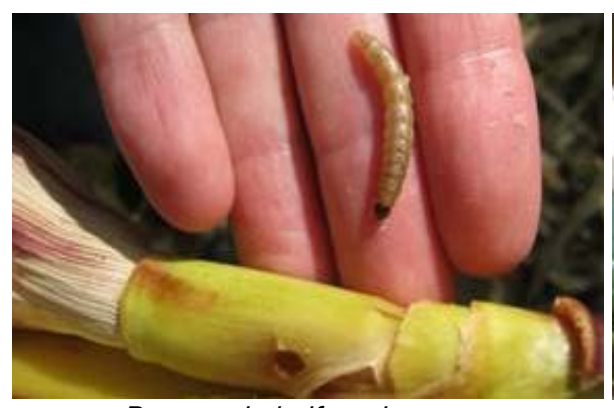

Boorgat in kolfsteel

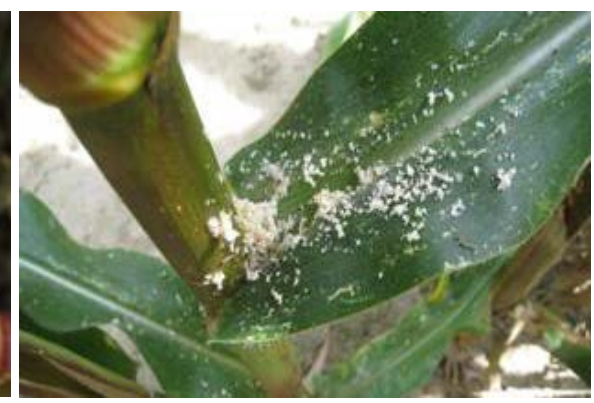

Schaafsel uit korrels

Schade

Nadat de stengelboorders de stengel bereikt hebben, vreten ze zich in het binnenste van de nog jonge maisplanten naar beneden. De vraatschade van de stengelboorder beperkt de water- en voedingsstoffenbevoorrading van de maisplanten. Dit resulteert in oogstverlies. De stengel wordt uitgehold en kan makkelijk omknikken. Gedurende het verloop van de vegetatieperiode vreten de stengelboorderlarven tot in de wortelkop. Bij wind, maar ook door het eigengewicht van de kolven knikken vele van de getroffen maisplanten. Deze legering leidt ook tot oogstverliezen.

De vraatsporen van de stengelboorder zijn invalspoorten voor schimmels. Door stengelboorder aangetaste maisplanten hebben een hoger gehalte aan mycotoxinen dan planten zonder aantasting. Uit onderzoek in Duitsland bleek dat bij een aantasting van ca. 15\% van de maisplanten met stengelboorder het gehalte aan mytotoxinen zo hoog was dat de mais niet meer als veevoer kon 
worden gebruikt. Het is daarom verstandig om zwaar aangetaste mais, waarbij zich veel schimmels op de kolf aanwezig zijn, te laten onderzoeken op mycotoxinen.

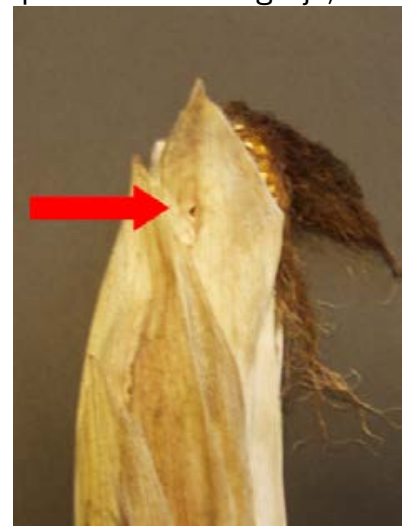

Boorgat in schutblad

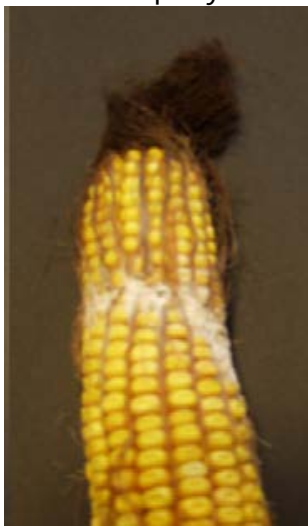

Aangeboorde korrels

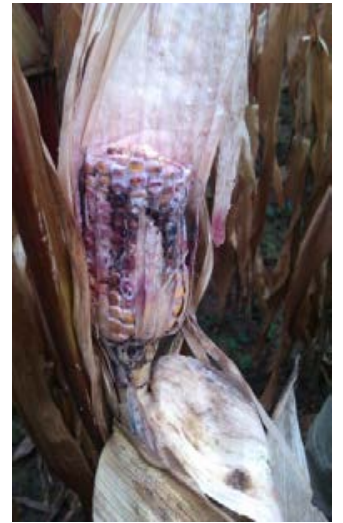

Schimmelvorming op kolf

\section{Bestrijding}

De maisstengelboorder moet in eerste instantie preventief bestreden worden. Teel vroegere rassen, zodat de rupsen met het gewas van het land worden afgevoerd en ingekuild waar ze zullen sterven. Korrelmais telen is ongunstig voor het inperken van de maisstengelboorder. Het gewas staat lang op het veld en de maisplant blijtt achter op het veld. Belangrijk onderdeel van de bestrijding is het vernietigen of klepelen van de maisstoppel. Dit is de plek waar de larve overwinterd. De druk van de maisstengelboorder komt uit achtergebleven plantenresten van de vorige oogst. Om de druk voor het volgend jaar te beperken is het belangrijk dat de gewasresten na de oogst zo goed en grondig mogelijk worden verwijderd of ondergeploegd. De vlinder van de maisstengelboorder is echter in staat om enkele kilometers te vliegen. Er is dus niet alleen sprake van een risico als er vorig jaar ook mais op hetzelfde perceel stond. De vlinder kan ook komen aanvliegen van honderden meters verder.

In de teelt zelf kan de maisstengelboorder chemisch bestreden worden voordat de larven zich in de stengels boren. Optimale tijdstip is de piek van de vlucht van de motten die veelal eind juni - begin juli zal zijn. Belangrijk voor een gerichte inzet van een insecticide is het juiste moment van spuiten. Goede waarnemingen zijn daarbij belangrijk. Plaats daarom vallen in de mais op plaatsen die aantrekkelijk zijn voor de vlinders. Dit zijn vooral plaatsen bij hagen en naast beschutte plekken. In 2015 en 2016 zijn op meerdere plaatsen in Nederland, in Zuid Limburg, maar ook in Brabant, Gelderland en Overijssel in Zuid Limburg feromoonvallen geplaatst. In 2016 zijn er ook motten gevonden in vallen in Brabant en Gelderland. Hier is nog geen sprake van echte druk want echt zichtbare schade is hier nog niet gezien. Het afzetten van eieren in mais lijkt vooralsnog alleen in Zuid-Limburg te gebeuren. Op de website evalio.dupont.com zijn deze vallen te bekijken en kun je vangsten volgen om op die manier het juiste spuitmoment te kiezen. Richtlijn is bij 12 motten in een val moet er bestreden worden. Ook wordt wel geadviseerd binnen een week te spuiten als er motten worden gevangen.

Ter bestrijding van de maisstengelboorder zijn de middelen Gladiator en Coragen toegelaten. Decis EC 25 is toegelaten voor bestrijding van maiswortelkever, maar heeft ook nevenwerking op maisstengelboorder. Pas $600 \mathrm{ml}$ Gladiator of $125 \mathrm{ml}$ Coragen per hectare toe met voldoende spuitvloeistof om een goede bedekking van het gewas te realiseren. Eventueel bespuiting Coragen na 2-3 weken herhalen, maximaal 2 toepassingen per jaar. Gladiator en Coragen zijn veilig voor bijen en hommels en voor alle natuurlijke vijanden van bladluizen zoals gaasvlieg, zweefvlieg, 
sluipwespen en lieveheersbeestje. Gladiator en Coragen zijn met name gericht op de bestrijding van rupsen. Coragen heeft ook een werking op uitkomende eieren. Het beste kan dit middel worden ingezet voordat de jonge rupsen uit de ei pakketjes komen. In Nederland is dit hetzelfde moment als het spuiten van bladschimmels net voor het uitkomen van de pluim. Doordat Coragen 3 weken werking geeft, heeft het een werking op de jonge rupsen en ook op de eitjes die daarna nog worden gelegd. Ook als de rupsen al in de plant zitten heeft Coragen hier een werking tegen, alleen doen ze dan al meer schade.

Decis EC 25 mag maximaal 2 keer per teelt worden ingezet $(0.5 \mathrm{~L}$ per ha per keer). Decis bestrijdt m.n. de motten (spuiten tijdens de vlucht). Aangezien eitjes aan de onderzijde van het blad worden afgelegd en de larven (rupsen) vrij snel het blad in gaan valt het raken hiervan niet mee, maar bij direct contact van de rupsen met Decis zou ook hier zeker werking verwacht mogen worden. Een optimale bestrijding van de maïsstengelboorder gaat eigenlijk gepaard met monitoring van de vlucht, welke sterk afhankelijk is van de regio (plaats in Europa), seizoen-/ weersomstandigheden. In met name Duitsland en Frankrijk wordt gewerkt aan biologische bestrijding door middel van inzet van sluipwespen. Larven hiervan kunnen de rupsen vernietigen. De larven worden over het maisperceel gestrooid met behulp van een drone. Ook worden kaartjes met eieren van de sluipwesp in het maisperceel gehangen. De eieren zitten in een verschillend ontwikkelingsstadium, zodat over langere periode sluipwespen beschikbaar komen. Juiste inzet is nog lastig, maar als de sluipwesp op het juiste moment wordt ingezet kan dit 50-70\% bestrijding opleveren.

Ook is het gewenst de mais relatief vroeg te oogsten (vroegere rassen), omdat de larve pas vrij laat in seizoen naar de wortel afdaalt. Bij een vroege snijmaisoogst zullen veel larven nog in de stengel zitten en bij de oogst van het perceel worden afgevoerd. Dit verlaagd de druk voor het volgende jaar. Belangrijk is ook na de oogst de stoppels te klepelen, waardoor beschutting voor de larven wordt verwijderd en mogelijk ook larven worden vernietigd. Gewasresten vervolgens goed onderploegen is de laatste stap. Bij de teelt van korrelmais is de bestrijding het moeilijkst, omdat er laat geoogst wordt en al het stro op het veld achterblijft. Hier dus extra aandacht nodig voor verkleinen van het materiaal en met name het voldoende diep onderwerken.

\section{Maïswortelkever}

De van oorsprong Noord-Amerikaanse maïswortelkever (Diabrotica virgifera virgifera) is sinds het begin van de negentiger jaren in Europa. Verspreiding over lange afstanden binnen Europa vindt via vliegverkeer plaats. Tot nu toe is de kever in Nederland in 2003 en 2005 in totaal op viff locaties aangetroffen. De NVWA heeft steeds maatregelen genomen om de kever uit te roeien. Onduidelijk is of de kever zich blijvend kan vestigen in Nederland. De larven van de kever kunnen aanzienlijke schade toebrengen aan de maïsplanten. Ze vreten aan de wortels van de jonge planten, waardoor de planten verzwakken en tenslotte kunnen omvallen. De volwassen kevers veroorzaken schade aan de kolf. In Amerika zijn in extreme gevallen oogstverliezen tot $80 \%$ gevonden Bestrijding is overigens mogelijk met deltamethrine (Decis EC 25). Het zaaizaadontsmettingsmiddel Sonido (thiacloprid) heeft een zeer lichte nevenwerking. 


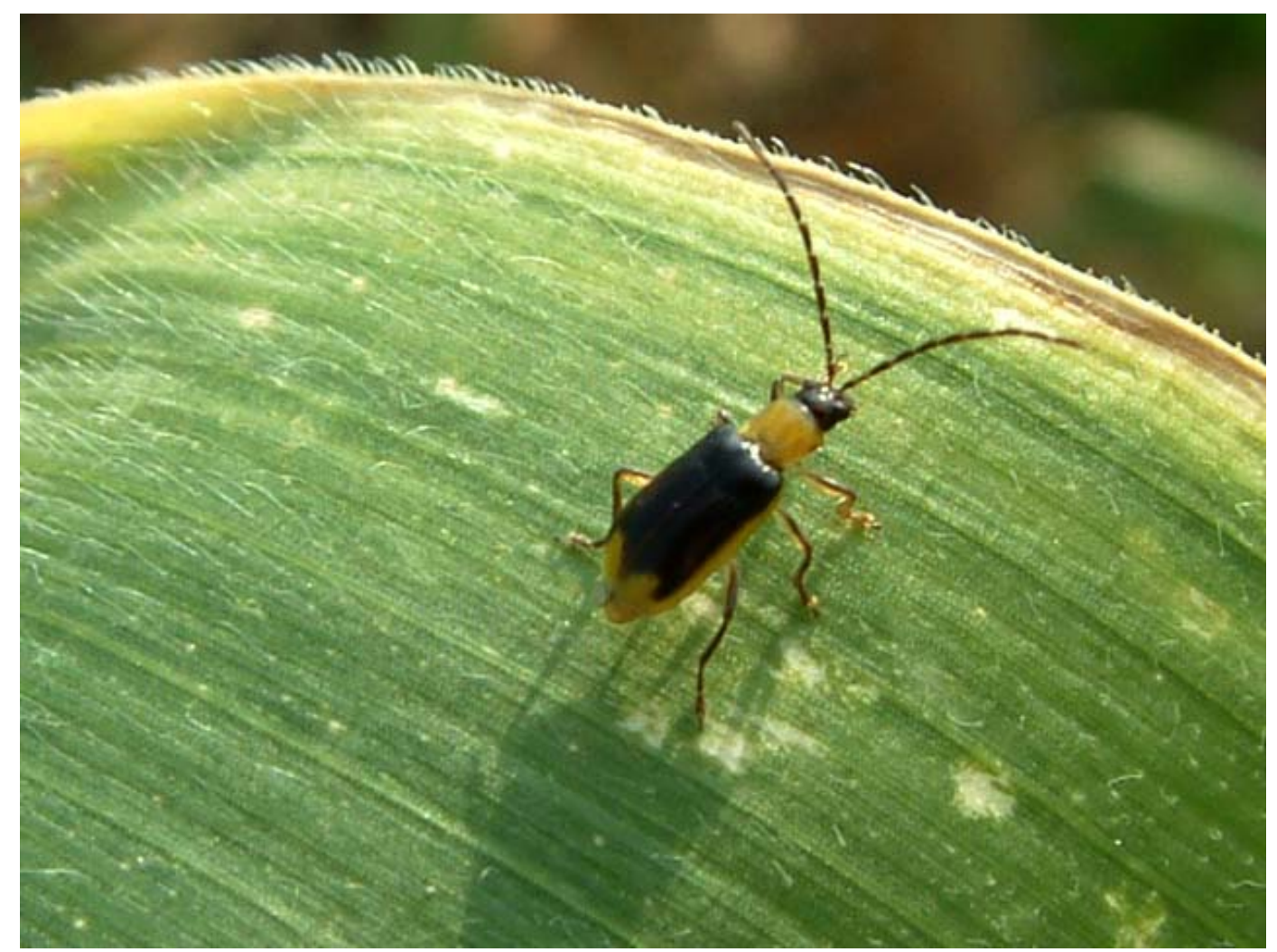

Maiswortelkever

\section{Bladluizen}

Vanaf eind juni kunnen we verschillende bladluizen in de maïs aantreffen. De belangrijkste soort is de vogelkersluis (Rhopalosiphum padi); daarnaast komen ook de roosgrasluis (Metopolophium dirhodum) en de grote graanluis (Sitobion avenae) voor.

De bladluizen veroorzaken in de eerste plaats zuigschade, terwijl ze daarnaast honingdauw uitscheiden. $\mathrm{Op}$ de honingdauw komen allerlei schimmels tot ontwikkeling, die de fotosynthese van het blad belemmeren. De schade is echter gering omdat de meeste luizen en de honingdauw voorkomen op de schutbladeren van de kolf en de bladeren beneden de kolf. Deze bladeren vertonen tijdens de korrelvullingsperiode geen of nauwelijks fotosynthetische activiteit.

\section{Schadeoorzaak luizen mogelijk niet alleen zuigschade}

Een aantal jaren geleden werden op sommige percelen in het zuiden van het land vroeg in het seizoen tijdens een warme periode zeer veel luizen aangetroffen. De jonge maïsplanten $\left(2^{\mathrm{e}}\right.$ a $3^{\mathrm{e}}$ bladstadium) ondervonden hiervan veel schade. De schade uitte zich door vervormde kromme planten en zelfs plantuitval. De indruk was dat er naast zuigschade ook schade ontstond door fytotoxische stoffen die de luizen afscheidden. 


\subsection{Vogels}

Vlak na het zaaien kunnen vogels schade aanrichten, zoals duiven, fazanten, kauwen, roeken en zwarte kraaien. Zowel zaden als jonge planten kunnen weggepikt worden. In extreme situaties kunnen de vogels hele percelen wegvreten. De kans op vogelvraat is kleiner door dieper te zaaien $(5-6 \mathrm{~cm})$ en door geen zaad te morsen. Indien het zaaizaad behandeld is met methiocarb (Mesurol FS FS), geeft dit voldoende bescherming tegen vogelschade. Zie voor meer info over vogelvraat beperken bij onbehandeld zaad hoofdstuk 7.2.

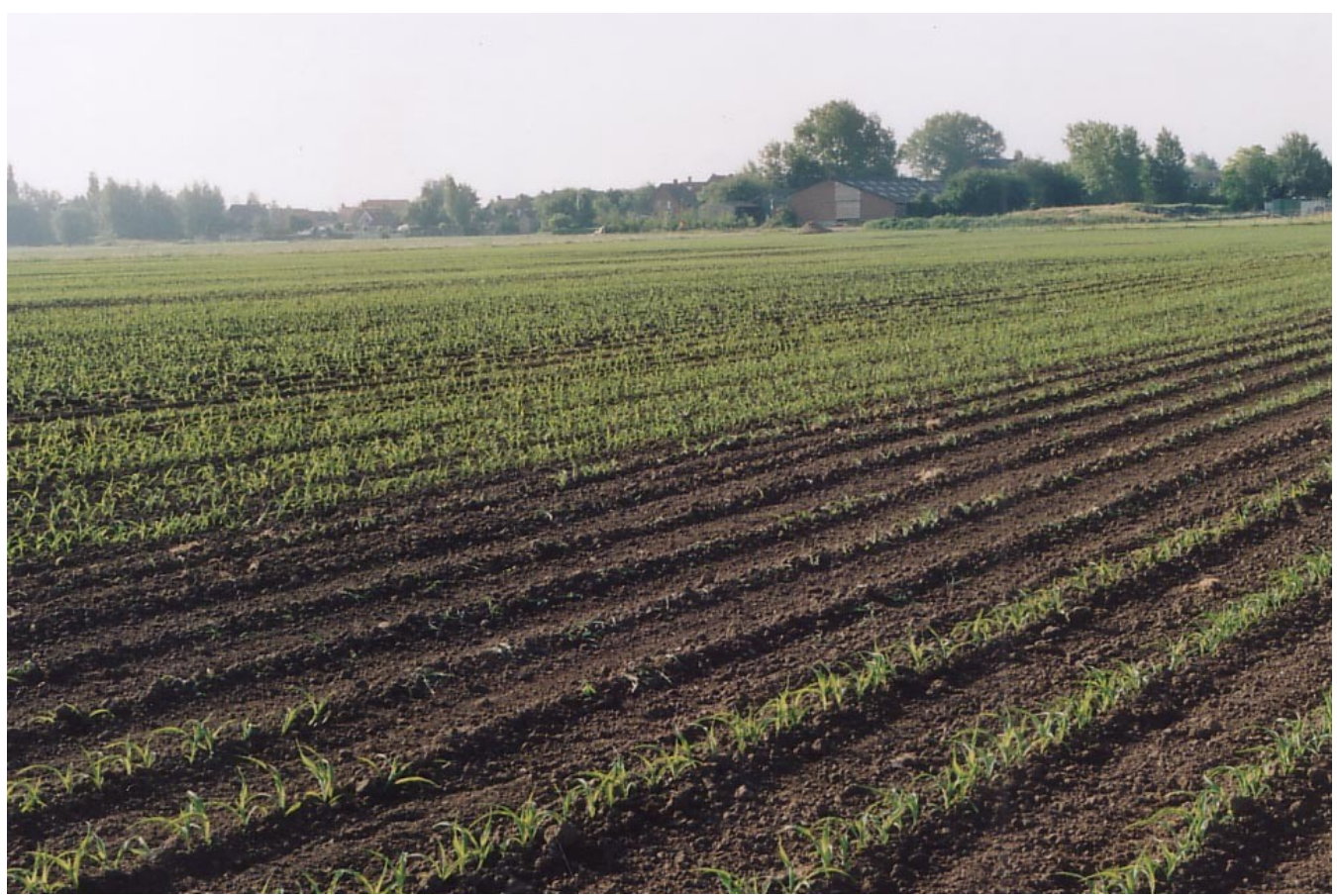

Roeken kunnen aanzienlijke schade aanrichten wanneer zaaizaad niet is behandeld

\subsection{Beschadigingen en stress}

\section{Onkruidbestrijding en bemesting}

Er kunnen beschadigingen van het gewas optreden tijdens de mechanische onkruidbestrijding. Door middel van een goede zaaibedbereiding, een goede afstelling van zowel de zaaimachine als de wiedof schoffelapparatuur en het kiezen van de juiste bewerkingstijdstippen kan deze schade beperkt worden. Ook bij de chemische onkruidbestrijding kan schade ontstaan. Zorg voor een zorgvuldige toepassing van juiste middelen onder de juiste omstandigheden. Soms kan aan de randen van maïspercelen schade ontstaan door onkruidbestrijdingsmiddelen die in andere gewassen worden toegepast. De schade kan variëren van witte vlekken op het blad tot vergroeide, kromme planten. Ook bij de bemesting na opkomst kan gewasbeschadiging ontstaan. Een stikstofbemesting met een kunstmeststrooier kan bladschade veroorzaken doordat kunstmestkorrels in de bladkokers terechtkomen en daar verbranding van het blad geven. Indien er extra kunstmest tijdens het 
groeiseizoen gegeven moet worden, is het aan te bevelen om dit in de vorm van een rijenbemesting te doen.

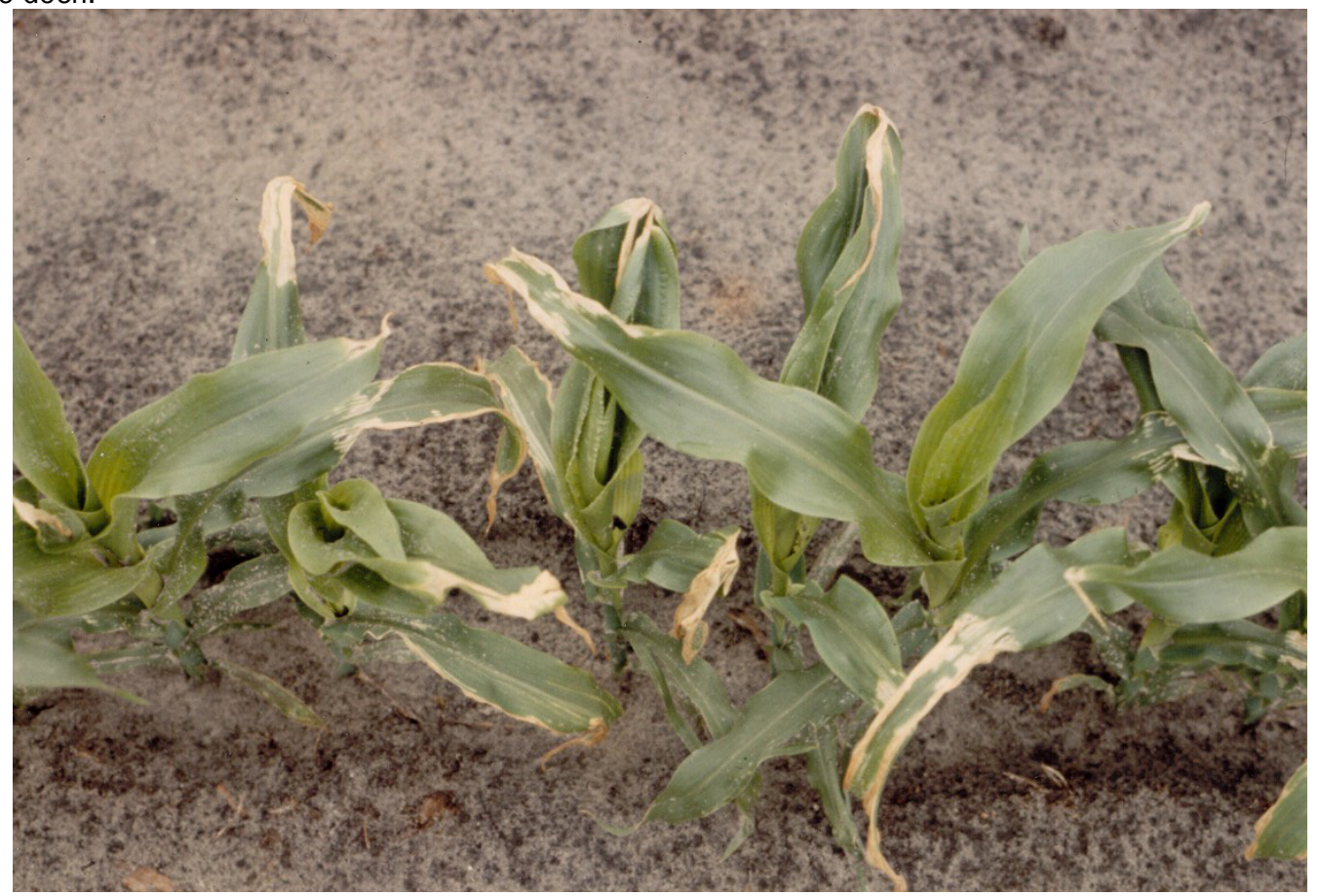

Schade bij bemesting na opkomst

\section{Hagelschade}

Hagelbuien kunnen forse schade aanrichten aan een maïsgewas. De schade kan dusdanig groot zijn dat herstel niet of nauwelijks meer mogelijk is. Lichte hagelschade is te herkennen aan gerafelde bladeren. De productie zal dan iets minder zijn en het gewas is mogelijk wat gevoeliger voor ziektes zoals bladvlekkenziekte. Wanneer in een jong stadium de bladeren kapot zijn gehageld maar het groeipunt is nog niet beschadigd zal het gewas zich herstellen. Wanneer in een later stadium naast de bladeren ook de mannelijke bloei en de kolfaanleg beschadigd zijn zal de productie fors lager zijn. Tegen hagelschade kan men zich verzekeren.
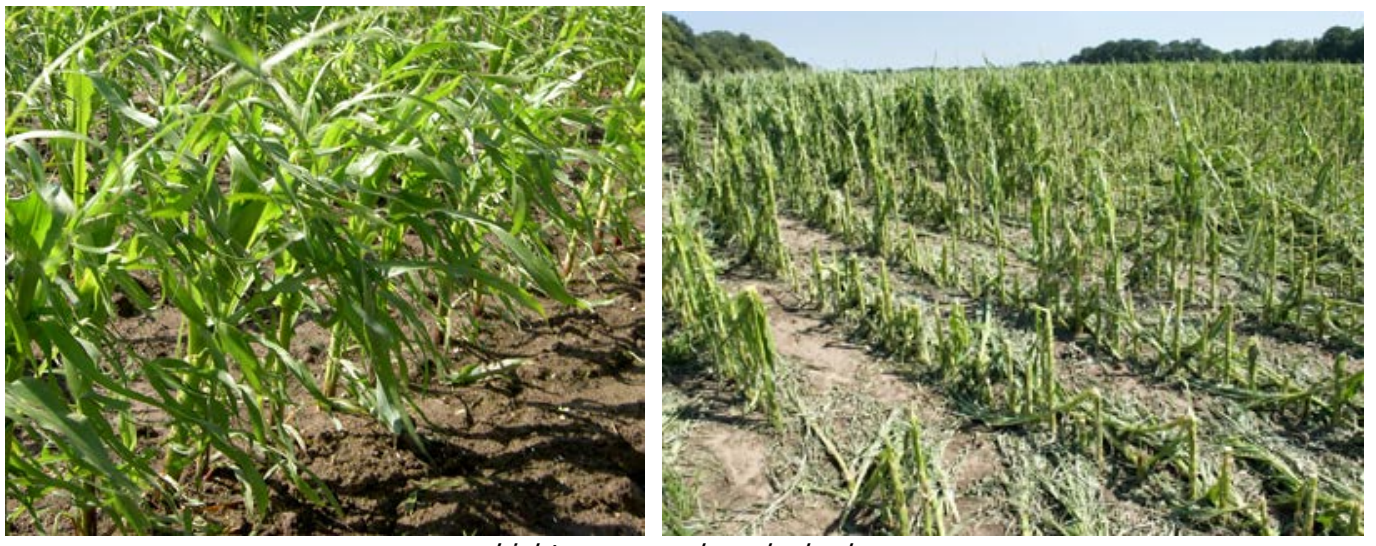

Licht en zware hagelschade 


\section{Nachtvorstschade}

Nachtvorstschade kan zowel in het voorjaar als in het najaar optreden. Vroeg in het seizoen is nachtvorstschade te zien aan afgestorven blad. Alleen bij zeer zware nachtvorst, waarbij ook het groeipunt bevroren is, treedt plantuitval op. Dit is het geval wanneer na een paar dagen geen nieuwe blaadjes meer worden gevormd. Een enkele keer is alleen de kolfaanleg beschadigd. Dit is alleen met behulp van een microscoop te constateren.

In de herfst kan door vroege nachtvorst het gewas vroegtijdig afsterven. De schade is zichtbaar aan het afgestorven blad. De afrijping van een bevroren gewas verloopt zeer traag, omdat er in de plant geen transport van water en koolhydraten meer plaatsvindt. Bevroren gewassen zijn gevoelig voor stengelrot en kunnen dan ook beter, afhankelijk van de mate van vorstschade en tijdstip waarop deze optreedt, zo snel mogelijk worden geoogst.

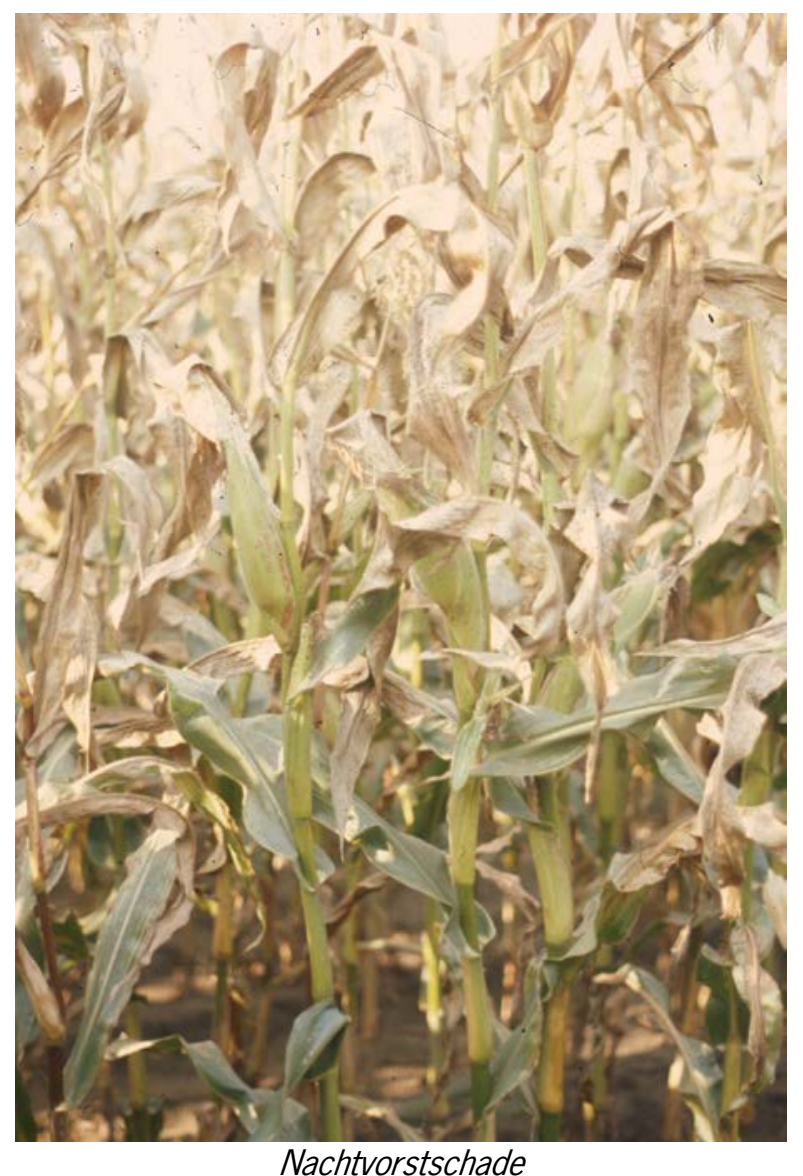

\section{Koude stress}

Koude stress kan naast de beginontwikkelingsperiode (zie paragraaf 2.3) ook optreden in juni. Bij de lage temperaturen die dan kunnen optreden worden de jongste, binnenste bladeren geel. Tijdens deze perioden en ook daarna groeit het gewas minder goed. Dit beeld van vergelende binnenste bladeren dient niet verward te worden met stikstofgebrek. In dat geval vergelen juist de oudste (onderste) bladeren. Soms worden tijdens koude perioden de bladeren rood-paars, een gevolg van een tijdelijk fosfaattekort, ontstaan door de kou. 


\section{Waterschade}

In voorjaar 2013 hebben maispercelen op de uiterwaarden van onder anderen de Rijn en de IJssel enkele dagen onder water gestaan. Dientengevolge zijn er planten "verdronken" en uiteindelijk dus afgestorven. Als mais langer dan twee dagen onder water staat is de kans op overleving heel klein. Soms zijn hele percelen verdwenen of heeft de mais op hogere delen van het perceel het nog net overleefd. Te overwegen is de mais over of bij te zaaien, maar na 15 juni heeft dit geen zin meer omdat het groeiseizoen dan te kort is. Inzaai van gras is dan wellicht de beste optie.

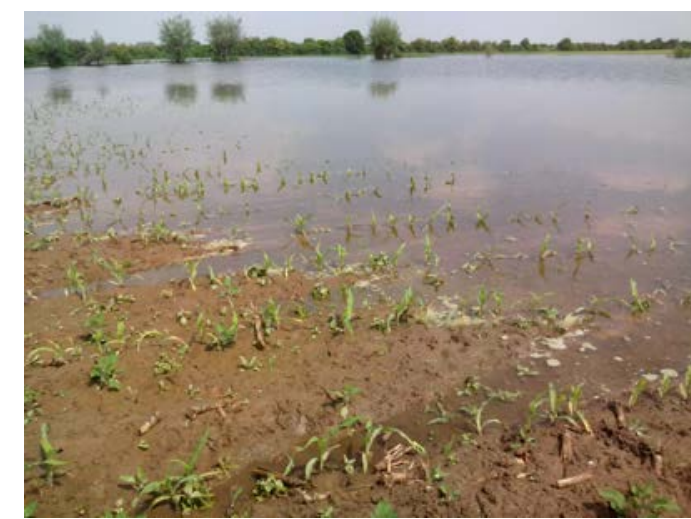

Ondergelopen maïspercelen op de uiterwaarden

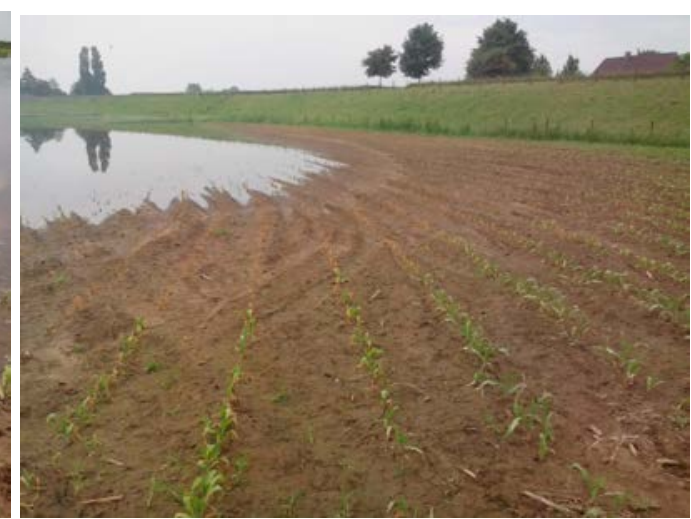

Maisplantjes die te lang onder water hebben gestaan zijn afgestorven

\section{Stormschade}

Tijdens het groeiseizoen kan het voorkomen dat de maïs door sterke wind tijdens buien omwaait. Met name eind juni begin juli wanneer de maïs snel groeit is het gevoelig voor legering als gevolg van wind. Wanneer de maïsstengel geknikt is maar nog niet afgeknapt dan zal het proberen zich te herstellen door in een boog omhoog te groeien. De kolfontwikkeling gaat dan meestal ook nog wel door.

Tijdens een herfststorm kan het gewas ook legeren. Daarbij kunnen planten bij de grond scheefgroeien of omvallen (wortelzwakte) of de stengels kunnen breken of knikken (stengelzwakte). De legeringsgevoeligheid is ras afhankelijk (zie ook hoofdstuk 6, Rassenkeuze). Bij zware herfstlegering kan gewas het best binnen één week geoogst worden. 

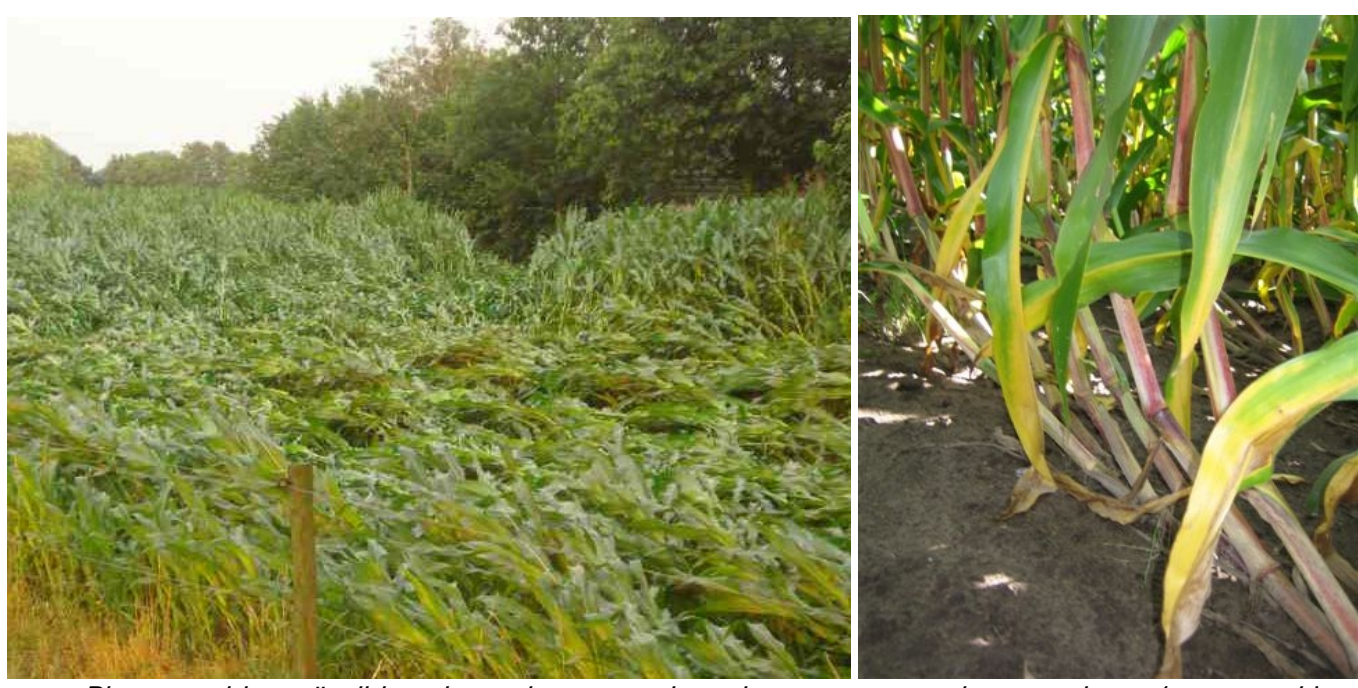

Platgewaaide maïs tijdens het seizoen groeit vaak weer met een boog omhoog (ganzennek)

\section{Droogteschade}

Droogteschade uit zich op verschillende wijzen. Afhankelijk van het ras kan het blad gaan krullen. Bij andere rassen krullen de bladeren niet, maar gaat veel van het onderste blad verloren. Droogte tijdens de bloei leidt tot een slechte korrelzetting (zie ook paragraaf 3.7).

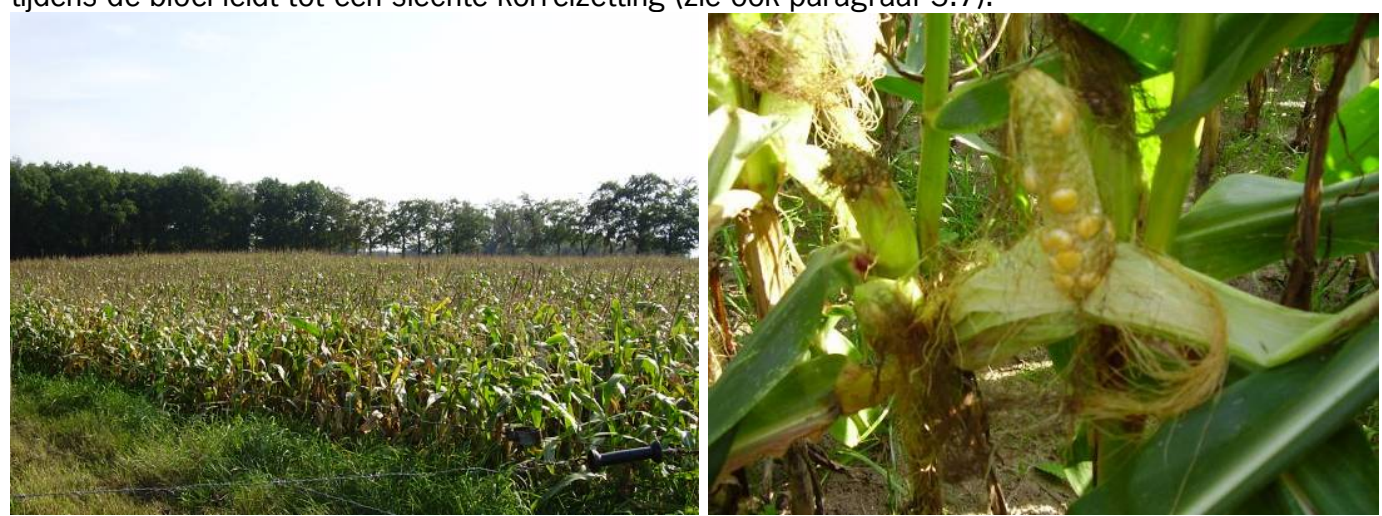

Droogte tijdens de bloei leidt tot een slechte korrelzetting

\section{Uitstoeling}

Stress (kou en/of droogte) in een jong stadium kan er toe leiden dat een maïsplant gaat uitstoelen. Hierbij worden naast de hoofdplant zijscheuten gevormd. Ook (mechanische) kneuzingen van ondergrondse delen (bijvoorbeeld door eggen) kunnen soms oorzaak zijn van extra zijscheuten. De mate van uitstoeling in een stress-situatie is vaak rasafhankelijk. De vorming van een enkele zijscheut geeft geen schade. Wanneer er erg veel zijscheuten worden gevormd dan kan dit de kwaliteit nadelig beïnvloeden. 


\section{Vingerkolven/veelkolvigheid}

Wanneer de maïsplant tijdens de kolfaanleg extreme stress krijgt te verduren door factoren als hitte, koude en droogte dan kan de plant daarop reageren door "vingerkolven" te ontwikkelen. Er wordt dan niet één hoofdkolf gevormd maar meerdere vaak kleinere kolven vanuit één oorsprong. Ook extreme late zaai kan dit verschijnsel opwekken. Vaak heeft dit verschijnsel een negatief effect op de kwaliteit.

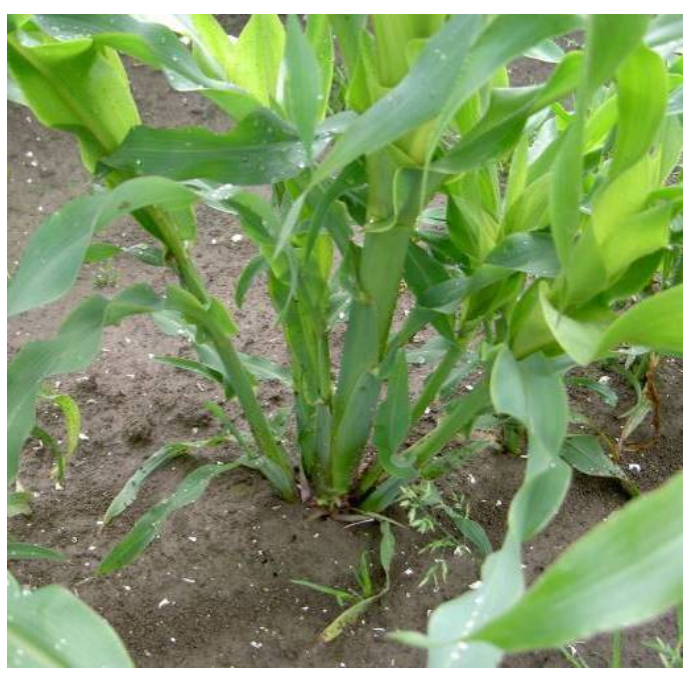

Uitstoelingen

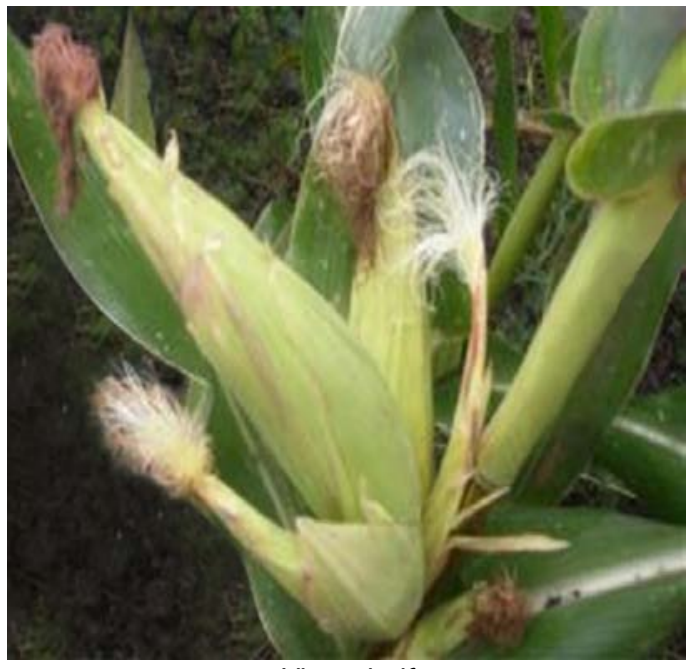

Vingerkolf

\subsection{Gebreksverschijnselen}

Stikstofgebrek in maïs is te herkennen aan gele onderste (oudste) bladeren. Indien dit in een jong gewas optreedt, is het noodzakelijk om extra stikstof te geven.

Fosfaatgebrek uit zich in een rood-paarse verkleuring van de bladeren door anthocyaanophoping. Het fosfaatgebrek kan ook veroorzaakt worden door koude omstandigheden of door droogte. Indien de fosfaattoestand van het perceel aan de lage kant is, is het gewenst om bij het zaaien een rijenbemesting met fosfaat te geven. Dit geldt in het bijzonder voor koudegevoelige percelen.

Kaligebrek uit zich in het geel worden en verdorren van de bladranden. In Nederland komt kaligebrek op de meeste maïspercelen nauwelijks voor door de vrij hoge giften dierlijke mest. In de toekomst kan echter door veranderingen in het mestbeleid een andere situatie ontstaan.

Magnesiumgebrek is herkenbaar aan overlangse strepen tussen de nerven ("tijgering"). In een later stadium sterven deze strepen af. Het verschijnsel wordt het eerst zichtbaar in de oudste bladeren, met name bij koud en nat weer.

Een slechte korrelzetting kan het gevolg zijn van vochtgebrek, maar ook van een gebrek aan borium of koper. Bij vochtgebrek is de korrelzetting vooral aan de top van de kolf slecht, terwijl dit bij boriumof kopergebrek meer verspreid is over de gehele kolf. Borium- en kopergebrek is niet te verwachten op percelen waarop men jaarlijks minimaal 35-40 ton dierlijke mest toepast. 

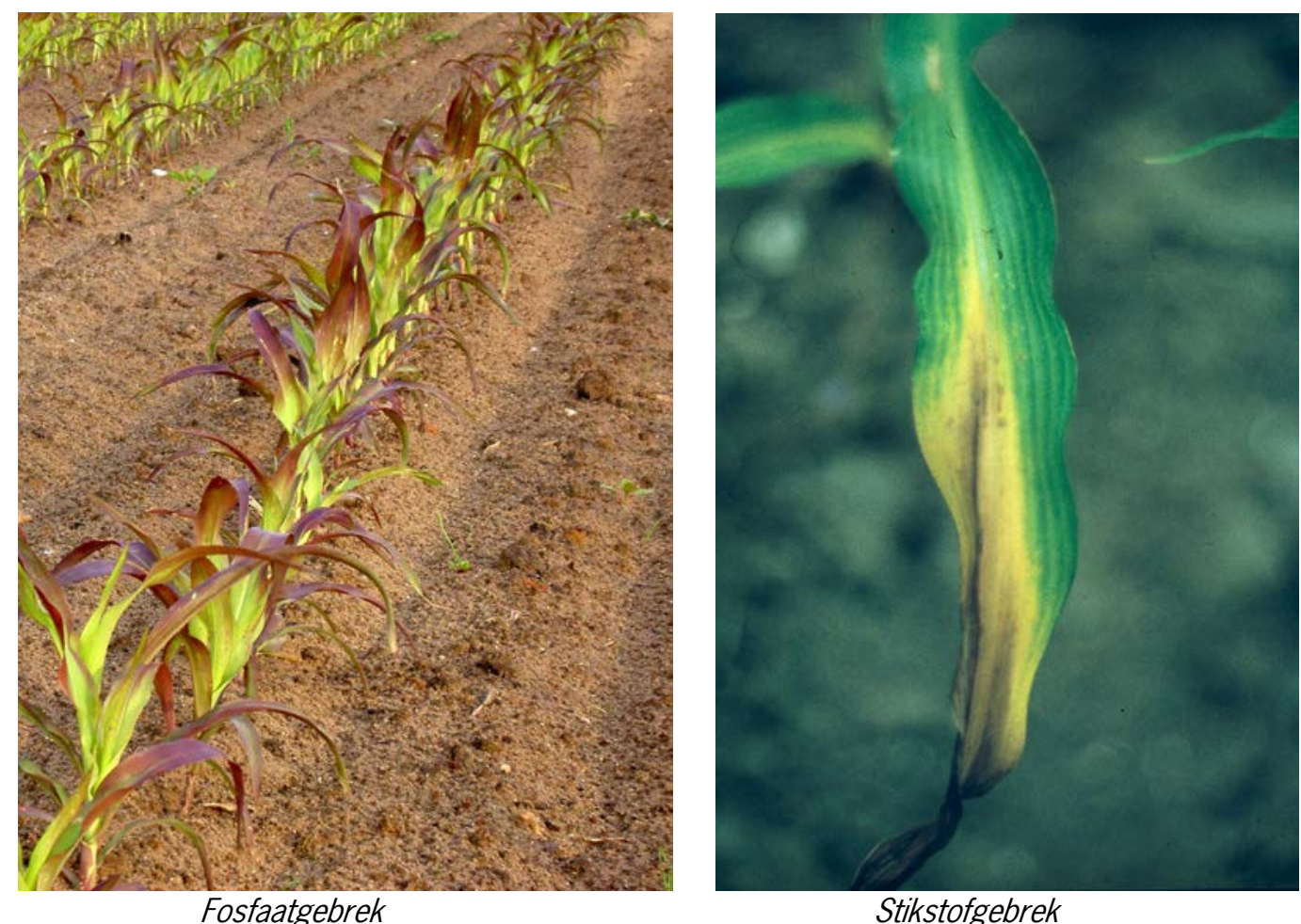

Stikstofgebrek
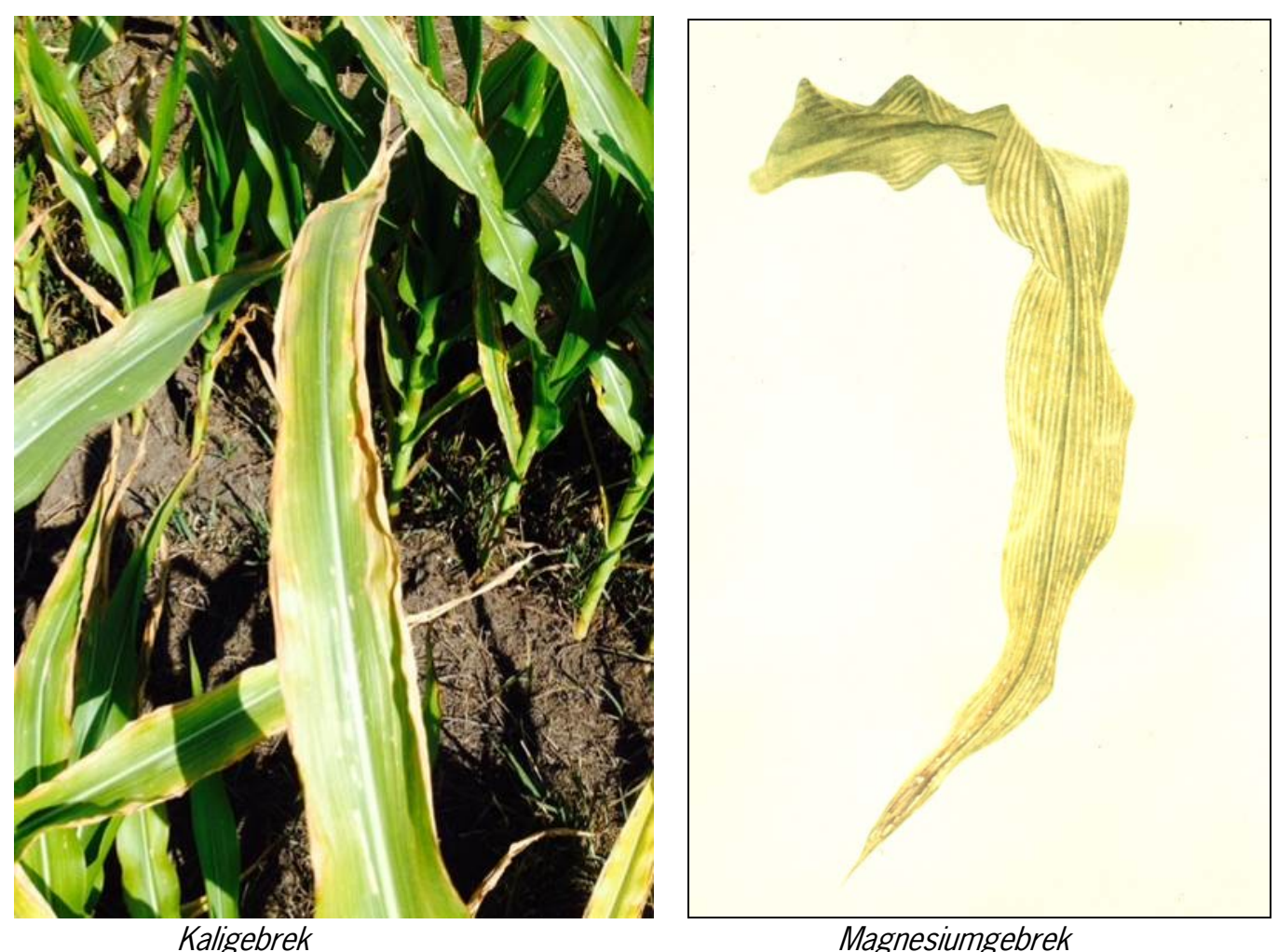


\section{Oogst}

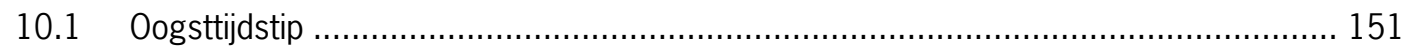

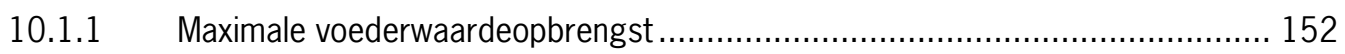

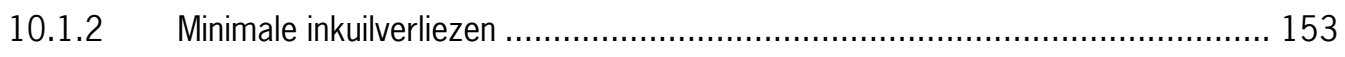

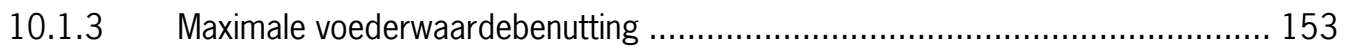

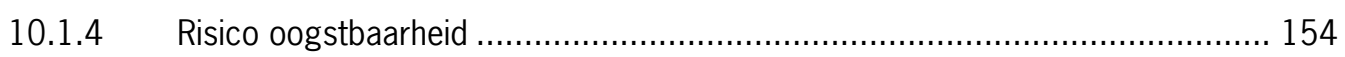

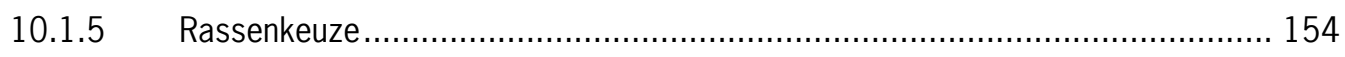

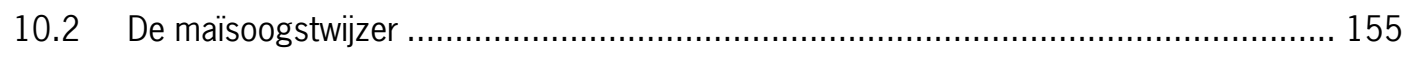

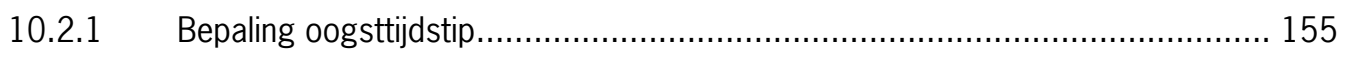

10.2.2 Inschatting drogestofgehalte van snijmaïs ................................................ 158

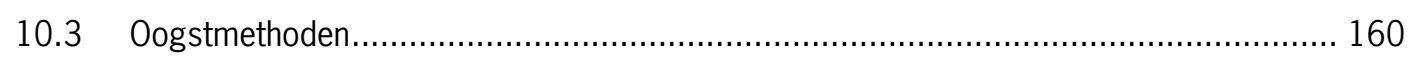

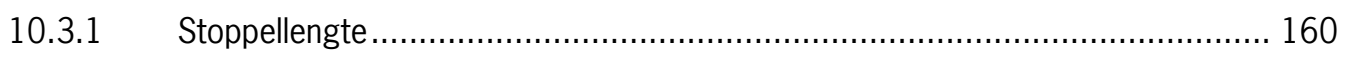

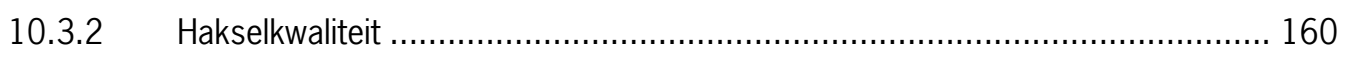

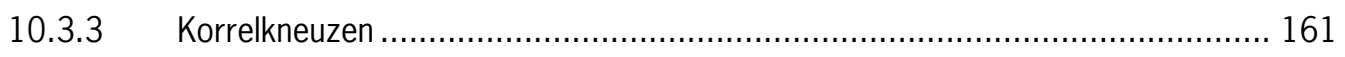

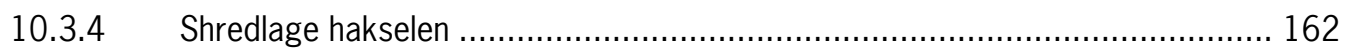




\section{Oogst}

Op veel bedrijven speelt snijmaïs een belangrijke rol als energiebron. Voor een optimale benutting in een rantsoen is het van groot belang om snijmaïs op het juiste tijdstip en op de juiste wijze te oogsten. In dit hoofdstuk gaan we in op de factoren die van invloed zijn op het oogsttijdstip, op welke manier men het oogsttijdstip kan bepalen en op de oogstmethode.

\subsection{Oogsttijdstip}

Het optimale oogsttijdstip van snijmaiis is het moment waarop het gewas de maximaal benutbare voederwaarde-opbrengst bereikt. In theorie wordt dat bereikt bij een combinatie van de maximale voederwaarde-opbrengst op het veld, minimale inkuilverliezen in de kuil en de hoogste benutting door het vee. In de praktijk hoeven deze factoren niet op hetzelfde moment of bij hetzelfde drogestofgehalte te vallen. Het beste oogstmoment is een compromis. Het rastype heeft hierop geen invloed (zie ook paragraaf 10.1.4). Het beste compromis wordt bereikt als de snijmaïs een drogestofgehalte heeft van $36 \%$ op het veld. De kolf heeft dan een drogestofgehalte tussen 55 à $60 \%$ en het gewas tussen 24 en $27 \%$. Dit drogestofgehalte van het gewas wordt veelal gerealiseerd als de helft tot een kwart van de bladeren nog groen zijn. Tot slot hebben ook de oogstbaarheid (stengelrot en legering) en de berijdbaarheid van het perceel invloed op het optimale oogsttijdstip.

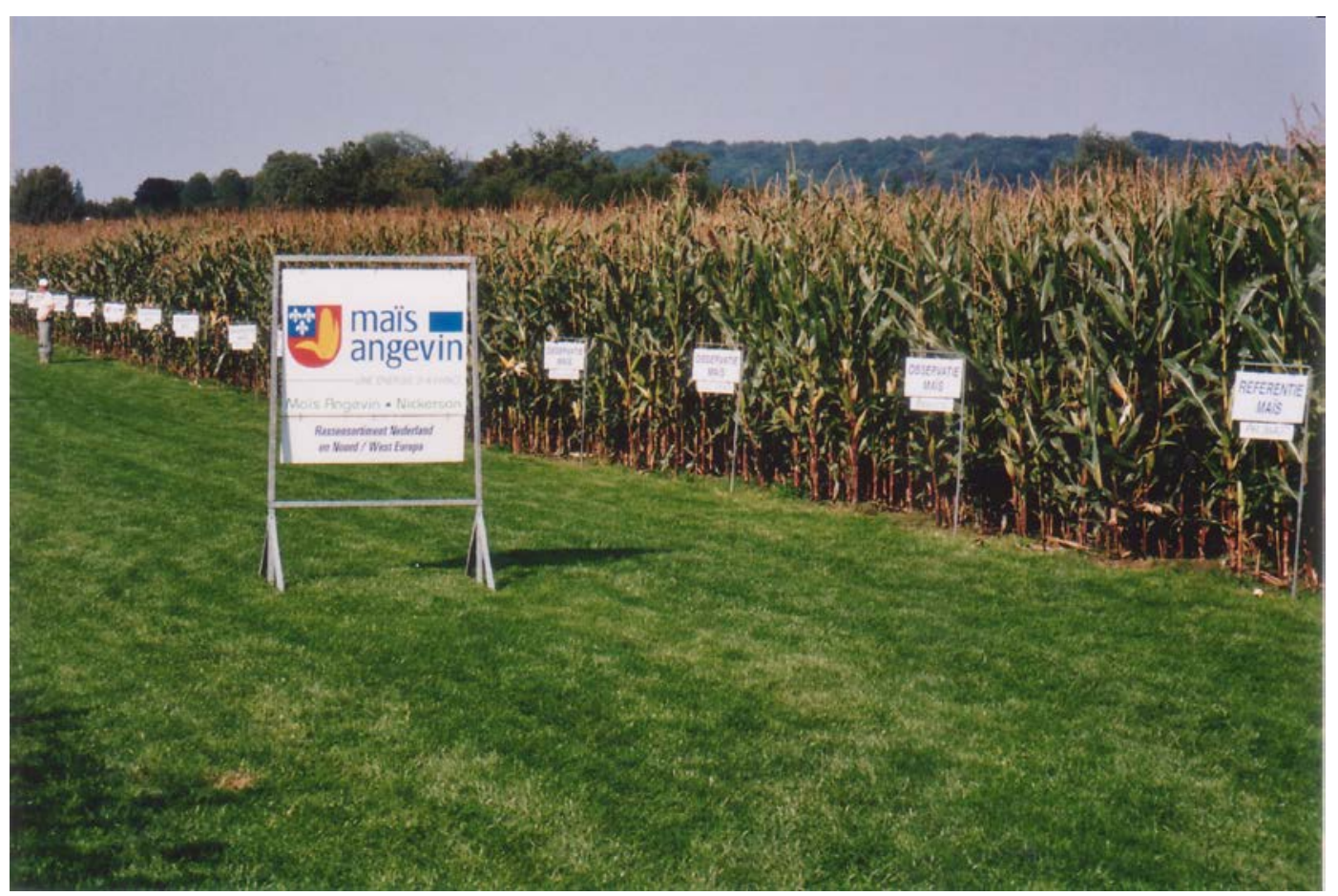

Steeds vroegere oogst door vroegere rassen 


\subsubsection{Maximale voederwaardeopbrengst}

Het drogestofgehalte waarbij de maximale voederwaarde-opbrengst op het veld wordt gerealiseerd ligt afhankelijk van het jaar tussen 34 en 40\% drogestof. In jaren met gunstige groeicondities is dit bij een hoger drogestofgehalte en vroeger in het jaar dan in jaren met minder gunstige groeicondities. De voederwaarde opbrengst is een resultante van de drogestof opbrengst en de verteerbaarheid (VEM per kg droge stof).

\section{Drogestof opbrengst}

Het tijdstip waarop de maximale drogestof opbrengst wordt bereikt is afhankelijk van de conditie van het blad, de temperatuur en de instraling (intensiteit en daglengte). De temperatuur en de instraling zijn uit te drukken naar tijdstip in het jaar. Begin september is de gemiddelde temperatuur en instraling hoger dan bijvoorbeeld begin oktober. De conditie van het blad is aan te geven met het aantal groene bladeren. De omstandigheden waarbij nog een toename van de drogestof plaatsvindt wordt aangegeven in onderstaande tabel 10.1.

Tabel 10.1 Tijdstip in het jaar en conditie van het blad waarbij nog productie plaatsvindt

\begin{tabular}{ll}
\hline Tijdstip & Aantal bladeren meer dan $50 \%$ groen \\
\hline $1^{\mathrm{e}}$ helft september: & $<2$ bladeren \\
$2^{\mathrm{e}}$ helft september: & $<3.5$ bladeren \\
$1^{\mathrm{e}}$ helft oktober: & $<5$ bladeren \\
\hline
\end{tabular}

Uit de tabel blijkt dat wanneer de eerste helft van september nog 2 bladeren voor meer dan de helft groen zijn, dus al een behoorlijk dood gewas, de drogestof opbrengst nog steeds toeneemt. In een gemiddeld jaar bedraagt de droge stoftoename van een gezond gewas met voldoende groene bladeren eind augustus circa $120 \mathrm{~kg}$ droge stof per dag. Eind september bedraagt deze nog circa $20 \mathrm{~kg}$ per dag. Na 10 oktober is er veelal sprake van een afname van de drogestof opbrengst, doordat de assimilatie overdag de verademing gedurende de nacht niet meer compenseert. Dit is extremer naarmate er meer groen blad is.

\section{Verteerbaarheid}

De verteerbaarheid van snijmaïs wordt voornamelijk bepaald door het zetmeelgehalte, het celwandgehalte en de verteerbaarheid van de celwanden. Tijdens de afrijping verandert de samenstelling van de maïs en daarmee de verteerbaarheid. De verteerbaarheid van stengel en blad (restplant) neemt af en die van de kolf neemt toe. Ten eerste door de omzetting van koolhydraten uit stengel en blad (suiker) naar zetmeel in de kolf. Het suikergehalte neemt af en de hoeveelheid zetmeel in de snijmaïs neemt toe. Door toename van het zetmeelgehalte neemt ook het celwandgehalte af. Ten tweede door de afname van de verteerbaarheid van de celwanden van de restplant.

Onder gunstige omstandigheden zal de zetmeelaanwas het verlies aan celwandverteerbaarheid meer dan compenseren. De verteerbaarheid gehele plant zal dan toenemen. Onder minder gunstige omstandigheden zal de zetmeelaanwas het verlies aan celwandverteerbaarheid niet kunnen compenseren en de totale verteerbaarheid zal dan iets afnemen. Gemiddeld over de jaren blijt de verteerbaarheid in het afrijpingstraject constant. Daar zeer vroege rassen vroeger in het seizoen, dus onder gunstige omstandigheden, al een bepaald drogestofgehalte halen, zal de kans op toename van de verteerbaarheid gehele plant bij deze rassen het grootst zijn.

Ook de samenstelling van het zetmeel verandert tijdens de afrijping. Het gehalte aan bestendig zetmeel neemt toe. Bestendig zetmeel wordt niet in de pens afgebroken, maar komt in de darm terecht wordt daar benut. Meer hierover in paragraaf 10.1.3 en hoofdstuk Voeding. 


\subsubsection{Minimale inkuilverliezen}

Het geoogste product moet goed conserveerbaar zijn. Dat betekent minimale inkuilverliezen en minimale kans op broei. Inkuilverliezen bestaan uit perssap- en conserveringsverliezen. Bij een drogestofgehalte boven de $32 \%$ treden geen perssapverliezen meer op. De conserveringsverliezen zijn het laagst bij een drogestofgehalte tussen 33 en 39\% (zie ook paragraaf 11.2). Bij een drogestofgehalte boven $36 \%$ neemt de kans op broei en schimmels tijdens het voeren van de kuil toe. Goed kuilmanagement kan de kans hierop aanzienlijk verminderen. Dit houdt in een korte haksellengte $(6-8 \mathrm{~mm})$, laagsgewijs verdichten, snel luchtdicht afwerken en eventueel toepassen van een broeibestrijdingsmiddel. Afhankelijk van de ervaringen met broei op een bedrijf kan gekozen worden voor een drogestofgehalte bij de oogst van 32-36\%.

In extreme situaties, waarbij de maïs een onvoldoende hoog drogestofgehalte kan bereiken, is het noodzakelijk in ieder geval te streven naar een drogestofgehalte van 28\%. De inkuilverliezen blijven dan beperkt tot $10 \%$.

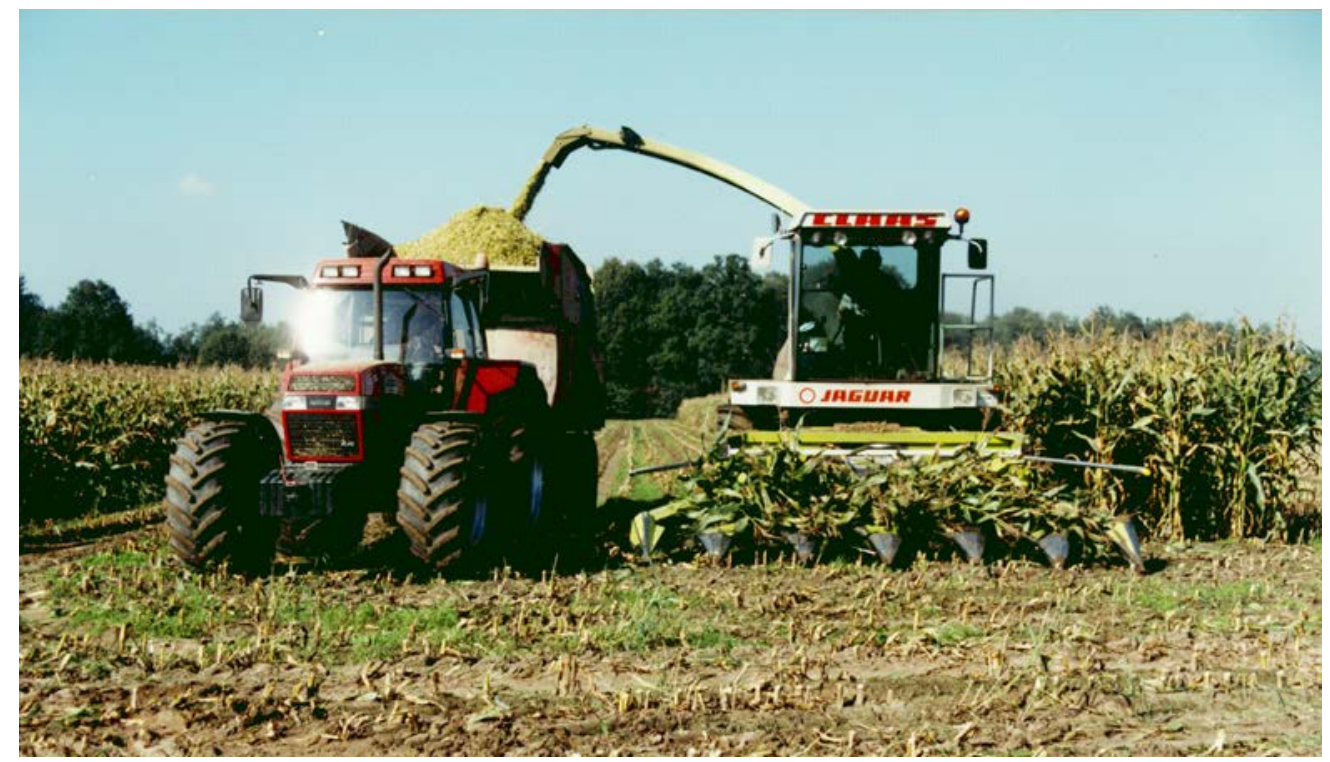

Optimaal oogststadium ligt bij $36 \%$ drogestof

\subsubsection{Maximale voederwaardebenutting}

Uit voederproeven (Wageningen Livestock Reserach 2005) bleek dat de benutting door hoogproductieve koeien hoger is bij een drogestofgehalte van $36 \%$ in vergelijking met $30 \%$. Bij $36 \%$ is zowel het zetmeelgehalte als de bestendigheid van het zetmeel hoger. Bestendig zetmeel wordt niet in de pens afgebroken, maar kan op darmniveau door de koe benut worden (zie hoofdstuk 12). Dit geeft een betere benutting en heeft bij hoogproductieve koeien een gunstig effect op de melkproductie. Verderop in de lactatie geeft bestendig zetmeel doorgaans dalende productie en toenemende kans op vervetting. Na de mid- en eindfase van de lactatie moet de hoeveelheid bestendig zetmeel in het rantsoen dan ook geleidelijk afnemen en afhangen van het productieniveau en de conditie van de koeien. Voorwaarde voor het goed kunnen benutten van veel bestendig zetmeel is dat de pens goed functioneert. 
Door een later oogsttijdstip neemt de hardheid van de korrel toe en daarmee de afbreekbaarheid af. De korrelkneuzer moet daarom altijd gebruikt worden. De korrel moet in minimaal 4 delen worden gekneusd om maximale benutting van de korrel mogelijk te maken.

\section{Oogststadium en methaanemissie}

Uit een recent onderzoek van Wageningen Livestock Research is gebleken dat de bestendigheid van het zetmeel verder toeneemt in het ds-gehalte traject van 36 tot $42 \%$. Door verschuiving van de zetmeelvertering naar de darm, neemt de methaanemissie door melkkoeien per kg drogestof af. Het later oogsten van snijmaïs bij een hoger ds-gehalte had in het onderzoek geen nadelige gevolgen voor de voeropname, melkproductie of broeigevoeligheid van snijmaiskuilen. Later oogsten (tot $42 \% \mathrm{ds}$ ) kan daarom in de praktijk worden toegepast als een kosteloze maatregel om de methaanemissie te verminderen. Voorwaarde is wel dat het inkuilmanagement (zoals een goede kuilverdichting, afdekken met zand en voldoende voersnelheid) optimaal is.

\subsubsection{Risico oogstbaarheid}

Op basis van de maximaal benutbare voederwaarde opbrengst ligt het optimale oogsttijdstip tussen bij 36\% drogestof. Er zijn echter andere factoren die het noodzakelijk maken hier van af te wijken. Naarmate het drogestofgehalte van het gewas toeneemt, groeit de kans op stengelrot (fusarium). Doordat stengelrot de stengelvoet aantast, worden voedingsstromen in de plant belemmerd en sterft de plant af. Het drogestofgehalte van de plant neemt sterk toe en de voederwaarde wordt negatief beinvloed. Tevens worden de suikers in de plant verbruikt door de fusariumschimmel, wat een negatief effect heeft op de inkuilbaarheid. Daarnaast veroorzaakt stengelrot een grotere kans op legering. Een gewas kan daarnaast ook legeren door gebrek aan stevigheid. Legering door vergroot de kans op opbrengstderving en grond in de kuil.

Een laatste factor die het oogsttijdstip beïnvloed is de berijdbaarheid van de grond, waardoor het moeilijk wordt het gewas te oogsten. Is er kans op stengelrot, gebrek aan stevigheid of een slechte berijdbaarheid dan moet ongeacht opbrengst, drogestofgehalte of kwaliteit zo snel mogelijk worden geoogst.

\subsubsection{Rassenkeuze}

Vroege rassen verkleinen het risico van een laag drogestofgehalte bij een groeiseizoen met lage gemiddelde temperaturen. Meestal zal een zeer vroeg ras de hoogste productie en een drogestofgehalte van 36\% vóór 1 oktober bereiken. Ook in een koud jaar of bij late zaai bereiken rassen uit de zeer vroege groep vóór 10 oktober een voldoende hoog drogestofgehalte (zie hoofdstuk Rassenkeuze). Onder gemiddelde omstandigheden zullen de middenvroege rassen van de Aanbevelende Rassenlijst vóór 10 oktober oogstrijp zijn.

Uit onderzoek in 2003 en 2004 met verschillende tegengestelde rastypen (vroeg/laat, staygreen/drydown en veel zetmeel/hoge celwandverteerbaarheid) is gebleken dat de maximale voederwaardeopbrengst bij alle rastypen werd bereikt bij hetzelfde droge stofgehalte. Dit betekent dat er geen verschil in optimaal oogststadium is tussen de verschillende rastypen. Daarnaast is gekeken naar de afrijpingssnelheid gedurende het traject van 24 tot $40 \%$ drogestof. Hieruit bleek dat ook dit voor alle rastypen praktisch gelijk was. Met andere woorden er is geen verschil in oogstelasticiteit (tijd die men heeft om de maïs rond het optimale oogststadium te oogsten) tussen de rastypen. 


\subsection{De maïsoogstwijzer}

Op basis van de informatie uit paragraaf 10.1 is de maïsoogstwijzer ontwikkeld. Het is een beslismodel waarmee op basis van de eigen bedrijfsomstandigheden het optimale oogsttijdstip van de snijmaiis bepaald kan worden. Hierbij is de bepaling van het drogestofgehalte essentieel (zie 10.2.2). Begin de laatste week augustus en realiseer je dat de loonwerker niet direct oproepbaar is en dat het drogestofgehalte gemiddeld met 2-3\% per week toeneemt. In extreme situaties, zoals bij warm zonnig weer én een behoorlijke stengelrotaantasting kan dit zelfs oplopen tot $6 \%$ per week. Is het bewolkt koud weer, dan kan de toename slechts $1 \%$ per week bedragen.

\subsubsection{Bepaling oogsttijdstip}

De Maïsoogstwijzer is weergegeven in figuur 10.1. Vanuit START geeft het rode blok de directe weg aan tot de oogst, waarbij we vóór 10 oktober bij geringe kans op broei streven naar een drogestofgehalte van $36 \%$ (maximaal benutbare voederwaarde-opbrengst) en bij een grotere kans op broei naar minimaal 32\% (geen perssapverliezen) . De overige blokken geven uitzonderingssituaties of keuzemogelijkheden weer.

\section{Na 10 oktober}

Wanneer het na 10 oktober is betekent dit, omdat men laatste week augustus gestart is, dat er al diverse keren beoordeeld is of het drogestofgehalte hoger is dan $32 \%$ en dat dit telkens nog niet het geval was. Na 10 oktober moet men bij een drogestofgehalte van $28 \%$ of hoger in principe altijd oogsten. Om de inkuilverliezen te beperken tot maximaal $10 \%$ moet men zich richten op minimaal $28 \%$ drogestof. Is dit nog niet bereikt en er is geen risico op slechte oogst- of berijdbaarheid dan kan men 1 week later weer kijken. Dit gaat wel ten koste van de voederwaarde opbrengst.

\section{Vóór 10 oktober en drogestofgehalte lager dan $32 \%$}

Hierbij zijn twee bijzondere situaties mogelijk. Situatie 1 is dat een harddeegrijpe korrel wordt gecombineerd met nog een heel groen gewas. In deze situatie moet gewacht worden met oogsten totdat het gewas iets begint te verkleuren omdat er anders te veel perssapverliezen zullen ontstaan. Situatie 2 is dat een dood gewas (maximale productie - aantal bladeren meer dan $50 \%$ groen) wordt gecombineerd met een zachte korrel. Dit kan bijvoorbeeld veroorzaakt zijn door droogte of vorstschade. In deze situatie moet men wachten met oogsten tot $28 \%$ drogestof is bereikt. Is er geen extreem verschil in rijpheid van plant en korrel dan moet men alleen nog oogsten indien er oogstbaarheids- en berijdbaarheidsrisico's zijn, anders moet men na een week het gewas opnieuw beoordelen.

\section{Vóór 10 oktober en drogestofgehalte tussen 32 en $36 \%$}

Het gewas is in principe oogstrijp en de kans op perssapverliezen bij conservering zijn minimaal. Voor een hogere voederwaarde opbrengst en benutting kan men zich nog richten op 36\% drogestof. Indien er de laatste jaren vaak broei is opgetreden op het bedrijf dan geen risico nemen en de maïs oogsten. Is er weinig kans op broei dan kan men naar het blok rechtsonder, waar beoordeeld kan worden of de maximale voederwaarde opbrengst al is bereikt. Is dit niet het geval dan kan men afhankelijk van oogst- en berijdbaarheidsrisico's oogsten of 1 week later opnieuw beoordelen. Is maximale opbrengst wel bereikt maar men wil een wat lagere bestendig zetmeelgehalte met men oogsten. Anders moet men nog wachten en afhankelijk van de risico's een week later opnieuw beoordelen tot dat een drogestofgehalte van $36 \%$ bereikt is. 
Bij oogst altijd een korrelkneuzer gebruiken die zodanig is afgesteld dat de korrels minimaal in 4 delen kapot wordt gemaakt.

\section{Extreme omstandigheden}

Er kunnen zich situaties voordoen waardoor het gangbare afrijpingspatroon ingrijpend wordt beïnloed. Dit is onder andere het geval bij droogte en nachtvorst tijdens de afrijping.

Droogte heeft een belangrijke invloed op het drogestofgehalte van snijmaiis. Droogte voor de bloei remt de loofontwikkeling. Als er vervolgens tijdens en na de bloei voldoende vocht beschikbaar is ontwikkelt de kolf zich normaal. In dat geval is er sprake van een normaal afrijpingspatroon.

Droogte tijdens de bloei heeft tot gevolg dat er een slechte korrelzetting plaatsvindt. Droogte na de bloei veroorzaakt een slechte korrelvulling. Dit heeft tot gevolg dat het kolfaandeel van verdroogde gewassen veel lager is dan dat van gewassen die voldoende vocht ter beschikking hebben. Daar het kolfaandeel van grote invloed is op het drogestofgehalte van het gewas bij de oogst, hebben gewassen met een laag kolfaandeel vaak een lager drogestofgehalte. Het drogestofgehalte van verdroogde maïs wordt daarom meestal overschat.

Ook bij verdroogde maïs moet er in principe gewacht worden met oogsten tot het gewas een drogestofgehalte van tenminste $28 \%$ bereikt heeft. Is het gewas echter door stengelrot aangetast dan moet toch tijdig geoogst worden ook al is het drogestofgehalte laag omdat de risico's van legering te groot zijn.

Bij vroeg in de herfst optredende nachtvorst kan het proces van afrijping abrupt worden afgebroken. Doordat de cellen kapot vriezen vindt er geen transport van water en koolhydraten in de plant meer plaats waardoor het gewas zeer langzaam indroogt. Bevroren gewassen zijn bovendien gevoelig voor stengelrotaantasting en kunnen dan ook maar beter, afhankelijk van mate van vorstschade en tijdstip waarop deze optreedt, zo snel mogelijk worden geoogst.

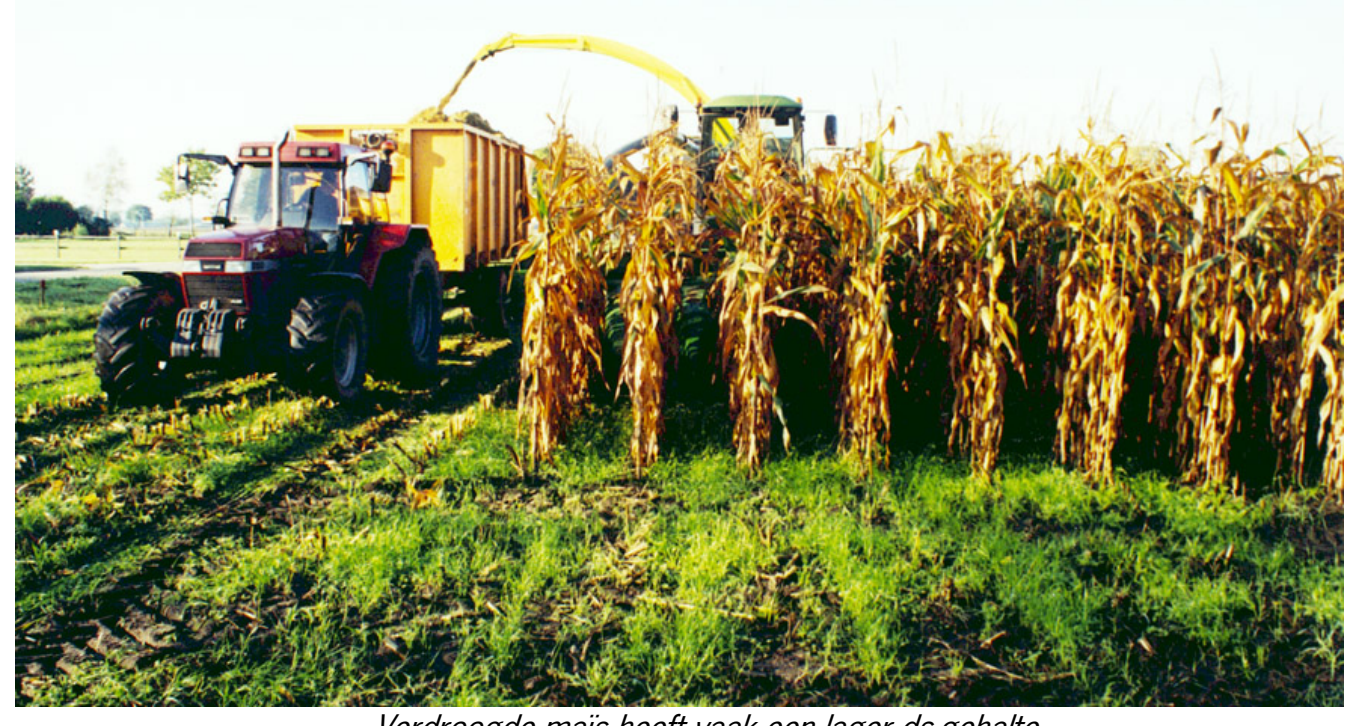

Verdroogde maïs heeft vaak een lager ds-gehalte 


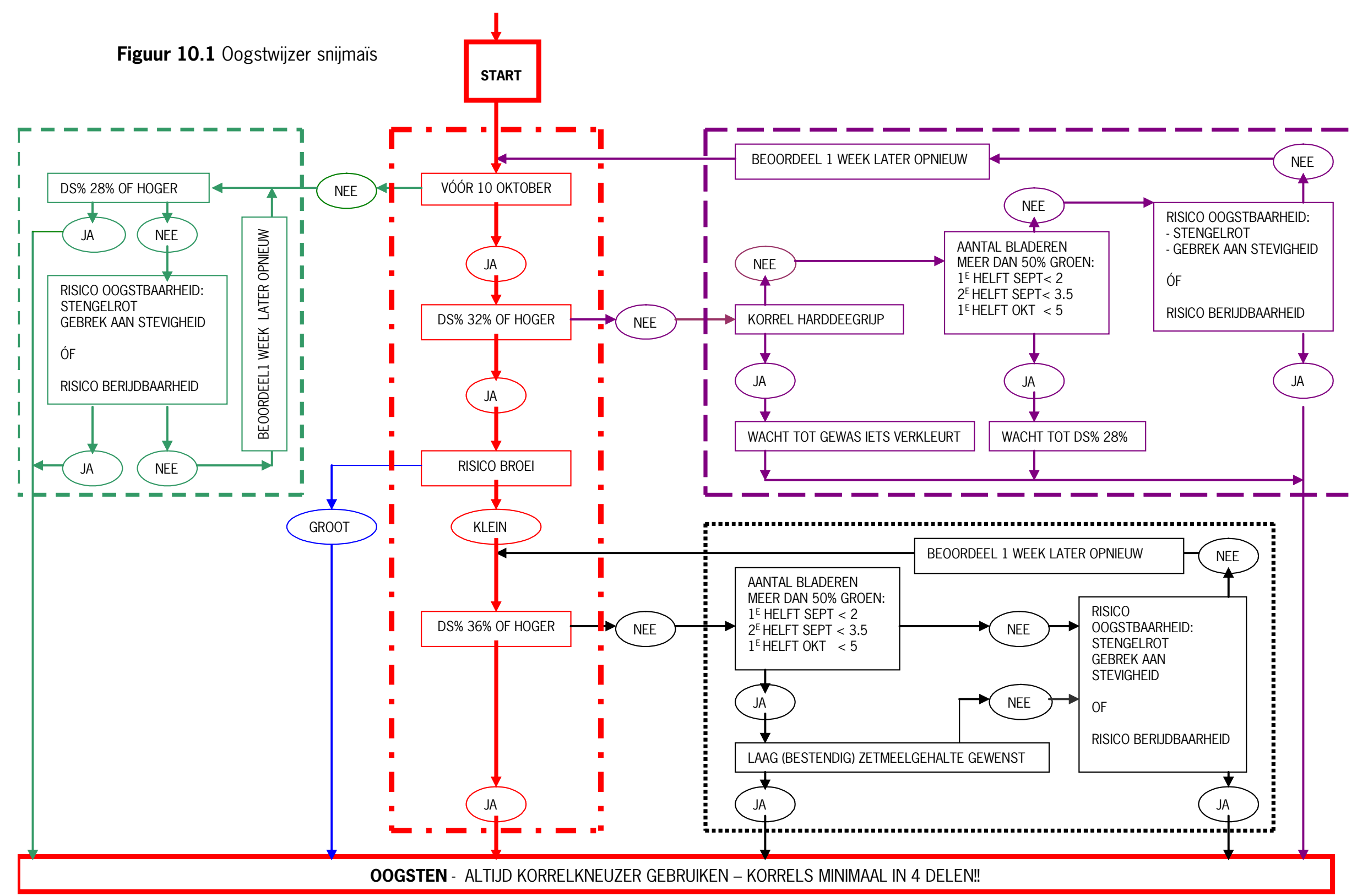




\subsubsection{Inschatting drogestofgehalte van snijmaïs}

Voor de keuze van het juiste oogstmoment is de inschatting van het drogestofgehalte van groot belang.

Het drogestofgehalte van de hele plant wordt bepaald door het kolfaandeel, het drogestofgehalte van stengel en blad en het drogestofgehalte van de kolf.

\section{Het kolfaandeel}

Het kolfaandeel is het aandeel van de kolf in de drogestof. Bij de inschatting van het kolfaandeel moet gelet worden op de groei- en gewasomstandigheden. Deze worden bepaald door enerzijds de groeiomstandigheden (weer, grondsoort en plantdichtheid) en anderzijds door de gewasomstandigheden (massaliteit van het gewas en grootte van de kolf). In onderstaande tabel 10.2 wordt de vertaling van omstandigheden naar kolfaandeel gemaakt.

Tabel 10.2 Schatting kolfaandeel

\begin{tabular}{ll}
\hline Groei- en gewasomstandigheden & $\begin{array}{l}\text { Kolfaandeel } \\
\text { op ds-basis }\end{array}$ \\
\hline $\begin{array}{l}\text { Slechte groei-omstandigheden, hoge plantdichtheid. Massaal gewas met kleine kolf. } \\
\text { Normale groei-omstandigheden, normale plantdichtheid. Massaal gewas met grote kolf of }\end{array}$ & $\begin{array}{l}40 \% \text { of lager } \\
\text { minder massaal gewas met normale kolf. }\end{array}$ \\
Goede groei-omstandigheden, lagere plantdichtheid. Minder massaal gewas met grote kolf. & $60 \%$ \\
\hline
\end{tabular}

\section{Het drogestofgehalte van stengel en blad}

Bij de bepaling van het drogestofgehalte van stengel en blad is de verkleuring van het blad en de sapstroom in de stengel bepalend. Om de mate van activiteit van de sapstroom te bepalen, moet men een aantal stengels doorsnijden en het snijvlak samenknijpen. De verkleuring van het blad kan worden uitgedrukt in aantal bladeren dat nog voor meer dan $50 \%$ groen is. In tabel 10.3 worden de relatie tussen hoedanigheid van de stengel en blad en het drogestofgehalte gegeven

Tabel 10.3 Schatting drogestofgehalte van stengel en blad

\begin{tabular}{ll}
\hline Hoedanigheid van blad en stengel & Drogestofgehalte stengel en blad \\
\hline Gehele plant nog groen en er loopt vocht uit de stengel & $18 \%$ \\
Plant $3 / 4$ groen en stengels zijn nog vochtig & $21 \%$ \\
Plant half groen en stengel praktisch droog & $24 \%$ \\
Plant $1 / 4$ groen en stengel geheel droog & $27 \%$ \\
Plant geen groene delen meer (gewas lijkt geheel dood) ${ }^{1}$ ) & $30 \%$ \\
\hline
\end{tabular}

${ }^{1}$ Indien plant al langer dood is droogt deze verder in tot $33-36 \%$ ds

\section{Het drogestofgehalte van de kolf}

Het drogestofgehalte van de kolf is te schatten op grond van de melklijn in de korrels. De melklijn is de scheiding tussen het vaste zetmeel en het melkgedeelte (zie figuur 10.2). De melklijn kan het beste beoordeeld worden aan een korrel die afkomstig is uit het midden van de kolf en die in de lengterichting is doorgesneden. In tabel 10.4 staan de verschillende rijpheidsstadia en de bijbehorende drogestofgehalten van de kolf aangegeven 
Figuur 10.2 Melklijn in de korrel

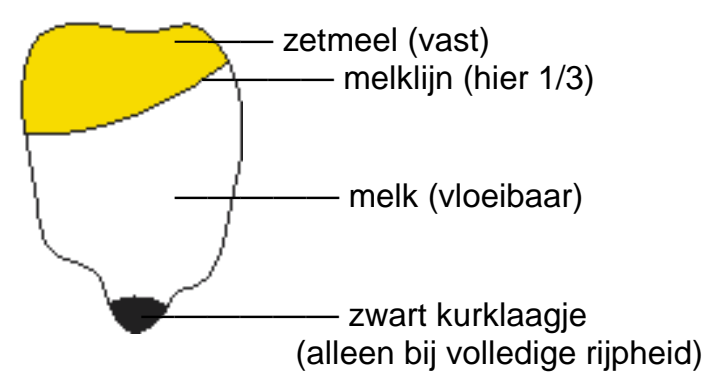

Tabel 10.4 Rijpingsstadia van maïskolven

\begin{tabular}{|l|l|l|}
\hline Stadium & Kenmerk & $\begin{array}{l}\text { Droge stof } \\
\text { Van de kolf }\end{array}$ \\
\hline Melkrijp & $\begin{array}{l}\text { korrel is witgeel, veel spanning in } \\
\text { korrel, inhoud lijkt op melk }\end{array}$ & $35 \%$ \\
\hline zachtdeegrijp & $\begin{array}{l}\text { korrel is geel, inhoud gedeeltelijk } \\
\text { deegachtig, spuit nog bij indrukken met } \\
\text { nagel }\end{array}$ & $40 \%$ \\
\hline $\begin{array}{l}\text { zachtdeegrijp } \\
\text { tot deegrijp }\end{array}$ & $\begin{array}{l}\text { korrel is donkerder geel, nog voor de } \\
\text { helft vochtig aan spilzijde, andere helft } \\
\text { inhoud is stevig }\end{array}$ & $45 \%$ \\
\hline Deegrijp & $\begin{array}{l}\text { donkergele korrel, nog vochtig aan } \\
\text { spilzijde, rest van inhoud is stevig }\end{array}$ & $50 \%$ \\
\hline Harddeegrijp & $\begin{array}{l}\text { donkergele korrel, inhoud is stevig, } \\
\text { moeilijk met nagel in te drukken en er } \\
\text { komt geen vocht meer uit, bovenkant } \\
\text { korrel is glazig of hoornig en begint in te } \\
\text { deuken. }\end{array}$ & $55 \%$ \\
\hline volledig rijp & $\begin{array}{l}\text { Harde korrel, niet meer met nagel in te } \\
\text { drukken, de glazige gedeelten zijn zo } \\
\text { hard als hoorn. Zwart kurklaagje onder } \\
\text { aan de korrel. }\end{array}$ & $60 \%$ \\
\hline
\end{tabular}

\section{Combineer en bepaal het drogestofgehalte totale plant}

In onderstaande tabel 10.5 kan het drogestofgehalte van de hele plant afgelezen worden aan de hand van de gevonden waarden voor kolfaandeel, drogestofgehalte stengel en blad en drogestofgehalte kolf. 
Tabel 10.5 Schatting drogestofgehalte (\%) van de totale plant

\begin{tabular}{|c|c|c|c|}
\hline Geschatte kolfaandeel op ds-basis (\%): & 40 & 50 & 60 \\
\hline Drogestofgehalte stengel en blad (\%): & 1821242730 & $\begin{array}{ll}18 & 21 \quad 2427 \quad 30\end{array}$ & $\begin{array}{lllll}18 & 21 & 24 & 27 & 30\end{array}$ \\
\hline \multicolumn{4}{|l|}{ Drogestofgehalte kolf (\%) } \\
\hline 35 & 2225273032 & 2426283032 & 2528303133 \\
\hline 40 & 2326293133 & $25 \quad 283032 \quad 34$ & $27 \quad 29323435$ \\
\hline 45 & 2427303235 & 2629313436 & $\begin{array}{lllll}28 & 31 & 33 & 36 & 38\end{array}$ \\
\hline 50 & 2427303336 & 2630323538 & $2932 \quad 353739$ \\
\hline 55 & 2528313437 & 2730333639 & $\begin{array}{lllll}30 & 33 & 36 & 39 & 41\end{array}$ \\
\hline 60 & 2528323538 & $\begin{array}{lllll}28 & 31 & 34 & 37 & 40\end{array}$ & $31 \quad 34384043$ \\
\hline $65^{1)}$ & 2529323538 & 2832353841 & $\begin{array}{lllll}32 & 35 & 39 & 42 & 44\end{array}$ \\
\hline
\end{tabular}

1) Nadat stadium volledig rijp (60\% ds) bereikt is kan door indroging het ds-gehalte verder oplopen tot 65 of hoger. Bestendigheid van zetmeel neemt dan ook nog toe.

\subsection{Oogstmethoden}

De meeste maïs oogst men met zelfrijdende hakselaars, die voorheen meestal waren uitgerust met een rijafhankelijke maïs-voorzetstuk, afgestemd op een rijafstand van $75 \mathrm{~cm}$. Tegenwoordig zijn de meeste hakselaars uitgerust met een rijonafhankelijk voorzetstuk. De aanschafprijs is wel wat hoger, maar de onderhoudskosten zijn veel lager en men is flexibeler wat betreft zaaimethode. Bij het openen van een perceel treedt minder verlies op en de zaairichting hoeft niet gevolgd te worden.

\subsubsection{Stoppellengte}

Afhankelijk van de vlakligging van het perceel is de optimale stoppellengte van snijmaïs $10-15 \mathrm{~cm}$. Een kortere stoppellengte is niet gewenst vanwege de grotere hoeveelheid aanklevende grond. Dit verlaagt de voederwaarde en geeft extra slijtage aan de hakselaar.

Stoppel en stengels hebben een hoger vochtgehalte dan de kolf en zijn minder goed verteerbaar. Hierdoor is het mogelijk om de opbrengst en de kwaliteit te beïnvloeden met de stoppellengte. Met iedere $10 \mathrm{~cm}$ extra stoppellengte stijgt de VEM-waarde met zes eenheden per $\mathrm{kg}$ droge stof en het drogestofgehalte met gemiddeld 0,6\% (absoluut). Daar staat tegenover dat de drogestofopbrengst met circa 2,5\% daalt. De totale voederwaardeopbrengst neemt met circa $2 \%$ af. Over het algemeen is daardoor verhoging van de stoppellengte een vrij dure methode om de voederwaarde te verhogen.

\subsubsection{Hakselkwaliteit}

De optimale haksellengte bedraagt 6-8 $\mathrm{mm}$. Een grotere haksellengte draagt nauwelijks bij aan een betere structuurvoorziening voor de koe en beïnvloed de opname nadelig (zie ook paragraaf 12.3). Bovendien geeft het grovere stukken (vooral spil) in de kuil. Hierdoor laat de kuil zich moeilijker vastrijden en na opening treedt er gemakkelijker lucht binnen. Een grotere kans op broei en schimmelvorming is het gevolg. Uit onderzoek van Wageningen Livestock Research is gebleken dat bij een haksellengte van $6 \mathrm{~mm}$ de dichtheid van de kuil gemiddeld 5-10\% hoger is dan bij een haksellengte van $15 \mathrm{~mm}$. 
Onvoldoende scherpe messen en een slechte afstelling van de messen geven een onregelmatig gehakseld product. $U$ kunt daarom het beste tijdens het hakselen een aantal keren de haksellengte en hakselkwaliteit controleren op de kuil. De lengte kan men controleren door de lengte van een aantal haaks doorgesneden stengeldelen te meten. Een slechte hakselkwaliteit uit zich in eerste instantie in lange rafelige delen droge stengel- en schutbladeren.

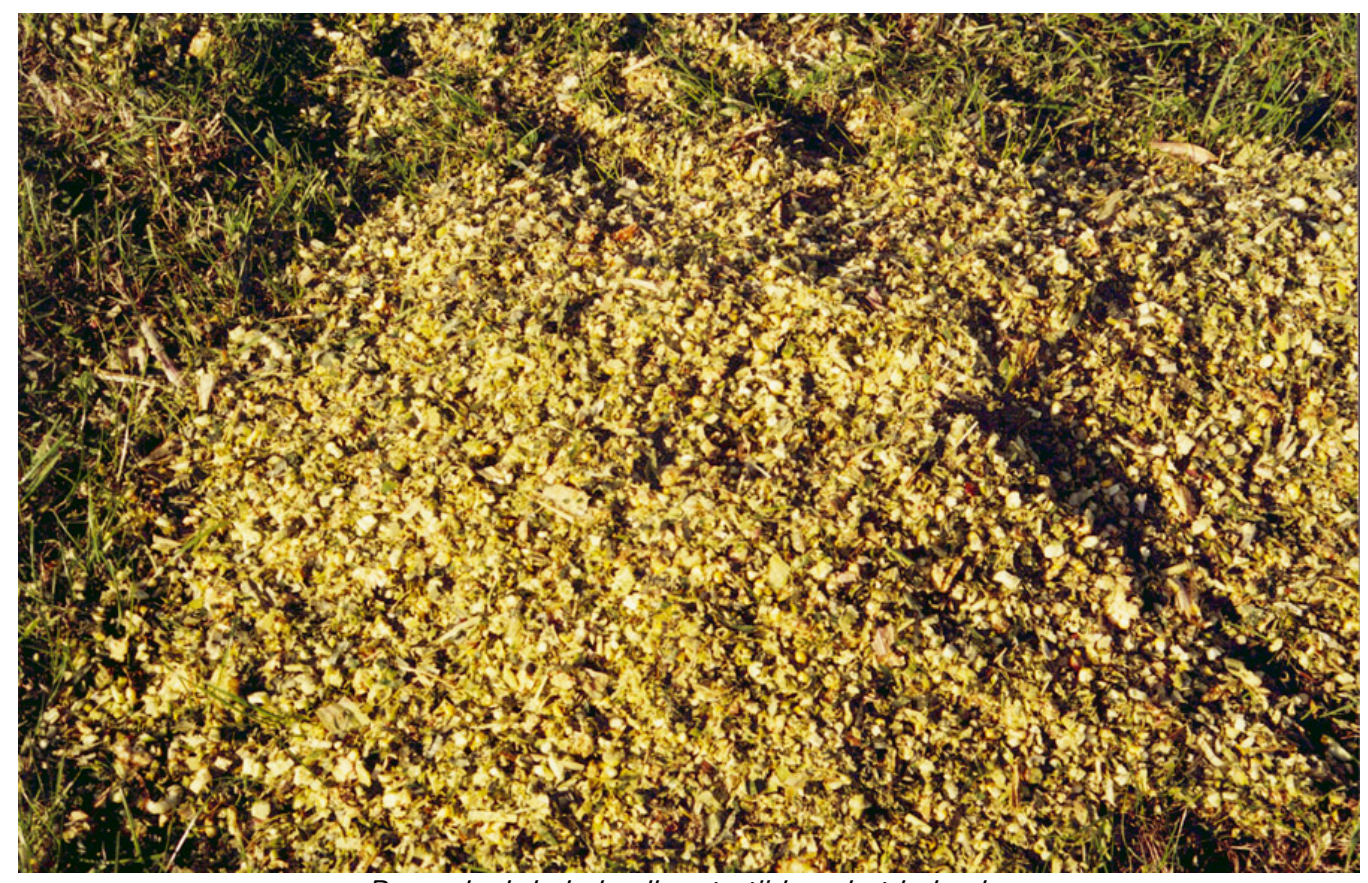

Beoordeel de haksellengte tijdens het hakselen

\subsubsection{Korrelkneuzen}

Voor een goede benutting van de snijmaïs door rundvee moeten alle korrels zodanig kapot gemaakt zijn dat de stukjes niet groter zijn dan een kwart van de korrel (zie ook hoofdstuk Voeding). Dit beschadigen kan met een rollenkneuzer, door een geribde bodemplaat onder de messenkooi of slaglijsten op de messen.

De meeste zelfrijdende hakselaars zijn uitgerust met een rollenkneuzer. Deze is achter de hakselunit gemonteerd en bestaat uit twee tegen elkaar in draaiende geribde kneusrollen. Doordat de kneusrollen met verschillende snelheden draaien, worden de korrels hiertussen stukgewreven. De structuur van de overige plantdelen wordt door de kneusrollen weinig aangetast. De afstand tussen de beide rollen is instelbaar. Hiermee regelt men de intensiteit van het kneuzen. Om goed te kneuzen moet de korrelkneuzer ingesteld kunnen worden op een minimale afstand van $1 \mathrm{~mm}$. Gebruik van een korrelkneuzer heeft gevolgen voor de capaciteit van de hakselaar. Doordat een in gebruik zijnde korrelkneuzer ongeveer 7,5 kW per rij extra vermogen vraagt, daalt de capaciteit bij een gelijkblijvend aandrijfvermogen. Bij de moderne zelfrijdende hakselaar is de korrelkneuzer vanuit de cabine in te stellen. 


\subsubsection{Shredlage hakselen}

Shredlage-hakselen is een hakseltechniek waarbij de maïs ten opzichte van de standaard hakselmethode op een grotere lengte van 25-30 mm wordt gehakseld en daarnaast intensiever wordt gekneusd. De intensievere kneuzing wordt vooral bewerkstelligd door een groter verschil in toerental tussen de kneusrollen en daarnaast door een aangepast profiel op de kneusrollen (zie ook hoofdstuk Voeding paragraaf 12.3)
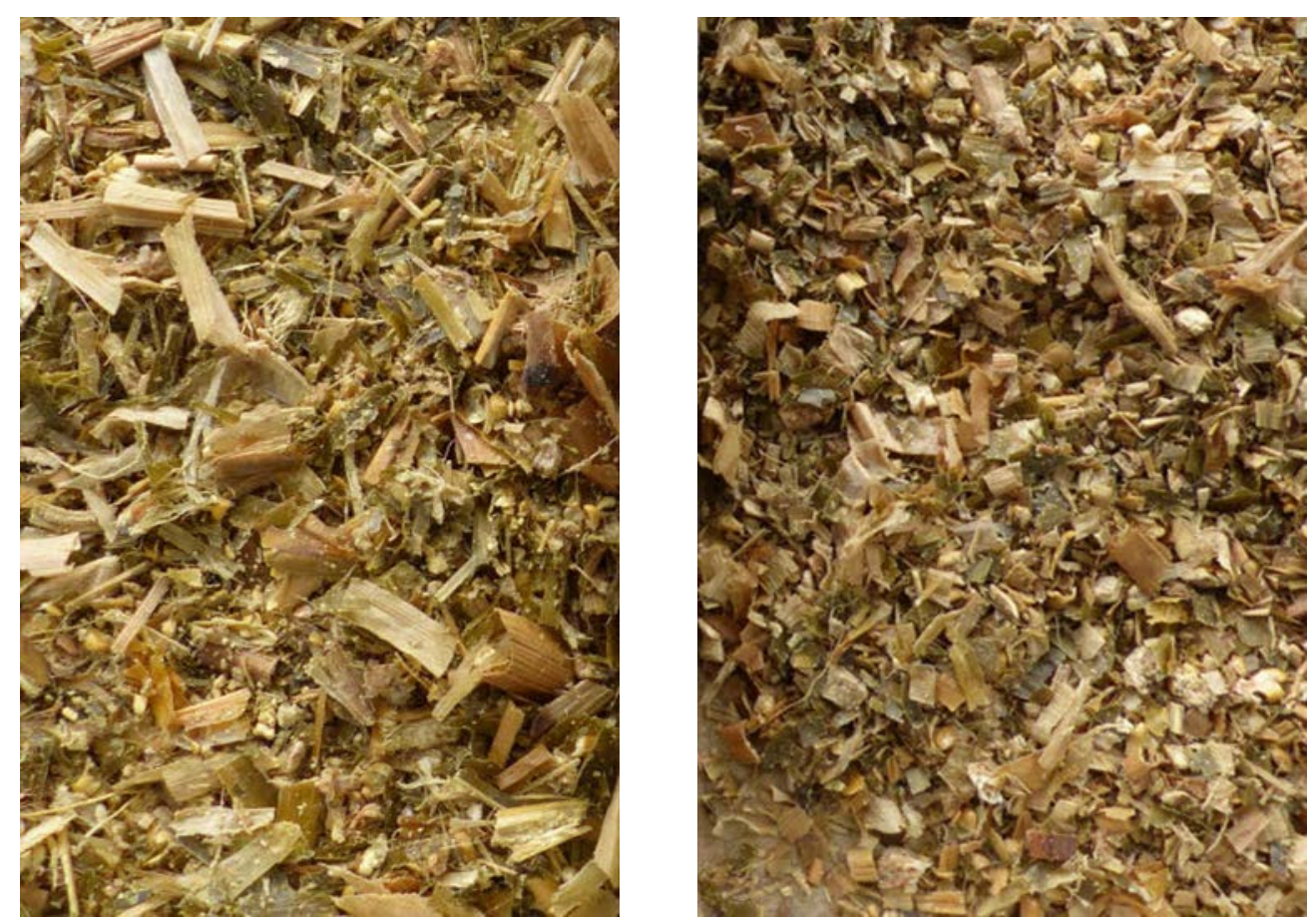

Snijmaïs gehakseld met shredlage methode (links) en volgens standaard methode (rechts) 


\section{Opslag en bewaring}

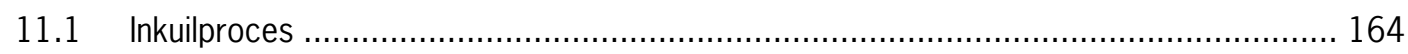

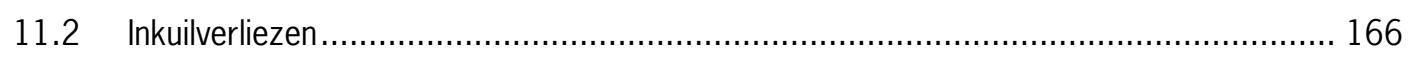

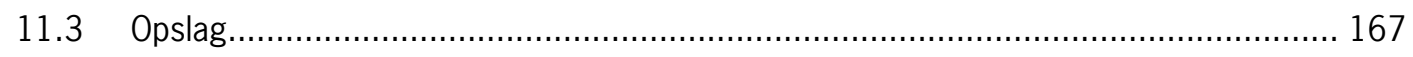

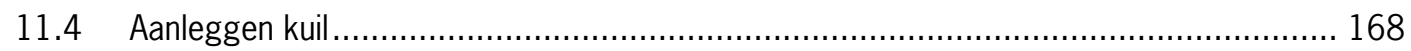

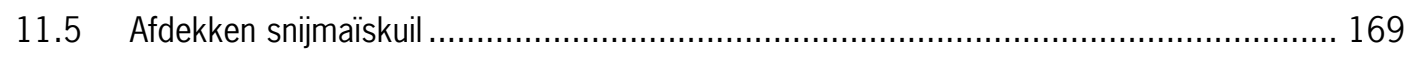

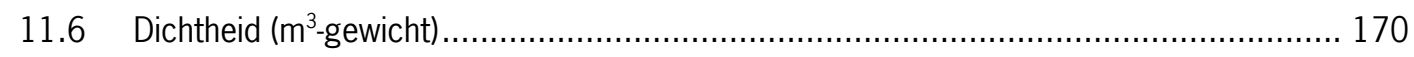

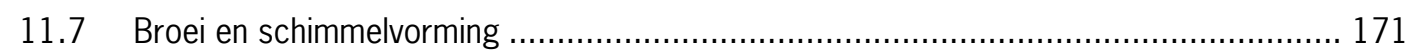

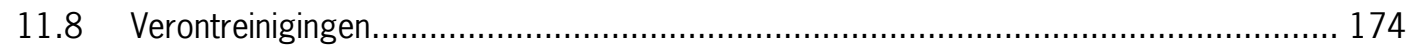

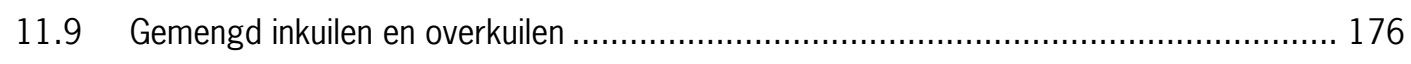




\section{Opslag en bewaring}

In dit hoofdstuk gaat de aandacht uit naar het inkuilproces en de inkuilverliezen. Ook broei, schimmelvorming en enkele verontreinigingen worden behandeld. Als laatste komen gemengd inkuilen en overkuilen van maïs nog aan de orde.

\subsection{Inkuilproces}

Bij het inkuilen van maïs wordt het luchtdicht afgedekt en ontstaat een anaërobe (zonder zuurstof) fermentatie. Tijdens deze fermentatie is er een snelle ontwikkeling van melkzuurbacteriën. Deze bacteriën zijn van nature aanwezig. De pH daalt daarbij zo snel dat schadelijke boterzuur- en rottingsbacteriën geen kans krijgen. De kuil is dan stabiel. De pH in een normale snijmaïskuil ligt meestal tussen 4,0 en 4,2. Komt de melkzuurvorming om een of andere reden (bijvoorbeeld te lang lucht aanwezig) niet goed op gang, dan kunnen de schadelijke bacteriën zorgen voor een conservering die niet goed verloopt en er kunnen grote verliezen ontstaan. Bij het inkuilen moeten daarom alle maatregelen erop gericht zijn de melkzuurbacteriën in een gunstige concurrentiepositie te brengen ten opzicht van de ongewenste bacteriën.

\section{Inkuilbaarheid snijmaïs}

Snijmaïs is een product wat zich goed laat conserveren door:

- $\quad$ voldoende suiker en melkzuurbacteriën. Door het hakselen komen suikers beschikbaar voor de melkzuurbacteriën waardoor de $\mathrm{pH}$ in de kuil snel daalt tot 4,0-4,2;

- $\quad$ het lage eiwit- en mineralengehalte. Eiwit vertraagt de verzuring (bufferwerking). Producten met veel eiwit zoals jong gras, zijn daardoor moeilijker te conserveren;

- $\quad$ de betrekkelijke lage temperaturen in de herfst, waardoor boterzuurbacteriën minder actief zijn.

Snijmaïskuil bevat door de goede conservering heel weinig of geen boterzuur en de $\mathrm{NH}_{3}$-fractie is laag. Bij de analyse van ingekuilde snijmaïs wordt de $\mathrm{NH}_{3}$-fractie daarom ook niet bepaald. Bij een goede wijze van inkuilen wordt in circa 2 weken voldoende melkzuur gevormd voor een stabiele kuil. De hoeveelheid melkzuur is mede afhankelijk van het drogestofgehalte, maar ligt meestal rond de $2 \%$ (in het product). Bij langzaam inkuilen (langer dan 1 dag) of na toetreden van lucht in de kuil stijgt de temperatuur in de kuil. Dit leidt tot meer azijnzuur en minder melkzuur. De conservering verloopt dan niet optimaal en het product wordt door de scherpere geur minder smakelijk voor het vee. Om de kuil voldoende te laten afkoelen verdient het de voorkeur om het 4 weken dicht te laten. 


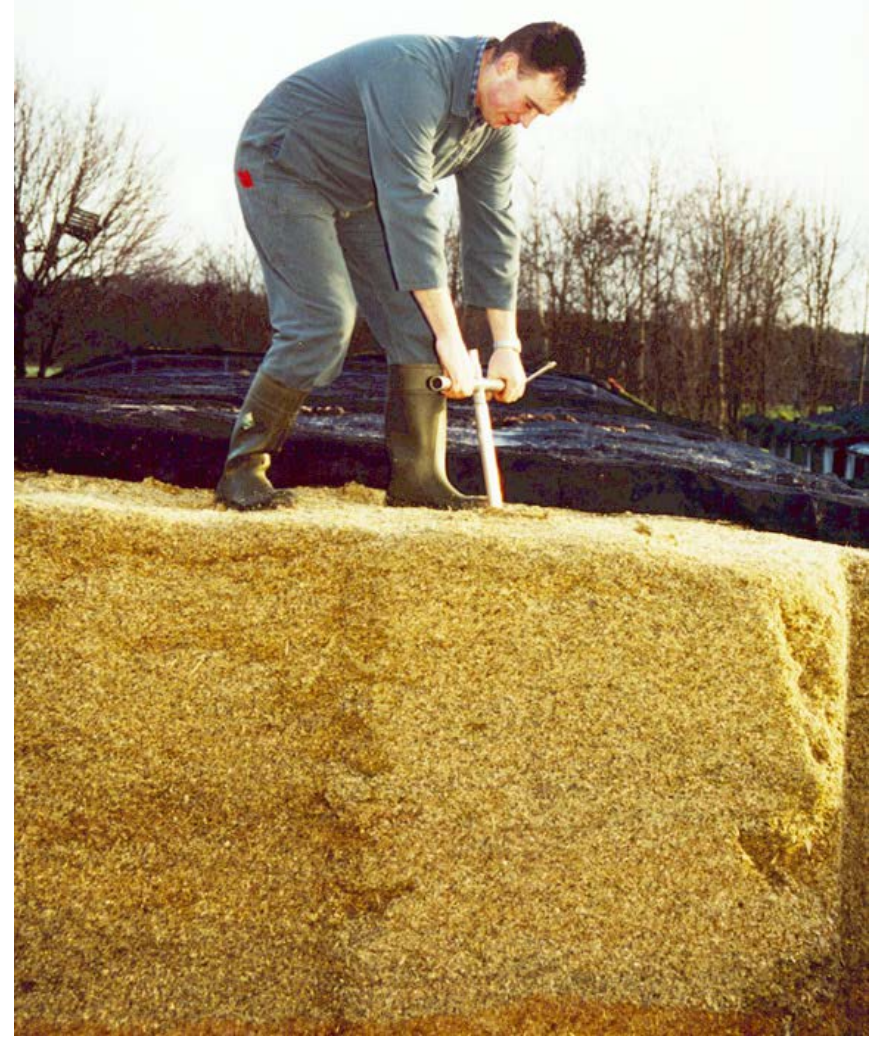

Snijmaïs laat zich goed conserveren

\section{Gasvorming}

Soms ontstaat kort na het afdekken van de maïskuil een sterke gasontwikkeling. Het plastic zeil kan daarbij zo bol komen te staan dat "aftappen" noodzakelijk is. Dit wordt veelal veroorzaakt door te vroeg geoogste maïs met nog veel groene plantdelen en een relatief laag drogestofgehalte. Ook wanneer maar een klein deel van de kuil dergelijke maïs bevat, bijvoorbeeld door schaduwwerking door houtwallen, kan al gasvorming ontstaan. Daarnaast wordt gasvorming bevordert door een zware bemesting en broei als gevolg van te langzaam inkuilen. Door de minder goede conservering ontstaat er extra koolzuur en waterstofgas, terwijl het nitraat (afkomstig uit de groene plantendelen) wordt afgebroken tot nitriet en andere stikstofverbindingen. Dit gasmengsel (nitreuze dampen) is geel/bruin van kleur en erg giftig. Bij inademen of contact met de huid kan er longbeschadiging respectievelijk huidbeschadiging (verbranding) optreden.

Wanneer een sterke gasontwikkeling in een kuil ontstaat, maak dan het plastic aan de zijkanten los en laat het gas ontsnappen. Omdat het een zwaar gas is, stroomt het over het grondvlak weg. Wanneer dit gas in aanraking komt met planten, kan verbranding (geelverkleuring) optreden. Hiermee dient rekening te worden gehouden bij de keuze van de plaats om af te tappen. Kort na het aftappen moet men de kuil weer luchtdicht afdekken. Soms is herhaling nodig.

Snijmaïskuilen met een sterke gasontwikkeling leveren geen gevaar op voor het vee bij de vervoedering. Ook de kwaliteit van deze snijmaïs wordt weinig of niet nadelig beïnvloed. De zijkanten 
van dergelijke kuilen zijn vaak oranje/bruin verkleurd. Gasvorming kan men voorkomen door de snijmaïs normaal te bemesten, op het juiste tijdstip te oogsten en snel en zorgvuldig in te kuilen.

\subsection{Inkuilverliezen}

Verliezen in de kuil ontstaan door ademhaling van de maïs in de beginfase van het conserveringsproces en door omzettingen van koolhydraten en eiwitten in organische zuren en ammoniak. Daarnaast kunnen bij vochtig snijmaïs (minder dan 32\% droge stof) verliezen optreden via het perssap. Bij voldoende droge snijmaïs zijn ook de verliezen door omzettingen beperkt zijn. Er is dan minder melkzuur nodig om een goed geconserveerde kuil te krijgen dan bij nattere maïs. Het drogestofgehalte van de snijmaiis bij het inkuilen is vooral bepalend voor de omvang van de verliezen (figuur 11.1 ). Uit onderzoek van de Wageningen Livestock Research en Wageningen Plant Research in 2003 en 2004 bleek dat er geen verschil was tussen de verschillende rastypen. De verliezen gelden bij een goede wijze van inkuilen en bewaren. Is dit niet het geval, dan kunnen de verliezen sterk stijgen door het optreden van broei, schimmel en rotting.

Bij de verliezen kan er onderscheid worden gemaakt tussen verliezen aan drogestof en voederwaarde (VEM). De VEM-verliezen zijn altijd hoger dan de drogestofverliezen, met name bij vochtig snijmaïs. Dit komt doordat bij het gistingsproces en met het perssap de best verteerbare stoffen het eerst verloren gaan. Daardoor daalt de verteerbaarheid van de droge stof en dus ook de VEM-waarde van het geconserveerde product.

Figuur 11.1 Relatie inkuilverliezen en droge stofgehalte bij inkuilen

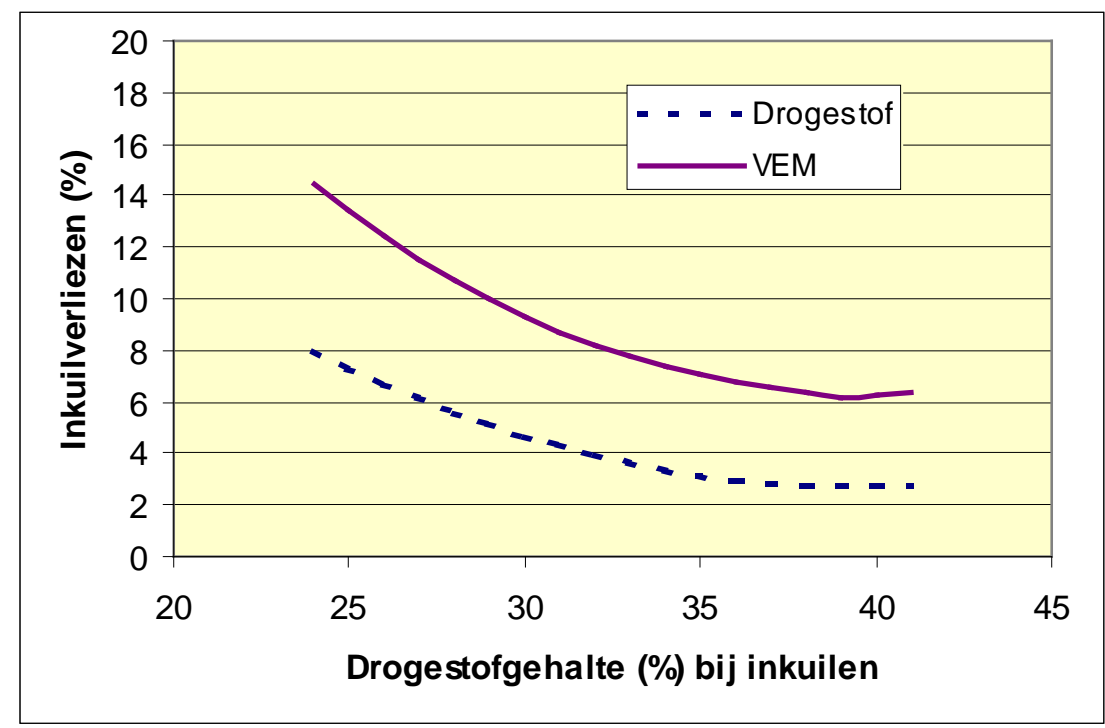

Uit genoemd inkuilonderzoek bleek dat er wel een verschil was in perssapverliezen tussen de stay green en dry down typen (zie figuur 11.2) . De perssapgrens (het drogestofgehalte waarboven geen perssapverliezen meer optreden) lag bij de dry down typen op 31\% en bij stay green typen op $32,5 \%$. Ook kwam bij de stay green rassen meer perssap vrij wanneer de maïs onvoldoende droog 
werd ingekuild. Bij $28 \%$ drogestof was de hoeveelheid perssap 14 en 25 I per ton voor resp. dry down en stay green typen. Dit komt bij een normale opbrengst van 15 ton drogestof per ha ongeveer overeen met 0,75 en 1,3 $\mathrm{m}^{3}$ per ha. De verschillen in perssap waren te klein om verschillen in voederwaardeverliezen te kunnen meten. Dit komt ment name door het lage drogestofgehalte van perssap. Toch is het zinvol voor de praktijk om perssap te voorkomen in verband met kans op slechtere opname en milieuproblematiek.

Figuur 11.2 Invloed van drogestofgehalte bij inkuilen op hoeveelheid perssap

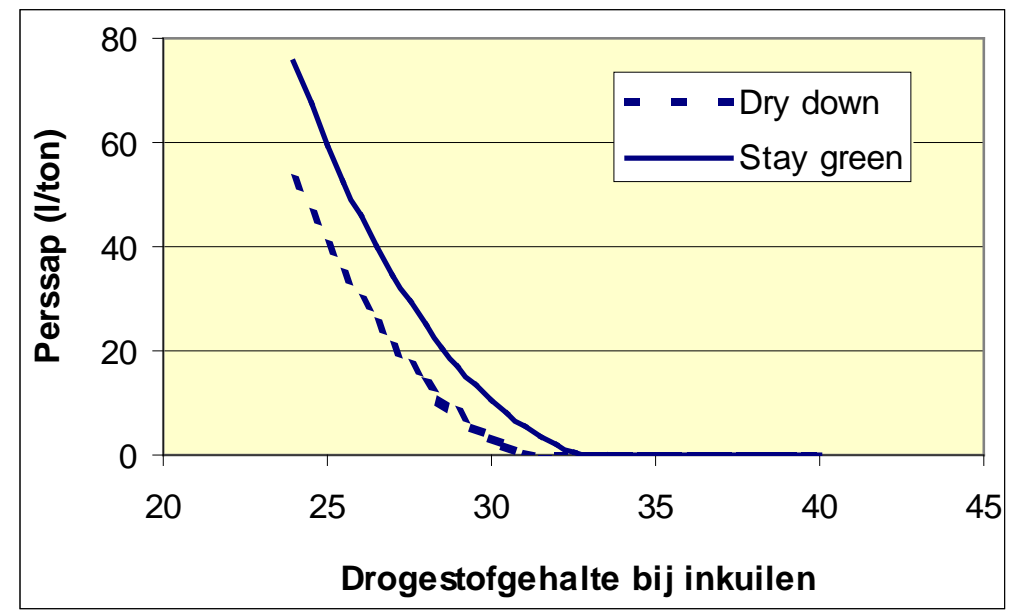

\subsection{Opslag}

Bij de opslag van snijmaïs moet men in de eerste plaats zorgen voor een lucht- en waterdichte afsluiting. Daarnaast is een verharde (betonnen) ondergrond nodig om de snijmaïs schoon en gemakkelijk in de kuil te brengen en er weer uit te halen. Zowel rijkuilen als sleufsilo's zijn prima geschikt voor de opslag.

\section{Rijkuil of sleufsilo}

Rijkuilen en sleufsilo's hebben beide voor- en nadelen. Bij rijkuilen zijn de investeringen voor verharding geringer. Daarnaast zijn plaats en afmetingen van rijkuilen minder definitief dan bij sleufsilo's. Opslag in rijkuilen vraagt echter meer oppervlakte en plastic. Bij opslag van meer dan ongeveer 60 ton droge stof snijmaïs zijn de jaarlijkse kosten van sleufsilo's gelijk of lager dan van rijkuilen. Bij geringere hoeveelheden is een rijkuil op verharding doorgaans goedkoper. In sleufsilo's is het kuilvoer beter (incl. zijkanten) te verdichten waardoor de kuil iets minder broeigevoelig is dan een rijkuil.

Het afdekken van sleufsilo's vraagt vooral bij tussentijds bijvullen extra werk dan bij rijkuilen. Dit speelt echter bij snijmaïs nauwelijks een rol, omdat het meestal in één keer geoogst wordt. 


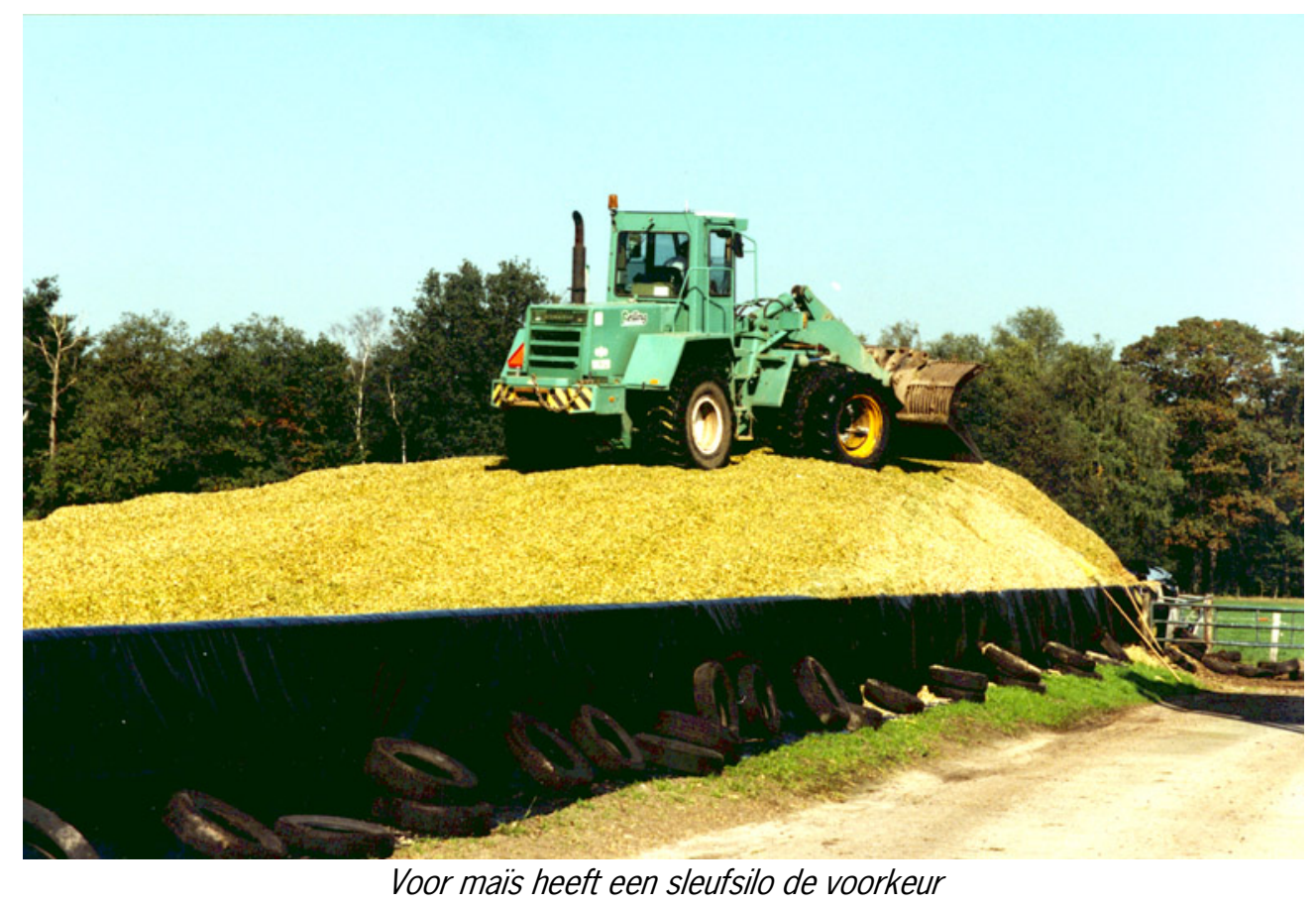

\section{Afmetingen}

De afmetingen van de rijkuil of sleufsilo hangen af van de voersnelheid die vereist is om de kans op broei en schimmel tot een minimum te beperken of te voorkomen. Bij het afdekken van het kuilvoer met een gronddek bedraagt de minimale voersnelheid 1,50 m per week, terwijl zonder gronddek een minimale voersnelheid van 2,00 $\mathrm{m}$ is vereist. Bij zelfvoedering is een voersnelheid van minimaal 1,25 $m$ vereist. Het is dus belangrijk dat men vóór het inkuilen nagaat welke afmetingen van de rijkuil of sleufsilo passen bij de bedrijfssituatie. De gewenste afmetingen van de kuil of silo kunnen vrij goed berekend worden als de hoeveelheid snijmaïskuil per $\mathrm{m}^{3}$ bekend is (zie tabel 11.2).

Tegenwoordig wordt op veel bedrijven snijmaïs bijgevoerd in de zomer. De voersnelheid is dan vaak lager dan in de winter, terwijl de buitentemperatuur hoger is. Het advies is om voor bijvoedering in de zomer een aparte smallere kuil te maken of om in het voorjaar de resterende maïs over te kuilen en opnieuw te verdelen over de kuilverharding om zodoende een hogere voersnelheid te krijgen.

\subsection{Aanleggen kuil}

Om rijkuilen en sleufsilo's te kunnen afdekken en de ruimte goed te benutten zodat een goed geconserveerd product wordt verkregen, zijn bij het inkuilen een aantal zaken van belang:

Bij sleufsilo's is het gewenst om stroken plastic langs de wanden aan te brengen (figuur 11.3) om een goede afdichting in de bovenhoeken te krijgen.

- De kuil opbouwen in dunne lagen en direct goed vastrijden geeft de beste verdichting. Shovel of zware trekker moeten continu blijven rijden.

- Maak de kuil in een zo kort mogelijke periode (maximaal 1 dag) en sluit de kuil direct luchtdicht af.

- $\quad$ Zet de rijkuil iets smaller op dan de uiteindelijke breedte. De kuil wordt door vastrijden altijd wat breder. 
- $\quad$ Zet bij rijkuilen de zijkanten schuin op om de kuil goed te kunnen afdekken. Bij rijkuilen zonder gronddek mag de zijkant steiler (circa 60 graden) zijn, dan bij rijkuilen met gronddek (circa 45 graden).

- $\quad$ Haal tijdens het opzetten van rijkuilen het losse product langs de zijkanten steeds weg. Daarmee voorkomt u dat de kuil te veel wordt "uitgereden" en te breed wordt met te steile zijkanten.

- Houd bij sleufsilo's het kuilvoer langs de wanden altijd iets hoger dan in het midden, dus hol vullen (zie figuur 11.1). De kanten worden dan beter vastgereden en de kans op beschadiging van de wanden en folie door de trekker is kleiner.

- Sleufsilo's moeten goed en gelijkmatig tot net boven de wanden worden gevuld om langs de wanden een goede lucht- en waterdicht afsluiting te kunnen maken.

- Werk rijkuilen en sleufsilo's aan de bovenkant glad en rond af. Het plastic kan men dan strak over het kuilvoer spannen en er blijt geen water op de kuil staan.

- $\quad$ Werk de op- en afritten zoveel mogelijk weg. Dit bespaart ruimte en plastic.

Figuur $\mathbf{1 1 . 3}$ Het hol vullen van een sleufsilo

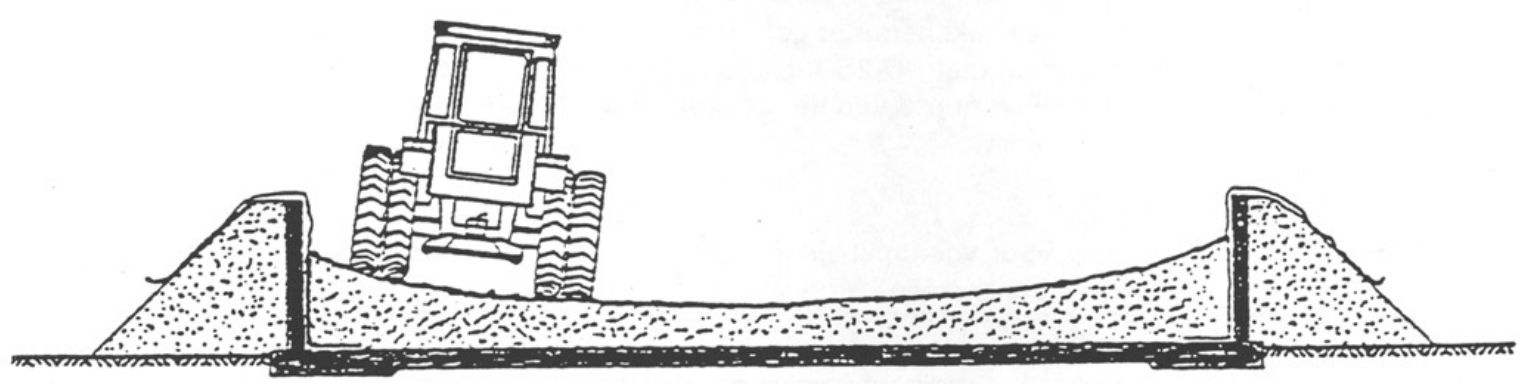

\subsection{Afdekken snijmaïskuil}

\section{Met gronddek}

Snijmaïs kan het beste afgedekt worden met een polyethyleen(PE) zeil van ongeveer 0,15 mm dik met daarop een gronddek van $10-15 \mathrm{~cm}$. Het plastic zorgt voor de lucht- en waterdichte afsluiting. Het gronddek beschermt het plastic tegen beschadiging en verhoogt de dichtheid met name van de buitenkant van de kuil, waardoor de kans op broei bij het voeren minder is. De zijkanten van de kuil dienen voldoende schuin opgezet te zijn om het plastic volledig met grond te kunnen bedekken.

\section{Zonder gronddek}

Bij het afdekken zonder gronddek moet men twee PE-folie's over elkaar leggen (figuur 11.4). Beide folie's moeten aan de zijkanten apart vastgelegd worden met een kraag zand of zandslurven. Voor extra bescherming tegen bijvoorbeeld honden, katten, vogels, ongedierte en wind, kan men nog een speciaal beschermzeil over de PE-folie's aanbrengen. Belangrijk is dat de folie's strak over het kuilvoer blijven liggen en regelmatig op beschadigingen worden gecontroleerd. Eventueel kan men zandslurven of kunststofbanden (met zandzakken of spannen aan de sleufsilomuur) gebruiken om invloed van wind te beperken. Aardappelbijproducten als toplaag over de maïs kunnen een hulpmiddel zijn om extra druk te geven en broei te voorkomen. 
Figuur 11.4 Wijze van afdekken van een sleufsilo met uitsluitend plastic

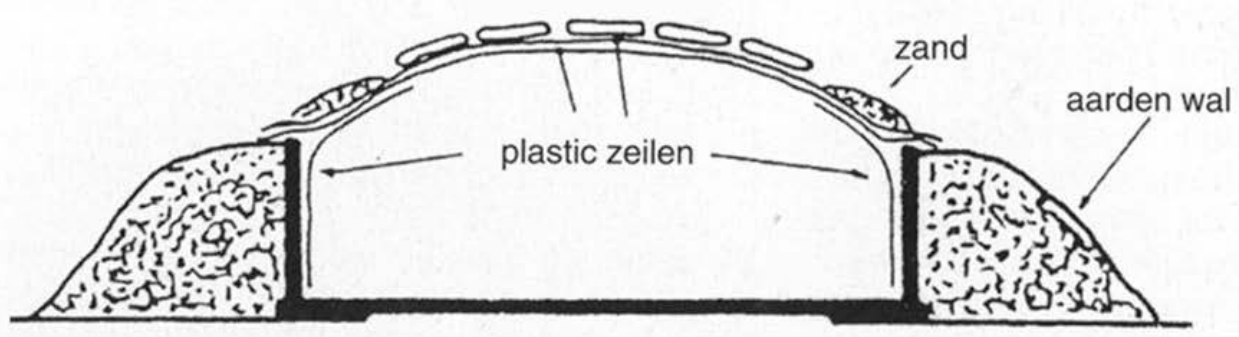

\subsection{Dichtheid ( $m^{3}$-gewicht)}

De dichtheid (in $\mathrm{kg}$ droge stof per $\mathrm{m}^{3}$ ) kan in snijmaïskuil sterk variëren onder invloed van onder andere stapelhoogte, afdekking, drogestofgehalte, haksellengte en mate van vast rijden. In tabel 11.1 zijn voor een aantal situaties de $\mathrm{m}^{3}$-gewichten van snijmaïskuil weergegeven. De dichtheid is weergeven als een gemiddelde van een kuil. Binnen een kuil is de dichtheid afhankelijk van de plek. Midden onderin is de dichtheid hoger dan aan de kanten. Met deze cijfers, het aantal dieren en de benodigde hoeveelheid snijmaïskuil per dier, zijn de gewenste afmetingen van de opslag redelijk te bepalen.

Tabel 11.1 Hoeveelheid snijmaïs ( $k g$ droge stof) per $\mathrm{m}^{3}$ van snijmaïskuil met gronddek

\begin{tabular}{|c|c|c|c|c|c|c|}
\hline \multirow{2}{*}{$\begin{array}{l}\text { Stapelhoogte: } \\
\text { Opslag in: }\end{array}$} & \multicolumn{2}{|c|}{$<1,30 \mathrm{~m}$} & \multicolumn{2}{|c|}{$1,30-1,80 \mathrm{~m}$} & \multicolumn{2}{|c|}{$>1,80 \mathrm{~m}$} \\
\hline & rijkuil & sleufsilo & rijkuil & sleufsilo & rijkuil & Sleufsilo \\
\hline$<25 \%$ droge stof & 210 & 220 & 220 & 235 & 235 & 245 \\
\hline $25-30 \%$ droge stof & 220 & 235 & 235 & 245 & 245 & 260 \\
\hline $30-35 \%$ droge stof 2 & 235 & 245 & 245 & 260 & 260 & 270 \\
\hline
\end{tabular}

${ }^{1}$ Bij opslag zonder gronddek is de dichtheid circa $5 \%$ lager

2 Boven de 35\% droge stof kan de dichtheid weer afnemen, met name bij kuilen zonder gronddek

\section{Andere methoden van inkuilen}

\section{Slurven}

Sinds een tiental jaren is het mogelijk om voer in plastic slurven in te kuilen. Dit gebeurt met een speciale machine die de gehakselde maïs in een langwerpige plastic worst perst. De doorsnee van de slurven is meestal circa $1,90 \mathrm{~m}$. De kosten van dit systeem zijn flink hoger dan van rijkuilen of sleufsilo's. Het systeem is daarom alleen interessant bij lage voersnelheden (2- 3 ton/week) en wanneer er onvoldoende ruimte is voor een rijkuil.

Ronde balen

Tegenwoordig is het ook mogelijk om maïs in te kuilen in ronde balen. Een speciale machine maakt deze balen van gehakselde maïs en wikkelt deze in plastic folie. Dit systeem is echter nog duurder dan het inkuilen in slurven. Het systeem past men wel toe wanneer er zeer kleine porties worden gevoerd, bijvoorbeeld door schapen-, geiten- en paardenhouders. Een voordeel is dat ronde balen gemakkelijk zijn te transporteren. 


\subsection{Broei, schimmelvorming en mycotoxinen}

In snijmaïskuil treedt gemakkelijk broei en schimmelvorming op. De oorzaak hiervan is lucht in het kuilvoer tijdens de bewaring en de vervoedering. Daardoor worden de diverse soorten bacteriën en schimmels weer actief en gaan zich vermeerderen. Dit leidt tot afbraak van voedingsstoffen en tot productie van warmte. De verliezen nemen toe naarmate de broei langer duurt en de temperatuur meer stijgt. In broeiend kuilvoer kunnen de verliezen aan voederwaarde 2-3\% (20-30 VEM) per dag bedragen. Daarnaast wordt het product minder smakelijk. Een vermindering van de drogestofopname met $10-20 \%$ is mogelijk. Uit onderzoek van NIZO food research bleek dat bij $50 \%$ van de kuilen waarvan gevoerd werd plekken voorkwamen met hoge aantallen sporen van boterzuurbacteriën (> 10.000 per gram voer). Geconcludeerd werd dat broei en schimmel als gevolg van luchttoetreding tijdens het bewaren en voeren hierbij een rol spelen.

\section{Maatregelen tegen broei}

Om broei en schimmelvorming in snijmaïskuil te voorkomen of te beperken dient men eerst de richtlijnen in acht te nemen die in de paragrafen $11.3 \mathrm{t} / \mathrm{m} 11.5$ zijn vermeld. Tijdens het uithalen en voeren kan men daarnaast de volgende maatregelen nemen:

- Tijdens het uithalen voorkomen dat de lucht tussen het plasticzeil en het voer ver de kuil kan binnendringen. Door een rij zandslurven vlak achter het snijvlak te leggen kan dit worden voorkomen.

- $\quad$ Tijdens de vervoedering voor een glad snijvlak zorgen. Minstens tweemaal per week voer uit de kuil halen en de kuil (zeker in de winterperiode) zo mogelijk tussentijds afsluiten. In de zomerperiode kan de kuil beter open blijven. Dit voorkomt dat de temperatuur en de luchtvochtigheid achter het plastic (vooral bij zwart plastic) erg hoog worden (broeikaseffect).

Het gebruik van broeibestrijdingsmiddelen is meestal niet nodig als bovenstaande maatregelen in acht worden genomen. Alleen in bijzondere situaties zoals vervoederen van kleine hoeveelheden of bij zeer droge snijmaïs in de zomerperiode, kunnen broeibestrijdingsmiddelen zinvol zijn. Als

broeibestrijdingsmiddelen kunnen chemische middelen (meestal op basis van propionzuur) of speciale bacteriemengsels met heterofermentatieve melkzuurbacteriën worden toegepast. Deze middelen remmen de activiteit van de micro-organismen. De kans op broei kan men verkleinen door tijdens het hakselen van de laatste vrachten die over de kuil komen een middel toe te voegen (bovenste 0,5 m). Met de chemische middelen kan eventueel alleen een toplaagbehandeling worden toegepast met een gieter, voorzien van een sproeiboom. Het effect hiervan is echter welk kleiner. Bij toepassing van een middel op basis van propionzuur tijdens het hakselen ligt de adviesdosering rond de 3 tot 4 liter per ton en bij een toplaagbehandeling op 0,5-0,75 I per $\mathrm{m}^{2}$.

Wanneer er toch broei en schimmel in het kuilvoer optreedt dan kan men de volgende maatregelen overwegen:

- De broeiende kuil luchtdicht afsluiten en laten afkoelen en een andere kuil open maken. Men kan ook dezelfde kuil aan de andere kant openen.

- $\quad$ Het broeiende gedeelte (2-4 m) uit de kuil halen en apart inkuilen (evt. met een broeibestrijdingsmiddel) en met het koelere gedeelte van de kuil verder gaan, dus een "herstart" maken.

- Bij kuilen met een te lage voersnelheid de gehele kuil openmaken en de bovenlaag van de kuil eraf halen, opnieuw inkuilen en alles weer goed afdekken. Door de geringere hoogte van de kuil neemt de voersnelheid weer toe. 


\section{Bijzondere schimmels}

Meestal ontstaat schimmelvorming aan de buitenkant van de kuil door toetreding van lucht. In snijmaïskuil ziet men soms ook schimmels met opvallende kleuren midden in een goed geconserveerde en bewaarde kuil. Het gaat hierbij om de schimmels Penicillium roqueforti, Monascus ruber en Chrysonilia sitophila.

\section{Penicillium roqueforti}

De Penicillium roqueforti vormt blauwgroene bollen met een doorsnede van 10-20 cm. De schimmelbollen komen vooral voor in het bovenste gedeelte (geringe dichtheid) van de kuil, maar meestal niet in de buitenste laag van 0-15 cm (te koud). Deze schimmel kan bijna zonder zuurstof groeien en kan een gifstof vormen. Bij onderzoek in de praktijk is deze gifstof echter zelden aangetroffen. Over de groeiomstandigheden van deze schimmel is nog niet alles bekend. Wel blijkt dat de schimmel vooral voorkomt in kuilen met een lage voersnelheid. De indruk bestaat dat de schimmel als het ware "vooruit loopt" in de kuil en vooral groeit in de eerste 1 à $2 \mathrm{~m}$ achter het snijvlak. Tot nu toe hebben zich bij het voeren van dergelijk kuilvoer nog geen duidelijke problemen voorgedaan. Schimmelvorming leidt tot een minder smakelijk product met een lagere voederwaarde. Het is daarom raadzaam om de blauw/groene schimmelbollen eruit te halen en niet te vervoederen. Een goed vastgereden kuil, een luchtdichte bewaring en een ruime voersnelheid tijdens de vervoedering kan het optreden van deze schimmel beperken of zelfs geheel voorkomen.

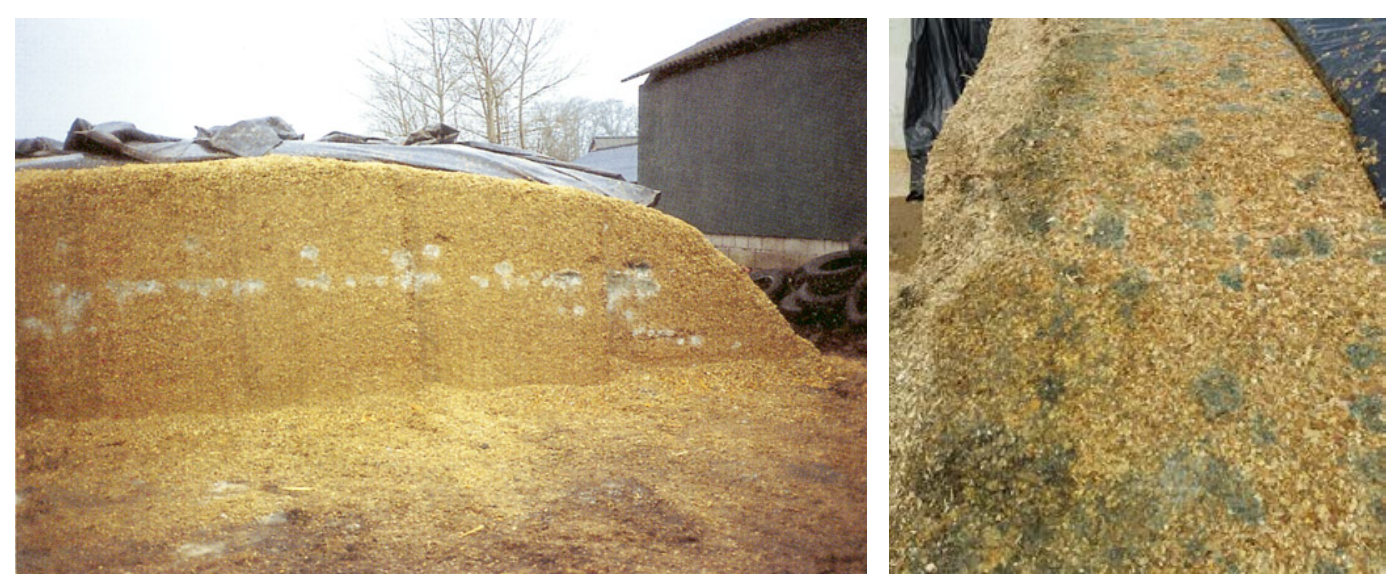

De blauwgroene bollen van de Penicillium roqueforti schimmel komt meestal net onder de buitenlaag voor (links), maar een enkele keer ook in de buitenlaag (rechts)

\section{Monascus ruber}

De Monascus ruber vormt roodpaarse bollen in de snijmaïskuil. De schimmel groeit onder dezelfde omstandigheden in de kuil als de blauwgroene schimmel. De Monascus produceert vrijwel zeker geen gifstof en is dus niet direct schadelijk. Ook hier adviseren we de schimmelbollen te verwijderen bij het uithalen of het voeren, maar eerst zorgen voor een goede bewaring en voldoende voersnelheid.

\section{Chrysonilia sitophila}

De Chrysonilia sitophila is een oranjekleurige schimmel die vooral voorkomt op het snijvlak van de kuil of blokken kuilvoer waarin al enige broei zit. De schimmel groeit vooral bij hogere temperaturen (25$30^{\circ} \mathrm{C}$ ) en kan in enkele dagen zeer veel oranjekleurige sporen vormen. Deze explosieve groei leidt tot extra broei en snelle achteruitgang in kwaliteit (verrotting). De schimmel staat als niet giftig bekend. 


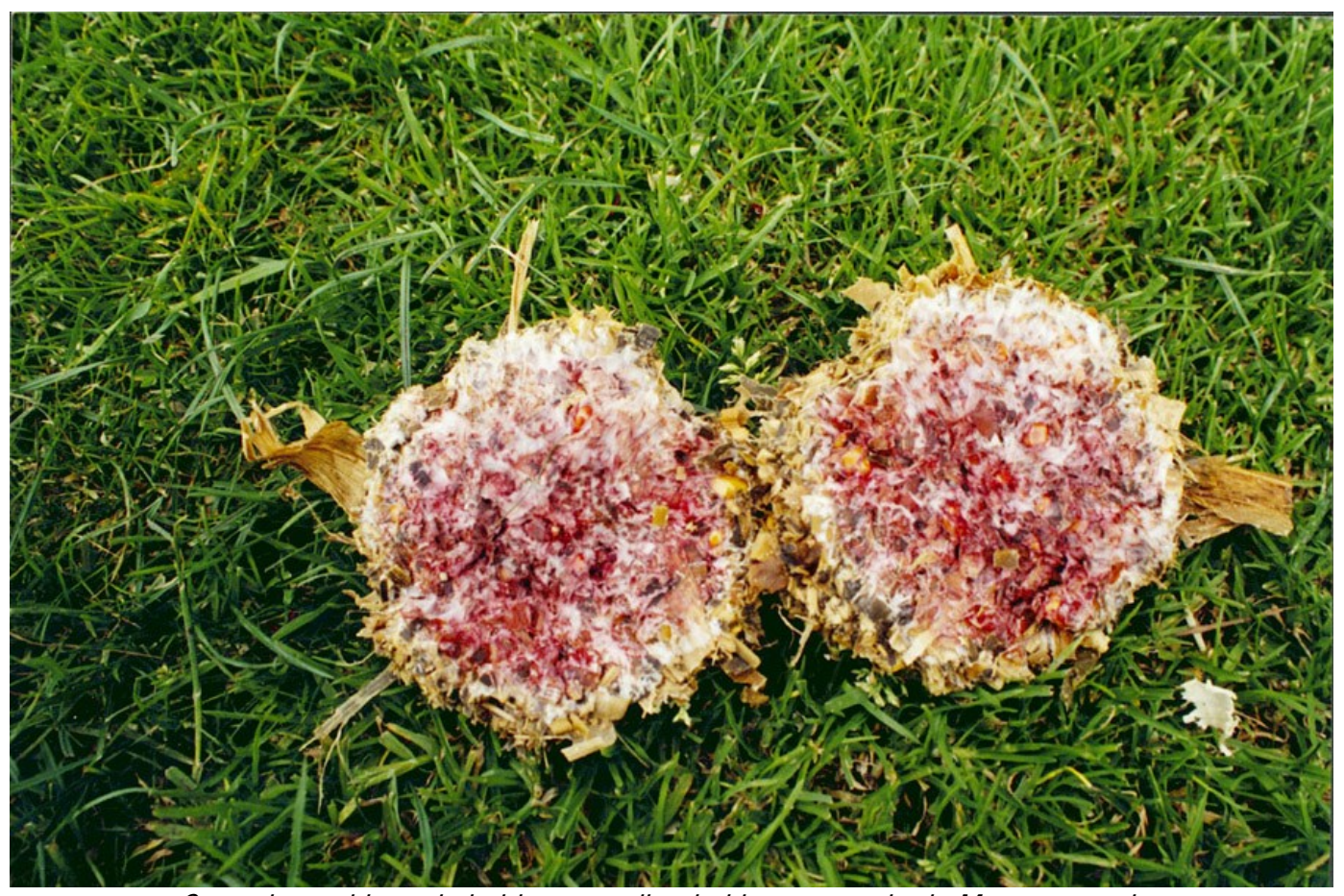

Sommige schimmels hebben opvallende kleuren, zoals de Monascus ruber

\begin{abstract}
Mycotoxinen
Mycotoxinen worden geproduceerd door schimmels. Globaal maken we onderscheid tussen velden opslagschimmels. De aanwezigheid van schimmels is afhankelijk van de omstandigheden. Bij veldschimmels spelen vooral weersomstandigheden (vocht en temperatuur), bodemwerking, bemesting en vruchtwisseling een rol, bij opslagschimmels vooral temperatuur, vochtigheid, tijd en conservering. In totaal zijn enkele honderden mycotoxinen bekend. Van de mycotoxinen die voor melkvee relevant zijn, komen deoxynivalenol (DON), zearalenon (ZEA) en roquefortine $C$ het meest voor. DON komt vaak voor in granen en maïs. ZEA komt vaak voor in maïs, gras en diverse diervoedergrondstoffen. Beide mycotoxinen worden gevormd door fusariumschimmels tijdens de teelt van het gewas (veldschimmels) en zijn stabiel in kuilvoer. Snijmaïskuil is in de gangbare rantsoenen voor melkvee met gras en maïs waarschijnlijk een belangrijke bron van DON en ZEA. Roquefortine $\mathrm{C}$ wordt gevormd door Penicillium roqueforti tijdens de opslag (opslagschimmel). De overdracht van genoemde mycotoxinen van voer naar melk is bijzonder laag $(0,03 \%$ of lager). Aflatoxine is een mycotoxine die wel overgedragen kan worden van voer naar melk. Aflatoxine is een gifstof die wordt geproduceerd door de schimmels Aspergillus flavus en Aspergillus parasiticus. Deze schimmels groeien op planten in warme, vochtige gebieden. Een enkele keer worden verhoogde concentraties aflatoxine aangetroffen in geimporteerde partijen maïs.

Over de stofwisseling en giftigheid van mycotoxinen in melkvee is nog relatief weinig bekend. DON wordt in belangrijke mate afgebroken in de pens. Bij melkvee zijn hiervan dan ook geen klinische effecten op de gezondheid of negatieve effecten op de voeropname en melkproductie te verwachten. ZEA wordt niet of nauwelijks in de pens afgebroken. Bij hoge belasting via het voer is een negatief effect op de vruchtbaarheid van melkvee niet onwaarschijnlijk. Over het effect van roquefortine $\mathrm{C}$ op melkvee bestaat nog onvoldoende kennis. In tabel 11.2 zijn de normen voor DON en ZEA in een rantsoen weergegeven die we op dit moment kennen voor rundvee in Nederland. De
\end{abstract}


hoeveelheid die in een enkelvoudig voedermiddel mag zitten is dus mede afhankelijk van de gehalten in de overige producten van het rantsoen. Voor enkelvoudige voedermiddelen is in 2004 door Productschap Diervoeder (PDV) vastgesteld dat $3 \times$ de norm voor rantsoenbasis kan worden aangehouden (Kwaliteitsreeks nr 96).

Bestrijding van DON en ZEA (en andere veldschimmels) dient via teeltmaatregelen te gebeuren, zoals onderploegen of verwijderen van stoppelresten. Bij maïs is nog niet aangetoond dat het kiezen van rassen met een hoge fusariumresistentie ook bijdraagt aan lagere gehalten aan DON en ZEA in het voer. Bestrijding van roquefortine $\mathrm{C}$ kan via de inkuilmethode en voermanagement.

Tabel 11.2 Normen voor mycotoxinen in het rantsoen van rundvee $(\mu \mathrm{g} / \mathrm{kg})$

\begin{tabular}{llcc}
\hline Mycotoxine & Diergroep & Afkeurgrens & Actiegrens \\
\hline DON & Kalveren tot 4 maanden & 2.000 & 1.600 \\
& Melkvee & 3.000 & 2.400 \\
& Overig rundvee & 5.000 & 4.000 \\
ZEA & Melkvee/pinken/kalveren & 500 & 400 \\
& Vleesvee & Geen grens & Geen grens \\
\hline
\end{tabular}

\subsection{Verontreinigingen}

Naast broei, schimmels en mycotoxinen kunnen in maïskuilen verschillende andere verontreinigingen voorkomen, zoals zwarte nachtschade en builenbrand.

\section{Zwarte nachtschade}

Dit onkruid bevat de gifstoffen Solanine en Solasodine. Deze stoffen behoren tot de groep glycoalkaloïden. Uit de literatuur is bekend dat de hoeveelheid gifstof zeer sterk kan variëren (van circa 25$1100 \mathrm{mg}$ per kg verse nachtschade) onder invloed van onder andere groeistadium en bemesting. De giftigheid neemt af in de volgorde van onrijpe bessen-bladeren-stengels-rijpe bessen. Als richtlijn kan worden aangehouden dat de toxische dosis (waarbij vergiftigingsverschijnselen optreden) voor melkkoeien ligt bij 1-3 gram Solanine plus Solasodine per dag en de lethale (dodelijke) dosis bij 2-6 gram per dag. Van Solasodine is ook bekend dat het abortus kan opwekken.

Nachtschade kan ook veel nitraat bevatten, tot zelfs $10 \%$ in de droge stof. De stengels zijn het meest nitraatrijk. Ook hier spelen bemesting en groeistadium een belangrijke rol. Problemen bij het voeren kunnen dus zowel het gevolg zijn van Solanine/Solasodine als van nitraat. Voor percelen snijmaïs met vrij veel (globaal meer dan $5 \%$ van het totale verse product) nachtschade, kan men het risico van eventueel te veel gifstof beperken door:

- de snijmaïs vrij rijp (laat) te oogsten. Rijpe bessen bevatten veel minder gifstof dan onrijpe, groene bessen

- de nachtschade tussen de maïsrijen plat te trappen en de maïs op een grotere stoppellengte te hakselen;

- $\quad$ de partij gelijkmatig te mengen met snijmaïs waarin weinig of geen nachtschade voorkomt;

- de partij apart te houden en deze aan bepaalde diergroepen (oudere vleesstieren) of in kleine hoeveelheden te voeren; de maïs niet als snijmaïs te oogsten, maar zo mogelijk bestemmen voor MKS, CCM of korrelmaïs. 
Door het inkuilen neemt de giftigheid weinig af. Alleen door weglopen van perssap (bij inkuilen van vochtige, onrijpe maïs) kan de giftigheid iets verminderen. Het oogsten van vrij rijpe maïs (minder gifstof in de bessen) is echter een betere maatregel.

Behalve het risico van vergiftiging is nachtschade ook nadelig voor de smakelijkheid van de snijmaïs.

Er zijn weinig onderzoeksgegevens over het voeren van snijmaïs met nachtschade. Het advies is echter om voorzichtig te zijn met het voeren van snijmaïs dat meer dan 10\% nachtschade (op basis van het verse product) bevat. Met name jonge dieren zijn erg gevoelig voor vergiftiging.

Vergiftigingsverschijnselen treden vaak pas na lange tijd op. Het advies is daarom om verontreinigde maïs niet langer dan 15 dagen achter elkaar te voeren met tussenpozen van 15 dagen. Het is daarbij nodig om de dieren goed in de gaten te houden. Wanneer zich moeilijkheden met de spijsvertering of andere afwijkingen voordoen, moet men onmiddellijk stoppen met voeren van deze snijmaïs. Vergiftigingsverschijnselen van Solanine/Solasodine zijn met name braken, koorts, diarree, productiedaling en verwerpen. De dieren worden slap, kortademig en gaan speekselen. Bij hogere doses treden maag-, darm-, en leveronsteking en bloedarmoede op. Tenslotte kan het centrale zenuwstelsel verlamd raken wat de dood tot gevolg kan hebben.

Kortom: een goede bestrijding van zwarte nachtschade is beslist aan te bevelen!

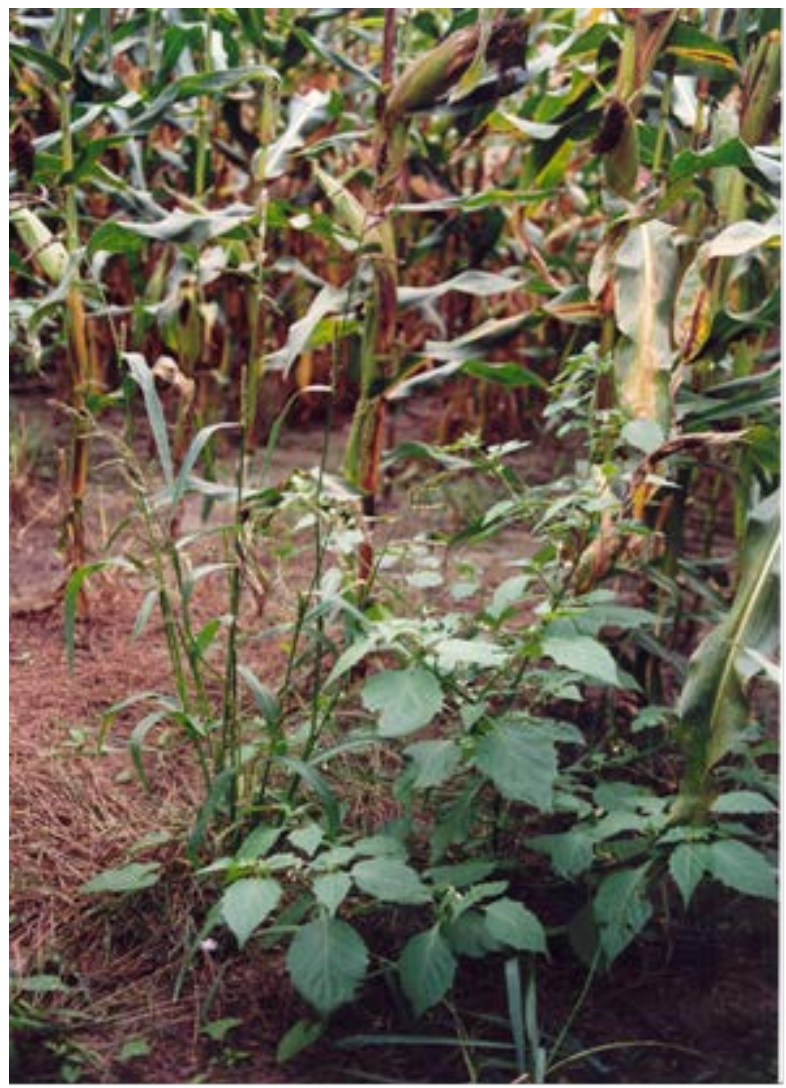

Zwarte nachtschade in de mais 


\section{Builenbrand}

Bij maïsplanten met een builenbrandaantasting op de kolf is het kolfaandeel gering. Dergelijke snijmaïs heeft daardoor een duidelijk lager drogestofgehalte. Bij 10\% aangetaste planten is het drogestofgehalte 0,5-0,8\% lager. De consequentie is dat de inkuilverliezen iets hoger zijn. Daarnaast kan het conserveringsproces ook iets minder goed verlopen door de ongunstige bacterie- en schimmelflora op het gewas. Het inkuilen en bewaren vraagt daarom bij sterk aangetaste snijmaïs extra aandacht. Het gebruik van een toevoegmiddel is echter niet nodig.

De sporen van de schimmel zijn niet giftig. Wel kunnen op de builen secundaire schimmels voorkomen die soms toxines vormen. Als vuistregel geldt dat verse vervoedering aan rundvee gevaarlijk kan zijn wanneer meer dan $30 \%$ van de planten aangetast is of wanneer de maïs meer dan tien gewichtsprocenten builen bevat. Dit laatste komt echter weinig voor. Na conservering van de maïs zijn er minder problemen te verwachten dan bij verse vervoedering. Door de conservering vermindert de giftigheid. Bij eventuele zwaardere aantastingen wordt geadviseerd wat later te oogsten. Hierdoor is de kans groter dat ten tijde van de oogst de builen reeds zijn open gebarsten, waardoor minder builweefsel in de kuil terechtkomt. Als het gewas tevens is aangetast door stengelrot moet men niet meer wachten met oogsten.

Uit diverse voederproeven met melk- en vleesvee is gebleken dat vervoedering van ingekuilde snijmaïs met veel builenbrand geen duidelijke problemen geeft voor diergezondheid, vruchtbaarheid, melkproductie en -samenstelling. Ook werd de aangetaste maïs in het algemeen vrij goed opgenomen door rundvee.

\subsection{Gemengd inkuilen en overkuilen}

Bij het inkuilen van snijmaïs worden soms gelijktijdig één of meer andere producten toegevoegd, zoals perspulp, aardappelpersvezels, aardappelen, bierbostel en gras. Dit gebeurt vooral omdat het arbeidstechnisch aantrekkelijk is. Men behoeft dan minder kuilen open te maken en ook minder kuilen tegelijk open te hebben bij het voeren. Daarnaast worden deze producten gebruikt als toplaag om de druk (dichtheid) te verhogen en luchtintreding te voorkomen tijdens het voeren (broei).

Voor de conservering van de snijmaïs is het toevoegen van een ander product zeker niet gunstig. Bij toevoegen van vochtige producten zoals bierbostel, komt perssap in de snijmaïs. Dit leidt tot iets hogere omzettingsverliezen bij de maïs. Door toevoegen van warme producten (onder andere perspulp en bierbostel) verloopt het conserveringsproces niet optimaal. Veelal ontstaat er dan minder melkzuur en meer azijnzuur. Voor de vochtige producten waarbij duidelijk perssap vrijkomt, kan gemengd inkuilen met een droger product, zoals rijpe snijmaïs, wel gunstig zijn. De verliezen door perssap zijn dan lager dan bij inkuilen van de afzonderlijke producten.

Bij gemengd inkuilen worden de producten meestal laagsgewijs ingekuild. Dit betekent variatie in reuk en smaak en leidt soms tot selectie door het vee.

\section{Overkuilen van snijmaïskuil}

Elk jaar wordt heel wat snijmaïs uit de kuil gehaald, op een andere bedrijf weer ingekuild en daarna vervoederd. Overkuilen van normale snijmaïs is goed mogelijk. De conservering en de kwaliteit verandert nauwelijks. Het extra verlies aan droge stof is bij vrij droge snijmaïs (boven $28 \%$ droge stof) gering en maximaal $2 \%$. Bij vochtige snijmaïs (beneden $25 \%$ droge stof) kunnen de verliezen aan droge stof oplopen tot 3 á $4 \%$. Deels worden deze verliezen veroorzaakt door weglopen van perssap. De voederwaarde (VEM en DVE) blijft nagenoeg gelijk. Belangrijk is dat het overkuilen snel gebeurt en dat de kuil weer goed wordt vastgereden. Duurt het overkuilen meerdere dagen, dan is er grote kans op broei en daarmee op extra verliezen. Zeer droge snijmaïs (boven 35\% droge stof) is minder geschikt voor overkuilen, door de grotere kans op broei. 


\section{Voeding}

12.1 Voederwaarde 178

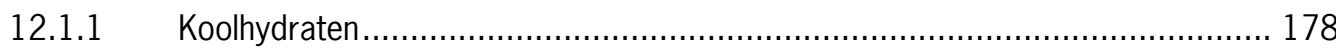

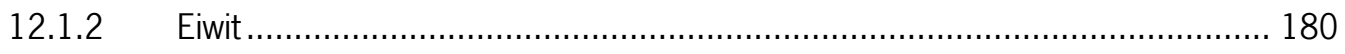

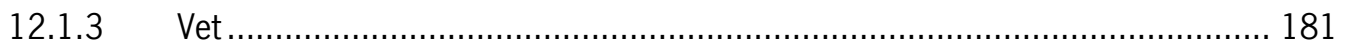

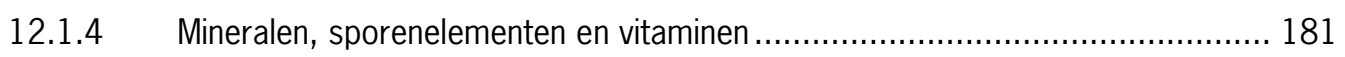

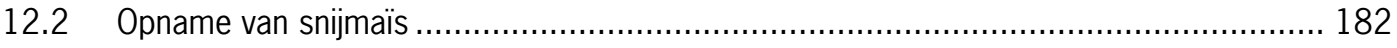

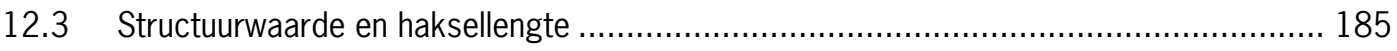

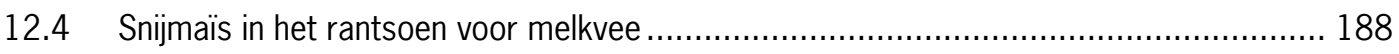

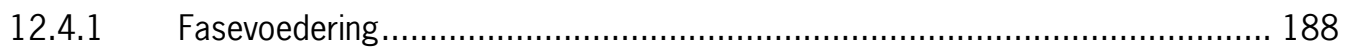

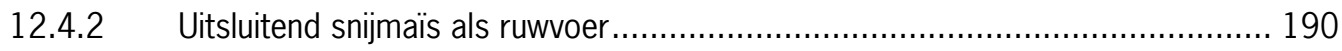

12.4.3 Snijmaïsbijvoeding tijdens weideperiode ................................................ 191 


\section{Voeding}

Snijmaiis is uitgegroeid tot het belangrijkste voedergewas na gras. Het succes van snijmaïs als voedergewas is mede te danken aan een hoge en constante voederwaarde (VEM) en snijmaïs past goed in een melkveerantsoen naast graslandproducten.

\subsection{Voederwaarde}

De voederwaarde van ruwvoer komt uit de verteerbare organische stof, die bestaat uit structurele koolhydraten en niet-structurele koolhydraten, eiwit en vetten. Bij de afbraak van de verteerbare organische stof in de pens en de darm komen nutriënten vrij die worden gebruikt voor de vorming van melkbestanddelen en de vorming van lichaamsreserves (tabel 12.1).

Tabel 12.1 Vorming van melkbestanddelen uit voer

\begin{tabular}{|c|c|c|c|c|}
\hline \multirow[b]{2}{*}{ Voerbestanddeel } & \multicolumn{2}{|c|}{ Plaats van vertering } & \multirow[b]{2}{*}{ Soort nutriënt } & \multirow{2}{*}{$\begin{array}{r}\text { Gebruikt voor } \\
\text { melkbestanddeel }\end{array}$} \\
\hline & Pens & Darm & & \\
\hline \multicolumn{5}{|c|}{ Structurele koolhydraten } \\
\hline Cellulose & Azijnzuur & - & Ketogeen & Melkvet \\
\hline Hemicellulose & Azijnzuur & - & Ketogeen & Melkvet \\
\hline Pectine & Propionzuur & - & Glucogeen & Lactose \\
\hline \multicolumn{5}{|c|}{ Niet-structurele koolhydraten } \\
\hline Suikers & Boterzuur/propionzuur & - & Ketogeen/glucogeen & Melkvet/Lactose \\
\hline Zetmeel & Propionzuur & Glucose & Glucogeen & Lactose \\
\hline Fructosanen & Boterzuur & & Ketogeen & Melkvet \\
\hline Eiwit & Microbieel eiwit & Aminozuren & Aminogeen/glucogeen ${ }^{1}$ & Eiwit/Lactose \\
\hline Vet & Triglyceriden/Netzuren & Triglyceriden/Netzuren & Ketogeen & Melkvet \\
\hline
\end{tabular}

\section{Voederwaardebepaling}

De routinematige kuilanalyse van snijmaïs wordt uitgevoerd met de NIRS-techniek (NIRS = Nabije InfraRood Spectofotometrie). Dit is een snelle en goedkope methode waarbij met infrarood licht de chemische samenstelling en de verteerbaarheid wordt bepaald. In de meeste gevallen voldoet deze methode uitstekend voor de praktijk, maar onder bijzondere omstandigheden, bijvoorbeeld wanneer door droogte de kolfzetting slecht is, is het beter om de voederwaardeanalyse op basis van de in-vitro verteerbaarheid te laten bepalen, omdat de NIRS-methode in die gevallen te onnauwkeurig is.

\subsubsection{Koolhydraten}

In snijmaïs zijn koolhydraten veruit de grootste leveranciers van energie (VEM) aan de koe. De koolhydraten verdelen we onder in structurele koolhydraten en niet-structurele koolhydraten. De structurele koolhydraten zijn vooral afkomstig van de celwandbestanddelen waaraan de plant zijn stevigheid ontleend. De celwanden maken ongeveer voor $40 \%$ deel uit van de verteerbare organische stof. De structurele koolhydraten die de meeste energie leveren zijn cellulose, hemi-cellulose en pectine. De niet-structurele koolhydraten bestaan uit zetmeel, suikers en fructosanen. De voornaamste structurele koolhydraten in snijmaïs zijn cellulose en hemi-celulose, afkomstig van het blad en de stengels. Cellulose en hemi-celulose worden grotendeels in de pens afgebroken en een deel verlaat onverteerd de koe. De afbraak van cellulose en hemi-cellulose in de pens levert vooral 
azijnzuur op, dat via de penswand in het bloed opgenomen wordt en dient als bouwstof voor de vorming van melkvet. Het gehalte aan structurele koolhydraten is af te leiden uit het ruwe celstofgehalte en de celwandfracties NDF, ADF en ADL. Het ruwe celstofgehalte geeft een indicatie van de hoeveelheid celwanden zonder onderscheid te maken tussen de celwandfracties. Met de celwandfracties NDF, ADF en ADL heeft men ook inzicht in de aard en de onderlinge verhouding van cellulose, hemicellulose en lignine (tabel 12.2). Er zijn echter nog geen behoeftenormen vastgesteld voor NDF, ADF en ADL.

Tabel 12.2 Samenstelling van NDF, ADF en ADL

$\begin{array}{ll}\mathrm{NDF}=\text { Neutral Detergent Fibre } & \mathrm{NDF}=\text { cellulose }+ \text { lignine }+ \text { hemicellulose } \\ \mathrm{ADF}=\text { Acid Detergent Fibre } & \mathrm{ADF}=\text { cellulose }+ \text { lignine } \\ \mathrm{ADL}=\text { Acid Detergent Lignin } & \mathrm{ADL}=\text { lignine (onverteerbaar) }\end{array}$

De belangrijkste niet-structurele koolhydraat in snijmaïs is zetmeel, afkomstig uit de kolf. Het zetmeelgehalte varieert afhankelijk van het rastype en het afrijpingsstadium. Bij een normaal ontwikkeld gewas snijmaïs in het traject tussen 28 en 35\% droge stof kan het zetmeelgehalte variëren tussen de 250 en 400 gram zetmeel per kg droge stof. De niet-structurele koolhydraten kunnen op basis van de snelheid van afbreekbaarheid en de plaats van afbraak in het maagdarmkanaal worden opgedeeld in verschillende fracties. Ten eerste zijn er suikers en snel afbreekbare zetmelen (SUSAZ). Hiertoe behoren de suikers en zetmelen waarvan de afbraaksnelheid gemeten in de pens groter is dan 12,5\% per uur. Daarnaast kan een deel van het zetmeel worden gerekend tot het langzaam afbreekbaar onbestendig zetmeel (LAOZ). Dit zetmeel wordt in de pens relatief langzaam afgebroken tot propionzuur. Het bestendige zetmeel (BZET) ontsnapt aan de afbraak in de pens en komt in de darm beschikbaar als glucose. Dit is energetisch gezien gunstig. In vergelijking met de meeste andere zetmeelrijke voeders verloopt bij snijmaïs de afbraak van zetmeel een stuk trager (zie tabel 12.3). Ongeveer 65 tot $80 \%$ van het zetmeel uit snijmaïs beschouwen we als langzaam afbreekbaar onbestendig zetmeel (LAOZ) dat wordt afgebroken in de pens; ongeveer 20 tot $35 \%$ van het zetmeel is bestendig zetmeel (BZET) dat de pens onverteerd passeert. Het zetmeel van snijmaïs bestaat vrijwel volledig uit LAOZ en BZET.

Tabel 12.3 Afbraaksnelheid ${ }^{11}$ zetmeel in voedermiddelen in vergelijking tot snijmaïs Afbraaksnelheid (\%/uur)

\begin{tabular}{lc}
\hline Snijmaïs & 7,9 \\
Maïskolvensilage & 7,7 \\
Corn Cob Mix & 7,2 \\
Maïs (korrel) & 4,0 \\
Gerst & 21,3 \\
Tarwe & 18,2 \\
\hline
\end{tabular}

${ }^{11}$ De afbraaksnelheden zijn gemiddelde waarden op basis van een reeks van onderzoeken. Deze getallen moeten worden gezien als een indicatie voor de rangordeverschillen tussen voedermiddelen. 


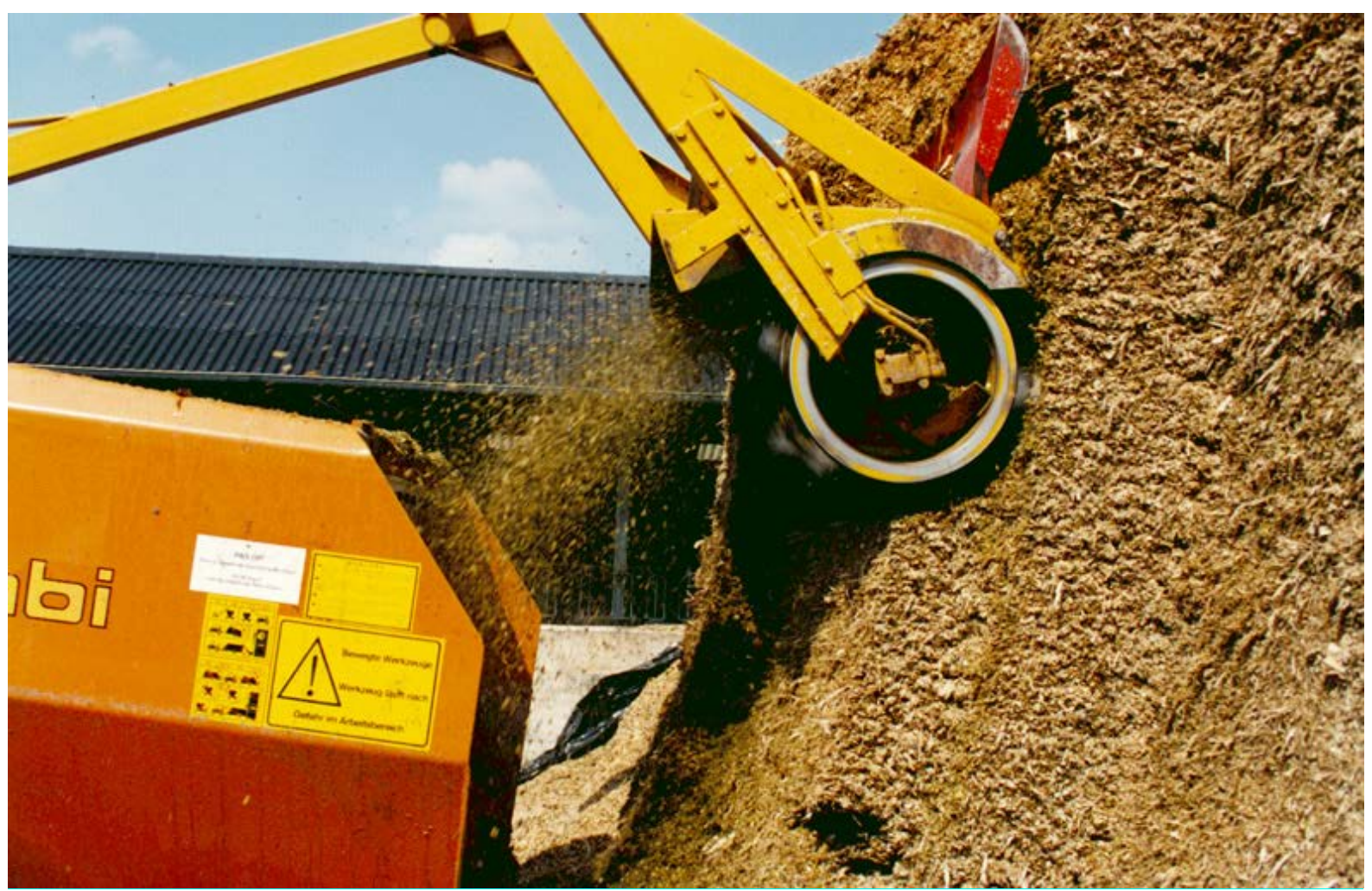

Snijmaïs dankt zijn hoge voederwaarde met name aan het hoge zetmeelgehalte

\subsubsection{Eiwit}

Snijmaïs bevat relatief weinig ruw eiwit en darmverteerbaar eiwit (DVE) en de onbestendig eiwitbalans (OEB) is negatief. De DVE-waarde geeft aan hoeveel verteerbaar eiwit netto beschikbaar komt in de dunne darm gecorrigeerd voor verliezen. Het DVE is afkomstig van microbieel eiwit dat in de pens wordt gevormd en van het verteerbare deel van het bestendige voereiwit. Voor de productie van microbieel eiwit in de pens zijn een stikstofbron en een energiebron nodig. De stikstofbron is voornamelijk ammoniak die vrijkomt bij de afbraak van het snelafbreekbare onbestendig voereiwit en van ureum dat via het speeksel in de pens komt. Een deel van de ammoniak wordt direct door de pensmicroben weer gebruikt als stikstofbron voor de vorming van microbieel eiwit. Een ander deel van de ammoniak wordt via de penswand in het bloed opgenomen en in de lever omgezet in ureum. De ureum wordt deels uitgescheiden in melk en urine, maar ook deels via het speeksel weer teruggevoerd naar de pens. De energiebron die nodig is voor de vorming van microbieel eiwit is afkomstig van de fermenteerbare organische stof. Bij snijmaïs bestaat deze uit de verteerbare celwandfracties en het onbestendige zetmeel. Snijmaïs heeft een negatieve OEB. Dit betekent dat er veel fermenteerbare energie beschikbaar is ten opzichte van onbestendig eiwit (stikstof) en dus een relatief tekort aan eiwit. Echter, de pensmicroben hebben een stikstofbron nodig om te kunnen groeien. Bij een tekort aan stikstof (dus wanneer de OEB van het rantsoen negatief is) wordt de afbraak van organische stof in de pens negatief beïnvloed. Een overmaat aan stikstof in de pens (positieve OEB) is ook nadelig. De stikstofovermaat wordt in de vorm van ammoniak opgenomen in het bloed. Omdat ammoniak giftig is, wordt het in lever omgezet in het niet giftige ureum. De vorming van ureum kost energie en bovendien wordt een groot deel van de ureum uitgescheiden in de urine. 
Omdat snijmaiis relatief weinig DVE en OEB bevat, past het goed in een rantsoen naast eiwitrijke voedermiddelen met een positieve OEB zoals weidegras en graskuil.

Behalve de hoeveelheid eiwit in een rantsoen kan ook de aminozuursamenstelling van het eiwit van belang zijn. Er wordt verondersteld dat in melkveerantsoenen de aminozuren methionine en lysine het eerst limiterend zijn. Er zijn nog geen normen opgesteld voor de behoefte aan darmverteerbaar methionine (DVmeth) en darmverteerbaar lysine (DVlys). Voorlopig luidt de richtlijn dat 2 tot 2,2\% van de totale DVE-behoefte in de vorm van DVmeth moet worden aangeboden. Voor DVlys geldt dat 5,7 tot $6 \%$ van de totale DVE-behoefte in de vorm van DVlys moet worden aangeboden. Snijmaïs bevat ongeveer 1,2 g DVmeth en 2,7g DVlys per kg droge stof. Dit komt neer op respectievelijk 2,6\% en $6 \%$ van de totale DVE. Wanneer de krachtvoeraanvulling bij een snijmaïsrijk rantsoen uit een mengvoer bestaat dat is samengesteld uit een groot aantal verschillende grondstoffen, zijn er geen problemen te verwachten met de aminozuurvoorziening. Maar wanneer de krachtvoeraanvulling uit een beperkt aantal enkelvoudige bijproducten bestaat, is er kans dat de voorziening van een aantal essentiële aminozuren in het gedrang komt.

\subsubsection{Vet}

Bij de afbraak van vet in de pens en de darm worden vetzuren en triglyceriden gevormd die kunnen worden gebruikt voor de vorming van melkvet. Snijmaïs bevat weinig vet, ongeveer tussen de 30 en 40 gram per kg droge stof. Vet uit snijmaïs levert dus maar een geringe bijdrage aan de vorming van melkbestanddelen.

\subsubsection{Mineralen, sporenelementen en vitaminen}

Mineralen en sporenelementen spelen een essentiële rol bij vorming van het skelet, transport van ionen door celmembranen, lichaamsvloeistoffen en bij zenuwfunctie, als functionele groepen in enzymen en antilichamen, en als katalysator bij vele andere biochemische processen. Omdat snijmaïs arm is aan mineralen moet dit worden aangevuld uit andere voeders in het rantsoen (krachtvoeders) of losse mineralenmengsels. Bij het toevoegen van losse mineralen aan het rantsoen moet men er op bedacht zijn dat niet alleen een tekort schadelijk is, maar dat een overmaat ook tot gezondheidsproblemen kan leiden. Een laag mineralengehalte kan ook voordelen hebben. Bij aankoop van ruwvoer in de vorm van snijmaïs worden weinig mineralen en ook zware metalen aangevoerd. Omdat de gehalten aan kalium en ruw eiwit laag zijn, wordt magnesium uit snijmaïs beter geabsorbeerd. Doordat snijmaïs ten opzichte van gras(kuil) weinig kalium bevat, is het kation-anion verschil (KAV) van snijmaïs veel lager dan van graslandproducten. Een laag KAV tijdens de droogstand stimuleert de mobilisatie van calcium uit het skelet, waardoor de kans op melkziekte verkleint. Snijmaïs in een droogstandsrantsoen kan daarom zinvol zijn. Maar omdat snijmaïs een energierijk product is, is het ook nodig tegelijkertijd een energiearm product als stro in het rantsoen op te nemen.

De vitaminenvoorziening van een herkauwer is voor veel vitaminen zelden een probleem. Bij een herkauwer worden in de pens een groot aantal vitaminen gevormd, met name het vitamine B-complex, vitamine C en $\mathrm{K}$. Voor herkauwers zijn de vetoplosbare vitamines A, D en E het meest essentieel. Plantaardige voeders bevatten geen vitamine A. Planten bevatten wel het pro-vitamine B-caroteen dat in het maagdarmkanaal wordt omgezet in vitamine A. De vitamine D-behoefte is afhankelijk van de calcium- en fosforstofwisseling. Vitamine D kan het dier onder invloed van UV-licht zelf synthetiseren. Het vitaminegehalte in ruwvoer is moeilijk te bepalen en bovendien gaan er tijdens de conservering vitaminen verloren. In de praktijk wordt daarom geen rekening gehouden met vitaminen uit het ruwvoer. In de gangbare veehouderij wordt aan het mengvoer standaard pre-mixen met mineralen, sporenelementen en vitamine A, D en E aan het krachtvoer toegevoegd. Wanneer het krachtvoer 
(voor een groot deel) in de vorm van losse enkelvoudige bijproducten gevoerd wordt, dient men extra aandacht aan de mineralen-, sporenelementen- en vitaminenvoorziening geven.

Tabel 12.4 Aanbevolen mineralen in het rantsoen en aanwezige mineralengehalten in snijmaïs en graskuil

\begin{tabular}{lccc}
\hline & $\begin{array}{c}\text { Aanbevolen gehalte } \\
\text { per kg droge stof }\end{array}$ & $\begin{array}{c}\text { Gehalten in snijmaïs } \\
\text { per kg droge stof }\end{array}$ & $\begin{array}{c}\text { Gehalten in graskuil } \\
\text { per kg droge stof }\end{array}$ \\
\hline Calcium (g) & $3,5-5,5$ & 1,6 & 5,4 \\
Fosfor (g) & $3,0-3,5$ & 1,9 & 4,1 \\
Natrium (g) & $1,0-1,5$ & 0,2 & 2,7 \\
Magnesium (g) & $2,0-5,0$ & 1,3 & 2,5 \\
Kalium (g) & 8 & 13 & 37 \\
Chloor (g) & 3,5 & 1,3 & 12 \\
Zwavel (g) & - & 1,0 & 2,8 \\
& & & \\
Jodium (mg) & 0,6 & 0,1 & 0,2 \\
Mangaan (mg) & 25 & 32 & 101 \\
Zink (mg) & 25 & 38 & 46 \\
IJzer (mg) & - & 152 & 532 \\
Koper (mg) & 10 & 3,6 & 8,5 \\
Molybdeen (mg) & - & 0,5 & 2,2 \\
Cobalt ( $\mu$ ) & 100 & 59 & 239 \\
Selenium ( $\mu$ g) & 150 & 23 & 49 \\
KAV (meq) & - & 230 & 560 \\
Vitamine A (IE) & $2000-5000$ & - & - \\
Vitamine D (IE) & $300-500$ & - & -
\end{tabular}

\subsection{Opname van snijmaïs}

Snijmaïs is een product dat, mits het goed geconserveerd en vrij van broei is, goed wordt opgenomen. De hoeveelheid droge stof die een koe kan opnemen wordt bepaald door enerzijds de voeropnamecapaciteit van het dier en anderzijds door de mate waarin een voedermiddel beslag legt op de beschikbare voeropnamecapaciteit, ook wel verzadigingswaarde genoemd. 


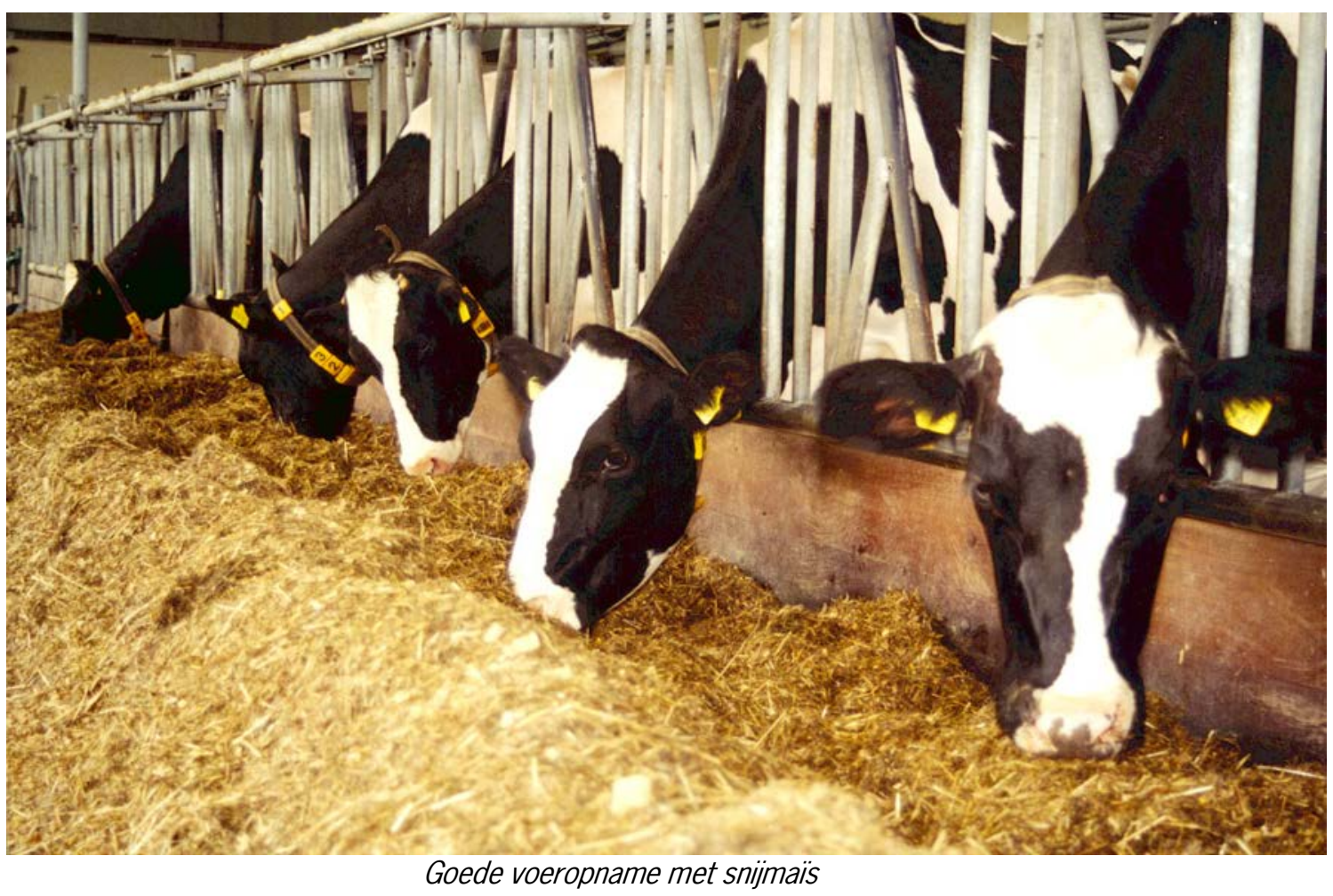

\section{Voeropnamecapaciteit en verzadigingswaarde}

De voeropnamecapaciteit (VOC) is afhankelijk van het lactatienummer, dagen in lactatie en dagen drachtig. In tabel 12.5 staat voor verschillende lactatiestadia aangegeven hoe groot de VOC is.

Tabel 12.5 Voeropnamecapaciteit (VOC) in verzadigingswaarde-eenheden per dag van dieren met een tussenkalftijd van 365 dagen (drachtig vanaf dag 90 van de lactatie)

\begin{tabular}{l|cccccc}
\hline & \multicolumn{7}{|c}{ Dagen in lactatie } \\
Lactatienummer & 1 & 60 & 90 & 120 & 180 & 305 \\
\hline 1 & 8,3 & 12,7 & 13,3 & 13,7 & 14,3 & 15,2 \\
2 & 10,7 & 15,6 & 15,8 & 15,8 & 15,7 & 15,3 \\
ouder & 11,5 & 16,5 & 16,7 & 16,6 & 16,3 & 15,7 \\
\hline
\end{tabular}

De mate waarin een voedermiddel beslag legt op de voeropnamecapaciteit wordt uitgedrukt in de verzadigingswaarde (VW) van het voedermiddel:

$$
\text { DS opname }=\frac{\mathrm{VOC}}{\mathrm{VW}(/ \mathrm{kg} \mathrm{ds})}
$$

Hoe lager de verzadigingswaarde, des te meer opname van een voedermiddel. De verzadigingswaarde (VW) van snijmaïs is afhankelijk van het drogestofpercentage (DS\%) en het gehalte verteerbare organische stof (VOS). De relatie tussen het drogestofgehalte en de VW is bij snijmaïs niet lineair (figuur 12.1). De verzadigingswaarde heeft een optimum bij circa 33\% droge stof. Op dat punt is de verzadigingswaarde het laagst. De maximale voeropname uit snijmaïs ligt op het optimale oogsttijdstip tussen de 31 en 35\% droge stof. De verzadigingswaarde van snijmaiis neemt lineair af met het gehalte aan VOS. In tegenstelling tot het drogestofgehalte, is het VOSgehalte moeilijk te beïnvloeden. Wel heeft de rassenkeuze hier enige invloed op. Omdat het VOS- 
gehalte nauw is gerelateerd aan de VEM-waarde, kan men voor praktisch gebruik stellen dat rassen met een hoge VEM-waarde per kg droge stof ook een hoog VOS-gehalte hebben.

Figuur 12.1 Links de relatie tussen drogestofgehalte (\%) en verzadigingwaarde bij een VOSgehalte van $700 \mathrm{~g} / \mathrm{kg}$ ds; Rechts de relatie tussen het VOS-gehalte (g/kg ds) en de verzadigingswaarde bij een drogestofgehalte van $33 \%$
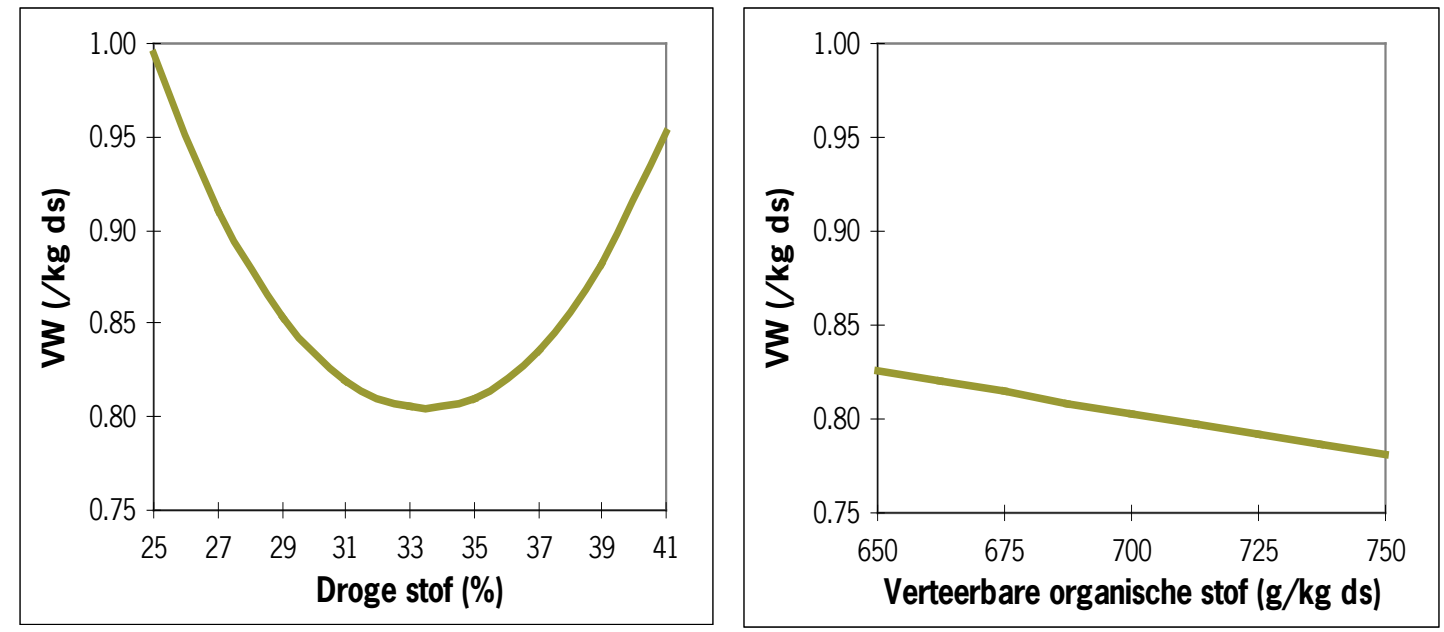

\section{Drogestofopname}

Snijmaïs heeft ten opzichte van de meeste andere gangbare ruwvoeders een lagere VW (tabel 12.6). Snijmaïs $(V W=0,83$ legt dus minder beslag op de opnamecapaciteit dan een gemiddelde graskuil $(\mathrm{VW}=1,0)$. Een deel van de graskuil vervangen door snijmaïs kan leiden tot een hogere drogestofopname en energieopname. Dit blijkt wanneer de voederwaarde wordt uitgedrukt in gehaltes per VW-eenheid in plaats van gehaltes per $\mathrm{kg}$ droge stof (tabel 12.7).

Tabel 12.6 Verzadigingswaarden VW van snijmaïs ten opzichte van andere voedermiddelen

\begin{tabular}{lcc}
\hline & Gemiddeld & Minimum - maximum \\
\hline Snijmaïs & 0,83 & $0,78-1,04$ \\
Graskuil & 1,00 & $0,91-1,16$ \\
Vers gras $^{1}$ & 0,92 & $0,88-1,10$ \\
Graan-GPS & 0,89 & $0,76-1,07$ \\
Luzernekuil & 0,96 & $0,91-1,03$ \\
Mengvoer & 0,35 & $0,29-0,40$ \\
\hline 1 & Deze warde
\end{tabular}


Figuur 12.2 Links de relatie tussen drogestofgehalte (\%) en drogestofopname door een volwassen koe uit een basisrantsoen bestaande uit 33\% (blauwe lijn), 66\% (groene lijn) of $100 \%$ (rode lijn) snijmaïs naast graskuil en $8 \mathrm{~kg}$ ds krachtvoer. Rechts de relatie tussen het VOS gehalte $(\mathrm{g} / \mathrm{kg}$ ds) en drogestofopname door een volwassen koe uit dezelfde basisrantsoenen
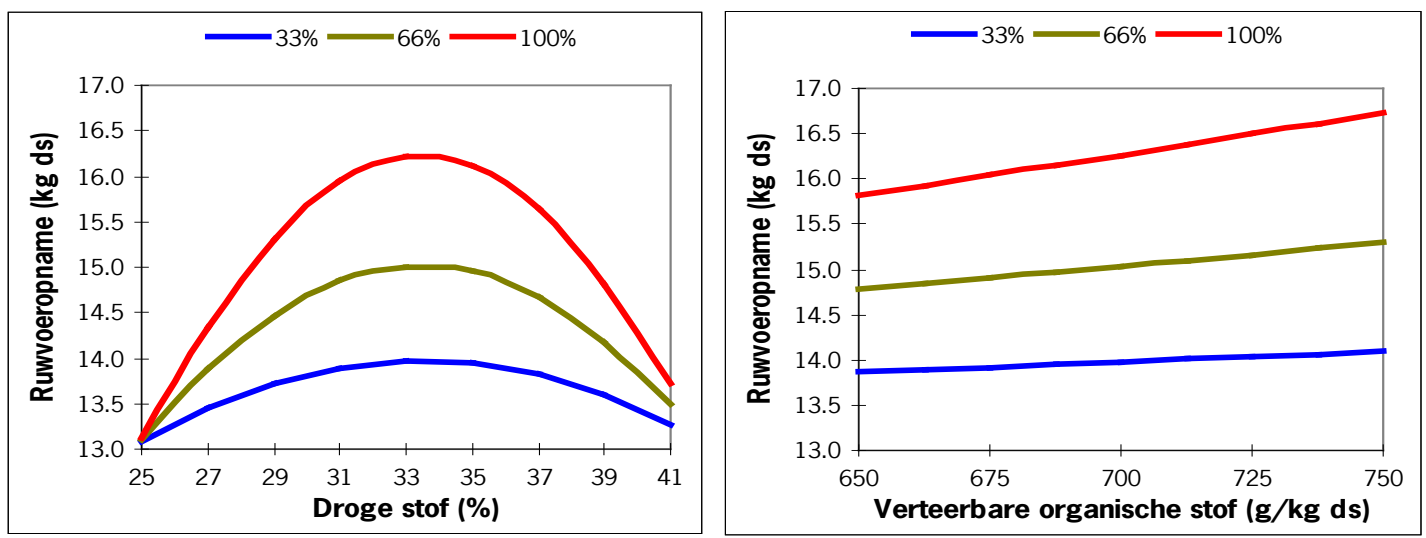

Tabel 12.7 Voederwaarde van snijmaïs uitgedrukt per kg droge stof en per verzadigingswaardeeenheid

\begin{tabular}{lcccc}
\hline Voederwaarde & Per kg droge stof & & Per VW-eenheid & \\
\hline & Snijmaïs & Graskuil & Snijmaïs & Graskuil \\
\hline Verzadigingswaarde (/kg ds) & 0.83 & 1.00 & - & - \\
VEM & 937 & 890 & 1130 & 890 \\
DVE $(g)$ & 47 & 75 & 57 & 75 \\
OEB $(\mathrm{g})$ & -28 & 32 & -34 & 32 \\
\hline
\end{tabular}

\subsection{Structuurwaarde}

Runderen kunnen door hun maagdarmkanaal en het herkauwen uitstekend "lang" structuurrijk ruwvoer verwerken. Voldoende structuur in het rantsoen van melkkoeien is nodig om herkauwen en beweging van de pens te stimuleren. Wanneer een koe herkauwt wordt er speeksel geproduceerd dat een bufferende werking heeft op de $\mathrm{pH}$ (zuurgraad) van de pens. Een voldoende hoge $\mathrm{pH}$ in de pens is noodzakelijk voor een goede fermentatie van organische stof, onvoldoende kan leiden tot pensverzuring en een verminderde voeropname. Om te beoordelen of een rantsoen voldoende fysieke structuur bevat kan het structuurwaarde systeem als een hulpmiddel worden gebruikt. Het structuurwaardesysteem geeft aan wat het kritieke (minimale) aandeel structuur in een rantsoen moet zijn voordat zich klinische verschijnselen van structuurgebrek voordoen. De structuurbehoefte van een koe is afhankelijk van de melkproductie, lactatienummer en de wijze waarop het krachtvoer wordt verstrekt. Daarnaast berekent het structuurwaardesysteem voor elk voedermiddel een structuurwaarde.

De structuurwaarde van snijmaiis is afhankelijk van het celwandgehalte (NDF en ruwe celstof) en de haksellengte. Een hoger celwandgehalte en een grotere haksellengte gaan gepaard gaat met een hogere structuurwaarde. Wanneer een gebrek aan structuur in het rantsoen wordt verwacht dan zou in theorie de structuurwaarde van snijmaïs kunnen worden verhoogd door een grotere 
haksellengte of te streven naar een hoog celwandgehalte door middel van de rassenkeuze of door manipulatie van het oogsttijdstip. Echter, uit onderzoek is gebleken dat al deze maatregelen per saldo niet effectief zijn en zelfs negatief kunnen uitwerken op de nutriëntenbenutting en melkproductie.

Een toename van de theoretische haksellengte met $1 \mathrm{~mm}$ leidt tot een $2 \%$ hogere structuurwaarde. Wanneer men een gebrek aan voldoende structuur in het rantsoen verwacht, lijkt het gunstig om snijmaïs grof te hakselen. Uit onderzoek is gebleken dat grof hakselen inderdaad kan leiden tot meer kauwactiviteit per kg droge stof of per kg NDF, een langere totale kauwtijd of tot een verschuiving tussen eettijd en herkauwtijd. Echter, de effecten op de totale kauwactiviteit (eettijd + herkauwtijd) zijn gering, omdat een grotere haksellengte vaak gepaard gaat met een lagere drogestofopname. Grof hakselen heeft nauwelijks of geen invloed op de pensfermentatie, de pH in de pens en de concentraties van vluchtige vetzuren. Er zijn dus geen aanwijzingen dat een verhoogde kauwactiviteit leidt tot een grotere buffering van de $\mathrm{pH}$ in de pens en een betere pensfermentatie. Daarentegen worden voederverliezen groter bij een langere haksellengte, omdat de koeien vooral de celwandrijkere delen laten liggen (spildelen en schutbladeren). Bij grover hakselen wordt vaak een betere celwandverteerbaarheid waargenomen, maar dit voordeel wordt teniet gedaan door een veel slechtere verteerbaarheid van zetmeel en de grotere verliezen van zetmeel en korreldelen in de mest. Fijn hakselen $(6-8 \mathrm{~mm})$ daarentegen leidt tot een betere verteerbaarheid en benutting van de voedingstoffen van de snijmaïs. Dit heeft weer positieve gevolgen voor de melkproductie. Uit onderzoek concluderen we dat grof hakselen van snijmaïs nauwelijks effect heeft op de structuurvoorziening en pensfermentatie, maar dat voeropname, voederverliezen en melkproductie nadelig worden beïnvloed. Bovendien zijn grofgehakselde kuilen veel broeigevoeliger dan fijn gehakselde kuilen.

Snijmaïsrassen van het celwandtype hebben bij dezelfde VEM-waarde een relatief hoog celwandgehalte en celwandverteerbaarheid gecombineerd met een relatief laag zetmeelgehalte. Oogsten in een minder afgerijpt stadium leidt eveneens tot een lager zetmeelgehalte en hoger celwandgehalte. Vanwege het hogere celwandgehalte heeft snijmaiis van het celwandtype of vroeg geoogste snijmaïs een hogere structuurwaarde. Echter, ook deze maatregelen zijn niet effectief gebleken. Dit blijkt uit een vergelijkend onderzoek op de Waiboerhoeve. Melkkoeien op een rantsoen met snijmaïskuil van een celwandtype namen meer NDF en minder zetmeel op maar produceerden uiteindelijk minder melk, melkeiwit en FPCM dan melkkoeien op een rantsoen met snijmaïskuil van een zetmeeltype. Vroeger oogsten bij $30 \%$ in plaats van $36 \%$ drogestof had geen enkel effect op de melkproductie en melksamenstelling. Deze resultaten geven aan dat ook bij een groot aandeel snijmaïs ( $80 \%$ van het ruwvoer en $50 \%$ van de totale drogestof) geen effect valt te verwachten van het gebruik van een snijmaïsras van het celwandtype op de structuurvoorziening.

\section{Shredlage-hakselen}

Shredlage-hakselen is een hakseltechniek waarbij de maïs ten opzichte van de standaard hakselmethode op een grotere lengte van 25-30 mm wordt gehakseld en daarnaast intensiever wordt gekneusd. De intensievere kneuzing wordt vooral bewerkstelligd door een groter verschil in toerental tussen de kneusrollen en daarnaast door een aangepast profiel op de kneusrollen. In 2015 en 2016 is deze methode in Nederland geïntroduceerd door Claas als een manier om de structuurwaarde van maïs in het rantsoen te verhogen. Hierdoor zouden structuurbronnen als stro, hooi en luzerne beperkt of weggelaten kunnen worden. Onderzoek in 2016 met melkkoeien op Haus Riswick in Kleve, Duitsland gaf geen effect op de melkproductie te zien. De opname van shredlage-maïs was iets hoger waardoor melkkoeien in begin van de lactatie iets minder snel in een negatieve energiebalans geraken. Verder kwam uit het onderzoek dat de dichtheid van de kuilen met shredlage-maïs circa 10\% lager was dan van kuilen met standaard kort gehakselde maïs. Dit geeft een verhoogde kans op broei tijdens het voeren. 
Uit een praktijkproef uitgevoerd door Dairy Academy Oenkerk in winter 2016-2017 bleek dat shredlage-mais in een rantsoen met een gangbaar maisaandeel ( $5 \mathrm{~kg} \mathrm{ds} / \mathrm{koe} / \mathrm{dag}$ ) niet tot productieverhoging en verbetering van gezondheidskenmerken bij melkvee leidt. Wel daalde het ureumgehalte in de melk van 20 naar 19 mg per 100 gram.

\section{Opheffen van structuurgebrek}

Wanneer een rantsoen onvoldoende structuur bevat, verdienen andere maatregelen de voorkeur boven grof hakselen, vroeg oogsten of het telen van een ras van het celwandtype. Bijvoorbeeld het verlagen van het aandeel krachtvoer(vervangers) in het rantsoen of een andere krachtvoersamenstelling met minder snel afbreekbare koolhydraten. Ook een verlaging van het aandeel snijmaiis in het rantsoen ten gunste van bijvoorbeeld graskuil, of het opnemen van hooi of stro in het rantsoen kunnen het structuurgebrek opheffen.

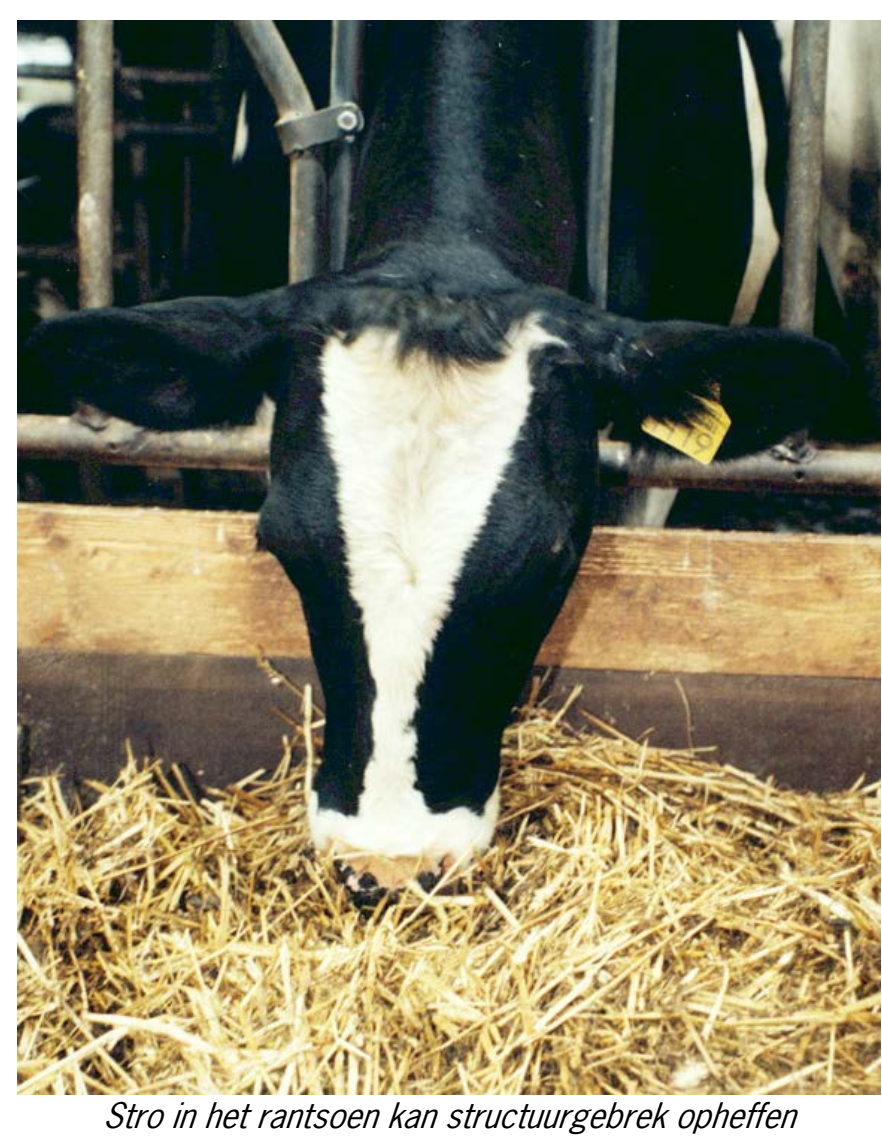


Handboek snijmaïs

\subsection{Snijmaïs in het rantsoen voor melkvee}

De samenstelling van rantsoenen voor melkvee moet bij voorkeur zodanig zijn dat het aanbod en de behoefte aan nutriënten op elkaar is afgestemd.

\subsubsection{Fasevoedering}

Gedurende de lactatie verandert de nutriëntenbehoefte van een koe voortdurend. De samenstelling van het rantsoen moet daarom mee veranderen met de behoefte van de koe. Fasevoedering houdt daar daadwerkelijk rekening mee. Bij fasevoedering worden meestal vijf fasen onderscheiden: fase 1 : de nieuwmelkte periode; fase 2: de herstelperiode; fase 3: eind lactatie; fase 4: de eerste 5 tot 7 weken van de droogstand en fase 5: de laatste 20 tot 10 dagen van de droogstand.

\section{Fase 1 Nieuwmelkte periode}

De nieuwmelkte periode geldt voor de eerste weken na afkalven. In deze periode is de energieopname lager dan de energiebehoefte en is er dus een negatieve energiebalans (NEB). Tijdens deze fase worden lichaamsreserves afgebroken, met name vet en in mindere mate eiwit en is de hormonale regulatie gericht op het stimuleren van de melkproductie en het afbreken van lichaamsreserves. In deze nieuwmelkte periode heeft een koe grote behoefte aan de glucogene nutriënten propionzuur en glucose om lactose te kunnen vormen. Glucose is de bouwstof voor lactose (melksuiker). Lactose is in grote mate bepalend voor het volume van de melkproductie. Een goede glucosevoorziening stimuleert dus de melkgift. Bij een tekort aan glucogene nutriënten kan glucose ook worden gevormd uit glucogene aminozuren. Het nadeel hiervan is dat deze aminozuren niet meer beschikbaar zijn voor de vorming van melkeiwit. Een ruim aanbod van glucogene energie is daarom in het begin van de lactatie gewenst. Recent onderzoek bij Wageningen University \& Research geeft aan dat koeien die een glucogeen (zetmeelrijk) rantsoen krijgen een minder negatieve energiebalans en minder lichaamsvet mobiliseren dan koeien op een lipogeen (celwandrijk) rantsoen. Een rantsoen met veel snijmaïs past daarom uitstekend in rantsoenen voor nieuwmelkte koeien. Een richtlijn voor het rantsoen van nieuwmelkte koeien is een minimum van ca. 150 gram zetmeel per kg drogestof, bij voorkeur met een groot aandeel pensbestendig zetmeel.

Uit een voederproef op de Waiboerhoeve kwam naar voren dat koeien die snijmaïs kregen met een groter aandeel bestendig zetmeel meer melk, melkeiwit en lactose produceerden. Dit wordt verklaard doordat zetmeel dat in de darm wordt verteerd efficiënter wordt benut dan zetmeel dat in de pens wordt afgebroken. Daarom moet het zetmeel in het rantsoen van nieuwmelkte koeien voor een groot deel pensbestendig zijn. Het is met de huidige stand van zake nog niet mogelijk om concrete adviezen voor het aandeel bestendig zetmeel in het rantsoen te geven. Daarvoor is het nodig dat er eerst onderzoek gedaan moet worden naar de bestendigheid van zetmeel en de behoeftenormen van melkvee.

Er is geen bovengrens aan de hoeveelheid zetmeel in het rantsoen van de nieuwmelkte periode, mits aan alle nutritionele eisen (DVE, OEB, structuurwaarde) wordt voldaan, en het zetmeel afkomstig is van bestendige zetmeelbronnen (bijv. snijmais). De eiwitvoeding in het begin van de lactatie verdient daarom extra aandacht, met name bij rantsoenen die voor een groot deel uit snijmaïs bestaan. De voorziening van eiwit (DVE en OEB) mag niet beperkend zijn. Voor een grote microbiële eiwitproductie is het nodig dat het aanbod van energie en stikstof in de pens in evenwicht is. Bij een negatieve OEB is sprake van een tekort aan stikstof en die remt de vorming van microbieel eiwit. Daarom moet een negatieve OEB worden voorkomen. Bij een hoog productieve koe is de microbiële eiwitproductie alleen vaak niet voldoende om volledig in de eiwitbehoefte te voorzien. Voor een voldoende DVEvoorziening zijn daarom vaak bestendige eiwitbronnen nodig. 


\section{Fase 2 Herstelperiode}

In de tweede fase van de lactatie is de energieopname groter dan de energiebehoefte en begint het herstel van de afgebroken lichaamsreserves. In deze fase gaat de bloedspiegel van het hormoon insuline omhoog en daalt de bloedspiegel van het melkstimulerende groeihormoon. Insuline speelt een belangrijke rol bij het aanzetten van lichaamsreserves. Wanneer de koe in een positieve energiebalans is, stimuleert een ruim aanbod van propionzuur en glucose de afgifte van het hormoon insuline. Dit hormoon bevordert de vorming van lichaamsreserves en remt de melkproductie. Een ruim aanbod van glucogene nutriënten (zetmeel) in de tweede helft van de lactatie moet daarom worden vermeden. Als richtlijn voor het rantsoen kan een maximum van 150 gram zetmeel per $\mathrm{kg}$ drogestof worden gehanteerd.

\section{Fase 3 Einde lactatie}

De derde fase van de lactatie beslaat de periode van ongeveer 30 weken na afkalven tot het begin van de droogstand. In deze periode dient het herstel van de lichaamsreserves die in eerste fase verloren zijn gegaan te worden voltooid. De koeien die ruim boven de VEM-norm worden gevoerd, hebben een sterke neiging tot vervetting. De hoeveelheid suikers en zetmeel in het rantsoen dient men te beperken, om een te royale conditie te voorkomen. Op het moment van droogzetten dient conditiescore 3 tot 3,5 te worden nagestreefd. Wanneer koeien te vet de droogstand ingaan heeft dat negatieve gevolgen voor de start van de nieuwe lactatie. Vette koeien hebben een lagere voeropnamecapaciteit en zijn mede daardoor gevoeliger voor slepende melkziekte. De hoeveelheden totaal zetmeel en bestendig zetmeel moeten bij voorkeur beperkt blijven tot respectievelijk maximaal 90 en 25 gram per kg droge stof.

\section{Fase 4 Eerste 5 tot 7 weken van de droogstand}

In de droogstandsfase wordt de koe weer voorbereid op de komende lactatie. Er zijn weinig mogelijkheden om een te schrale of te royale conditie te corrigeren. In de eerste 5 tot 7 weken van de droogstand is een energiearm en structuurrijk rantsoen gewenst. Dit bevordert het opdrogen van de uier. Dit kan worden bereikt door naast graskuil en snijmaïs stro in het rantsoen op te nemen om de energiedichtheid te verminderen.

\section{Fase $\mathbf{5}$ Laatste $\mathbf{1 0}$ tot $\mathbf{2 0}$ dagen van de droogstand}

In het laatste deel van de droogstand moet de energiedichtheid worden opgevoerd omdat de opnamecapaciteit van de koe afneemt. Door in deze fase energie- en zetmeelrijker te voeren kan de microbenpopulatie zich aanpassen aan het basisrantsoen dat in het begin van de lactatie wordt gevoerd. Het moment van overschakelen naar het basisrantsoen ligt minimaal 10 tot ongeveer 20 dagen voor de te verwachten afkalfdatum. Het tijdstip hangt mede af van de conditie van het dier. Wanneer te vroeg voor afkalven wordt begonnen met een energierijk rantsoen te voeren, kan dit zucht (uieroedeem) veroorzaken.

Wanneer men krachtvoer individueel verstrekt, kan men in de laatste 10 tot 20 dagen van de droogstand hetzelfde basisrantsoen voeren als aan de nieuwmelkte koeien, eventueel aangevuld met een kleine hoeveelheid krachtvoer (maximaal $2 \mathrm{~kg}$ ). Op bedrijven die een totaal gemengd rantsoen voeren, kan in de laatste fase hetzelfde rantsoen worden gevoerd als aan de laagproductieve melkkoeien.

\section{Praktische uitvoering van fasevoedering}

Wanneer alle zetmeel in het rantsoen afkomstig is uit snijmaïs, en het overige ruwvoer uit graslandproducten bestaat, kan men de richtlijnen in tabel 12.08 aanhouden voor het minimum en maximum aandeel snijmaïs in het ruwvoer. 
Tabel 12.08 Aanbevolen minimum en maximum hoeveelheid (\%) snijmaïs van het ruwvoer

\begin{tabular}{lcc}
\hline & Minimum (\%) & Maximum (\%) \\
\hline Fase 1: nieuwmelkte fase & 60 & 100 \\
Fase 2: week 12 - 30 van de lactatie & 40 & 60 \\
Fase 3: week 30 tot einde lactatie & 0 & 40 \\
\hline
\end{tabular}

Waar men het melkvee in meerdere productiegroepen houdt, kan voor elke fase van de lactatie een aparte groep worden gevormd. Dit is met name aantrekkelijk op grote bedrijven. Is dit niet het geval, dan kan men de koeien in twee groepen houden, bijvoorbeeld een hoog- en een laagproductieve groep met een rantsoen waarvan het ruwvoer voor respectievelijk 60 en $40 \%$ uit snijmaïs bestaat. Wanneer niet met productiegroepen wordt gewerkt, kan het snijmaïsaandeel in het ruwvoer $40 \%$ bedragen. De hoogproductieve melkkoeien moeten dan extra (bestendig) zetmeel uit het krachtvoer krijgen.

\subsubsection{Uits/uitend snijmais als ruwvoer}

Onder sommige specifieke bedrijfsomstandigheden kan het een optie zijn om uitsluitend snijmaïs als ruwvoer te gebruiken, bijvoorbeeld als er geen of een te kleine huiskavel is of wanneer en geen of te weinig grond beschikbaar is voor ruwvoerproductie. Op praktijkcentrum Cranendonck is een systeemvergelijking uitgevoerd tussen een bedrijfssysteem met gras en snijmaïs en systeem met uitsluitend snijmaïs.

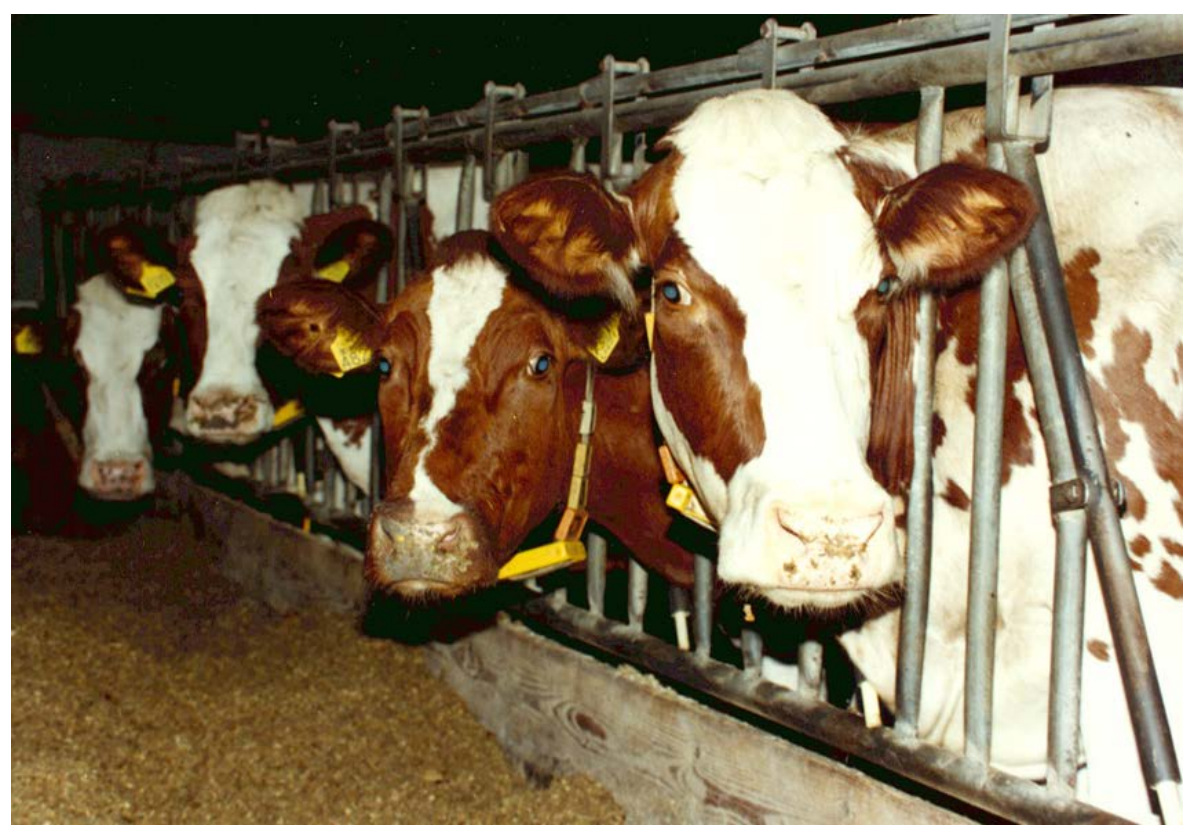

Uits/uitend snijmais voor melkkoeien op Cranendonck van 1986-1991 
Tabel 12.09 Overzicht van voor- en nadelen uitsluitend snijmaïs als ruwvoer

\begin{tabular}{ll}
\hline Voordelen & Nadelen \\
\hline Eenvoudige bedrijfsvoering & Rantsoen bevat teveel (bestendig) zetmeel \\
Constante voerkwaliteit en voeropname & Risico van vervetting laagproductief melk- en \\
& jongvee \\
Constantere melkproductie & Duurder (eiwitrijk) krachtvoer \\
Hogere melkproductie & Hoger krachtvoerverbruik \\
Efficiënt mineralengebruik & Hogere kosten huisvesting en mestopslag \\
Lagere mechanisatiekosten & Lager netto bedrijsresultaat \\
\hline
\end{tabular}

Vanuit voedingstechnisch oogpunt gezien is een rantsoen in het tweede deel van de lactatie niet ideaal met uitsluitend snijmaïs. Het verloop van de conditiescore van het jongvee en de laagproductieve melkkoeien moet daarom scherp in de gaten worden gehouden. Tegenwoordig zijn door veredeling het zetmeelgehalte en de VEM-waarde aanmerkelijk hoger, waardoor het risico op een te royale voeding ondanks een hogere melkproductie groter is geworden.

\subsubsection{Snijmaisbijvoeding tijdens weideperiode}

Snijmaïs past uitstekend als bijvoeding bij beweiding. Naast goed eiwitrijk weidegras kan een te grote overmaat aan eiwit in het rantsoen worden voorkomen. Bovendien kan men door de hoeveelheid bijvoeding te variëren inspelen op een wisselend grasaanbod. Op (biologische) bedrijven met gras/klaver kan men door snijmaïsbijvoedering trommelzucht voorkomen.

\section{Snijmaïs naast onbeperkte of beperkte beweiding}

Bij onbeperkt weiden hebben de koeien na het melken de gelegenheid om snijmaïs op te nemen. De snijmaïsgift is dan beperkt tot in totaal ongeveer maximaal $4 \mathrm{~kg}$ droge stof per dag.

Bij beperkt weiden worden de koeien een deel van de dag opgestald. Bijvoeding bij beperkt weiden moet voldoende hoog zijn, omdat anders de koeien te veel beperkt worden in hun drogestofopname. Bij 12 uur weidegang moet het totale bijvoedingniveau (snijmaïs én krachtvoer) tenminste $10 \mathrm{~kg}$ droge stof bedragen. Bij een lager bijvoedingsniveau wordt het voor de melkkoeien erg moeilijk om voldoende te compenseren met grasopname uit de weide, zeker bij een matig grasaanbod. Bij een beweidingsduur korter dan 8 uur per dag kan men als vuistregel voor de drogestofopname uit weidegras aanhouden dat bij een ruim aanbod van kwalitatief goed gras een koe ongeveer $1 \mathrm{~kg}$ droge stof per uur opneemt. Bij 8 uur weidegang moet dan ongeveer 14 tot $15 \mathrm{~kg}$ droge stof uit snijmaïs en krachtvoer worden bijgevoerd. Bij een zeer beperkte weidegang met daarnaast snijmaïs als enigst ruwvoer kan de DVE-voorziening te krap worden en moet er een eiwitaanvulling uit krachtvoer komen.

\section{Siëstabeweiding}

Bij beperkt weiden kan men de koeien tussen twee melkmalen stallen en bijvoeren met snijmaïs. Dit is arbeidstechnisch een aantrekkelijke methode omdat men de koeien maar eenmaal per dag naar het land moet brengen en ophalen. Een alternatieve methode van beperkt weiden is siëstabeweiding. Hierbij worden de koeien twee keer per dag na het melken 4 tot 6 uur geweid. De rest van de dag zijn de koeien binnen en krijgen snijmaiis bijgevoerd. Het idee achter siëstabeweiding is dat in theorie het aanbod van eiwit (stikstof) uit gras beter wordt afgestemd op het energieaanbod uit snijmaiis. In de praktijk blijkt dit niet zo'n vaart te lopen. Wanneer het gras voldoende eiwit bevat, komt door ureumrecycling de stikstofvoorziening in pens ook bij een ongelijkmatige verdeling van het gras en snijmaïsaanbod over de dag (bv. overdag weiden en 's nachts opstallen) niet in gevaar. 
Uit proeven is gebleken dat siëstabeweiding bij eenzelfde aantal uren weidegang per dag, een hogere melk- en melkeiwitproductie oplevert dan traditioneel beperkt weiden. Tevens is bij siëstabeweiding de grasopname hoger en de snijmaïsopname lager en bij een gelijk aantal uren weidegang zijn er geen verschillen in stikstofefficiëntie tussen siëstabeweiding en traditionele beperkte beweiding. Een deel van de verschillen tussen de beweidingsmethoden wordt mogelijk veroorzaakt door een verminderde hittestress, omdat bij siëstabeweiding de koeien het warmste deel van de dag binnen zijn. Hittestress bij gangbaar beperkt weiden kan worden voorkomen door de koeien overdag op stal te houden en 's avonds en 's nachts te weiden. De ventilatiecapaciteit van de stal moet dan wel voldoende groot zijn. Het productievoordeel van siëstabeweiding moet men afzetten tegen de extra inzet van arbeid voor het ophalen en wegbrengen van de koeien.

\section{Snijmaïs in de rantsoenen van jongvee}

Snijmaïs past ook goed in rantsoenen voor jongvee, maar ook hier bestaat een risico voor vervetting. Bij jongvee jonger dan 1 jaar dat naast ruwvoer nog (eiwitrijk) krachtvoer krijgt, kan men snijmaïs als enig ruwvoer gebruiken. Bij het oudere jongvee moet de hoeveelheid snijmaïs worden beperkt tot maximaal $40 \%$ van het ruwvoer.

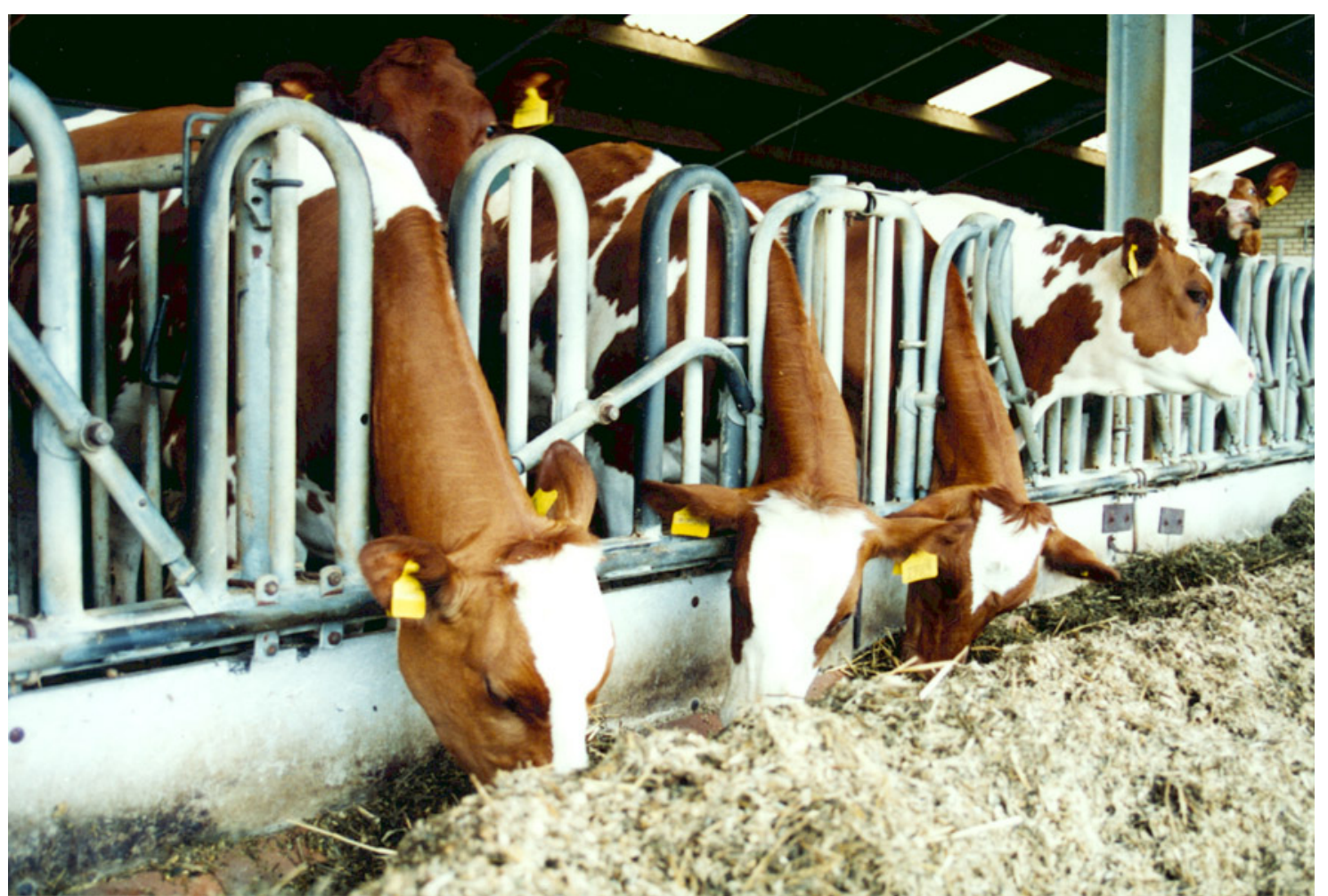

Grotere kans op vervetting bij jongvee met veel snijmaïs 


\section{Economie}

13.1 Teeltkosten en opbrengsten

13.2 Snijmaïs in bedrijfsverband.......

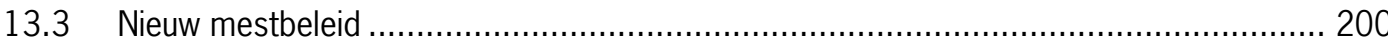

13.4 Aankoop en verkoop snijmaïs in melkveehouderij ................................................ 201 


\section{Economie}

Snijmaïs is in de veehouderij een belangrijk voedergewas. Jaarlijks wordt circa 215.000 ha snijmaïs geteeld. Naast diverse teelt- en voedingsaspecten is ook het economische resultaat van groot belang.

In algemene zin kunnen we goede uitspraken doen over het economisch resultaat van een hectare snijmaïs of het effect van snijmaïs als onderdeel van het totale melkveebedrijf. Echter, de specifieke bedrijfssituatie is vaak doorslaggevend op de afweging van het economische resultaat. De belangrijkste factoren die hierin een rol spelen, zijn het wel of niet (gedeeltelijk) telen van snijmaïs in loonwerk, de verkaveling van het bedrijf, de afstand tot het perceel en niet als minste de opbrengst en voederwaarde die daadwerkelijk worden behaald. De effecten van snijmaïs in bedrijfsverband zijn opgenomen in paragraaf 13.2.

Per 1 januari 2006 is het nieuwe mestbeleid van kracht en hebben landbouwbedrijven te maken met een systeem van gebruiksnormen. Voor een goede uitvoering van de nitraatrichtlijn krijgt ieder bedrijf te maken met een gebruiksnorm voor dierlijke mest van $170 \mathrm{~kg}$ stikstof $(\mathrm{N})$ en een gebruiksnorm voor stikstof en fosfaat per gewas. Een individueel bedrijf kan derogatie (uitzondering tot 230 of $250 \mathrm{~kg} \mathrm{~N}$ per ha) aanvragen op de gebruiksnorm van $170 \mathrm{~kg} \mathrm{~N}$ per ha. Zie hierover meer in paragraaf 13.3. Voor actuele informatie over plaatsingsnormen en gebruiksnormen kijk op www.rvo.nl.

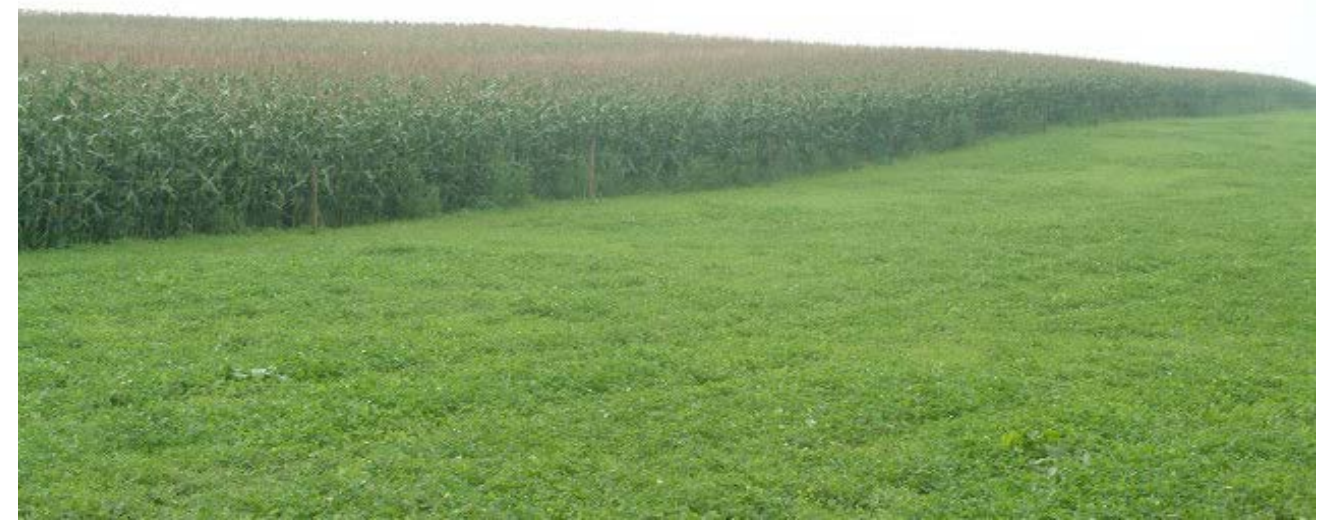

Snijmaïs is een belangrijk gewas voor de melkveehouderij 


\subsection{Teeltkosten en opbrengsten}

Om een goede indruk te kriigen van kosten en opbrengsten van snijmaïs is voor verschillende grondsoorten en opbrengstniveaus een saldoberekening gemaakt. Basis hiervoor is de KWINVeehouderij 2012-2013. De prijzen zijn afkomstig van o.a. het LEl en een aantal leveranciers van landbouwproducten. De loonwerktarieven zijn gebaseerd op gegevens van enkele loonwerkers verspreid over Nederland. Het is bekend dat in bepaalde regio's deze tarieven soms 10-20\% lager zijn.

Alle werkzaamheden in deze berekening worden als loonwerk in rekening gebracht voor een zuivere vergelijking. Wanneer werkzaamheden plaatsvinden in eigen beheer, moeten de loonwerkkosten vervangen worden door de kosten van eigen werktuigen en arbeid.

De werkelijke kosten van loonwerk en eigen mechanisatie zijn sterk afhankelijk van de loonwerker in de buurt en de specifieke bedrijfssituatie. De kosten voor eigen mechanisatie zijn afhankelijk van de oppervlakte waarop men het werktuig inzet, van eventuele samenwerking met buren, van de waarde van de werktuigen (nieuw of tweedehands) en de daadwerkelijke onderhoudskosten. Over het algemeen geldt dat de jaarlijkse kosten voor rente, afschrijving, onderhoud, verzekering en stalling ongeveer $20 \%$ van de nieuwwaarde bedragen.

\section{Kosten}

In tabel 13.1 staan de directe kosten voor de teelt van een ha snijmaïs vermeld. Als basis dient de teelt van snijmaïs op zandgrond. Voor de snijmaïsteelt op kleigrond zijn enkele toeslagen gerekend. Bij de kosten voor bemesting is uitgegaan van een normale hoeveelheid dierlijke mest, eventueel aangevuld met kunstmest. Ook de kosten voor aanwending van de organische mest en de kunstmest zijn hierin opgenomen. Op zangrond zijn de bemestingskosten $€ 10$,- lager dan op kleigrond omdat er bij de bemesting rekening is gehouden met de nawerking uit een groenbemester.

Voor het ploegen geldt op kleigrond $€ 15$,- hogere kosten en voor zaaiklaarmaken $€ 30$,- hogere kosten (rotorkopeg in plaats van cultivatorcombinatie).

Bij de onkruidbestrijding in snijmaïs gelden voor alle grondsoorten de uitgangspunten eenmaal volveldsbespuiting $(€ 42,-)$ en de kosten voor de bestrijdingsmiddelen (€ 85,--). Bij een volledige mechanische onkruidbestrijding bedragen de totale kosten ongeveer $€ 200,-$ (driemaal eggen à $€$ 23,- en tweemaal schoffelen + evt. aanaarden à $€ 65$,-).

De kosten voor transport tot en met het erf zijn bij de kosten voor oogsten inbegrepen. In het nieuwe mestbeleid is de teelt van een groenbemester op zand - en lössgronden verplicht. Daarom zijn tabel 13.1 de kosten bij zandgrond uitgebreid met de kosten voor de teelt van een groenbemester. 
Tabel 13.1 Directe kosten teelt en oogst van snijmaïs ( $€$ per ha, excl BTW)

\begin{tabular}{|c|c|c|}
\hline Omschrijving & $\begin{array}{r}\text { Snijmaïs } \\
\text { Zand }\end{array}$ & $\begin{array}{r}\text { Snijmaïs } \\
\text { Klei }\end{array}$ \\
\hline \multicolumn{3}{|l|}{ Middelen } \\
\hline Zaaizaad (incl. mesurol) & 195 & 195 \\
\hline Meststoffen + aanwending. & 186 & 196 \\
\hline \multirow[t]{2}{*}{ Gewasbeschermingsmiddelen } & 78 & 78 \\
\hline & 459 & 469 \\
\hline \multicolumn{3}{|l|}{ Loonwerk } \\
\hline Ploegen & 127 & 142 \\
\hline Zaaiklaar maken & 58 & 88 \\
\hline Zaaien (excl. meststoffen) & 77 & 77 \\
\hline Spuiten & 36 & 36 \\
\hline Oogsten & 380 & 380 \\
\hline Aanriijden & 67 & 67 \\
\hline Cultivateren & 58 & 58 \\
\hline \multirow[t]{2}{*}{ Slootonderhoud } & 26 & 26 \\
\hline & 829 & 874 \\
\hline \multicolumn{3}{|l|}{ Groenbemester } \\
\hline Zaaien (in combinatie met cultivateren) & 20 & \\
\hline Zaaizaad & 54 & \\
\hline \multirow[t]{2}{*}{ Extra kosten inwerken } & 65 & \\
\hline & 139 & \\
\hline Rente & 9 & 9 \\
\hline Totaal & 1436 & 1352 \\
\hline
\end{tabular}

\section{Opbrengsten}

De snijmaïsopbrengst kan per regio, per grondsoort en per perceel sterk variëren. Als norm voor bruto-opbrengsten per ha wordt aangehouden:
- zeer goed
$20.000 \mathrm{~kg} \mathrm{ds}$
- goed
$17.000 \mathrm{~kg} d \mathrm{~s}$
- matig
$14.000 \mathrm{~kg} d \mathrm{~s}$
- slecht
$11.000 \mathrm{~kg}$ ds

Goede snijmaïs bevat per kilo droge stof 980 VEM, 52 DVE en -35 OEB.

Uitgaande van een goede bruto-opbrengst van $17.000 \mathrm{~kg}$ ds per ha en $5 \%$ ds-verlies bij inkuilen, bedraagt de netto-opbrengst per ha dan:

- $\mathrm{ds}=17.000-5 \%=16.150 \mathrm{~kg} \mathrm{ds}$

- $\mathrm{VEM}=16.150 \times 0,980=15.827 \mathrm{kVEM}$

- $\mathrm{VEVI}=16.150 \times 0,995=16.069 \mathrm{kVEVI}$

- $\mathrm{DVE}=16.150 \times 0,052=840 \mathrm{kDVE}$

- $\mathrm{OEB}=16.150 \times-0,035=-565 \mathrm{kOEB}$ 
Om een inschatting te maken van de waarde van deze opbrengsten, zijn de opbrengsten gewaardeerd tegen de gemiddelde voederwaarde prijzen van 2017 (www.voederwaardeprijzen.nl): KVEM: $€ 0,16$ en DVE-toeslag: $€ 0,65$. De financiële opbrengsten komen veel hoger uit dan normaal geldende marktprijzen, maar wel wordt duidelijk welke waarde de opbrengst vertegenwoordigt in relatie tot de prijzen van krachtvoer en (vochtige) bijproducten. Als indicatie zijn voor drie opbrengstniveaus de opbrengsten doorgerekend en vermeld in tabel 13.2.

Tabel 13.2 Opbrengsten snijmaïs

\begin{tabular}{lccc}
\hline Omschrijving & $\begin{array}{c}\text { Snijmaïs } \\
\text { Matig }\end{array}$ & $\begin{array}{c}\text { Snijmaïs } \\
\text { Goed }\end{array}$ & $\begin{array}{c}\text { Snijmaïs } \\
\text { Zeer goed }\end{array}$ \\
\hline Bruto opbrengst (kg ds/ha) & 14.000 & 17.000 & 20.000 \\
Netto opbrengst (kg ds/ha) & 13.300 & 16.150 & 19.000 \\
KVEM opbrengst (VEM/ha) & 13.034 & 15.27 & 18.620 \\
KDVE opbrengst (DVE/ha) & 692 & 840 & 988 \\
KVEM opbrengst (€/ha) & 2085 & 2532 & 2979 \\
KDVE opbrengst (€/ha) & 450 & 546 & 642 \\
Totale opbrengst (€/ha) & 2535 & 3078 & 3621 \\
\hline
\end{tabular}

Door de voederwaardeopbrengst per hectare te verminderen met de kosten ontstaat het financieel resultaat per ha snijmaïs. Deze staan vermeld in tabel 13.3. Vanwege de hogere teeltkosten op kleigrond is onderscheidt gemaakt tussen zand en klei. Voor het berekenen van het financieel resultaat bij verkoop op stam moeten de totale kosten vermindert worden met de oogstkosten. De teeltkosten voor zand en kleigrond zijn dan resp. €1017,- en €930,-.

Tabel 13.3 Opbrengsten en kosten snijmaïs per ha (€ per ha)

\begin{tabular}{lccc}
\hline Omschrijving & $\begin{array}{c}\text { Snijmaïs } \\
\text { Matig }\end{array}$ & $\begin{array}{c}\text { Snijmaïs } \\
\text { Goed }\end{array}$ & $\begin{array}{c}\text { Snijmaïs } \\
\text { Zeer goed }\end{array}$ \\
\hline Totale opbrengst (€/ha) & 2535 & 3078 & 3621 \\
Totale kosten op zand & 1436 & 1436 & 1436 \\
Financieel resultaat op zand & 1099 & 1642 & 2185 \\
Totale kosten op klei & 1352 & 1352 & 1352 \\
Financieel resultaat op klei & 1183 & 1726 & 2269 \\
\hline
\end{tabular}

\subsection{Snijmaïs in bedrijfsverband}

Voor een praktijkbedrijf is het van belang om maïs zo economisch mogelijk binnen het bedrijf in te passen. In 2003 is een studie uitgevoerd "Snijmaïs op melkveebedrijven: gevolgen voor milieu en economie" en vastgelegd in Praktijkrapport nr 24 van Wageningen Livestock Research (toenmalige Praktijkonderzoek Veehouderij). Het MINAS systeem speelde hierin een belangrijke rol. Hoewel dit systeem is vervallen zijn veel conclusies nog relevant. Uitgangspunt voor de studie waren bedrijven met een wisselende intensiteit van 13.000 tot $18.000 \mathrm{~kg}$ melk/ha, graslandgebruik met weidegang, 15 tot $50 \%$ van de bedrijfsoppervlakte snijmaïs binnen het bedrijf en grondsoort variërend van droog zand tot klei. De snijmaïsteelt werd uitgevoerd in loonwerk. 


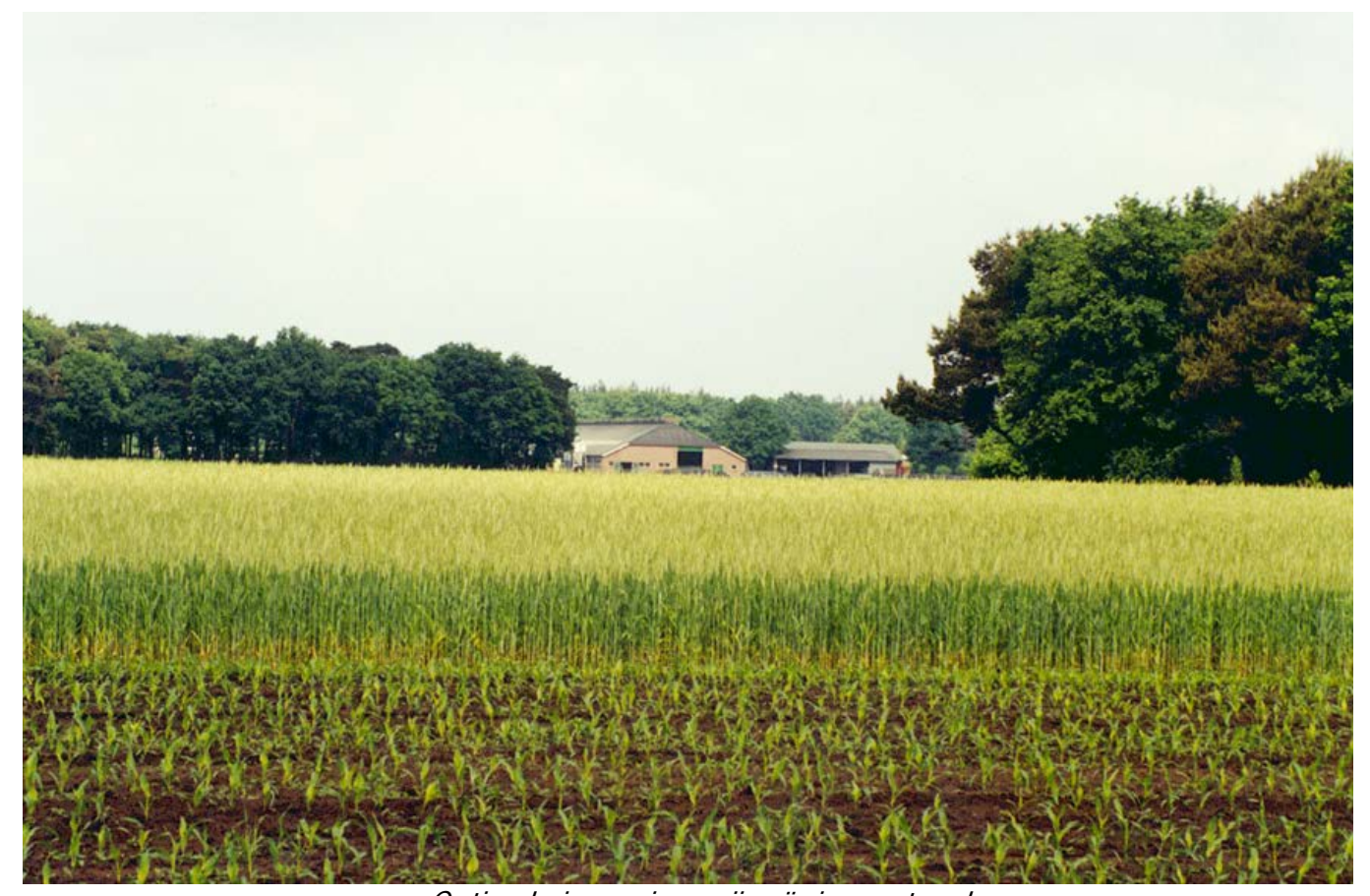

Optimale inpassing snijmaïs is maatwerk

\section{Invloed verkaveling}

Snijmaïs telen op afstand in plaats van gras dat men alleen maait, is gunstig voor de arbeidsopbrengst wanneer alle werkzaamheden in loonwerk worden uitgevoerd.

Grasland op de huiskavel vervangen door snijmaïs verlaagt de arbeidsopbrengst meer dan grasland (alleen maaien) op afstand vervangen door snijmaïs. Meer snijmaïs op de huiskavel is gunstig voor de mestbenutting als daardoor minder geweid kan worden. Als de koeien meer op stal staan, komt er meer mest in de put en kan men deze beter benutten.

In de praktijk leidt snijmaïs telen op afstand in plaats van gras op afstand tot een daling van de arbeidsopbrengst als men werkzaamheden als maaien, schudden en harken in eigen beheer uitvoert. Maar meer snijmaïs telen op afstand leidt altijd tot minder arbeidsinzet. De beschikbaarheid van arbeid en de toch al hoge werkdruk op een melkveebedrijf zorgen ervoor dat veehouders (terecht) de keuze maken voor snijmaïs op afstand. Als de arbeidstijd ook in kosten uitgedrukt wordt, is deze keuze ook bedrijfseconomisch te onderbouwen.

In de praktijk is het soms ook mogelijk om jongvee op afstand te weiden. Dit beperkt de arbeidstijd voor het grasland op afstand en kan een goed argument zijn om dit grasland niet te vervangen door snijmaïs. De keuze van grondgebruik hangt sterk af van de specifieke bedrijfssituatie.

\section{Verhouding grasland/maïsland}

Meer snijmaïs telen leidt veelal tot lagere mineralen-overschotten, echter vaak ook tot hogere nitraatgehaltes in het grondwater. De arbeidsopbrengst daalt bij meer snijmaïs door met name hogere loonwerkkosten.

In de praktijk geeft meer snijmaïs geeft lagere voerkosten, maar hogere loonwerkkosten en is daarom ongunstig voor de arbeidsopbrengst. De eisen die aan een ruwvoerrantsoen worden gesteld (aandeel gras) bepalen de grens van het aandeel maïsland. Om binnen de nieuwe mestwet derogatie te krijgen ligt het maximum aandeel maïsland op $30 \%$. 


\section{Graslandgebruiksysteem}

Meer snijmaïs verbouwen betekent vaak minder weidegang, omdat er minder graslandoppervlakte beschikbaar is. Minder weiden en de koeien langer opstallen leidt tot lagere stikstofoverschotten en lagere nitraatconcentraties in het grondwater, maar ook de arbeidsopbrengst daalt bij minder weidegang.

In de praktijk is het aan te bevelen een graslandgebruiksysteem te kiezen dat het juiste evenwicht weerspiegelt van mestbenutting (meer opstallen) en een zo goed mogelijk economisch resultaat (meer weiden). De keuze is afhankelijk van specifieke bedrijfsomstandigheden, de grootte van de huiskavel, de grondeigenschappen en het melksysteem. Bij deze keuze van het juiste graslandsysteem speelt de bijvoeding en het aandeel snijmaïs een grote rol. (kijk ook op www.livestockresearch.wur.nl onder tabblad 'Livestock Research' daarna onder 'Faciliteiten en Producten ' en vervolgens onder 'Gratis tools en software' en kies voor Beweidingswijzer).

\section{Vanggewas/groenbemester telen}

Een groenbemester/vanggewas telen onder of na de snijmaïs en dit in maart onderwerken verlaagt de stikstofverliezen en verlaagt het nitraatgehalte in het grondwater. De arbeidsopbrengst daalt als alle werkzaamheden in loonwerk plaatsvinden.

Wanneer het vanggewas niet wordt ondergewerkt, maar wordt gemaaid en in mei ondergeploegd, is de stikstofbenutting iets kleiner. Hoewel de opbrengst hoger is, komt er minder stikstof beschikbaar voor de maïs en moet er iets meer bemest worden. Het effect op het nitraatgehalte van het grondwater is minimaal.

In de praktijk is het goed mogelijk om op de kosten van loonwerk te besparen door zelf het vanggewas met een kunstmeststrooier in te zaaien. Naast beperken van stikstofverliezen kan toepassen van een vanggewas ook zorgen voor een structuurverbetering van de bodem en een welkome aanvulling zijn op de organische stofvoorziening. Dit is voordelig bij grondsoorten met een laag organisch stofgehalte in combinatie met lage mestgiften.

Bij het maaien van een vanggewas voor het onderploegen daalt de snijmaïsopbrengst met gemiddeld $5 \%$ door een later zaaitijdstip en een onregelmatig zaaibed. Door een later zaaitijdstip wordt het oogsttijdstip verlaat en neemt het oogstrisico toe. Ook speelt de vochtvoorziening van het maïsland een rol bij de lagere snijmaïsopbrengst. Vochttekorten treden vooral op droge zandgronden op.

\section{Vruchtwisseling toepassen}

Snijmaïs wordt vaak jaren achtereen op hetzelfde perceel verbouwd. Gras en snijmaïs in vruchtwisseling verbouwen leidt tot een betere stikstofbenutting wanneer de zode tijdig (voor 1 april) wordt ondergeploegd en de stikstofnawerking in mindering wordt gebracht op de bemesting.

Wanneer voor het inzaaien van snijmaïs nog een maaisnede gras wordt gewonnen, daalt de stikstofbenutting en stijgt het nitraatgehalte aanzienlijk door de hogere mestgift.

GPS opnemen in een bouwplan met gras en maïs leidt tot een betere mineralenbenutting; echter, deze verbetering is minder dan bij vruchtwisseling met alleen gras en snijmaïs.

In een aantal gevallen is vruchtwisseling nadelig voor de arbeidsopbrengst door met name hogere loonwerkkosten voor herinzaai.

In de praktijk wordt regelmatig grasland vernieuwd, vruchtwisseling met maïs kan hierin vaak automatisch meedraaien zonder dat dit ten koste gaat van het areaal blijvend grasland. Daarbij verkleint de teelt van GPS tussen snijmaïs en herinzaai met gras het risico dat ontwikkeling van de graszode na inzaai mislukt. Dit komt omdat de inzaai van gras na GPS begin augustus al mogelijk is. Wanneer dit na de teelt van snijmaïs in september/oktober gebeurt, is de kans groter op slechte weers- en bodemomstandigheden die de begingroei van het gras kunnen belemmeren. Om succesvol gras in te zaaien na de teelt van GPS is ook sterk afhankelijk van de vochtvoorziening. Opgemerkt moet worden dat op een bedrijf met derogatie het telen van GPS ten koste gaat van de oppervlakte snijmaïs die geteeld kan worden. 
Bij lagere mestgiften op maïs kan vruchtwisseling met gewassen die veel organische stof achterlaten (gras, graan) de organische stofvoorziening verbeteren in vergelijking met continuteelt van snijmaïs.

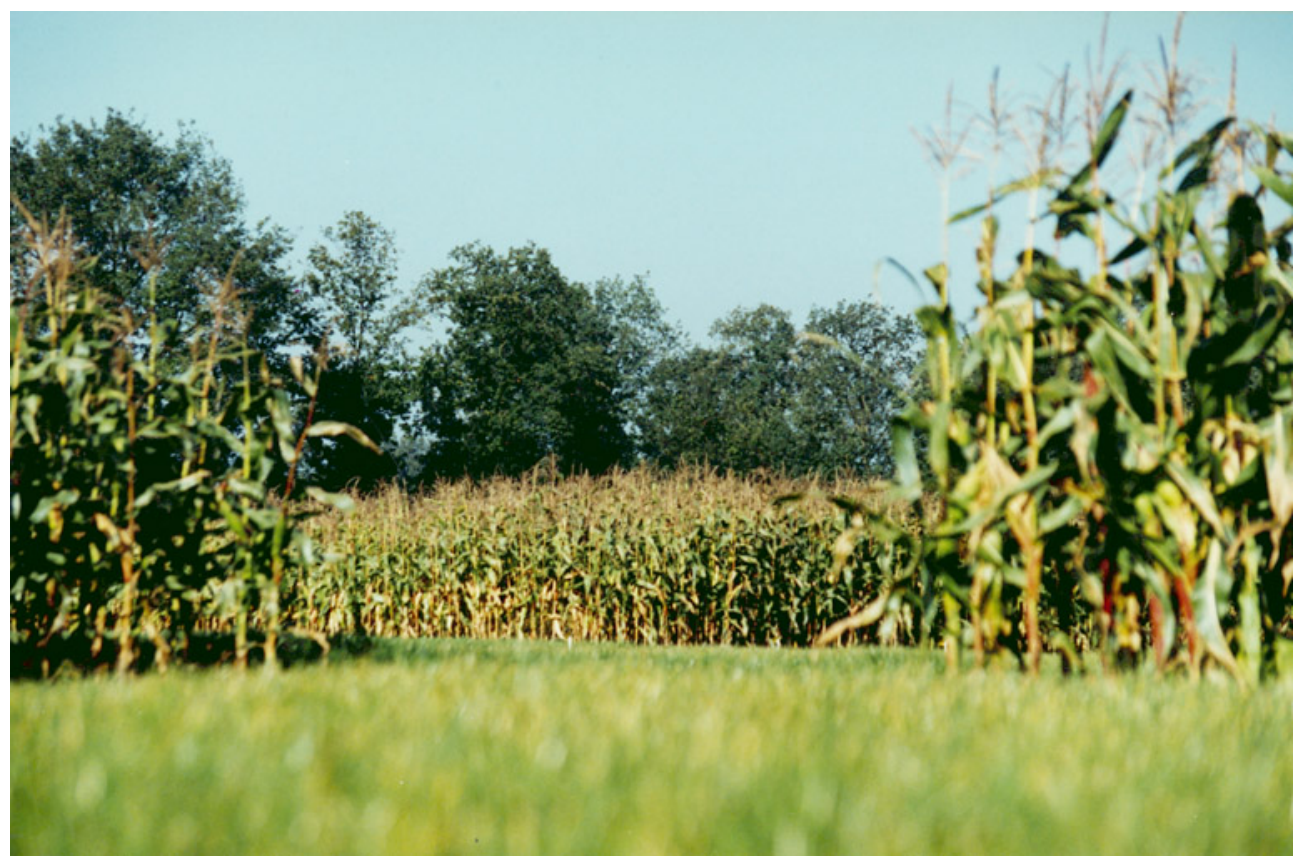

Vruchtwisseling geeft betere organische stofvoorziening

\section{Beregenen van snijmaïs op droge zandgrond}

Algemene uitspraken over rendabiliteit van beregenen zijn erg moeilijk door de specifieke bedrijfsomstandigheden (o.a. grondsoort) en weersomstandigheden. Duidelijk is wel dat bij droogte op droge zandgrond beregenen van snijmaïs tijdens de kolfzetting en bloei gunstig is voor de mineralenbenutting en voor verlaging van het nitraatgehalte in het grondwater. Of beregenen financieel aantrekkelijk is, hangt af van de extra kosten die men ervoor moet maken en de extra opbrengsten die hier tegenover staan.

In de praktijk is het aan te bevelen om bij beregenen snijmaïspercelen voorrang te geven boven percelen met grasland. Bij droogte tijdens de bloei is beregenen altijd verantwoord, omdat dan de korrelzetting plaatsvindt. Snijmaïs benut het water voor gewasgroei beter dan gras. Mede daardoor is de verhoging van de mineralenbenutting door het beregenen van snijmaïs groter dan door het beregenen van gras.

\subsection{Nieuw mestbeleid}

Vanaf 2006 geldt een nieuw mestbeleid. Centraal onderdeel in dit nieuwe beleid is het stelsel van gebruiksnormen. Deze normen zijn in hoofdstuk 5 verder beschreven. Het nieuwe beleid heeft in bedrijfsverband globaal de volgende effecten:

- Hoe meer mest men in de stal opvangt (dat wil zeggen hoe beperkter de beweiding), hoe beter de mest op maïs (en gras) tot benutting kan worden gebracht. 
- Minimaal $80 \%$ grasland is nodig in het bouwplan om in aanmerking te komen voor derogatie met 230 of $250 \mathrm{~kg} \mathrm{~N}$ per ha uit graasdierenmest. Derogatie geldt voor de totale bedrijfsoppervlakte.

- Bij een groot aandeel maïs in het bouwplan (> $20 \%$ ) is er geen mogelijkheid tot derogatie. Minder maïsteelt om toch derogatie aan te mogen vragen is bedrijfseconomisch gezien praktisch altijd aantrekkelijk.

- Bij melkveebedrijven met weidegang kan men een lager werkingscoëfficiënt voor dierlijke mest hanteren (45\%). Hierdoor ontstaat voor snijmaïs iets meer ruimte voor kunstmestaanvoer.

Wanneer het bouwplan op een bedrijf dicht bij het omslagpunt van wel/geen derogatie (80\% gras) ligt, zal het bedrijfseconomisch effect van meer of minder maïs veel groter zijn dan in het verleden, omdat meer of minder maïs ook van invloed is op de plaatsingsnorm. Voor actuele informatie over gebruiksnormen voor dierlijke mest en gebruiksnormen voor stikstof en fosfaat kijk op www.rvo.nl.

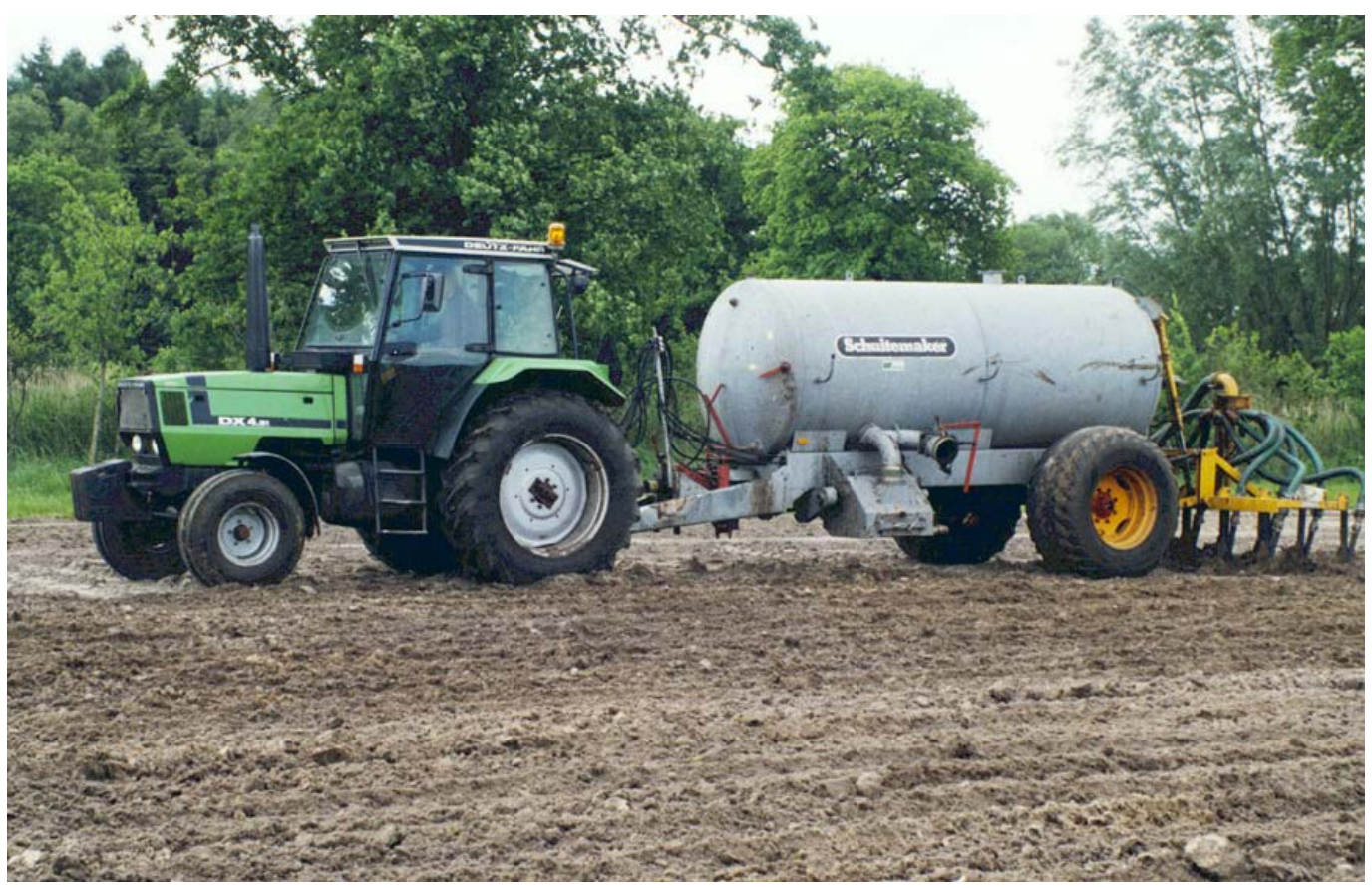

Vanaf 2006 gelden nieuwe regels voor gebruik van dierlijke mest

\subsection{Aankoop en verkoop snijmaïs in melkveehouderij}

Rond 1985 werd naar schatting 25-30\% van alle snijmaïs verhandeld. In die periode was er behoefte aan ruwvoer en werden goede prijzen voor snijmaïs betaald. Door de melkquotering en de dalende veebezetting in de tweede helft van de jaren tachtig, is de behoefte aan aankoop van ruwvoer gedaald. Vanaf 1990 wordt niet meer dan 10-15\% van de oppervlakte snijmaïs verkocht.

De handel in snijmaïs vindt plaatst via diverse kanalen, zoals verkoop tussen boeren onderling, maïsbanken, loonwerkers en foeragehandelaren. Het grootste deel van de snijmaïs gaat via de loonwerker direct van teler naar koper. Een gedeelte van de snijmaïs 
wordt door de handel (of telers) zelf ingekuild en vervolgens in de winter of in de zomer weer verkocht, vooral als de marktprijs van verse snijmaïs tegenvalt.

De snijmaïsprijs hangt sterk af van de opbrengst, de kwaliteit, de voorraad graskuil en de prijs van het krachtvoer. In perioden met een ruime voorraad ruwvoer of lage krachtvoerprijzen is de snijmaïsprijs meestal lager, zo ook de laatste jaren.

De prijs hangt af van gestelde voorwaarden bij verkoop:

- Snijmaïs op stam, dus exclusief de oogst- en transportkosten

- $\quad$ Gehakselde snijmaïs, franco geleverd bij de koper direct na de oogst

- $\quad$ Ingekuilde snijmaïs, franco geleverd bij de koper in winter- of zomerperiode

- $\quad$ Prijzen per ha, per kuub, per ton product, per kg droge stof of per KVEM

- $\quad$ Algemeen geldende aan- en verkoopprijzen

De verschillende manieren van verkoop maken het moeilijk om te beoordelen of de maïs duur of goedkoop is. Het beste is de marktprijs van snijmaïs te vergelijken met de voederwaardeprijs en daarbij rekening te houden met de bijkomende kosten van oogsten, transport, opslag, verliezen en extra arbeid. De voederwaardeprijs is de prijs per ton snijmaïs, waarbij de hoeveelheid VEM en DVE per ton is vermenigvuldigd met de berekende KVEM- en DVE-toeslagpriijs. Deze prijzen worden maandelijks door Wageningen Livestock Research berekend (www.voederwaardeprijzen.nl).

Naast de verschillende manieren van aan- en verkoop van snijmaïs heeft ook het percentage droge stof grote invloed op de prijsstelling. Het aankopen op basis van een afgesproken prijs per kg droge stof of per kVEM heeft daarom de voorkeur. Indien een prijs per ton wordt afgesproken, dan dient duidelijk aangegeven te worden bij welk drogestofgehalte dit is (bijvoorbeeld $32 \%$ droge stof) en welke prijscorrectie per drogestofpercentage wordt gehanteerd.

\section{Voorbeeld berekening van aan- en verkoopprïzen}

Uitgaande van een opbrengst van 17 ton ds/ha snijmaïs met $35 \%$ droge stof $(=48,6$ ton vers/ha), een prijs van snijmaiis op stam van $€ 2150,-$, $€ 447$,- voor de oogst en extra transportkosten van

$€ 115,-$ per ha levert dit de gegevens in tabel 13.4 op.

Tabel 13.4 Voorbeeld berekening aan- en verkoopprijzen snijmaïs

\begin{tabular}{lccc}
\hline & $€$ per ha & $€$ per ton vers & $€$ per kg ds \\
\hline Verkoop op stam & 2150 & 44 & 0,13 \\
Oogst en aanrijden & 447 & 9 & 0,03 \\
Extra transport & 115 & 2 & 0,01 \\
Aankoop vers gehakseld & 2.712 & 55 & 0,17 \\
\hline
\end{tabular}

Voor berekening van de prijs van het ingekuild product moet men rekening houden met de inkuilverliezen. Gemiddeld zijn deze verliezen aan drogestof- en voederwaardeopbrengst bij $35 \%$ drogestof respectievelijk 3 en $7 \%$. 


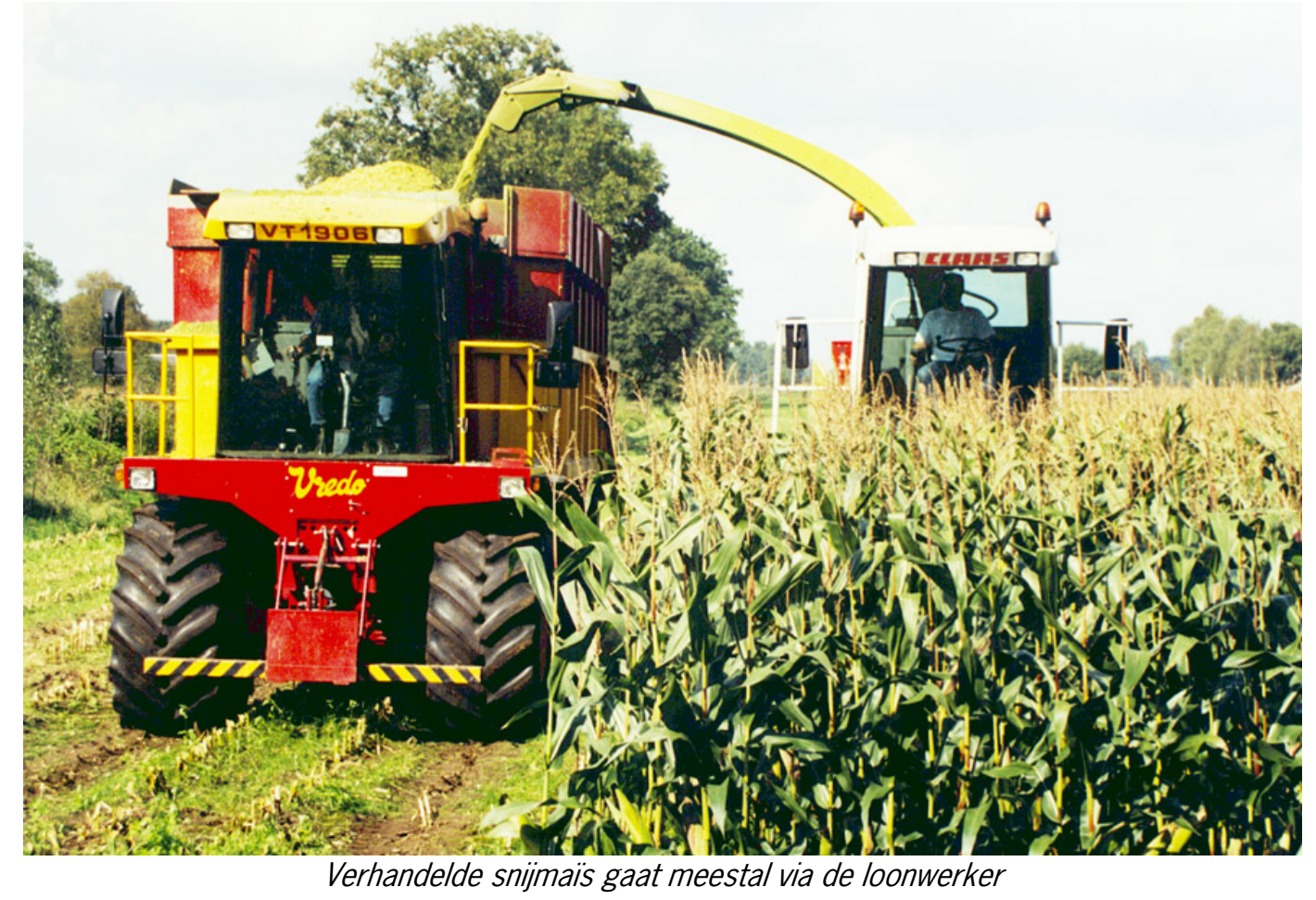



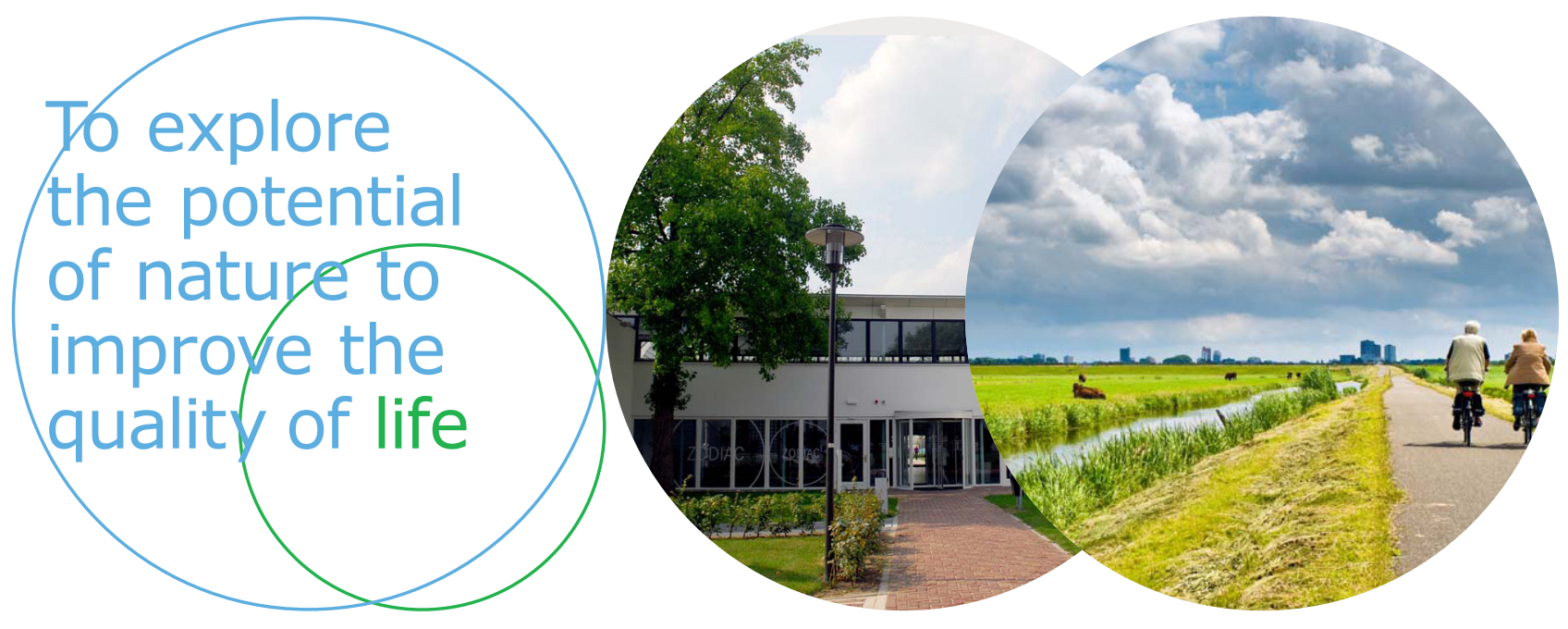

Wageningen Livestock Research Postbus 338

Wageningen Livestock Research ontwikkelt kennis voor een zorgvuldige en $6700 \mathrm{AH}$ Wageningen

T 0317483953

renderende veehouderij, vertaalt deze naar praktijkgerichte oplossingen en innovaties, en zorgt voor doorstroming van deze kennis. Onze wetenschappelijke E info.livestockresearch@wur.nl www.wur.nl/ livestock-research kennis op het gebied van veehouderijsystemen en van voeding, genetica, welzijn en milieu-impact van landbouwhuisdieren integreren we, samen met onze klanten, tot veehouderijconcepten voor de $21 \mathrm{e}$ eeuw.

De missie van Wageningen University \& Research is 'To explore the potential of nature to improve the quality of life'. Binnen Wageningen University \& Research bundelen 9 gespecialiseerde onderzoeksinstituten van Stichting Wageningen Research en Wageningen University hun krachten om bij te dragen aan de oplossing van belangrijke vragen in het domein van gezonde voeding en leefomgeving. Met ongeveer 30 vestigingen, 6.500 medewerkers en 10.000 studenten behoort Wageningen University \& Research wereldwijd tot de aansprekende kennisinstellingen binnen haar domein. De integrale benadering van de vraagstukken en de samenwerking tussen verschillende disciplines vormen het hart van de unieke Wageningen aanpak. 